Portland State University

PDXScholar

7-12-2015

\title{
Naturally Occurring Background Levels of Arsenic in the Soils of Southwestern Oregon
}

Heather Ann Hurtado

Portland State University

Follow this and additional works at: https://pdxscholar.library.pdx.edu/open_access_etds

Part of the Geology Commons, and the Soil Science Commons

Let us know how access to this document benefits you.

\section{Recommended Citation}

Hurtado, Heather Ann, "Naturally Occurring Background Levels of Arsenic in the Soils of Southwestern Oregon" (2015). Dissertations and Theses. Paper 2996.

https://doi.org/10.15760/etd.2997

This Thesis is brought to you for free and open access. It has been accepted for inclusion in Dissertations and Theses by an authorized administrator of PDXScholar. Please contact us if we can make this document more accessible: pdxscholar@pdx.edu. 


\section{Naturally Occurring Background Levels of Arsenic in the Soils of Southwestern Oregon}

by

Heather Ann Hurtado

A thesis submitted in partial fulfillment of the requirements for the degree of

Master of Science

in Geology

Thesis Committee:

Scott F. Burns, Chair

Adam M. Booth

R. Benjamin Perkins

Portland State University

2016 


\begin{abstract}
This study examines the natural background concentrations of arsenic in the soils of southwest Oregon, using new samples in addition to data collected from previous theses (Khandoker, 1997 and Douglas, 1999). The original 213 samples were run by ICPAES with a reporting limit of 20 ppm, and only three samples had detected values. The original samples were tested again (2013) at a detection limit of $0.20 \mathrm{ppm}$ by ICP-MS, as were 42 new samples (2013), to better ascertain the natural levels of arsenic in undisturbed soils. The aim is to add to the existing DEQ data set, which has been used to establish new regulatory levels based on natural levels in the environment that are both safer and more economically viable than the former risk-based remediation levels (DEQ, 2013).
\end{abstract}

The maximum and mean concentrations, respectively, for each province (with high formation map unit) are 85.4 and 21.99 ppm for South Willamette Valley (Tfee), 45.4 and $5.42 \mathrm{ppm}$ for the Klamath Mountains (Jub), 11.9 and 2.76 ppm for the Cascade Range (Tbaa), 10.6 and 5.15 ppm for the Coast Range (Ty), 2.32 and 1.29 ppm for the Basin and Range (Qba) and 1.5 and 1.20 ppm for the High Lava Plains (Tmv).

In addition, the distribution and variance of arsenic in the A and B soil horizons is assessed in this study; one of 18 new sites sampled for this study (distinguished with the HH prefix), site HH11, was randomly chosen for this purpose. Site HH11 is an Inceptisol soil above volcanic rock (KJdv map unit) located at 275 meters elevation in Douglas County within the Klamath province. Five samples were taken from the A and from the B 
horizons at site HH11. The mean and standard deviation, respectively, was $3.74 \pm 0.44$ for the A horizon and $4.53 \pm 0.39$ for the B horizon. The consistency and low deviation within each horizon indicate that a single sample within a horizon is a good representative of that horizon and supports the field methodology used in this study of taking only one sample in the A horizon and one sample in the B horizon. The Wilcoxon Rank-Sum test (p-value: 0.76) determined that A and B horizons for the 119 sites that had data for both the A and B horizons were not statistically different. However, 47 sites $(39.5 \%)$ are higher in arsenic in the A horizon while 63 sites $(52.9 \%)$ are higher in the B horizon, with 9 sites $(7.6 \%)$ having no value detected. This is strong support for sampling in both the A and B horizons to ensure a sample is collected from the horizon with the highest arsenic value, and critical for an accurate assessment of the maximum levels for naturally occurring arsenic in soils.

Lastly, this study statistically examines six potentially important environmental predictors of naturally occurring arsenic in southwestern Oregon: site elevation, geomorphic province, mapped rock type and age, and sample soil order and color (redness). A Classification and Regression Tree Model (CART) determined soil order, elevation and rock type to be of significant importance in determining arsenic concentrations in the natural environment. According to the regression tree, arsenic concentrations are greater within Alfisol and Ultisol/Alfisol and Vertisol soil orders, at lower elevations below 1,207 meters, and within soils from sedimentary, mixed volcanic/sedimentary and unconsolidated rock types. 
The relationship between environmental factors and high levels of arsenic is complex and research is ongoing. However, soil order is likely to be a significant factor for predicting levels of arsenic since soil order is defined by its horizon development. Negatively charged arsenic ions adsorb to positively charged minerals, commonly iron, aluminum and magnesium oxides and clay. Any soils with a zone of mineral accumulation (B horizon) — such as Alfisol, Ultisol and Vertisol soils have — are likely to attract, retain and concentrate arsenic in the soil.

The relationship between elevation and rock type to arsenic level is less clear. Arsenic values could be higher in lower elevations because weather and gravity have transported arsenic-bearing sediments to lower topography where it accumulates, or a result of more chemical processes in the more temperate climates at lower elevation, or is correlated with other factors such as depositional regime of the rock. Rock type as a predictive factor also requires more research; the degree of arsenic enrichment in rock and arsenic released through physical and chemical weathering are likely to have a high degree of local variability than will ultimately not allow definitive association of high arsenic levels by rock type. 


\section{Acknowledgements}

Dr. Scott Burns, your encouragement and confidence has made the process of creating this Master's thesis much more enjoyable than I imagined it could be. Also, I learned a lot from you! David Anderson from DEQ and Neil Morton from

GeoEngineers, Inc. were both invaluable resources for questions I had regarding the DEQ data set. I thank Kassandra Lindsey and Aubrey Frimoth for being my post-surgery arms and legs with their physical contributions (digging many holes) and can-do attitude in the field. Classmates Traci Parker and Kimberly Yazzie joined me in playing with my data for a class project, helped troubleshoot appropriate analyses for the data and traded ideas for what the results may imply.

To my immediate family: thank you, parents, for emotional support and perspective, always. I also very much appreciate my dog, Daisy, who has kept my toes warm while snuggled under my desk during all of my higher education. My fantastic husband, Josh, with his patience of steel, earns my lifetime of gratitude; he has sacrificed many date-nights through both my Bachelor's and Master's education. Josh, without your sense of humor and support, I would not have had the fun and focus that I am grateful to have experienced through these degrees. Last but not least... Liam, welcome to the world, my son! 


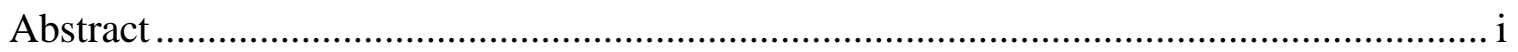

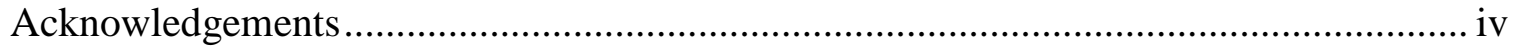

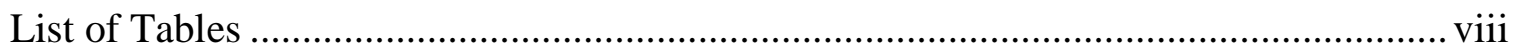

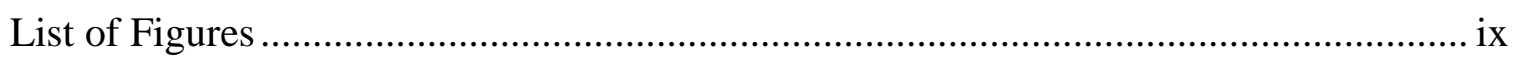

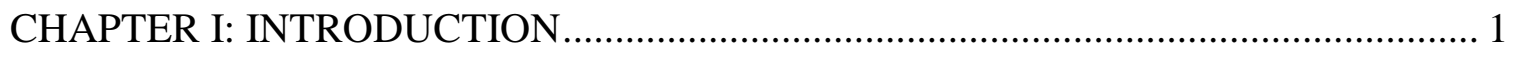

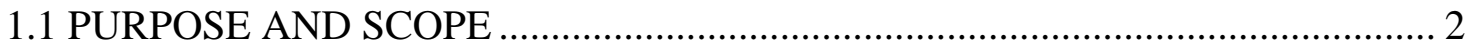

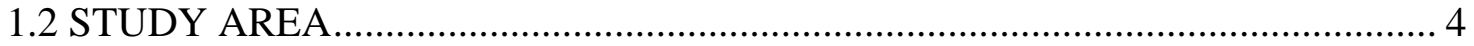

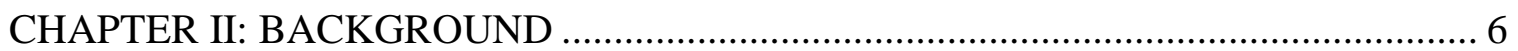

2.1 PHYSIOGRAPHIC PROVINCES OF OREGON ............................................. 6

2.2 GEOLOGIC HISTORY OF SOUTHWEST OREGON ..................................... 6

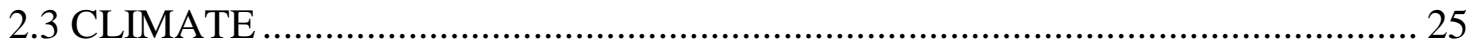

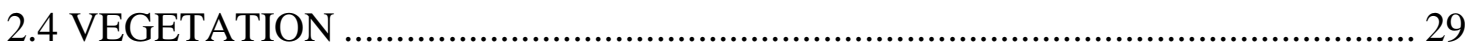

CHAPTER III: BACKGROUND WORK ON THE CONCENTRATION OF ARSENIC

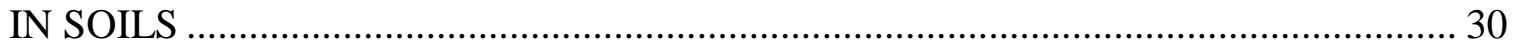

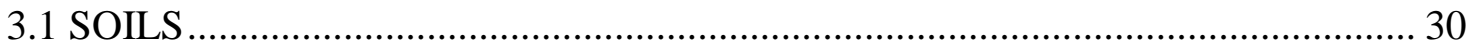

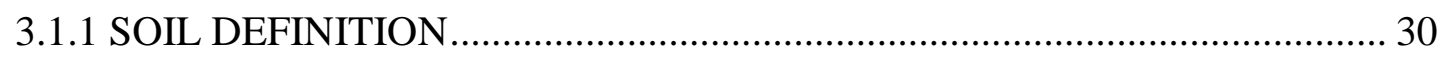

3.1.2 SOIL PROFILES AND HORIZON NOMENCLATURE ............................ 30

3.1.3 FIELD SOIL CHARACTERISTICS AND PROPERTIES ........................... 32 
3.2 SOURCES OF NATURALLY OCCURRING ARSENIC................................. 38

3.3 GEOCHEMISTRY: ARSENIC SPECIES AND TRANSPORTATION ................ 39

3.4 PREVIOUS WORK: ARSENIC IN SOILS IN SOUTHWEST OREGON ........... 41

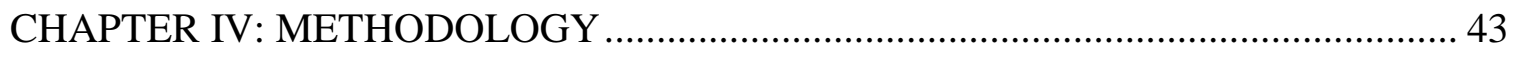

4.1 GEOGRAPHIC INFORMATION SYSTEMS …………………………............ 43

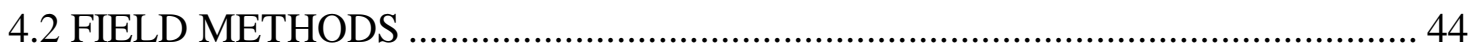

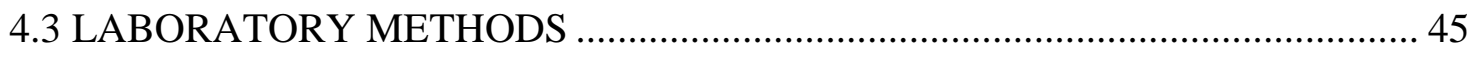

4.4 GROUPINGS FOR STATISTICAL ANALYSES …............................................. 46

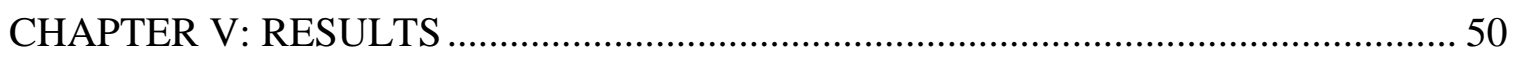

5.1 ARSENIC CONCENTRATIONS IN SOUTHWEST OREGON ……………....... 50

5.2 DISTRIBUTION OF ARSENIC IN A AND B SOIL HORIZONS …………….... 51

5.3 DISTRIBUTION OF ARSENIC IN SOUTHWEST OREGON BY PROVINCE. 56

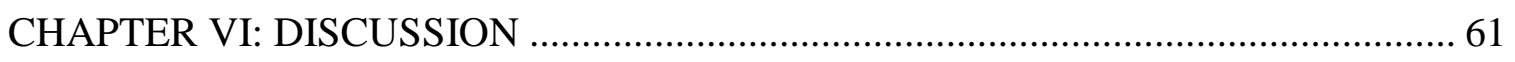

6.1 LEVELS OF ARSENIC IN SOUTHWEST OREGON SOILS ............................ 61

6.1.1 DISTRIBUTION OF ARSENIC IN A AND B HORIZONS ........................... 61

6.1.2 COMPARISON BETWEEN DEQ AND PSU DATA SETS ............................ 61

6.2 RELATIONSHIP OF ARSENIC WITH ENVIRONMENTAL FACTORS .......... 64

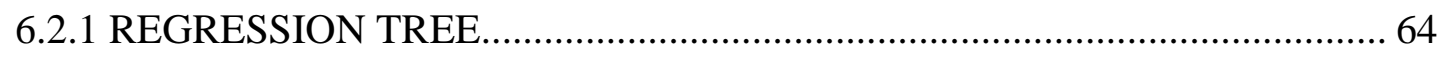




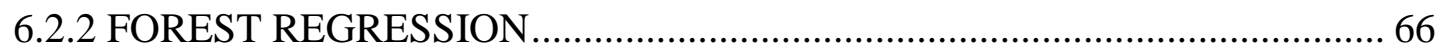

6.2.3 RELATIONSHIP OF ARSENIC TO SOIL ORDER...................................... 67

6.2.4 RELATIONSHIP OF ARSENIC TO ELEVATION ....................................... 69

6.2.5 RELATIONSHIP OF ARSENIC TO ROCK TYPES ....................................... 71

6.2.6 SUMMARY OF TOP THREE PREDICTORS............................................. 73

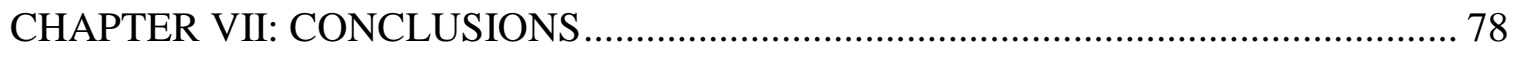

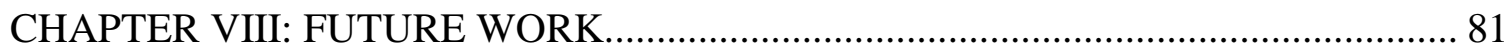

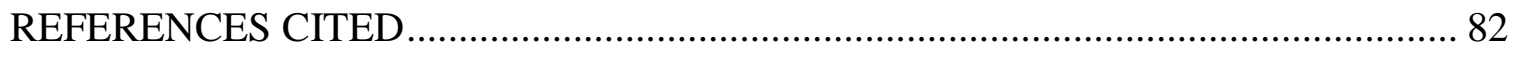

APPENDIX A: Stratigraphy of Provinces within Southwest Oregon ............................... 85

APPENDIX B: Description of Geologic Units by Province ……………........................ 90

APPENDIX C: Site and soil Pit Images for HH Sites ................................................... 106

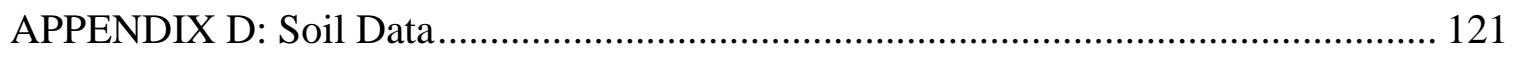

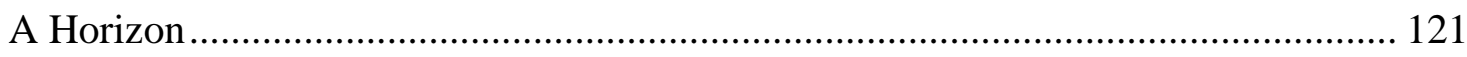

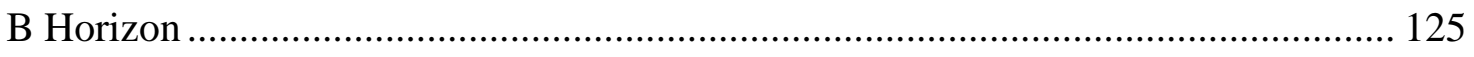

APPENDIX E: Sampling Site Characteristics ....................................................... 129

APPENDIX F: Analysis Categories Data................................................................ 135

APPENDIX G: Apex Labs Sample ID and Control Data ............................................. 13 


\section{List of Tables}

Table 1. Historic and new maximum limits of arsenic established by DEQ................... 3

Table 2. Description of geologic units sampled within Klamath Mountain Province...... 10

Table 3. Description of geologic units sampled within the Coast Range....................... 15

Table 4. Description of geologic units sampled within the Cascade Range Province...... 19

Table 5. Description of geologic units sampled within the South Willamette Valley...... 20

Table 6. Description of geologic units sampled within the Basin and Range Province... 23

Table 7. Description of geologic units sampled within High Lava Plains Province. ....... 25

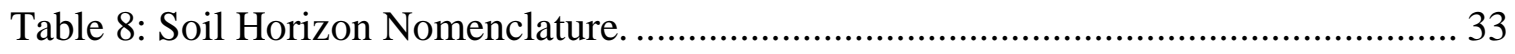

Table 9: Typical arsenic concentrations in rocks and unconsolidated sediments............. 39

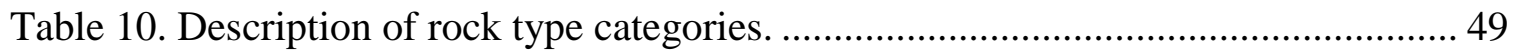

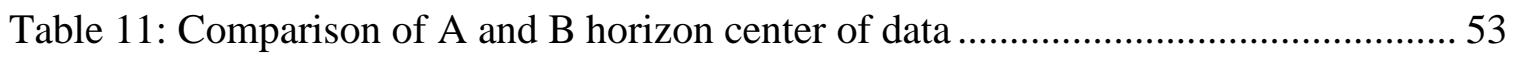

Table 12. Arsenic concentrations for samples collected in the A horizon....................... 54

Table 13. Arsenic concentrations for samples collected in the B horizon....................... 55

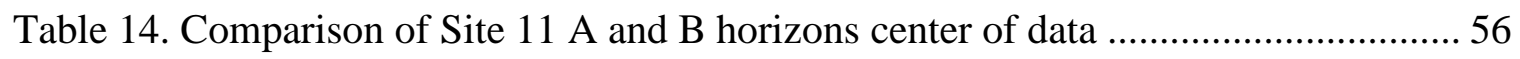

Table 15. Summary statistics for the DEQ and PSU data sets................................... 59

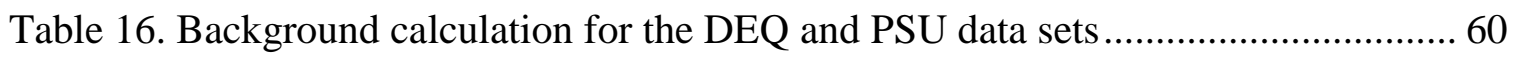

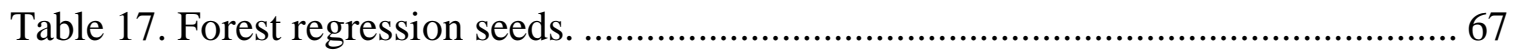

Table 18: Summary of statistical tests run on the regression tree for soil order.............. 69

Table 19: Summary of statistical tests run on the regression tree for elevation .............. 71

Table 20: Summary of statistical tests run on the regression tree for rock type ............... 72

Table 21. Summary of results for arsenic level and three important factors by province. 80 


\section{List of Figures}

Figure 1. Physiographic provinces within Southwest Oregon study area with sample

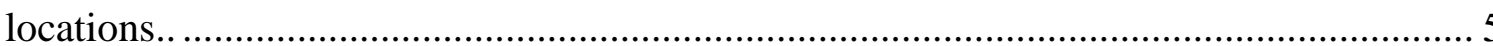

Figure 2. The Klamath Mountain province is comprised of east-dipping terranes, imbricated by subduction and thrust faults........................................................ 12

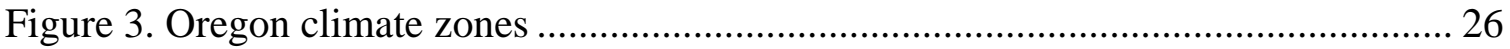

Figure 4: Approximate relations between texture class, grittiness and wet consistence .. 34

Figure 5: Simplified fate of arsenic in the soil environment. ..................................... 40

Figure 6: Simplified pe-pH diagram for the As-S-H2O system at $25^{\circ} \mathrm{C} \ldots \ldots \ldots \ldots \ldots \ldots \ldots \ldots . . . . . . . . . .41$

Figure 7. Maximum arsenic concentrations of 136 PSU-collected sites ........................ 51

Figure 8. Variance of arsenic within the A and the B horizons for 119 PSU sites.......... 52

Figure 9. Variance of raw arsenic values within A and B horizons at Site HH11........... 56

Figure 10: Regression tree showing key factors and splits.................................... 65

Figure 11: Variable importance plot showing the predictive ranking of variables.......... 67

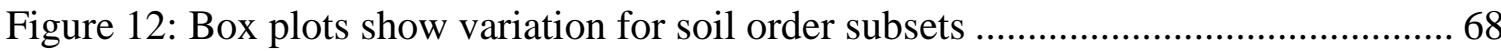

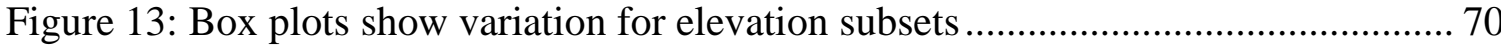

Figure 14: Box plots show variation for rock type subsets...................................... 71 


\section{CHAPTER I: INTRODUCTION}

Some elements that are natural to the environment can lead to significant, even fatal health effects and so must be managed to ensure human health and safety. In Oregon a major element of concern is arsenic (As). Exposure and poisoning from this naturally occurring metalloid can occur from drinking water, inhaling dust, or ingesting foods grown in high-arsenic soils or irrigated with high-arsenic waters. Anthropogenic sources also contribute to elevated arsenic by introducing products with arsenic content, such as some pesticides and treated lumber. The Environmental Protection Agency has classified inorganic arsenic as a human carcinogen. Inorganic arsenic poisoning has also been linked to various cancers, skin lesions, and decreased function in the cardiovascular, neurological and respiratory systems (U.S. Department of Health, 2007).

Originally, the Department of Environmental Quality (DEQ) set remediation standards to one part per million (ppm) of arsenic, but Khandoker (1997) found natural values can be higher in Oregon. For northwest Oregon, Ricker (2013) showed many samples from undisturbed soils were higher in arsenic than one ppm. Khandoker's southwest Oregon samples were originally tested for arsenic with a minimum reporting limit of $20 \mathrm{ppm}$. In this study, his arsenic samples were re-tested at a detection limit of $<0.20 \mathrm{ppm}$ to investigate the arsenic in soil to assess naturally occurring levels of arsenic in southwest Oregon. Soil nomenclature and a background of arsenic in soils is introduced in Chapter III. 


\subsection{PURPOSE AND SCOPE}

The regulatory authority for setting standards and assuring compliance for environmental quality at the state level is the Department of Environmental Quality (DEQ). The maximum exposure levels for metal and metalloid elements, chosen by DEQ, have historically been established using risk-based concentrations (RBC's) using data not specific to Oregon, where risk from exposure is defined as the product of a chemical's toxicity and the degree of exposure to it (DEQ, 2003). The difference between the scenarios for exposure is the frequency of the exposure expected in a given year (DEQ, 2003).

Risk-based concentrations for arsenic in soils in Oregon were based on duration of exposure and ranged from 0.4 to $1.7 \mathrm{ppm}$ for residential and occupational environments (Table 1). Studies in northwest Oregon (Ricker, 2013) have shown most natural soil samples are above that number. To move away from RBC's and refine cleanup standards, an understanding of natural background levels of arsenic and other elements in soils is needed. Regional background elemental concentrations data will aid the design of standards that are more reasonable and therefore economically sustainable for cleanup. To accomplish this, the DEQ has compiled data from Portland State University, the United States Geological Survey, the National Geochemical Database, the Umatilla Chemical Depot and samples and analysis from GeoEngineers. The DEQ has recently completed the re-evaluation of background data for elements of concern in Oregon, and released a report (DEQ, 2013) with the project phase information and values based on background concentration data to replace the previous values. Concentrations 
were grouped by physiographic province (Figure 1), and new standards dictate that metals require remediation when exceeding the regional $95 \%$ upper tolerance limit of the default background concentrations (Table 1).

The objective of this study is to determine the range of naturally occurring arsenic in southwest Oregon soils. The data in this thesis will add to the dataset that supports the evaluation of background levels of arsenic for Oregon. In addition, environmental factors were assessed to see if there are more readily measurable environmental parameters. A potential relationship may justify more research to determine if an environmental source may be used as a "red flag" indicator of potentially high soil arsenic content. Factors being assessed are rock type and age, soil order, soil color, elevation, and geomorphic region.

Table 1. Historic and new maximum limits of arsenic established by DEQ (2012, 2013).

Risk-Based Concentration Method (DEQ, 2012)

\begin{tabular}{|c|c|c|c|c|c|c|}
\hline $\begin{array}{l}\text { Maximum } \\
\text { Exposure } \\
\text { Scenario }\end{array}$ & Residential & $\begin{array}{c}\text { Urban } \\
\text { Residential }\end{array}$ & Occupational & $\begin{array}{l}\text { Construction } \\
\text { Worker }\end{array}$ & $\begin{array}{l}\text { Excavation } \\
\text { Worker }\end{array}$ & \\
\hline soil (ppm) & 0.4 & 1.0 & 1.7 & 13.0 & 370.0 & \\
\hline \multicolumn{7}{|c|}{$\begin{array}{c}\text { Regional 95\% Upper Prediction Limit (UPL) Default Background } \\
\text { Concentrations within Southwest Oregon (DEQ, 2013) }\end{array}$} \\
\hline $\begin{array}{c}\text { Physiographic } \\
\text { Province }\end{array}$ & $\begin{array}{l}\text { Basin and } \\
\text { Range }\end{array}$ & $\begin{array}{l}\text { Cascade } \\
\text { Range }\end{array}$ & Coast Range & $\begin{array}{l}\text { High Lava } \\
\text { Plains }\end{array}$ & $\begin{array}{l}\text { Klamath } \\
\text { Mountains }\end{array}$ & $\begin{array}{l}\text { South } \\
\text { Willamette } \\
\text { Valley }\end{array}$ \\
\hline soil (ppm) & 12.0 & 19.0 & 12.0 & 7.2 & 12.0 & 18.0 \\
\hline
\end{tabular}




\subsection{STUDY AREA}

The study area is from the Pacific Ocean on the west to the city of Bend on the east, the Oregon-California border on the south up to the city of Eugene on the north. The bounds of this study area were chosen to be consistent with a study by Khandoker (1997), since soil samples from Khandoker's study were retested for arsenic for use in this study. The primary physiographic provinces in the study area (Figure 1) are the Klamath Mountains, the Coast Range and the Cascade Range (Orr and Orr, 2012). This study also includes the southernmost portion of Willamette Valley and a few sites within the westernmost portions of the High Lava Plains and Basin and Range provinces. The varied physiography within southwest Oregon is a result of tectonic accretion and deformation, volcanism and Quaternary glaciation. Detailed unit descriptions (Walker and MacLeod, 1991) are in Appendix B. 


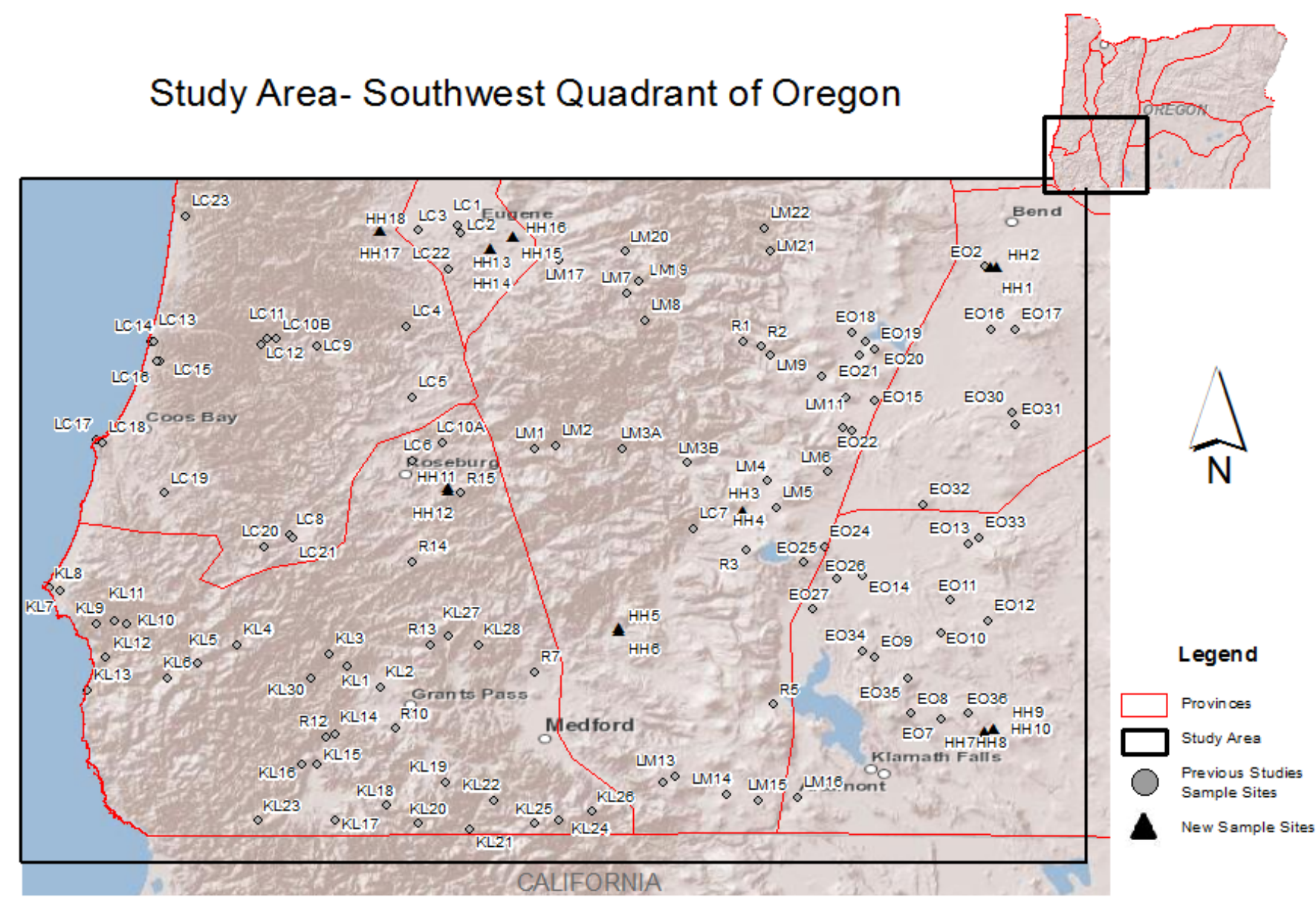

Figure 1.

Physiographic

provinces (Orr

and Orr, 2012)

within

Southwest

Oregon study

area with

sample

locations.

Physiographic

provinces from

lower left

corner,

clockwise, are

the Klamath

Mountains,

Coast Range,

South

Willamette

Valley, Cascade

Range, High

Lava Plains

and Basin and

Range.

Province lines are from DEQ (2013). 


\section{CHAPTER II: BACKGROUND}

\subsection{PHYSIOGRAPHIC PROVINCES OF OREGON}

Of Oregon's ten physiographic provinces (Orr and Orr, 2012), six lie within the bounds of the southwest quadrant of Oregon. The Klamath Mountains dominate the study area while parts of the Coast Range, Cascade Range, Willamette Valley, Basin and Range and High Lava Plains stretch into it (Figure 1). Southwest Oregon was covered by ocean until about $150 \mathrm{Ma}$ (Orr and Orr, 2006). The diverse geography we see today in southwest Oregon - with half of all Oregon geophysical provinces present in the southwest quadrant - illustrates the dynamic earth processes that formed them.

\subsection{GEOLOGIC HISTORY OF SOUTHWEST OREGON}

The Klamath Mountains are formed of accreted ocean crust from the Farallon and later Juan de Fuca plates, and volcanic island chains active in the Mesozoic era (Orr and Orr, 2012). Collision with the North American plate folded and thrust slabs of this material beneath each other, stacking successive terranes like shingles with the oldest terrane ( 210 Ma) inland to the east. Various igneous plutons intruded all belts of the Klamath Mountains from 174-136 Ma, which bound the terranes together. Paleomagnetic data from these plutonic intrusions indicate the clockwise rotation of terranes was active during off-shore Jurassic deposition, prior to collision with North America and was mostly completed by about $100 \mathrm{Ma}$ in the early Cretaceous Period (Orr and Orr, 2012).

About 140 Ma, uplift of the Klamath Mountains began (Orr and Orr, 2012). Uplift and an ocean transgressive period continued into the Cenozoic. The Willamette Valley 
subsided in the late Cenozoic into a northward- dipping marine trough, collecting Klamath debris and sand, mud and silts consistent with marine deposition. The ocean receded, and Willamette Valley held lakes, meandering streams and swamp lands.

The Cenozoic era was dominated by volcanism and sedimentation (Orr and Orr, 2012). Eocene to Oligocene volcanism was brought on by the collision of the Farallon and North American plates. From 35-17 Ma plate subduction and rising plumes resulted in a volcanic arc that produced lavas and ash that created the Western Cascade Range, which is composed of andesites, basaltic andesites and dacites. Plate collision also created a north-south crustal fold that rotated and uplifted marine sediments and Klamath erosional debris and Tertiary ocean-bottom basalts to become the Coast Range. EastWest crustal extension of the Basin and Range in the Miocene resulted in basaltic to rhyolitic flow of lavas across the Basin and Range and High Lava Plains (17- $10 \mathrm{Ma}$ ), an elevated desert plateau. Crustal failure also resulted in northwest-trending faults for hundreds of miles, active until 7-8 Ma.

From the late Miocene to Holocene (10,000 BP), basaltic and basaltic-andesite lavas from stratovolcanoes and shield volcanoes formed the High Cascade peaks. Less than $2 \mathrm{Ma}$ to $12,000 \mathrm{BP}$, glacial and interglacial periods resulted in massive geomorphic change in all provinces. Marine terracing occurred along the Oregon coast in the Coast Range and Klamath Mountains, and lahars flowed down High Cascade Mountain sides. Catastrophic flooding covered older bedrock with alluvial fans and gravel terraces and deposited thick silts in the Willamette Valley (Orr and Orr, 2012). 


\section{Klamath Mountains}

The Klamath Mountains province is bordered by the Pacific Ocean on the west, the Western Cascades to the east, and extends $402 \mathrm{~km}$ (250 miles) south from the Coast Range into northwest California. Overall, the summits in this region are of uniform relief. Mount Ashland is the highest point in the Oregon Klamath Mountains at 2,295 m (7,530 feet). From Port Orford, coastal terrain is rocky headlands south to Ophir, then 18- to 24m (59- to 79-feet) wide sandy beaches to Gold Beach at the mouth of the Rogue River. Cliffs dominate the remaining coastline into California, with occasional thin strips of coastal terraces. The Klamath, Rogue and Chetco rivers drain the province into the Pacific Ocean.

Early Paleozoic to Mesozoic ocean crust and volcanic island arcs accreted through collision and subduction under the North American plate. Successive slab collisions in late Mesozoic resulted in an east-dipping imbrication of terranes, bounded by thrust-faults, with the oldest terrane inland and progressively younger terranes westward to the Pacific Ocean (Figure 2). These terranes were delineated and further divided into subterranes and formations. Descriptions of the Klamath Mountain formations are summarized from Walker and MacLeod (1991) in Appendix A and listed in Table 2. Descriptions of the terranes in the text also list spatially concurrent formations or map units.

The western Paleozoic and Triassic belt was accreted in the mid- to late-Jurassic and rotated to its current position in the late Mesozoic to early Cenozoic. This $322 \mathrm{~km}$ 
long and $80 \mathrm{~km}$ (200 by 50 miles) wide belt is divided into four terranes, two of which are in Oregon. The Rattlesnake Creek Terrane (Js, Ju, Jub, Jv, Kc, KJg, mc, Qal, Qt, TRPv, TRPzm) is described as an ophiolitic mélange overlain by ocean arc rocks (Jm, Js and Jv). The Western Hayfork volcanic arc terrane (Jm, Ju, Kc, KJg, Qal, Qf, Qt, TRPv, TRPzs) covered Rattlesnake Creek by the middle Jurassic and was then intruded by plutons (Orr and Orr, 2012).

Jurassic May Creek Terrane (mc) and Condrey Mountain Terrane $(\mathrm{cm})$ are backarc basin remnants that were thrust beneath the Rattlesnake Creek and Western Hayfork terranes. May Creek Terrane is comprised of ophiolites metamorphosed to amphibolites. The Condrey Mountain Terrane is late-Jurassic schist that was then uplifted in the Miocene into a dome structure; the Condrey Mountain dome is believed to be the result of lateral pressure between the Juan de Fuca and North America plates (Orr and Orr, 2012).

The Western Klamath Terrane is composed of ophiolites, island arc volcanic rocks and deep ocean basin sediments (Orr and Orr, 2006) accreted in the late-Jurassic. The Western Klamath Terrane is to the west of the Western Paleozoic and Triassic belt, separated by the Orleans Fault. It runs 322 km (200 miles) along the western edge of the Oregon and California Klamath Mountains. From east to west, the Western Klamath Terrane includes the Smith River, Rogue Valley, Briggs Creek, Dry Butte and Elk subterranes (Figure 2). 
The Smith River Subterrane (Js, Jss, JTRgd, Ju, Jub, Kc, KJg, Qal, Qf, Qt)

consists of ophiolite, overlain by a thick layer of deep-water shales and turbidite

sandstone known as the Galice Formation. The Josephine Ophiolite (160 Ma) developed

in a back-arc basin between the Rogue-Chetco volcanic arc and the mainland. It is

famous for being one of the world's largest and most complete ophiolite sequences and

for its rich economic mineral content, yielding gold, silver, copper, nickel and chromite.

Galice Formation sediment sources include both accreted terrain and volcanic arc

materials (Orr and Orr, 2012).

Northwest of the Smith River Subterrane are the Rogue Valley (Js, JTRgd, Ju,

Jub, Jv, KJg, Qal), Briggs Creek (bc, Jv) and Dry Butte (JTRgd, Ju, Jv, Qls) subterranes.

Table 2. Description of geologic units sampled within Klamath Mountain Province. Unit description summarized from Walker and MacLeod (1991) and province boundary defined by DEQ (2013). Detailed descriptions are found in Appendix B.

\begin{tabular}{|c|c|c|}
\hline \begin{tabular}{|l|l|l} 
Geologic \\
Unit
\end{tabular} & \begin{tabular}{|l} 
Primary Rock Types/ \\
Additional Rock Types \\
\end{tabular} & Description of Map Units \\
\hline $\mathrm{bc}$ & amphibolite, quartzite, schist, chert & $\begin{array}{l}\text { Amphibolite of Briggs Creek: amphibolite, micaceous quartzite, quartz } \\
\text { schist and recrystallized manganifererous chert }\end{array}$ \\
\hline $\mathrm{cm}$ & schist/ chert & $\begin{array}{l}\text { Condrey Mountain Schist: a variety of schistose rocks; rare metachert and } \\
\text { metagabbro }\end{array}$ \\
\hline cs & pelitic schist/ meta-basalt & $\begin{array}{l}\text { Colebrook Schist: metamorphosed sedimentary rocks; subordinate } \\
\text { metamorphosed submarine pillow lavas and basaltic pyroclastics }\end{array}$ \\
\hline $\mathrm{Jm}$ & $\begin{array}{l}\text { melange: volcanic, metamorphic and } \\
\text { sedimentary rocks }\end{array}$ & $\begin{array}{l}\text { melange: complex mix of basaltic rocks, serpentinite, chert, argillite, } \\
\text { conglomerate, silty sandstone and marble lenses }\end{array}$ \\
\hline Jop & $\begin{array}{l}\text { melange: greywacke, mudstone, } \\
\text { siltstone, shale/ various metamorphic rocks }\end{array}$ & $\begin{array}{l}\text { Otter Point Fm./Melange(?): highly sheared greywacke, mudstone, } \\
\text { siltstone, shale; lenses of greenstone limestone, chert, blueschist and } \\
\text { serpentine }\end{array}$ \\
\hline $\mathrm{Js}$ & $\begin{array}{l}\text { sedimentary rocks, tuff/ metamorphic } \\
\text { rocks }\end{array}$ & $\begin{array}{l}\text { mudstone, shale, siltstone, graywacke, andesitic to dacitic tuff; minor } \\
\text { limestone, phyllite, slate }\end{array}$ \\
\hline Jss & $\begin{array}{l}\text { shale, mudstone, sandstone/ pebble } \\
\text { conglomerate }\end{array}$ & sedimentary rocks with local lenses of pebble conglomerate \\
\hline JTrgd & granite, diorite & $\begin{array}{l}\text { felsic to intermediate granitoids: muscovite granodiorite, hornblende } \\
\text { gabro, tonalite and quartz diorite }\end{array}$ \\
\hline $\mathrm{Ju}$ & harzburgite, dunite/ serpentinite, gabbro & ultramafic and related rocks of ophiolite sequence \\
\hline $\mathrm{Jub}$ & basalt, breccia/ shale, siltstone, mudstone & $\begin{array}{l}\text { basaltic volcanic and sedimentary rocks: basalt flows, breccia, } \\
\text { agglomerate, pillow basalt and breccia; lesser shale, chert siltstone and } \\
\text { mudstone of ophiolitic complexes }\end{array}$ \\
\hline
\end{tabular}

(table continues on next page) 


\begin{tabular}{|c|c|c|}
\hline $\begin{array}{l}\text { Geologic } \\
\text { Unit } \\
\end{array}$ & \begin{tabular}{|l|} 
Primary Rock Types/ \\
Additional Rock Types \\
\end{tabular} & Description of Map Units \\
\hline $\mathrm{Jv}$ & $\begin{array}{l}\text { andesite, basalt to rhyolite flows/ tuff, } \\
\text { tuffaceous sedimentary rocks }\end{array}$ & $\begin{array}{l}\text { volcanic rocks: lava flows, flow breccia and agglomerate dominantly } \\
\text { andesite; flow rocks basaltic to rhyolitic; interlayered tuff and tuffaceous } \\
\text { sedimentary rocks }\end{array}$ \\
\hline $\mathrm{Kc}$ & sandstone, conglomerate & fossiliferous clastic sedimentary rocks \\
\hline KJds & $\begin{array}{l}\text { sandstone, conglomerate, graywacke/ } \\
\text { chert }\end{array}$ & sedimentary rocks related to Dothan Formation; chert lenses \\
\hline $\mathrm{KJdv}$ & basalt & $\begin{array}{l}\text { volcanic rocks related to Dothan Formation: basaltic pillow lavas, } \\
\text { volcanic breccia and silicified basalt lava flows }\end{array}$ \\
\hline $\mathrm{KJg}$ & $\begin{array}{l}\text { tonalite, quartz diorite/ other granitoid } \\
\text { rocks }\end{array}$ & granitic rocks \\
\hline KJgu & $\begin{array}{l}\text { gabbro/ pyroxenite, pyroxene, peridotite, } \\
\text { dunite, serpentinite }\end{array}$ & $\begin{array}{l}\text { gabbro and ultramafic rocks associated with granitic plutons: hornblende } \\
\text { gabbro, gabbro and olivine gabbro; includes pyroxenite, hornblende } \\
\text { pyroxene; minor peridotite, dunite, serpentinite }\end{array}$ \\
\hline $\mathrm{KJm}$ & $\begin{array}{l}\text { conglomerate, sandstone, siltstone, } \\
\text { limestone }\end{array}$ & Myrtle Group; locally fossiliferous \\
\hline Ks & graywacke, conglomerate, shale & $\begin{array}{l}\text { marine graywacke and subgraywacke; conglomerate composed of } \\
\text { volcanic, metavolcanic, metasedimentary and plutonic rocks }\end{array}$ \\
\hline $\mathrm{mc}$ & amphibolite, schist, gneiss, quartzite & May Creek Schist \\
\hline Qt & terrace/ alluvium & $\begin{array}{l}\text { terrace, pediment and lag gravels: unconsolidated gravel, cobbles and } \\
\text { boulders intermixed with clay, silt and sand }\end{array}$ \\
\hline Tmss & sandstone, siltstone, mudstone & shallow marine sedimentary rocks; contains foraminifera \\
\hline $\operatorname{Tn}$ & $\begin{array}{l}\text { conglomerate, sandstone, siltstone, } \\
\text { mudstone }\end{array}$ & nonmarine sedimentary rocks with abundant biotite and muscovite \\
\hline $\mathrm{TrPv}$ & $\begin{array}{l}\text { intermediate metavolcanic rock/ andesite, } \\
\text { tuff, basalt }\end{array}$ & $\begin{array}{l}\text { meta-andesite, meta-basalt, spilite, keratophyre, volcanic breccia; } \\
\text { andesite flows, breccia, agglomerate, tuff, basalt flows and dacitic tuffs of } \\
\text { Applegate Group }\end{array}$ \\
\hline TrPzm & $\begin{array}{l}\text { melange: metasedimentary and } \\
\text { metavolcanic rocks }\end{array}$ & $\begin{array}{l}\text { Melange of Dutchmans Peak: heterogeneous mix metamorphosed to } \\
\text { upper greenschist, serpentinite, gabbro and metagabbro }\end{array}$ \\
\hline TrPzs & $\begin{array}{l}\text { shale, mudstone, sandstone, graywacke, } \\
\text { conglomerate, tuff, chert, marble/ } \\
\text { argillite, chert, phyllite, quartzite, limestone, } \\
\text { marble }\end{array}$ & $\begin{array}{l}\text { Applegate Group: partially metamorphosed, poorly bedded sedimentary } \\
\text { rocks; impure limestone and marble }\end{array}$ \\
\hline Tsr & $\begin{array}{l}\text { basalt/ siltstone, sandstone, tuff, } \\
\text { conglomerate }\end{array}$ & $\begin{array}{l}\text { Siletz River Volcanics and related rocks: visicular pillow flows, tuff- } \\
\text { breccias, massive lava flows and sills of tholeiitic and alkali basalt; upper } \\
\text { part of sequence contains interbeds of basaltic sedimentary rocks }\end{array}$ \\
\hline
\end{tabular}

The Rogue Valley Terrane was deposited at the same time as the Galice Formation; it is eight $\mathrm{km}$ (5 miles) wide and composed of undersea volcanic flows and ash. The Galice

Formation has been locally altered to slate which interfingers with the Rogue Formation

volcanics. Briggs Creek Terrane is coarse-grained metamorphic rock, which includes

chert, quartzite and folded and altered garnet amphibolites; this is the basement rock for

the Rogue Valley volcanic arc. The late-Jurassic, Dry Butte Subterrane is an igneous

batholith, thrust beneath Briggs Creek. The Briggs Creek and Dry Butte subterranes are 
currently considered mid- to late-Jurassic components of the Rogue Valley Arc (Orr and Orr, 2012).

The Elk Subterrane (cs, Js, JTRgd, Ju, Ks, Qt, Tmsc) is composed of sandy turbidites, shales and andesitic lavas. Although this terrane is over $32 \mathrm{~km}$ (20 miles) north of the main Western Klamath Terrane, it is placed in the Western Klamath belt due to the thick sequences of Galice Formation submarine slides found within it. The Elk

Subterrane is believed to be tectonically displaced $160 \mathrm{~km}$ (100 miles) northward from California by faulting (Orr and Orr, 2012).

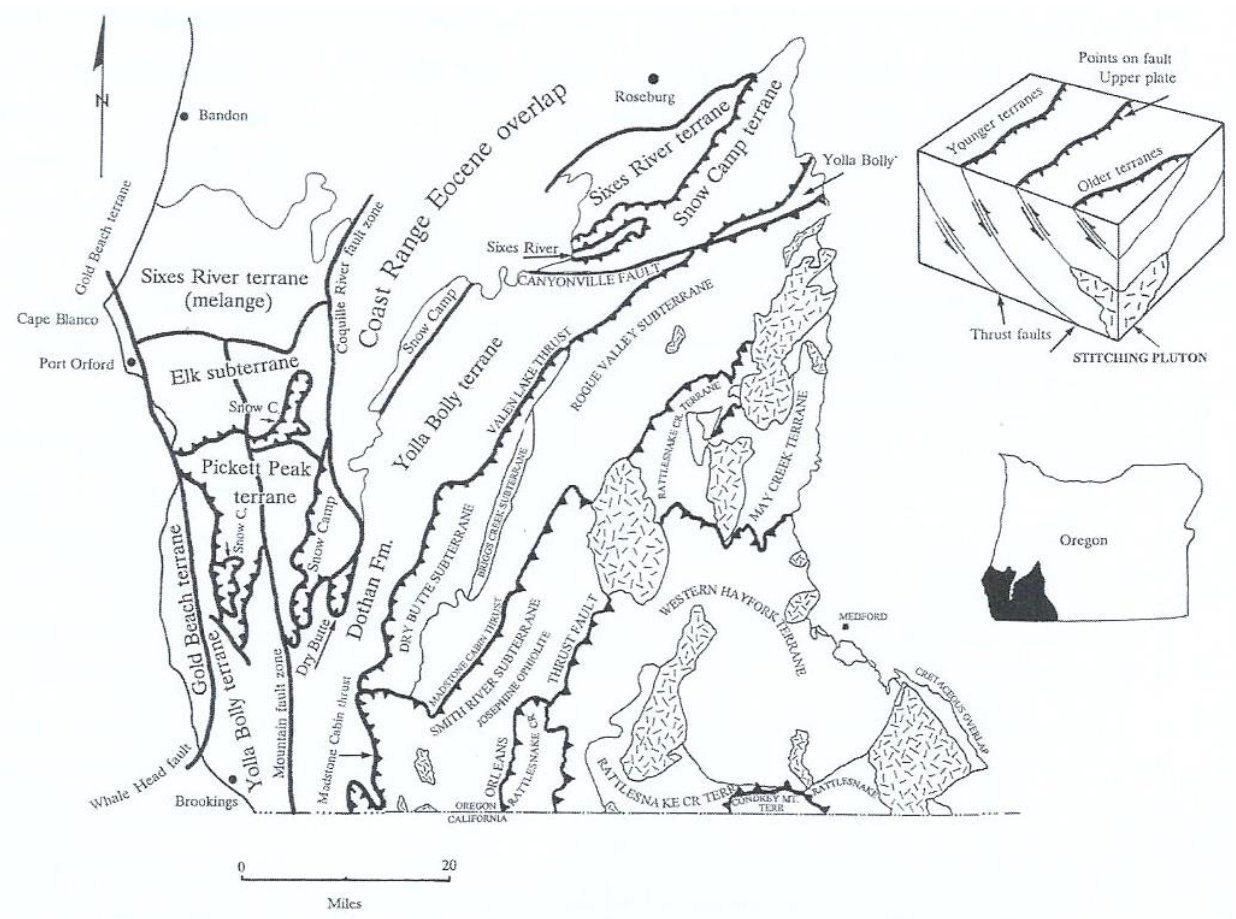

Figure 2. The Klamath Mountain province is comprised of east-dipping terranes, imbricated by subduction and thrust faults. The oldest terrane is to the east with progressively younger terranes to the west (Orr and Orr, 2012).

The southwest Oregon terranes (Figure 2) are the Snow Camp (Jc, Ju, Jv, KJds, KJg, KJm, Qal, Qls, Qt, Tfe, Tut), Pickett Peak (Ju, KJds, KJm), Yolla Bolly (cs, Jc, 
JTRgd, Ju, Jv, KJds, KJdv, Qls, Tia, Tmsc), Gold Beach (Jop, Ju, KJds, Qal, Tcs) and the Sixes River (cs, Ju, KJds Qt, Tmsc, Tmsm, Tt) terranes and are located on the southwest Oregon Coast and were displaced from the Western Klamath Terrane and transported from the south by early Cretaceous thrust faulting. Formations within the Snow Camp Terrane include the Coast Range ophiolite, late Jurassic Mule Mountain Volcanics, the Jurassic Riddle Formation and the Cretaceous Days Creek conglomerates, silts and sands.

The Oregon section of the Pickett Peak Terrane is made of blueschist; deep sea tuffs, cherts and pillow lavas were metamorphosed in the early Cretaceous into Colebrooke Schist. Late Jurassic to early Cretaceous Yolla Bolly Terrane is composed of forearc basin sands, muds and deep-water cherts. These sediments, known as the Dothan Formation, were transported by turbidity currents from continental and volcanic arc sources (Orr and Orr, 2012).

Gold Beach Terrane includes the late Jurassic Otter Point Formation, and late Cretaceous Cape Sebastian and Hunters Cove formations. The deep-water Otter Point Formation was part of an accretionary wedge at a subduction zone. Cape Sebastian Sandstone and Hunters Cove siltstone include turbidite-deposited deeper sands and shales as remnants from past storms. Sixes River Terrane includes Jurassic and Cretaceous mudstones, sandstones and conglomerates with blueschist and eclogite outsized clasts, as well as limestones, deep-water shales and pillow lavas.

The Klamath terranes were accreted, subject to faulting and clockwise rotation and intruded by plutons. According to paleomagnetic data, rotation occurred from late- 
Triassic to early-Jurassic and continued into the early Cretaceous. The late Cretaceous brought a transgressing seaway that inundated most of Oregon. Cretaceous to Cenozoic uplift of the Klamath Mountains pushed the shoreline north and provided sedimentation to the surrounding basin. Fluctuating sea levels resulted in raised marine terraces, some of which are still intact along the southwest Oregon coast. See Appendix A, Figure A.1 for stratigraphy of this province (Orr and Orr, 2012).

\section{Coast Range}

The Coast Range extends south from the Columbia River to the Middle Fork of the Coquille River on the northern side of the Klamath Mountains, and west from the Willamette Valley into the Pacific Ocean (Figure 1). The heavy marine influence has extensively eroded the west slopes of the Cascade Range, and heavy precipitation has produced an intricate drainage system and dense forests. Coastal terrain includes abrupt headlands, sea stacks, marine terraces, bays, estuaries, small beaches, sand dunes and spits. Drainage within the province is provided by moderately-sized rivers (Orr and Orr, 2012).

The geologic history of the province includes submarine volcanism, subsidence, uplift and sedimentation (Orr and Orr, 2012). Oblique plate subduction of the Juan de Fuca plate under North America resulted in Eocene to Pleistocene clockwise rotation, faulting and uplift of the Coast Range. However, only the southern part of this province is included in the study area, with the north border of the study area extending from Eugene, Oregon to approximately Florence, Oregon at the coast. Descriptions of the 
Coast Range formations within the study area are summarized from Walker and

MacLeod (1991) in Table 3.

Table 3. Description of geologic units sampled within the Coast Range. Unit description summarized from Walker and MacLeod (1991) and province boundary defined by DEQ (2013). Detailed descriptions are found in Appendix B.

\begin{tabular}{|c|c|c|}
\hline \begin{tabular}{|l|} 
Geologic \\
Unit
\end{tabular} & $\begin{array}{l}\text { Primary Rock Types/ } \\
\text { Additional Rock Types } \\
\end{array}$ & Description of Map Units \\
\hline Qal & sand, gravel, silt/ talus, slope wash & alluvial deposits; locally, thin peat beds and high in organic material \\
\hline Qd & sand & dune sand; mostly feldspar and quartz minerals \\
\hline Qls & $\begin{array}{l}\text { landslide: basalt, andesite, tuff/ slope } \\
\text { wash, colluvium }\end{array}$ & $\begin{array}{l}\text { landslide and debris flow deposits are unstratified mixtures of fragments } \\
\text { of adjacent bedrock; largest slides and flow occur where thick sections of } \\
\text { basalt and andesite flows overlie clayey tuffaceous rocks }\end{array}$ \\
\hline Qt & terrace/ alluvium & $\begin{array}{l}\text { terrace, pediment and lag gravels: unconsolidated gravel, cobbles and } \\
\text { boulders intermixed with clay, silt and sand }\end{array}$ \\
\hline $\mathrm{Ti}$ & gabbro/ granitoid & mafic intrusions: sheets, sills and dikes of granohpyric ferrogabbro \\
\hline Tmsm & $\begin{array}{l}\text { sandstone, siltstone, mudstone/ } \\
\text { conglomerate }\end{array}$ & $\begin{array}{l}\text { Roseburg Formation: marine sedimentary rocks with } \\
\text { minor conglomerate; contains foraminifera }\end{array}$ \\
\hline Tmss & sandstone, siltstone, mudstone & shallow marine sedimentary rocks; contains foraminifera \\
\hline $\mathrm{Tpb}$ & basalt/ basaltic andesite, dacite & $\begin{array}{l}\text { lava flows and breccia of porphyritic basalt, minor basaltic andesite and } \\
\text { rare dacite }\end{array}$ \\
\hline Tsr & $\begin{array}{l}\text { basalt/ siltstone, sandstone, tuff, } \\
\text { conglomerate }\end{array}$ & $\begin{array}{l}\text { Siletz River Volcanics and related rocks: visicular pillow flows, tuff- } \\
\text { breccias, massive lava flows and sills of tholeiitic and alkali basalt; upper } \\
\text { part of sequence contains interbeds of basaltic sedimentary rocks }\end{array}$ \\
\hline Tss & mudstone, siltstone, sandstone/ tuff & $\begin{array}{l}\text { tuffaceous marine sedimentary rocks; contains calcareous concretions } \\
\text { and foraminiferal assemblage }\end{array}$ \\
\hline $\mathrm{Tt}$ & sandstone, siltstone/ dacite tuff & $\begin{array}{l}\text { Tyee Formation: rhythmically-bedded marine sandstone and micaceous } \\
\text { carbonaceous siltstone; minor interbeds of dacite tuff; foraminifera }\end{array}$ \\
\hline Ty & siltstone, sandstone/ basalt, lapilli tuff & $\begin{array}{l}\text { Yamhill Formation and related rocks: marine siltstone; thin interbeds } \\
\text { of arkosic, glauconitic and basaltic SS; locally interlayered basalt lava } \\
\text { flows and lapilli tuff; foraminiferal assemblages }\end{array}$ \\
\hline
\end{tabular}

The oldest Coast Range rocks in the south part of the range are Eocene pillow basalts and breccias, named the Roseburg Volcanics. These ocean-bottom flows were produced in the Siletzia Terrane, which was a Paleocene-Eocene coastal marine basin. The 644-kilometer-long (400 mile) Siletzia platform subsided into a forearc basin in the middle Eocene; deposition from deep-sea fans and deltas and subsequent uplift closed the seaway by late Miocene. This deposition covered Roseburg Volcanics with fluvial and marine deposits: the Lookingglass (Tmsc), Flournoy (Tmss) and Tyee (Tt) Formations. Slope deposits during sea transgression created the Lookingglass Formation. The 
Flournoy Formation includes conglomerates, pebbly sandstones and siltstones deposited during the seaway retreat. The Tyee Formation, overlying the Flournoy, is composed of huge submarine fans from river-transported Klamath Mountain sediments. In the middle to late Eocene, inland streams provided sediments to the Elkton, Bateman and Coaledo formations (Tss). These sediments from the Western Cascade Range and northern Klamath Mountains settled in the forearc basin at Coos Bay. The Elkton Formation is mudstone, which coarsens up through the Bateman submarine fan to the Coaledo's coarse delta sandstones. Ash and pyroclastics from the early Western Cascade eruptions provided sediment for the bathyal Bastendorff Shales (Tsd) and overlying marine embayment Tunnel Point Sandstones (Orr and Orr, 2012).

Oligocene marine sedimentation was limited to the central and north coast. Late Oligocene to mid-Miocene included regional uplift that shifted the shoreline near to its present-day location. The Western Cascades eruptions continued to deposit ash into the ocean. The Miocene Tarheel Formation is fossiliferous sandstone and is overlain by the sandstone of both the mid-Miocene Floras Lake Formation and late Miocene Empire Formation. The Empire Formation (Tm, not sampled) is an estuary deposit of silts and fine sands full of mollusks and marine vertebrate fossils. The Roseburg Formation (Tmsm) is composed of deep-sea turbidite mudstone and shales (Orr and Orr, 2012).

Erosion predominated in the Pliocene before Pleistocene glaciations widened coastal plains and rapidly down-cut estuaries and stream valleys. About 11,000 years ago, the climate reversed, and ocean levels rose and submerged the coastline. The Port Orford and Elk River Formations at Cape Blanco and the Coquille Formation at Bandon, Oregon 
are shallow-water terrace deposits dominated with mollusks. See Appendix A, Figure A.2 for stratigraphy of this province.

\section{Cascade Range}

The Cascade Mountains extend north-south 966 km (600 miles) from British Columbia, through the entirety of Oregon (Figure 1). The Oregon Cascade Range is divided into the Western Cascades and the High Cascades. In contrast to the older, eroded Western Cascades (518 to 1,768 m), the younger High Cascades are near double the elevation at greater than 3,353 meters (Orr and Orr, 2012).

The major rivers in the Cascades drain west. Near the study area, the McKenzie River drains into the Willamette River just north of Eugene. Within the study area, the Middle Fork Willamette River also joins the Willamette River system. The Umpqua River drains $180 \mathrm{~km}$ (112 miles) from the Western Cascades, through Roseburg and the Coast Range to the Pacific Ocean at Reedsport. East-draining rivers are much smaller, averaging 48 to $56 \mathrm{~km}$ (30 to 35 miles) in length.

During the Eocene, a volcanic arc formed along the Pacific Ocean from the subduction of the Farallon Plate. From Eocene to Miocene (40 to 7.5 Ma), thick deposits of volcanic debris, intrusives and marine sediments built the Western Cascades. Volcanic activity prior to 17 Ma produced andesites, basaltic andesites and dacites, after which production lessened and transitioned to lava and ash. Tectonic tilting and folding ceased deposition about $5 \mathrm{Ma}$, and volcanic activity moved eastward. Basaltic and basaltic andesite lava and ash from the late-Miocene to Holocene stratovolcanoes and shield 
volcanoes of the High Cascades obscured much of the Western Cascades and were active as recently as a few thousand years before present. Significant volcanic peaks within the study area include the Crater Lake stratovolcano, and the Mt. Bachelor, Mt. Thielsen and Mt. McLoughlin volcanoes (Orr and Orr, 2012).

The geology of the Cascade Range formations within the study area is summarized from Walker and MacLeod (1991) in Table 4. The Western Cascades shared the same depositional regimes as the Coast Range, and therefore include some of the same significant formations (Appendix A, Figure A.3) within the study area. The Umpqua and Lookingglass Formation (Tmsc) siltstone, sandstone and conglomerate present in the Coast Range as siltstone, sandstone and mudstone extends into the Western Cascades. The Roseburg Formation (Tmsm) is partly a shelf and slope facies, and Eugene and Fisher (Tfe, Tfee) Formations are marine and nearshore sands and tuffs, all present across provinces.

Volcanic activity produced the basaltic and andesitic rock Elk Lake and Nohorn Creek (Tbaa). Little Butte, Mehama, Breitenbush and Molalla Formations (Tv) are composed of flows and tuffs. The Sardine Formation (Trb) is described as having andesitic, basaltic andesite and dacitic lavas. In the High Cascades, Mount Mazama eruption resulted in rhyodacitic to andesitic ash-flow deposits (Qma), and more recently the Newberry and South Sister volcanoes (Qrd) produced rhyolite and dacite flow breccia. See Appendix A, Figure A.3 for stratigraphy of this province. 
Table 4. Description of geologic units sampled within the Cascade Range Province. Unit description summarized from Walker and MacLeod (1991) and province boundary defined by DEQ (2013). Detailed descriptions are found in Appendix $B$.

\begin{tabular}{|c|c|c|}
\hline $\begin{array}{l}\text { Geologic } \\
\text { Unit } \\
\end{array}$ & $\begin{array}{l}\text { Primary Rock Types/ } \\
\text { Additional Rock Types }\end{array}$ & Description of Map Units \\
\hline Qa & andesite, basaltic andesite/ dacite, basalt & $\begin{array}{l}\text { andesite phenocrysts are principally pyroxene, olivine, plagioclase, few } \\
\text { hornblende }\end{array}$ \\
\hline Qal & sand, gravel, silt/ talus, slope wash & alluvial deposits; locally, thin peat beds and high in organic material \\
\hline Qba & basal tic andesite, basalt & $\begin{array}{l}\text { flows and flow breccia; basaltic andesite of plagioclase, olivine, pyroxene } \\
\text { phenocrysts and olivine basalt }\end{array}$ \\
\hline Qg & boulder gravel, sand, rock flour & glacial deposits in ground terminal and lateral moraines \\
\hline Qgf & boulder gravel, sand, rock flour & $\begin{array}{l}\text { partly sorted glaciofluvial deposits in ground terminal and lateral } \\
\text { moraines }\end{array}$ \\
\hline Qls & $\begin{array}{l}\text { landslide: basalt, andesite, tuff/ slope } \\
\text { wash, colluvium }\end{array}$ & $\begin{array}{l}\text { landslide and debris flow deposits are unstratified mixtures of fragments } \\
\text { of adjacent bedrock; largest slides and flow occur where thick sections of } \\
\text { basalt and andesite flows overlie clayey tuffaceous rocks }\end{array}$ \\
\hline Qma & rhyodacitic to andesitic ash-flow & Mount Mazama ash-flow deposits \\
\hline Qmp & rhyodacite pumice & Mount Mazama primary and reworked air-fall pumice deposits \\
\hline Qrd & rhyolite, dacite & $\begin{array}{l}\text { domes and related aphric and porphyritic flows and flow breccia on } \\
\text { Newberry and South Sister volcanoes }\end{array}$ \\
\hline Qs & $\begin{array}{l}\text { clay, silt sand, gravel/ mudflow, fluvial } \\
\text { deposits, peat }\end{array}$ & $\begin{array}{l}\text { unconsolidated to semi-consolidated lacustrine and fluvial sedimentary } \\
\text { rocks }\end{array}$ \\
\hline Qta & andesite, basal tic andesite & $\begin{array}{l}\text { flows and flow breccia; plagioclase, olivine, clinopyroxene, and lesser } \\
\text { hypersthene and hornblende phenocrysts }\end{array}$ \\
\hline QTba & basalt, basaltic andesite & $\begin{array}{l}\text { flows, flow breccia and pyroclastic deposits; bytownite and labradorite, } \\
\text { olivine, calcic augite and hypersthene phenocrysts }\end{array}$ \\
\hline QTmv & $\begin{array}{l}\text { basalt, basaltic andesite, andesite/ } \\
\text { pyroclastic rocks }\end{array}$ & mafic vent complexes: plugs, dikes, breccia, cinders and agglutinate \\
\hline QTp & basalt, andesite & basaltic and andesitic ejecta: scoriaceous cinders, bombs and agglutinate \\
\hline Tbaa & basalt, andesite & $\begin{array}{l}\text { lava flows and flow breccia of hypersthene and olivine andesite, basaltic } \\
\text { andesite with plagioclase and pyroxene phenocrysts, and basalt }\end{array}$ \\
\hline Tfc & basaltic andesite, andesite/ dacite & $\begin{array}{l}\text { undifferentiated flows and clastic rocks: lava flows, flow breccia, } \\
\text { mudflows and volcanic conglomerates }\end{array}$ \\
\hline Thi & $\begin{array}{l}\text { diorite, quartz diorite/ gabbro, biotite } \\
\text { quartz monzonite, granodiorite }\end{array}$ & hypabyssal intrusive rocks \\
\hline Tmsc & $\begin{array}{l}\text { conglomerate, sandstone, siltstone, } \\
\text { mudstone }\end{array}$ & marine sedimentary rocks; foraminifera \\
\hline Trb & basaltic andesite, olivine basalt & ridge-capping basalt and basaltic andesite flows and flow breccia \\
\hline Tsv & rhyolite, dacite & silicic vent complexes \\
\hline $\mathrm{Tu}$ & complexly interstratified epiclastic and & undifferentiated tuffs, tuffaceous sedimentary rocks, and basalt: \\
\hline Tub & basalt, basaltic andesite & basaltic lava flows and breccia \\
\hline Tus & sedimentary and volcanic rocks/ tuff & basaltic to dacitic sedimentary and volcaniclastic rocks: lapilli tuff, \\
\hline Tut & ash-flow tuff & $\begin{array}{l}\text { welded to unwelded vitric tuff; glass locally altered to clay, zeolites and } \\
\text { secondary silica minerals }\end{array}$ \\
\hline Qyb & basalt, basaltic andesite & $\begin{array}{l}\text { youngest basalt and basaltic andesite: flows and associated breccia on } \\
\text { slopes of Newberry Volcano }\end{array}$ \\
\hline
\end{tabular}

\section{Willamette Valley}

The Willamette Valley province is a synclinal valley bounded by the Cascade Mountains on the east and the Coast Range on the west, with up to $64 \mathrm{~km}$ (40 miles) 
between the borders. The province is tapered at both ends, with Cottage Grove, Oregon at its southern point, and the Columbia River 130 miles to the north. The basin is a northdipping syncline, with 122 meters (400 feet) of elevation at Eugene decreasing to near sea level at Portland. The Willamette River meanders north through alluvial plain from near Eugene to the Columbia River. Topography in the southern portion of the valley is fairly flat. This province supports 70 percent of Oregon's population and a diverse agriculture (Orr and Orr, 2012).

Table 5. Description of geologic units sampled within the South Willamette Valley. Unit description summarized from Walker and MacLeod (1991) and province boundary defined by DEQ (2013). Detailed descriptions are found in Appendix $B$.

\begin{tabular}{|l|l|l|}
\hline $\begin{array}{l}\text { Geologic } \\
\text { Unit }\end{array}$ & $\begin{array}{l}\text { Primary Rock Types/ } \\
\text { Additional Rock Types }\end{array}$ & Description of Map Units \\
\hline Qs & $\begin{array}{l}\text { clay, silt sand, gravel/ mudflow, fluvial } \\
\text { deposits, peat }\end{array}$ & $\begin{array}{l}\text { unconsolidated to semi-consolidated lacustrine and fluvial sedimentary } \\
\text { rocks }\end{array}$ \\
\hline Qt & terrace/ alluvium & $\begin{array}{l}\text { terrace, pediment and lag gravels: unconsolidated gravel, cobbles and } \\
\text { boulders intermixed with clay, silt and sand }\end{array}$ \\
\hline Tfe & $\begin{array}{l}\text { sandstone, siltstone/ lapilli tuff, breccia, } \\
\text { ash }\end{array}$ & $\begin{array}{l}\text { Fisher and Eugene Formations and correlative rocks; marine arkosic } \\
\text { and micaceous sandstone and siltstone }\end{array}$ \\
\hline Tfeb & $\begin{array}{l}\text { basalt } \\
\text { Tfee }\end{array}$ & basaltic rocks, Fisher Formation(?) \\
pebbly conglomerate
\end{tabular}

The environments and sediments of the Willamette Valley are the result of the same geologic influences as the Coast Range. The Siletzia Volcanic Island Terrane collided and accreted with the North America plate, subsided into a forearc basin in the middle Eocene and was buried by marine sediments through the Oligocene. Siletzia volcanics are the basement rock for both the Coast Range and Willamette Valley.

The Willamette Valley subsided into a trough concurrent with the late Cenozoic uplift and tilting of the Coast Range; uplift, tilting and increased sedimentation led to the 
northward retreat of the ocean. Pleistocene melt-waters increased sediment transport and filled the valley with alluvial sediments. The Missoula Floods then covered the basin with thick silts from 18,000 to about 15,000 calendar years ago (Allen et al., 2009).

Descriptions of the South Willamette Valley formations within the study area are summarized from Walker and MacLeod (1991) in Table 5. The formations in the Willamette Valley province within the southwest Oregon study area are the Eugene Formation (Tfe, Tfee), Lacomb and Leffler Gravels (Qt), and the Rowland Formation (Qs) with overlying Holocene alluvium. The Eugene Formation consists of thick, shallow marine and non-marine sandstones and siltstones deposited during the late Eocene to Oligocene. In the mid- to late-Pliocene, glacio-fluvial sediments from the Cascades and Coast Range created the Lacomb and Leffler (2.5 to 0.5 Ma) gravels. The Rowland Formation (formerly Linn Formation) is composed of thick, glacial outwash gravel fans that invaded from the Cascades (420 ka) after further subsidence and river downcutting in the valley (Orr and Orr, 2012). See Appendix A, Figure A.4 for stratigraphy of this province.

\section{Basin and Range}

The Oregon Basin and Range is made of alternating north-south trending mountains and wide valleys, and it extends from the Cascade Mountains on the west to the Owyhee Uplands in the east. The north and south borders are the High Lava Plains and California, respectively. Overall, the elevation average is $1,219 \mathrm{~m}(3,999 \mathrm{ft}$.$) , with$ the highest elevations east of the study area at Steens Mountain (2,947 m; 9,669 ft.) and 
Warner Peak (2,458 m; 8,064 ft.). All drainage is small and toward the interior, except the $31,080 \mathrm{~km}^{2}$ (12,000 square miles) Klamath River watershed, which reaches the Pacific Ocean from Klamath Lake through northern California (Orr and Orr, 2012).

Regional uplift and crustal extension with consequent faulting and volcanism has resulted in horst and graben physiography by Miocene north-west strike-slip faults and Quaternary north-northeast normal faults. North American plate movement over a mantle plume produced flood basalts at Steens Mountain (17 Ma) and rhyolitic eruptions that prograded across the Oregon Basin and Range and High Lava Plains (Orr and Orr, 2012). Pleistocene cooling increased precipitation and introduced pluvial lakes in the valley lowlands. Descriptions of the Basin and Range formations within the study area are summarized from Walker and MacLeod (1991) in Table 6. The eastern border of the southwest Oregon study area is approximately $233 \mathrm{~km}$ (145 miles) west of Steens Mountain.

Significant stratigraphy in the west part of this province includes the Gearhart Mountain Volcanics (Tvm), the Yamsay Mountain Volcanics (Tob, Trh), and the Yonna Formation (Ts) (Appendix A, Figure A.5). Gearhart Mountain is a mid- to late-Miocene andesitic volcano. The Yamsay Mountain shield cone produced basalt, then rhyolitic lavas in the Pliocene (4.7 Ma), emitting a small amount of basalt at the end of its cycle. The Yonna Formation is lacustrine-deposited Pliocene ash and debris (Orr and Orr, 2012).

Both Tertiary and Quaternary deposition were dominated by volcanics, pyroclastics and sediments of basaltic and andesitic composition. Tertiary and Quaternary 
geologic units sampled within the Basin and Range Province descriptions are

summarized in Table 6. For the full description, see Appendix B. See Appendix A, Figure

A.5 for stratigraphy of this province.

Table 6. Description of geologic units sampled within the Basin and Range Province. Unit description summarized from Walker and MacLeod (1991) and province boundary defined by DEQ (2013). Detailed descriptions are found in Appendix B.

\begin{tabular}{|c|c|c|}
\hline $\begin{array}{l}\text { Geologic } \\
\text { Unit }\end{array}$ & $\begin{array}{l}\text { Primary Rock Types/ } \\
\text { Additional Rock Types }\end{array}$ & Description of Map Units \\
\hline Qba & basal tic andesite, basalt & $\begin{array}{l}\text { flows and flow breccia; basaltic andesite of plagioclase, olivine, pyroxene } \\
\text { phenocrysts and olivine basalt is part of the volcanic sequence of the High } \\
\text { Cascade Range }\end{array}$ \\
\hline Qf & $\begin{array}{l}\text { alluvial fan, slope wash, colluvium, talus/ } \\
\text { silt, basalt fragments }\end{array}$ & fanglomerate \\
\hline Qma & rhyodacitic to andesitic ash-flow & Mount Mazama ash-flow deposits \\
\hline QTb & olivine basalt/ palagonite tuff, breccia & basalt grades laterally through tuff and breccia into sedimentary rocks \\
\hline QTs & $\begin{array}{l}\text { sandstone, siltstone/ ashy and palagonitic } \\
\text { sedimentary rocks, palagonitized basaltic } \\
\text { debris, pebble conglomerate }\end{array}$ & $\begin{array}{l}\text { semiconsolidated lacustrine and fluvial sedimentary rocks, mostly } \\
\text { tuffaceous SS and siltstone }\end{array}$ \\
\hline QTvm & basalt, andesite/ pyroclastic rocks & $\begin{array}{l}\text { mafic vent deposits: agglomerate, breccia, scoria, cinder, ash, restricted } \\
\text { flows and small basaltic intrusions }\end{array}$ \\
\hline $\mathrm{Tb}$ & $\begin{array}{l}\text { basalt/ andesite, tuff, tuffaceous } \\
\text { sedimentary rocks }\end{array}$ & $\begin{array}{l}\text { basalt flows, flow breccia and basaltic peperite; minor andesite flows; } \\
\text { tuffaceous interbeds }\end{array}$ \\
\hline Tob & olivine basalt/ andesite & $\begin{array}{l}\text { basalt grades laterally through palagonite breccia and tuff into tuffaceous } \\
\text { sedimentary rocks (Ts) }\end{array}$ \\
\hline $\mathrm{Tp}$ & basalt, andesite & basaltic and andesitic ejecta: scoriaceous cinders, bombs and agglutinate \\
\hline Tps & $\begin{array}{l}\text { pyroclastic/ some lacustrine sedimentary } \\
\text { rock interbeds }\end{array}$ & $\begin{array}{l}\text { subaqueous pyroclastic rocks of basaltic cinder cones: bombs, breccia } \\
\text { and mafic to intermediate tuff }\end{array}$ \\
\hline Trh & rhyolite, dacite/ andesite, andesite breccia & $\begin{array}{l}\text { ash-flow tuff, lava flows, pumice-lapilli tuff, coarse pumicite, blow } \\
\text { breccia and rhyolitic to dacitic domal complexes }\end{array}$ \\
\hline Ts & various sedimentary rocks/ tuff & $\begin{array}{l}\text { tuffaceous sedimentary rocks and tuff: tuffaceous SS, siltstone, } \\
\text { mudstone, claystone, pumicite, diatomite, vitric ash, palagonitic tuff and } \\
\text { tuff breccia, fluvial SS and conglomerate }\end{array}$ \\
\hline Tvm & basalt, andesite/ pyroclastic rocks & $\begin{array}{l}\text { mafic and intermediate vent deposits: agglomerate, breccia, scoria, } \\
\text { cinder, flow and inrusive masses forming lava cones and shields }\end{array}$ \\
\hline Tvs & rhyolite, rhyodacite, dacite & silicic vent rocks: near-vent flows, flow breccia, obsidian, perlite, pumice \\
\hline
\end{tabular}

\section{High Lava Plains}

The High Lava Plains province is an elevated desert plateau bordering five other provinces (Figure 1), extending $241 \mathrm{~km}$ (150 miles) to the east from central Oregon, and with about $80 \mathrm{~km}$ (50 miles) between the northern and southern border. Only the 
southwestern portion of the High Lava Plains is within the study area, with the Cascade Range bordering to the west, and the Basin and Range to the south (Orr and Orr, 2012).

Topography is mostly level, with an average elevation of $1.6 \mathrm{~km}$ (1 mile) above sea level. Highest elevation is 2,434 m (7,984 feet) at Paulina Peak, located only about five $\mathrm{km}$ (three miles) east of the study area. Low rounded domes and steep, flat-topped ridges provide moderate relief between Paulina Peak and the Harney Basin on the east end of the province. Streams are seasonal, with water provided by modest precipitation and snowmelt from nearby mountains.

Descriptions of the High Lava Plains formations within the study area are summarized from Walker and MacLeod (1991) in

Table 7. The High Lava Plains deposition is dominated by Tertiary and Quaternary bimodal lava flows. From the Harney Basin, eruptions progressed northwest to the Newberry Crater (Appendix A, Figure A.6); the oldest eruptions at Duck Creek Butte in Harney Basin are dated at over 10 million years, while the Newberry flows (Qyb) are as recent at 1,300 years ago. Within the study area, the oldest units sampled range from 4 to $10 \mathrm{Ma}$ and include the Devine Canyon and Prater Creek (Tmv) ash-flow tuffs, overlain by Rattlesnake Tuff (Tat). Younger stratigraphy is predominantly basalt and basaltic andesite flows dated less than 6,800 year old $\left({ }^{14} \mathrm{C}\right)$, found on the flanks of the Newberry Volcano and to the northwest in the Bend, Oregon area. See Appendix A, Figure A.6 for stratigraphy of this province (Orr and Orr, 2012). 
Table 7. Description of geologic units sampled within High Lava Plains Province. Unit description summarized from Walker and MacLeod (1991) and province boundary defined by DEQ (2013). Detailed descriptions are found in Appendix $B$.

\begin{tabular}{|c|c|c|}
\hline $\begin{array}{l}\text { Geologic } \\
\text { Unit }\end{array}$ & $\begin{array}{l}\text { Primary Rock Types/ } \\
\text { Additional Rock Types }\end{array}$ & Description of Map Units \\
\hline $\mathrm{Qb}$ & basalt, andesite & basalt, basaltic andesite, olivine basalt \\
\hline QTps & basalt, andesite & $\begin{array}{l}\text { subaqueous basaltic and andesitic ejecta: scoriaceous cinders, bombs, } \\
\text { breccia, minor agglutinate }\end{array}$ \\
\hline QTst & $\begin{array}{l}\text { rhyolitic to andesitic tuff/ mud flows, } \\
\text { alluvium }\end{array}$ & tuffacious sedimentary rocks and tuffs \\
\hline Qyb & basalt, basaltic andesite & $\begin{array}{l}\text { youngest basalt and basaltic andesite: flows and associated breccia on } \\
\text { slopes of Newberry Volcano }\end{array}$ \\
\hline Tat & $\begin{array}{l}\text { rhyolitic to dacitic tuff/ tuffaceous } \\
\text { sedimentary rocks }\end{array}$ & silicic ash-flow tuff; minor tuffaceous sedimentary rocks \\
\hline Tmv & $\begin{array}{l}\text { basalt, basaltic andesite, andesite/ } \\
\text { pyroclastic rocks }\end{array}$ & mafic vent complexes: plugs, dikes, breccia, cinders and agglutinate \\
\hline
\end{tabular}

\subsection{CLIMATE}

Oregon is divided into nine climatic zones, six of which are represented in this southwest Oregon study area (Figure 3) (Taylor and Hannan, 1999). Zones were established by the National Climatic Data Center using average precipitation and temperature values from NOAA weather stations (Taylor and Hannan, 1999). The following descriptions of the climatic zones and climate 30-year normal averages (19611990) are summarized from Taylor and Hannan (1999).

The Coastal Area (zone 1) is characterized by wet winters, relatively dry summers and mild temperatures throughout the year. Annual precipitation averages 165 to $229 \mathrm{~cm}$ (65 to 90 inches) along the coast where elevations are lower, and up to $508 \mathrm{~cm}$ (200 inches) in the upper elevations of the west slopes in the Coast Range. Summer temperatures increase only about $8{ }^{\circ} \mathrm{C}\left(15^{\circ} \mathrm{F}\right)$ above January temperatures. The study area includes the lower half of zone 1. 


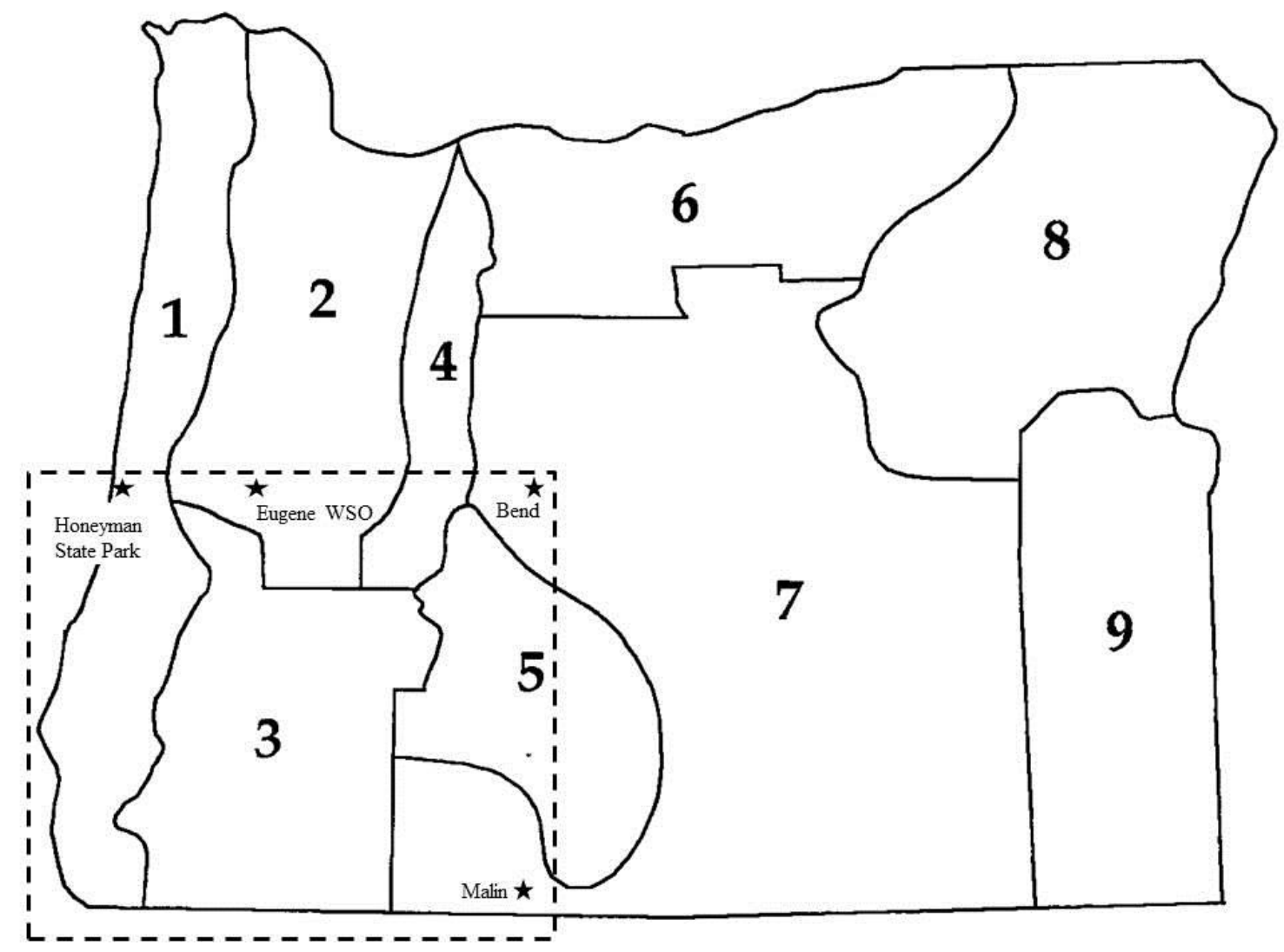

Figure 3. Oregon climate zones (Taylor and Hannan, 1999), with southwest Oregon study area defined within the dashed box. Zones are defined as: Zone 1, the Coastal Area; Zone 2, the Willamette Valley; zone 3, Southwestern Interior; Zone 4, Northern Cascades; Zone 5, the High Plateau; Zone 6, the North Central Area; Zone 7, the South Central Area; Zone 8, the Northeast Area; Zone 9, the Southeast Area. Stations along the study area border are included as a spatial reference.

The Willamette Valley (zone 2) has a mild climate throughout the year with cool, wet winters and warm, dry summers. As with the coastal area, typically half the annual rainfall occurs in the winter months, from December to February. Annual precipitation varies in the valley, with more precipitation at higher elevations. Precipitation in Portland (6.4 $\mathrm{m}$ above sea level) averages below $102 \mathrm{~cm}$ (40 inches). Average precipitation in Eugene (109 $\mathrm{m}$ above sea level) is $117 \mathrm{~cm}$ (46 inches) and is greater than $203 \mathrm{~cm}(80$ inches) in the Cascade and Coast Range foothills. Sample sites lie in the southernmost 
part of this climate zone, near the city of Eugene. The stations local to Eugene are Eugene WSO (110 m, 360 ft.), Noti (137 m, 450 ft.), Cottage Grove (198 m, 650 ft.), Leaburg (207 m, $680 \mathrm{ft}$.$) and Dorena Dam (250 m, 820 \mathrm{ft}$.). Precipitation averages for these stations are 125-, 154-, 116-, 163-, and 118-cm, respectively $(49.25,60.65,45.54,64.11$ and 46.65 inches). Mean temperature in zone 2 ranges from about $-1^{\circ} \mathrm{C}$ to $5^{\circ} \mathrm{C}\left(30^{\circ} \mathrm{F}\right.$ to $\left.40^{\circ} \mathrm{F}\right)$ during cold months and average from the low $10^{\circ} \mathrm{C}$ to low $27^{\circ} \mathrm{C}\left(50^{\circ} \mathrm{F}\right.$ to $\left.80^{\circ} \mathrm{F}\right)$ in the summer months (Taylor and Hannan, 1999).

All of the Southwestern Interior (zone 3) is included in the study area. The rugged terrain of high mountain ridges and incised river valleys results in precipitation averages from $48 \mathrm{~cm}$ (18.85 inches) in the Rogue Valley, to in excess of $305 \mathrm{~cm}$ (120 inches) in the Klamath Mountains. Temperature fluctuations in the southwestern interior are large. Mean temperature in zone 3 ranges from $-1^{\circ} \mathrm{C}\left(30^{\circ} \mathrm{F}\right)$ to the mid- $10 \mathrm{~s}{ }^{\circ} \mathrm{C}\left(\sim 50{ }^{\circ} \mathrm{F}\right)$ during cold months and average from the low $10^{\circ} \mathrm{C}$ to $32^{\circ} \mathrm{C}\left(50^{\circ} \mathrm{F}\right.$ to $\left.90^{\circ} \mathrm{F}\right)$ in the summer months (Taylor and Hannan, 1999).

The lower quarter of the Northern Cascades (zone 4) is part of the study area. This zone encompasses high elevations west of the Cascade crest and includes average elevations over $2,743 \mathrm{~m}(9,000 \mathrm{ft}$.$) , extending from 43.5^{\circ} \mathrm{N}$ latitude to the Columbia River. The northern Cascades receive from $203 \mathrm{~cm}$ to over $381 \mathrm{~cm}$ (80- to 150 -inches) of precipitation (mostly snow), where precipitation increases and temperature decreases with increasing elevation. The Oakridge station (1280 ft.) is the only station listed within the study area, and averages $114.8 \mathrm{~cm}$ (45.18 inches) of precipitation annually. The 
minimum average temperature is $-1.3^{\circ} \mathrm{C}\left(29.7^{\circ} \mathrm{F}\right)$, maximum average $28.3^{\circ} \mathrm{C}(82.9$ ${ }^{\circ} \mathrm{F}$ ), and an average temperature range from a few degrees Celsius to $10{ }^{\circ} \mathrm{C}$ (high $30 \mathrm{~s}{ }^{\circ} \mathrm{F}$ to $50 \mathrm{~s}^{\circ} \mathrm{F}$ ) in the winter to about $18{ }^{\circ} \mathrm{C}$ (mid-60's ${ }^{\circ} \mathrm{F}$ ) in July (Taylor and Hannan, 1999).

The western half of the High Plateau climatic zone (zone 5) is within the study area. The Plateau has cool temperatures due to its largely high elevations, which average $1,676 \mathrm{~m}(5,500 \mathrm{ft}$.). The rain-shadow effect produced by the Cascades is less here than to the north of this zone, because the Cascade crest averages a lower elevation here, and the Plateau elevation is higher, allowing for less of a temperature difference. As a result, there is greater precipitation in zone 5 than the surrounding zone 7, with more than 165 $\mathrm{cm}$ (65 inches) in the west at Crater Lake and less than $30.5 \mathrm{~cm}$ (12 inches) to the east. The Crater Lake (1975 m, 6480 ft.), Odell Lake (1463 m, 4800 ft.) and Wickiup Dam $(1329 \mathrm{~m}, 4360 \mathrm{ft}$.) stations are within the study area. Mean precipitation is $168-, 85-$ and 54-cm, respectively $(66.28,33.35$ and 21.23 inches). The average temperature ranges from $-3{ }^{\circ} \mathrm{C}\left(26^{\circ} \mathrm{F}\right)$ to about $2{ }^{\circ} \mathrm{C}\left(\operatorname{mid}-30 \mathrm{~s}^{\circ} \mathrm{F}\right)$ in the winter and about $13{ }^{\circ} \mathrm{C}($ mid-50s ${ }^{\circ} \mathrm{F}$ ) at Crater Lake and about $14^{\circ} \mathrm{C}$ to $17^{\circ} \mathrm{C}\left(57^{\circ} \mathrm{F}\right.$ to $\left.62^{\circ} \mathrm{F}\right)$ in the summer for Odell Lake and Wickiup Dam (Taylor and Hannan, 1999).

The South Central Area (zone 7) is only partially represented in the study area; only Sisters (969 m, 3180 ft.), Bend (198 m, 650 ft.), Sprague River (1329 m, 4360 ft.), Klamath Falls (1250 m, $4100 \mathrm{ft}$.) and Malin (1411 m, $4630 \mathrm{ft}$.) stations are within the study area, which includes the westernmost part of the zone to the left of the "U" created by zone 5 . This climate zone is defined by low precipitation. Annual precipitation for the 
stations listed above is 36-, 30-, 43-, 34- and 34.5-cm, respectively $(14.18,11.70,16.97$, 13.47 and 13.59 inches). The average temperature ranges from $-2.6^{\circ} \mathrm{C}$ to about $6{ }^{\circ} \mathrm{C}$ $\left(27.4{ }^{\circ} \mathrm{F}\right.$ to low $\left.40 \mathrm{~s}{ }^{\circ} \mathrm{F}\right)$ in the winter and $16.9{ }^{\circ} \mathrm{C}$ to $19.9^{\circ} \mathrm{C}\left(62.5^{\circ} \mathrm{F}\right.$ to $\left.67.9{ }^{\circ} \mathrm{F}\right)$ in the summer for these stations (Taylor and Hannan, 1999).

\subsection{VEGETATION}

To obtain the natural distribution of metals in the soil profiles, samples were collected from vegetated locations away from anthropogenic influences. Most sites were heavily forested with species of fir and pine prevailing. In drier climates, Pacific madrone and scrub oak were predominant. Pictures of foliage are included in Appendix C, and vegetation listed by sample site in Appendix E. 


\section{CHAPTER III: BACKGROUND WORK ON THE CONCENTRATION OF ARSENIC IN SOILS}

\subsection{SOILS}

\subsubsection{SOIL DEFINITION}

The definition of soil varies by profession. To an engineer, soil is unconsolidated surficial material (Birkeland, 1999). As disciplines require more details about the soil to study-- for example, its chemistry, mechanical properties or pedogenesis-- the definition becomes more complex. For the purpose of this study, soil is defined as: "a natural body consisting of layers (horizons) of mineral and/or organic constituents of variable thicknesses, which differ from the parent materials in their morphological, physical, chemical, and mineralogical properties and their biological characteristics" (Birkeland, 1999). All soil terms and concepts discussed in this chapter are summarized from Birkeland (1999), unless cited otherwise.

\subsubsection{SOIL PROFILES AND HORIZON NOMENCLATURE}

The profile of a soil is a two-dimensional vertical arrangement of all the horizons down to the parent material. As soil forms (pedogenesis) and deposition occurs above the parent material, physical and chemical weathering result in horizons within the soil.

The major factors that influence soil formation were defined in a formula by Jenny (1941):

$$
\text { Soil }=f(c l, o, r, p, t, \ldots) .
$$


The abbreviations within the parentheses represent the following factors: "cl" for climate, "o" for biota, "r" the topography, "p" the parent material and "t" the time. The ellipsis allows for the addition of unspecified factors that may have local or regional importance to soil formation. All factors despite real world influences on other factors are considered independent variables, where changing a factor will change the soil. By analyzing a single factor and holding the others constant, soil properties may be predicted.

Climate dictates rate of weathering, transport and changes in element species. Organisms recycle nutrients and provide pathways for water, while bacterial decomposition is known to affect the solubility (Banning and Rude, 2010), and therefore transportation of arsenic. Topography influences water flow, water storage and temperature; in the Northern Hemisphere, north-facing slopes, which have thicker A and B horizons, are generally cooler and wetter than south-facing slopes (Birkeland, 1999). Parent material affects the soil type and rate of development. Time is required for soil formation (Jenny, 1941) and allows the other factors to have greater influence on development.

Anthropogenic sources also contribute to elevated arsenic by introducing products with arsenic content, such as some pesticides (organic arsenic), mining and treated lumber, but samples were collected away from these potential human influences. The formation factors are relevant to this thesis only wherein topography, parent material and time were included in the analysis as potential influences on the levels of arsenic in soils. 
Soil horizons are termed using capital letters for the master horizons, and lowercase letters to describe characteristics of the sub-horizons. Soil horizon nomenclature and characteristics common to profiles in southwest Oregon are listed in Table 8. The samples for this study were taken only in the A and B master horizons. The A horizon is found at the surface or near the surface beneath the $\mathrm{O}$ horizon. The A horizon is defined as having relatively high organic matter mixed with mineral fraction, where the mineral fraction dominates the humified organic matter (Birkeland, 1999). The B horizon is found beneath the A or an E horizon. The B horizon will develop characteristics from the influence of overlying horizons or its parent material; it accumulates clay translated from above horizons and metal compounds such as iron and aluminum, and is typically brown to red in color from iron released from the parent material.

Both horizons were sampled because Burns et al. (1991) found that sometimes the maximum concentration of a metal is found in the A horizon and in older soils it is found in the B horizon. The purpose of this project was to find the maximum concentration so both horizons were sampled.

\subsubsection{FIELD SOIL CHARACTERISTICS AND PROPERTIES}

Color, texture, organic matter, structure and soil $\mathrm{pH}$ are used as aids in the field to qualitatively determine soil materials and current or previous processes that are or have acted on the soil. Use of a Munsell soil color book allows for consistent soil color comparison using notation for the hue, value and chroma, where hue is the dominant color, value ranges from one (dark) to 8 (light), and chroma is the strength of the spectral color from one (least vivid) to 8 (most vivid). Soil with organic matter will present dark 
brown to black in color with a low value and chroma, and value will decrease (get darker) as organic matter increases. Leaching of oxides and hydroxides above the B horizon,

\section{Table 8: Soil Horizon Nomenclature (Birkeland, 1999).}

\section{Master Horizons $\underline{\text { Description }}$}

O horizon Surface accumulations of mainly organic material; may or may not be, or has been, saturated with water.

A horizon Accumulation of humified organic matter mixed with mineral fraction; mineral fraction dominant. Occurs at the surface or below O horizon in forest soils.

E horizon Usually underlies $\mathrm{O}$ or A horizon. Characterized by less organic matter and/or fewer sesquioxides iron and aluminum compounds) and/or less clay than underlying horizon; light in color.

B horizon Underlies O, A, or E horizon. Shows little or no evidence of original sediment or rock structure. Subdivided by illuvial accumulations or residual concentrations of materials.

B horizon subdivisions:

Bt horizon-Accumulation of silicate clay formed in situ or by clay translocation; greater amount of clay than assumed parent material and/or the overlying horizon.

Bw horizon—Development of color (redder hue or higher chroma relative to C) or structure, or both, with little or no apparent illuvial accumulation or material.

C horizon A subsurface horizon, excluding R, like or unlike material from which the soil formed, or is presumed to have formed. Lacks properties of A and B horizons, but includes materials in various stages of weathering.

R horizon Consolidated bedrock underlying soil. 
gibbsite within the B horizon in humid areas, and carbonate or gypsum below the B horizon in arid areas will result in a bleaching effect on the soil. Pedogenic iron will color the soil brown or red. Redoxymorphic conditions will result in mottled (red and gray) soils or gray soils if conditions are fully reduced (gleyed) in poorly drained soils.

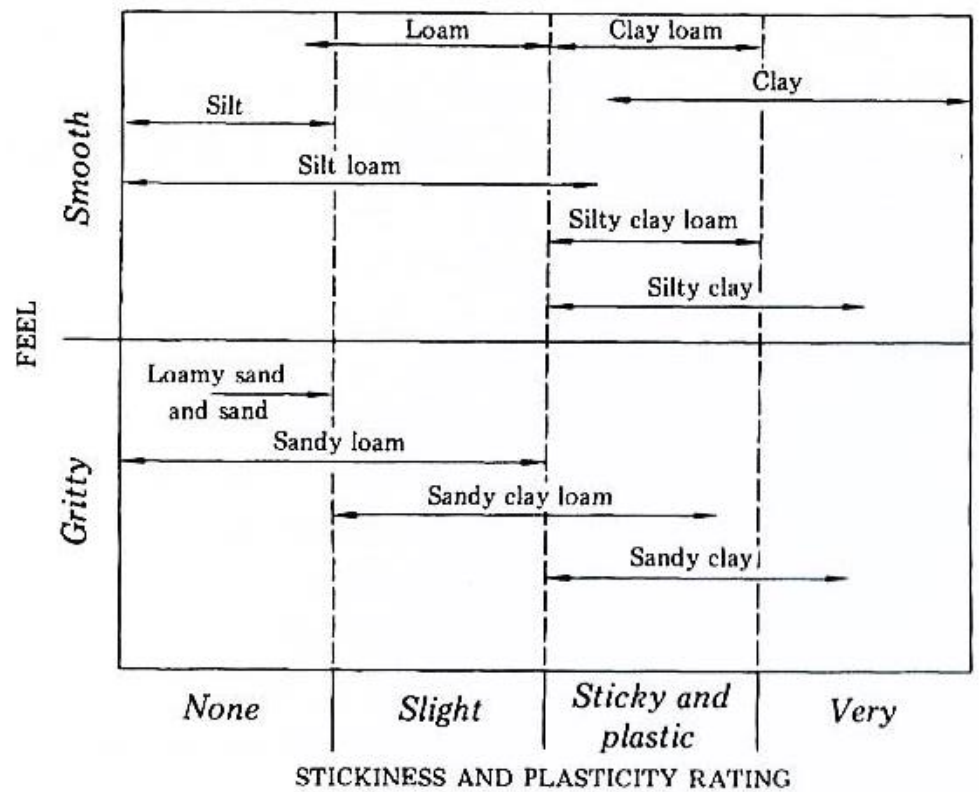

Figure 4: Approximate relations between texture class, grittiness, and wet consistence (Birkeland, 1999).

The texture class is based on the proportion of sand, silt and clay with a particle size less than $2 \mathrm{~mm}$ in diameter in the soil. Texture can be determined in the field using Figure 4 and techniques outlined in Appendix 1 of Birkeland (1999). The variation of texture between horizons is a useful tool to interpret the pedogenic and geologic history of the soil. Clay variation with depth can be used to estimate age; the greater the clay 
content, the older the soil is. Also, soils that are finer in texture will be more chemically active and weather faster (Birkeland, 1999).

Organic matter will be concentrated at the surface. It affects soil structures and reactions, increasing the soil's ability to hold water and the cation-exchange capacity; the increase in chemical reactions results in carbonic acid buildup, a decrease in $\mathrm{pH}$ and an increase in weathering.

Structure is classified by the aggregated shape of soil particles. Since horizon formation and subsequent aggregation is a result of the past and active pedogenic processes which then create shapes favorable to the processes, the shapes can be related with particular horizons. A granular structure is indicative of high organic matter, or an A-horizon. B horizons have higher clay content, which is conducive to blocky, prismatic or columnar structures. Platy structures are the result of precipitation and cementation, and will be in an E or K horizon, or labeled as a subhorizon. Structure highly affects water movement and erosion; granular structure has more voids between aggregates, allowing for infiltration of surface water. As porosity decreases due to clay infilling or more compactable structures, the soil's storage capacity will be exceeded and surface runoff will result in erosion. Structure was noted in the field but was not used in the total analysis (Birkeland, 1999).

Soil acidity or alkalinity, measured as $\mathrm{pH}$, influences mineral solubility; dissolution and precipitation is reliant on the proportion of exchangeable ions present in the soil. In acidic soils $(\mathrm{pH}<7)$, the exchangeable ions of $\mathrm{H}^{+}, \mathrm{Al}^{3+}$ and aluminum 
hydroxides dominate. In alkaline soils $(\mathrm{pH}>7)$ the base cations of $\mathrm{K}^{+}, \mathrm{Ca}^{2+} \mathrm{Mg}^{2+}$ and $\mathrm{Na}^{+}$ dominate. The $\mathrm{pH}$ varies within a soil and should only be used as an estimate of soil weathering and mineral stability (Adriano, 2001).

The $\mathrm{pH}$ can also be used to help identify diagnostic soil horizons for soil classification. Base saturation, the percentage of exchangeable base ions (non-hydrogen) that make up the total available cations, is defined to classify soils. However, since base saturation and $\mathrm{pH}$ have a positive correlation, and $\mathrm{pH}$ is easier to obtain, the $\mathrm{pH}$ can be used as a proxy for base saturation for classification. A regional $\mathrm{pH}$-base saturation relationship should be established, but in general $50 \%$ base saturation occurs between $\mathrm{pH}$ 5 and 6 (Birkeland, 1999). Neither the base saturation nor $\mathrm{pH}$ was collected for samples in this study but are discussed as important properties for soil classification.

\subsubsection{SOIL CLASSIFICATION}

Within the United States, soil is typically classified using the scheme in Keys to Soil Taxonomy (USDA, 2010). Using soil characteristics in the field and laboratory settings, a soil can be grouped into one of eleven soil orders: Entisols, Inceptisols, Aridisols, Mollisols, Alfisols, Spodosols, Andisols, Ultisols, Oxisols, Vertisols and Histosols (USDA, 2010). The soil orders in this study region include Entisols, Inceptisols, Mollisols, Alfisols, Spodosols and Ultisols.

The 11 orders of Soil Taxonomy (USDA, 2010) are generally grouped from least to most developed, where a young soil may begin high in nutrients, then develop and increase in clay, and eventually be leached of nutrients (old soil). However, not all orders 
are classified by development. The 11 soil orders can be further broken down into 47 suborders and 230 great groups based on more detailed characteristics beyond the scope of this study (Birkeland, 1999).

For the soil orders represented in this study, we focus only on the degree of soil and clay development (Birkeland, 1999). Entisols are young soils with a very mild degree of weathering and slight degree of soil development. Inceptisols are recent soils with mild weathering and a slight degree of soil development. Alfisols consist of mildly acidic clays and have an intermediate degree of weathering and soil development. Ultisols are old, well-developed and leached soils that consist of strongly acid clays with intermediate to strong degree of weathering and soil development. Mollisols are soft, dark, and fertile soils with an intermediate degree of weathering and soil development. Spodosols are commonly found in cool, wet and sandy environments and have an intermediate to strong degree of weathering and soil development. Parent material is bedrock in which soil horizons form from; its physical and chemical composition plays an important role in early soil development.

For analysis, two categories were created that are not technically soil orders. An Alfisols/Ultisols category was assigned to samples where base saturation, the distinguishing characteristic between those two orders, was not determined; physical characteristics between these orders are too similar to make an accurate differentiation without lab testing. This combined Alfisol/Ultisol category shows an intermediate to strong degree of weathering and soil development. The Parent Material category represents sample sites where no soil horizon has developed. 


\subsection{SOURCES OF NATURALLY OCCURRING ARSENIC}

Globally, arsenic concentrations in uncontaminated topsoil $(5.1$ to $20 \mathrm{~cm})$ can range from 1-100 ppm (McLaren et al., 2006). In the U.S., the range of arsenic in soil and other surficial materials is $<0.1-97 \mathrm{ppm}$, with a mean of $7.2 \mathrm{ppm}$ (USDH, 2007). The range of background arsenic concentrations in soils has been attributed to differences in the soils parent material and its degree of weathering. Typical arsenic concentrations in general rock types were compiled from various sources by Ravenscroft et al. (2009) (Table 9).

Arsenic exists in primary arsenic-bearing minerals which are found in high concentrations in sulfide deposits (Adriano, 2001), or adsorbed onto various mineral phases (Ravenscroft et al., 2009). The common mineral phases — iron, manganese and aluminum oxides - are discussed in the geochemistry section (3.3). Sedimentary rocks have been shown to reach much higher levels of arsenic concentrations than igneous and metamorphic rocks (Table 9). Enrichment of arsenic in rock is attributed to hydrothermal activity in igneous and metamorphic rock; sedimentary rock enrichment is due to pyrite accumulation in swamps for coal and iron hydroxide adsorption in oxic conditions for ironstone (Ravenscroft et al., 2009).

While outside the scope of this study, atmospheric deposition is another source of arsenic accumulation in soils. Despite the large influence of anthropogenic sources on arsenic emissions and subsequent deposition, natural sources of arsenic from volcanic activity and low-temperature volatilization still contribute from 30 to $60 \%$ of total global arsenic emissions to the atmosphere (McLaren et al., 2006). 
Table 9: Typical arsenic concentrations in rocks and unconsolidated sediments (Ravenscroft et al., 2009).

\begin{tabular}{|c|c|c|}
\hline \multicolumn{3}{|c|}{$\underline{\text { Arsenic }(\mathrm{mg} / \mathrm{kg} \text { or } \mathrm{ppm})}$} \\
\hline Lithology (location) & Mean & Range \\
\hline \multicolumn{3}{|c|}{ Igneous rocks: } \\
\hline volcanic glass & 5.9 & $2.2-12$ \\
\hline granite, aplite & 1.3 & $0.2-15$ \\
\hline andesite, trachyte & 2.7 & $0.5-5.8$ \\
\hline basalt & 2.3 & $0.18-113$ \\
\hline gabbro, dolerite & 1.5 & $0.06-28$ \\
\hline ultrabasic igneous rocks & 1.5 & $0.03-16$ \\
\hline \multicolumn{3}{|c|}{ Metamorphic rocks: } \\
\hline phyllites, slate & 18 & $0.5-143$ \\
\hline schist, gneiss & 1.1 & $<0.1-19$ \\
\hline amphibolite & 6.3 & $0.4-45$ \\
\hline \multicolumn{3}{|c|}{ Sedimentary rocks: } \\
\hline shale, mudstone & ** & $3-15$ \\
\hline sandstone & 4.1 & $0.6-120$ \\
\hline limestone, dolomite & 2.6 & $0.1-20$ \\
\hline ironstones & $* *$ & $1-2,900$ \\
\hline coal & $* *$ & $0.3-35,000$ \\
\hline \multicolumn{3}{|c|}{ Unconsolidated sediments: } \\
\hline alluvial sand (Bangladesh) & 2.9 & $1.0-6.2$ \\
\hline alluvial mud (Bangladesh & 6.5 & $2.7-15$ \\
\hline Holocene mud (West Bengal) & 7.7 & $2.8-17$ \\
\hline Holocene sand (West Bengal) & 5.2 & $0.3-16$ \\
\hline Pleistocene sand (West Bengal & 1.2 & $0.1-2.3$ \\
\hline glacial till (Canada) & $* *$ & $1.5-45$ \\
\hline loess (Argentina) & ** & $5.4-18$ \\
\hline peat & 13 & $2-36$ \\
\hline
\end{tabular}

Loess is atypical because of high volcanic ash content.

** is not reported.

\subsection{GEOCHEMISTRY: ARSENIC SPECIES AND TRANSPORTATION}

The fate and transport of arsenic in soil can be simplified by Figure 5. In this study, we are concerned with arsenic retained in the solid phase of uncontaminated soil. In the near-surface environment in soils, the chemical species of arsenic primarily occurs as $\mathrm{As}(\mathrm{V})$ or $\mathrm{As}(\mathrm{III})$; corresponding primary arsenic compounds are arsenate $\left(\mathrm{AsO}_{4}{ }^{3-}\right)$ and arsenite $\left(\mathrm{AsO}_{3}{ }^{3-}\right)$. Retention (adsorption) of arsenic by soils and release (desorption) from 
soils is influenced by its oxidation state, the surface charge of minerals, the $\mathrm{pH}$ of the soil and redox potential. Arsenite is more soluble, mobile and toxic than arsenate, whereas arsenate is generally more readily attracted to and retained by soils and sediments (Adriano, 2001). The negatively charged arsenite and arsenate ions adsorb to positively charged mineral surfaces, most commonly iron, aluminum and magnesium oxides, or to clay due to its high surface area (Ravenscroft et al., 2009). Iron oxides dominate arsenic adsorption, retaining arsenic on the surface of clay particles or as microaggregates (McLaren et al., 2006). The $\mathrm{pH}$ affects the charge of oxides; at low $\mathrm{pH}$ oxides are positively charged and allow adsorption. In general, as $\mathrm{pH}$ increases, adsorption of arsenate will decrease and adsorption of arsenite will increase (Adriano, 2001).

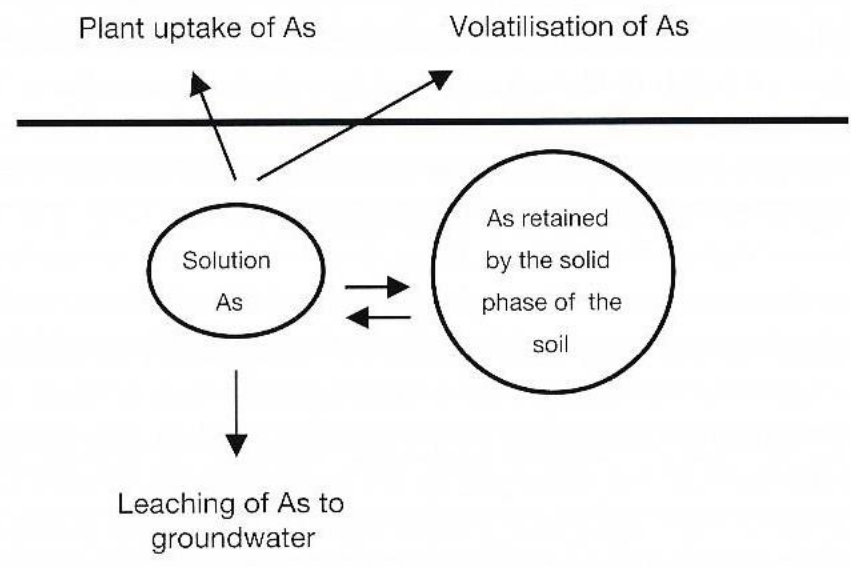

Figure 5: Simplified fate of arsenic in the soil environment (McLaren et al., 2006).

To predict the stability of the arsenic species in different environments, pe-pH diagrams can be used. Redox potential, shown as pe or $E_{h}(m V)$, is a measure of a species ability to acquire electrons and be reduced. As shown in Figure 6, arsenate is more stable 
under oxidized conditions, while arsenite is more stable at moderate to low redox potentials below the limits for arsenate (Inskeep et al., 2002).

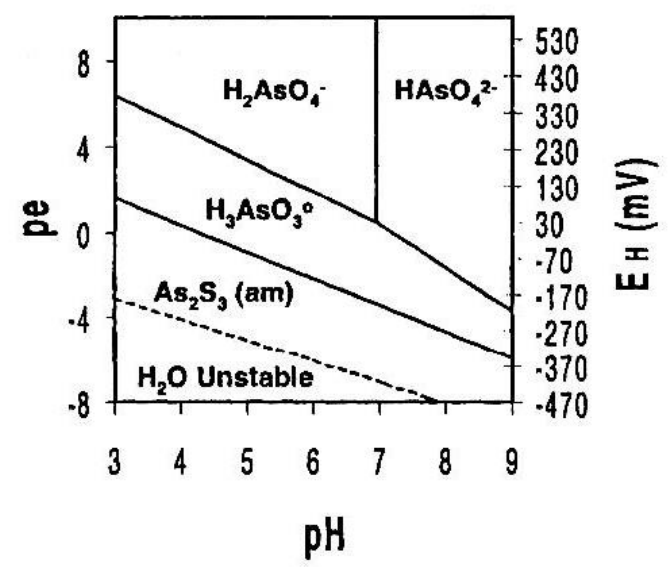

Figure 6: Simplified pe-pH diagram for the As-S-H2O system at $25^{\circ} \mathrm{C}$ (Inskeep et al., 2002).

\subsection{PREVIOUS WORK: ARSENIC IN SOILS IN SOUTHWEST OREGON}

Khandoker (1997) sampled 118 sites throughout southwest Oregon in the A and B horizons and found only three samples above the reporting limit of $20 \mathrm{ppm}$; the B horizon at site R13 had 29.4 ppm, and site KL21 had 36.4 and 46.5 ppm in the A and B horizons, respectively. Locations of these sites are in Figure 1 and characteristics in Appendix E. When retested with the lower detection limit of $0.20 \mathrm{ppm}$, site R13 was $13.6 \mathrm{ppm}$, and site KL21 had 32.6 and $26.1 \mathrm{ppm}$ in the A and B horizons, respectively. Both sites are in the Klamath Mountain province. The sample from site R13 is from basaltic volcanic and sedimentary rock unit (Jub) and an Ultisol/Alfisol soil. The samples from site KL21 are from the Condrey Mountain Schist formation (cm) and are Alfisol soils. 
DEQ has more recently released a report of the maximum limits permissible by physiographic province (DEQ, 2013). The DEQ analyzed default background concentrations collected by regulatory and educational institutions and consultants; summary statistics and background statistics were used to calculate a regional default background concentration at the 95-percent upper limit (Table 1).

No other current studies were found specific to naturally occurring levels of arsenic in soils in southwest Oregon outside of those related to the Oregon DEQ reports (2013), although there is a study assessing arsenic in groundwater that attributes higher arsenic values to aquifers within specific rock units (Hinkle and Polette, 1999). 


\section{CHAPTER IV: METHODOLOGY}

\subsection{GEOGRAPHIC INFORMATION SYSTEMS}

The geologic map of Oregon created by the United States Geological Survey (Walker and MacLeod, 1991) was used as a base map for this study to ensure consistency with arsenic studies done in Oregon previous to this study (Khandoker, 1997; Douglas, 1999). The map was obtained online, and ArcGIS software was used to isolate the lithologic polygons in the southwest Oregon study area. Lithologic units on the map were assumed to be correctly labeled for this analysis. The mapped units were used to ensure good sample coverage in the soils overlying them. In drier climates, such as in eastern Oregon, eolian processes have a much higher influence on arsenic distribution. However, for this study area, it is assumed that soil development is influenced by the weathering of the underlying bedrock.

ArcGIS software was then used to assess the lithologic units (Appendix E: geologic unit) to determine where additional field sampling should be done to maximize sample coverage within the study area. First, the sum of area for each lithologic unit in southwest Oregon was calculated using analysis tools in ArcGIS. The largest units by total area that were not sampled by previous studies (Khandoker, 1997; Douglas, 1999) were selected for sampling: Qyb, Tvm, Thi, Tfeb, Tvs, KJdv, QTa, and Ti. In addition, the previously sampled Tfee unit in Eugene, which had the largest arsenic concentration in Khandoker's study (1997), was selected for resampling. Ultimately, the sum of the area of all lithologic units underlying soil sample sites within the PSU data set represent over $99 \%$ of the mapped bedrock in the study area. GIS was also used to determine what 
formations are within terranes in much of the study area by orthorectifying and digitizing Figure 2, then spatially joining geologic units within the terrane polygons.

\subsection{FIELD METHODS}

Forty-two samples from soils overlying the nine selected units were acquired July 21-23, 2013. Field sampling was done exactly the same way as was done by Douglas (1999) and Khandoker (1997). Samples from the A and B horizons were collected from uncontaminated, remote and undisturbed soils to avoid anthropogenic influences and obtain the natural distribution of metals in the soil profiles. Once the location was selected, a soil pit was dug with a shovel to reveal the A horizon, and some of the B horizon. A horizons were sampled within the top $4 \mathrm{~cm}$ of soil, and B horizons sampled from different locations around the walls of the pit where soil was the most red in color.

To both assess the variability of arsenic within each horizon and validate the consistency of ICP-MS analysis, five samples from the A horizon and five samples from the B horizon were collected for testing. Samples were taken from site HH 11 at different locations around the pit wall within each horizon to test the validity of taking only one sample from the A and B horizons. This one site was chosen randomly for this analysis; additional samples from different pits above this unit, or from other sites, would have added statistical robustness but were not collected because additional sample analysis was cost prohibitive.

The location of each pit was determined by Garmin GPS, using the WGS84 datum with horizontal accuracy of \pm 3 meters. Soil properties were recorded using 
techniques outlined by Birkeland (1999, Appendix 1). Photographs of soil pits and local vegetation at each site were taken (Appendix C). Samples were then placed in a labeled zip-lock bag, and pits filled back in.

\subsection{LABORATORY METHODS}

In the Portland State University soil lab, the 42 new samples were air dried and soil classifications (USDA, 2010) determined using field notes of soil texture, consistency, and dry Munsell color. Samples were disaggregated using a mortar and pestle, then sieved with a number 10 sieve. Approximately 300 grams were repackaged into labeled zip-lock bags and delivered to Apex Laboratory for testing; however, Apex Laboratories only requires a maximum of 2 grams for ICP-MS analysis.

Soil samples from former studies (Khandoker, 1997; Douglas, 1999) had also been prepared by air drying after the original collection. They were then disaggregated, shaken through a \#10 sieve and approximately 300 grams of soil for each sample was bagged for later machine testing. Arsenic concentrations were originally determined by inductively coupled plasma-atomic emission spectrometry (Khandoker, 1997) at a minimum reporting limit of $20 \mathrm{ppm}$.

For this study, Apex Labs used U.S. Environmental Protection Agency’s Method 6020A (EPA, 2007b) for analysis by inductively coupled plasma-mass spectrometry (ICPMS). Prior to analysis sediments were prepared using acid digestion Method 3051A (EPA, 2007a, which dissolves almost all elements that could become "environmentally available.” See Appendix G for partial copies of Apex Labs reports. Samples by work 
order, quality control sample results, sample preparation information and notes and definitions used in Apex reports are included. Results pages are omitted; these reports are for all samples used for Oregon metals evaluation, only some of which are samples collected by PSU. Results of arsenic for PSU-collected samples are in Appendix D.

All 118 former soil samples (Khandoker, 1997; Douglas, 1999) were re-tested in 2010 by Apex Laboratories in Tigard using ICP-MS with a detection limit of 0.20 ppm, which allows for a more accurate exploration of the true background levels of arsenic in soils of southwest Oregon. Arsenic concentrations of the 42 new samples from July 2013 field work were also tested by Apex Laboratories in October 2013 using the same method and detection limit.

\subsection{GROUPINGS FOR STATISTICAL ANALYSES}

The statistical analysis started with an examination of the data. Statistical tests used were the Shapiro-Wilk test for normality, Fisher's F-ratio for variance and the Welch t-test for comparison of means between the groups. Wilcoxon Rank-Sum was used for comparison of medians when data was not normally distributed. Horizons were compared to determine if the arsenic in the A horizon (Table 12) should be analyzed separate from the B horizon (Table 13). The detection limit for arsenic is $0.20 \mathrm{ppm}$. Nondetect samples were assigned a value of $0.001 \mathrm{ppm}$ half the detection limit of the originally reported $0.002 \mathrm{ppm}$; this method is commonly used for analysis (Helsel, 2006).

A comparison between the samples collected by Portland State University (PSU) students for this study area and a modified DEQ data set was conducted. The samples 
collected by Douglas (1999) and Khandoker (1997) were first removed from the DEQ data set. The maximum concentration of arsenic measured in samples from each PSU site (136 total sites) was used to compare to the remaining 673 sites from the DEQ data for the provinces in southwest Oregon. Summary statistics and estimates for the two data sets were run using ProUCL Version 4.1.

The maximum arsenic concentrations at each site were then evaluated by their relationship to the following predictors: soil color, soil order, elevation, geomorphic province, and rock age and rock type. The highest value per sample site was used for analysis following the industry standard for determining maximum background levels (Burns et al., 1991). For sites where both the A horizon and B horizon were ND but soil color or order differed, the B horizon was selected for use in analyses. This was done because high arsenic concentrations are often associated with iron oxides and sulfide minerals on clay surfaces (McLaren et al., 2006), which typically concentrate in the B horizon.

To assess a potential relationship with color (or soil development), dry Munsell data were converted to the Buntley-Westin color index (Buntley and Westin, 1965), which indicates the redness of the soil. This color index has assigned values for each hue in the Munsell Color Book and is calculated by multiplying the hue value with chroma. Soil order as recorded by former studies (Khandoker, 1997; Douglas, 1999) was combined with field observations from this study. 
Rock analyses in this study include dominant rock type and rock age. The variety of dominant rock types (i.e., sandstone, shale) mapped by the USGS (Walker and MacLeod, 1991) have been simplified to the process that formed them (i.e., sedimentary, metamorphic). The categories were assigned using lithologies described by USGS (Walker and MacLeod, 1991) and the Oregon Department of Geology and Mineral Industries, or DOGAMI (McClaughry et al., 2010). Where mixed lithology did not clearly indicate a primary rock type, assignment was dictated by the parameters listed in Table 10. Descriptions for rocks that included verbiage such as "minor interbeds" and "locally includes" were not considered a primary rock type. For category assignments and lithologic descriptions of each unit, see Appendix B. The reclassification includes the following categories: Metamorphic, Plutonic, Volcanic, Sedimentary, mixed Volcanic/Sedimentary and Unconsolidated sediments (Table 10). Elevation from USGS metadata (Walker and MacLeod, 1991) was converted from feet to meters.

To analyze rock age, the minimum and maximum ages according to the rock unit description (Walker and MacLeod, 1991) were averaged. This was done to provide a single number for relative comparison while taking the duration of deposition into account. For example, a Cretaceous rock unit (65.5 Ma to 145.5 Ma) has a value of 105.5, and a Mesozoic and Paleozoic rock unit (65.5 Ma to $542 \mathrm{Ma}$ ) a value of 303.75. A Paleozoic rock unit (251 Ma to $542 \mathrm{Ma}$ ) has a value of 396.5. This assigns rocks of similar age but longer duration of deposition a higher value, while maintaining a higher ranking for older deposition. Rock unit ages and ranking are included in Appendix F. 
Table 10. Description of rock type categories; mixed lithologies were discerned following these descriptors within the unit descriptions by Walker and MacLeod (1991).

\begin{tabular}{|c|l|}
\hline M & $\begin{array}{l}\text { Metamorphic: primary rocks are metamorphic, or mixed lithologies are } \\
\text { described as mélange, highly sheared or altered. }\end{array}$ \\
\hline P & Igneous Plutonic: primary rocks are granite, diorite. \\
\hline V & Igneous Volcanic: primary rocks are basalt, andesite. \\
\hline S & Sedimentary: primary rocks are sandstone, siltstone, mudstone, limestone. \\
\hline VS & $\begin{array}{l}\text { Mixed Volcanic and Sedimentary: primary rocks are described as volcanic and } \\
\text { sedimentary, tuffaceous sedimentary, undifferentiated or undivided volcanic } \\
\text { and sedimentary, or as having one lithology (volcanic or sedimentary) as part } \\
\text { of the sequence. }\end{array}$ \\
\hline U & Unconsolidated sediments of any lithology not falling under "VS." \\
\hline
\end{tabular}

Statistical analyses were done to test the validity of the splits in the regression tree using the Shapiro-Wilk Test for normality, Fisher's F- ratio for variance, and the Wilcoxon Rank-Sum Test to compare the center of data between the two groups defined by the split. A regression forest was then done to check the predictions of the regression tree, since forests have been shown to produce better predictions than a single tree (Shih, 2011). 


\section{CHAPTER V: RESULTS}

\subsection{ARSENIC CONCENTRATIONS IN SOUTHWEST OREGON}

A total of 255 samples from 136 sites were collected by PSU and used in this study; 123 samples are from the top of the A horizon (Table 12) and 132 samples were taken from within the B horizon (Table 13). The highest arsenic concentrations measured in samples from the A and B horizons, respectively, are $63.2 \mathrm{ppm}$ and $85.4 \mathrm{ppm}$. These maximum values are both from the Eugene Formation, a marine sedimentary deposit exposed along the eastern margin of the Willamette Valley from Creswell on the south to north of the study area in Scio, Oregon (McLaughry et al., 2010). Of the 255 samples, arsenic was not detected (ND) in $20(7.8 \%)$ of the samples tested at a minimum detection limit of $0.20 \mathrm{ppm}$; of the ND samples, 11 were from the A horizon and 9 from the B horizon.

Maximum concentrations of arsenic for the 136 PSU-collected sites were mapped using ArcGIS and classed using Jenks natural breaks (Figure 7). The Jenks method clusters data to minimize the average deviation from the mean within each class and maximize the deviation from the means of other classes. The Jenks class with the lowest arsenic concentrations ( 0.00 to $2.82 \mathrm{ppm}$ ) includes $60.3 \%$ of the maximum arsenic concentrations, $8.1 \%$ of which have no arsenic detected. The second class includes $24.3 \%$ of the data. The third, fourth and fifth arsenic classes constitute $13.2 \%, 1.5 \%$ and $0.7 \%$ of the data, respectively. 


\section{Arsenic Concentrations- Southwest Quadrant of Oregon}

\section{Legend

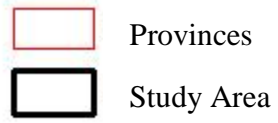

Maximum Arsenic (ppm) at Sample Site:
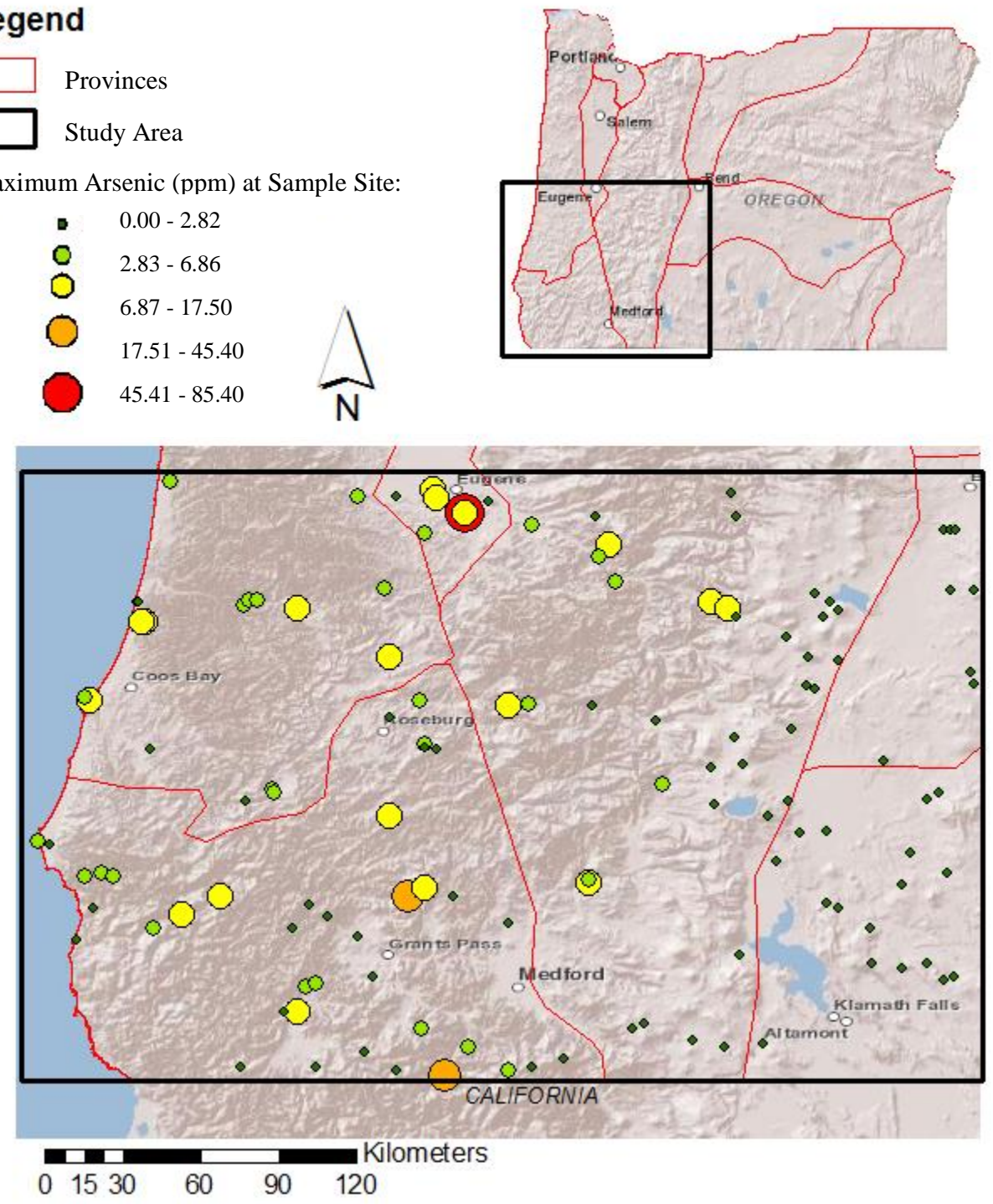

Figure 7. Maximum arsenic concentrations of 136 PSU-collected sites are classed using Jenks natural breaks. Province lines are from DEQ (2013).

\subsection{DISTRIBUTION OF ARSENIC IN A AND B SOIL HORIZONS}

To test whether the concentration of arsenic was greater in the A or B horizon, the two groups were compared using the results in Table 12 and Table 13. Of 136 sites, 119 
sites had samples for both the A and the B horizon; 17 sites were omitted for not having a representative sample in the adjacent horizon. The Shapiro-Wilk normality test (Ellison and Gotelli, 2013) concluded that arsenic levels in both A and B horizons deviated from normality (p-values both <2.2e-16). Fisher's F-ratio (Ellison and Gotelli, 2013) was used to interpret variation. The F-ratio (0.5436) indicates the variance among arsenic samples in the $\mathrm{A}$ and $\mathrm{B}$ horizon groups is small relative to the variation within the groups $\mathrm{A}$ and $\mathrm{B}$ (Figure 8).

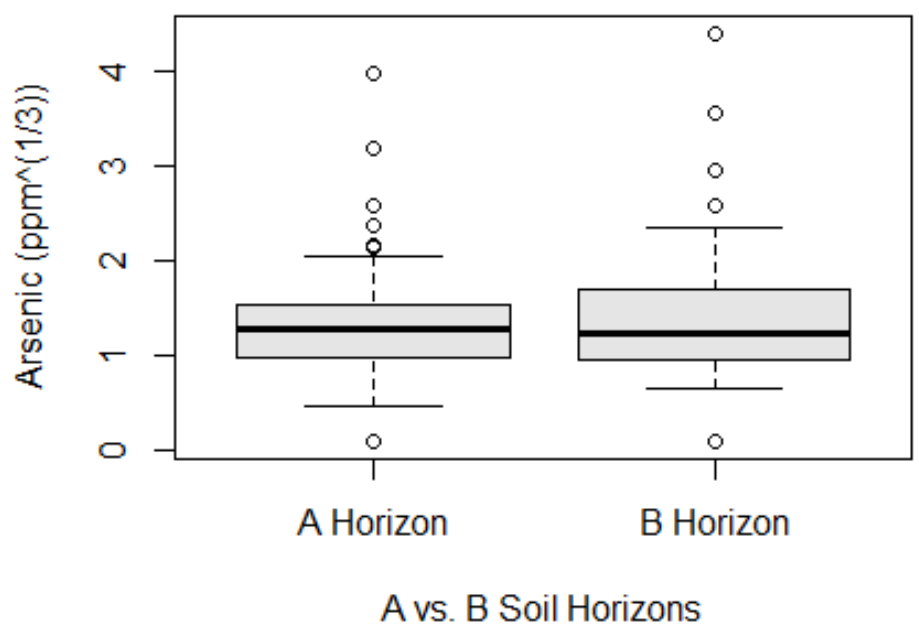

Figure 8. Cube root transformed variance of arsenic within the $A$ and the $B$ horizons for the 119 sites that had samples for both the A and B horizons.

Since the groups deviate from normality, the Wilcoxon rank sum test (Ellison and Gotelli, 2013) was used to compare the median between groups. The center of data for each horizon does not differ significantly (p-value: 0.7567$)$ at a 95\% confidence level. The $\mathrm{W}$ value (W: 6915.5) is large, so results are less likely to have occurred by chance. Although 47 sites (39.5\%) are higher in arsenic in the A horizon while 63 sites (52.9\%) 
are higher in the B horizon, with 9 sites (7.6\%) having no value detected, the A and $\mathrm{B}$ horizons are not statistically different (Table 11).

Table 11: Comparison on A and B horizon indicates center of data between horizons is not significantly different.

\begin{tabular}{|l|l|l|l|}
\hline $\begin{array}{l}\text { Data Type: } \\
\text { A vs. B horizon }\end{array}$ & Statistical Test & Test Result & p-value (a=0.05) \\
\hline Raw Arsenic Values & Shapiro -Wilk & $\mathrm{W}=0.4099$ & $\begin{array}{l}<2.2 \mathrm{e}-16 \\
\text { (A horizon) }\end{array}$ \\
\cline { 3 - 4 } & $\mathrm{W}=0.3696$ & $\begin{array}{l}<2.2 \mathrm{e}-16 \\
\text { (B horizon) }\end{array}$ \\
\cline { 2 - 4 } & F-test & $\mathrm{F}=0.5436$ & 0.001044 \\
\cline { 2 - 4 } & $\begin{array}{l}\text { Wilcoxon Rank } \\
\text { Sum }\end{array}$ & $\mathrm{W}=6915.5$ & 0.7567 \\
\hline
\end{tabular}

Site HH11 was randomly chosen to compare arsenic between A and B horizons and to assess variation within a horizon. Site HH11 is an Inceptisol soil above volcanic rock (KJdv map unit) located at 275 meters elevation in Douglas County within the Klamath province. Five samples were taken from the A and from the B horizons at site HH11. The Shapiro-Wilk normality test concluded that arsenic levels in both A and B horizons have a normal deviation with p-values 0.8981 and 0.8596 for $\mathrm{A}$ and $\mathrm{B}$ horizons, respectively. Fisher's F-ratio was used to interpret variation. The F-ratio (1.2997) indicates the variance between arsenic samples in the A and B horizon groups is larger relative to the variation within the groups A and B (Figure 9). Since the groups are normally distributed, the Welch Two-Sample t-test was used to compare the median between groups. The test results (Table 14) indicate that with $95 \%$ confidence there is a significant difference between the center of data for each horizon subset ( $p$-value:

$0.01699)$. 
Table 12. Arsenic concentrations for samples collected in the A horizon, in order of increasing concentration.

\begin{tabular}{|c|c|c|c|c|c|c|c|}
\hline \multicolumn{8}{|c|}{ Arsenic in A Horizon (ppm) } \\
\hline Sample & As & Sample & As & Sample & As & Sample & As \\
\hline HH01 & 0.001 & LM11 & 0.957 & LC04 & 2.1 & HH11.2 & 3.95 \\
\hline HH02 & 0.001 & LM22 & 0.965 & LM12 & 2.1 & $\mathrm{LC} 12$ & 4.27 \\
\hline НH03 & 0.001 & KL02 & 0.995 & $\mathrm{EO} 27$ & 2.15 & HН17 & 4.28 \\
\hline HH04 & 0.001 & R15 & 1 & KL18 & 2.22 & HH1 1.1 & 4.38 \\
\hline НH07 & 0.001 & LM21 & 1.03 & LC17 & 2.28 & HH18 & 4.54 \\
\hline HH08 & 0.001 & EO33 & 1.07 & LM16 & 2.32 & LC10A & 4.58 \\
\hline НH09 & 0.001 & $\mathrm{EO} 22$ & 1.12 & KL13 & 2.36 & HH05 & 4.88 \\
\hline HH10 & 0.001 & EO34 & 1.15 & LM15 & 2.38 & KL19 & 4.88 \\
\hline HH12 & 0.001 & EO24 & 1.22 & LC13 & 2.52 & LC08 & 4.96 \\
\hline HH15 & 0.001 & KL24 & 1.22 & KL03 & 2.57 & LC11 & 4.96 \\
\hline HH16 & 0.001 & LC14 & 1.25 & LM20 & 2.57 & LM02 & 5.04 \\
\hline KL28 & 0.1085 & LM05 & 1.26 & LC20 & 2.58 & KL08 & 5.11 \\
\hline LC06 & 0.301 & KL26 & 1.3 & KL11 & 2.59 & KL15 & 5.14 \\
\hline LM10 & 0.371 & EO16 & 1.31 & $\mathrm{LC} 23$ & 2.66 & KL05 & 5.26 \\
\hline KL23 & 0.438 & EO02 & 1.36 & KL14 & 2.67 & LM01 & 6.35 \\
\hline EO26 & 0.483 & KL17 & 1.43 & KL12 & 2.82 & LC15 & 6.44 \\
\hline LM09 & 0.608 & KL20 & 1.44 & KL25 & 2.88 & $\mathrm{LC} 18$ & 6.95 \\
\hline EO01 & 0.666 & EO07 & 1.46 & LM07 & 2.99 & HH06 & 7.29 \\
\hline $\mathrm{EO} 21$ & 0.687 & EO17 & 1.47 & $\mathrm{LC} 21$ & 3.09 & LC09 & 7.36 \\
\hline EO18 & 0.718 & KL01 & 1.49 & LM17 & 3.13 & KL27 & 7.48 \\
\hline EO20 & 0.724 & EO32 & 1.5 & KL10 & 3.19 & R01 & 7.94 \\
\hline KL30 & 0.761 & EO08 & 1.57 & HH11.3 & 3.24 & KL04 & 7.97 \\
\hline EO30 & 0.762 & EO36 & 1.57 & LC22 & 3.29 & LC05 & 8.74 \\
\hline KL07 & 0.765 & KL22 & 1.57 & KL06 & 3.43 & R14 & 10 \\
\hline EO15 & 0.776 & EO35 & 1.62 & R02 & 3.47 & $\mathrm{LC} 02$ & 10.1 \\
\hline LC19 & 0.799 & LM14 & 1.63 & HH11.4 & 3.48 & HН13 & 13.5 \\
\hline EO31 & 0.821 & KL16 & 1.7 & KL09 & 3.5 & R13 & 13.6 \\
\hline EO23 & 0.845 & R03 & 1.72 & LC07 & 3.64 & LC01 & 17.2 \\
\hline EO14 & 0.869 & LM13 & 1.81 & HH11.5 & 3.65 & KL21 & 32.6 \\
\hline EO25 & 0.892 & LM03A & 1.92 & LM08 & 3.71 & HH14 & 63.2 \\
\hline LM06 & 0.914 & LC03 & 2.08 & LC16 & 3.73 & & \\
\hline
\end{tabular}

The values for site HH11 in the A horizon were 4.38, 3.95, 3.24, 3.65 and 3.48 with a mean of 3.74 and standard deviation of \pm 0.44 . Values in the B horizon were 4.99 , $4.83,4.51,4.29$ and 4.04 with a mean of 4.53 and standard deviation of \pm 0.39 . Variation within each Site 11 horizon is low (Figure 9); variation is 0.1949 for the A horizon and 0.1499 for the B horizon. Standard deviation for Site 11 A and B horizons is 0.4414 and 
0.3872, respectively. Although this should be verified with more pits, the consistency and low deviation within each horizon support that a single sample within a horizon is a good representative of that horizon. This supports the field methodology used in this study of taking only one sample in the A horizon and one sample in the B horizon.

Table 13. Arsenic concentrations for samples collected in the B horizon, in order of increasing concentration.

\begin{tabular}{|c|c|c|c|c|c|c|c|}
\hline \multicolumn{8}{|c|}{ Arsenic in B Horizon (ppm) } \\
\hline Sample & As & Sample & As & Sample & As & Sample & As \\
\hline HH03 & 0.001 & EO18 & 0.923 & LM09 & 1.79 & HH11.2 & 4.83 \\
\hline HH04 & 0.001 & EO12 & 0.941 & LM12 & 1.86 & $\mathrm{LC} 04$ & 4.9 \\
\hline HH07 & 0.001 & EO17 & 0.965 & KL17 & 1.9 & $\mathrm{LC} 12$ & 4.98 \\
\hline HH08 & 0.001 & LM11 & 0.977 & LM03B & 1.96 & HH11.3 & 4.99 \\
\hline HH09 & 0.001 & LM06 & 1 & LM20 & 2.02 & KL08 & 5.04 \\
\hline HH10 & 0.001 & LM10 & 1 & R07 & 2.02 & KL10 & 5.28 \\
\hline HH12 & 0.001 & E016 & 1.01 & LM13 & 2.03 & KL11 & 5.38 \\
\hline HH15 & 0.001 & EO14 & 1.02 & LM04 & 2.16 & LC02 & 5.59 \\
\hline HH16 & 0.001 & EO32 & 1.02 & KL18 & 2.26 & KL09 & 5.7 \\
\hline LC06 & 0.274 & EO02 & 1.03 & LC20 & 2.33 & $\mathrm{R} 12$ & 5.95 \\
\hline KL28 & 0.328 & EO13 & 1.05 & KL03 & 2.39 & LC08 & 5.97 \\
\hline LC19 & 0.347 & EO10 & 1.08 & KL12 & 2.54 & HH06 & 6.10 \\
\hline EO19 & 0.349 & LM05 & 1.1 & LM15 & 2.56 & KL19 & 6.52 \\
\hline EO09 & 0.496 & EO11 & 1.13 & KL13 & 2.59 & LC17 & 6.86 \\
\hline R10 & 0.52 & EO24 & 1.14 & LM07 & 2.85 & $\mathrm{R} 02$ & 7.13 \\
\hline LM21 & 0.543 & $\mathrm{EO} 27$ & 1.14 & LC23 & 2.9 & LC16 & 7.31 \\
\hline EO30 & 0.579 & EO08 & 1.15 & LC07 & 3.02 & LM19 & 7.31 \\
\hline EO22 & 0.587 & EO35 & 1.21 & KL25 & 3.12 & KL05 & 7.38 \\
\hline EO31 & 0.633 & KL24 & 1.29 & HH17 & 3.13 & LM01 & 7.53 \\
\hline KL26 & 0.637 & R03 & 1.29 & HH18 & 3.32 & KL27 & 7.7 \\
\hline EO15 & 0.655 & EO36 & 1.31 & LM17 & 3.32 & LC15 & 7.7 \\
\hline EO21 & 0.661 & KL16 & 1.31 & LC22 & 3.38 & LC18 & 7.94 \\
\hline EO26 & 0.693 & EO07 & 1.45 & KL22 & 3.59 & KL15 & 8.63 \\
\hline EO34 & 0.757 & LM22 & 1.48 & LC10B & 3.79 & KL04 & 8.71 \\
\hline EO23 & 0.783 & LM14 & 1.52 & KL06 & 3.82 & LC05 & 10.3 \\
\hline EO20 & 0.806 & KL02 & 1.56 & KL14 & 3.84 & LC09 & 10.6 \\
\hline LM16 & 0.809 & R05 & 1.61 & HH11.4 & 4.04 & HH13 & 11.5 \\
\hline KL07 & 0.814 & KL01 & 1.62 & LC11 & 4.11 & R01 & 11.9 \\
\hline EO33 & 0.826 & $\mathrm{R} 15$ & 1.64 & HH11.5 & 4.29 & R14 & 12.9 \\
\hline EO25 & 0.83 & $\mathrm{LC} 21$ & 1.67 & HH11.1 & 4.51 & LC01 & 17.5 \\
\hline EO01 & 0.846 & KL20 & 1.73 & LM08 & 4.74 & KL21 & 26.1 \\
\hline KL30 & 0.884 & LC03 & 1.73 & HH05 & 4.78 & R13 & 45.4 \\
\hline KL23 & 0.915 & LC14 & 1.74 & LM02 & 4.8 & HH14 & 85.4 \\
\hline
\end{tabular}




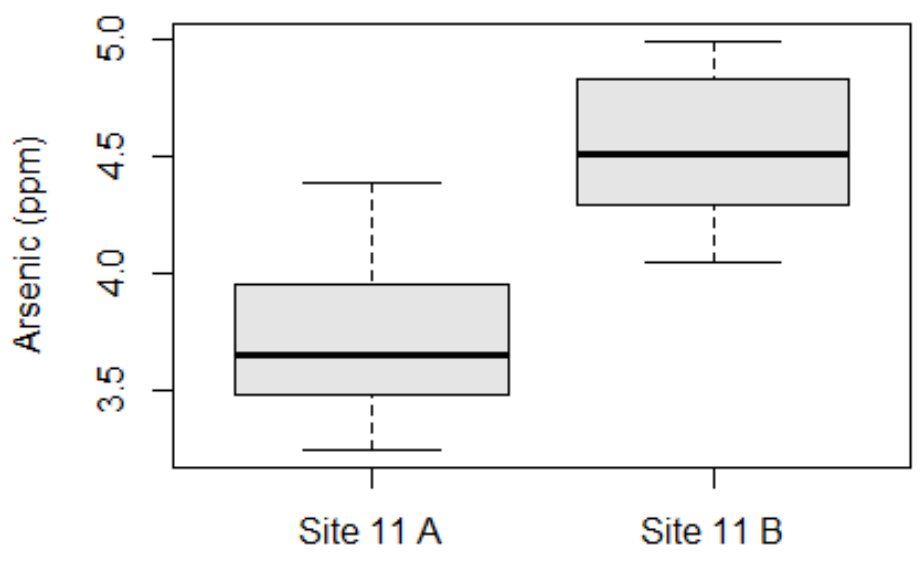

Site 11 Soil Horizons

Figure 9. Variance of raw arsenic values within the $A$ and the $B$ horizons at Site 11. The boxplot shows two distinct populations.

Table 14. Comparison on Site $11 \mathrm{~A}$ and $\mathrm{B}$ horizons indicates center of data between horizons is significantly different.

\begin{tabular}{|l|l|l|}
\hline $\begin{array}{l}\text { Statistical Tests } \\
\text { Site HH 11 }\end{array}$ & $\begin{array}{l}\text { Raw Values } \\
\text { Test Result }\end{array}$ & -value $(\mathrm{a}=\mathbf{0 . 0 5})$ \\
\hline \multirow{3}{*}{ Shapiro-Wilk } & $\mathrm{W}=0.9737$ & $\begin{array}{l}0.8981 \\
\text { (A horizon) }\end{array}$ \\
\cline { 2 - 3 } & $\mathrm{W}=0.9676$ & $\begin{array}{l}0.8596 \\
\text { (B horizon) }\end{array}$ \\
\hline $\begin{array}{l}\text { F-test } \\
\text { Welch Two Sample } \\
\text { t-test }\end{array}$ & $\mathrm{F}=1.2997$ & 0.8056 \\
\hline
\end{tabular}

\subsection{DISTRIBUTION OF ARSENIC IN SOUTHWEST OREGON BY PROVINCE}

The Oregon Department of Environmental Quality (DEQ) reported new

maximum levels by province. Maximum concentration of arsenic at each PSU site (136 total sites) was compared to the modified DEQ data set (673 sites after PSU sites were removed) for the provinces in southwest Oregon. Summary statistics and background calculations for the two data sets are listed in Table 15 and Table 16, which mirror the 
format of the DEQ report (2013) for easy comparison. The DEQ data set used in this study only includes data for provinces covered in this study, and does not include the sites collected by former PSU students. As such, these DEQ results differ slightly from the Oregon statewide report by DEQ (DEQ, 2013). It is also important to note that DEQ averaged the concentrations of arsenic for each site to calculate statistics-PSU studies used the maximum value for each site—-to define maximum levels.

Summary statistics report detectable arsenic in $92.8 \%$ of DEQ data and $87.6 \%$ in PSU data. Both DEQ and PSU data sets report Willamette Valley to have the highest average concentrations. All other rankings differ. The maximum detected concentration and also the largest standard deviation was in the Cascades for DEQ data and Willamette Valley for PSU data. The lowest detection was in the Basin and Range for DEQ data but is in the Klamath Mountains for PSU data. For the PSU data, the highest and average concentrations with standard deviation for each province, respectively, are: South Willamette Valley, 85.4 and $21.99 \pm 10.5$ ppm; Klamath Mountains, 45.4 and $5.42 \pm 3.0$ ppm; Cascade Range, 11.9 and $2.76 \pm 1.2$ ppm; Coast Range, 10.6 and $5.15 \pm 3.0$ ppm; Basin and Range, 2.32 and $1.29 \pm 0.5$ ppm; High Lava Plains, 1.5 and $1.20 \pm 0.2$ ppm. The geological units with the maximum concentration for each province for PSU data are Tfee for Willamette Valley, Jub for Klamath Mountains, Tbaa in the Cascade Range, Ty in the Coast Range, Qba in the Basin and Range and Tmv in the High Lava Plains.

Nonparametric background statistics for data sets with non-detects was run using ProUCL, v4.1.1 to compute reliable upper percentiles of background arsenic 
concentrations, upper tolerance limits (UTLs) and upper prediction limits (UPLs). See Table 16 for background calculation results.

DEQ is currently using 95\% UPLs as the new not-to-exceed values (DEQ, 2013). Background calculation ranks the 95\% Upper Prediction Limit (UPL) from highest to lowest for the DEQ data set as Cascades (20.5), South Willamette Valley (17.9), Basin and Range (12.8), Coast Range (12.7), Klamath Mountains (9.9) and High Lava Plains (20.5). For PSU data, provinces are ranked South Willamette Valley (70.1), Klamath Mountains (19.0), Coast Range (10.6), Cascades (7.0), Basin and Range (2.1) and High Lava Plains (1.7). The 95\% UPL set for the state of Oregon (DEQ, 2013) by province is Cascades (19), South Willamette Valley (18), Basin and Range (12), Coast Range (12), Klamath Mountains (12) and High Lava Plains (7.2). Removing the PSU data from the DEQ data set resulted in 95\% UPLs greater than the Oregon limit for Basin and Range, Cascades Coast Range and High Lava Plains in the new DEQ data set and in higher UPLs in the Klamath Mountains and South Willamette Valley for the PSU data set. There are 31 detected values ( $4.6 \%$ of data set) in the DEQ data and 4 values (3.2\% of data set) in the PSU data that are greater than the new Oregon limits. 
Table 15. Summary statistics for the DEQ and PSU data sets were run for comparison using ProUCL v4.1.

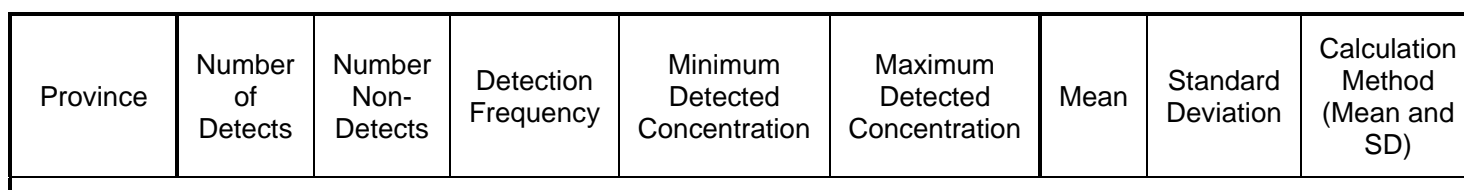

\section{DEQ Summary Statistics: All Concentrations in ppm}

\begin{tabular}{|l|c|c|c|c|c|c|c|l|}
\hline $\begin{array}{l}\text { Basin and } \\
\text { Range }\end{array}$ & 111 & 80 & $58.12 \%$ & 0.7 & 43 & 4.29 & 5.13 & $\begin{array}{l}\text { Kaplan- } \\
\text { Meier }\end{array}$ \\
\hline Cascades & 143 & 2 & $98.62 \%$ & 0.288 & 73.4 & 6.17 & 8.64 & $\begin{array}{l}\text { Kaplan- } \\
\text { Meier }\end{array}$ \\
\hline $\begin{array}{l}\text { Coast } \\
\text { Range }\end{array}$ & 119 & 0 & $100.00 \%$ & 0.9 & 16.4 & 5.72 & 3.44 & Standard \\
\hline $\begin{array}{l}\text { High Lava } \\
\text { Plains }\end{array}$ & 89 & 10 & $89.90 \%$ & 1.28 & 14 & 3.67 & 2.21 & $\begin{array}{l}\text { Kaplan- } \\
\text { Meier }\end{array}$ \\
\hline $\begin{array}{l}\text { Klamath } \\
\text { Mountains }\end{array}$ & 59 & 2 & $96.72 \%$ & 1.38 & 12.8 & 5.14 & 2.80 & $\begin{array}{l}\text { Kaplan- } \\
\text { Meier }\end{array}$ \\
\hline $\begin{array}{l}\text { Willamette } \\
\text { Valley }\end{array}$ & 58 & 0 & $100.00 \%$ & 1.96 & 58.9 & 9.64 & 8.20 & Standard \\
\hline
\end{tabular}

\begin{tabular}{|l|c|c|c|c|c|c|c|l|}
\hline Province & $\begin{array}{c}\text { Number } \\
\text { of } \\
\text { Detects }\end{array}$ & $\begin{array}{c}\text { Number } \\
\text { Non- } \\
\text { Detects }\end{array}$ & $\begin{array}{l}\text { Detection } \\
\text { Frequency }\end{array}$ & $\begin{array}{c}\text { Minimum } \\
\text { Detected } \\
\text { Concentration }\end{array}$ & $\begin{array}{c}\text { Maximum } \\
\text { Detected } \\
\text { Concentration }\end{array}$ & Mean & $\begin{array}{l}\text { Salandard } \\
\text { Deviation }\end{array}$ & $\begin{array}{c}\text { Calation } \\
\text { Method } \\
\text { (Mean and } \\
\text { SD) }\end{array}$ \\
\hline \multicolumn{2}{|l|}{ PSU Summary Statistics: All Concentrations in ppm } \\
$\begin{array}{l}\text { Basin and } \\
\text { Range }\end{array}$ & 15 & 4 & $78.95 \%$ & 0.496 & 2.3 & 1.29 & 0.49 & $\begin{array}{l}\text { Kaplan- } \\
\text { Meier }\end{array}$ \\
\hline Cascades & 37 & 2 & $94.87 \%$ & 0.349 & 11.9 & 2.76 & 1.21 & $\begin{array}{l}\text { Kaplan- } \\
\text { Meier }\end{array}$ \\
\hline $\begin{array}{l}\text { Coast } \\
\text { Range }\end{array}$ & 19 & 0 & $100.00 \%$ & 0.799 & 10.6 & 5.15 & 2.97 & Standard \\
\hline $\begin{array}{l}\text { High Lava } \\
\text { Plains }\end{array}$ & 6 & 2 & $75.00 \%$ & 0.762 & 1.5 & 1.20 & 0.22 & $\begin{array}{l}\text { Kaplan- } \\
\text { Meier }\end{array}$ \\
\hline $\begin{array}{l}\text { Klamath } \\
\text { Mountains }\end{array}$ & 42 & 1 & $97.67 \%$ & 0.301 & 45.4 & 5.42 & 2.97 & $\begin{array}{l}\text { Kaplan- } \\
\text { Meier }\end{array}$ \\
\hline $\begin{array}{l}\text { Willamette } \\
\text { Valley }\end{array}$ & 6 & 2 & $75.00 \%$ & 2.08 & 85.4 & 22.00 & 10.47 & $\begin{array}{l}\text { Kaplan- } \\
\text { Meier }\end{array}$ \\
\hline
\end{tabular}


Table 16. Background calculation for the DEQ and PSU data sets were run for comparison using ProUCL v4.1.

\begin{tabular}{|c|c|c|c|c|c|c|c|c|}
\hline Province & $\begin{array}{c}\text { 90th } \\
\text { Percentile }\end{array}$ & $\begin{array}{c}\text { 95th } \\
\text { Percentile }\end{array}$ & $\begin{array}{l}\text { Calculation } \\
\text { Method } \\
\text { (Percentiles) }\end{array}$ & $\begin{array}{l}90 \% \\
\text { UTL }\end{array}$ & $\begin{array}{l}90 \% \\
\text { UPL }\end{array}$ & $\begin{array}{l}\text { Calculation } \\
\text { Method }\end{array}$ & $\begin{array}{l}95 \% \\
\text { UPL }\end{array}$ & $\begin{array}{l}\text { Calculation } \\
\text { Method }\end{array}$ \\
\hline \multicolumn{9}{|c|}{ DEQ Background Calculations: All Concentrations in ppm } \\
\hline $\begin{array}{l}\text { Basin and } \\
\text { Range }\end{array}$ & 10.87 & 12.74 & $\begin{array}{l}\text { Nonparametric } \\
\mathrm{KM}(\mathrm{z})\end{array}$ & 11.5 & 10.9 & $\begin{array}{l}90 \% \text { UTL } 90 \% \\
\text { Coverage; } 90 \% \\
\text { KM UPL(t) }\end{array}$ & 12.8 & $\begin{array}{l}95 \% \mathrm{KM} \\
\text { UPL(t) }\end{array}$ \\
\hline Cascades & 17.24 & 20.37 & $\begin{array}{l}\text { Nonparametric } \\
\mathrm{KM}(\mathrm{z})\end{array}$ & 18.6 & 17.3 & $\begin{array}{l}90 \% \text { UTL } 90 \% \\
\text { Coverage; } 90 \% \\
\text { KM UPL(t) }\end{array}$ & 20.5 & $\begin{array}{l}95 \% \mathrm{KM} \\
\text { UPL(t) }\end{array}$ \\
\hline $\begin{array}{l}\text { Coast } \\
\text { Range }\end{array}$ & 10.49 & 12.16 & Nonparametric & 11.4 & 10.9 & $\begin{array}{l}90 \% \text { UTL } 90 \% \\
\text { Coverage; } 90 \% \\
\text { UPL }\end{array}$ & 12.7 & $95 \%$ UPL \\
\hline $\begin{array}{l}\text { High Lava } \\
\text { Plains }\end{array}$ & 6.50 & 7.31 & $\begin{array}{l}\text { Nonparametric } \\
\mathrm{KM}(\mathrm{z})\end{array}$ & 6.9 & 6.5 & $\begin{array}{l}90 \% \text { UTL } 90 \% \\
\text { Coverage; } 90 \% \\
\text { KM UPL(t) }\end{array}$ & 7.4 & $\begin{array}{l}95 \% \mathrm{KM} \\
\text { UPL(t) }\end{array}$ \\
\hline $\begin{array}{l}\text { Klamath } \\
\text { Mountains }\end{array}$ & 8.73 & 9.75 & $\begin{array}{l}\text { Nonparametric } \\
\mathrm{KM}(\mathrm{z})\end{array}$ & 9.4 & 8.8 & $\begin{array}{l}90 \% \text { UTL } 90 \% \\
\text { Coverage; } 90 \% \\
\text { KM UPL(t) }\end{array}$ & 9.9 & $\begin{array}{l}95 \% \mathrm{KM} \\
\text { UPL(t) }\end{array}$ \\
\hline $\begin{array}{l}\text { Willamette } \\
\text { Valley }\end{array}$ & 16.12 & 17.53 & Nonparametric & 17.5 & 16.9 & $\begin{array}{l}90 \% \text { UTL } 90 \% \\
\text { Coverage; } 90 \% \\
\text { UPL }\end{array}$ & 17.9 & $95 \%$ UPL \\
\hline Province & $\begin{array}{c}\text { 90th } \\
\text { Percentile }\end{array}$ & $\begin{array}{c}\text { 95th } \\
\text { Percentile }\end{array}$ & $\begin{array}{l}\text { Calculation } \\
\text { Method } \\
\text { (Percentiles) }\end{array}$ & $\begin{array}{l}90 \% \\
\text { UTL }\end{array}$ & $\begin{array}{l}90 \% \\
\text { UPL }\end{array}$ & $\begin{array}{l}\text { Calculation } \\
\text { Method }\end{array}$ & $\begin{array}{l}95 \% \\
\text { UPL }\end{array}$ & $\begin{array}{l}\text { Calculation } \\
\text { Method }\end{array}$ \\
\hline \multicolumn{9}{|c|}{ PSU Background Calculations: All Concentrations in ppm } \\
\hline $\begin{array}{l}\text { Basin and } \\
\text { Range }\end{array}$ & 1.81 & 2.00 & $\begin{array}{l}\text { Nonparametric } \\
\mathrm{KM}(\mathrm{z})\end{array}$ & 2.1 & 1.9 & $\begin{array}{l}90 \% \text { UTL } 90 \% \\
\text { Coverage; } 90 \% \\
\text { KM UPL(t) }\end{array}$ & 2.1 & $\begin{array}{l}95 \% \mathrm{KM} \\
\text { UPL(t) }\end{array}$ \\
\hline Cascades & 5.88 & 6.80 & $\begin{array}{l}\text { Nonparametric } \\
\mathrm{KM}(\mathrm{z})\end{array}$ & 6.7 & 6.0 & $\begin{array}{l}90 \% \text { UTL } 90 \% \\
\text { Coverage; } 90 \% \\
\text { KM UPL(t) }\end{array}$ & 7.0 & $\begin{array}{l}95 \% \mathrm{KM} \\
\text { UPL(t) }\end{array}$ \\
\hline $\begin{array}{l}\text { Coast } \\
\text { Range }\end{array}$ & 8.41 & 10.33 & Nonparametric & 10.3 & 10.3 & $\begin{array}{l}90 \% \text { UTL } 90 \% \\
\text { Coverage; } 90 \% \\
\text { UPL }\end{array}$ & 10.6 & $95 \%$ UPL \\
\hline $\begin{array}{l}\text { High Lava } \\
\text { Plains }\end{array}$ & 1.51 & 1.62 & $\begin{array}{l}\text { Nonparametric } \\
\mathrm{KM}(\mathrm{z})\end{array}$ & 1.8 & 1.6 & $\begin{array}{l}90 \% \text { UTL } 90 \% \\
\text { Coverage; } 90 \% \\
\text { KM UPL(t) }\end{array}$ & 1.7 & $\begin{array}{l}95 \% \mathrm{KM} \\
\text { UPL(t) }\end{array}$ \\
\hline $\begin{array}{l}\text { Klamath } \\
\text { Mountains }\end{array}$ & 15.59 & 18.5 & $\begin{array}{l}\text { Nonparametric } \\
\mathrm{KM}(\mathrm{z})\end{array}$ & 18.0 & 15.9 & $\begin{array}{l}90 \% \text { UTL } 90 \% \\
\text { Coverage; } 90 \% \\
\text { KM UPL(t) }\end{array}$ & 19.0 & $\begin{array}{l}95 \% \mathrm{KM} \\
\text { UPL(t) }\end{array}$ \\
\hline $\begin{array}{l}\text { Willamette } \\
\text { Valley }\end{array}$ & 50.9 & 60.5 & $\begin{array}{l}\text { Nonparametric } \\
\mathrm{KM}(\mathrm{z})\end{array}$ & 75.7 & 56.7 & $\begin{array}{l}90 \% \text { UTL } 90 \% \\
\text { Coverage; } 90 \% \\
\text { KM UPL(t) }\end{array}$ & 70.1 & $\begin{array}{l}95 \% \mathrm{KM} \\
\text { UPL(t) }\end{array}$ \\
\hline
\end{tabular}




\section{CHAPTER VI: DISCUSSION}

The primary purpose of this study was to measure the range of naturally occurring arsenic concentrations in southwestern Oregon soils. I will now discuss the distribution of arsenic within horizons, why the DEQ and PSU data differ, as well as what natural factors may be contributing to those levels. Regression tests were applied to assess potential causal relationships between arsenic and environmental factors.

\subsection{LEVELS OF ARSENIC IN SOUTHWEST OREGON SOILS}

\subsubsection{DISTRIBUTION OF ARSENIC IN A AND B HORIZONS}

The box plot (Figure 8) for Site HH11 samples illustrates that the A and B horizons are separate populations, and demonstrates the necessity of sampling separate horizons in order to correctly determine the largest concentration of arsenic at a site. The A and B horizon comparisons for the 119 PSU sites taken as a whole set of numbers did not show the horizons to be statistically different. However, if only the A horizon was sampled (Table 12), 53\% of the higher concentrations found in the B horizon (Table 13) would have been missed. Likewise, if only the B horizon was sampled, $40 \%$ of the samples would have been incorrectly assessed. This practice would result in the interpretation that naturally occurring arsenic concentrations are lower than is actually the case. It is clear that sampling both horizons is important to increase the probability that the highest value within the profile is collected.

\subsubsection{COMPARISON BETWEEN DEQ AND PSU DATA SETS}

Mapped arsenic concentrations (Figure 7) of the PSU samples show that arsenic 
from the Cascade Range, and eastward within the study area, only contain low levels of arsenic $(<2.82 \mathrm{ppm})$. This finding is not in agreement with the $95 \%$ limit of upper concentrations ( 7.2 and $12 \mathrm{mg} / \mathrm{kg}$, respectively) set by the Oregon DEQ for the High Lava Plains and Basin and Range provinces. The DEQ data set includes sites that are outside the study area. To obtain the 95\% limit used as the DEQ standard (DEQ, 2013), sites to the east of the study area must have much higher concentrations of arsenic in soils. No other spatial relationship is evident between arsenic concentrations and province; west of the Cascade Range, low to moderate soil arsenic concentrations (0-17.5 ppm) were measured.

The difference from the new set standard (DEQ, 2013) in the modified DEQ data set was not large but the 95\% UPL calculated for the PSU data set was significantly different from the standard (Table 16). For the PSU data set, UPLs in the Klamath Mountains and South Willamette Valley were higher than the new standard (DEQ, 2013) but much lower for all other provinces. The PSU data set is small enough that it may not be representative of the spectrum of arsenic concentrations in Oregon. Also, the sites in the PSU data set are constrained to the study area, whereas the modified DEQ data set includes all sites within the listed provinces; spatial data was not a part of the DEQ data set and so sites outside the study area could not be removed. This means that sites from formations that are not found within the study area are represented in the modified DEQ data set. Another probable factor contributing to these differences is that DEQ used an average of all values collected at each site to calculate maximum background levels; PSU 
used the maximum value. In any event, the relationship of arsenic in soils is much more complex than can be defined by the province it is located in.

\subsubsection{COMPARISON WITH A FORMER PSU DATA SET}

In a study of arsenic concentrations in northwest Oregon, Ricker (2013) evaluated 186 samples from both the A and B horizons. The northwest Oregon study area also included the Coast Range, Cascade Range and Willamette Valley provinces. Results for mean and standard deviation for A and B horizons, respectively, are $6.09 \pm 2.65$ and $10.26 \pm 4.65$ for the Coast Range, $3.59 \pm 3.72$ and $3.25 \pm 2.23$ for Willamette Valley and $2.45 \pm 4.29$ and $3.12 \pm 4.47$ for the Cascade Range.

In comparison, southwest Oregon results for mean and standard deviation for the set of 136 maximum values are $5.15 \pm 2.97$ for the Coast Range, $21.99 \pm 10.47$ for South Willamette Valley and $2.76 \pm 1.21$ for the Cascade Range. The difference in values between studies can be explained by differences in geology in different parts of these provinces. For example, mid-Miocene Columbia River Basalt volcanics occur in the central and northern extent of the Coast Range, but do not extend into the southern part of the range which is dominated by both fluvial and marine deposits of the Umpqua Group — Roseburg (Tmsm), Lookingglass (Tmsc) and Flournoy (Tmss) Formations — and the Tyee (Tt) Formation. Eugene Formation silts and sands (Tfe, marine Tfee) and Fisher Formation tuffs and conglomerates (Tfe) are marine and nearshore deposits (Orr and Orr, 2012) from the late Eocene, when the eastern border of what became Willamette Valley was ocean shoreline (Orr and Orr, 2012). In the late Quaternary, the Missoula Floods brought silts from Montana into Willamette Valley to Eugene (McClaughry et al, 2010); 
samples in this study were taken south of Eugene. Samples and statistics by Ricker (2013) for the Willamette Valley likely reflect Missoula Flood deposits. In contrast, the Eugene and Fisher Formations exposed in South Willamette Valley have long been known to have high arsenic (Ravenscroft et al., 2009; Hinkle and Polette, 1999). The values for the Cascade Range are similar because the Cascades are younger soils; the soils have not had enough time to develop a B horizon where oxides accumulate and can adsorb and concentrate higher levels of naturally occurring arsenic.

\subsection{RELATIONSHIP OF ARSENIC WITH ENVIRONMENTAL FACTORS}

\subsubsection{REGRESSION TREE}

Regression analysis was done to assess the relationship of six environmental factors to arsenic concentrations: rock type, rock age, soil order, soil color, elevation and geomorphic province. Rock and soil factors were chosen because former studies have stated correlations with rock type (Ravenscroft et al., 2009; Hinkle and Polette, 1999) or with clays (Ravenscroft et al., 2009) to high arsenic. Elevation and province were chosen to investigate potential spatial relationships, since new DEQ limits are delineated by province.

Using a statistical regression tree produced the root, node 1: soil order, node 2: elevation and node 3: rock type as the strongest influences on arsenic concentrations (Figure 10). Each node was looked at individually and tested for normality and variance using the Shapiro-Wilk test and the F-Test, respectively (Ellison and Gotelli, 2013). The leaves of the tree report the number of observations and mean of arsenic concentrations. 


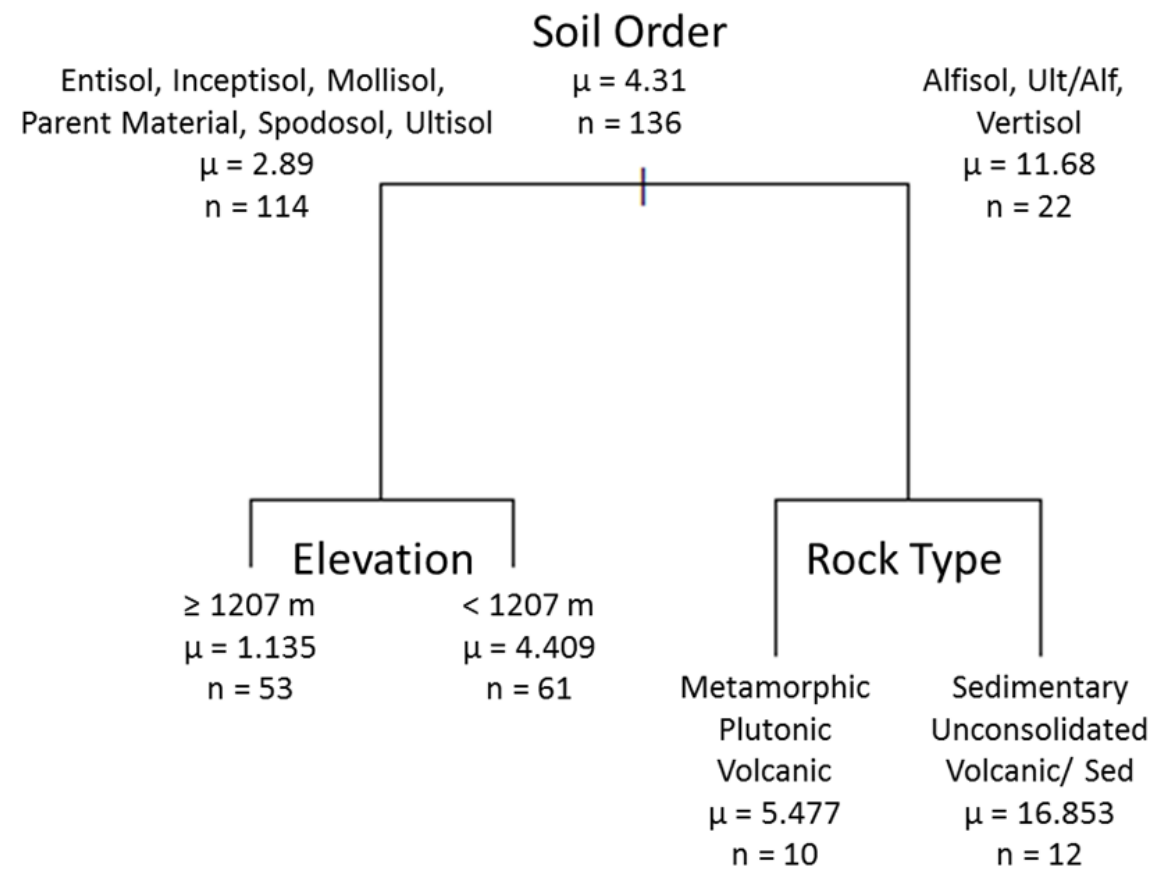

Figure 10: Regression tree indicates soil order, elevation and rock type are key factors. The regression splits groups with higher mean arsenic concentration to the right branches.

Node 1, soil order, splits the data at the mean of arsenic $(\mu=4.31)$.This splits the data into groups Node 1L and Node 1R. Node 1L $(n=114)$ consists of soil order groups Entisols, Inceptisols, Mollisols, Parent Material, Spodosols and Ultisols. Node 1R (n=22) consists of Alfisols, Ultisols/Alfisols and Vertisols. Node 2, the left split from Node 1L, is based on the elevation of the 114 samples that do not include Alfisol or Vertisol orders. Node 2L consists of elevations greater than or equal to 1,207 meters $(n=53)$. Node2R contains elevations less than or equal to 1,207 meters $(n=61)$. Node 3 splits Alfisols, Ultisol/Alfisols and Vertisols by rock type into Node 3L $(n=10)$ and Node 3R $(n=12)$. Node 3L includes metamorphic, plutonic and volcanic rock types, and Node 3R includes sedimentary, unconsolidated sediments and mixed volcanic/sedimentary units. 


\subsubsection{FOREST REGRESSION}

The random forest was performed on the data set multiple times using the R Party Package; a conditional permutation scheme provides unbiased variable selection and variable importance for predictor variables of different types, as well as reduces the appearance that correlated predictor variables are more important that uncorrelated ones (Strobl et al., 2009). Conditional variable importance is calculated by randomly shuffling the values of a given independent variable thereby "breaking" the variable's bond to the response. Then, the difference of the model accuracy before and after the random permutations, averaged over all trees in the forest, tells us how important that predictor is for determining the outcome (Shih, 2011; Strobl et al., 2009).

At 2,000 trees, the results were consistent between forests with different random seeds set (Table 17). The variable importance plot ranked elevation high, followed by soil order and rock type (Figure 11). The forest regression predicts the same three variables as the regression tree for significant predictors of arsenic, however, the regression tree ranked soil order as more significant than elevation. Predictors in the forest regression are considered significant when they rank larger than the absolute value of the largest negative value in the variable importance test. 


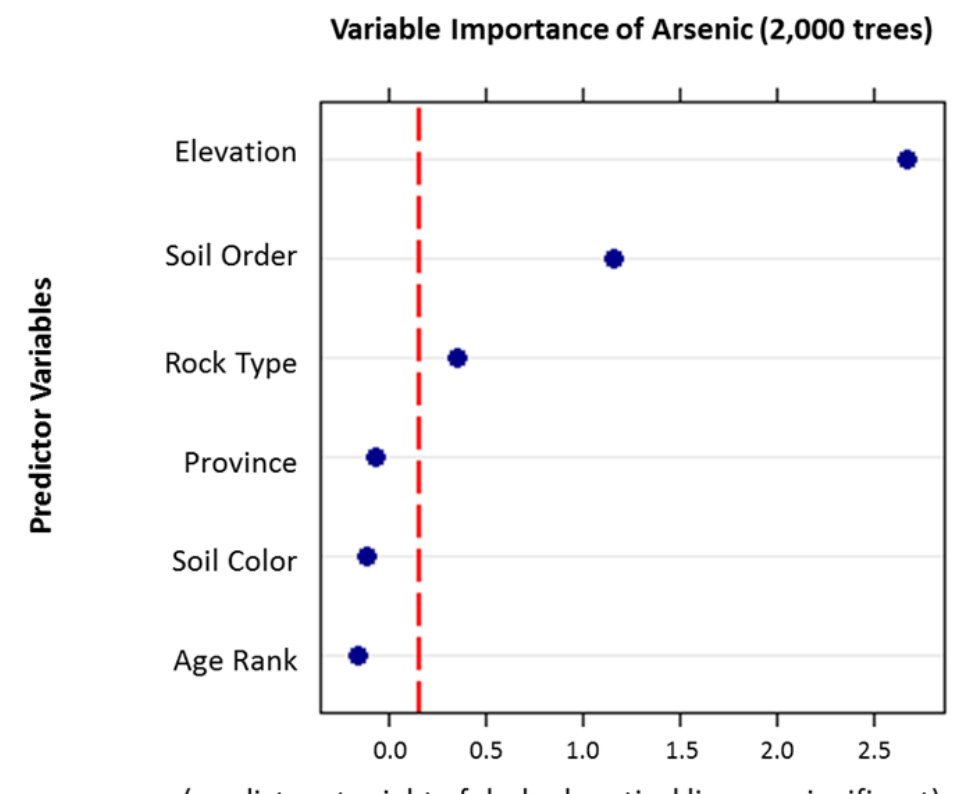

Figure 11: Variable importance plot showing the predictive ranking of variables using a 2,000 trees forest and random seed of 729 .

Table 17. Using the Party Package in $R$, forest regressions were done with increasing tree numbers until ranking for significant predictors did not vary with different seeds.

Variable Importance Results from Three 2,000-Tree Forests

\begin{tabular}{|c|c|c|c|c|c|c|}
\hline Seed & Elevation & Soil Order & Rock Type & Province & Soil Color & Age Rank \\
\hline 729 & 2.6674 & 1.1541 & 0.3470 & -0.0632 & -0.1080 & -0.1564 \\
1052 & 2.8072 & 1.4535 & 0.3697 & -0.1224 & -0.1390 & -0.2547 \\
2594 & 2.6708 & 1.2964 & 0.3773 & -0.1837 & -0.1018 & -0.1484 \\
\hline
\end{tabular}

\subsubsection{RELATIONSHIP OF ARSENIC TO SOIL ORDER}

The box plot for Node 1 (Figure 12) shows the variance within each sub-group. A comparison between the soil order sub-groups indicates that Alfisol and Vertisol soils have a much higher variation. The Shapiro-Wilk normality test shows that neither Node 1R nor Node 1L has a normal distribution (p-values: 1.2e-06 and 5.8e-09, respectively). Box-Cox analysis was completed to see if a normal distribution could be obtained through transformation $(\lambda=0.2626$ at $95 \%$ confidence interval $)$, and indicated cube root 
transformation would convert raw data to a distribution closer to normal. Cube transformation resulted in a normal distribution for Node 1R, only (Shapiro-Wilk pvalues: 0.125 versus $1.59 \mathrm{e}-4$ for Node $1 \mathrm{~L})$ so node data was not transformed for regression tests. Data were cube root transformed for variance plots for visual clarity. The means of the two groups are widely separated compared to within each group (F-ratio: 55.8534), so variance in Node $1 \mathrm{R}$ is unequal to the variance in Node $1 \mathrm{~L}$.

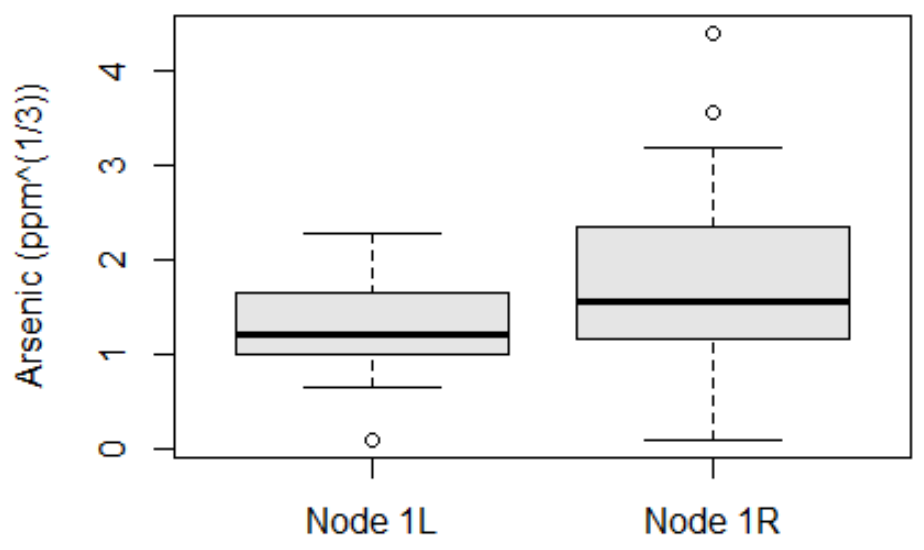

Soil Orders

Figure 12: Cube root transformed variance of Alfisols, Ultisols/Alfisols and Vertisols (Node 1R) versus Entisols, Inceptisols, Mollisols, Parent Material, Spodosols and Ultisols.

To determine if there is a significant difference between soil order groups a nonparametric test was used, since it does not require normal distributions or equal variance to be valid. The Wilcoxon rank sum test (Ellison and Gotelli, 2013), which is moderately robust for non-normal distributions and unequal variance, was used and the results indicate that the means of arsenic concentrations in the two soil order groups are significantly different ( $\mathrm{p}$-value $=0.01463$ ). The F-ratio and Wilcoxon test support that Node 1R and Node 1L are statistically different; the arsenic concentrations for soil orders 
that include Alfisols and Vertisols are significantly different than arsenic concentrations for soil orders that do not include Alfisols and Vertisols. This is a reasonable division; Alfisols, Ultisols and Vertisols are older than the other soils, and therefore have had more time to accumulate the oxides and clays that retain and concentrate arsenic. Statistical results are listed in Table 18.

Table 18: Summary of statistical tests run on Node 1 of the regression tree for soil order by split: orders that include Alfisols and Vertisols versus other orders.

\begin{tabular}{|l|l|l|l|}
\hline Data Type: Node 1 & Statistical Test & Test value & p-value ( $\boldsymbol{\alpha}=\mathbf{0 . 0 5})$ \\
\hline Raw Arsenic Values & Shapiro -Wilk & $\mathrm{W}=0.5957$ & $\begin{array}{l}1.193 \mathrm{e}-06 \\
\text { (Alfisols, Ult/Alfs and Vertisols) }\end{array}$ \\
\cline { 3 - 4 } & & $\mathrm{W}=0.8605$ & $\begin{array}{l}5.814 \mathrm{e}-09 \\
\text { (non-Alfisol and Vertisol soils) }\end{array}$ \\
\cline { 3 - 4 } & F-test & $\mathrm{F}=55.8534$ & $<2.2 \mathrm{e}-16$ \\
\cline { 2 - 4 } & Wilcoxon Rank Sum & $\mathrm{W}=1667.5$ & 0.01463 \\
\hline Cube Root Arsenic Values & Shapiro -Wilk & $\mathrm{W}=0.9304$ & $\begin{array}{l}0.125 \\
\text { (Alfisols, Ult/Alfs and Vertisols) }\end{array}$ \\
\cline { 3 - 4 } & & $\mathrm{W}=0.9456$ & $\begin{array}{l}1.59 \mathrm{e}-4 \\
\text { (non-Alfisol and Vertisol soils) }\end{array}$ \\
\cline { 3 - 4 } & & $\mathrm{F}=3.6943$ & $6.837 \mathrm{e}-06$ \\
\hline & F-test & $\mathrm{W}=1667.5$ & 0.01463 \\
\hline & Wilcoxon Rank Sum & & \\
\hline
\end{tabular}

\subsubsection{RELATIONSHIP OF ARSENIC TO ELEVATION}

The two subsets from Node 2 of the regression tree were split based on elevation. Higher arsenic concentrations occur in the lower elevation subset which also has more variability as can be seen in the box plots that were created to graphically represent these two subsets (Figure 13). The Shapiro-Wilk normality test indicates that arsenic concentrations in the low elevation subset (Node 2R) is not normally distributed, but data at elevations greater than 1,207 meters are normally distributed (p-values: 2.759e-16 and 0.0797, respectively). To see if normality could be attained by transforming the data, Box-Cox analysis (Gotelli and Ellison, 2013) was conducted $(\lambda=0.2626$ at $95 \%$ 
confidence interval). The lambda $(\lambda)$ value from the Box-Cox indicates that a cube root transformation of arsenic data may show normal distributions for arsenic concentrated in samples collected from low elevation. Results from the Shapiro-Wilk normality test show that subsets defined by Node $2 \mathrm{R}$ and Node $2 \mathrm{~L}$ are not normally distributed despite cube root transformation of the data, so raw data were again used for further analysis (ShapiroWilk p-values: 9.5e-06 and 6.7e-08, respectively). The cube root transformed data were again used for variance plots for visual clarity and for comparability.

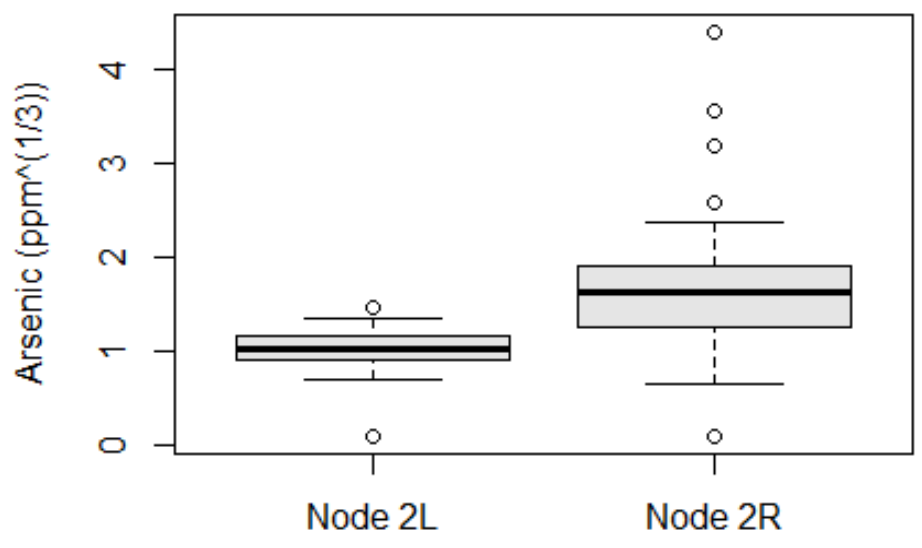

Elevation

Figure 13: Box plots for subsets created by the regression tree at Node 2. Node $2 \mathrm{~L}$ contains the data set with elevations above $1,207 \mathrm{~m}$. while Node $2 R$ is the data set below $1,207 \mathrm{~m}$.

The F-ratio test indicates that the two data sets do not have equal variance (Fratio: 238.4). Since distribution is not normal, the Wilcoxon test was again used; the means of Node2R and Node 2L are statistically different (p-value: 4.4e-13). Higher soil arsenic concentrations are found at elevations lower than 1,207 meters. Statistical results are listed in Table 1. 
Table 19: Summary of statistical tests run on Node 2 of the regression tree for both elevation splits: less than or equal to $1,207 \mathrm{~m}$. and greater than or equal to $1,207 \mathrm{~m}$.

\begin{tabular}{|l|l|l|ll|}
\hline Data Type & Statistical Test & Test value & p-value (o=0.05) \\
\hline \multirow{4}{*}{ Raw Arsenic Values } & Shapiro -Wilk & $\mathrm{W}=0.4275$ & $2.759 \mathrm{e}-16 \quad(1,207 \mathrm{~m})$ \\
\cline { 2 - 5 } & & $\mathrm{W}=0.9614$ & $0.0797 \quad(1,207 \mathrm{~m})$ \\
\cline { 2 - 5 } & F-test & $\mathrm{F}=238.4135$ & $<2.2 \mathrm{e}-16$ & \\
\cline { 2 - 5 } & Wilcoxon Rank Sum & $\mathrm{W}=3842.5$ & $4.4 \mathrm{e}-13$ & \\
\hline Cube Root Arsenic Values & Shapiro -Wilk & $\mathrm{W}=0.8997$ & $9.483 \mathrm{e}-06 \quad(1,167 \mathrm{~m})$ \\
\cline { 2 - 5 } & & $\mathrm{W}=0.7655$ & $6.718 \mathrm{e}-08 \quad(1,167 \mathrm{~m})$ \\
\cline { 2 - 5 } & F-test & $\mathrm{F}=2.8591$ & $7.891 \mathrm{e}-05$ & \\
\cline { 2 - 5 } & Wilcoxon Rank Sum & $\mathrm{W}=3842.5$ & $4.4 \mathrm{e}-13$ & \\
\hline
\end{tabular}

\subsubsection{RELATIONSHIP OF ARSENIC TO ROCK TYPES}

Node three of the regression tree separated subsets based on rock type. The most variability of all the subsets analyzed occurs in the group containing sedimentary and mixed volcanic and sedimentary rock types and unconsolidated sediments. The highest arsenic concentrations are also in this subset (Node 3R) as can be seen by the box plots that were created to graphically present both subsets of Node 3 (Figure 14).

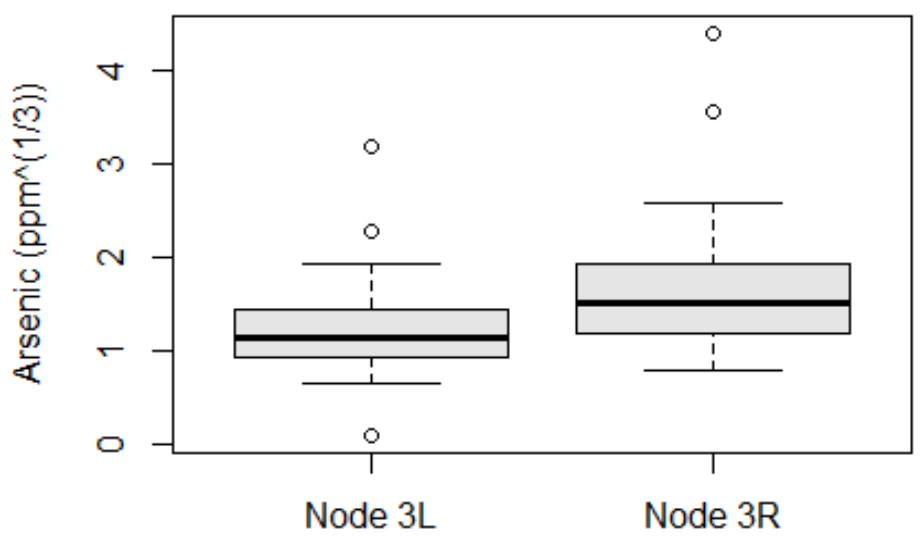

Rock Type

Figure 14: Box plots of arsenic values for the subsets created by the regression tree at Node 3. Node 3R contains sedimentary, mixed volcanic/ sedimentary rock types and unconsolidated sediments while Node 3L contains metamorphic, plutonic and volcanic rock types. 
Results of the Shapiro-Wilk normality test (Table 20) indicate that arsenic concentrations in both splits of Node 3 do not have normal distributions (p-values: 3.6e14 and 1.1e-14, respectively). Box-Cox analysis indicates that the two subsets may show normal distributions after cube root transformation of the data $(\lambda=0.2626$ at a $95 \%$ confidence interval). The Shapiro-Wilk normality test was conducted on the cube transformed data, and the results for the rock type groups defined by Node 3R and Node 3L (p-values: $1.3 \mathrm{e}-06$ and $2.8 \mathrm{e}-04$, respectively) still show that the data sets are not normally distributed. Therefore, raw data were preserved for regression analyses, and again, cube root transformed data were used for variance plots for visual clarity and comparability.

Table 20: Summary of statistical tests run on Node 3 subsets for both rock type origin splits: sedimentary with mixed sedimentary/volcanic and unconsolidated sediments versus metamorphic, plutonic and volcanic rock types.

\begin{tabular}{|c|c|c|c|}
\hline Data Type & Statistical Test & Test value & p-value $(\alpha=0.05)$ \\
\hline \multirow[t]{4}{*}{ Raw Arsenic Values } & \multirow[t]{2}{*}{ Shapiro -Wilk } & $\mathrm{W}=0.4079$ & $\begin{array}{l}\text { 3.637e-14 (Sedimentary, } \\
\text { Volcanic/ Sed, Unconsolidated) }\end{array}$ \\
\hline & & $\mathrm{W}=0.4984$ & $\begin{array}{l}\text { 1.087e-14 } \\
\text { (Metamorphic, Plutonic, Volcanic) }\end{array}$ \\
\hline & F-test & $\mathrm{F}=238.4135$ & $<2.2 \mathrm{e}-16$ \\
\hline & Wilcoxon Rank Sum & $\mathrm{W}=3326.5$ & $4.527 \mathrm{e}-06$ \\
\hline \multirow[t]{4}{*}{ Cube Root Arsenic Values } & \multirow[t]{2}{*}{ Shapiro -Wilk } & $\mathrm{W}=0.8373$ & $\begin{array}{l}1.315 \mathrm{e}-06 \quad \text { (Sedimentary, } \\
\text { Volcanic/ Sed, Unconsolidated) }\end{array}$ \\
\hline & & $\mathrm{W}=0.9264$ & $\begin{array}{l}0.0002829 \\
\text { (Metamorphic, Plutonic, Volcanic) }\end{array}$ \\
\hline & F-test & $\mathrm{F}=1.166$ & 0.5267 \\
\hline & Welch's T-Test & $\mathrm{t}=4.7053$ & $6.751 \mathrm{e}-06$ \\
\hline
\end{tabular}

The F-ratio test was conducted and shows that there is not equal variance between the two subsets (F-ratio: 238.4) and indicates there is a large separation in the means of these groups compared to within each group. Since the two subsets failed to show normal distributions the Wilcoxon rank sum test was used to see if arsenic concentrations 
are significantly different between rock type subsets. The test results (Table 20) indicate that there is a significant difference between the two subsets (p-value: 4.5e-06).

\subsubsection{SUMMARY OF TOP THREE PREDICTORS}

Statistical analyses of 255 soil samples were studied to determine any relationships that exist between six environmental predictors and arsenic concentrations in southwestern Oregon. Initial analysis included a Classification and Regression Trees (CART) model, which determined that three of the six environmental predictors are influential on arsenic levels: soil order, elevation and rock type. Validation of the CART model with random forest analysis resulted in the same three variables selected as important predictors. Non-parametric analysis using the Wilcoxon test was used as the raw data for three predictors did not show equal variance or normal distribution. For all three predictors, the null hypothesis was rejected as there is a significant difference between the median within each subgroup. This validates the logic of the splits in the CART models.

According to Ravenscroft et al. (2009), high soil-As or inorganic arsenic is associated with carbonaceous shales and volcanic materials and rocks, with silt and clayey soils generally containing more arsenic than sandy soils. This study was found to concur that soil with more clay contain higher arsenic; percent clay was not tested, however soil orders defined as having a well-developed B-horizon, which accumulates clay minerals, were grouped as having a higher mean of arsenic concentrated in soil. Sedimentary rocks showed the highest arsenic levels; soils collected from sample sites 
underlain by sedimentary, mixed sedimentary and volcanic or unconsolidated rock had the highest mean of arsenic $(\mu=16.85)$.

The first important predictor of arsenic levels was soil order. The few soil orders that do contain Alfisol, Ultisol/Alfisol and Vertisol soils $(\mathrm{n}=22)$, showed greater variation and higher arsenic levels ranging from 0.001-85.4 ppm (Figure 12). Entisols, Inceptisols, Mollisols, Spodosols, Ultisols, and Parent Material, $(\mathrm{n}=114)$, have less variation in arsenic levels, 0.001-11.9 ppm. In general, Alfisols, Ultisols and Vertisols have increased weathering, soil and clay development and support literature that arsenic levels are greater in soil orders with increased clay development (Ravenscroft et al., 2009). Despite Ultisol being the most well developed soil, it was grouped by the regression tree with less developed soils. The mean for Ultisol soils was 3.52 and 3.94 for the A and B horizons, respectively. The Ult/Alf order had a higher mean of 8.2 for the A horizon and 15.12 for the B horizon. The $\mathrm{pH}$ and reclassification of the Ult/Alf samples to Ultisol or Alfisol orders would be necessary to determine if these higher values would raise the mean arsenic for Ultisols enough to fit with the other well developed soils in the regression analysis.

Elevation was a second important predictor of arsenic levels (the most important predictor by forest regression). Samples taken from lower elevation 1,207 m, ( $\mathrm{n}=61)$, have higher levels of arsenic between 0.001-85.4 ppm, while samples collected at higher elevation $1,207 \mathrm{~m},(\mathrm{n}=53)$, were found to contain lower levels of arsenic, 0.001-3.12 ppm (Figure 13). The highest values were in Eugene, Oregon at only 292 meters. 
Rock weathering is a natural process leading to the release of arsenic and its introduction to the aquatic environment (Mitsunobu et al., 2006). The mountain ranges of this study area receive a considerable amount of rain, where arsenic is carried downstream in water or sediments and accumulates in low-lying areas. These findings may indicate that biota and communities at lower elevations are at a greater risk for exposure to arsenic but to what degree is not a part of this study.

Node 3 split arsenic concentrations by rock type. Study of rock type revealed that variation in arsenic levels with mixed volcanic and sedimentary, sedimentary and unconsolidated rock $(\mathrm{n}=12)$ is greater with a range of 0.496-85.4 ppm, compared to arsenic levels in Metamorphic, Plutonic and Volcanic origins $(\mathrm{n}=10)$, with a range of 0.001-32.6 ppm (Figure 14). The split by the CART model again seems logical; volcanic activity and rock weathering release arsenic, hydrologic processes transport arsenic from high mountain ranges to areas below where sediments accumulate, then arsenic adsorbs to sediments. The highest arsenic concentrations in this study are within a region where the high arsenic concentration in aquifers is associated with volcanic and sedimentary rock (Hinkle and Polette, 1999). Lastly, the map scale of 1:500,000 (Walker and MacLeod, 1991) only provides for the dominant rock type where the sample was taken, so error may be introduced if it is not the parent material for that soil.

A potential issue in the study of arsenic concentration is how non-detect samples are reported for analyses. Helsel (2006) indicates that replacing the detection limit with an arbitrary fraction results in inaccurate analyses of regression slopes, correlation coefficients, means and standard deviation. As further research on arsenic concentration 
is conducted, this must be factored into the analysis. R packages (NADA) are available to help analyze non-detects (Helsel, 2006), and the ProUCL software has tests specifically for data sets that include non-detect samples.

Caution was exercised when creating the data set for our CART model to avoid inflating predictors; the maximum sample from each site was selected instead of including all data and treating each sample as independent despite being taken from the same site. Development of proximal horizons certainly share the same environmental influences, however, the degree of influence on one horizon from another is difficult to measure and beyond the scope of this study.

Power is a factor that must be considered when performing data analysis. As data are reformatted and transformed away from their original format, power is lost. When data have unequal variance and non-normal distribution, non-parametric tests like the Wilcoxon Rank Sum test are used. This statistic ranks data, thereby lowering the power. The lower the power of the test, the higher will be the probability of a type II error as power is the probability of rejecting the null hypothesis when it is false (Crawley, 2007).

Further, caution is imperative when studying real world problems. Arsenic concentrations have dire effects on the health of our ecosystem and therefore human consumption. While this study only shows sample location and arsenic concentration, and the investigation of potential arsenic sources does not prescribe remediation, the potential for error was still heavily taken into account. In this analysis, we are claiming that we are 
$95 \%$ confident that the hypothesis is true while we are okay with a $5 \%$ chance of making a type I or type II error, where a test statistic of $\alpha=0.05$, was used.

A type I error using the Shapiro-Wilk test as an example would occur if the null hypothesis that arsenic concentrations are normally distributed is rejected when it is true. The fact that arsenic concentrations are higher at lower elevations may not be addressed, thereby undermining the importance of elevation as a predictor of arsenic. On the other hand, a type II error would occur if the null hypothesis that ranked medians of arsenic are not different at high and lower elevations is not rejected when the difference is significant. Either type of error could result in wasted resources in research time and false claims by investigating a predictor variable that does not have a true effect on the level of arsenic, or by undermining the importance of an environmental predictor.

The findings from this study are in general agreement with literature (Ravenscroft et al., 2009) where arsenic levels are higher in soils with increased weathering and clay development, in this case Alfisols, Ultisol/Alfisols and Vertisols. Samples taken from lower elevations than 1,207 $\mathrm{m}$ were found to contain higher levels of arsenic as natural weather events carry arsenic downstream and is adsorbed to and concentrates within sediments (Mitsunobu et al., 2006). Further, samples of sedimentary rock origin were also found to have higher levels of arsenic by Hinkle and Polette (1999). 


\section{CHAPTER VII: CONCLUSIONS}

There are 255 total samples from 136 sites in this study; 123 samples are from the A horizon (Table 12) and 132 samples were taken from the B horizon (Table 13). The highest value in the A and B horizons, respectively, are $63.2 \mathrm{ppm}$ and $85.4 \mathrm{ppm}$. These maximum values are both from the Eugene Formation (Tfe, or Tfee where mapped separately as marine).

Comparison of arsenic between the A and B horizons at site HH11 showed arsenic to be centered on different means with low deviation. This supports that collection of one sample per horizon is a reliable representation of the level of arsenic within that horizon. This also demonstrates the necessity of sampling separate horizons in order to correctly determine the largest concentration of arsenic at a site.

Comparison of A and B horizons for all 119 PSU sites that had arsenic in both A and B did not show a statistical difference. In this study arsenic was not found to be higher in the A or the B horizon; if just the A or just the B horizon were sampled, the maximum concentration would not have been collected half the time. In this study $39.5 \%$ of sites are higher in arsenic in the A horizon while 52.9\% are higher in the B horizon, with $7.6 \%$ of sites having no detectible arsenic (at minimum detection limit of 0.20 ppm). Collection from both horizons ensures the site is better represented and that the sample of maximum value is used for analysis.

Regression analysis of six environmental factors was done to assess for potential predictors for arsenic in undisturbed soils. The regression tree indicated soil order, elevation and rock type to have the strongest relationship with arsenic. In this study area 
arsenic concentrations were found in greater levels within Alfisol and Ultisol/Alfisol and Vertisol soil orders, at lower elevations below 1,207 meters, and within soils from sedimentary, mixed volcanic/sedimentary and unconsolidated rock types. The regression forest confirmed the same factors as environmental predictors with elevation the strongest predictor, followed by soil order and rock type. Province, soil color and the age ranking of rock deposition were not considered significant.

Marine sediments have higher arsenic values than other lithologies. Data with the highest value and highest mean are in the South Willamette Valley. This site was mapped as the Eugene Formation, a marine sedimentary deposit, by both Walker and MacLeod (1991) and McClaughry et al. (2010). Marine sediments were also found to have the highest $(>7 \mathrm{ppm})$ concentrations of arsenic in the northwest Oregon study area (Ricker, 2013).

The map units associated with the maximum values for each province are all described as either having a marine sediment composition (Jub, Tfe, Tfee, Ty), or as basaltic (Jub, Tbaa, Qba) or mafic (Tmv) by Walker and MacLeod (1991). This is in keeping with other research that sedimentary rocks reach much higher levels of arsenic than igneous and metamorphic sources (Ravenscroft et al., 2009), although basalt can also have a large range $(0.18-113 \mathrm{ppm})$ for arsenic concentration (Ravenscroft et al., 2009).

A summary of the three important factors for each of the high-value samples and the mean arsenic of each province are listed in Table 21. Factor descriptions for these representative sites are in alignment with the results of the regression analyses. Rock 
types for the highest value sites include sedimentary and mixed igneous volcanic and sedimentary rock types, as well as igneous volcanic. The sedimentary and mixed rock types are the highest by mean concentration $(5.15-21.99 \mathrm{ppm})$ with all igneous volcanic sites lower by mean $(1.20-2.76 \mathrm{ppm})$. The soil orders for the two highest value sites are the Alfisol or Ultisol soils; these soils are older and have had time to concentrate higher levels of arsenic. Lastly, arsenic is higher in lower elevations and less concentrated at higher elevations. Weathering, gravity and topography result in sediment transportation and accumulation in sinks or valleys, however, topographical influences were outside the scope of this study.

Table 21. Summary of results for arsenic level and three important factors by province.

\begin{tabular}{|c|c|c|c|c|c|c|}
\hline Province & $\begin{array}{c}\text { Highest } \\
\text { Value (ppm) }\end{array}$ & Map Unit & Rock Type & Soil Order & $\begin{array}{c}\text { Elevation } \\
\text { (meters) }\end{array}$ & $\begin{array}{l}\text { Mean } \\
\text { (ppm) }\end{array}$ \\
\hline S. Willamette Valley & 85.4 & Tfe, Tfee & Sedimentary & Alfisol & 292 & 21.99 \\
\hline Klamath Mountains & 45.4 & Jub & $\begin{array}{c}\text { Mixed } \\
\text { Volc./ Sed. }\end{array}$ & Alf/Ult & 730 & 5.42 \\
\hline Cascade Range & 11.9 & Tbaa & Volcanic & Inceptisol & 803 & 2.76 \\
\hline Coast Range & 10.6 & Ty & Sedimentary & Mollisol & 134 & 5.15 \\
\hline Basin and Range & 2.32 & Qba & Volcanic & Mollisol & 1289 & 1.29 \\
\hline High Lava Plains & 1.5 & Tmv & Volcanic & Entisol & 1891 & 1.20 \\
\hline
\end{tabular}




\section{CHAPTER VIII: FUTURE WORK}

This study tested for arsenic in undisturbed soils, increasing the coverage of arsenic data from different rock types found in southwest Oregon. The purpose of this study was to provide location and arsenic concentration data to DEQ to increase the current data set. While Oregon coverage is now fairly robust, the causes driving the concentration of arsenic are still being explored.

In order to study environmental variables as potential causes or predictors of arsenic, it first would be necessary to verify the accuracy each environmental variable in the field and lab. Elevation and geomorphic region are easy to verify, but soil order and rock type should be verified at the site and with lab testing ( $\mathrm{pH}$ for soils and $\mathrm{X}$-ray diffraction to determine parent material) as the site could vary from the mapped soil order and unit, which are generally mapped over a much larger area. In the lab, percent clay content should be determined to hone its relationship as and adsorber of arsenic. Also, enough samples should be collected per site in order to make statistical analyses valid. Further analysis could also be done using separate CART models for the A and B horizons for a comparison of important predictor variables between horizons. 


\section{REFERENCES CITED}

Adriano, D. C., 2001, Trace Elements in Terrestrial Environments: Biogeochemistry, Bioavailability, and Risks of Metals, New York, Springer, 867 p.

Allen, J. E., Burns, M., and Burns, S., 2009, Cataclysms on the Columbia: the Great Missoula Floods, Portland, OR, Ooligan Press, $2^{\text {nd }}$ ed., 216 p.

Banning, A., and Rude, T. R., 2010, Enrichment processes of arsenic in oxidic sedimentary rocks-- From geochemical and genetic characterization to potential mobility: Water Research, v. 44, p. 5512-5531.

Birkeland, P. W., 1999, Soils and Geomorphology, New York, Oxford University Press, $430 \mathrm{p}$.

Buntley, G. J., and Westin, F. C., 1965, A comparitive study of developmental color in a Chestnut-Chernozem-Brunizem soil climosequence.: Soil Science Society of American Proceedings, v. 29, p. 579-582.

Burns, S.F., Thompson, R.H., Beck, J.N. and Meriwether, J.R., 1991, Thorium, uranium and cesium-137 in Louisiana soils: Migration trends in a soil catena near Dubach, Louisiana, USA, Radiochimica and Cosmochemica Acta 52/53, p. 241-247.

Crawley, M. J., 2007, The R Book, Chichester, England, Wiley, 950 p.

DEQ, 2003, Risk-Based Decision Making for the Remediation of PetroleumContaminated Sites, Oregon Department of Environmental Quality, Land Quality Division, Environmental Cleanup and Tanks Program, p. 200. $<$ http://www.deq.state.or.us/lq/pubs/docs/RBDMGuidance.pdf $>$

DEQ, 2012, Risk-Based Concentrations for Individual Chemicals, Oregon Department of Environmental Quality, Land Quality Division, Environmental Cleanup and Tanks Program.

$<$ http://www.deq.state.or.us/lq/pubs/docs/RBDMTable.pdf $>$

DEQ, 2013, Development of Oregon Background Metals Concentrations in Soil: Oregon Department of Environmental Quality, Land Quality Division, Cleanup Program.

Douglas, W. H., 1999, Distribution of Naturally Occurring Soil Radionuclides and Radon Potential of Southwest Oregon, Master of Science: Portland State University Geology Department.

Ellison, A.M., and Gotelli, N.J., 2012, A Primer of Ecological Statistics: Second Edition, Massachusetts, Sinauer Associates, Inc., 579 p. 
Environmental Protection Agency (EPA), 2007a, Environmental Protection Agency Method 3051A: Microwave assisted acid digestion of sediments, sludges, soils, and oils.

< http://www.epa.gov/solidwaste/hazard/testmethods/sw846/pdfs/3051a.pdf>

Environmental Protection Agency (EPA), 2007b, Environmental Protection Agency Method 6020A: Inductively coupled plasma mass spectrometry. < http://www.epa.gov/osw/hazard/testmethods/sw846/pdfs/6020a.pdf>

Helsel, D. R., 2006, Fabricating data: How substituting values for nondetects can ruin results, and what can be done about it: Chemosphere, v. 65, no. 11, p. 2434-2439.

Hinkle, S.R. and Polette, D.J., 1999, Arsenic in Ground Water of the Willamette Basin, Oregon, United States Geological Survey Water-Resources Investigations Report 98-4205, $34 \mathrm{p}$.

Inskeep, W. P., McDermott, T. R., and Fendorf, S., 2002, Arsenic (V)/(III) cycling in soils and natural waters: chemical and microbiological processes, in Frankenberger, W. T., ed., Environmental Chemistry of Arsenic: New York, Marcel Dekker, p. 183-215.

Jenny, H., 1941, Factors of Soil Formation, New York, McGraw-Hill, 281 p.

Khandoker, R. A., 1997, Distribution of Heavy Metals and Trace Elements in Soils of Southwest Oregon, Master of Science: Portland State University Geology Department.

McClaughry, J. D., Wiley, T. J., and Madin, I. P., 2010, Digital Geologic Map of the Southern Willamette Valley, Benton, Lane, Linn, Marion, and Polk Counties, Oregon: Oregon Department of Geology and Mineral Industries, O-10-03.

McLaren, R. G., Megharaj, M., and Naidu, R., 2006, Fate of Arsenic in the Soil Environment, Managing Arsenic in the Environment from Soil to Human Health: Melbourne, CSIRO Publishing, p. 157-182.

Mitsunobu, S., Harda, T., and Takahashi, Y., 2006, Comparison of antimony behavior with that of arsenic under various redox conditions: Environmental Sciences and Technology, v. 40, no. 23, p. 7270-7276.

Orr, E. L., and Orr, W. N., 2012, Oregon Geology: 6th Edition, Corvallis, Oregon State University Press, 304 p.

Orr, W. N., and Orr, E. L., 2006, Geology of the Pacific Northwest, Long Grove, Ill., Waveland Press, 254 p. 
Ravenscroft, P., Brammer, H., and Richards, K., 2009, Arsenic Pollution: a Global Synthesis, West Sussex, UK, Wiley-Blackwell, 618 p.

Ricker, T. R., 2013, Arsenic in the Soils of Northwest Oregon, Master of Science: Portland State University Geology Department, 169 p.

Shih, S., 2011, Random forests for classification trees and categorical dependent variables: an informal quick start $\mathrm{R}$ guide, Stanford University, CA and University of California, Berkeley, $8 \mathrm{p}$.

$<$ http://cogsci.ucmerced.edu/shih/R-randomforest-guide.pdf $>$

Strobl, Carolin; Torsten Hothorn; and Achim Zeileis, 2009. Party on! A new, conditional variable-importance measure for random forests available in the party package. The R Journal, Vol. 1/2: p. 14-17.

Taylor, G. H., and Hannan, C., 1999, The Climate of Oregon: from Rain Forest to Desert, Corvallis, OR, Oregon State University Press, 211 p.

U.S. Department of Health (USDH), 2007, Toxicological Profile for Arsenic: Agency for Toxic Substances and Disease Registry, 559 p.

$<$ http://www.atsdr.cdc.gov/toxprofiles/tp2.pdf $>$

U.S. Department of Agriculture (USDA), 2010, Keys to Soil Taxonomy, U. S.

Department of Agriculture and Natural Resources Conservation Service, $11^{\text {th }}$ ed., USA, Books Express Publishing, 346 p.

Walker, G.W. and MacLeod, N.S., 1991, Geologic Map of Oregon: U.S. Geological Survey, scale 1:500,000.

$<$ http://tin.er.usgs.gov/geology/state/state.php?state $=\mathrm{OR}>$ 
APPENDIX A: Stratigraphy of Provinces within Southwest Oregon

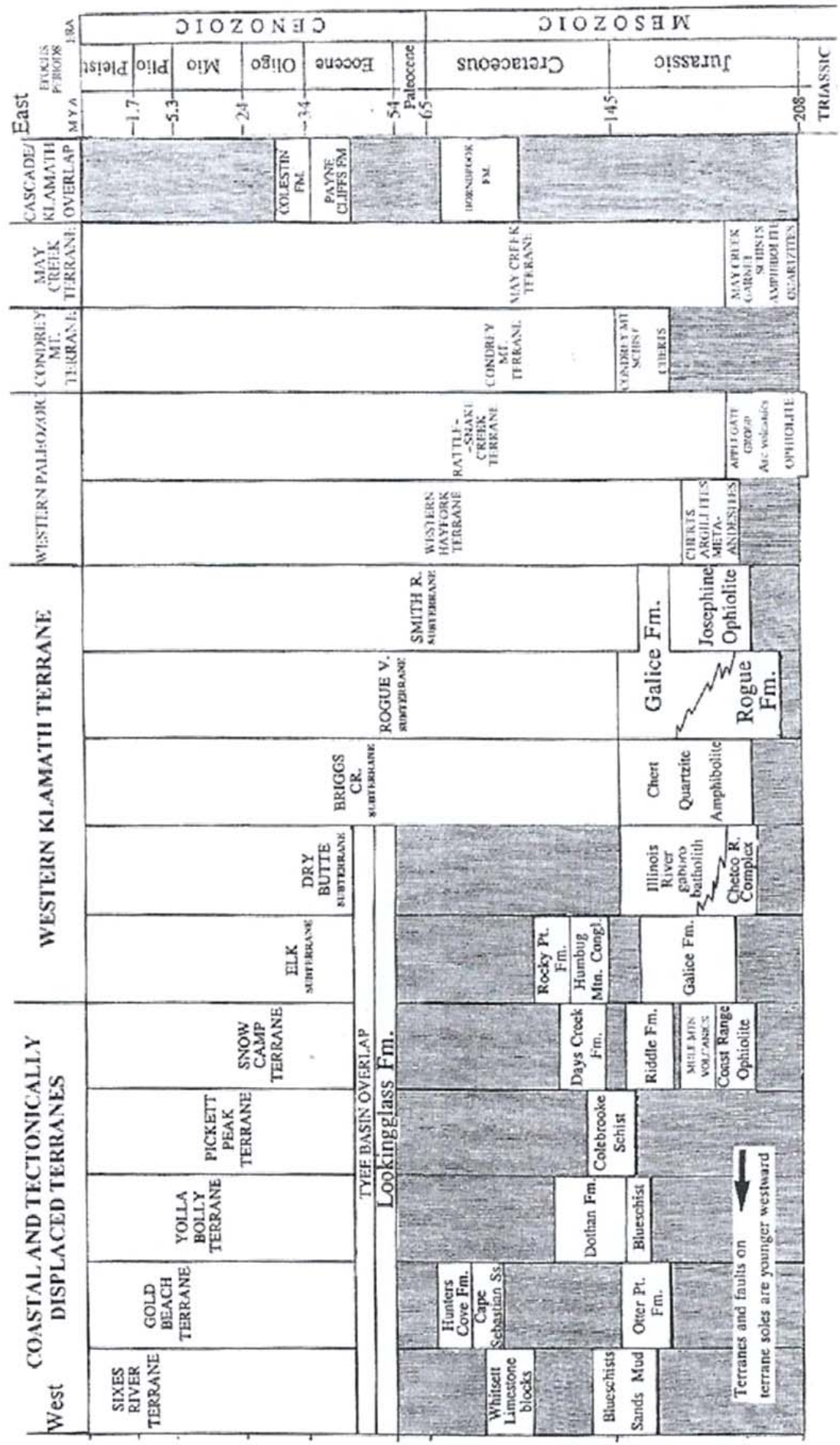

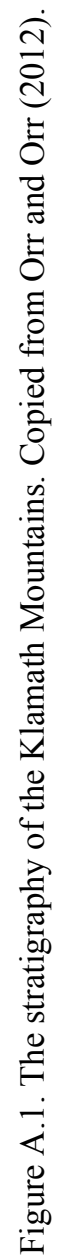




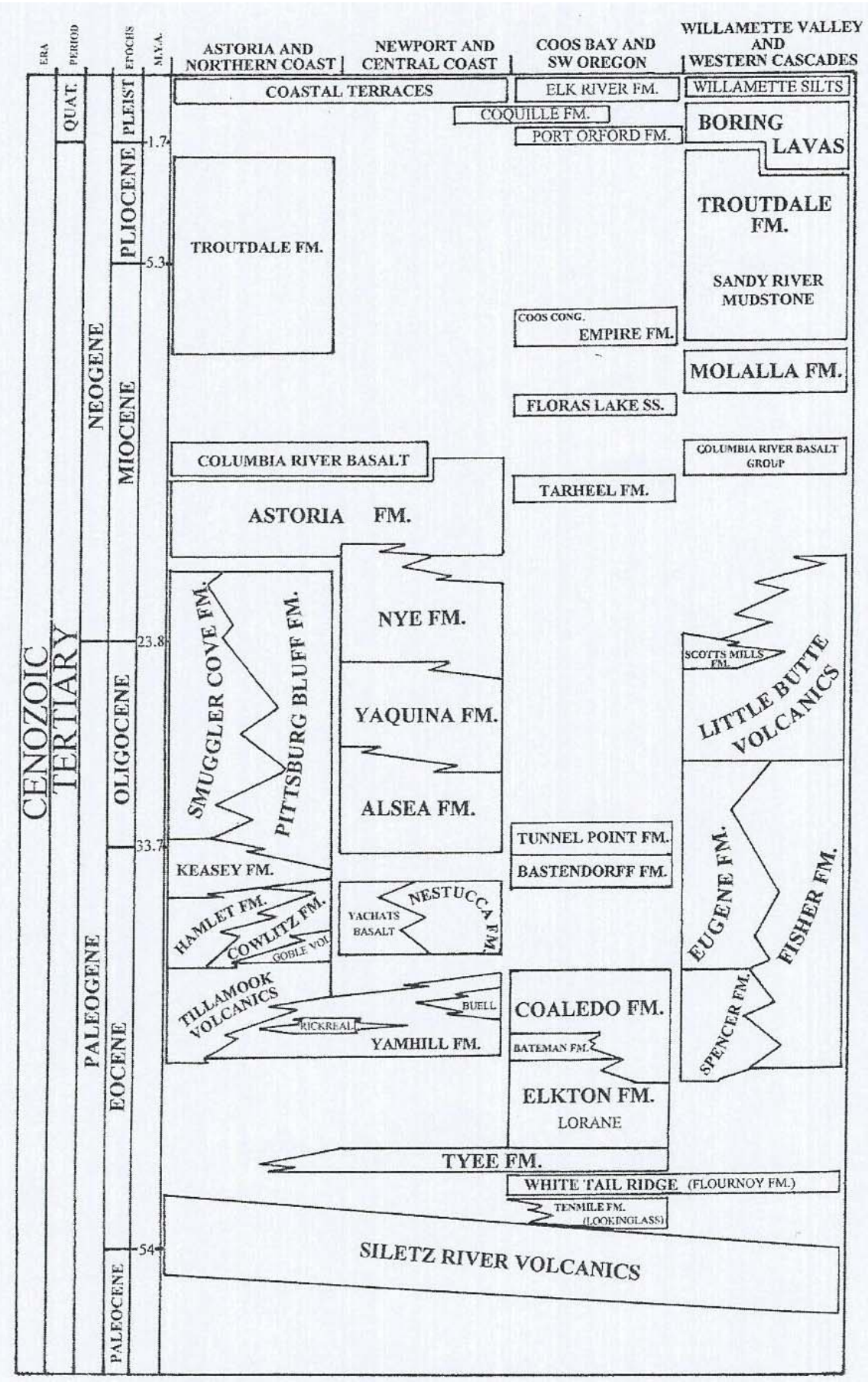

Figure A.2. The stratigraphy of the Coast Range province. Coos Bay and SW Oregon formations are within the study area. Copied from Orr and Orr (2012). 


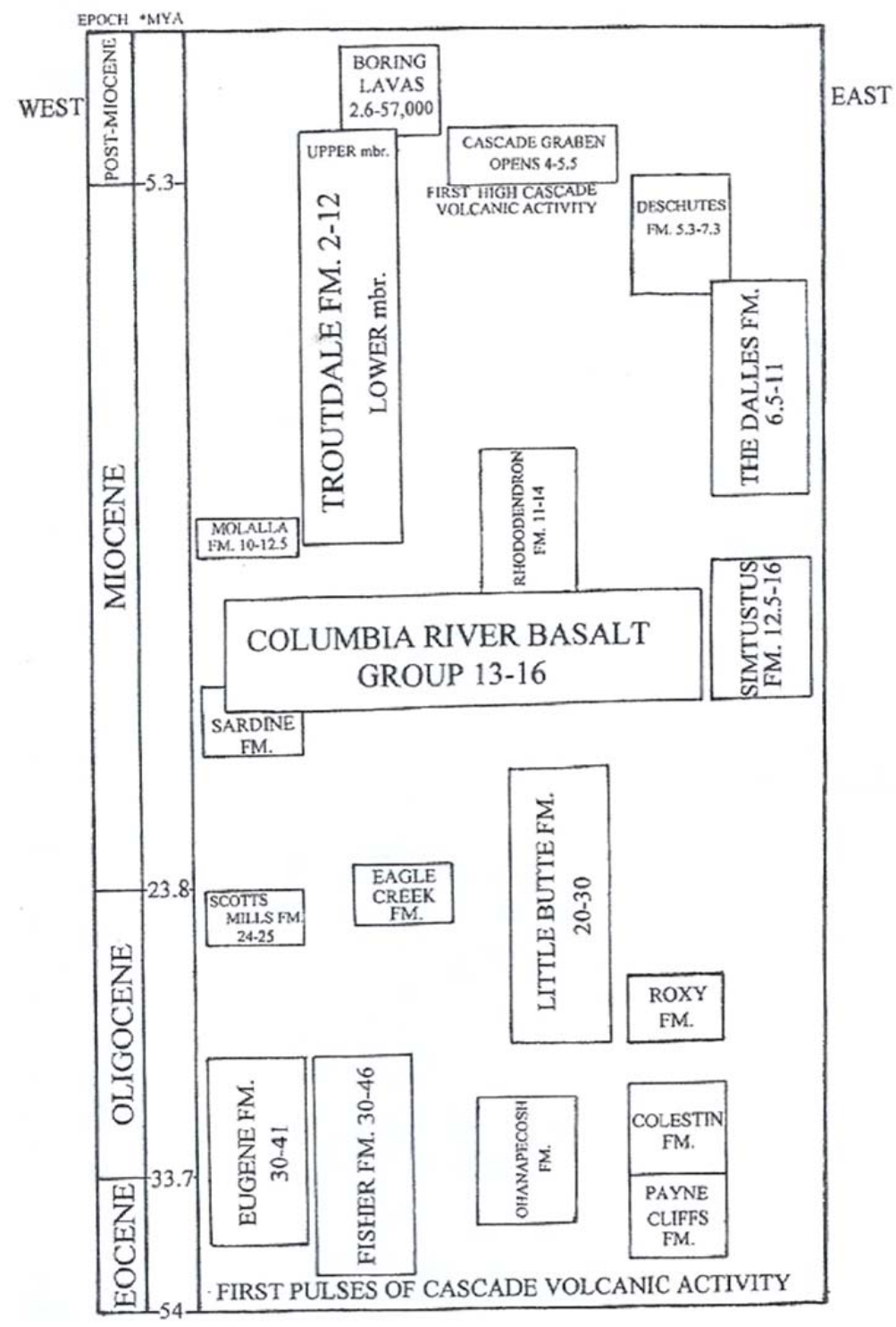

Figure A.3. The stratigraphy of the Cascade Range province. Copied from Orr and Orr (2012). 


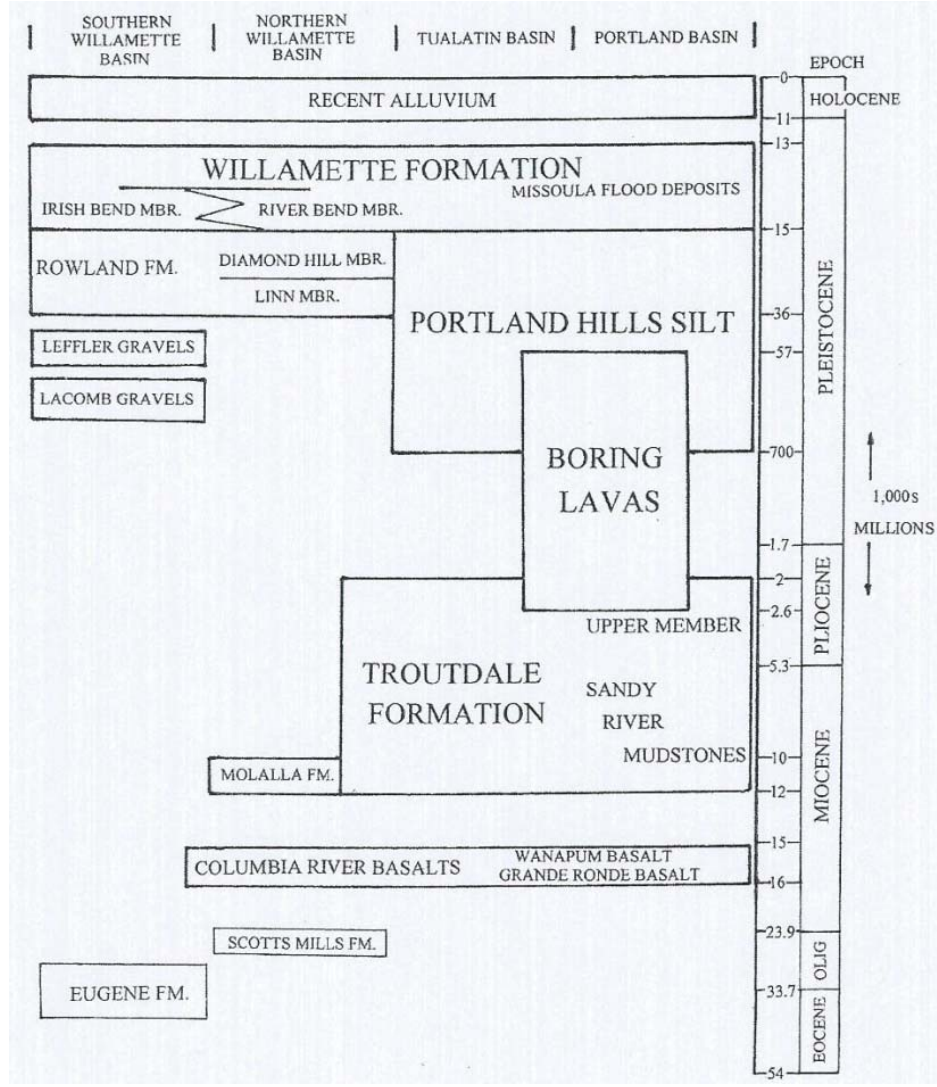

FigureA.4. The stratigraphy of the Willamette Valley province. Copied from Orr and Orr (2012). 


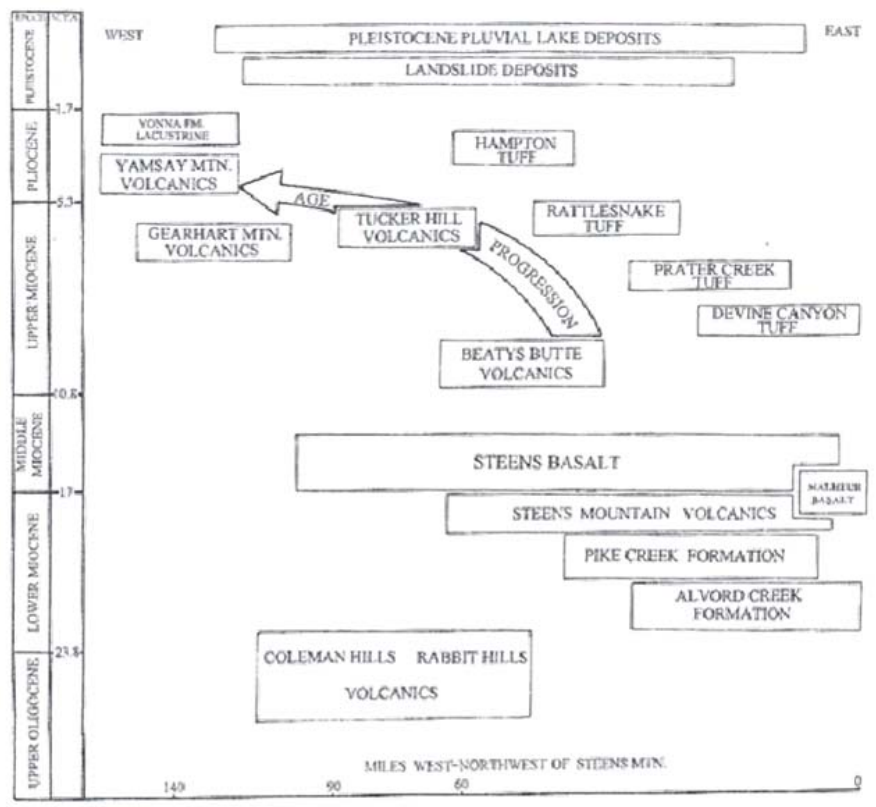

Figure A.5. The stratigraphy of the Basin and Range province. Copied from Orr and Orr (2012).

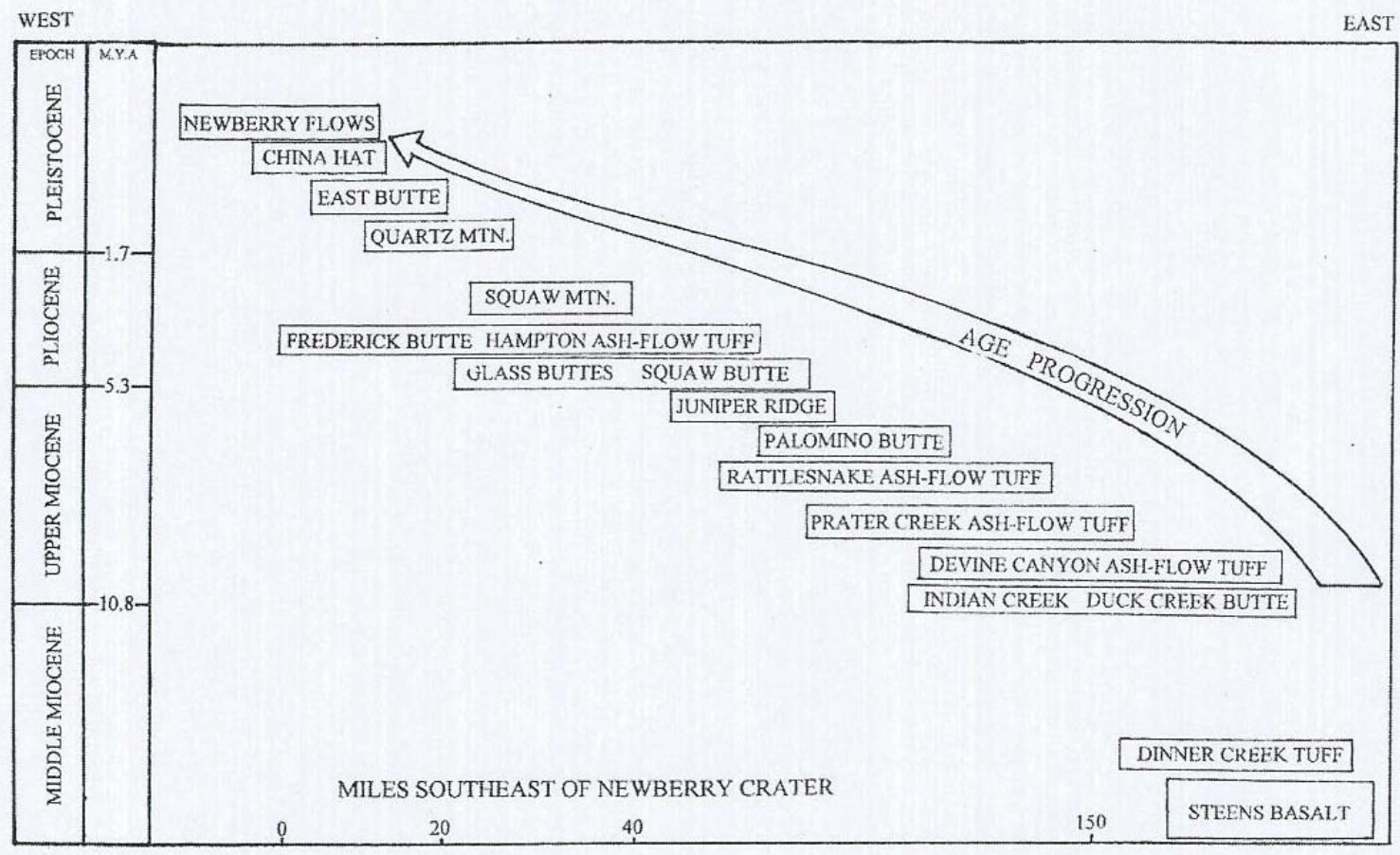

Figure A.6. The stratigraphy of the High Lava Plains province. Copied from Orr and Orr (2012). 


\section{APPENDIX B: Description of Geologic Units (Walker and MacLeod, 1991) by Province (DEQ, 2013) that Correlate with Sample Locations}

Basin and Range

Qba Basaltic andesite and basalt (Holocene? and Pleistocene) -Flows and flow breccia dominantly of basaltic andesite containing plagioclase, olivine, and pyroxene phenocrysts and olivine-bearing basalt representing part of the volcanic sequence of the High Cascade Range. Unit mostly forms small shield volcanoes, gentle-sided lava cones, and, in places, intracanyon flows.

Qf Fanglomerate (Holocene? and Pleistocene)—Poorly sorted and poorly stratified alluvial fan debris, slope wash, colluvium, and talus; composed mostly of silt and fragments of basalt, basaltic andesite, and andesite. In places includes small areas of pediment gravels and colluvium.

Qma Mazama ash-flow deposits (Holocene) - Rhyodacitic to andesitic ash-flow deposits related to climactic eruptions of Mount Mazama about 6,845 yr B.P. $\left({ }^{14} \mathrm{C}\right)$.

QTb Basalt (Pleistocene and Pliocene) - Thin flows and minor flow breccia of opentextured (diktytaxitic) olivine basalt in southeastern part of map area. Locally contains thin interbeds of sedimentary rocks. Grades laterally through palagonite tuff and breccia into sedimentary rocks (unit QTs).

QTs Sedimentary rocks (Pleistocene and Pliocene)—Semiconsolidated lacustrine and fluvial ashy and palagonitic sedimentary rocks, mostly tuffaceous sandstone and siltstone; locally contains abundant palagonitized basaltic debris and some pebble conglomerate. In places, grades laterally through palagonite tuff and breccia into basalt flows (Qtb).

QTvm Mafic vent deposits (Pleistocene, Pliocene, and Miocene?)-Mostly in small stratovolcanoes or shield volcanoes and lava cones of basalt and andesite. 
Includes agglomerate, breccia, scoria, cinder, ash, restricted flows, and small basaltic intrusive bodies. Transitional into pyroclastic rocks of cinder cones (QTp). May also include rocks of late Miocene (?) age.

$\mathrm{Tb}$ Basalt (upper and middle Miocene) - Basalt flows, flow breccia, and basaltic peperite; minor andesite flows; some interbeds of tuff and tuffaceous sedimentary rocks. Basalt is aphyric to moderately porphyritic with phenocrysts of plagioclase and olivine and exhibits both subophitic and diktytaxitic textures.

Tob Olivine basalt (Pliocene and Miocene) - Thin, commonly open-textured (diktytaxitic), subophitic to intergranular olivine basalt flows, intercalated with and grades laterally through palagonite breccia and tuff into tuffaceous sedimentary rocks (unit Ts). In places includes flows of platy olivine andesite or basaltic andesite.

Tp Basaltic and andesitic ejecta-Mostly unconsolidated, oxidized, fine to coarse, scoriaceous cinders, bombs, and agglutinate deposited in subaerial environment.

Tps Subaqueous pyroclastic rocks of basaltic cinder cones-Deposits of bombs, breccia, and mafic to intermediate tuff occurs as palagonitic tuff and breccia cones, rings, and ridges. In places interbedded with lacustrine sedimentary rocks.

Trh Rhyolite and dacite (Pliocene? and Miocene) - Ash-flow tuff, lava flows, pumice-lapilli tuff, coarse pumicite, blow breccia, and domal complexes of rhyolitic, rhyodacitic, and dacitic composition; in places includes peralkaline rhyolite and some andesite and andesite breccia. Locally porphyritic with phenocrysts of alkali feldspar, plagioclase, and minor augite, ferro-hedenbergite, hornblende, hypersthene, or biotite. Commonly flow banded; locally glassy. Many of the ash-flow tuffs exhibit flow features and only obscure vitro-clastic textures.

Ts Tuffaceous sedimentary rocks and tuff (Pliocene and Miocene)Semiconsolidated to well-consolidated mostly lacustrine tuffaceous sandstone, 
siltstone, mudstone, concretionary claystone, pumicite, diatomite, air-fall and water-deposited vitric ash, palagonitic tuff and tuff breccia, and fluvial sandstone and conglomerate. Palagonitic tuff and breccia grade laterally into altered and unaltered basalt flows of unit Tob. In places includes layers of fluvial conglomerate and, in parts of the Deschutes-Umatilla Plateau, extensive deposits of fanglomerate composed mostly of Miocene basalt debris and silt. Also includes thin, welded and nonwelded ash-flow tuffs.

Tvm Mafic and intermediate vent rocks (Pliocene? and Miocene)—Basaltic and andesitic agglomerate, breccia, scoria, cinders, flow, and intrusive masses forming lava cones and small shields.

Tvs Silicic vent rocks (Pliocene, Miocene, Oligocene, and Eocene?)—Plugs and domal complexes of rhyolitic, rhyodactic, and dacitic composition; includes related near-vent flows, flow breccia, and deposits of obsidian, perlite, and pumice. Locally includes resurgent domes related to caldera complexes.

\section{Cascade Range}

Qa Andesite (Holocene and Pleistocene)—Forms major stratovolcanoes dominantly of aphyric to porphyritic basaltic andesite and andesite; phenocrysts are principally pyroxene, olivine, plagioclase, and, rarely, hornblende. Locally includes dacite and minor basalt.

Qal Alluvial deposits (Holocene) - Sand, gravel, and silt forming flood plains and filling channels of present streams. In places includes talus and slope wash. Locally includes soils containing abundant organic material, and thin peat beds.

Qba Basaltic andesite and basalt (Holocene? and Pleistocene) —Flows and flow breccia dominantly of basaltic andesite containing plagioclase, olivine, and pyroxene phenocrysts and olivine-bearing basalt representing part of the volcanic 
sequence of the High Cascade Range. Unit mostly forms small shield volcanoes, gentle-sided lava cones, and, in places, intracanyon flows.

Qg Glacial deposits (Pleistocene) - Unsorted boulder gravel, sand, and rock flour in ground, terminal, and lateral moraines. Locally include: glaciofluvial deposits (Qgf).

Qgf Glaciofluvial deposits-Partly sorted.

Q1s Landslide and debris-flow deposits (Holocene and Pleistocene) — Unstratified mixtures of fragments of adjacent bedrock. Locally includes slope wash and colluvium. Largest slides and debris flow occur where thick sections of basalt and andesite flows overlie clayey tuffaceous rocks. May include some deposits of late Pliocene age.

Qma Mazama ash-flow deposits (Holocene) - Rhyodacitic to andesitic ash-flow deposits related to climactic eruptions of Mount Mazama about 6,845 yr B.P. $\left({ }^{14} \mathrm{C}\right)$.

Qmp Mazama pumice deposits (Holocene) — Primary and reworked air-fall rhyodacite pumice related to climactic eruptions of Mount Mazama about 6,845 yr B.P. $\left({ }^{14} \mathrm{C}\right)$. Mapped only where it extensively covers older units. Thickness shown by isopachs (in meters).

Qrd Rhyolite and dacite (Holocene and Pleistocene) - Domes and related flows and flow breccia of aphyric and plagioclase and hornblende porphyritic rhyolite and dacite. Includes rhyolite and dacite on Newberry volcano and at South Sister volcano in the Cascade Range that are younger than Mazama ash deposits (Qma, Qmp; radiometrically dated by ${ }^{14} \mathrm{C}$ methods at approximately 6,800 yr old).

Qs Lacustrine and fluvial sedimentary rocks (Pleistocene) - Unconsolidated to semiconsolidated lacustrine clay, silt, sand, and gravel; in places includes mudflow and fluvial deposits and discontinuous layers of peat. 
Qta Andesite (Pleistocene and Pliocene) - Flows and flow breccia in the High Cascade Province composed dominantly of aphyric to porphyritic basaltic andesite and andesite. Mostly represents remnants of moderately to deeply eroded staratovolcanoes. Phenocrysts are mostly plagioclase, olivine, clinopyroxene, and lesser hypersthene and hornblende.

QTba Basalt and basaltic andesite (Pleistocene and Pliocene) - Flows, flow breccia, and pyroclastic deposits of the High Cascades Province. Flows are aphanitic to finely crystalline, commonly diktytaxitic, and aphyric to porphyritic. Textures are mostly intergranular grading to intersertal; some andesite flows are finely trachytic and a few basalt flows are subophitic. Phenocrysts, mostly unaltered, include bytownite and labradorite, olivine, calcic augite, and hypersthene. Flows and breccia form shields, lava cones, and valley fill; in places greatly dissected and modified by glacial and fluvial erosion.

QTmv Mafic vent complexes (Pleistocene, Pliocene, and Miocene?)-Plugs, dikes, and related near-vent flows, breccia, cinders, and agglutinate of basalt, basaltic andesite, and andesite; commonly in the form of either little-modified lava cones or partly eroded piles of reddish, iron-stained thin flows and fragmental ejecta cut by mafic intrusions. May also include rocks of late Miocene(?) age.

QTp Basaltic and andesitic ejecta-Mostly unconsolidated, oxidized, fine to coarse, scoriaceous cinders, bombs, and agglutinate deposited in subaerial environment.

Tbaa Basaltic and andesitic rocks (upper and middle Miocene) — Lava flows and flow breccia of hypersthene and olivine andesite, basaltic andesite containing plagioclase and pyroxene phenocrysts, and basalt; many flows contain phenocrysts of both hypersthene and augite. Includes interbedded volcaniclastic and epiclastic rocks mostly of andesitic composition, but partly of dacitic or rhyodacitic composition. Includes areally restricted flows of silicic andesite or dacite. Upper part of unit mostly unaltered, although olivine crystals are locally altered to clay minerals. Lower parts commonly altered; secondary minerals 
include nontronite and saponite, chalcedony, calcite, and zeolites. Older parts of this unit locally are propylitically altered adjacent to larger intrusions. Erupted mostly from widespread, northwest- and north-trending dikes and dike swarms and related plugs and lava cones.

Tfc Flows and clastic rocks, undifferentiated (Miocene) - Chiefly basaltic andesite and andesite lava flows and flow breccia containing plagioclase and pyroxene (hypersthene and augite) phenocrysts, mudflows (lahars), and volcanic conglomerates; locally includes some dacite flows. Includes lesser, coarse- to fine- grained epiclastic volcanic sedimentary rocks and ash-flow and air-fall tuffs. Partly equivalent in age to unit Tba and may be partly coeval with younger parts of unit Tstb. Locally altered adjacent to larger intrusions.

Thi Hypabyssal intrusive rocks (Miocene) - Hypabyssal, medium-grained, hornblende diorite and quartz diorite in small stocks and large dikes; includes intrusions of medium- to fine-grained gabbro and plugs and small stocks of commonly porphyritic biotite quartz monzonite and leucocratic granodiorite. Many of these intrusive bodies are moderately to intensely propylitized, as are wallrocks they intrude; locally, along shears, the rocks also are sericitized.

Tmsc Marine siltstone, sandstone, and conglomerate (lower Eocene) — Cobble and pebble conglomerate, pebbly sandstone, lithic sandstone, siltstone, and mudstone; massive to thin bedded; shelf and slope depositional setting. Contains foraminiferal faunas referred to the Penutian Stage of early Eocene age.

Tn Nonmarine sedimentary rocks (Eocene) - Continentally derived conglomerate, pebble conglomerate, sandstone, siltstone, and mudstone containing abundant biotite and muscovite, Dominantly nonvolcanic; clastic material derived from underlying older rocks.

Trb Ridge-capping basalt and basaltic andesite (Pliocene and upper Miocene)Flows and flow breccia of basaltic andesite and lesser diktytaxitic to intergranular 
olivine basalt. Includes some dense, aphyric flows, commonly with either cryptocrystalline of pilotaxitic to trachytic texture, and porphyritic flows with phenocrysts and glomerocrysts of olivine, hypersthene, and labradorite, A few flows contain both hypersthene and calcic augite phenocrysts. Olivine mostly fresh or slightly altered to iddingsite in flows high in section; flow low in section show some alteration to clays (nontronite and saponite), secondary silica minerals, and calcite; pinkish-brown glass in some flows unaltered. Locally includes some andesite and dacite.

Tsv Silicic vent complexes (Pliocene, Miocene, and upper Oligocene)—Large, rhyolitic to dacitic vent areas in the Cascade Range that commonly include multiple intrusions and much associated silicic eruptive breccia and erosional debris and some flows.

$\mathrm{Tu}$ Undifferentiated tuffaceous sedimentary rocks, tuffs, and basalt (Miocene and Oligocene) - Heterogeneous assemblage of continental, largely volcanogenic deposits of basalt and basaltic andesite, including flows and breccia, complexly interstratified with epiclastic and volcaniclastic deposits of basaltic to rhyodacitic composition. Includes extensive rhyodacitic to andesitic ash-flow and air-fall tuffs, abundant lapilli tuff and tuff breccia, andesitic to dacitic mudflow (lahar) deposits, poorly bedded to well-bedded, fine- to coarse-grained tuffaceous sedimentary rocks, and volcanic conglomerate. In places subdivided into: sedimentary and volcaniclastic rocks (Tus), tuff (Tut) and basaltic lava flows (Tub).

Tub Basaltic lava flows - Basaltic and basaltic andesite lava flows and breccia; grades laterally into rare bedded palagonitic tuff and breccia.

Tus Sedimentary and volcaniclastic rocks - Lapilli tuff, mudflow deposits (lahars), flow breccia, and volcanic conglomerate, mostly of basaltic to dacitic composition; rare iron-stained palagonitic tuff and breccia of basaltic and andesitic composition; and ash-flow, air-fall, and water-laid tuff of dacitic to 
rhyolitic composition. The palagonite tuff and breccia grade laterally into peperite and into lava flows of basalt and basaltic andesite.

Tut Tuff-Welded to unwelded, mostly vitric crystal and vitric ash-flow tuff of several ages. Glass in tuff locally altered to clay, zeolites, and secondary silica minerals.

\section{Coast Range}

Qal Alluvial deposits (Holocene) - Sand, gravel, and silt forming flood plains and filling channels of present streams. In places includes talus and slope wash. Locally includes soils containing abundant organic material, and thin peat beds.

Qd Dune sand (Holocene) - Large areas of windblown sand composed of rockforming minerals, mostly feldspar and small amounts of quartz.

Q1s Landslide and debris-flow deposits (Holocene and Pleistocene) — Unstratified mixtures of fragments of adjacent bedrock. Locally includes slope wash and colluvium. Largest slides and debris flow occur where thick sections of basalt and andesite flows overlie clayey tuffaceous rocks. May include some deposits of late Pliocene age.

Qt Terrace, pediment, and lag gravels (Holocene and Pleistocene)Unconsolidated deposits of gravel, cobbles, and boulders intermixed and locally interlayered with clay, silt, and sand. Mostly on terraces and pediments above present flood plains.

$\mathrm{Ti}$ Mafic intrusions (Oligocene) - Sheets, sills and dikes of massive granophyric ferrogabbro; some bodies strongly differentiated and include pegmatitic gabbro, ferrogranophyre, and granophyre.

Tmsm Marine sandstone, siltstone and mudstone (lower Eocene and Paleocene?)Rhythmically interbedded sandstone, siltstone, and mudstone with minor 
conglomerate; deposited in deep-sea fan depositional setting on submarine basalts of the Siletz River Volcanics.

Tmss Marine sandstone and siltstone (middle Eocene) - Thin- to thick-bedded, crossbedded, well-sorted, fine- to medium-grain sandstone, siltstone, and mudstone; characterized by sparse fine white mica; shallow marine depositional setting at least partly of deltaic origin.

Tpb Porphyritic basalt (upper Eocene) - Subaerial lava flows and breccia of porphyritic basalt, minor basaltic andesite, and rare dacite.

Tsr Siletz River Volcanics and related rocks (middle and lower Eocene and Paleocene) - Aphanitic to porphyritic, vesicular pillow flows, tuff-breccias, massive lava flows and sills of tholeiitic and alkali basalt. Upper part of sequence contains numerous interbeds of basaltic siltstone and sandstone, basaltic tuff, and locally derived basalt conglomerate. Rocks of unit pervasively zeolitized and veined with calcite. Most of these rocks are of marine origin and have been interpreted as oceanic crust and seamounts.

Tss Tuffaceous siltstone an sandstone (upper and middle Eocene) - Thick- to thinbedded marine tuffaceous mudstone, siltstone, and sandstone; fine to coarse grained. Contains calcareous concretions and, in places, is carbonaceous and micaceous.

Tt Tyee Formation (middle Eocene) — Very thick sequence of rhythmically bedded, medium- to fine-grained micaceous, feldspathic, lithic, or arkosic marine sandstone and micaceous carbonaceous siltstone; contains minor interbeds of dacite tuff in upper part.

Ty Yamhill Formation and related rocks (upper and middle Eocene) - Massive to thin-bedded concretionary marine siltstone and thin interbeds of arkosic, glauconitic, and basaltic sandstone; locally contains interlayered basalt lava flows and lapilli tuff. 
High Lava Plains

Qb Basalt and basaltic andesite (Holocene and Pleistocene) - Thin flows of aphyric and porphyritic basalt and basaltic andesite, and open-textured (diktytaxitic), generally nonporphyritic, subophitic olivine basalt that commonly is highly feldspathic. Also includes some dissected intracanyon flows of porphyritic basalt and related vent complexes. Pressure ridges and tumuli on upper surfaces well preserved. Occurs principally along crest of Cascade Range; also in areas near and east of Newberry volcano, along southeast margin of Harney Basin, and in Rome Basin.

QTps Subaqueous basaltic and andesitic ejecta of basaltic and andesitic cinder cones (Holocene, Pleistocene, Pliocene, and Miocene?) —-Partly consolidated, palagonitized, fine to coarse, scoriaceous altered cinders, bobs, breccia, and minor agglutinate, mostly deposited in subaqueous environment. Commonly with some interlayers and intermixed lacustrine sedimentary rocks. Forms palagonitic tuff and breccia cones and rings (maars) and, in places, palagonitic tuff ridges.

\section{QTst Tuffaceous sedimentary rocks and tuffs (lower? Pleistocene or Pliocene)-}

Rhyolitic to andesitic ash-flow tuffs, pumice-fall deposits, minor mud flows, and older alluvium on the flanks of Newberry volcano.

Qyb Youngest basalt and basaltic andesite (Holocene)—Little-modified flows and associated breccia of basaltic andesite and some basalt on slopes of Newberry Volcano. Relations to Mazama pumice deposits indicate most of these rocks are less than $6,800 \mathrm{yr}$ old $\left({ }^{14} \mathrm{C}\right)$; isotopic ages on flows range from about 1,000 to 6,000 yr B.P. $\left({ }^{14} \mathrm{C}\right)$.

Tat Silicic ash-flow tuff (lower Pliocene and upper Miocene) - Ash-flow tuff and associated pumiceous air-fall tuff mostly of rhyolitic and rhyodacitic composition; includes minor tuffaceous sedimentary rocks. Grades laterally through less- 
densely welded tuff to nonwelded ash-flow tuff and interlayered tuffaceous sediments of unit Ts.

Tmv Mafic vent complexes (Miocene) - Intrusive plugs and dike swarms and related near-vent flows, breccias, cinders, and agglutinate of basaltic andesite, basalt, and andesite; commonly in the form of eroded piles of red, iron-stained thin flows, cinders, and agglutinate cut by mafic intrusions.

\section{Klamath Mountains}

bc Amphibolite of Briggs Creek (Mesozoic or Paleozoic) - Consists of amphibolite, micaceous quartzite, quartz schist, and recrystallized manganiferous chert. Includes structurally complex amphibole schist and quartz-rich hornblende gneiss of unknown age exposed at and near Chetco Peak west of Cave Junction.

cm Condrey Mountain Schist (Triassic? and Paleozoic?) — Consists of a variety of schistose rocks characterized by different proportions of muscovite, quartz, graphite, chlorite, actinolite, and epidote, rare thin layers of metachert, and clinozoisite-actinolite-albite-garnet metagabbro.

cs Colebrooke Schist (Mesozoic or Paleozoic) -Metamorphosed politic sedimentary rocks and subordinate metamorphosed submarine pillow lavas and pyroclastic beds of basaltic composition. Metamorphic age is Early Cretaceous (about $130 \mathrm{Ma}$ ).

Jm Mélange (Jurassic) — Structurally complex mixture of basaltic rocks, serpentinite, chert, argillite, conglomerate, silty sandstone, and lenses of marble composing the mélange of the Takilma area.

\section{Jop Otter Point Formation of Dott (1971) and related rocks (Upper Jurassic) -}

Highly sheared greywacke, mudstone, siltstone, and shale with lenses and pods of sheared greenstone, limestone, chert, blueschist, and serpentine. Identified as mélange by some investigators. 
Js Sedimentary rocks (Jurassic) —Black and gray mudstone, shale, siltstone, graywacke, andesitic to dacitic water-laid tuff, porcelaneous tuff, and minor interlayers and lenses of limestone and fine-grained sediments metamorphosed to phyllite or slate. Locally includes some felsite, andesite and basalt flows, breccia, and agglomerate. Marine invertebrate fauna indicates age range from Early Jurassic (Hettangian) to early Late Jurassic (Oxfordian). In Klamath Mountains of southwest Oregon, includes Galice Formation and unnamed, hornblende- and (or) pyroxene-bearing clastic rocks of Jurassic age.

Jss Shale, mudstone, and sandstone (Jurassic)—Black to gray shale, mudstone, and sandstone with local lenses of pebble conglomerate. Overlies Josephine ophiolite (unit Ju).

JTrgd Granite and diorite (Jurassic and Triassic) — Felsic to intermediate, granitoid intrusive rocks. Includes Jurassic muscovite granodiorite, hornblende gabbro, tonalite, and quartz diorite of southwest Oregon.

$\mathrm{Ju} \quad$ Ultramafic and related rocks of ophiolite sequences (Jurassic) Predominantly harzburgite and dunite with both cumulate and tectonite fabrics. Locally altered to serpentinite. Includes gabbroic rocks and sheeted diabasic dike complexes. Comprises Josephine ophiolite, ophiolites of Onion Mountain, Sexton Mountain, Pearsoll Peak, Rogue River, and Riddle areas and Coast Range ophiolite and serpentinite mélange. In southwest Oregon, locally includes small bodies of early Mesozoic or late Paleozoic serpentinized and sheared ultramafic rocks, mostly in shear zones. Locally, volcanic and sedimentary rocks shown separately.

Jub Basaltic volcanic and sedimentary rocks-Basalt flows, flow breccia, agglomerate, pillow basalt and pillow breccia, and lesser shale, chert siltstone, and mudstone of ophiolitic complexes. 
Jv Volcanic rocks (Jurassic) - Lava flows, flow breccia, and agglomerate dominantly of plagioclase, pyroxene, and hornblende porphyritic and aphyric andesite. Includes flow rocks that range in composition from basalt to rhyolite as well as some interlayered tuff and tuffaceous sedimentary rocks. Commonly metamorphosed to greenschist facies; locally foliated, schistose or gneissic. Includes the Rogue Formation and volcanic rocks commonly assigned to the Galice Formation. Considered to be accreted island-arc terrane.

Kc Clastic sedimentary rocks (Upper and Lower Cretaceous) - Locally fossiliferous sandstone and conglomerate; marine fossils indicate Early Cretaceous (Albian) age.

KJds Sedimentary rocks related to the Dothan Formation (Lower Cretaceous and Upper Jurassic) - Sandstone, conglomerate, graywacke, rhythmically banded chert lenses. Includes western Dothan and Otter Point Formations.

KJdv Volcanic rocks related to the Dothan Formation (Lower Cretaceous and Upper Jurassic) - Basaltic pillow lavas, volcanic breccia, and silicified basalt lava flows.

KJg Granitic rocks (Cretaceous and Jurassic) - Mostly tonalite and quartz diorite but including lesser amounts of other granitoid rocks. Potassium-argon ages determined on hornblende indicates plutons range in age from 143 to $166 \mathrm{Ma}$.

KJgu Gabbro and ultramafic rocks associated with granitic plutons (Cretaceous and Jurassic) - Predominantly hornblende gabbro, gabbro, and olivine gabbro, but includes pyroxenite, hornblende pyroxene, and minor peridotite, dunite, and serpentinite.

KJm Myrtle Group (Lower Cretaceous and Upper Jurassic) — Conglomerate, sandstone, siltstone, and limestone. Locally fossiliferous. As shown, includes Riddle and Days Creek Formations. 
Ks Sedimentary rocks (Cretaceous) - Marine graywacke, subgraywacke, conglomerate, and shale. Pebbles and cobbles in conglomerate are well-rounded volcanic and metavolcanic rocks, low-grade metasedimentary rocks, quartzite, chert, and minor silicic and intermediate plutonic rocks, Shales are gray to black and are fissile to blocky, Sandstones commonly display graded bedding; conglomerate beds are commonly thick and poorly bedded. Shales, near Mitchell, have yielded latest Early Cretaceous (Albian) fossils' some earliest Late Cretaceous (Cenomanian) fossils occur in beds southeast of Mitchell.

mc May Creek Schist (Paleozoic) — Layered amphibolite, schist, gneiss, and quartzite. Protolith considered to be of Paleozoic age.

Qt Terrace, pediment, and lag gravels (Holocene and Pleistocene)Unconsolidated deposits of gravel, cobbles, and boulders intermixed and locally interlayered with clay, silt, and sand. Mostly on terraces and pediments above present flood plains. Includes older alluvium in the Klamath Mountains and both high- and low-level terraces along Oregon coast.

Tmss Marine sandstone and siltstone (middle Eocene) - Thin- to thick-bedded, crossbedded, well-sorted, fine- to medium-grain sandstone, siltstone, and mudstone; characterized by sparse fine white mica; shallow marine depositional setting at least partly of deltaic origin. Contains foraminiferal and molluscan faunas of early middle Eocene age.

Tn Nonmarine sedimentary rocks (Eocene) - Continentally derived conglomerate, pebble conglomerate, sandstone, siltstone, and mudstone containing abundant biotite and muscovite, dominantly nonvolcanic; clastic material derived from underlying older rocks.

TrPv Volcanic rocks (Triassic and Permian) - Massive flows of porphyritic metaandesite, metabasalt, spilite, and keratophyre, volcanic breccia, and subordinate amounts of fine-grained volcaniclastic rocks. In southwest Oregon includes 
hornblende, pyroxene, and plagioclase porphyritic andesite flows, breccia, agglomerate, tuff, and locally, some basalt flows and dacitic tuffs of the Applegate Group.

TrPzm Mélange of Dutchmans Peak (Triassic or Paleozoic) — Heterogeneous mixture of interlayered metasedimentary and metavolcanic rocks metamorphosed to upper greenschist and (or) almandine-amphibolite facies, and serpentinite, gabbro, and metagabbro.

TrPzs Sedimentary rocks, partly metamorphosed (Triassic and Paleozoic)-Poorly bedded argillite, chert, phyllite, phyllitic quartzite, calc-phyllite, impure limestone, and marble. In places rocks are strongly foliated. In Klamath Mountains of southwest Oregon, includes shale, mudstone, volcaniclastic sandstone, graywacke, conglomerate, tuff, and minor radiolarian chert and marble of the Applegate Group.

Tsr Siletz River Volcanics and related rocks (middle and lower Eocene and Paleocene) - Aphanitic to porphyritic, vesicular pillow flows, tuff-breccias, massive lava flows and sills of tholeiitic and alkali basalt. Upper part of sequence contains numerous interbeds of basaltic siltstone and sandstone, basaltic tuff, and locally derived basalt conglomerate. Rocks of unit pervasively zeolitized and veined with calcite. Most of these rocks are of marine origin and have been interpreted as oceanic crust and seamounts.

Willamette Valley

Qs Lacustrine and fluvial sedimentary rocks (Pleistocene)-Unconsolidated to semiconsolidated lacustrine clay, silt, sand, and gravel; in places includes mudflow and fluvial deposits and discontinuous layers of peat.

Qt Terrace, pediment, and lag gravels (Holocene and Pleistocene)Unconsolidated deposits of gravel, cobbles, and boulders intermixed and locally interlayered with clay, silt, and sand. Mostly on terraces and pediments above 
present flood plains. Includes older alluvium in the Klamath Mountains and both high- and low-level terraces along Oregon coast.

Tfe Fisher and Eugene Formations and correlative rocks (Oligocene and upper Eocene) - Thin to moderately thick bedded, coarse-to fine-grained arkosic and micaceous sandstone and siltstone, locally highly pumiceous, of the marine Eugene Formation; and coeval and older andesitic lapilli tuff, breccia, water-laid and air-fall silicic ash of the continental Fisher and Colestin Formations; upper parts of the Fisher Formation apparently lap onto ad interfingers with the Eugene Formation.

Tfeb Basaltic rocks-Probably part of Fisher Formation.

Tfee Marine Eugene Formation, where mapped separately. 
APPENDIX C: Site and soil Pit Images for HH Sites. (Rock units in parentheses.)
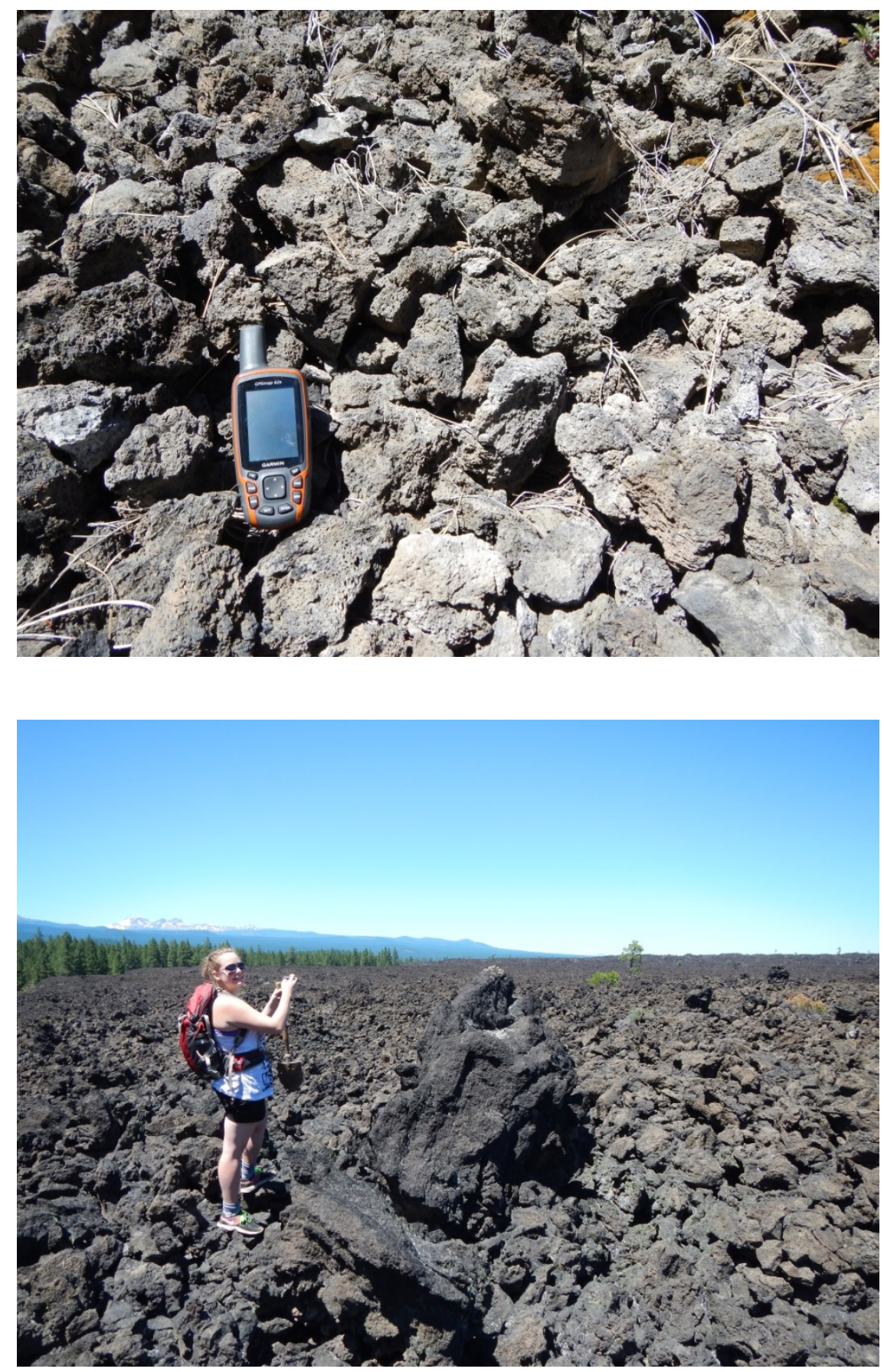

Site HHO1 and HHO2 are both from the south edge of the Newberry Lava Flow (Qyb). 

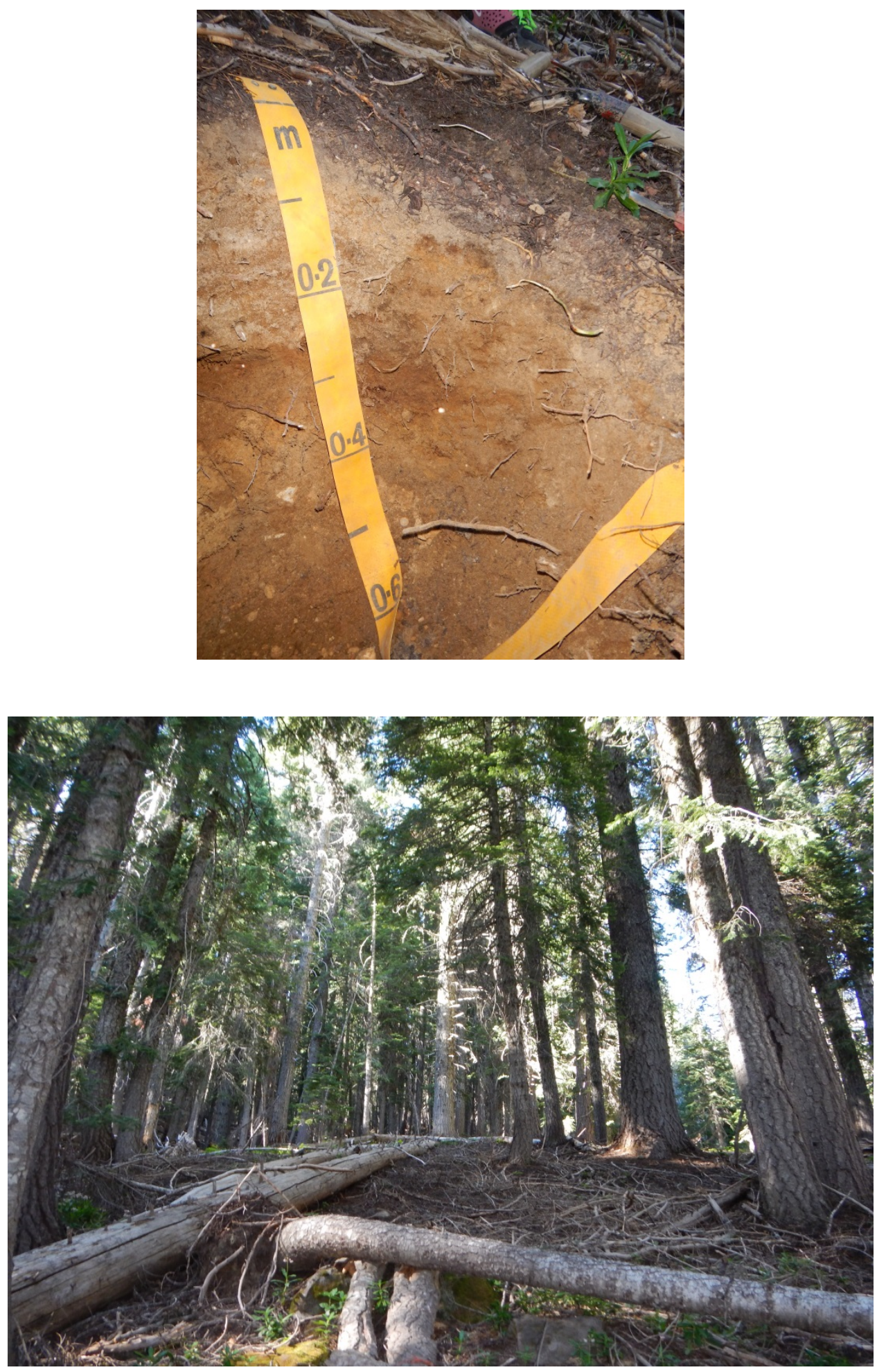

Site HH03 (QTa) 

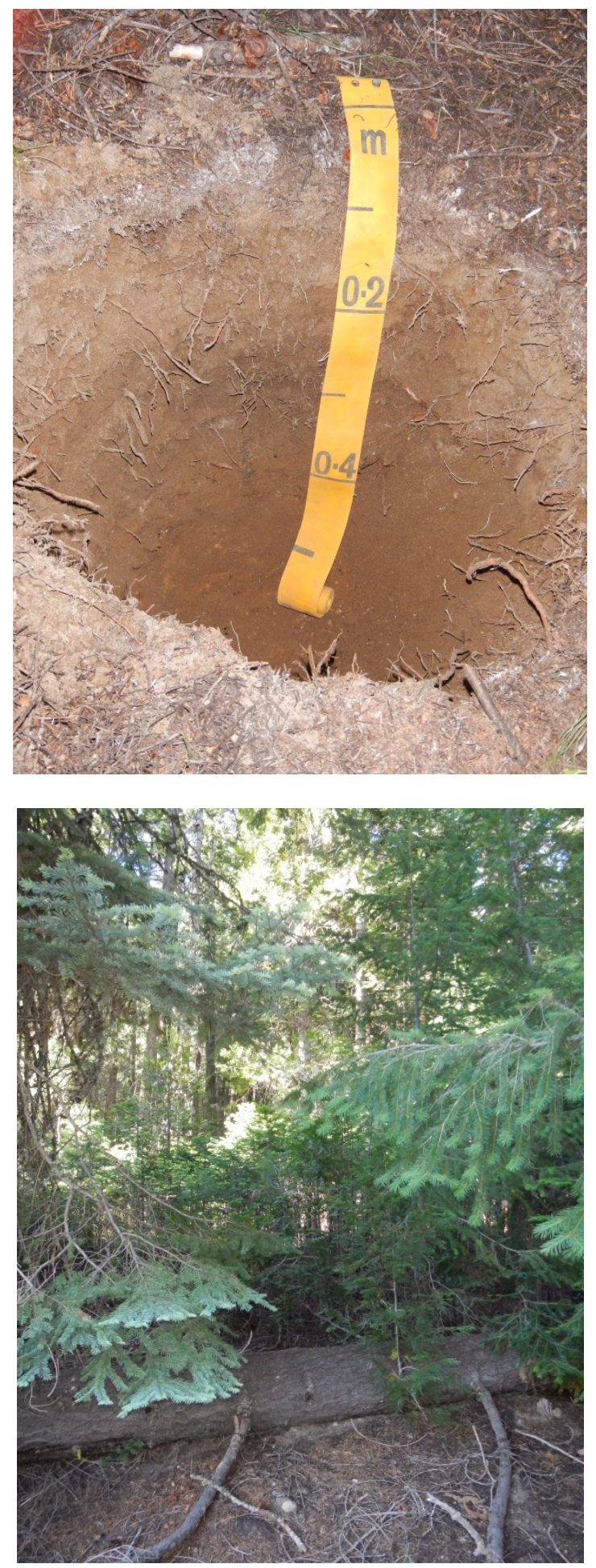

Site HH04 (QTa) 

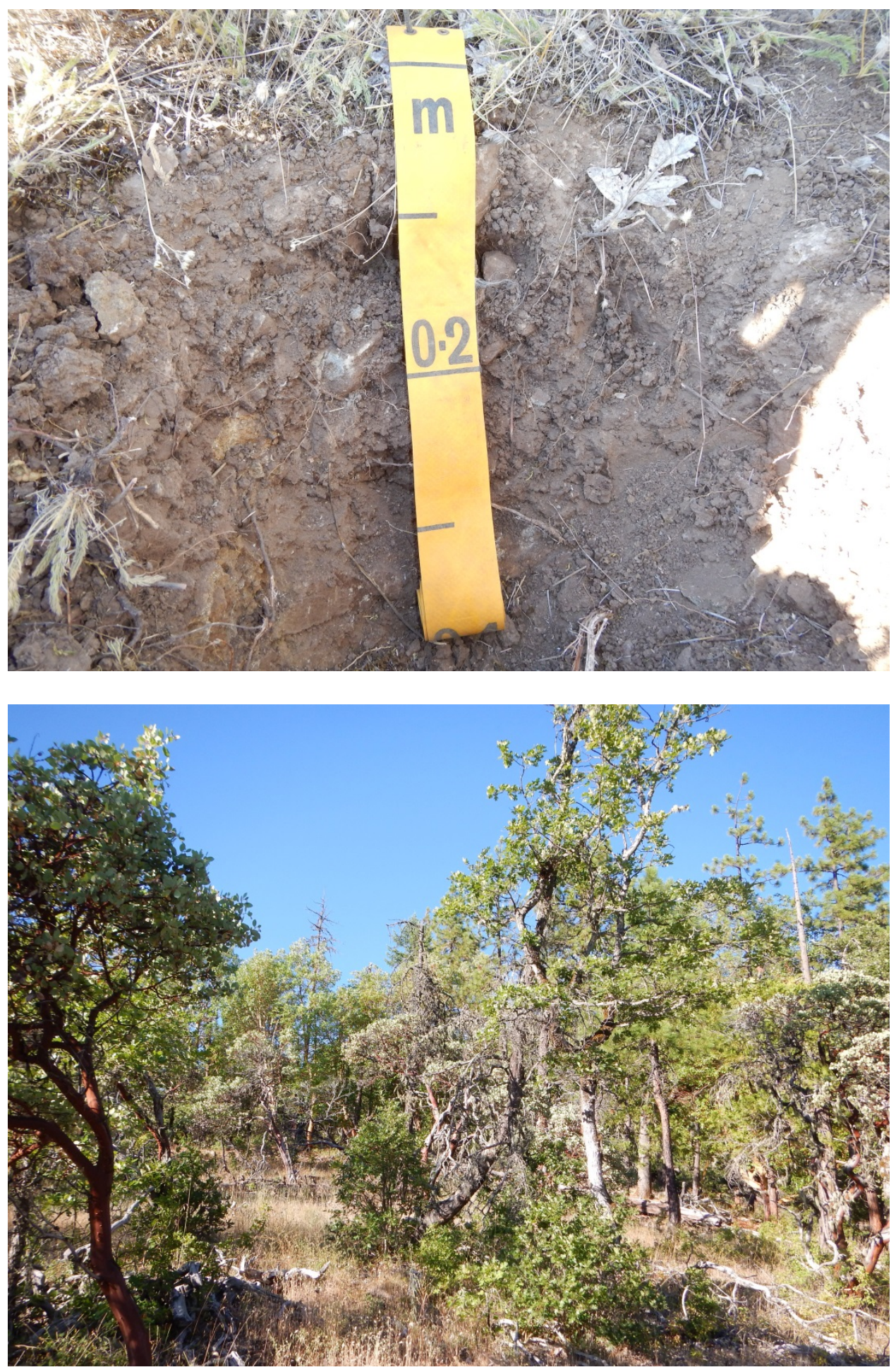

Site HH05 (Thi) 

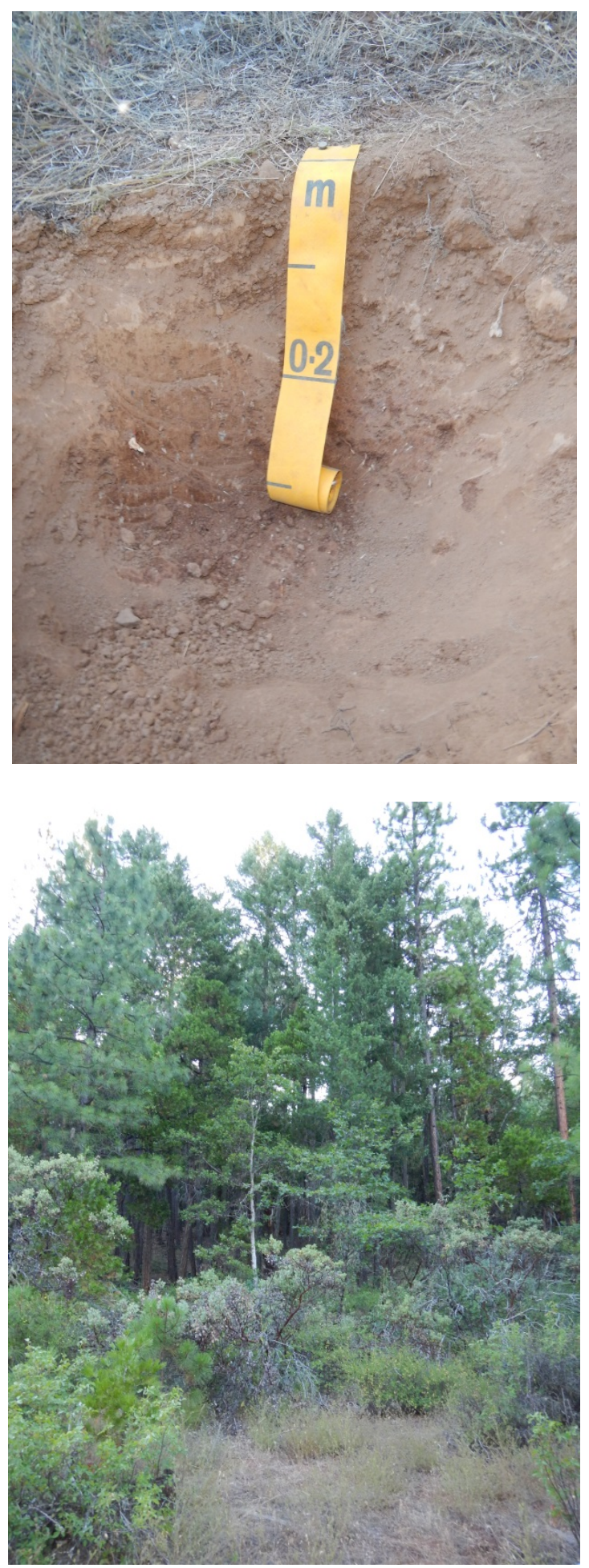

Site HH06 (Thi) 

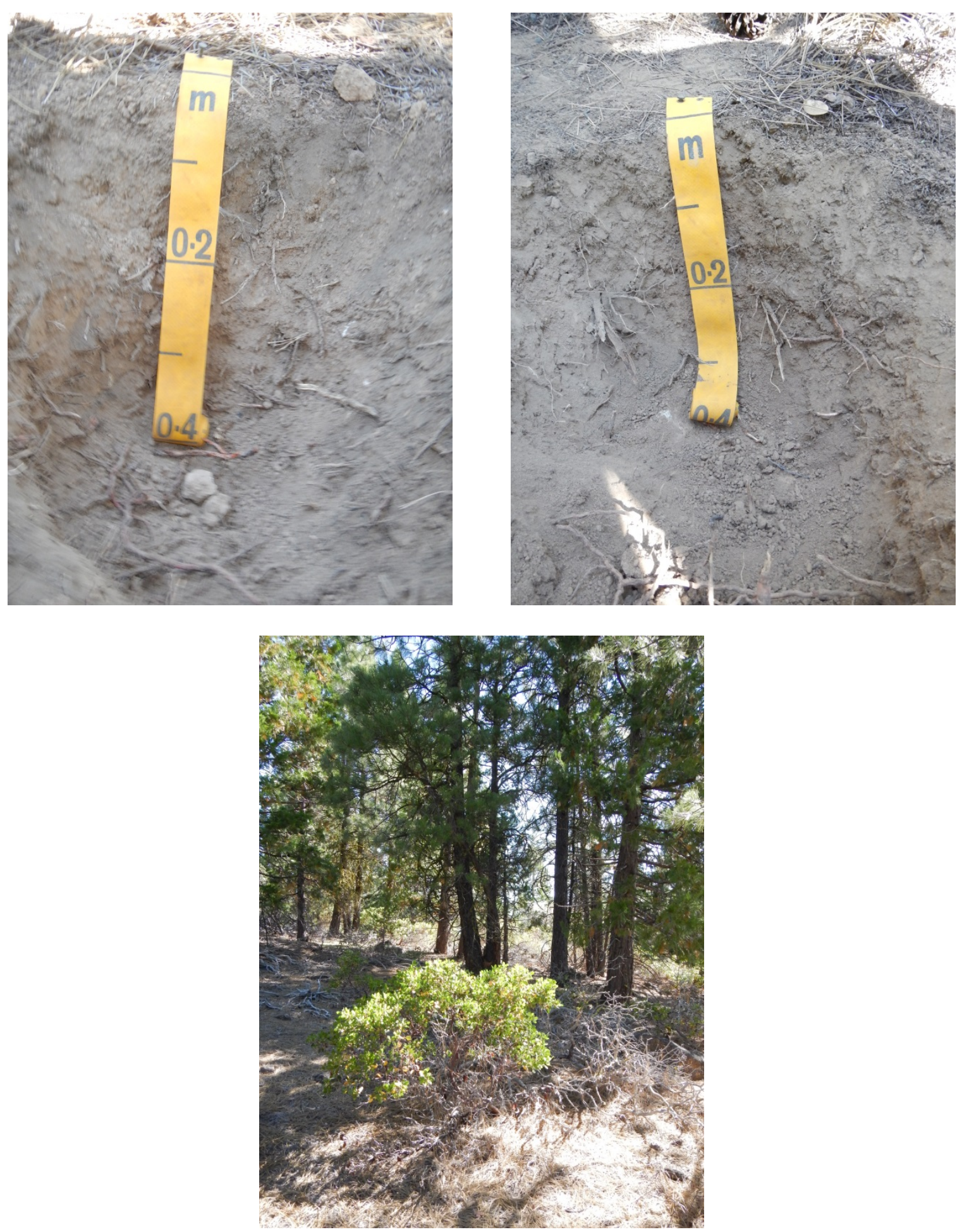

Site HH07 (upper left) and HH08 had the same vegetation (Tvs) 

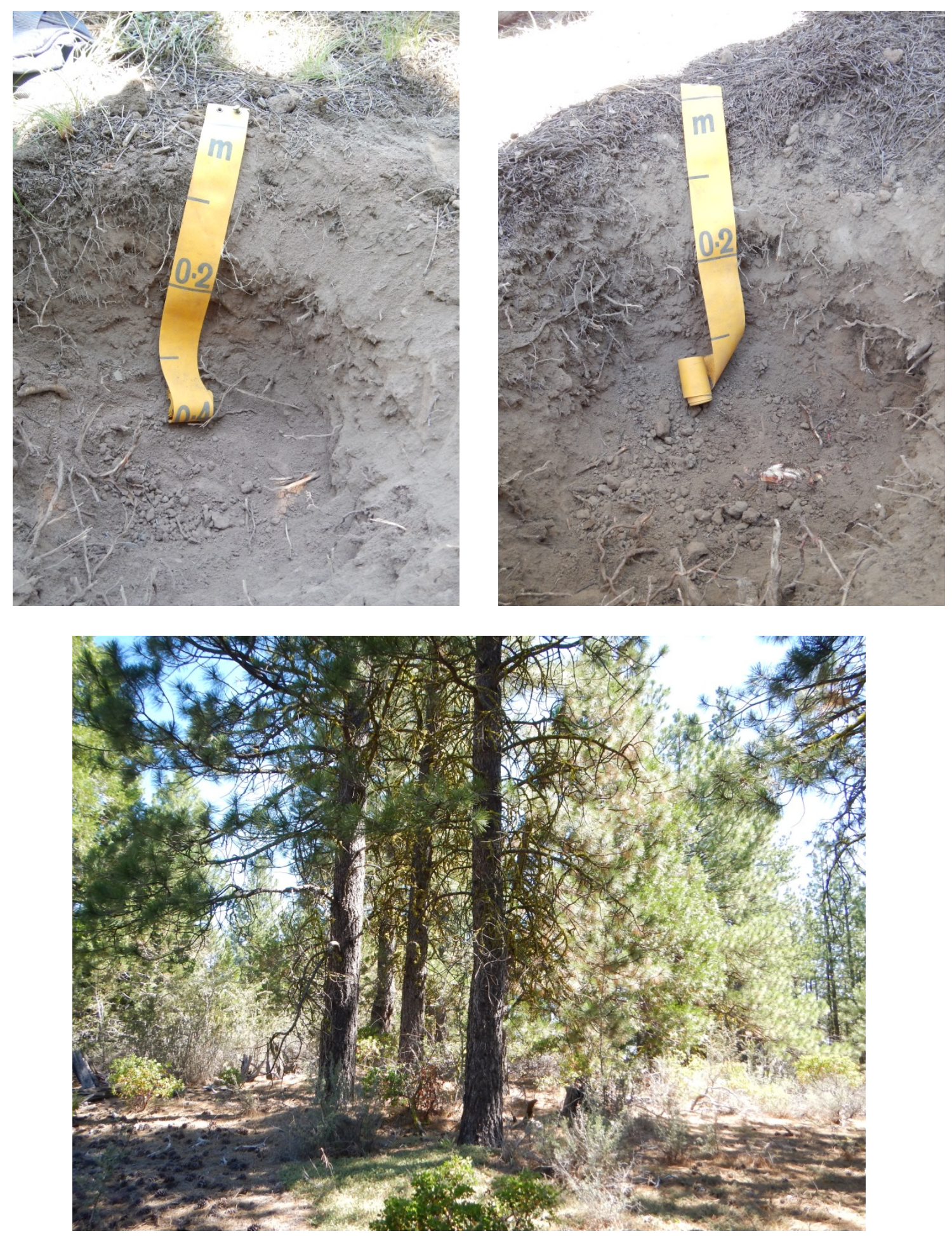

Site HH09 (upper left) and HH10 had the same vegetation (Tvm) 

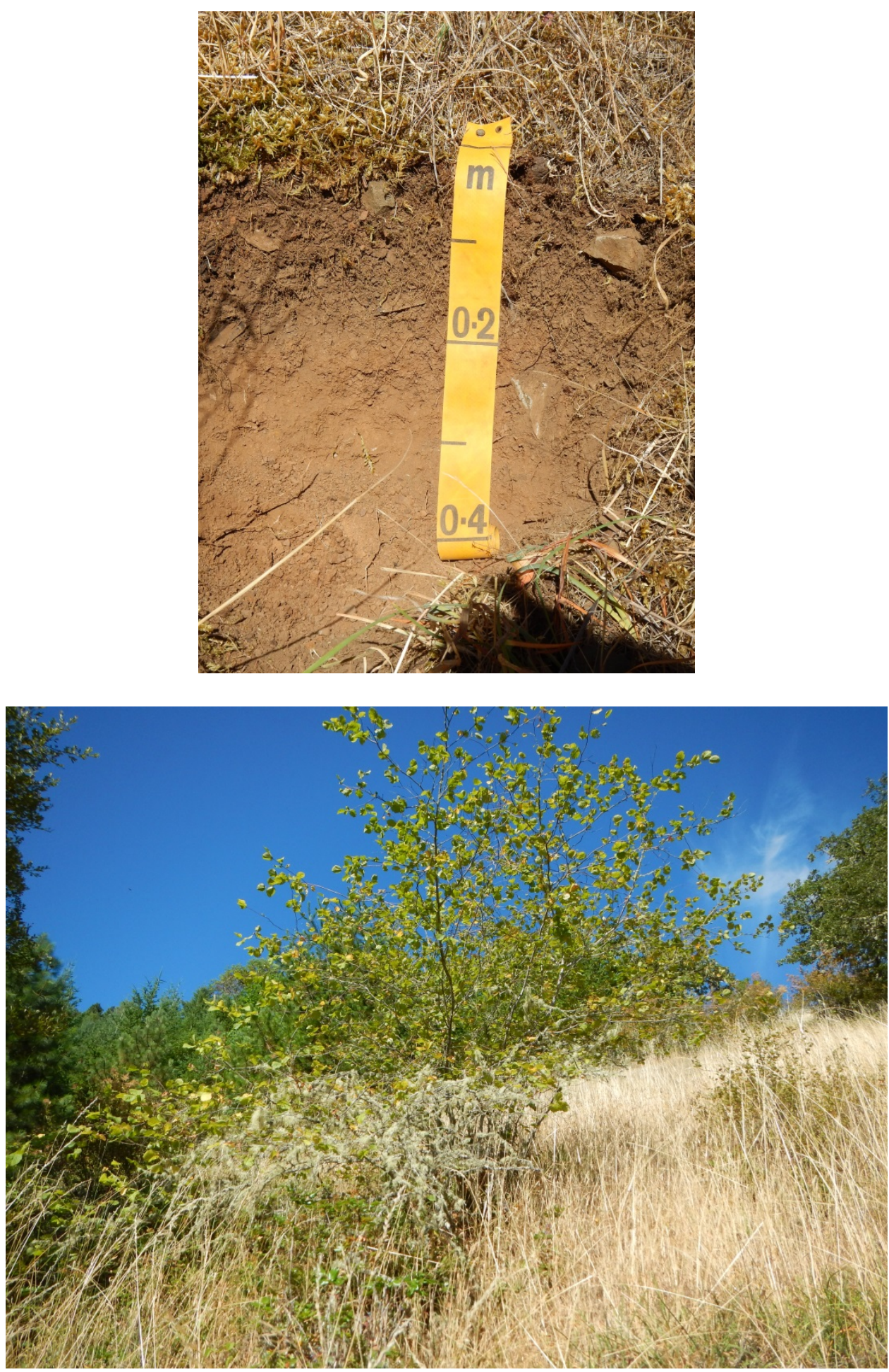

Site HH11 (KJdv) 

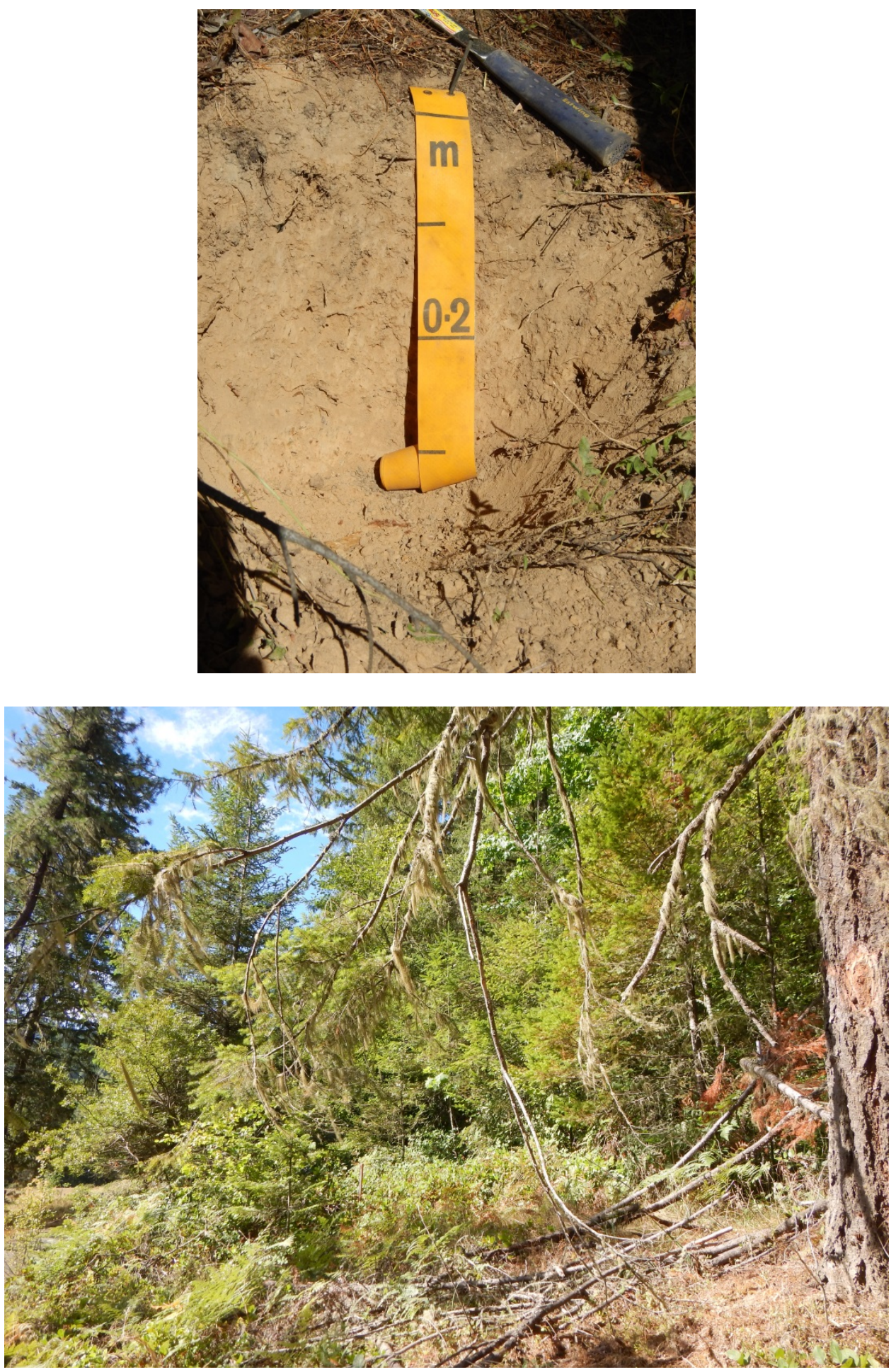

Site HH12 (KJdv) 

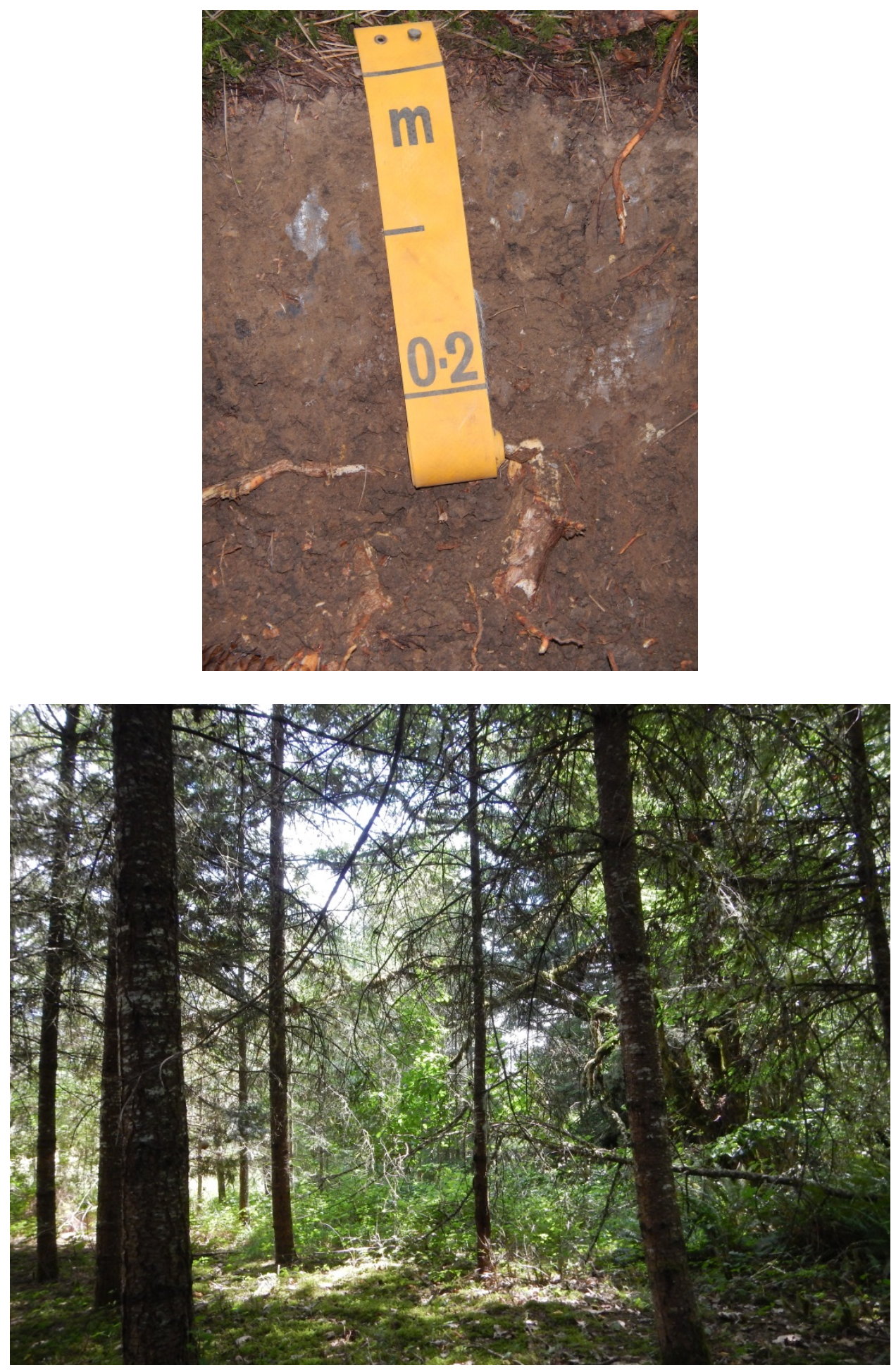

Site HH13 (Tfee) 

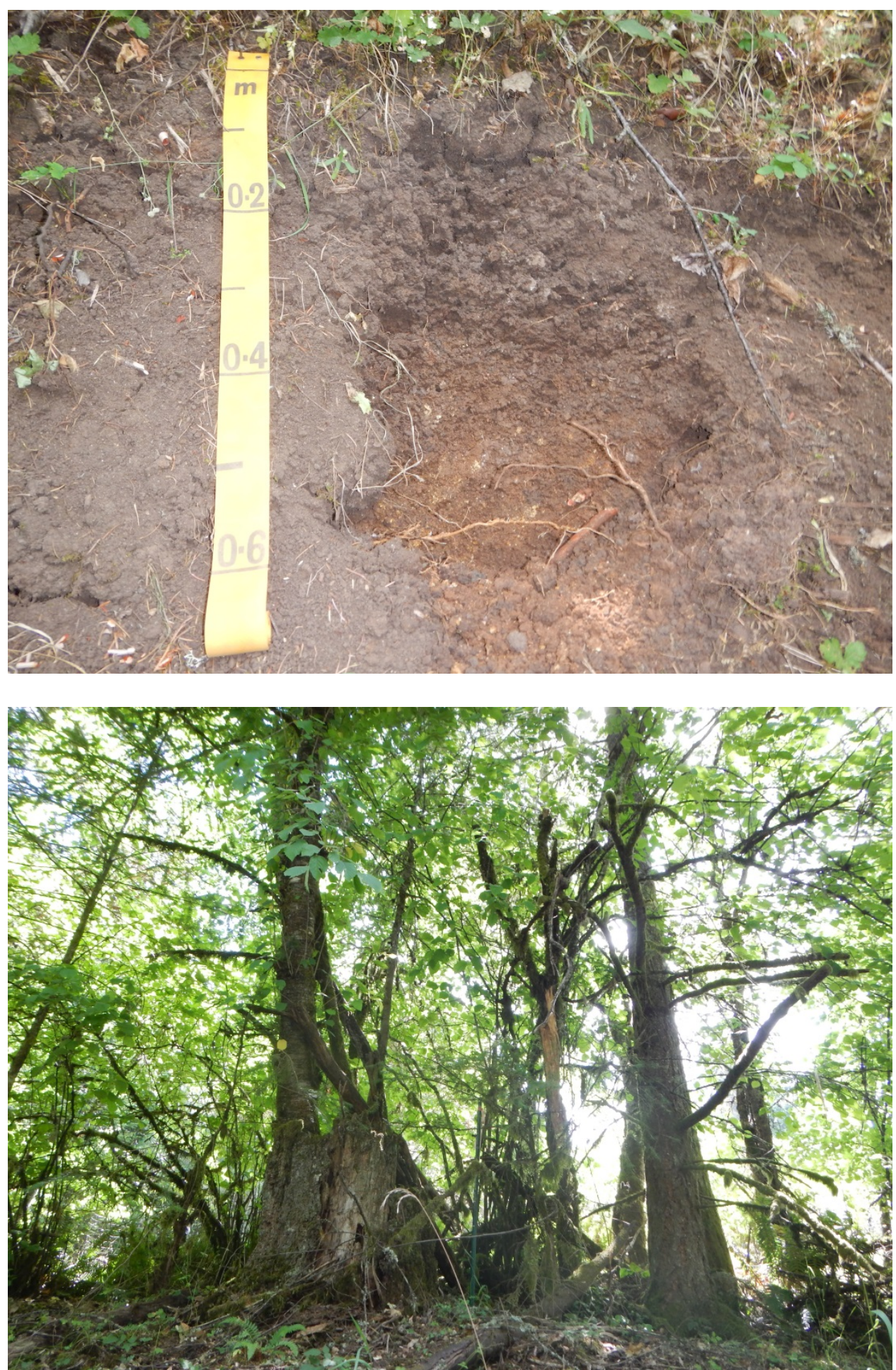

Site HH14 (Tfee) 

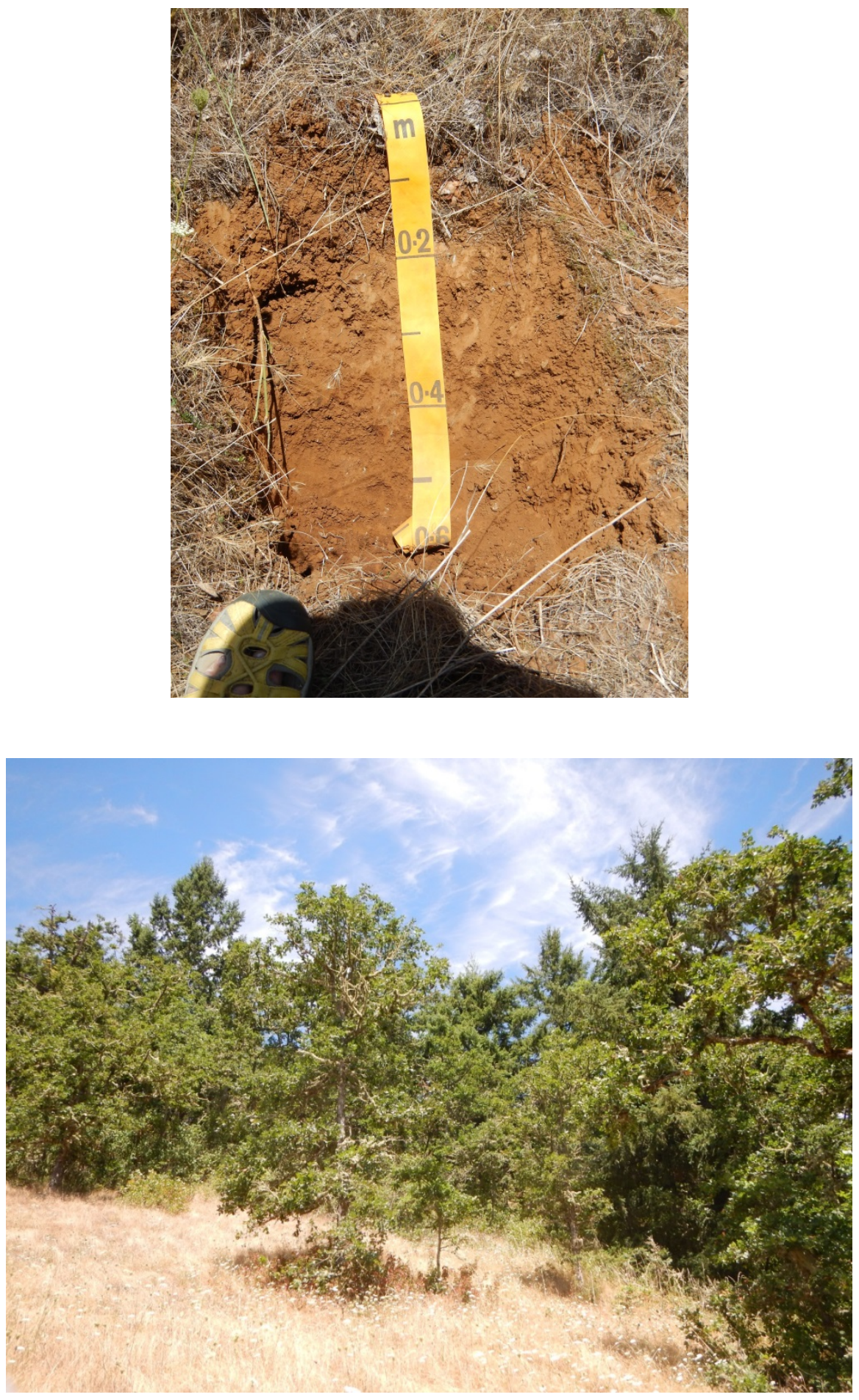

Site HH15 (Tfeb) 

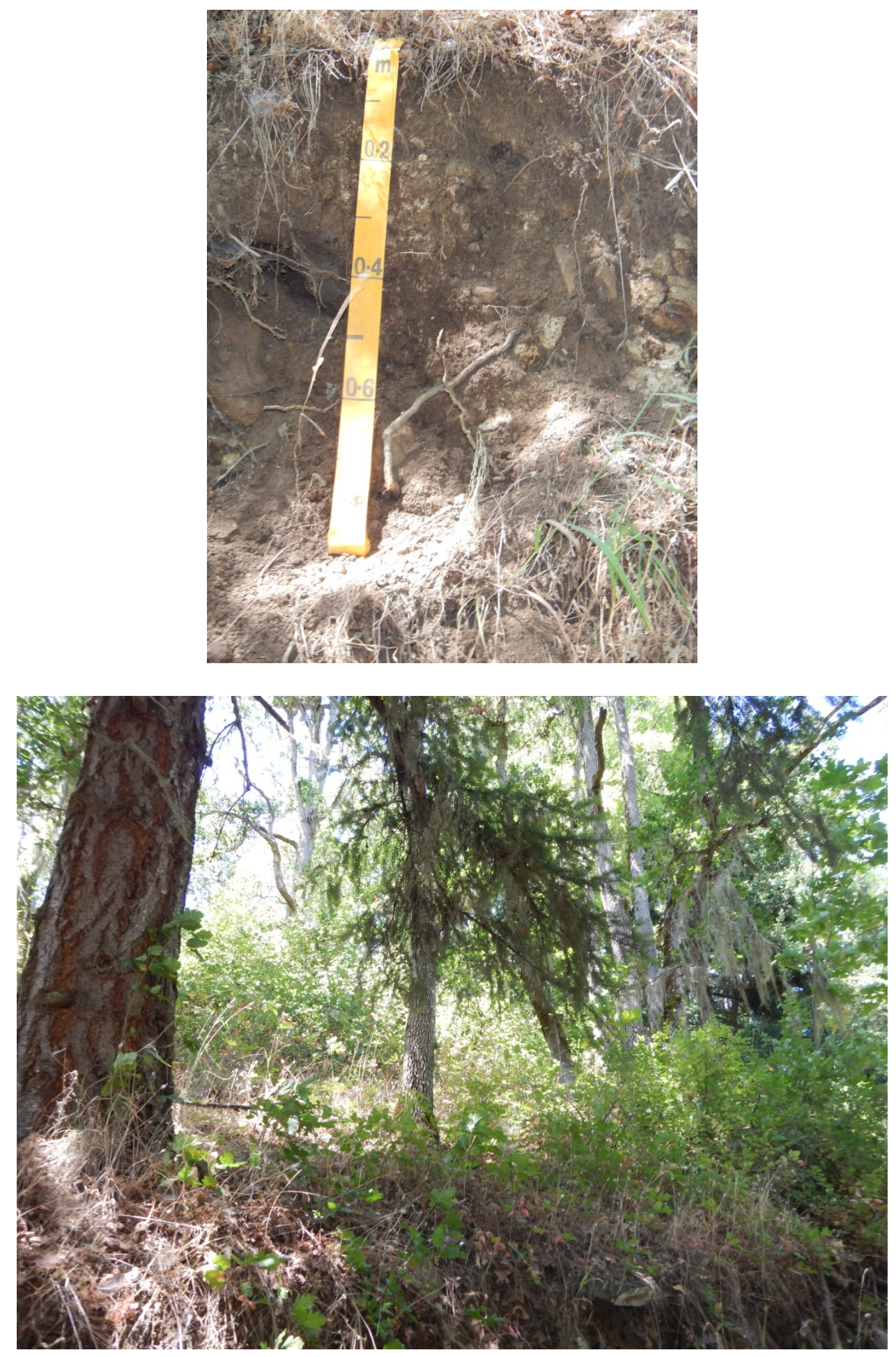

Site HH16 (Tfeb) 

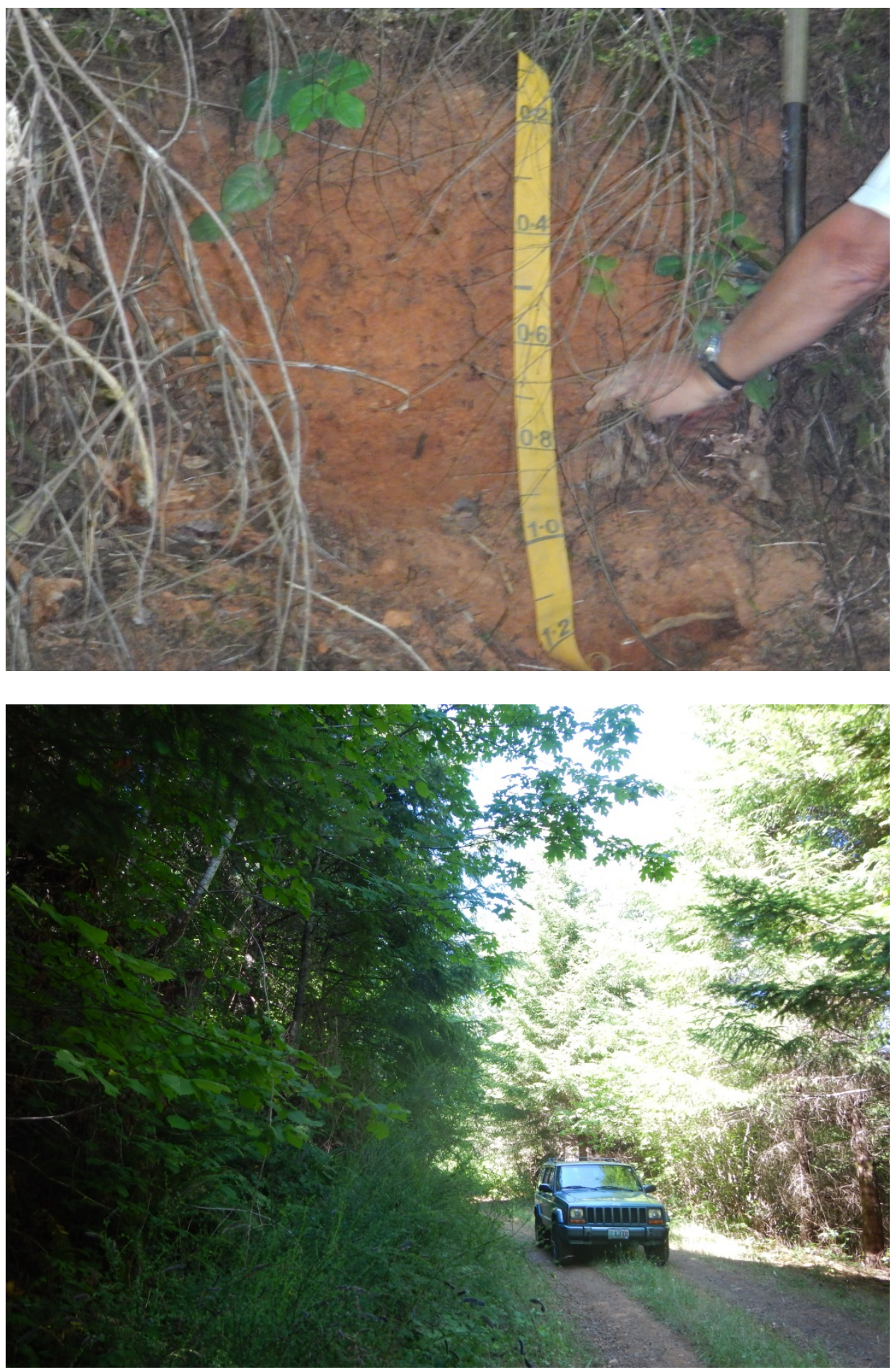

Dr. Burns points to a demarcation in the Bt $(20-60+\mathrm{cm})$ horizon at Site HH17 (Ti), where below the soil is a darker red. 

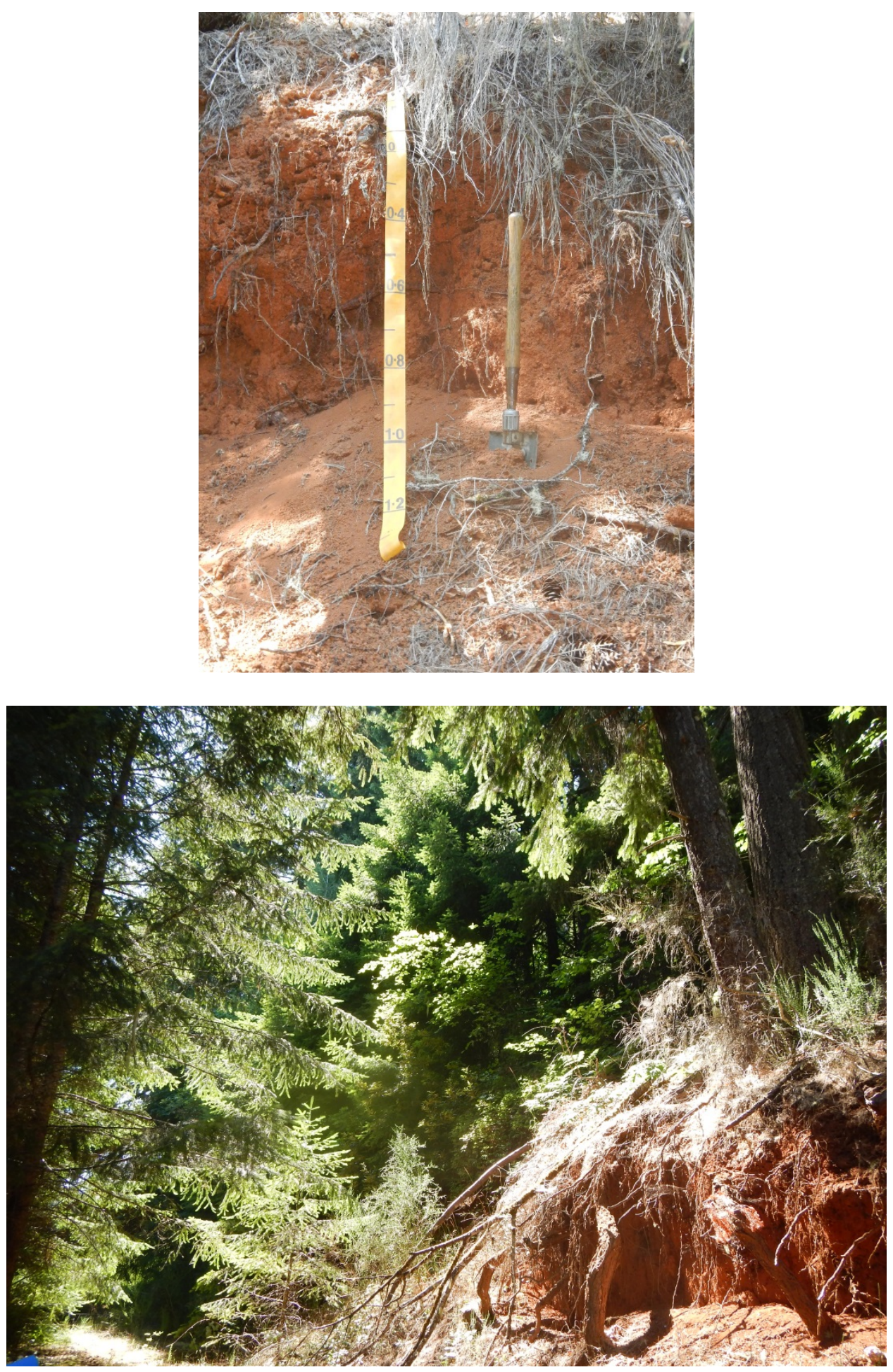

Site HH18 (Ti) 


\section{APPENDIX D: Soil Data}

\section{A Horizon}

\begin{tabular}{|c|c|c|c|c|c|}
\hline \multicolumn{2}{|c|}{ A Horizon Samples } & \multicolumn{3}{|c|}{ Munsell Colors (dry) } & \multirow{2}{*}{$\begin{array}{c}\text { Color Index } \\
\text { B-W }\end{array}$} \\
\hline Sample & As (ppm) & Hue & $\begin{array}{c}\text { Value/ } \\
\text { Chroma }\end{array}$ & Munsell Color & \\
\hline EO01 & 0.666 & & & (no color data) & \\
\hline $\mathrm{EO} 02$ & 1.36 & & & (no color data) & \\
\hline $\mathrm{EO} 07$ & 1.46 & $10 \mathrm{YR}$ & $4 / 3$ & brown & 9 \\
\hline EO08 & 1.57 & $10 \mathrm{YR}$ & $4 / 2$ & dark grayish brown & 6 \\
\hline EO14 & 0.869 & $10 \mathrm{YR}$ & $3 / 2$ & very dark grayish brown & 6 \\
\hline EO15 & 0.776 & $2.5 \mathrm{Y}$ & $4 / 3$ & olive brown & 6 \\
\hline EO16 & 1.31 & $2.5 \mathrm{Y}$ & $4 / 2$ & dark grayish brown & 4 \\
\hline EO17 & 1.47 & $2.5 \mathrm{Y}$ & $4 / 3$ & olive brown & 6 \\
\hline EO18 & 0.718 & $2.5 \mathrm{Y}$ & $4 / 3$ & olive brown & 6 \\
\hline $\mathrm{EO} 20$ & 0.724 & $2.5 \mathrm{Y}$ & $4 / 3$ & olive brown & 6 \\
\hline $\mathrm{EO} 21$ & 0.687 & $2.5 \mathrm{Y}$ & $4 / 2$ & dark grayish brown & 4 \\
\hline $\mathrm{EO} 22$ & 1.12 & $2.5 \mathrm{Y}$ & $5 / 3$ & grayish brown & 6 \\
\hline $\mathrm{EO} 23$ & 0.845 & $2.5 \mathrm{Y}$ & $4 / 2$ & dark grayish brown & 4 \\
\hline $\mathrm{EO} 24$ & 1.22 & $2.5 \mathrm{Y}$ & $4 / 3$ & olive brown & 6 \\
\hline $\mathrm{EO} 25$ & 0.892 & $2.5 \mathrm{Y}$ & $5 / 3$ & grayish brown & 6 \\
\hline $\mathrm{EO} 26$ & 0.483 & $2.5 \mathrm{Y}$ & $4 / 2$ & dark grayish brown & 4 \\
\hline $\mathrm{EO} 27$ & 2.15 & $2.5 \mathrm{Y}$ & $4 / 3$ & olive brown & 6 \\
\hline EO30 & 0.762 & $2.5 \mathrm{Y}$ & $7 / 4$ & pale yellow & 8 \\
\hline EO31 & 0.821 & $2.5 \mathrm{Y}$ & $4 / 3$ & olive brown & 6 \\
\hline EO32 & 1.5 & $2.5 \mathrm{Y}$ & $4 / 3$ & olive brown & 6 \\
\hline EO33 & 1.07 & $2.5 \mathrm{Y}$ & $4 / 3$ & olive brown & 6 \\
\hline EO34 & 1.15 & $2.5 \mathrm{Y}$ & $5 / 3$ & grayish brown & 6 \\
\hline EO35 & 1.62 & $10 \mathrm{YR}$ & $5 / 4$ & yellowish brown & 12 \\
\hline EO36 & 1.57 & $10 \mathrm{YR}$ & $3 / 3$ & dark brown & 9 \\
\hline HH01 & $<0.20$ & $7.5 \mathrm{YR}$ & $3 / 1$ & very dark gray & 4 \\
\hline $\mathrm{HH} 02$ & $<0.20$ & $7.5 \mathrm{YR}$ & $3 / 1$ & very dark gray & 4 \\
\hline $\mathrm{HH} 03$ & $<0.20$ & $5 \mathrm{YR}$ & $3 / 1$ & very dark gray & 5 \\
\hline HH04 & $<0.20$ & $10 \mathrm{YR}$ & $4 / 2$ & dark grayish brown & 6 \\
\hline HH05 & 4.88 & $7.5 \mathrm{YR}$ & $4 / 2$ & brown & 8 \\
\hline HH06 & 7.29 & $7.5 \mathrm{YR}$ & $4 / 3$ & brown & 12 \\
\hline HH07 & $<0.20$ & $10 \mathrm{YR}$ & $4 / 2$ & dark grayish brown & 6 \\
\hline HH08 & $<0.20$ & $10 \mathrm{YR}$ & $4 / 3$ & brown & 9 \\
\hline HH09 & $<0.20$ & $7.5 \mathrm{YR}$ & $4 / 3$ & brown & 12 \\
\hline HH10 & $<0.20$ & $10 \mathrm{YR}$ & $4 / 2$ & dark grayish brown & 6 \\
\hline
\end{tabular}


APPENDIX D: Soil Data, A Horizon (cont.)

\begin{tabular}{|c|c|c|c|c|c|}
\hline \multicolumn{2}{|c|}{ A Horizon Samples } & \multicolumn{3}{|c|}{ Munsell Colors (dry) } & \multirow{2}{*}{$\frac{\text { Color Index }}{\text { B-W }}$} \\
\hline Sample & As (ppm) & Hue & $\begin{array}{l}\text { Value/ } \\
\text { Chroma }\end{array}$ & Munsell Color & \\
\hline HH1 1.1 & 4.38 & $10 \mathrm{YR}$ & $4 / 3$ & brown & 9 \\
\hline HH1 1.2 & 3.95 & $5 \mathrm{YR}$ & $4 / 2$ & dark reddish gray & 10 \\
\hline $\mathrm{HH} 11.3$ & 3.24 & $10 \mathrm{YR}$ & $4 / 3$ & brown & 9 \\
\hline HH1 1.4 & 3.48 & $10 \mathrm{YR}$ & $4 / 3$ & brown & 9 \\
\hline HH1 1.5 & 3.65 & $10 \mathrm{YR}$ & $4 / 3$ & brown & 9 \\
\hline HH12 & $<0.20$ & $10 \mathrm{YR}$ & $6 / 3$ & pale brown & 9 \\
\hline HH13 & 13.5 & $10 \mathrm{YR}$ & $4 / 3$ & brown & 9 \\
\hline HH14 & 63.2 & $10 \mathrm{YR}$ & $3 / 2$ & very dark grayish brown & 6 \\
\hline HH15 & $<0.20$ & $7.5 \mathrm{YR}$ & $4 / 3$ & brown & 12 \\
\hline HH16 & $<0.20$ & $10 \mathrm{YR}$ & $4 / 2$ & dark grayish brown & 6 \\
\hline HH17 & 4.28 & $5 \mathrm{YR}$ & $5 / 6$ & yellowish red & 30 \\
\hline HH18 & 4.54 & $5 \mathrm{YR}$ & $4 / 4$ & reddish brown & 20 \\
\hline KL01 & 1.49 & $10 \mathrm{YR}$ & $5 / 6$ & yellowish brown & 18 \\
\hline KL02 & 0.995 & $2.5 \mathrm{Y}$ & $4 / 3$ & olive brown & 6 \\
\hline KL03 & 2.57 & $10 \mathrm{YR}$ & $6 / 6$ & brownish yellow & 18 \\
\hline KL04 & 7.97 & $10 \mathrm{YR}$ & $4 / 4$ & dark yellowish brown & 12 \\
\hline KL05 & 5.26 & $10 \mathrm{YR}$ & $4 / 3$ & brown & 9 \\
\hline KL06 & 3.43 & $7.5 \mathrm{YR}$ & $5 / 6$ & strong brown & 24 \\
\hline KL07 & 0.765 & $2.5 \mathrm{Y}$ & $3 / 1$ & very dark gray & 2 \\
\hline KL08 & 5.11 & $10 \mathrm{YR}$ & $3 / 3$ & dark brown & 9 \\
\hline KL09 & 3.5 & $7.5 \mathrm{YR}$ & $5 / 6$ & strong brown & 24 \\
\hline KL10 & 3.19 & $10 \mathrm{YR}$ & $4 / 3$ & brown & 9 \\
\hline KL11 & 2.59 & $10 \mathrm{YR}$ & $4 / 4$ & dark yellowish brown & 12 \\
\hline KL12 & 2.82 & $10 \mathrm{YR}$ & $4 / 4$ & dark yellowish brown & 12 \\
\hline KL13 & 2.36 & $10 \mathrm{YR}$ & $3 / 3$ & dark brown & 9 \\
\hline KL14 & 2.67 & $10 \mathrm{YR}$ & $4 / 3$ & brown & 9 \\
\hline KL15 & 5.14 & $10 \mathrm{YR}$ & $4 / 3$ & brown & 9 \\
\hline KL16 & 1.7 & $5 \mathrm{YR}$ & $4 / 6$ & yellowish red & 30 \\
\hline KL17 & 1.43 & $10 \mathrm{YR}$ & $4 / 4$ & dark yellowish brown & 12 \\
\hline KL18 & 2.22 & $2.5 \mathrm{Y}$ & $5 / 3$ & grayish brown & 6 \\
\hline KL19 & 4.88 & $10 \mathrm{YR}$ & $5 / 4$ & yellowish brown & 12 \\
\hline KL20 & 1.44 & $10 \mathrm{YR}$ & $4 / 4$ & dark yellowish brown & 12 \\
\hline KL21 & 32.6 & $10 \mathrm{YR}$ & $4 / 4$ & dark yellowish brown & 12 \\
\hline KL22 & 1.57 & $10 \mathrm{YR}$ & $4 / 3$ & brown & 9 \\
\hline KL23 & 0.438 & $2.5 \mathrm{Y}$ & $5 / 3$ & grayish brown & 6 \\
\hline KL24 & 1.22 & $10 \mathrm{YR}$ & $3 / 2$ & very dark grayish brown & 6 \\
\hline KL25 & 2.88 & $10 \mathrm{YR}$ & $3 / 3$ & dark brown & 9 \\
\hline KL26 & 1.3 & $10 \mathrm{YR}$ & $4 / 3$ & brown & 9 \\
\hline
\end{tabular}


APPENDIX D: Soil Data, A Horizon (cont.)

\begin{tabular}{|c|c|c|c|c|c|}
\hline \multicolumn{2}{|c|}{ A Horizon Samples } & \multicolumn{3}{|c|}{ Munsell Colors (dry) } & \multirow{2}{*}{$\frac{\text { Color Index }}{\text { B-W }}$} \\
\hline Sample & As (ppm) & Hue & $\begin{array}{l}\text { Value/ } \\
\text { Chroma }\end{array}$ & Munsell Color & \\
\hline KL27 & 7.48 & $7.5 \mathrm{YR}$ & $4 / 4$ & brown & 16 \\
\hline KL28 & 0.1085 & $2.5 \mathrm{Y}$ & $4 / 3$ & olive brown & 6 \\
\hline KL30 & 0.761 & $5 \mathrm{YR}$ & $3 / 3$ & dark reddish brown & 15 \\
\hline $\mathrm{LC} 01$ & 17.2 & $2.5 \mathrm{Y}$ & $5 / 2$ & grayish brown & 4 \\
\hline $\mathrm{LC} 02$ & 10.1 & $7.5 \mathrm{YR}$ & $3 / 3$ & dark brown & 12 \\
\hline LC03 & 2.08 & $2.5 \mathrm{Y}$ & $5 / 3$ & grayish brown & 6 \\
\hline LC04 & 2.1 & $10 \mathrm{YR}$ & $5 / 4$ & yellowish brown & 12 \\
\hline LC05 & 8.74 & $2.5 \mathrm{Y}$ & $5 / 4$ & light olive brown & 8 \\
\hline LC06 & 0.301 & $10 \mathrm{YR}$ & $4 / 4$ & dark yellowish brown & 12 \\
\hline LC07 & 3.64 & $10 \mathrm{YR}$ & $4 / 4$ & dark yellowish brown & 12 \\
\hline LC08 & 4.96 & $10 \mathrm{YR}$ & $4 / 2$ & dark grayish brown & 6 \\
\hline LC09 & 7.36 & $1.5 \mathrm{Y}$ & $5.5 / 4$ & light yellowish olive brown & 10 \\
\hline LC10A & 4.58 & $10 \mathrm{YR}$ & $4 / 2$ & dark grayish brown & 6 \\
\hline LC11 & 4.96 & $10 \mathrm{YR}$ & $5 / 4$ & yellowish brown & 12 \\
\hline LC12 & 4.27 & $1.5 \mathrm{Y}$ & $4 / 3$ & olive brown & 7.5 \\
\hline LC13 & 2.52 & $2.5 \mathrm{Y}$ & $5 / 2$ & grayish brown & 4 \\
\hline $\mathrm{LC} 14$ & 1.25 & $10 \mathrm{YR}$ & $4 / 1$ & dark gray & 3 \\
\hline LC15 & 6.44 & $10 \mathrm{YR}$ & $3 / 2$ & very dark grayish brown & 6 \\
\hline LC16 & 3.73 & & & (no color data) & \\
\hline $\mathrm{LC} 17$ & 2.28 & $10 \mathrm{YR}$ & $3 / 2$ & very dark grayish brown & 6 \\
\hline LC18 & 6.95 & $10 \mathrm{YR}$ & $3 / 2$ & very dark grayish brown & 6 \\
\hline LC19 & 0.799 & $10 \mathrm{YR}$ & $4 / 4$ & dark yellowish brown & 12 \\
\hline LC20 & 2.58 & $10 \mathrm{YR}$ & $4 / 2$ & dark grayish brown & 6 \\
\hline LC21 & 3.09 & $7.5 \mathrm{YR}$ & $4 / 4$ & brown & 16 \\
\hline LC22 & 3.29 & $6.5 \mathrm{YR}$ & $4 / 4$ & brown & 18 \\
\hline LC23 & 2.66 & $7.5 \mathrm{YR}$ & $4 / 4$ & brown & 16 \\
\hline LM01 & 6.35 & $10 \mathrm{YR}$ & $4 / 3$ & brown & 9 \\
\hline LM02 & 5.04 & $10 \mathrm{YR}$ & $4 / 2$ & dark grayish brown & 6 \\
\hline LM03A & 1.92 & $10 \mathrm{YR}$ & $3 / 2$ & very dark grayish brown & 6 \\
\hline LM05 & 1.26 & $10 \mathrm{YR}$ & $3 / 2$ & very dark grayish brown & 6 \\
\hline LM06 & 0.914 & $2.5 \mathrm{Y}$ & $4 / 3$ & olive brown & 6 \\
\hline LM07 & 2.99 & $2.5 \mathrm{Y}$ & $4 / 3$ & olive brown & 6 \\
\hline LM08 & 3.71 & $10 \mathrm{YR}$ & $3 / 2$ & very dark grayish brown & 6 \\
\hline LM09 & 0.608 & $10 \mathrm{YR}$ & $3 / 2$ & very dark grayish brown & 6 \\
\hline LM10 & 0.371 & $10 \mathrm{YR}$ & $4 / 2$ & dark grayish brown & 6 \\
\hline LM11 & 0.957 & $10 \mathrm{YR}$ & $3 / 2$ & very dark grayish brown & 6 \\
\hline LM12 & 2.1 & $10 \mathrm{YR}$ & $3 / 2$ & very dark grayish brown & 6 \\
\hline LM13 & 1.81 & $10 \mathrm{YR}$ & $3 / 2$ & very dark grayish brown & 6 \\
\hline
\end{tabular}


APPENDIX D: Soil Data, A Horizon (cont.)

\begin{tabular}{|c|c|c|c|c|c|}
\hline \multicolumn{2}{|c|}{ A Horizon Samples } & \multicolumn{3}{|c|}{ Munsell Colors (dry) } & Color Index \\
\hline Sample & As (ppm) & Hue & $\begin{array}{c}\text { Value/ } \\
\text { Chroma }\end{array}$ & Munsell Color & B-W \\
\hline LM14 & 1.63 & 7.5 YR & $3 / 2$ & dark brown & 8 \\
\hline LM15 & 2.38 & 10 YR & $4 / 4$ & dark yellowish brown & 12 \\
\hline LM16 & 2.32 & 10 YR & $4 / 3$ & brown & 9 \\
\hline LM17 & 3.13 & 10 YR & $4 / 3$ & brown & 9 \\
\hline LM20 & 2.57 & & & (no color data) & 9 \\
\hline LM21 & 1.03 & 10 YR & $4 / 3$ & brown & 6 \\
\hline LM22 & 0.965 & 10 YR & $3 / 2$ & very dark grayish brown & 4 \\
\hline R01 & 7.94 & 10 YR & $5 / 2$ & grayish brown & 6 \\
\hline R02 & 3.47 & $2.5 \mathrm{Y}$ & $3 / 2$ & very dark grayish brown & 9 \\
\hline R03 & 1.72 & $2.5 \mathrm{Y}$ & $4 / 3$ & olive brown & 20 \\
\hline R13 & 13.6 & $10 \mathrm{YR}$ & $3 / 3$ & dark brown & 15 \\
\hline R14 & 10 & $7.5 \mathrm{YR}$ & $6 / 5$ & reddish yellow & \\
\hline R15 & 1 & $10 \mathrm{YR}$ & $5 / 5$ & yellowish brown & \\
\hline
\end{tabular}




\section{B Horizon}

\begin{tabular}{|c|c|c|c|c|c|}
\hline \multicolumn{2}{|c|}{ B Horizon Samples } & \multicolumn{3}{|c|}{ Munsell Colors (dry) } & \multirow{2}{*}{$\frac{\text { Color Index }}{\text { B-W }}$} \\
\hline Sample & As (ppm) & Hue & $\begin{array}{l}\text { Value/ } \\
\text { Chroma }\end{array}$ & Munsell Color & \\
\hline EO01 & 0.846 & & & (no color data) & \\
\hline EO02 & 1.03 & & & (no color data) & \\
\hline EO07 & 1.45 & $10 \mathrm{YR}$ & $4 / 4$ & dark yellowish brown & 12 \\
\hline EO08 & 1.15 & $10 \mathrm{YR}$ & $4 / 2$ & dark grayish brown & 6 \\
\hline EO09 & 0.496 & $10 \mathrm{YR}$ & $5 / 2$ & grayish brown & 6 \\
\hline EO10 & 1.08 & $2.5 \mathrm{Y}$ & $6 / 4$ & light yellowish brown & 8 \\
\hline EO11 & 1.13 & $2.5 \mathrm{Y}$ & $6 / 3$ & light yellowish brown & 6 \\
\hline EO12 & 0.941 & $2.5 \mathrm{Y}$ & $6 / 4$ & light yellowish brown & 8 \\
\hline EO13 & 1.05 & $2.5 \mathrm{Y}$ & $6 / 3$ & light yellowish brown & 6 \\
\hline EO14 & 1.02 & $10 \mathrm{YR}$ & $6 / 4$ & light yellowish brown & 12 \\
\hline EO15 & 0.655 & $2.5 \mathrm{Y}$ & $6 / 4$ & light yellowish brown & 8 \\
\hline EO16 & 1.01 & $2.5 \mathrm{Y}$ & $6 / 4$ & light yellowish brown & 8 \\
\hline EO17 & 0.965 & $2.5 \mathrm{Y}$ & $6 / 4$ & light yellowish brown & 8 \\
\hline EO18 & 0.923 & $2.5 \mathrm{Y}$ & $6 / 4$ & light yellowish brown & 8 \\
\hline EO19 & 0.349 & & & (no color data) & \\
\hline EO20 & 0.806 & $2.5 \mathrm{Y}$ & $6 / 6$ & olive yellow & 8 \\
\hline EO21 & 0.661 & $2.5 \mathrm{Y}$ & $6 / 4$ & light yellowish brown & 8 \\
\hline EO22 & 0.587 & $2.5 \mathrm{Y}$ & $7 / 3$ & pale yellow & 6 \\
\hline EO23 & 0.783 & $2.5 \mathrm{Y}$ & $6 / 4$ & light yellowish brown & 8 \\
\hline $\mathrm{EO} 24$ & 1.14 & $10 \mathrm{YR}$ & $6 / 4$ & light yellowish brown & 12 \\
\hline EO25 & 0.83 & $2.5 \mathrm{Y}$ & $7 / 3$ & pale yellow & 6 \\
\hline EO26 & 0.693 & $2.5 \mathrm{Y}$ & $5 / 6$ & light olive brown & 12 \\
\hline $\mathrm{EO} 27$ & 1.14 & $2.5 \mathrm{Y}$ & $7 / 4$ & pale yellow & 8 \\
\hline EO30 & 0.579 & $2.5 \mathrm{Y}$ & $7 / 4$ & pale yellow & 8 \\
\hline EO31 & 0.633 & $2.5 \mathrm{Y}$ & $7 / 3$ & pale yellow & 6 \\
\hline EO32 & 1.02 & $2.5 \mathrm{Y}$ & $6 / 4$ & light yellowish brown & 8 \\
\hline EO33 & 0.826 & $2.5 \mathrm{Y}$ & $6 / 4$ & light yellowish brown & 8 \\
\hline EO34 & 0.757 & $2.5 \mathrm{Y}$ & $6 / 4$ & light yellowish brown & 8 \\
\hline EO35 & 1.21 & $9 \mathrm{YR}$ & $5 / 4$ & yellowish brown & 14 \\
\hline EO36 & 1.31 & $10 \mathrm{YR}$ & $5 / 4$ & yellowish brown & 12 \\
\hline $\mathrm{HH} 03$ & $<0.20$ & $10 \mathrm{YR}$ & $5 / 4$ & yellowish brown & 12 \\
\hline $\mathrm{HH} 04$ & $<0.20$ & $10 \mathrm{YR}$ & $5 / 4$ & yellowish brown & 12 \\
\hline HH05 & 4.78 & $7.5 \mathrm{YR}$ & $4 / 3$ & brown & 12 \\
\hline HH06 & 6.10 & $7.5 \mathrm{YR}$ & $4 / 4$ & brown & 16 \\
\hline HH07 & $<0.20$ & $10 \mathrm{YR}$ & $5 / 3$ & brown & 9 \\
\hline HH08 & $<0.20$ & $7.5 \mathrm{YR}$ & $5 / 4$ & brown & 16 \\
\hline
\end{tabular}


APPENDIX D: Soil Data, B Horizon (cont.)

\begin{tabular}{|c|c|c|c|c|c|}
\hline \multicolumn{2}{|c|}{ B Horizon Samples } & \multicolumn{3}{|c|}{ Munsell Colors (dry) } & \multirow{2}{*}{$\frac{\text { Color Index }}{\text { B-W }}$} \\
\hline Sample & As (ppm) & Hue & $\begin{array}{l}\text { Value/ } \\
\text { Chroma }\end{array}$ & Munsell Color & \\
\hline HH09 & $<0.20$ & $7.5 \mathrm{YR}$ & $4 / 3$ & brown & 12 \\
\hline HH10 & $<0.20$ & $7.5 \mathrm{YR}$ & $4 / 3$ & brown & 12 \\
\hline HH11.1 & 4.51 & $7.5 \mathrm{YR}$ & $5 / 6$ & strong brown & 24 \\
\hline HH1 1.2 & 4.83 & $7.5 \mathrm{YR}$ & $5 / 4$ & brown & 16 \\
\hline HH1 1.3 & 4.99 & $7.5 \mathrm{YR}$ & $5 / 4$ & brown & 16 \\
\hline HH1 1.4 & 4.04 & $7.5 \mathrm{YR}$ & $5 / 4$ & brown & 16 \\
\hline HH1 1.5 & 4.29 & $7.5 \mathrm{YR}$ & $4 / 4$ & brown & 16 \\
\hline HH12 & $<0.20$ & $10 \mathrm{YR}$ & $6 / 4$ & light yellowish brown & 12 \\
\hline HH13 & 11.5 & $10 \mathrm{YR}$ & $4 / 3$ & brown & 9 \\
\hline HH14 & 85.4 & $7.5 \mathrm{YR}$ & $3 / 3$ & dark brown & 12 \\
\hline HH15 & $<0.20$ & $7.5 \mathrm{YR}$ & $4 / 4$ & brown & 16 \\
\hline HH16 & $<0.20$ & $10 \mathrm{YR}$ & $3 / 3$ & dark brown & 9 \\
\hline HH17 & 3.13 & $2.5 \mathrm{YR}$ & $4 / 6$ & red & 36 \\
\hline HH18 & 3.32 & $2.5 \mathrm{YR}$ & $4 / 6$ & red & 36 \\
\hline KL01 & 1.62 & $7.5 \mathrm{YR}$ & $6 / 6$ & reddish yellow & 24 \\
\hline KL02 & 1.56 & $10 \mathrm{YR}$ & $5 / 6$ & yellowish brown & 18 \\
\hline KL03 & 2.39 & $10 \mathrm{YR}$ & $7 / 6$ & yellow & 18 \\
\hline KL04 & 8.71 & $2.5 \mathrm{YR}$ & $5 / 4$ & reddish brown & 24 \\
\hline KL05 & 7.38 & $10 \mathrm{YR}$ & $6 / 5$ & brownish yellow & 15 \\
\hline KL06 & 3.82 & $5 \mathrm{YR}$ & $5 / 6$ & yellowish red & 30 \\
\hline KL07 & 0.814 & $2.5 \mathrm{Y}$ & $5 / 3$ & light olive brown & 6 \\
\hline KL08 & 5.04 & $10 \mathrm{YR}$ & $4 / 4$ & dark yellowish brown & 12 \\
\hline KL09 & 5.70 & $7.5 \mathrm{YR}$ & $5 / 6$ & strong brown & 24 \\
\hline KL10 & 5.28 & $10 \mathrm{YR}$ & $5 / 3$ & brown & 9 \\
\hline KL11 & 5.38 & $10 \mathrm{YR}$ & $3 / 4$ & dark yellowish brown & 12 \\
\hline KL12 & 2.54 & $10 \mathrm{YR}$ & $4 / 4$ & dark yellowish brown & 12 \\
\hline KL13 & 2.59 & $10 \mathrm{YR}$ & $3 / 3$ & dark brown & 9 \\
\hline KL14 & 3.84 & $10 \mathrm{YR}$ & $5 / 6$ & yellowish brown & 18 \\
\hline KL15 & 8.63 & $10 \mathrm{YR}$ & $3 / 4$ & dark yellowish brown & 12 \\
\hline KL16 & 1.31 & $2.5 \mathrm{YR}$ & $3 / 8$ & dark red & 48 \\
\hline KL17 & 1.90 & $7.5 \mathrm{YR}$ & $4 / 4$ & brown & 16 \\
\hline KL18 & 2.26 & $10 \mathrm{YR}$ & $6 / 6$ & brownish yellow & 18 \\
\hline KL19 & 6.52 & $10 \mathrm{YR}$ & $6 / 6$ & brownish yellow & 18 \\
\hline KL20 & 1.73 & $7.5 \mathrm{YR}$ & $4 / 6$ & strong brown & 24 \\
\hline KL21 & 26.1 & $7.5 \mathrm{YR}$ & $5 / 6$ & strong brown & 24 \\
\hline KL22 & 3.59 & $10 \mathrm{YR}$ & $6 / 6$ & brownish yellow & 18 \\
\hline KL23 & 0.915 & $2.5 \mathrm{Y}$ & $5 / 4$ & light olive brown & 8 \\
\hline KL24 & 1.29 & $10 \mathrm{YR}$ & $4 / 4$ & dark yellowish brown & 12 \\
\hline
\end{tabular}


APPENDIX D: Soil Data, B Horizon (cont.)

\begin{tabular}{|c|c|c|c|c|c|}
\hline \multicolumn{2}{|c|}{ B Horizon Samples } & \multicolumn{3}{|c|}{ Munsell Colors (dry) } & \multirow{2}{*}{$\frac{\text { Color Index }}{\text { B-W }}$} \\
\hline Sample & As (ppm) & Hue & $\begin{array}{l}\text { Value/ } \\
\text { Chroma }\end{array}$ & Munsell Color & \\
\hline KL25 & 3.12 & $10 \mathrm{YR}$ & $4 / 4$ & dark yellowish brown & 12 \\
\hline KL26 & 0.637 & $10 \mathrm{YR}$ & $5 / 4$ & yellowish brown & 12 \\
\hline KL27 & 7.70 & $7.5 \mathrm{YR}$ & $5 / 6$ & strong brown & 24 \\
\hline KL28 & 0.328 & $2.5 \mathrm{Y}$ & $5 / 3$ & light olive brown & 6 \\
\hline KL30 & 0.884 & $5 \mathrm{YR}$ & $4 / 6$ & yellowish red & 30 \\
\hline LC01 & 17.5 & $2.5 \mathrm{Y}$ & $5 / 2$ & grayish brown & 4 \\
\hline LC02 & 5.59 & $7.5 \mathrm{YR}$ & $5 / 8$ & strong brown & 32 \\
\hline $\mathrm{LC} 03$ & 1.73 & $2.5 \mathrm{Y}$ & $6 / 4$ & light yellowish brown & 8 \\
\hline LC04 & 4.90 & $10 \mathrm{YR}$ & $5 / 4$ & yellowish brown & 12 \\
\hline LC05 & 10.3 & $2.5 \mathrm{Y}$ & $5 / 4$ & light olive brown & 8 \\
\hline LC06 & 0.274 & $10 \mathrm{YR}$ & $4 / 4$ & dark yellowish brown & 12 \\
\hline LC07 & 3.02 & $10 \mathrm{YR}$ & $6 / 4$ & light yellowish brown & 12 \\
\hline $\mathrm{LC} 08$ & 5.97 & $10 \mathrm{YR}$ & $6 / 4$ & light yellowish brown & 12 \\
\hline LC09 & 10.6 & $1.5 \mathrm{Y}$ & $5 / 6$ & light olive brown & 15 \\
\hline LC10B & 3.79 & $10 \mathrm{YR}$ & $4 / 4$ & dark yellowish brown & 12 \\
\hline $\mathrm{LC} 11$ & 4.11 & $10 \mathrm{YR}$ & $4 / 3$ & brown & 9 \\
\hline $\mathrm{LC} 12$ & 4.98 & $10 \mathrm{YR}$ & $5 / 4$ & yellowish brown & 12 \\
\hline $\mathrm{LC14}$ & 1.74 & $10 \mathrm{YR}$ & $6 / 7$ & brownish yellow & 21 \\
\hline LC15 & 7.70 & $10 \mathrm{YR}$ & $4 / 4$ & dark yellowish brown & 12 \\
\hline LC16 & 7.31 & & & (no color data) & \\
\hline $\mathrm{LC} 17$ & 6.86 & $10 \mathrm{YR}$ & $5 / 4$ & yellowish brown & 12 \\
\hline LC18 & 7.94 & $10 \mathrm{YR}$ & $4 / 4$ & dark yellowish brown & 12 \\
\hline LC19 & 0.347 & $10 \mathrm{YR}$ & $4 / 4$ & dark yellowish brown & 12 \\
\hline LC20 & 2.33 & $10 \mathrm{YR}$ & $4 / 3$ & brown & 9 \\
\hline $\mathrm{LC} 21$ & 1.67 & $7.5 \mathrm{YR}$ & $5 / 8$ & strong brown & 32 \\
\hline LC22 & 3.38 & $4 \mathrm{YR}$ & $4 / 4$ & reddish brown & 20 \\
\hline LC23 & 2.90 & $6.5 \mathrm{YR}$ & $4 / 4$ & brown & 16 \\
\hline LM02 & 4.80 & $10 \mathrm{YR}$ & $5 / 3$ & brown & 9 \\
\hline LM03B & 1.96 & $10 \mathrm{YR}$ & $6 / 4$ & light yellowish brown & 12 \\
\hline LM04 & 2.16 & $2.5 \mathrm{Y}$ & $6 / 4$ & light yellowish brown & 8 \\
\hline LM05 & 1.10 & $10 \mathrm{YR}$ & $6 / 4$ & light yellowish brown & 12 \\
\hline LM06 & 1.00 & $2.5 \mathrm{Y}$ & $7 / 4$ & pale yellow & 8 \\
\hline LM07 & 2.85 & $2.5 \mathrm{Y}$ & $5 / 3$ & light olive brown & 6 \\
\hline LM08 & 4.74 & $10 \mathrm{YR}$ & $4 / 4$ & dark yellowish brown & 12 \\
\hline LM09 & 1.79 & $10 \mathrm{YR}$ & $6 / 3$ & pale brown & 9 \\
\hline LM1 & 7.53 & $10 \mathrm{YR}$ & $5 / 4$ & yellowish brown & 12 \\
\hline LM10 & 1.00 & $10 \mathrm{YR}$ & $6 / 4$ & light yellowish brown & 12 \\
\hline LM11 & 0.977 & $10 \mathrm{YR}$ & $6 / 4$ & light yellowish brown & 12 \\
\hline
\end{tabular}


APPENDIX D: Soil Data, B Horizon (cont.)

\begin{tabular}{|c|c|c|c|c|c|}
\hline \multicolumn{2}{|c|}{ B Horizon Samples } & \multicolumn{3}{|c|}{ Munsell Colors (dry) } & \multirow{2}{*}{ Color Index } \\
\hline Sample & As (ppm) & Hue & $\begin{array}{c}\text { Value/ } \\
\text { Chroma }\end{array}$ & Munsell Color & B-W \\
\hline LM12 & 1.86 & $10 \mathrm{YR}$ & $3 / 3$ & dark brown & 9 \\
\hline LM13 & 2.03 & $10 \mathrm{YR}$ & $4 / 4$ & dark yellowish brown & 12 \\
\hline LM14 & 1.52 & $7.5 \mathrm{YR}$ & $4 / 4$ & brown & 16 \\
\hline LM15 & 2.56 & $7.5 \mathrm{YR}$ & $4 / 4$ & brown & 16 \\
\hline LM16 & 0.809 & $10 \mathrm{YR}$ & $4 / 3$ & brown & 9 \\
\hline LM17 & 3.32 & $10 \mathrm{YR}$ & $5 / 4$ & yellowish brown & 12 \\
\hline LM19 & 7.31 & $2.5 \mathrm{Y}$ & $5 / 3$ & light olive brown & 6 \\
\hline LM20 & 2.02 & & & (no color data) & \\
\hline LM21 & 0.543 & $10 \mathrm{YR}$ & $5 / 4$ & yellowish brown & 12 \\
\hline LM22 & 1.48 & $10 \mathrm{YR}$ & $6 / 4$ & light yellowish brown & 12 \\
\hline R01 & 11.9 & $10 \mathrm{YR}$ & $6 / 2$ & light brownish gray & 6 \\
\hline R02 & 7.13 & $2.5 \mathrm{Y}$ & $7 / 2$ & light gray & 4 \\
\hline R03 & 1.29 & $2.5 \mathrm{Y}$ & $6 / 4$ & light yellowish brown & 8 \\
\hline R05 & 1.61 & $9 \mathrm{YR}$ & $5 / 6$ & yellowish brown & 21 \\
\hline R07 & 2.02 & $10 \mathrm{YR}$ & $6 / 4$ & light yellowish brown & 12 \\
\hline R10 & 0.520 & $2.5 \mathrm{Y}$ & $5 / 4$ & light olive brown & 8 \\
\hline R12 & 5.95 & $10 \mathrm{YR}$ & $6 / 4$ & light yellowish brown & 12 \\
\hline R13 & 45.4 & $5 \mathrm{YR}$ & $4 / 8$ & yellowish red & 40 \\
\hline R14 & 12.9 & $7.5 \mathrm{YR}$ & $6 / 6$ & reddish yellow & 24 \\
\hline R15 & 1.64 & $9 \mathrm{YR}$ & $5 / 6$ & yellowish brown & 21 \\
\hline
\end{tabular}


APPENDIX E: SAMPLING SITE CHARACTERISTICS

\begin{tabular}{|c|c|c|c|c|c|c|c|c|c|c|}
\hline SITE & PROVINCE & $\begin{array}{c}\text { COUNTY } \\
\text { NAME }\end{array}$ & QUADRANGLE & $\mathrm{MRC}$ & \begin{tabular}{|c|} 
GEOLOGIC \\
UNIT
\end{tabular} & $\begin{array}{c}\text { SOIL } \\
\text { ORDER }\end{array}$ & VEGETATION & LAT & LONG & $\begin{array}{c}\text { ELEV } \\
(\mathrm{m})\end{array}$ \\
\hline EO02 & High Lava Plains & Deschutes & Benham Falls & $43121-\mathrm{H} 4$ & $\mathrm{Qb}$ & Inceptisol & $p$ & 43.91 & -121.40 & 1368 \\
\hline EO08 & Basin and Range & Klamath & Swan Lake Point & 42121-D6 & QTb & Mollisol & $f, p$ & 42.41 & -121.65 & 1885 \\
\hline EO09 & Basin and Range & Klamath & Chiloquin & 42121-E7 & Ts & Entisol & $p, b r, g$ & 42.60 & -121.77 & 1286 \\
\hline EO10 & Basin and Range & Klamath & Calimus Butte & 42121-F5 & QTb & Entisol & $\mathrm{p}, \mathrm{br}$ & 42.68 & -121.55 & 1617 \\
\hline E011 & Basin and Range & Klamath & Buckhorn Springs & 42121-G5 & Ts & Entisol & $p$ & 42.79 & -121.52 & 1447 \\
\hline EO12 & Basin and Range & Klamath & Fuego Mountain & 42121-F4 & Tob & Entisol & $p$ & 42.72 & -121.39 & 1484 \\
\hline E013 & Basin and Range & Klamath & Gordon Lake & 42121-H4 & QTs & Entisol & $p$ & 42.98 & -121.46 & 1423 \\
\hline EO14 & Basin and Range & Klamath & Fuego & 42121-G7 & Qma & Inceptisol & $p$ & 42.87 & -121.81 & 1377 \\
\hline E015 & Cascade Range & Klamath & Odell Butte & 43121-D7 & Qs & Entisol & $\mathrm{p}$ & 43.46 & -121.77 & 1392 \\
\hline E016 & High Lava Plains & Deschutes & Finley Butte & 43121-F4 & QTst & Entisol & $\mathrm{p}$ & 43.70 & -121.38 & 1435 \\
\hline EO17 & High Lava Plains & Deschutes & Paulina Peak & 43121-F3 & QTst & Entisol & $p$ & \begin{tabular}{|l|}
43.70 \\
\end{tabular} & -121.30 & 1836 \\
\hline EO19 & Cascade Range & Deschutes & Davis Mountain & 43121-F7 & Qyb & Parent & none & 43.66 & -121.80 & 1332 \\
\hline EO20 & Cascade Range & Deschutes & Davis Mountain & 43121-F7 & QTmv & Entisol & $f, p$ & 43.63 & -121.77 & 1824 \\
\hline EO21 & Cascade Range & Klamath & Hamner Butte & 43121-E7 & QTba & Entisol & $f, p$ & 43.61 & -121.82 & 1338 \\
\hline EO22 & Cascade Range & Klamath & Muttonchop Butte & $43121-C 7$ & QTp & Entisol & $\mathrm{p}$ & 43.36 & -121.85 & 1514 \\
\hline EO23 & Cascade Range & Klamath & Burn Butte & $43121-C 8$ & Qmp & Entisol & $\mathrm{p}$ & 43.37 & -121.88 & 1471 \\
\hline EO24 & Cascade Range & Klamath & Pothole Butte & 42121-H8 & Qrd & Entisol & $f, p$ & 42.97 & -121.94 & 1824 \\
\hline EO25 & Cascade Range & Klamath & Crater Lake East & 42122-H1 & QTba & Entisol & & 42.92 & -122.01 & 1569 \\
\hline EO26 & Basin and Range & Klamath & Sun Pass & 42121-G8 & Qf & Entisol & $p$ & 42.86 & -121.90 & 1386 \\
\hline
\end{tabular}


APPENDIX E: Sampling Sites Characteristics (cont.)

\begin{tabular}{|c|c|c|c|c|c|c|c|c|c|c|}
\hline SITE & PROVINCE & $\begin{array}{c}\text { COUNTY } \\
\text { NAME }\end{array}$ & QUADRANGLE & MRC & $\begin{array}{c}\text { GEOLOGIC } \\
\text { UNIT }\end{array}$ & $\begin{array}{c}\text { SOIL } \\
\text { ORDER }\end{array}$ & VEGETATION & LAT & LONG & $\begin{array}{c}\text { ELEV } \\
(\mathrm{m})\end{array}$ \\
\hline EO27 & Basin and Range & Klamath & Sun Pass & 42121-G8 & Tob & Entisol & $f, p$ & 42.76 & -121.98 & 1435 \\
\hline EO30 & High Lava Plains & Lake & Big Hole & 43121-D3 & QTps & Entisol & $p, g, b r$ & 43.42 & -121.31 & 1404 \\
\hline E031 & High Lava Plains & Lake & Big Hole & 43121-D3 & Tat & Entisol & $p, b r$ & 43.38 & -121.30 & 1490 \\
\hline EO32 & High Lava Plains & Klamath & Sugarpine Mountain & 43121-A5 & Tmv & Entisol & $p, g, b r$ & 43.11 & -121.61 & 1891 \\
\hline EO33 & Basin and Range & Klamath & Gordon Lake & 42121-H4 & $\mathrm{Tp}$ & Entisol & $p$ & 43.00 & -121.42 & 1526 \\
\hline EO35 & Basin and Range & Klamath & S'Ocholis Canyon & 42121-E6 & QTvm & Inceptisol & $f, p$ & 42.53 & -121.66 & 1544 \\
\hline EO36 & Basin and Range & Klamath & Sprague River East & 42121-D4 & Trh & Mollisol & $f, p, g$ & 42.41 & -121.46 & 1569 \\
\hline $\mathrm{HHO1}$ & High Lava Plains & Deschutes & Benham Falls & $43121-\mathrm{H} 4$ & Qyb & Parent & none & 43.91 & -121.38 & 1328 \\
\hline $\mathrm{HHO2}$ & High Lava Plains & Deschutes & Lava Butte & 43121-H3 & Qyb & Parent & none & 43.91 & -121.36 & 1379 \\
\hline $\mathrm{HHO3}$ & Cascade Range & Douglas & Pumice Desert West & $43122-\mathrm{A} 2$ & Qta & Inceptisol & $f$ & 43.09 & -122.21 & 1672 \\
\hline $\mathrm{HHO4}$ & Cascade Range & Douglas & Pumice Desert West & 43122-A2 & Qta & Inceptisol & $f, h$ & 43.09 & -122.21 & 1644 \\
\hline $\mathrm{HHO6}$ & Cascade Range & Jackson & McLeod & 42122-F6 & Thi & Alfisol & $c, m d, o, p$ & 42.69 & -122.63 & 646 \\
\hline $\mathrm{HH} 07$ & Basin and Range & Klamath & Yonna & 42121-C4 & Tvs & Inceptisol & $c, m d, p$ & 42.35 & -121.40 & 1551 \\
\hline $\mathrm{HHO8}$ & Basin and Range & Klamath & Yonna & 42121-C4 & Tvs & Inceptisol & $c, m d, p$ & 42.35 & -121.40 & 1567 \\
\hline $\mathrm{HHO9}$ & Basin and Range & Klamath & Yainax Butte & 42121-C3 & Tvm & Inceptisol & $c, m d, p$ & 42.36 & -121.37 & 1618 \\
\hline $\mathrm{HH} 10$ & Basin and Range & Klamath & Yainax Butte & $42121-C 3$ & Tvm & Inceptisol & $c, m d, p$ & 42.36 & -121.37 & 1620 \\
\hline $\mathrm{HH} 11$ & Klamath & Douglas & Dixonville & 43123-B2 & $\mathrm{KJdV}$ & Inceptisol & $\mathrm{g}, \mathrm{md}, \mathrm{p}, \mathrm{o}$ & 43.17 & -123.20 & 275 \\
\hline $\mathrm{HH} 12$ & Klamath & Douglas & Dixonville & 43123-B2 & $\mathrm{KJdv}$ & Inceptisol & $c$, frn, $p$ & 43.16 & -123.20 & 282 \\
\hline $\mathrm{HH} 13$ & Willamette & Lane & Creswell & 43123-H1 & \multirow{2}{*}{ Tfee } & Alfisol & $f$ & 43.97 & -123.06 & 264 \\
\hline $\mathrm{HH} 14$ & Willamette & Lane & Creswell & 43123-H1 & & Alfisol & $\mathrm{frn}, \mathrm{f}, \mathrm{hz}, \mathrm{md}$ & 43.97 & -123.06 & 292 \\
\hline $\mathrm{HH} 15$ & Willamette & Lane & Springfield & 44122-A8 & Tfeb & Alfisol & $f, g, o$ & 44.01 & -122.98 & 201 \\
\hline
\end{tabular}


APPENDIX E: Sampling Sites Characteristics (cont.)

\begin{tabular}{|c|c|c|c|c|c|c|c|c|c|c|}
\hline SITE & PROVINCE & $\begin{array}{c}\text { COUNTY } \\
\text { NAME }\end{array}$ & QUADRANGLE & MRC & $\begin{array}{c}\text { GEOLOGIC } \\
\text { UNIT } \\
\end{array}$ & $\begin{array}{c}\text { SOIL } \\
\text { ORDER }\end{array}$ & VEGETATION & LAT & LONG & $\begin{array}{c}\text { ELEV } \\
(\mathrm{m}) \\
\end{array}$ \\
\hline $\mathrm{HH} 16$ & Willamette & Lane & Springfield & $44122-A 8$ & Tfeb & Inceptisol & $f, o$ & 44.01 & -122.98 & 214 \\
\hline $\mathrm{HH} 17$ & Coast Range & Lane & Noti & 44123-A4 & $\mathrm{Ti}$ & Ultisol & $b, f$ & 44.03 & -123.43 & 240 \\
\hline $\mathrm{HH} 18$ & Coast Range & Lane & Noti & 44123-A4 & $\mathrm{Ti}$ & Ultisol & $b, f$ & 44.03 & -123.43 & 228 \\
\hline KL01 & Klamath & Josephine & Galice & 42123-E5 & Js & Ultisol & $p, f(o l d)$ & 42.57 & -123.54 & 426 \\
\hline KL02 & Klamath & Josephine & Wilderville & 42123-D4 & $\mathrm{KJg}$ & Inceptisol & $m, f, p$ & 42.50 & -123.43 & 316 \\
\hline KL04 & Klamath & Curry & Marial & 42123-F8 & KJds & Inceptisol & $\mathrm{df}(\mathrm{old})$ & 42.64 & -123.91 & 1094 \\
\hline KL05 & Klamath & Curry & Agness & 42124-E1 & Tmss & Alfisol & $f, p o, g$ & 42.58 & -124.04 & 122 \\
\hline KL06 & Klamath & Curry & Soldier Camp Mtn. & 42124-E2 & $\mathrm{CS}$ & Alfisol & $p, f$ & 42.53 & -124.14 & 195 \\
\hline KL07 & Klamath & Curry & Cape Blanco & 42124-G5 & Qt & Inceptisol & $f$ & 42.82 & -124.50 & 52 \\
\hline KL08 & Klamath & Curry & Cape Blanco & 42124-G5 & Qt & Inceptisol & $p$ & 42.83 & -124.54 & 61 \\
\hline KL09 & Klamath & Curry & Port Orford & $42124-\mathrm{F} 4$ & JTrgd & Ultisol & $f, m, a$ & 42.71 & -124.38 & 219 \\
\hline $\mathrm{KL11}$ & Klamath & Curry & Father Mountain & 42124-F3 & Js & Inceptisol & $f$ & 42.72 & -124.32 & 146 \\
\hline $\mathrm{KL} 12$ & Klamath & Curry & Brushy Bald Mountain & 42124-E3 & $\mathrm{CS}$ & Ultisol & $f$ & 42.60 & -124.35 & 24 \\
\hline KL13 & Klamath & Curry & Gold Beach & 42124-D4 & Jop & Inceptisol & $f$ & 42.49 & -124.41 & 49 \\
\hline $\mathrm{KL} 14$ & Klamath & Josephine & Selma & $42123-\mathrm{C5}$ & Jss & Alfisol & $f$ & 42.34 & -123.58 & 462 \\
\hline $\mathrm{KL} 15$ & Klamath & Josephine & Cave Junction & 42123-B6 & Jss & Inceptisol & $f$ & 42.24 & -123.64 & 389 \\
\hline KL16 & Klamath & Josephine & Cave Junction & 42123-B6 & $\mathrm{Ju}$ & Ultisol & $f, p$ & 42.24 & -123.69 & 365 \\
\hline KL17 & Klamath & Josephine & Takilma & 42123-A5 & $\mathrm{Jm}$ & Alf/Ult & $f$ & 42.05 & -123.58 & 584 \\
\hline KL18 & Klamath & Josephine & Oregon Caves & 42123-A4 & TrPzS & Alfisol & f(old) & 42.10 & -123.41 & 1021 \\
\hline KL19 & Klamath & Jackson & Tallowbox Mountain & 42123-B2 & TrPv & Alf/Ult & $f$ & 42.18 & -123.21 & 657 \\
\hline KL20 & Klamath & Josephine & Grayback Mountain & 42123-A3 & TrPzs & Inceptisol & $f, p$ & 42.04 & -123.30 & 1386 \\
\hline
\end{tabular}

$\breve{\omega}$ 
APPENDIX E: Sampling Sites Characteristics (cont.)

\begin{tabular}{|c|c|c|c|c|c|c|c|c|c|c|}
\hline SITE & PROVINCE & $\begin{array}{c}\text { COUNTY } \\
\text { NAME }\end{array}$ & QUADRANGLE & MRC & $\begin{array}{c}\text { GEOLOGIC } \\
\text { UNIT } \\
\end{array}$ & $\begin{array}{c}\text { SOIL } \\
\text { ORDER }\end{array}$ & VEGETATION & LAT & LONG & $\begin{array}{c}\text { ELEV } \\
(\mathrm{m}) \\
\end{array}$ \\
\hline $\mathrm{KL} 21$ & Klamath & Jackson & Carberry Creek & 42123-A2 & $\mathrm{cm}$ & Alfisol & $f, p$ & 42.02 & -123.13 & 657 \\
\hline $\mathrm{KL} 22$ & Klamath & Jackson & Squaw Lakes & 42123-A1 & TrPv & Inceptisol & $f, p$ & 42.12 & -123.05 & 584 \\
\hline $\mathrm{KL} 23$ & Klamath & Josephine & Buckskin Peak & 42123-A7 & JTrgd & Alfisol & $f, p$ & 42.05 & -123.84 & 1143 \\
\hline $\mathrm{KL} 24$ & Klamath & Jackson & Siskiyou Peak & 42122-A7 & TrPzm & Alfisol & $f($ old $)$ & 42.05 & -122.83 & 2019 \\
\hline $\mathrm{KL} 25$ & Klamath & Jackson & Dutchman Peak & 42122-A8 & TrPzm & Inceptisol & $f$ & 42.04 & -122.91 & 1946 \\
\hline $\mathrm{KL} 27$ & Klamath & Jackson & King Mountain & 42123-F2 & Kc & Alf/Ult & $f$ & 42.67 & -123.20 & 778 \\
\hline $\mathrm{KL} 28$ & Klamath & Jackson & Skeleton Mountain & 42123-F1 & $\mathrm{mc}$ & Inceptisol & $f, p$ & 42.64 & -123.10 & 754 \\
\hline KL30 & Klamath & Josephine & Mount Peavine & 42123-E6 & bc & Alfisol & $o, f, p$ & 42.53 & -123.66 & 745 \\
\hline LC01 & Willamette & Lane & Eugene West & 44123-A2 & Qs & Mollisol & $g$ & 44.05 & -123.17 & 119 \\
\hline $\mathrm{LCO} 2$ & Willamette & Lane & Eugene West & 44123-A2 & Tfee & Ultisol & df(young) & 44.02 & -123.16 & 249 \\
\hline LCO3 & Willamette & Lane & Veneta & 44123-A3 & Qt & Mollisol & $\mathrm{df}$ & 44.03 & -123.30 & 106 \\
\hline LC05 & Coast Range & Douglas & Sutherlin & 43123-D3 & Tmsm & Inceptisol & $0, \mathrm{df}$ & 43.47 & -123.32 & 269 \\
\hline LC06 & Klamath & Douglas & Winchester & 43123-C3 & Tsr & Mollisol & $0,1 p$ & 43.26 & -123.32 & 213 \\
\hline LC07 & Cascade Range & Douglas & Fish Mountain & 43122-A4 & Tmsc & Inceptisol & $d f, I p$ & 43.03 & -122.38 & 316 \\
\hline LC08 & Coast Range & Douglas & Camas Valley & 43123-A6 & Tmss & Inceptisol & $\mathrm{df}$ & 43.01 & -123.73 & 340 \\
\hline LC09 & Coast Range & Douglas & Devils Graveyard & 43123-F6 & Ty & Mollisol & $d f, o$ & 43.64 & -123.64 & 134 \\
\hline LC10A & Klamath & Douglas & Oak Creek Valley & 43123-C2 & Tsr & Ultisol & $I p, f, g$ & 43.32 & -123.22 & 182 \\
\hline LC10B & Coast Range & Douglas & Scottsburg & 43123-F7 & Ty & Ultisol & h, c & 43.67 & -123.78 & 24 \\
\hline LC11 & Coast Range & Douglas & Scottsburg & 43123-F7 & Qal & Inceptisol & $\mathrm{w}, \mathrm{m}$ & 43.67 & -123.81 & 0 \\
\hline LC12 & Coast Range & Douglas & Scottsburg & 43123-F7 & $\mathrm{Tt}$ & Inceptisol & $m, f$ & 43.65 & -123.83 & 24 \\
\hline LC13 & Coast Range & Douglas & Winchester Bay & 43124-F2 & Qd & Entisol & $\mathrm{mb}, \mathrm{sb}$ & 43.66 & -124.20 & 0 \\
\hline
\end{tabular}


APPENDIX E: Sampling Sites Characteristics (cont.)

\begin{tabular}{|c|c|c|c|c|c|c|c|c|c|c|}
\hline SITE & PROVINCE & $\begin{array}{c}\text { COUNTY } \\
\text { NAME }\end{array}$ & QUADRANGLE & MRC & $\begin{array}{c}\text { GEOLOGIC } \\
\text { UNIT } \\
\end{array}$ & $\begin{array}{c}\text { SOIL } \\
\text { ORDER }\end{array}$ & VEGETATION & LAT & LONG & $\begin{array}{c}\text { ELEV } \\
(\mathrm{m}) \\
\end{array}$ \\
\hline LC14 & Coast Range & Douglas & Winchester Bay & 43124-F2 & Qd & Spodosol & $d f, c s, s$ & 43.66 & -124.19 & 0 \\
\hline LC15 & Coast Range & Coos & Lakeside & 43124-E2 & Tss & Inceptisol & $f, a$ & 43.59 & -124.17 & 24 \\
\hline LC16 & Coast Range & Coos & Lakeside & 43124-E2 & Qt & Inceptisol & $f$ & 43.59 & -124.18 & 0 \\
\hline LC17 & Coast Range & Coos & Cape Arago & 43124-C4 & Qt & Ultisol & $f(o l d)$ & 43.33 & -124.38 & 0 \\
\hline LC18 & Coast Range & Coos & Charleston & 43124-C3 & Tss & Ultisol & $f(o l d)$ & 43.32 & -124.36 & 109 \\
\hline LC20 & Coast Range & Douglas & Bone Mountain & $42123-\mathrm{H} 7$ & Qls & Inceptisol & $a, f$ & 42.97 & -123.82 & 170 \\
\hline LC21 & Coast Range & Douglas & Chipmunk Ridge & 43123-H6 & Tmss & Alfisol & $f, c s$ & 43.00 & -123.72 & 334 \\
\hline LC22 & Willamette & Lane & Fox Hollow & $43123-\mathrm{H} 2$ & Tfe & Ultisol & $f$ & 43.90 & -123.20 & 489 \\
\hline LC23 & Coast Range & Lane & Mercer Lake & 44124-A1 & $\mathrm{Tpb}$ & Inceptisol & $f$ & 44.08 & -124.08 & 397 \\
\hline LM01 & Cascade Range & Douglas & Old Fairview & $43122-\mathrm{C} 8$ & Qls & Inceptisol & $d f, m, a$ & 43.30 & -122.91 & 268 \\
\hline LM02 & Cascade Range & Douglas & Mace Mountain & $43122-C 7$ & Tus & Inceptisol & df & 43.31 & -122.84 & 316 \\
\hline LM03B & Cascade Range & Douglas & Fish Creek Desert & 43122-B4 & QTba & Inceptisol & $\mathrm{df}$ & 43.25 & -122.40 & 827 \\
\hline LM04 & Cascade Range & Douglas & Diamond Lake & 43122-B2 & Qg & Entisol & $p$ & 43.19 & -122.13 & 1301 \\
\hline LM05 & Cascade Range & Douglas & Pumice Desert East & 43122-A1 & Qma & Entisol & $p, d f$ & 43.10 & -122.10 & 1860 \\
\hline LM06 & Cascade Range & Klamath & Miller Lake & 43121-B8 & Qmp & Entisol & $p, d f$ & 43.22 & -121.93 & 1745 \\
\hline LM07 & Cascade Range & Lane & Westfir West & 43122-G5 & Qal & Inceptisol & $\mathrm{m}, \mathrm{df}, \mathrm{c}, \mathrm{cw}$ & 43.82 & -122.60 & 292 \\
\hline LM08 & Cascade Range & Lane & Holland Point & 43122-F5 & $\mathrm{Tu}$ & Ultisol & $\mathrm{df}$ & 43.73 & -122.54 & 778 \\
\hline LM09 & Cascade Range & Lane & Willamette Pass & 43122-E1 & Qba & Inceptisol & $\mathrm{df}$ & 43.61 & -122.12 & 1240 \\
\hline LM10 & Cascade Range & Klamath & Odell Lake & 43121-E8 & $\mathrm{Qg}$ & Entisol & $p$ & 43.54 & -121.95 & 1453 \\
\hline LM11 & Cascade Range & Klamath & Odell Butte & 43121-D7 & QTmv & Entisol & $\mathrm{df}$ & 43.47 & -121.87 & 1873 \\
\hline LM12 & Cascade Range & Jackson & Hyatt Reservoir & 42122-B4 & Tub & Mollisol & $g f, d f(o l d)$ & 42.18 & -122.48 & 1654 \\
\hline
\end{tabular}

$\ddot{\omega}$ 
APPENDIX E: Sampling Sites Characteristics (cont.)

\begin{tabular}{|c|c|c|c|c|c|c|c|c|c|c|}
\hline SITE & PROVINCE & $\begin{array}{l}\text { COUNTY } \\
\text { NAME }\end{array}$ & QUADRANGLE & MRC & $\begin{array}{c}\text { GEOLOGIC } \\
\text { UNIT }\end{array}$ & $\begin{array}{c}\text { SOIL } \\
\text { ORDER }\end{array}$ & VEGETATION & LAT & LONG & $\begin{array}{l}\text { ELEV } \\
(\mathrm{m})\end{array}$ \\
\hline LM13 & Cascade Range & Jackson & Hyatt Reservoir & 42122-B4 & Tus & Mollisol & $\mathrm{df}$ & 42.20 & -122.44 & 1526 \\
\hline LM14 & Cascade Range & Klamath & Little Chinquapin Mtn. & 42122-B3 & Trb & Mollisol & df & 42.14 & -122.27 & 1325 \\
\hline LM15 & Cascade Range & Klamath & Mule Hill & $42122-A 2$ & QTba & Mollisol & $d f(o l d)$ & 42.12 & -122.16 & 1350 \\
\hline LM16 & Basin and Range & Klamath & Spencer Creek & 42122-B1 & Qba & Mollisol & $p$ & 42.13 & -122.03 & 1289 \\
\hline LM17 & Cascade Range & Lane & Lowell & $43122-\mathrm{H} 7$ & Qal & Mollisol & $d f, m, p$ & 43.93 & -122.83 & 182 \\
\hline LM19 & Cascade Range & Lane & Westfir West & $43122-G 5$ & Tut & Inceptisol & df & 43.86 & -122.56 & 486 \\
\hline LM20 & Cascade Range & Lane & Saddleblanket Mtn. & $43122-\mathrm{H} 5$ & Tsv & Inceptisol & df & 43.96 & -122.61 & 292 \\
\hline LM21 & Cascade Range & Lane & Chucksney Mountain & $43122-\mathrm{H} 1$ & Qgf & Inceptisol & $d f(o l d)$ & 43.96 & -122.12 & 730 \\
\hline LM22 & Cascade Range & Lane & Cougar Reservoir & $44122-\mathrm{A} 2$ & Tfc & Inceptisol & $\mathrm{df}, \mathrm{m}$ & 44.04 & -122.14 & 462 \\
\hline R01 & Cascade Range & Lane & Mount David Douglas & $43122-\mathrm{F} 2$ & Tbaa & Inceptisol & $\mathrm{df}(\mathrm{old})$ & 43.66 & -122.21 & 803 \\
\hline R02 & Cascade Range & Lane & Mount David Douglas & $43122-\mathrm{F} 2$ & Tbaa & Inceptisol & $\mathrm{df}(\mathrm{old}), \mathrm{vm}$ & 43.64 & -122.15 & 1094 \\
\hline R03 & Cascade Range & Klamath & Crater Lake West & $42122-\mathrm{H} 2$ & Qa & Inceptisol & Ip, h (old) & 42.96 & -122.20 & 1933 \\
\hline R05 & Cascade Range & Klamath & Pelican Bay & 42122-D1 & QTp & Inceptisol & $\mathrm{pp}, \mathrm{df}(\mathrm{few})$ & 42.44 & -122.11 & 1277 \\
\hline R07 & Klamath & Jackson & Boswell Mountain & 42122-E8 & $\mathrm{Tn}$ & Inceptisol & $\mathrm{md}, \mathrm{pp}, \mathrm{po}$ & 42.55 & -122.91 & 456 \\
\hline $\mathrm{R} 10$ & Klamath & Josephine & Murphy Mountain & $42123-\mathrm{C4}$ & KJgu & Alf/Ult & $\mathrm{md}, \mathrm{po}, \mathrm{pp}$ & 42.36 & -123.38 & 353 \\
\hline R12 & Klamath & Josephine & Selma & $42123-\mathrm{C5}$ & Jub & Inceptisol & df, md, pi & 42.33 & -123.61 & 486 \\
\hline R13 & Klamath & Josephine & Golden & 42123-F3 & Jub & Alf/Ult & $\mathrm{df}, \mathrm{md}$ (few) & 42.64 & -123.26 & 730 \\
\hline R14 & Klamath & Douglas & Canyonville & $42123-\mathrm{H} 3$ & $\mathrm{KJm}$ & Alf/Ult & df, md, pp & 42.92 & -123.32 & 340 \\
\hline R15 & Klamath & Douglas & Dixonville & $43123-B 2$ & $\mathrm{KJm}$ & Alf/Ult & $\mathrm{df}, \mathrm{pp}, \mathrm{md}$ & 43.15 & -123.16 & 271 \\
\hline
\end{tabular}

Appendix E Key

MRC = Map Reference Code

Vegetation: a alder, b blackberry, br brush, c cedar, cs citrus spruce, cw cottonwood, df Douglas fir, f fir, frn fern, g grass, gf ground, h hemlock, hz hazelnut, lp lodgepole pine, m maple, mb myrtle bush, md madrone, mgc mossy ground cover, ml mountain laurel, o oak, p pine, pi poison ivy, po poison oak, pp ponderosa pine, sb scotch broom, s salal, ss sitka spruce, w willow, wmb wax myrtle bush, wp wetland and prairie plants. 


\section{APPENDIX F: Analysis Categories Data}

\begin{tabular}{|c|c|c|c|c|c|c|c|}
\hline Site & As & BW & Soil Order & Province & Origin & $\begin{array}{c}\text { Age } \\
\text { Rank }\end{array}$ & $\begin{array}{c}\text { Elev } \\
(\mathrm{m})\end{array}$ \\
\hline EO02 & 1.36 & no data & Inceptisol & High Lava Plains & $\mathrm{V}$ & 1.30 & 1372 \\
\hline EO07 & 1.46 & 9 & Mollisol & Basin and Range & $\mathrm{V}$ & 10.65 & 1402 \\
\hline EO08 & 1.57 & 6 & Mollisol & Basin and Range & $\mathrm{V}$ & 2.66 & 1896 \\
\hline EO09 & 0.496 & 6 & Entisol & Basin and Range & VS & 12.80 & 1295 \\
\hline EO10 & 1.08 & 8 & Entisol & Basin and Range & V & 2.66 & 1634 \\
\hline EO11 & 1.13 & 6 & Entisol & Basin and Range & VS & 12.80 & 1457 \\
\hline EO12 & 0.941 & 8 & Entisol & Basin and Range & V & 7.60 & 1494 \\
\hline EO13 & 1.05 & 6 & Entisol & Basin and Range & $S$ & 2.66 & 1433 \\
\hline EO14 & 1.02 & 12 & Inceptisol & Basin and Range & $\mathrm{V}$ & 0.005 & 1382 \\
\hline EO15 & 0.776 & 6 & Entisol & Cascade Range & $\mathrm{U}$ & 1.31 & 1398 \\
\hline EO16 & 1.31 & 4 & Entisol & High Lava Plains & VS & 3.55 & 1442 \\
\hline EO17 & 1.47 & 6 & Entisol & High Lava Plains & VS & 3.55 & 1847 \\
\hline EO18 & 0.923 & 8 & Inceptisol & Cascade Range & $\mathrm{V}$ & 2.66 & 1405 \\
\hline EO19 & 0.349 & no data & Parent Material & Cascade Range & $\mathrm{V}$ & 0.005 & 1332 \\
\hline EO20 & 0.806 & 8 & Entisol & Cascade Range & $\mathrm{V}$ & 11.51 & 1829 \\
\hline EO21 & 0.687 & 4 & Entisol & Cascade Range & $\mathrm{V}$ & 2.66 & 1347 \\
\hline EO22 & 1.12 & 6 & Entisol & Cascade Range & $\mathrm{U}$ & 11.50 & 1521 \\
\hline EO23 & 0.845 & 4 & Entisol & Cascade Range & $\mathrm{V}$ & 0.005 & 1481 \\
\hline EO24 & 1.22 & 6 & Entisol & Cascade Range & $\mathrm{V}$ & 1.30 & 1835 \\
\hline EO25 & 0.892 & 6 & Entisol & Cascade Range & $\mathrm{V}$ & 1.30 & 1579 \\
\hline EO26 & 0.693 & 12 & Entisol & Basin and Range & $\mathrm{U}$ & 1.30 & 1396 \\
\hline EO27 & 2.15 & 6 & Entisol & Basin and Range & V & 7.60 & 1445 \\
\hline EO30 & 0.762 & 8 & Entisol & High Lava Plains & $\mathrm{V}$ & 11.50 & 1410 \\
\hline EO31 & 0.821 & 6 & Entisol & High Lava Plains & $\mathrm{V}$ & 7.60 & 1494 \\
\hline EO32 & 1.5 & 6 & Entisol & High Lava Plains & $\mathrm{V}$ & 14.15 & 1899 \\
\hline EO33 & 1.07 & 6 & Entisol & Basin and Range & VS & 13.30 & 1530 \\
\hline EO34 & 1.15 & 6 & Entisol & Basin and Range & $\mathrm{V}$ & 13.30 & 1335 \\
\hline EO35 & 1.62 & 12 & Inceptisol & Basin and Range & $\mathrm{V}$ & 11.51 & 1554 \\
\hline EO36 & 1.57 & 9 & Mollisol & Basin and Range & $\mathrm{V}$ & 12.80 & 1579 \\
\hline HH01 & 0.001 & 4 & Parent Material & High Lava Plains & $\mathrm{V}$ & 0.005 & 1328 \\
\hline HH02 & 0.001 & 4 & Parent Material & High Lava Plains & $\mathrm{V}$ & 0.005 & 1379 \\
\hline HH03 & 0.001 & 12 & Inceptisol & Cascade Range & $\mathrm{V}$ & 2.66 & 1672 \\
\hline HH04 & 0.001 & 12 & Inceptisol & Cascade Range & $\mathrm{V}$ & 2.66 & 1644 \\
\hline HH05 & 4.88 & 8 & Alfisol & Cascade Range & $\mathrm{P}$ & 14.15 & 688 \\
\hline
\end{tabular}


APPENDIX F: Analysis Categories Data (cont.)

\begin{tabular}{|c|c|c|c|c|c|c|c|}
\hline Site & As & BW & Soil Order & Province & Origin & $\begin{array}{c}\text { Age } \\
\text { Rank }\end{array}$ & $\begin{array}{c}\text { Elev } \\
(\mathrm{m})\end{array}$ \\
\hline HH06 & 7.29 & 12 & Alfisol & Cascade Range & $\mathrm{P}$ & 14.15 & 646 \\
\hline HH07 & 0.001 & 9 & Inceptisol & Basin and Range & $\mathrm{V}$ & 29.20 & 1551 \\
\hline HH08 & 0.001 & 16 & Inceptisol & Basin and Range & $\mathrm{V}$ & 29.20 & 1567 \\
\hline HH09 & 0.001 & 12 & Inceptisol & Basin and Range & $\mathrm{V}$ & 12.80 & 1618 \\
\hline HH10 & 0.001 & 12 & Inceptisol & Basin and Range & $\mathrm{V}$ & 12.80 & 1620 \\
\hline HH11.1 & 4.51 & 24 & Inceptisol & Klamath Mountains & $\mathrm{V}$ & 130.30 & 275 \\
\hline HH11.2 & 4.83 & 16 & Inceptisol & Klamath Mountains & V & 130.30 & 275 \\
\hline HH11.3 & 4.99 & 16 & Inceptisol & Klamath Mountains & $\mathrm{V}$ & 130.30 & 275 \\
\hline HH11.4 & 4.04 & 16 & Inceptisol & Klamath Mountains & $\mathrm{V}$ & 130.30 & 275 \\
\hline HH11.5 & 4.29 & 16 & Inceptisol & Klamath Mountains & $\mathrm{V}$ & 130.30 & 275 \\
\hline HH12 & 0.001 & 12 & Inceptisol & Klamath Mountains & $\mathrm{V}$ & 130.30 & 282 \\
\hline HH13 & 13.5 & 9 & Alfisol & Willamette Valley & $S$ & 28.45 & 264 \\
\hline HH14 & 85.4 & 12 & Alfisol & Willamette Valley & $S$ & 28.45 & 292 \\
\hline HH15 & 0.001 & 16 & Alfisol & Willamette Valley & $\mathrm{V}$ & 31.70 & 201 \\
\hline HH16 & 0.001 & 9 & Inceptisol & Willamette Valley & $\mathrm{V}$ & 31.70 & 214 \\
\hline HH17 & 4.28 & 30 & Ultisol & Coast Range & $\mathrm{P}$ & 28.45 & 240 \\
\hline HH18 & 4.54 & 20 & Ultisol & Coast Range & $\mathrm{P}$ & 28.45 & 228 \\
\hline KL01 & 1.62 & 24 & Alfisol & Klamath Mountains & $S$ & 173.55 & 434 \\
\hline KL02 & 1.56 & 18 & Inceptisol & Klamath Mountains & $\mathrm{P}$ & 133.55 & 317 \\
\hline KL03 & 2.57 & 18 & Alfisol & Klamath Mountains & $\mathrm{V}$ & 173.55 & 236 \\
\hline KL04 & 8.71 & 24 & Inceptisol & Klamath Mountains & $\mathrm{S}$ & 130.30 & 1097 \\
\hline KL05 & 7.38 & 15 & Alfisol & Klamath Mountains & $\mathrm{S}$ & 44.50 & 122 \\
\hline KL06 & 3.82 & 30 & Alfisol & Klamath Mountains & $\mathrm{M}$ & 303.75 & 207 \\
\hline KL07 & 0.814 & 6 & Inceptisol & Klamath Mountains & $\mathrm{U}$ & 1.30 & 52 \\
\hline KL08 & 5.11 & 9 & Inceptisol & Klamath Mountains & $\mathrm{U}$ & 1.30 & 62 \\
\hline KL09 & 5.7 & 24 & Ultisol & Klamath Mountains & $\mathrm{P}$ & 198.25 & 232 \\
\hline KL10 & 5.28 & 9 & Inceptisol & Klamath Mountains & $\mathrm{S}$ & 105.50 & 183 \\
\hline KL11 & 5.38 & 12 & Inceptisol & Klamath Mountains & $\mathrm{S}$ & 173.55 & 158 \\
\hline KL12 & 2.82 & 12 & Ultisol & Klamath Mountains & $\mathrm{M}$ & 303.75 & 24 \\
\hline KL13 & 2.59 & 9 & Inceptisol & Klamath Mountains & $M$ & 153.25 & 61 \\
\hline KL14 & 3.84 & 18 & Alfisol & Klamath Mountains & $\mathrm{S}$ & 173.55 & 475 \\
\hline KL15 & 8.63 & 12 & Inceptisol & Klamath Mountains & $\mathrm{S}$ & 173.55 & 402 \\
\hline KL16 & 1.7 & 30 & Ultisol & Klamath Mountains & VS & 173.55 & 378 \\
\hline KL17 & 1.9 & 16 & Ultisol & Klamath Mountains & $\mathrm{M}$ & 173.55 & 597 \\
\hline
\end{tabular}


APPENDIX F: Analysis Categories Data (cont.)

\begin{tabular}{|c|c|c|c|c|c|c|c|}
\hline Site & As & BW & Soil Order & Province & Origin & $\begin{array}{c}\text { Age } \\
\text { Rank }\end{array}$ & $\begin{array}{l}\text { Elev } \\
(\mathrm{m})\end{array}$ \\
\hline KL18 & 2.26 & 18 & Alfisol & Klamath Mountains & $S$ & 371.80 & 1036 \\
\hline KL19 & 6.52 & 18 & Ultisol & Klamath Mountains & $\mathrm{V}$ & 250.30 & 671 \\
\hline KL20 & 1.73 & 24 & Inceptisol & Klamath Mountains & $S$ & 371.80 & 1402 \\
\hline KL21 & 32.6 & 12 & Alfisol & Klamath Mountains & $M$ & 250.30 & 671 \\
\hline KL22 & 3.59 & 18 & Inceptisol & Klamath Mountains & $\mathrm{V}$ & 250.30 & 597 \\
\hline KL23 & 0.915 & 8 & Alfisol & Klamath Mountains & $P$ & 198.25 & 1158 \\
\hline KL24 & 1.29 & 12 & Alfisol & Klamath Mountains & $M$ & 371.80 & 2036 \\
\hline KL25 & 3.12 & 12 & Inceptisol & Klamath Mountains & $\mathrm{M}$ & 371.80 & 1963 \\
\hline KL26 & 1.3 & 9 & Inceptisol & Klamath Mountains & $\mathrm{P}$ & 133.55 & 2060 \\
\hline KL27 & 7.7 & 24 & Alfisol & Klamath Mountains & $\mathrm{S}$ & 105.50 & 792 \\
\hline KL28 & 0.328 & 6 & Inceptisol & Klamath Mountains & $\mathrm{M}$ & 396.50 & 768 \\
\hline KL30 & 0.884 & 30 & Alfisol & Klamath Mountains & M & 303.75 & 754 \\
\hline LC01 & 17.5 & 4 & Vertisol & Willamette Valley & $\mathrm{U}$ & 1.31 & 119 \\
\hline LC02 & 10.1 & 12 & Ultisol & Willamette Valley & $\mathrm{S}$ & 28.45 & 253 \\
\hline LC03 & 2.08 & 6 & Mollisol & Willamette Valley & $\bar{U}$ & 1.30 & 114 \\
\hline LC04 & 4.9 & 12 & Ultisol & Coast Range & S & 44.50 & 232 \\
\hline LC05 & 10.3 & 8 & Inceptisol & Coast Range & $S$ & 57.05 & 269 \\
\hline LC06 & 0.301 & 12 & Mollisol & Klamath Mountains & $\mathrm{V}$ & 52.95 & 213 \\
\hline LC07 & 3.64 & 12 & Inceptisol & Cascade Range & $\mathrm{S}$ & 52.20 & 317 \\
\hline LC08 & 5.97 & 12 & Inceptisol & Coast Range & $S$ & 44.50 & 341 \\
\hline LC09 & 10.6 & 15 & Inceptisol & Coast Range & $S$ & 41.25 & 134 \\
\hline LC10A & 4.58 & 6 & Mollisol & Klamath Mountains & $\mathrm{V}$ & 52.95 & 195 \\
\hline LC10B & 3.79 & 12 & Mollisol & Coast Range & $\mathrm{S}$ & 41.25 & 24 \\
\hline LC11 & 4.96 & 12 & Inceptisol & Coast Range & $\bar{U}$ & 0.005 & 12 \\
\hline LC12 & 4.98 & 12 & Inceptisol & Coast Range & $\mathrm{S}$ & 44.50 & 24 \\
\hline LC13 & 2.52 & 4 & Entisol & Coast Range & $\bar{U}$ & 0.005 & 12 \\
\hline LC14 & 1.74 & 21 & Spodosol & Coast Range & $\bar{U}$ & 0.005 & 12 \\
\hline LC15 & 7.7 & 12 & Inceptisol & Coast Range & VS & 41.25 & 37 \\
\hline LC16 & 7.31 & no data & Inceptisol & Coast Range & $\mathrm{U}$ & 1.30 & 12 \\
\hline LC17 & 6.86 & 12 & Ultisol & Coast Range & $\mathrm{U}$ & 1.30 & 12 \\
\hline LC18 & 7.94 & 12 & Ultisol & Coast Range & VS & 41.25 & 110 \\
\hline LC19 & 0.799 & 12 & Ultisol & Coast Range & $\mathrm{V}$ & 52.95 & 27 \\
\hline LC20 & 2.58 & 6 & Inceptisol & Coast Range & $\mathrm{U}$ & 1.30 & 171 \\
\hline LC21 & 3.09 & 16 & Alfisol & Coast Range & $\mathrm{S}$ & 44.50 & 343 \\
\hline
\end{tabular}


APPENDIX F: Analysis Categories Data (cont.)

\begin{tabular}{|c|c|c|c|c|c|c|c|}
\hline Site & As & BW & Soil Order & Province & Origin & $\begin{array}{c}\text { Age } \\
\text { Rank }\end{array}$ & $\begin{array}{l}\text { Elev } \\
(\mathrm{m})\end{array}$ \\
\hline LC22 & 3.38 & 20 & Ultisol & Willamette Valley & VS & 31.70 & 489 \\
\hline LC23 & 2.9 & 16 & Inceptisol & Coast Range & $\mathrm{V}$ & 37.15 & 397 \\
\hline LM01 & 7.53 & 12 & Inceptisol & Cascade Range & $\bar{U}$ & 1.30 & 280 \\
\hline LM02 & 5.04 & 6 & Inceptisol & Cascade Range & VS & 19.60 & 329 \\
\hline LM03A & 1.92 & 6 & Inceptisol & Cascade Range & VS & 19.60 & 445 \\
\hline LM03B & 1.96 & 12 & Inceptisol & Cascade Range & $\mathrm{V}$ & 2.66 & 841 \\
\hline LM04 & 2.16 & 8 & Inceptisol & Cascade Range & $\mathrm{U}$ & 1.31 & 1317 \\
\hline LM05 & 1.26 & 6 & Inceptisol & Cascade Range & $\mathrm{V}$ & 0.005 & 1865 \\
\hline LM06 & 1 & 8 & Inceptisol & Cascade Range & $\mathrm{V}$ & 0.005 & 1753 \\
\hline LM07 & 2.99 & 6 & Inceptisol & Cascade Range & $\bar{U}$ & 0.005 & 305 \\
\hline LM08 & 4.74 & 12 & Inceptisol & Cascade Range & VS & 19.60 & 792 \\
\hline LM09 & 1.79 & 9 & Ultisol & Cascade Range & $\mathrm{V}$ & 1.30 & 1256 \\
\hline LM10 & 1 & 12 & Inceptisol & Cascade Range & $\bar{U}$ & 1.31 & 1460 \\
\hline LM11 & 0.977 & 12 & Inceptisol & Cascade Range & $\mathrm{V}$ & 11.51 & 1881 \\
\hline LM12 & 2.1 & 6 & Inceptisol & Cascade Range & $\mathrm{V}$ & 19.60 & 1664 \\
\hline LM13 & 2.03 & 12 & Mollisol & Cascade Range & VS & 19.60 & 1530 \\
\hline LM14 & 1.63 & 8 & Mollisol & Cascade Range & $\mathrm{V}$ & 7.10 & 1335 \\
\hline LM15 & 2.56 & 16 & Mollisol & Cascade Range & $\mathrm{V}$ & 2.66 & 1359 \\
\hline LM16 & 2.32 & 9 & Mollisol & Basin and Range & $\mathrm{V}$ & 1.30 & 1298 \\
\hline LM17 & 3.32 & 12 & Mollisol & Cascade Range & $\mathrm{U}$ & 0.005 & 189 \\
\hline LM19 & 7.31 & 6 & Mollisol & Cascade Range & $\mathrm{V}$ & 19.60 & 500 \\
\hline LM20 & 2.57 & ND & Inceptisol & Cascade Range & $\mathrm{V}$ & 15.50 & 305 \\
\hline LM21 & 1.03 & 9 & Inceptisol & Cascade Range & $\mathrm{U}$ & 1.31 & 744 \\
\hline LM22 & 1.48 & 12 & Inceptisol & Cascade Range & $\mathrm{V}$ & 14.15 & 463 \\
\hline R01 & 11.9 & 6 & Inceptisol & Cascade Range & $\mathrm{V}$ & 10.65 & 817 \\
\hline R02 & 7.13 & 4 & Inceptisol & Cascade Range & $\mathrm{V}$ & 10.65 & 1158 \\
\hline R03 & 1.72 & 6 & Inceptisol & Cascade Range & $\mathrm{V}$ & 1.30 & 1942 \\
\hline R05 & 1.61 & 21 & Inceptisol & Cascade Range & $\mathrm{U}$ & 11.50 & 1280 \\
\hline R07 & 2.02 & 12 & Inceptisol & Klamath Mountains & $S$ & 44.85 & 465 \\
\hline R10 & 0.52 & 8 & Ult/Alf & Klamath Mountains & $\mathrm{P}$ & 133.55 & 354 \\
\hline R12 & 5.95 & 12 & Inceptisol & Klamath Mountains & VS & 173.55 & 488 \\
\hline R13 & 45.4 & 40 & Ult/Alf & Klamath Mountains & VS & 173.55 & 732 \\
\hline R14 & 12.9 & 24 & Ult/Alf & Klamath Mountains & $\mathrm{S}$ & 130.30 & 354 \\
\hline R15 & 1.64 & 21 & Ult/Alf & Klamath Mountains & $S$ & 130.30 & 271 \\
\hline
\end{tabular}


APPENDIX F: Analysis Categories Data (cont.)

\begin{tabular}{|c|c|c|c|c|c|c|c|}
\hline Site & As & BW & Soil Order & Province & Origin & $\begin{array}{l}\text { Age } \\
\text { Rank }\end{array}$ & $\begin{array}{c}\text { Elev } \\
(\mathrm{m})\end{array}$ \\
\hline LC22 & 3.38 & 20 & Ultisol & Willamette Valley & VS & 31.70 & 489 \\
\hline LC23 & 2.9 & 16 & Inceptisol & Coast Range & $\mathrm{V}$ & 37.15 & 397 \\
\hline LM01 & 7.53 & 12 & Inceptisol & Cascade Range & $\mathrm{U}$ & 1.30 & 280 \\
\hline LM02 & 5.04 & 6 & Inceptisol & Cascade Range & VS & 19.60 & 329 \\
\hline LM03A & 1.92 & 6 & Inceptisol & Cascade Range & VS & 19.60 & 445 \\
\hline LM03B & 1.96 & 12 & Inceptisol & Cascade Range & $\mathrm{V}$ & 2.66 & 841 \\
\hline LM04 & 2.16 & 8 & Inceptisol & Cascade Range & $\mathrm{U}$ & 1.31 & 1317 \\
\hline LM05 & 1.26 & 6 & Inceptisol & Cascade Range & $\mathrm{V}$ & 0.005 & 1865 \\
\hline LM06 & 1 & 8 & Inceptisol & Cascade Range & $\mathrm{V}$ & 0.005 & 1753 \\
\hline LM07 & 2.99 & 6 & Inceptisol & Cascade Range & $\mathrm{U}$ & 0.005 & 305 \\
\hline LM08 & 4.74 & 12 & Inceptisol & Cascade Range & VS & 19.60 & 792 \\
\hline LM09 & 1.79 & 9 & Ultisol & Cascade Range & $\mathrm{V}$ & 1.30 & 1256 \\
\hline LM10 & 1 & 12 & Inceptisol & Cascade Range & $\mathrm{U}$ & 1.31 & 1460 \\
\hline LM11 & 0.977 & 12 & Inceptisol & Cascade Range & $\mathrm{V}$ & 11.51 & 1881 \\
\hline LM12 & 2.1 & 6 & Inceptisol & Cascade Range & $\mathrm{V}$ & 19.60 & 1664 \\
\hline LM13 & 2.03 & 12 & Mollisol & Cascade Range & VS & 19.60 & 1530 \\
\hline LM14 & 1.63 & 8 & Mollisol & Cascade Range & $\mathrm{V}$ & 7.10 & 1335 \\
\hline LM15 & 2.56 & 16 & Mollisol & Cascade Range & $\mathrm{V}$ & 2.66 & 1359 \\
\hline LM16 & 2.32 & 9 & Mollisol & Basin and Range & $\mathrm{V}$ & 1.30 & 1298 \\
\hline LM17 & 3.32 & 12 & Mollisol & Cascade Range & $\mathrm{U}$ & 0.005 & 189 \\
\hline LM19 & 7.31 & 6 & Mollisol & Cascade Range & $\mathrm{V}$ & 19.60 & 500 \\
\hline LM20 & 2.57 & ND & Inceptisol & Cascade Range & $\mathrm{V}$ & 15.50 & 305 \\
\hline LM21 & 1.03 & 9 & Inceptisol & Cascade Range & $\mathrm{U}$ & 1.31 & 744 \\
\hline LM22 & 1.48 & 12 & Inceptisol & Cascade Range & $\mathrm{V}$ & 14.15 & 463 \\
\hline R01 & 11.9 & 6 & Inceptisol & Cascade Range & $\mathrm{V}$ & 10.65 & 817 \\
\hline R02 & 7.13 & 4 & Inceptisol & Cascade Range & $\mathrm{V}$ & 10.65 & 1158 \\
\hline R03 & 1.72 & 6 & Inceptisol & Cascade Range & $\mathrm{V}$ & 1.30 & 1942 \\
\hline R05 & 1.61 & 21 & Inceptisol & Cascade Range & $\mathrm{U}$ & 11.50 & 1280 \\
\hline R07 & 2.02 & 12 & Inceptisol & Klamath Mountains & $\mathrm{S}$ & 44.85 & 465 \\
\hline R10 & 0.52 & 8 & Ult/Alf & Klamath Mountains & $\mathrm{P}$ & 133.55 & 354 \\
\hline R12 & 5.95 & 12 & Inceptisol & Klamath Mountains & VS & 173.55 & 488 \\
\hline R13 & 45.4 & 40 & Ult/Alf & Klamath Mountains & VS & 173.55 & 732 \\
\hline R14 & 12.9 & 24 & Ult/Alf & Klamath Mountains & $\mathrm{S}$ & 130.30 & 354 \\
\hline R15 & 1.64 & 21 & Ult/Alf & Klamath Mountains & $\mathrm{S}$ & 130.30 & 271 \\
\hline
\end{tabular}

Appendix F Key:

Rock type defined in Table 10.

Age Rank is the average of minimum and maximum deposition age as defined by Walker and MacLeod (1999). 


\section{APPENDIX G: Apex Labs Sample ID and Control Data}

This appendix contains sample identification, quality control results, sample preparation information and notes and definitions used in Apex Labs reports for the following work orders:

- A10D053

- A10D059

- A10D066

- A10D071

- A10D077

- A10E125

These samples were tested for concentrations of various metals for Oregon, but only arsenic results were used in this study. The pages reporting results from different metals are not included, but results for arsenic concentrations in soils collected by PSU are in Appendix D. 


\section{Apex Labs}

12232 S.W. Garden Phace

Tigard, OR 97223

503-718-2323 Phone

503-718-0333 Fax

Thursday, May 13, 2010

Neil Morton

GeoEngineers-Seattle

600 Stewart St. Suite 1700

Seattle, WA 98101

RE: Oregon Metals Evaluation / 2787-050-000

Enclosed are the results of analyses for work order $\mathrm{A10D053}$, which was received by the laboratory on $4 / 2 / 2010$ at $3: 35: 00 \mathrm{PM}$

Thank you for using Apex Labs. We appreciate your business and strive to provide the highest quality service s to the environmental industry.

If you have any questions concerning this report or the services we offer, please feel free to contact me by email at: pnerenbera@apex-labs.com, or by phone at 503-718-2323.

Apex Laboratories




\section{Apex Labs}

12232 S.W. Garden Phace

Tigard, OR 97223

503-718-2323 Phone

503-718-0333 Fax

\begin{tabular}{llc} 
GeoEngineers -Seattle & Project OregonMetals Evahuation \\
600 StewartSt. Suite 1700 & Project Humber. 2787-0s0-000 \\
Seattle, WA 98101 & Project Marager. Neil Morton & Reported \\
\hline
\end{tabular}

ANAL YTICAL REPORT FOR SAMPLES

\begin{tabular}{|c|c|c|c|c|}
\hline \multicolumn{5}{|c|}{ SAMPLE INF ORHATION } \\
\hline Sample ID & Laboratory ID & Matrix & Date Sampled & Date Received \\
\hline P05B & A10D053-01 & Soil & 01/01/9400:00 & $04,02 / 1015: 35$ \\
\hline P06Ala & A10D053-02 & Soil & 01:01/9400:00 & $04,02 / 1015: 35$ \\
\hline P06Bla & A10D053-03 & Soil & 01:01/9400:00 & $04 / 02 / 1015: 35$ \\
\hline P07Ala & A10D053-04 & Soil & 01:01/9400:00 & $04 / 02 / 1015: 35$ \\
\hline P0TBla & A10D053-05 & Soil & 01:01/9400:00 & $04,02 / 1015: 35$ \\
\hline P08Ala & A10D053-06 & Soil & 01/01/9400:00 & $04,02 / 1015: 35$ \\
\hline P08Bla & A10D053-07 & Soil & 01:01/9400:00 & $04 / 02 / 1015: 35$ \\
\hline P09Ala & A10D053-08 & Soil & 01/01/9400:00 & $04,02 / 1015: 35$ \\
\hline P09Bla & A10D053-09 & Soil & 01/01/9400:00 & $04,02 / 1015: 35$ \\
\hline P10Ala & A10D053-10 & Soil & 01:01/9400:00 & $04 / 02 / 1015: 35$ \\
\hline PloBla & A10D053-11 & Soil & 01/01/9400:00 & $04,02 / 1015: 35$ \\
\hline Pllala & A10D053-12 & Soil & 01:01/9400:00 & $04,02 / 1015: 35$ \\
\hline PllCla & A10D053-13 & Soil & 01:01/9400:00 & 04:02/10 15:35 \\
\hline P12Ala & A10D053-14 & Soil & 01:01/9400:00 & $04 / 02 / 1015: 35$ \\
\hline Pl2Bla & A10D053-15 & Soil & 01/01/9400:00 & $04,02 / 1015: 35$ \\
\hline Pl3Ala & A10D053-16 & Soil & 01:01/9400:00 & 04:02/10 15:35 \\
\hline P13Bla & A10D053-17 & Soil & 01:01/9400:00 & 04:02/10 15:35 \\
\hline P14Ala & A10D053-18 & Soil & 01:01/9400:00 & $04,02 / 1015: 35$ \\
\hline Pl4Cla & A10D053-19 & Soil & 01:01/9400:00 & 04:02/10 15:35 \\
\hline Pl5Ala & A10D053-20 & Soil & 01:01/9400:00 & 04:02/10 15:35 \\
\hline PlsBla & A10D053-21 & Soil & 01:01/9400:00 & $04,02 / 1015: 35$ \\
\hline Pl6Ala & A10D053-22 & Soil & 01/01/9400:00 & $04,02 / 1015: 35$ \\
\hline Pl6Bla & A10D053-23 & Soil & 01:01/9400:00 & 04:02/10 15:35 \\
\hline Pl6Cla & A10D053-24 & Soil & 01:01/9400:00 & 04:02/10 15:35 \\
\hline PlTAla & A10D053-25 & Soil & 01:01/9400:00 & $04,02 / 1015: 35$ \\
\hline PlTBla & A10D053-26 & Soil & 01:01/9400:00 & 04:02/10 15:35 \\
\hline PlTCla & A10D053-27 & Soil & 01:01/9400:00 & 04:02/10 15:35 \\
\hline Pl8Ala & A10D053-28 & Soil & 01:01/9400:00 & $04,02 / 1015: 35$ \\
\hline Pl8Bla & A10D053-29 & Soil & 01:01/9400:00 & 04:02/10 15:35 \\
\hline $\mathrm{Sn} 2 \mathrm{Ala}$ & A10D053-30 & Soil & 01:01/9400:00 & 04:02/10 15:35 \\
\hline S02Bla & A10D053-31 & Soil & 01:01/9400:00 & $04,02 / 1015: 35$ \\
\hline S03Ala & A10D053-32 & Soil & 01:01/9400:00 & 04:02/10 15:35 \\
\hline S04A & A10D053-33 & Soil & 01:01/9400:00 & $04,02 / 1015: 35$ \\
\hline S05Ala & A10D053-34 & Soil & 01:01/9400:00 & $04,02 / 1015: 35$ \\
\hline S05Bla & A10D053-35 & Soil & 01/01/9400:00 & $04 / 02 / 1015: 35$ \\
\hline
\end{tabular}

Apex Laboratories

The results in this report appiy to the samples analyzed in accordaxce with the chain of

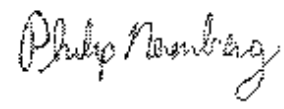
custody document This arahtical repont mus be reprodiced in it entivety.

Fhilip Nerenberg For Darwin Thomas, Business Development Director

Page 2 of 53 


\section{Apex Labs}

12232 S.W. Garden Place

Tigard, OR 97223

503-718-2323 Phone

503-718-0333 Fax

\begin{tabular}{|llr}
\hline GeoEngineers -Seattle & Project OregonMetals Evaluation \\
600 S tewartSt. Suite 1700 & Project Humber. 2787-050-000 \\
Seattle, WA 98101 & Project Manager. Neil Morton & Reported \\
\hline
\end{tabular}

ANAL YTICAL REPORT FOR SAMPLES

\begin{tabular}{|c|c|c|c|c|}
\hline \multicolumn{5}{|c|}{ SAMPLE INF ORMATION } \\
\hline Sample ID & Laboratory ID & Matrix & Date Sampled & Date Received \\
\hline S06Ala & A10D053-36 & Soil & 01/01/9400:00 & $04,02 / 1015: 35$ \\
\hline S06Bla & A10D053-37 & Soil & 01/01/9400:00 & $04,02 / 1015: 35$ \\
\hline SOTAla & A10D053-38 & Soil & 01:01/9400:00 & $04: 02 / 1015: 35$ \\
\hline SOTBla & A10D053-39 & Soil & 01:01/9400:00 & $04,02 / 1015: 35$ \\
\hline So8Alb & A10D053-40 & Soil & 01/01/9400:00 & $04,02 / 1015: 35$ \\
\hline So8Blb & A10D053-41 & Soil & 01:01/9400:00 & $04,02 / 1015: 35$ \\
\hline So9Ala & A10D053-42 & Soil & 01:01/9400:00 & $04 / 02 / 1015: 35$ \\
\hline SogBla & A10D053-43 & Soil & 01:01/9400:00 & $04,02 / 1015: 35$ \\
\hline SI0Ala & A10D053-44 & Soil & 01/01/9400:00 & $04,02 / 1015: 35$ \\
\hline SI0Bla & A10D053-45 & Soil & 01:01/9400:00 & $04,02 / 1015: 35$ \\
\hline SIlAlb & A10D053-46 & Soil & 01:01/9400:00 & $04 / 02 / 1015: 35$ \\
\hline SIlBlb & A10D053-47 & Soil & 01:01/9400:00 & $04,02 / 1015: 35$ \\
\hline S12Ala & A10D053-48 & Soil & 01/01/9400:00 & $04,02 / 1015: 35$ \\
\hline SI2Bla & A10D053-49 & Soil & 01:01/9400:00 & $04: 02 / 1015: 35$ \\
\hline WolA la & A10D053-50 & Soil & 01:01/9400:00 & $04,02 / 1015: 35$ \\
\hline wolB2a & A10D053-51 & Soil & 01:01/9400:00 & $04,02 / 1015: 35$ \\
\hline W02A la & A10D053-52 & Soil & 01/01/9400:00 & $04,02 / 1015: 35$ \\
\hline W02B2a & A10D053-53 & Soil & 01:01/9400:00 & $04: 02 / 1015: 35$ \\
\hline W03Ala & A10D053-54 & Soil & 01:01/9400:00 & $04,02 / 1015: 35$ \\
\hline W03B2a & A10D053-55 & Soil & 01:01/9400:00 & $04,02 / 1015: 35$ \\
\hline W04A2a & A10D053-56 & Soil & 01/01/9400:00 & $04,02 / 1015: 35$ \\
\hline W04B2a & A10D053-57 & Soil & 01:01/9400:00 & $04,02 / 1015: 35$ \\
\hline W05A7 & A10D053-58 & Soil & 01:01/9400:00 & $04 / 02 / 1015: 35$ \\
\hline W05B2a & A10D053-59 & Soil & 01/01/9400:00 & $04,02 / 1015: 35$ \\
\hline W06A2a & A10D053-60 & Soil & 01/01/9400:00 & $04 / 02 / 1015: 35$ \\
\hline W06B2a & A10D053-61 & Soil & 01:01/9400:00 & $04 / 02 / 1015: 35$ \\
\hline WoTAla & A10D053-62 & Soil & 01:01/9400:00 & $04,02 / 1015: 35$ \\
\hline WoTBla & A10D053-63 & Soil & $01 / 01 / 9400: 00$ & $04,02 / 1015: 35$ \\
\hline W08Ala & A10D053-64 & Soil & 01/01/9400:00 & $04,02 / 1015: 35$ \\
\hline W08Bla & A10D053-65 & Soil & 01:01/9400:00 & $04 / 02 / 1015: 35$ \\
\hline W09A la & A10D053-66 & Soil & 01:01/9400:00 & $04,02 / 1015: 35$ \\
\hline Wo9Bla & A10D053-67 & Soil & 01/01/9400:00 & $04 / 02 / 1015: 35$ \\
\hline R0lAa & A10D053-68 & Soil & 01/01/9400:00 & $04 / 02 / 1015: 35$ \\
\hline R01Ba & A10D053-69 & Soil & 01/01/9400:00 & $04,02 / 1015: 35$ \\
\hline $\mathrm{R} 02 \mathrm{Aa}$ & A10D053-70 & Soil & 01:01/9400:00 & $04,02 / 1015: 35$ \\
\hline
\end{tabular}

Apex Laboratories

The results in this report asply to the samples analyzed in accordaxce with the c knin of

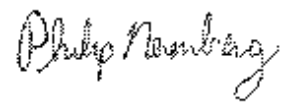

custody document This andaticalrepon mus be reproduced in it entivety.

Philip Nerenberg For Darwin Thomas, Business Development Director

Page 3 of 53 


\section{Apex Labs}

12232 S.W. Garden Phace

Tigard, OR 97223

503-718-2323 Phone

503-718-0333 Fax
GeoEngineers -Seattle

600 S tewartSt. Suite 1700

Seattle, WA 98101
Project OregonMetals Evahuation

Project Humber. 2787-050-000

Project Manazer. Heil Morton
Reported:

05/13/1022:21

ANAL YTICAL REPORT FOR SAMPLES

\begin{tabular}{|c|c|c|c|c|}
\hline \multicolumn{5}{|c|}{ SAMPLE INF ORMATION } \\
\hline S:mple ID & Laboratory ID & Matrix & Date Sampled & Date Received \\
\hline R02Ba & A10D053-71 & Soil & 01:01/9400:00 & $04,02 / 1015: 35$ \\
\hline R03Aa & A10D053-72 & Soil & 01:01/9400:00 & $04: 02 / 1015: 35$ \\
\hline R03Ba & A10D053-73 & Soil & 01:01/9400:00 & $04 / 02 / 1015: 35$ \\
\hline R05Ba & A10D053-74 & Soil & 01:01/9400:00 & $04,02 / 1015: 35$ \\
\hline $\mathbf{R 0 T B a}$ & A10D053-75 & Soil & 01:01/9400:00 & $04 / 02 / 1015: 35$ \\
\hline Rl0Ba & A10D053-76 & Soil & 01:01/9400:00 & $04,02 / 1015: 35$ \\
\hline Rl2Ba & A10D053-77 & Soil & 01/01/9400:00 & $04,02 / 1015: 35$ \\
\hline Rl3Aa & A10D053-78 & Soil & 01/01/9400:00 & $04,02 / 1015: 35$ \\
\hline Rl3Ba & A10D053-79 & Soil & 01:01/9400:00 & $04,02 / 1015: 35$ \\
\hline Rl4Aa & A10D053-80 & Soil & 01:01/9400:00 & $04,02 / 1015: 35$ \\
\hline Rl4Ba & A10D053-81 & Soil & 01/01/9400:00 & $04,02 / 1015: 35$ \\
\hline Rl5Aa & A10D053-82 & Soil & 01/01/9400:00 & $04,02 / 1015: 35$ \\
\hline Rl5Ba & A10D053-83 & Soil & 01:01/9400:00 & $04 / 02 / 1015: 35$ \\
\hline KL01A1 & A10D053-84 & Soil & 01:01/9400:00 & $04: 02 / 1015: 35$ \\
\hline KL01Bl & A10D053-85 & Soil & 01:01/9400:00 & $04 / 02 / 1015: 35$ \\
\hline KL02A 1 & A10D053-86 & Soil & 01:01/9400:00 & $04 / 02 / 1015: 35$ \\
\hline KL02B1 & A10D053-87 & Soil & 01:01/9400:00 & $04: 02 / 1015: 35$ \\
\hline KLOBAl & A10D053-88 & Soil & 01:01/9400:00 & $04 / 02 / 1015: 35$ \\
\hline KL03B1 & A10D053-89 & Soil & 01:01/9400:00 & $04,02 / 1015: 35$ \\
\hline KL04A 1 & A10D053-90 & Soil & 01/01/9400:00 & $04,02 / 1015: 35$ \\
\hline
\end{tabular}

Apex Laboratories

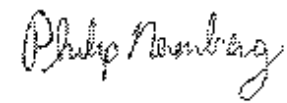

Philip Nerenberg For Darwin Thoras, Business Development Director

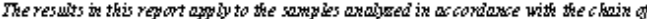
custody document This mapticalrepon mus be reproduced in it entirety.

Page 4 of 53 


\section{Apex Labs}

12232 S.W. Garden Place

Tigard, OR 97223

503-718-2323 Phone

503-718-0333 Fax

$\begin{array}{lcc}\text { GeoEngineers -Seatfle } & \text { Project } \text { OregonMetals Evaluation } \\ 600 \text { S tewartSt. Suite } 1700 & \text { Project Humber. } 2787-050-000 & \text { Reported } \\ \text { Seattle, WA } 98101 & \text { ProjectManazer. Neil Morton } & 05 / 3 / 1022: 21\end{array}$

QUALITY CONTROL (QC) SAMPLE RESULTS

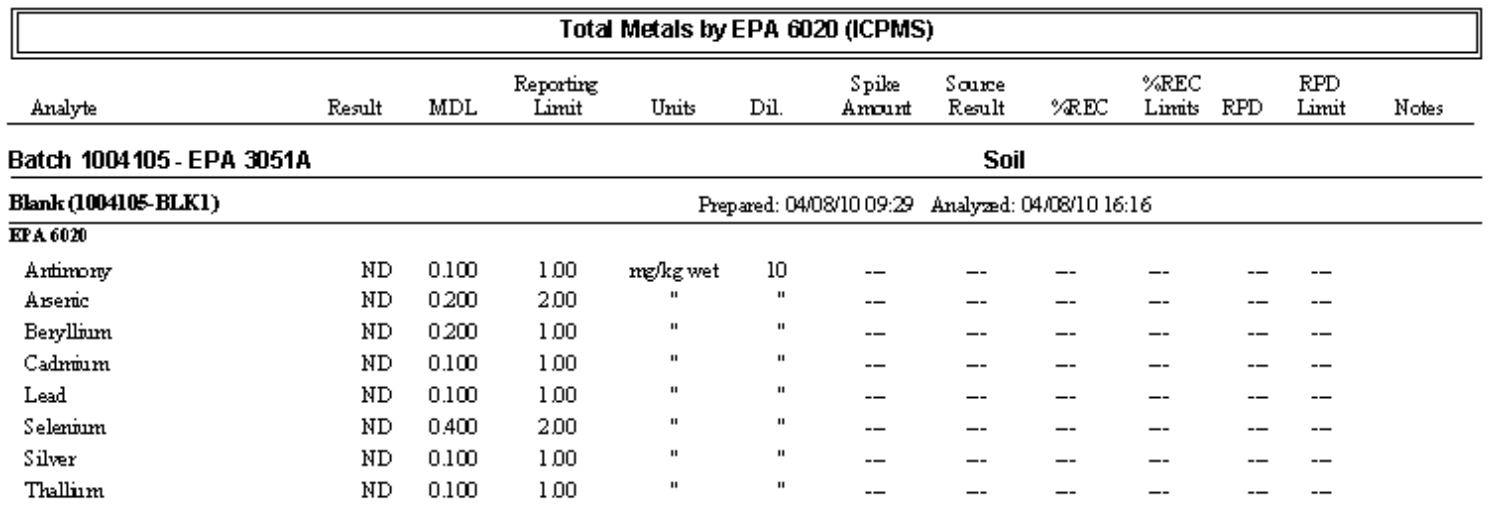

LCS(1004105-BS1)

Prepared: 04/08/10 09:29 Analyzed: 04/08/10 15:58

\begin{tabular}{|c|c|c|c|c|c|c|c|c|c|c|}
\hline Antimory & 25.8 & 0.100 & 100 & $\mathrm{mg} / \mathrm{kg}$ wet & 10 & 25.0 & -- & 103 & $80-120 \%$ & - \\
\hline Aseric & 48.9 & 0200 & 200 & $"$ & $"$ & 50.0 & -- & 98 & $"$ & - \\
\hline Beryllium & 24.7 & 0200 & 100 & $"$ & $"$ & 25.0 & - & 99 & $"$ & - \\
\hline Cadnim & 50.1 & 0.100 & 100 & $"$ & $"$ & 50.0 & - & 100 & $"$ & -- \\
\hline Lead & 46.6 & 0.100 & 100 & $"$ & $"$ & $"$ & -- & 93 & $"$ & -- \\
\hline Selenvium & 23.9 & 0.400 & 200 & $"$ & $"$ & 25.0 & -- & 96 & $"$ & -- \\
\hline Silver & 24.6 & 0.100 & 100 & $"$ & $"$ & $"$ & -- & 99 & $"$ & -- \\
\hline Thallinm & 23.8 & 0.100 & 100 & $"$ & $"$ & $"$ & -- & 95 & $"$ & -- \\
\hline
\end{tabular}

Duplicate (1004105-DUPI)

Prepared: 04,08/10 09:29 Analyzd: 04/08/10 16:54

\begin{tabular}{|c|c|c|c|}
\hline \multicolumn{4}{|c|}{ QC Sarre S ample: Y07Bla (Al0D053-05) } \\
\hline \multicolumn{4}{|l|}{ EPA 6020 } \\
\hline Antimory & 0.300 & 0.111 & 1.1 \\
\hline Aseric & 269 & 0222 & 222 \\
\hline Beryllium & $0.4 \pi$ & 0222 & 1.1 \\
\hline Cadrimum & 0.111 & 0.111 & 1.1 \\
\hline Lead & 16.2 & 0.111 & 1. \\
\hline Selenvium & HD & 0.444 & 23 \\
\hline Silver & ND & 0.111 & \\
\hline Thallimm & 0.133 & 0.111 & 1. \\
\hline
\end{tabular}

Matrix Spile (1004105-MS1)

Qc Saurce S ample: P07Bla (A10D053-05)

Apex Laboratories

The results in this report appiy to the samples analysed in accordance with the chnin of

1)

custody document This atadicolvepon mus be reproduced in it entivety

Philip Nerenberg For Darwin Thomas, Business Development Director

Page 34 of 53 


\section{Apex Labs}

12232 S.W. Garden Place

Tigard, OR 97223

503-718-2323 Phone

503-718-0333 Fax
GeoEngineers - Seatle

600 S tewart St. Suite 1700

Seattle, WA 98101
Project Oregon Metals Evahuation

Project Humber. 2787-050-000

Project Manager. Heil Morton
Reported

$05 / 13 / 1022: 21$

QUALITY CONTROL (QC) SAMPLE RESULTS

\begin{tabular}{|c|c|c|c|c|c|c|c|c|c|c|c|c|}
\hline \multicolumn{13}{|c|}{ Total Metals by EPA 6020 (ICPMS) } \\
\hline Analyte & Result & MDL & $\begin{array}{c}\text { Reporting } \\
\text { Limit }\end{array}$ & Units & Dil. & $\begin{array}{c}\text { Spike } \\
\text { Amount }\end{array}$ & $\begin{array}{l}\text { Source } \\
\text { Result }\end{array}$ & $\%$ & $\begin{array}{l}\text { \%REC } \\
\text { Limits }\end{array}$ & RPD & $\begin{array}{l}\text { RPD } \\
\text { Limit }\end{array}$ & Notes \\
\hline
\end{tabular}

Batch 1004105 - EPA 3051A

Soil

Matrix Spile (1004105-MS1)

Prepared: 04,08/10 09:29 Analyzed: 04/08/10 16:57

QC S aurce S ample: P07B1a (Al0DO53-05)

EPA 6020

Antimory

Aseric

Beryllium

Cadrimem

Lead

Seleriim

Silver

Thallium

$\begin{array}{lll}23.8 & 0.112 \quad 1.12\end{array}$

$53.0 \quad 0224 \quad 224$

$25.0 \quad 0224 \quad 1.12$

$\begin{array}{lll}53.2 & 0.112 & 1.12\end{array}$

$\begin{array}{lll}65.1 & 0.112 & 1.12\end{array}$

$\begin{array}{lll}25.3 & 0.448 & 224\end{array}$

$25.2 \quad 0.112 \quad 1.12$

$\begin{array}{lll}25.4 & 0.112 & 1.12\end{array}$

$\begin{array}{cc}28.0 & 0.352 \\ 56.0 & 2.81 \\ 28.0 & 0.494 \\ 56.0 & 0.176 \\ " & 15.9 \\ 28.0 & \text { ND } \\ " & \text { HD } \\ " & 0.143\end{array}$

$\begin{array}{ccc}75-125 \% & -- & - \\ " & - & - \\ " & - & - \\ " & - & - \\ " & - & - \\ " & - & - \\ " & - & - \\ " & - & -\end{array}$

Matric Spife (1004105-MS2)

Prepared: 04/08/1009:29 Analyzed: 04/08/10 17:34

oc Sarces ample: P12A12 (A10D053-14)

EPA 6020

\begin{tabular}{|c|c|c|c|c|c|c|c|c|c|c|}
\hline Antimory & 21.0 & 0.108 & 108 & $m g / \mathrm{kg} d r y$ & 10 & 26.9 & 0.186 & $n$ & $75-125 \%$ & -- \\
\hline Aseric & 52.3 & 0215 & 2.15 & $"$ & $"$ & 53.8 & 2.95 & 92 & $"$ & -- \\
\hline Beryllium & 25.2 & 0215 & 108 & $"$ & $"$ & 26.9 & 0.616 & 91 & $"$ & -- \\
\hline Cadnim & 52.1 & 0.108 & 108 & $"$ & $"$ & 53.8 & 0.442 & 95 & $"$ & -- \\
\hline Lead & 72.4 & 0.108 & 108 & $"$ & $"$ & $"$ & 27.0 & 84 & $"$ & -- \\
\hline Selenvium & 24.9 & 0.431 & 2.15 & $"$ & $"$ & 26.9 & HD & 93 & $"$ & -- \\
\hline Silver & 25.2 & 0.108 & 108 & $"$ & $"$ & $"$ & HD & 94 & $"$ & -- \\
\hline Thallinm & 24.7 & 0.108 & 108 & $"$ & $"$ & $"$ & HD & 92 & $"$ & -- \\
\hline
\end{tabular}

Apex Laboratories

The results in this report apply to the samples analyed in accoriaxe with the chain of

custody document This anditical repont mus be reproduced in it entrety.

Philip Nerenberg For Darwin Thomas, Business Development Director

Puge 35 of 53 


\section{Apex Labs}

12232 S.W. Garden Place

Tigard, OR 97223

503-718-2323 Phone

503-718-0333 Fax

GeoEngineers - Seatf

600 S tewartSt. Suite 1700

Seattle, WA 9810
Project OregonMetals Evahuation

Project Number. 2787-050-000

Project Marager. Neil Morton
Reported

$05 / 13 / 1022: 21$

QUALITY CONTROL (QC) SAMPLE RESULTS

\begin{tabular}{|c|c|c|c|c|c|c|c|c|c|c|c|c|}
\hline \multicolumn{13}{|c|}{ Total hietals by EPA 6020 (ICPHSS) } \\
\hline Analyte & Result & MDL & $\begin{array}{l}\text { Reporting } \\
\text { Limit }\end{array}$ & Units & Dil. & $\begin{array}{l}\text { Spike } \\
\text { Amourt }\end{array}$ & $\begin{array}{l}\text { Sounce } \\
\text { Reult }\end{array}$ & $\%$ REC & $\begin{array}{l}\% \mathrm{REC} \\
\text { Limits }\end{array}$ & RPD & $\begin{array}{l}\text { RPD } \\
\text { Limit }\end{array}$ & Notes \\
\hline
\end{tabular}

Batch 1004114 - EPA 3051A

Soil

Blank (10041 14-BLKl)

EPA 6020

Antimory

Aseric

Beryllium

Cadrimim

Lead

Selenium

Silver

Thallinm

LCS(1004114BS1)

EPA 6020

Antimory
Axeric
Beryllim
Cadrium
Lead
Selenim
Silver
Thallim

Duplicate (1004114DUPI)

Qc Sarces ample: P16B1a (Al0D053-23)

EPA 6020

$\begin{array}{lccc}\text { Antimory } & \mathbf{0 . 2 3 3} & 0.111 & 1.11 \\ \text { Aseric } & \mathbf{4 7 0} & 0222 & 222 \\ \text { Beryllium } & \mathbf{0 . 6 7 6} & 0.222 & 1.11 \\ \text { Cadrium } & \mathbf{0 . 3 1 0} & 0.111 & 1.11 \\ \text { Lead } & \mathbf{6 4 3} & 0.111 & 1.11 \\ \text { Selenim } & \text { HD } & 0.443 & 222 \\ \text { Silver } & \text { ND } & 0.111 & 1.11 \\ \text { Thallimm } & \mathbf{0 . 1 5 5} & 0.111 & 1.11\end{array}$

Matric Spile (1004114-MS1)

Qc S aurce S mqle: P16B1a (AlOD(53-23)

$\begin{array}{lll}24.1 & 0.100 & 1.00 \\ 47.6 & 0200 & 200 \\ 24.4 & 0200 & 1.00 \\ 48.2 & 0.100 & 100 \\ 46.7 & 0.100 & 100 \\ 24.1 & 0.400 & 200 \\ 23.8 & 0.100 & 100 \\ 23.8 & 0.100 & 100\end{array}$

Prepared: 04/08/10 12:16 Analyrad: 04/08/10 17:51

\begin{tabular}{|c|c|c|c|c|c|c|c|c|c|}
\hline $\mathrm{HD}$ & 0.100 & 100 & $\mathrm{mg} / \mathrm{kg}$ wet & 10 & -- & -- & -- & -- & - \\
\hline $\mathrm{HD}$ & 0200 & 200 & $"$ & $"$ & -- & -- & -- & -- & - \\
\hline $\mathrm{ND}$ & 0200 & 100 & $"$ & $"$ & -- & -- & -- & -- & - \\
\hline $\mathrm{ND}$ & 0.100 & 100 & $"$ & $"$ & -- & -- & -- & -- & -- \\
\hline $\mathrm{HD}$ & 0.100 & 100 & $"$ & $"$ & -- & -- & -- & -- & - \\
\hline $\mathrm{HD}$ & 0.400 & 200 & $"$ & $"$ & -- & -- & -- & -- & - \\
\hline $\mathrm{ND}$ & 0.100 & 100 & $"$ & $"$ & -- & -- & -- & -- & - \\
\hline ND & 0.100 & 100 & $"$ & $"$ & -- & -- & -- & -- & - \\
\hline
\end{tabular}

Prepared: 04,08/10 12:16 Analyzed: 04/08/10 17:54

\begin{tabular}{|c|c|c|c|c|c|c|}
\hline $\mathrm{mg} / \mathrm{kg}$ wet & 10 & 25.0 & -- & 97 & $80-120 \%$ & - \\
\hline$"$ & $"$ & 50.0 & -- & 95 & $"$ & - \\
\hline$"$ & $"$ & 25.0 & -- & 98 & $"$ & -- \\
\hline$"$ & $"$ & 50.0 & -- & 96 & $"$ & -- \\
\hline$"$ & $"$ & $"$ & -- & 93 & $"$ & - \\
\hline$"$ & $"$ & 25.0 & -- & 96 & $"$ & -- \\
\hline$"$ & $"$ & $"$ & -- & 95 & $"$ & -- \\
\hline$"$ & $"$ & " & -- & 95 & " & - \\
\hline
\end{tabular}

Prepared: 04/08/10 12:16 Analyzd: 04/08/10 18:15

\begin{tabular}{|c|c|c|c|c|c|c|c|c|}
\hline$m g / \lg d r y$ & 10 & - & 0.244 & -- & -- & 5 & $40 \%$ & J \\
\hline " & " & - & 4.80 & -- & -- & 2 & $40 \%$ & \\
\hline$"$ & " & - & 0.676 & -- & -- & 0 & $40 \%$ & J \\
\hline$"$ & $"$ & - & 0.244 & -- & -- & 24 & $40 \%$ & J \\
\hline$"$ & $"$ & - & 6.63 & -- & -- & 3 & $40 \%$ & \\
\hline$"$ & $"$ & - & HD & -- & -- & & $40 \%$ & \\
\hline$"$ & $"$ & -- & $\mathrm{HD}$ & -- & -- & & $40 \%$ & \\
\hline " & $"$ & - & 0.155 & -- & -- & 0 & $40 \%$ & J \\
\hline
\end{tabular}

Prepared: 04,08/10 12:16 Analyzed: 04/08/10 18:18
The results in this report aspiy to the samples analyzed in accoriase with the chain of custody document This anditicalvepon must be reproduced in it entivety.

Philip Nerenberg For Darwin Thomas, Business Development Director

Puge 36 of 53 


\section{Apex Labs}

12232 S.W. Garden Place

Tigard, OR 97223

503-718-2323 Phone

503-718-0333 Fax
GeoEngineers -Seattle

600 S tewartSt. Suite 1700

Seattle, WA 98101
Project Oregon Metals Evaluation

Project Humber. 2787-050-000

Project Manager. Neil Morton
Reported

$05 / 13 / 1022: 21$

QUALITY CONTROL (QC) SAMPLE RESULTS

\begin{tabular}{|c|c|c|c|c|c|c|c|c|c|c|c|c|}
\hline \multicolumn{13}{|c|}{ Total Metals by EPA 6020 (ICPMS) } \\
\hline Analyte & Result & MDL & $\begin{array}{c}\text { Reporting } \\
\text { Limit }\end{array}$ & Units & Dil. & $\begin{array}{c}\text { Spike } \\
\text { Amount }\end{array}$ & $\begin{array}{l}\text { Source } \\
\text { Revult }\end{array}$ & $\%$ & $\begin{array}{l}\% \mathrm{REC} \\
\text { Limits }\end{array}$ & RPD & $\begin{array}{l}\text { RPD } \\
\text { Limit }\end{array}$ & Notes \\
\hline
\end{tabular}

Batch 1004114 - EPA 3051A

Soil

Matrix Spile (1004114MS1)

Prepared: 04/08/10 12:16 Analyzed: 04/08/10 18:18

Qc Sarces ample: P16B1a (Al0Do53-23)

EPA 6020

$\begin{array}{llll}\text { Axtimory } & 23.0 & 0.114 & 1.14 \\ \text { Aseric } & 58.3 & 0228 & 228 \\ \text { Beryllimm } & 27.0 & 0228 & 1.14 \\ \text { Cadrimim } & 56.4 & 0.114 & 1.14 \\ \text { Lead } & 58.1 & 0.114 & 1.14 \\ \text { Selenium } & 25.5 & 0.456 & 228 \\ \text { Silver } & 27.4 & 0.114 & 1.14 \\ \text { Thallim } & 25.4 & 0.114 & 1.14\end{array}$

Matrix spile (1004114Ms)

Prepared: 04/08/10 12:16 Analyzed: 04/00/10 19:23

QC S aurce S mple: S06B1a (AlOD053-37)

EPA 6020

Antimory

Aseric

Beryllium

Cadrimim

Lead

Selenium

Silver

Thallinm

$\begin{array}{lll}18.7 & 0.114 & 1.14 \\ 54.6 & 0228 & 228 \\ 28.1 & 0228 & 1.14 \\ 55.8 & 0.114 & 1.14 \\ 71.7 & 0.114 & 1.14 \\ 24.7 & 0.457 & 228 \\ 27.5 & 0.114 & 1.14 \\ 25.6 & 0.114 & 1.14\end{array}$

Post Spile (1004114PS1)

QC Sarce S mqle: S06B1a (Al0D053-37)

EPA 6020

Antimory

129

$\mathrm{ug} / \mathrm{L}$

$\mathrm{m} / \mathrm{kg} \mathrm{d} y$
$"$
$"$
$"$
$"$
$"$
$"$
"

$28.6 \quad 0.277$

57.1

28.6

57.1

"

$28.6 \quad 0.889$

" ND

Frepared: 04/12/10 11:45 Analyzed: 04/12/10 12:31

10

128

2.37

99

$80-120 \%$

Apex Laboratories

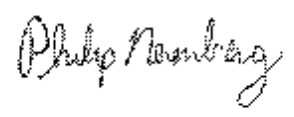

Philip Nerenberg For Dawin Thomas, Business Development Director

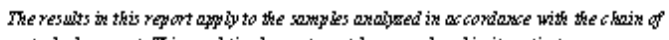

custody doument This anditical repont mus be reproduced in it entivety. 


\section{Apex Labs}

12232 S.W. Garden Phace

Tigard, OR 97223

503-718-2323 Phone

503-718-0333 Fax
GeoEngineers -Seattle

600 S tewartSt. Suite 1700

Seattle, WA 98101
Project Oregon Metals Evaluation

Project Humber. 2787-050-000

Project Manager. Neil Morton
Reported

$05 / 13 / 1022: 21$

QUALITY CONTROL (QC) SAMPLE RESULTS

\begin{tabular}{|c|c|c|c|c|c|c|c|c|c|c|c|c|}
\hline \multicolumn{13}{|c|}{ Total Metals by EPA 6020 (ICPHS) } \\
\hline Analyte & Result & MDL & $\begin{array}{l}\text { Reporting } \\
\text { Limit }\end{array}$ & Units & Dil. & $\begin{array}{l}\text { Spike } \\
\text { Amourt }\end{array}$ & $\begin{array}{l}\text { Sounce } \\
\text { Reult }\end{array}$ & $\%$ REC & $\begin{array}{l}\% \mathrm{REC} \\
\text { Limrits }\end{array}$ & RPD & $\begin{array}{l}\text { RPD } \\
\text { Limit }\end{array}$ & Notes \\
\hline
\end{tabular}

Batch 1004123 - EPA 3051A

Soil

Blank (1004123-BLK1)

Prepared: 04/09/10 08:49 Analyzed: 04/00/10 19:29

\section{EPA 6020}

Antimory

Aseric

Beryllium

Cadrimim

Lead

Selenium

Silver

Thallinm

LCS(1004123-BS1)

EPA 6020

Antimory

Aseric

Beryllium

Cadrinim

Lead

Selenium

Silver

Thallinm

$\begin{array}{lll}\text { HD } & 0.100 & 1.00 \\ \text { HD } & 0200 & 200 \\ \text { HD } & 0200 & 1.00 \\ \text { HD } & 0.100 & 1.00 \\ \text { HD } & 0.100 & 1.00 \\ \text { HD } & 0.400 & 200 \\ \text { HD } & 0.100 & 1.00 \\ \text { HD } & 0.100 & 1.00\end{array}$

Duplicate (1004123-DUPI)

Prepared: 04/09/10 08:49 Analyzed: 04/09/10 19:44

OC Sarces ample: S09Ala (A10D053-42)

EPA 6020

Antimory

Aseric

Beryllium

Cadrimim

Lead

Selenium

Silver

Thallimm

$\begin{array}{ccc}\mathbf{0 . 1 8 2} & 0.101 & 1.01 \\ \mathbf{4 8 0} & 0.203 & 2.03 \\ \mathbf{0 . 5 6 7} & 0.203 & 1.01 \\ \mathbf{0 . 3 4 4} & 0.101 & 1.01 \\ \mathbf{6 9 9} & 0.101 & 1.01 \\ \mathbf{0 . 4 4 6} & 0.405 & 2.03 \\ \text { HD } & 0.101 & 1.01 \\ \text { HD } & 0.101 & 1.01\end{array}$

Matric Spife (1004123-MS1)

$\begin{array}{lll}25.2 & 0.100 & 1 \\ 49.4 & 0200 & 200 \\ 24.4 & 0.200 & 100 \\ 46.7 & 0.100 & 100 \\ 45.8 & 0.100 & 100 \\ 24.0 & 0.400 & 200 \\ 23.6 & 0.100 & 100 \\ 23.0 & 0.100 & 100\end{array}$

QC S aurce S ample: S09Ala (AlODO53-47)

Apex Laboratories

The results in this reyort apsiy to the samples analysed in accoriaxe with the chanin of

$$
\text { 1) }
$$

Philip Nerenberg For Darwin Thomas, Business Development Director

Puge 38 of 53 


\section{Apex Labs}

12232 S.W. Garden Phace

Tigard, OR 97223

503-718-2323 Phone

503-718-0333 Fax
GeoEnginers -Seatile

600 S tewartSt. Suite 1700

Seattle, WA 98101
Project Oregon Metals Evahuation

Project Humber. 2787-050-000

Project Manager. Neil Morton
Reported $05 / 13 / 1022: 21$

QUALITY CONTROL (QC) SAMPLE RESULTS

\begin{tabular}{|c|c|c|c|c|c|c|c|c|c|c|c|c|}
\hline \multicolumn{13}{|c|}{ Total Metals by EPA 6020 (ICPMS) } \\
\hline Analyte & Result & MDL & $\begin{array}{l}\text { Reporting } \\
\text { Limit }\end{array}$ & Units & Dil. & $\begin{array}{l}\text { Spike } \\
\text { Amourt }\end{array}$ & $\begin{array}{l}\text { Source } \\
\text { Reunlt }\end{array}$ & $\%$ REC & $\begin{array}{l}\% \mathrm{REC} \\
\text { Linnits }\end{array}$ & RPD & $\begin{array}{l}\text { RPD } \\
\text { Limit }\end{array}$ & Notes \\
\hline
\end{tabular}

Batch 1004123 - EPA 3051A

Soil

Matrix Spile (1004123-MS1)

QC S aurce S mmle: S09Ala (A10D053-4n

EPA 6020

Antimory

Aseric

Beryllium

Cadrinim

Lead

Selenium

Silver

Thallinm

Prepared: 04/09/10 08:49 Analyred: 04/09/10 19:47

Matrix Spile (1004123-MS2)

$52.7 \quad 0210$

$25.0 \quad 0210$

$49.8 \quad 0.105$

$528 \quad 0105$

$23.9 \quad 0.421$

$24.6 \quad 0.105$

$23.0 \quad 0.105$

105
2.10
105
105
105
2.10
105
105

$\begin{array}{lrr}/ \mathrm{lg} d \mathrm{dr} & 10 & 26.3 \\ " & 1 & 52.6\end{array}$

"

"

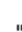

"

Prepared: 04/09/10 08:49 Analyred: 04/12/10 12:28

QC Sarce S mqle: W04B2a (A10D053-57)

EPA 6020

Antimon

Aseric

Beryllium

Cadrum

Lead

Selenium

Silver

Thallim

$18.6 \quad 0.100$

109

$25.0 \quad 0218$

53.20 .100

$56.5 \quad 0.100$

$25.2 \quad 0.435$

$25.5 \quad 0.100$

$24.4 \quad 0.100$

Post Spile (1004123-PS1)

QC Sarce S mqle: Wo4B2a (A10D053- 57)

\section{EPA 6020}

Antimory

180

$\mathrm{ug} / \mathrm{L}$

10

196

1.57

91

$80-120 \%$

Apex Laboratories

$$
\text { (1) }
$$

Philip Nerenberg For Darwin Thomas, Business Development Director
The results in this report appiy to the somples analyed in accoriase with the chain of custody document This anapticalirepont mus be reproduced in it entivety. 


\section{Apex Labs}

12232 S.W. Garden Place

Tigard, OR 97223

503-718-2323 Phone

503-718-0333 Fax

GeoEngineers -Seattle

600 S tewart St. Suite 1700

Seattle, WA 98101

Project OregonMetals Evahuation

Project Humber. 2787-050-000

Reported.

Project Manager. Neil Morton

QUALITY CONTROL (QC) SAMPLE RESULTS

\begin{tabular}{|c|c|c|c|c|c|c|c|c|c|c|c|c|}
\hline \multicolumn{13}{|c|}{ Total hetals by EPA 6020 (ICPHS) } \\
\hline Analyte & Result & MDL & $\begin{array}{c}\text { Reporting } \\
\text { Limit }\end{array}$ & Units & Dil. & $\begin{array}{c}\text { Spike } \\
\text { Amourt }\end{array}$ & $\begin{array}{l}\text { Source } \\
\text { Revult }\end{array}$ & $\%$ RC & $\begin{array}{l}\text { \%REC } \\
\text { Limits }\end{array}$ & RPD & $\begin{array}{l}\text { RPD } \\
\text { Limit }\end{array}$ & Notes \\
\hline Batch 1004125 - EPA 3051A & & & \multicolumn{10}{|c|}{ Soil } \\
\hline Blank (1004125-BLK1) & \multicolumn{12}{|c|}{ Prepared: 04/09/10 11:01 Analyzed: 04/12/10 13:33 } \\
\hline \multicolumn{13}{|l|}{$\overline{\text { EPA 6020 }}$} \\
\hline Antimory & HD & 0.100 & 100 & $\mathrm{mg} / \mathrm{kg}$ wet & 10 & - & -- & - & -- & - & - & \\
\hline Aseric & 0.200 & 0200 & 200 & $"$ & $"$ & - & -- & -- & -- & - & - & $\mathrm{J}$ \\
\hline Beryllium & $\mathrm{HD}$ & 0200 & 1.00 & $"$ & $"$ & - & -- & -- & -- & - & - & \\
\hline Cadruim & $\mathrm{HD}$ & 0.100 & 100 & $"$ & $"$ & - & -- & -- & -- & - & - & \\
\hline Lead & $\mathrm{HD}$ & 0.100 & 100 & $"$ & $"$ & - & -- & -- & -- & - & - & \\
\hline Selerinum & $\mathrm{HD}$ & 0.400 & 200 & $"$ & $"$ & - & -- & -- & -- & - & - & \\
\hline Silver & $\mathrm{HD}$ & 0.100 & 100 & $"$ & $"$ & -- & -- & -- & -- & - & - & \\
\hline Thallinm & $\mathrm{HD}$ & 0.100 & 100 & $"$ & $"$ & - & -- & -- & -- & - & - & \\
\hline
\end{tabular}

LCS(1004125-BS1)

Prepared: 04/09/10 11:01 Analyzd: 04/12/10 13:36

EPA 602

\begin{tabular}{|c|c|c|c|c|c|c|c|c|c|c|}
\hline Antimory & 25.7 & 0.100 & 100 & $\mathrm{mg} / \mathrm{kg}$ wet & 10 & 25.0 & - & 103 & $80-120 \%$ & -- \\
\hline Aseruc & 48.4 & 0200 & 200 & $"$ & $"$ & 50.0 & -- & 97 & $"$ & - \\
\hline Beryllium & 24.1 & 0200 & 100 & $"$ & $"$ & 25.0 & -- & 96 & $"$ & - \\
\hline Cadruim & 48.9 & 0.100 & 100 & $"$ & $"$ & 50.0 & -- & 98 & $"$ & -- \\
\hline Lead & 48.6 & 0.100 & 100 & $"$ & $"$ & $"$ & -- & 97 & $"$ & -- \\
\hline Selenvium & 24.3 & 0.400 & 200 & $"$ & $"$ & 25.0 & -- & 97 & $"$ & - \\
\hline Silver & 24.4 & 0.100 & 100 & $"$ & $"$ & $"$ & -- & 98 & $"$ & - \\
\hline Thallinm & 24.4 & 0.100 & 100 & " & $"$ & $"$ & -- & 98 & $"$ & - \\
\hline
\end{tabular}

Duplicate (1004125-DUPI)

Prepared: 04/09/10 11:01 Analyred: 04/12/10 14:16

QC S aurce S mqle: Wo8Bla (Al0D053-66)

EFA 6020

Antimory

Aseric

Beryllium

Cadrimim

Lead

Selerinum

Silver

Thalliom

$\begin{array}{ccc}\mathbf{0 . 2 6 7} & 0.116 & 1.16 \\ \mathbf{5 0 3} & 0.232 & 232 \\ \mathbf{1 . 1 7} & 0232 & 1.16 \\ \mathbf{0 . 4 6} & 0.116 & 1.16 \\ \mathbf{1 2 5} & 0.116 & 1.16 \\ \text { HD } & 0.464 & 232 \\ \text { HD } & 0.116 & 1.16 \\ \mathbf{0 . 2 9 0} & 0.116 & 1.16\end{array}$

Matrix Spile (1004125-MS1)

$\begin{array}{cc}\operatorname{mg} / \mathrm{kg} d r y & 10 \\ " & " \\ " & " \\ " & " \\ " & " \\ " & " \\ " & \text { " }\end{array}$

$\begin{array}{lc}- & 0.273 \\ -- & 4.86 \\ -- & 1.20 \\ -- & 0.459 \\ -- & 12.4 \\ -- & \text { ND } \\ -- & \text { HD } \\ - & 0.284\end{array}$

$\begin{array}{ll}-- & - \\ -- & - \\ -- & - \\ -- & - \\ -- & - \\ -- & - \\ -- & - \\ -- & -\end{array}$

--
--
--
--
--
--
--

Prepared: 04/09/10 11:01 Analyzed: 04/12/10 14:19

QC S aurce S mqle: Wo8Bla (A10D053-66)

Apex Laboratories

(1)
The results in this report apply to the sawples analyzed in accoriaxe with the $c$ knin of custody document This onatical repon mus be reproduced in it entivety.

Philip Nerenberg For Darwin Thomas, Business Development Director 


\section{Apex Labs}

12232 S.W. Garden Place

Tigard, OR 97223

503-718-2323 Phone

503-718-0333 Fax

GeoEngineers -Seattle

600 S tewartSt. Suite 1700

Seattle, WA 98101
Project Oregon Metals Evahuation

Project Manager. Neil Morton
Project Number. 2787-050-000
Reported:

$05 / 13 / 1022: 21$

QUALITY CONTROL (QC) SAMPLE RESULTS

\begin{tabular}{|c|c|c|c|c|c|c|c|c|c|c|c|c|}
\hline \multicolumn{13}{|c|}{ Total hetals by EPA 6020 (ICPHS) } \\
\hline Analyte & Result & MDL & $\begin{array}{l}\text { Reporting } \\
\text { Limit }\end{array}$ & Units & Dil. & $\begin{array}{l}\text { Spike } \\
\text { Amourt }\end{array}$ & $\begin{array}{l}\text { Source } \\
\text { Result }\end{array}$ & $\%$ REC & $\begin{array}{l}\% \mathrm{REC} \\
\text { Limits }\end{array}$ & RPD & $\begin{array}{l}\text { RPD } \\
\text { Limit }\end{array}$ & Hotes \\
\hline
\end{tabular}

Batch 1004125 - EPA 3051A

Soil

Matrix Spile (1004125-MS1)

Prepared: 04/09/10 11:01 Analyzd: 04/12/10 14:19

QC S aurce S mple: Wo8Bla (A10D053-66)

EPA 6020

\begin{tabular}{|c|c|c|c|c|c|c|c|c|c|c|c|c|}
\hline Antimory & 18.1 & 0.100 & 109 & $\mathrm{mg} / \mathrm{kg} \mathrm{dry}$ & 10 & 27.3 & 0.273 & 65 & $75-125 \%$ & - & - & Q-01 \\
\hline Aseric & 53.5 & 0219 & 2.19 & $"$ & $"$ & 54.7 & 4.86 & 89 & $"$ & - & - & \\
\hline Beryllium & 25.6 & 0219 & 109 & $"$ & $"$ & 27.3 & 1.20 & 89 & $"$ & - & - & \\
\hline Cadrumim & 54.4 & 0.100 & 109 & $"$ & $"$ & 54.7 & 0.459 & 99 & $"$ & - & - & \\
\hline Selervium & 24.8 & 0.437 & 2.19 & $"$ & $"$ & 27.3 & HD & 91 & $"$ & -- & -- & \\
\hline Silver & 25.7 & 0.100 & 109 & $"$ & $"$ & $"$ & ND & 98 & $"$ & - & - & \\
\hline Thallium & 25.7 & 0.100 & 109 & $"$ & $"$ & $"$ & 0.284 & 93 & $"$ & - & - & \\
\hline
\end{tabular}

Matrix spife (1004125-MS2)

Prepared: 04/09/10 11:01 Analyzd: 04/12/10 15:01

QC Saurce S mqle: R10Ba (Al0D053-76)

EPA 6020

Antimory

Aseric

Beryllium

Cadrium

Lead

Selenium

Silver

Thallimm

$\begin{array}{lll}18.7 & 0.113 & 1.13 \\ 53.4 & 0225 & 226 \\ 25.3 & 0225 & 1.13 \\ 56.1 & 0.113 & 1.13 \\ 54.5 & 0.113 & 1.13 \\ 25.5 & 0.451 & 226 \\ 27.9 & 0.113 & 1.13 \\ 25.8 & 0.113 & 1.13\end{array}$

Post Spile (1004125-PSI)

$m g / k d x y \quad 10$

" "

"

"

"

" "

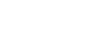

Prepared: 04/12/10 15:02 Analyzed: 04/12/10 15:05

OC S aurce $S$ mple: Wo8B1a (A10D053-66)

\section{EPA 6020}

Antimory

186

Post spile (1004125-PS2)

$\mathrm{ugl}$

Prepared: 04/12/10 15:08 Analyæd: 04/12/10 15:38

OC S aurce S mple: RlOBa (Al0D053-76)

EPA 6020

Antimory

184

\begin{tabular}{cc}
28.2 & HD \\
56.4 & 0.520 \\
28.2 & HD \\
56.4 & HD \\
$"$ & 0.571 \\
28.2 & HD \\
$"$ & HD \\
\hline
\end{tabular}

66
94
93
99
96
94
99

$75-125 \%$

" - - - -

$--$

$-\quad-$

$--$

$-$

$-$

$--$

$--$

Apex Laboratories

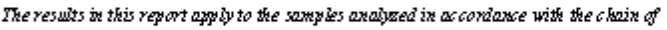

custody document This andoticalrepon must be reproduced in it entirety.

Philip Nerenberg For Darwin Thomas, Business Development Director

Puge 41 of 53 


\section{Apex Labs}

12232 S.W. Garden Place

Tigard, OR 97223

503-718-2323 Phone

503-718-0333 Fax
GeoEngineers -Seattle

600 S tewartSt. Suite 1700

Seattle, WA 98101
Project OregonMetals Evaluation

Project Number. 2787-050-000

Project Manager. Neil Morton
Reported:

05/1310 22:21

QUALITY CONTROL (QC) SAMPLE RESULTS

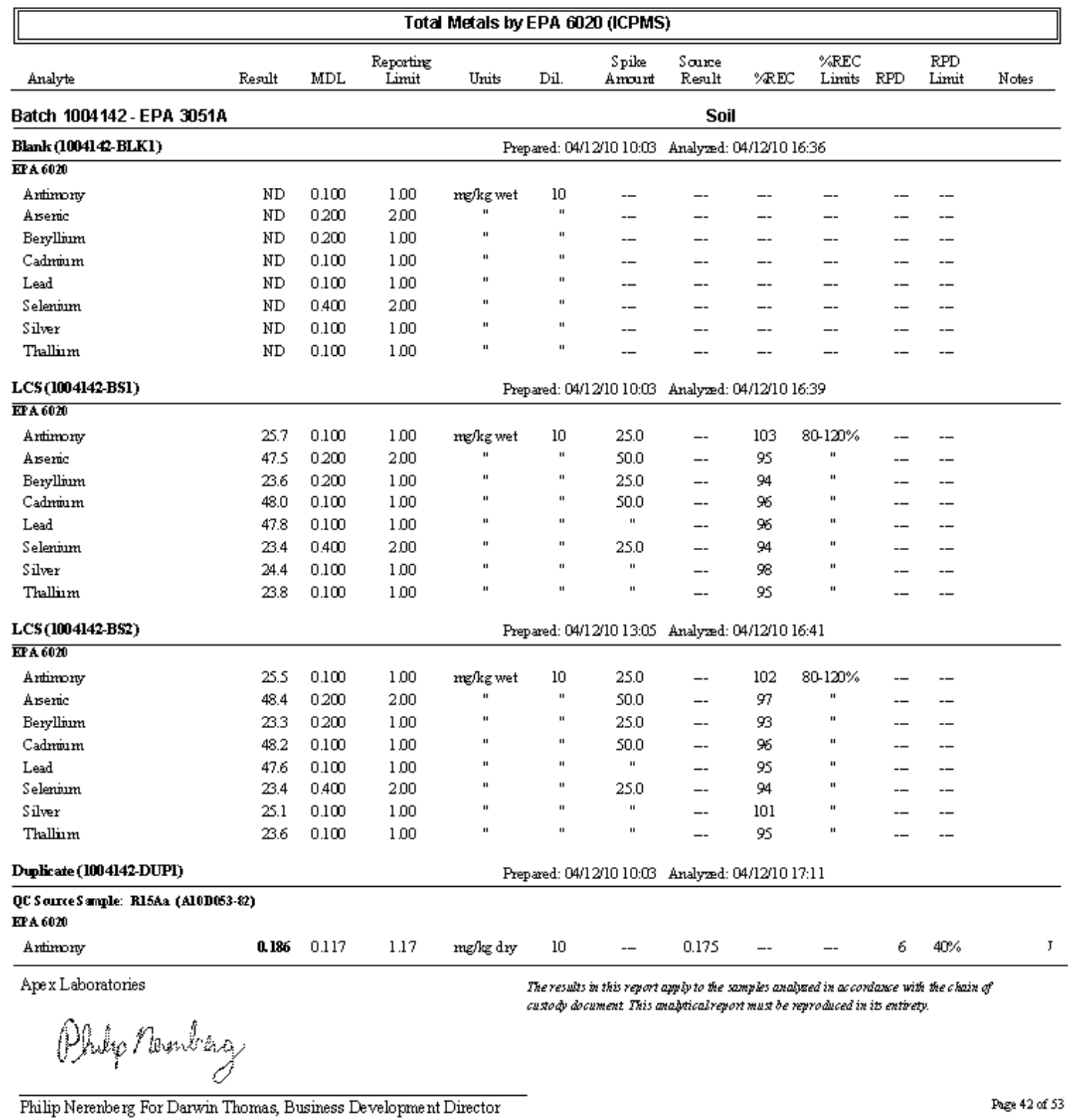




\title{
Apex Labs
}

12232 S.W. Garden Phace

Tigard, OR 97223

503-718-2323 Phone

503-718-0333 Fax
GeoEngineers -Seattle

600 S tewartSt. Suite 1700

Seattle, WA 98101
Project Oregon Metals Evahuation

Project Humber. 2787-050-000

Project Manager. Neil Morton
Reported

$0513 / 1022: 21$

QUALITY CONTROL (QC) SAMPLE RESULTS

\begin{tabular}{|c|c|c|c|c|c|c|c|c|c|c|c|c|}
\hline \multicolumn{13}{|c|}{ Total hetals by EPA 6020 (ICPHS) } \\
\hline Analyte & Result & MDL & $\begin{array}{l}\text { Reporting } \\
\text { Limit }\end{array}$ & Units & Dil. & $\begin{array}{l}\text { Spike } \\
\text { Amourt }\end{array}$ & $\begin{array}{l}\text { Source } \\
\text { Result }\end{array}$ & $\%$ REC & $\begin{array}{l}\text { \%REC } \\
\text { Limits }\end{array}$ & RPD & $\begin{array}{l}\text { RPD } \\
\text { Limit }\end{array}$ & Notes \\
\hline
\end{tabular}

Batch 1004142 - EPA $3051 A$

Soil

\begin{tabular}{lrrr}
\hline Duplicate (1004142-DUP1) & & & \\
\hline Qc Saurce S mqle: R15Aa (Al0D053-82) & & & \\
Aseric & $\mathbf{1 . 1 2}$ & 0233 & 233 \\
Beryllium & $\mathbf{0 . 3 1 5}$ & 0233 & 1.1 \\
Cadrium & $\mathbf{0 . 1 8 6}$ & 0.117 & 1. \\
Lead & $\mathbf{5 . 7 6}$ & 0.117 & 1.7 \\
Selenium & HD & 0.466 & 2.3 \\
Silver & HD & 0.117 & 1.1 \\
Thallimm & HD & 0.117 & 1.
\end{tabular}

Matric Spile (1004142-MS1)

ND $0.117 \quad 1.17$

QC SaurceS mqle: R15Aa (AlODO53-82)

EPA 6020

Antimory

Aseric

Berylliom

Cadrixum

Lead

Selenium

Silver

Thallinm

\begin{tabular}{|c|c|c|c|}
\hline 22.9 & 0.115 & 1.15 & $\mathrm{~m} g / \mathrm{kg} \mathrm{d} y$ \\
\hline$\$ 2.2$ & 0229 & 229 & " \\
\hline 25.5 & 0220 & 1.15 & $"$ \\
\hline 55.6 & 0.115 & 1.15 & $"$ \\
\hline 58.5 & 0.115 & 1.15 & $"$ \\
\hline 25.0 & 0.450 & 229 & $"$ \\
\hline 28.0 & 0.115 & 1.15 & $"$ \\
\hline 25.7 & 0.115 & 1.15 & $"$ \\
\hline
\end{tabular}

Prepared: 04/12/10 10:03 Analyæad: 04/12/10 17:11

$\begin{array}{cccccccc}\operatorname{mg} / \mathrm{k} d r y & " & -- & 1.00 & -- & -- & 11 & 40 \% \\ " & " & -- & 0.304 & -- & -- & 4 & 40 \% \\ " & " & -- & 0.140 & -- & -- & 28 & 40 \% \\ " & \text { " } & -- & 5.42 & -- & -- & 6 & 40 \% \\ " & \text { " } & -- & \text { HD } & -- & -- & & 40 \% \\ " & \text { " } & -- & \text { ND } & -- & -- & & 40 \% \\ " & \text { " } & -- & \text { HD } & -- & -- & & 40 \%\end{array}$

Prepared: 04/12/10 10:03 Analyzed: 04/12/10 17:14

(n)

\begin{abstract}
$26.7-0.115 \quad 1.15$
\end{abstract}

$\begin{array}{lccc} & & & \\ " \mathrm{~d} y & 10 & 28.7 & 0.175 \\ " & " & 57.4 & 1.00 \\ " & " & 28.7 & 0.304 \\ " & " & 57.4 & 0.140 \\ " & " & " & 5.42 \\ " & 4 & 28.7 & \text { HD } \\ " & \text { " } & & \text { HD } \\ & & & \text { HD }\end{array}$

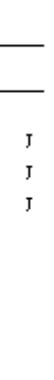




\section{Apex Labs}

12232 S.W. Garden Phace

Tigard, OR 97223

503-718-2323 Phone

503-718-0333 Fax
GeoEngineers -Seatile

600 S tewartSt. Suite 1700

Seattle, WA 98101
Project Oregon Metals Evahuation

Project Number. 2787-050-000

Project Manager. Heil Morton
Reported $05 / 13 / 1022: 21$

QUALITY CONTROL (QC) SAMPLE RESULTS

\begin{tabular}{|c|c|c|c|c|c|c|c|c|c|c|c|c|}
\hline \multicolumn{13}{|c|}{ Total hetals by EPA 6020 (ICPHS) } \\
\hline Analyte & Result & MDL & $\begin{array}{c}\text { Reporting } \\
\text { Limit }\end{array}$ & Units & Dil. & $\begin{array}{c}\text { Spike } \\
\text { Amount }\end{array}$ & $\begin{array}{l}\text { Source } \\
\text { Reult }\end{array}$ & $\%$ & $\begin{array}{l}\text { \%REC } \\
\text { Limits }\end{array}$ & $\mathrm{RPD}$ & $\begin{array}{l}\text { RPD } \\
\text { Limit }\end{array}$ & Wotes \\
\hline
\end{tabular}

Batch 1004144 - EPA 3051A

Blank (1004144-BLK1)

\section{EPA 6020}

\section{Antimory}

Aseric

Beryllium

Cadrium

Lead

Selenium

Silver

Thallinm

LCS (1004144-BS1)

EPA 6020

Antimory

Aseric

Beryllium

Cadrimim

Lead

Selenium

Silver

Thalling Soil

Result MDL Limit

Soil

Prepared: 04/12/10 10:52 Analyzed: 04/14/10 13:57

$$
\begin{array}{cccccc}
\operatorname{mg} / \mathrm{kg} \text { wet } & 10 & -- & -- & -- & - \\
\text { " } & \text { " } & -- & -- & -- & - \\
" & \text { " } & -- & -- & -- & - \\
" & \text { " } & -- & -- & -- & - \\
" & \text { " } & -- & -- & -- & - \\
" & \text { " } & -- & -- & -- & - \\
" & \text { " } & -- & -- & -- & - \\
" & \text { " } & -- & -- & -- & -
\end{array}
$$

Prepared: 04/12/10 10:S2 Analyred: 04/14/10 14:00

Post Spile (1004144-PS1)

OC S aurce S ample: Post Spike (A10D059-06)

EPA 6020

Antimory

244

Post spile (1004144-PS2)

QC S aurce S mple: Post Spike (A10D059-14)

EPA 6020

Antimory 232

$\mathrm{ug} / \mathrm{L}$

$\begin{array}{ccccc}-- & 104 & 80-120 \% & -- & - \\ -- & 96 & " & -- & - \\ -- & 94 & " & - & - \\ -- & 97 & " & -- & - \\ -- & 94 & " & -- & - \\ -- & 94 & " & -- & - \\ -- & 96 & " & - & - \\ -- & 93 & 1 & -- & -\end{array}$

Prepared: 04/14/10 16:46 Analyrad: 04/14/10 16:48

$\begin{array}{llllll}\text { ug/L } & 10 & 244 & 2.15 & 99 & 80-120 \%\end{array}$

Prepared: 04/14/10 16:46 Analyzd: 04/14/10 16:51

$\begin{array}{llllll} & 10 & 244 & 1.76 & 94 & 80-120 \%\end{array}$

Apex Laboratories

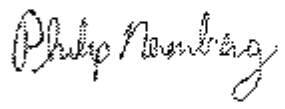

Philip Nererberg For Darwin Thomas, Business Development Director
The results in this report appiy to the samples andiszed in accoriaxe with the chnin of custody document This anditical repon mus be reproduced in it entivety. 


\section{Apex Labs}

12232 S.W. Garden Place

Tigard, OR 97223

503-718-2323 Phone

503-718-0333 Fax

GeoEngineers -Seattle

600 S tewartSt. Suite 1700

Seattle, WA 98101
Project Oregon Metals Evaluation

Project Humber. 2787-050-000

Project Manager. Neil Morton
Reported:

$05 / 131022: 21$

QUALITY CONTROL (QC) SAMPLE RESULTS

\begin{tabular}{|c|c|c|c|c|c|c|c|c|c|c|c|c|}
\hline \multicolumn{13}{|c|}{ Percent Dry Weight by D2216 } \\
\hline Analyte & Result & MDL & $\begin{array}{l}\text { Reporting } \\
\text { Limit }\end{array}$ & Units & Dil. & $\begin{array}{c}\text { Spike } \\
\text { Amourt }\end{array}$ & $\begin{array}{l}\text { Source } \\
\text { Reult }\end{array}$ & $\% R E C$ & $\begin{array}{l}\% \mathrm{REC} \\
\text { Limits }\end{array}$ & RPD & $\begin{array}{l}\text { RPD } \\
\text { Limit }\end{array}$ & Notes \\
\hline
\end{tabular}

Batch 1004136 - Dry Weight

Soil

Duplicate (1004136-DUP2) $\quad$ Prepared: 04/10/10 13:53 Analyzid: 04/11/1000:57

QC S aurces ample: P07Bla (Al0Do53-05)

$\mathbf{D} 216$

$\begin{array}{lllllllllllllll}\% \text { Solids } & 980 & - & 100 & \% \text { by Weight } & 1 & - & & 98.1 & -- & - & 0.1 & 29 \%\end{array}$

Batch 1004146 - Dry Weight

Soil

Duplicate (1004146-DUPI)

Qc Sarces amqle: S05B1a (A10D053-35)

D2m16

$\begin{array}{llllllllllllllll}\% \text { Solids } & 928 & - & 100 & \% \text { by Weight } & 1 & - & 92.8 & -- & - & 0 & 20 \%\end{array}$

Batch 1004169 - Dry Weight

Soil

Duplicate (1004169-DUPI)

Frepared: 04/13/10 14:13 Analyrad: 04/14/1000:22

QC S aurce S mqle: S11B1b (A10D063-47)

D2m16

$\begin{array}{lllllllllllllll}\% \text { Solids } & 95.0 & - & & 100 & \% \text { by Weight } & 1 & - & & 94.9 & -- & - & 0.1 & 20 \%\end{array}$

Duplicate (1004169-DUP2)

Prepared: 04/13/10 14:13 Analyzed: 04/14/1000:22

QC S aurces ample: Wo4A2a (A10D053-50)

D2m16

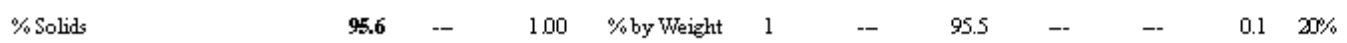

Duplicate (1004169-DUP3)

Prepared: 04/13/10 14:13 Analyred: 04/14/1000:22

QC S aurce S mple: Wo9Ala (A10D053-60)

$\mathbf{D} 216$

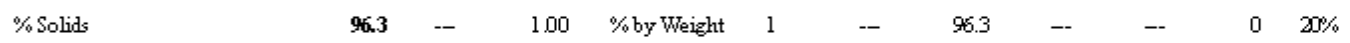

Duplicate (1004169-DUP4)

Prepared: 04/13/10 14:13 Analyzd: 04/14/1008:22

QC S aurces ample: R13Ba (AlOD053-79)

D2m16

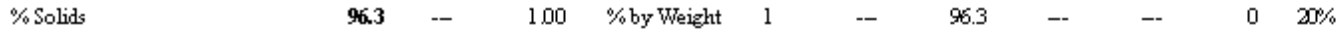

Duplicate (1004169-DUF5)

Prepared: 04/13/10 14:13 Analyzed: 04/14/1000:22

QC Sarce S mqle: KIOBBI (Al0D053-89)

Apex Laboratories

$$
\text { (1) }
$$

Philip Nerenberg For Darwin Thomas, Business Development Director
The results in this report arpily to the samples analysed in accoriaxe with the chnin of custody document This mathicalrepon must be reproduced in it entivety. 


\section{Apex Labs}

12232 S.W. Garden Place

Tigard, OR 97223

503-718-2323 Phone

503-718-0333 Fax

GeoEngineers -Seattle

600 S tewart St. Suite 1700

Seattle, WA 98101

Project Oregon Metals Evahuation

Project Number. 2787-050-000

Reporter

Project Manager. Neil Morton

QUALITY CONTROL (QC) SAMPLE RESULTS

\begin{tabular}{|c|c|c|c|c|c|c|c|c|c|c|c|c|}
\hline \multicolumn{13}{|c|}{ Percent Dry Weight by D2216 } \\
\hline Analyte & Result & MDL & $\begin{array}{l}\text { Reporting } \\
\text { Limit }\end{array}$ & Units & Dil. & $\begin{array}{c}\text { Spike } \\
\text { Amourt }\end{array}$ & $\begin{array}{l}\text { Source } \\
\text { Revult }\end{array}$ & $\%$ REC & $\begin{array}{l}\% \mathrm{REC} \\
\text { Limits }\end{array}$ & RPD & $\begin{array}{l}\text { RPD } \\
\text { Limit }\end{array}$ & Notes \\
\hline
\end{tabular}

Batch 1004169 - Dry Weight

Soil

Duplicate (1004169-DUP5)

Prepared: 04/13/10 14:13 Analyzd: 04/14/1000:22

QC S aurce S mple: KL (3B1 (A10D053-89)

D2m16

$\%$ Solids

$96.6 \quad--\quad 100 \quad \%$ by Weight 1

96.6

$-0 \quad 020 \%$

The results in this report apply to the samples analysed in accoriaxe with the c knin of custody document This andaticalrepont mus be reproduced in it entirety. 


\section{Apex Labs}

12232 S.W. Garden Phace

Tigard, OR 97223

503-718-2323 Phone

503-718-0333 Fax

\begin{tabular}{|c|c|c|}
\hline GeoEngineers -Seattle & Project OregonMetals Evaluation & \\
\hline 600 S tewart St. Suite 1700 & Project Humber. $2787-050-000$ & Reported: \\
\hline Seattle, WA 98101 & Project Manager. Heil Morton & $0513 / 1022: 21$ \\
\hline
\end{tabular}

SAMPLE PREPARATION INF ORMATION

\begin{tabular}{|c|c|c|c|c|c|c|c|}
\hline \multicolumn{8}{|c|}{ Total Metals by EPA 6020 (ICPMS) } \\
\hline Prep: EPA 3051A & & & & & Sample & Default & RL Prep \\
\hline Lab Number & Matix & Method & Sampled & Phepared & Iritial/Final & Iritial/Final & Factor \\
\hline \multicolumn{8}{|l|}{ Batch: 1004105 } \\
\hline A10D053-01 & Soil & EPA 6020 & $01 / 01 / 9400: 00$ & $04 / 08 / 1009: 29$ & $0.474 \mathrm{~g} / 50 \mathrm{~mL}$ & $0.5 \mathrm{~g} / 50 \mathrm{~mL}$ & 1.05 \\
\hline A10D053-02 & Soil & EPA 6020 & $01 / 01 / 9400: 00$ & 04/08:1009:29 & $0.455 \mathrm{~g} / 50 \mathrm{~mL}$ & $0.5 \mathrm{~g} / 50 \mathrm{~mL}$ & 1.10 \\
\hline A10D053-03 & Soil & EPA 6020 & $01 / 01 / 9400: 00$ & 04/08/1009:29 & $0.465 \mathrm{~g} / 50 \mathrm{~mL}$ & $0.5 \mathrm{~g} / 50 \mathrm{~mL}$ & 1.08 \\
\hline A10D053-04 & Soil & EPA 6020 & 01/01/9400:00 & $04,08: 1009: 29$ & $0.464 \mathrm{~g} / 50 \mathrm{~mL}$ & $0.5 \mathrm{~g} / 50 \mathrm{~mL}$ & 1.08 \\
\hline A10D053-05 & Soil & EPA 6020 & 01/01/9400:00 & $04,08: 1009: 29$ & $0.464 \mathrm{~g} / 50 \mathrm{~mL}$ & $0.5 \mathrm{~g} / 50 \mathrm{~mL}$ & 1.08 \\
\hline A10D053-06 & Soil & EPA 6020 & 01:01/9400:00 & 04/08:1009:29 & $0.45 \mathrm{~g} / 50 \mathrm{~mL}$ & $0.5 \mathrm{~g} / 50 \mathrm{~mL}$ & 1.11 \\
\hline A10D053-0? & Soil & EPA 6020 & $01 / 01 / 9400: 00$ & 0408:1009:29 & $0.505 \mathrm{~g} / 50 \mathrm{~mL}$ & $0.5 \mathrm{~g} / 50 \mathrm{~mL}$ & 0.99 \\
\hline A10D053-08 & Soil & EPA 6020 & 01:01/9400:00 & 04/08/1009:29 & $0.498 \mathrm{~g} / 50 \mathrm{~mL}$ & $0.5 \mathrm{~g} / 50 \mathrm{~mL}$ & 1.00 \\
\hline A10D053-09 & Soil & EPA 6020 & 01/01/9400:00 & 04/08/1009:29 & $0.475 \mathrm{~g} / 50 \mathrm{~mL}$ & $0.5 \mathrm{~g} / 50 \mathrm{~mL}$ & 1.05 \\
\hline A10D053-10 & Soil & EPA 6020 & 01:01/9400:00 & $04,08 / 1009: 29$ & $0.491 \mathrm{~g} / 50 \mathrm{~mL}$ & $0.5 \mathrm{~g} / 50 \mathrm{~mL}$ & 1.02 \\
\hline A10D053-11 & Soil & EPA 6020 & 01/01/9400:00 & 04:08:1009:29 & $0.46 \mathrm{~g} / 50 \mathrm{~mL}$ & $0.5 \mathrm{~g} / 50 \mathrm{~mL}$ & 1.09 \\
\hline A10D053-12 & Soil & EPA 6020 & 01:01:9400:00 & $04 / 08 / 1009: 29$ & $0.465 \mathrm{~g} / 50 \mathrm{~mL}$ & $0.5 \mathrm{~g} / 50 \mathrm{~mL}$ & 1.08 \\
\hline A10D053-13 & Soil & EPA 6020 & 01:01/9400:00 & $04,08: 1009: 29$ & $0.451 \mathrm{~g} / 50 \mathrm{~mL}$ & $0.5 \mathrm{~g} / 50 \mathrm{~mL}$ & 1.11 \\
\hline A10D053-14 & Soil & EPA 6020 & 01:01:9400:00 & $0408: 1009: 29$ & $0.452 \mathrm{~g} / 50 \mathrm{~mL}$ & $0.5 \mathrm{~g} / 50 \mathrm{~mL}$ & 1.11 \\
\hline A10D053-15 & Soil & EPA 6020 & 01:01:9400:00 & $04,08: 1009: 29$ & $0.504 \mathrm{~g} / 50 \mathrm{~mL}$ & $0.5 \mathrm{~g} / 50 \mathrm{~mL}$ & 0.99 \\
\hline A10D053-16 & Soil & EPA 6020 & 01/01/9400:00 & 0408:1009:29 & $0.472 \mathrm{~g} / 50 \mathrm{~mL}$ & $0.5 \mathrm{~g} / 50 \mathrm{~mL}$ & 1.06 \\
\hline A10D053-17 & Soil & EPA 6020 & 01/01/9400:00 & 0408:1009:29 & $0.473 \mathrm{~g} / 50 \mathrm{~mL}$ & $0.5 \mathrm{~g} / 50 \mathrm{~mL}$ & 1.06 \\
\hline A10D053-18 & Soil & EPA 6020 & 01/01/9400:00 & $04,08 / 1009: 29$ & $0.486 \mathrm{~g} / 50 \mathrm{~mL}$ & $0.5 \mathrm{~g} / 50 \mathrm{~mL}$ & 1.03 \\
\hline A10D053-19 & Soil & EPA 6020 & 01:01/9400:00 & 04:08:1009:29 & $0.46 \mathrm{~g} / 50 \mathrm{~mL}$ & $0.5 \mathrm{~g} / 50 \mathrm{~mL}$ & 1.09 \\
\hline \multicolumn{8}{|l|}{ Batch: 1004114} \\
\hline A10D053-20 & Soil & EPA 6020 & $01 / 01 / 9400: 00$ & $0408: 1012: 16$ & $0.475 \mathrm{~g} / 50 \mathrm{~mL}$ & $0.5 \mathrm{~g} / 50 \mathrm{~mL}$ & 1.05 \\
\hline A10D053-21 & Soil & EPA 6020 & 01/01/9400:00 & $04 / 08 / 1012: 16$ & $0.525 \mathrm{~g} / 50 \mathrm{~mL}$ & $0.5 \mathrm{~g} / 50 \mathrm{~mL}$ & 0.95 \\
\hline A10D053-22 & Soil & EPA 6020 & 01/01/9400:00 & $04 / 08 / 1012: 16$ & $0.517 \mathrm{~g} / 50 \mathrm{~mL}$ & $0.5 \mathrm{~g} / 50 \mathrm{~mL}$ & 0.97 \\
\hline A10D053-23 & Soil & EPA 6020 & 01/01/9400:00 & $04,08 / 1012: 16$ & $0.463 \mathrm{~g} / 50 \mathrm{~mL}$ & $0.5 \mathrm{~g} / 50 \mathrm{~mL}$ & 1.08 \\
\hline A10D053-24 & Soil & EPA 6020 & 01/01/9400:00 & $04 / 08 / 1012: 16$ & $0.501 \mathrm{~g} / 50 \mathrm{~mL}$ & $0.5 \mathrm{~g} / 50 \mathrm{~mL}$ & 1.00 \\
\hline A10D053-25 & Soil & EPA 6020 & 01:01:9400:00 & $04,08 / 1012: 16$ & $0.472 \mathrm{~g} / 50 \mathrm{~mL}$ & $0.5 \mathrm{~g} / 50 \mathrm{~mL}$ & 1.06 \\
\hline A10D053-26 & Soil & EPA 6020 & 01/01/9400:00 & $04 / 08 / 1012: 16$ & $0.486 \mathrm{~g} / 50 \mathrm{~mL}$ & $0.5 \mathrm{~g} / 50 \mathrm{~mL}$ & 1.03 \\
\hline A10D053-27 & Soil & EPA 6020 & 01:01/9400:00 & $04,08 / 1012: 16$ & $0.529 \mathrm{~g} / 50 \mathrm{~mL}$ & $0.5 \mathrm{~g} / 50 \mathrm{~mL}$ & 0.95 \\
\hline A10D053-28 & Soil & EPA 6020 & 01:01/9400:00 & $04 / 08 / 1012: 16$ & $0.473 \mathrm{~g} / 50 \mathrm{~mL}$ & $0.5 \mathrm{~g} / 50 \mathrm{~mL}$ & 1.06 \\
\hline A10D053-29 & Soil & EPA 6020 & $01 / 01 / 9400: 00$ & $04 / 08 / 1012: 16$ & $0.482 \mathrm{~g} / 50 \mathrm{~mL}$ & $0.5 \mathrm{~g} / 50 \mathrm{~mL}$ & 1.04 \\
\hline A10D053-30 & Soil & EPA 6020 & 01/01/9400:00 & $0408 / 1012: 16$ & $0.499 \mathrm{~g} / 50 \mathrm{~mL}$ & $0.5 \mathrm{~g} / 50 \mathrm{~mL}$ & 1.00 \\
\hline A10D053-31 & Soil & EPA 6020 & 01/01/9400:00 & $04 / 08 / 1012: 16$ & $0.441 \mathrm{~g} / 50 \mathrm{~mL}$ & $0.5 \mathrm{~g} / 50 \mathrm{~mL}$ & 1.13 \\
\hline A10D053-32 & Soil & EPA 6020 & 01/01/9400:00 & $04 / 08 / 1012: 16$ & $0.446 \mathrm{~g} / 50 \mathrm{~mL}$ & $0.5 \mathrm{~g} / 50 \mathrm{~mL}$ & 1.12 \\
\hline
\end{tabular}

Apex Laboratories

The results in this report appiy to the samples andisyed in accordaxe with the c knin of

(1)

custody document This anditicalregon mus be reproduced in it entivety.

Philip Nerenberg For Darwin Thomas, Business Development Director

Puge 47 of 53 


\section{Apex Labs}

12232 S.W. Garden Place

Tigard, OR 97223

503-718-2323 Phone

503-718-0333 Fax

\begin{tabular}{llc} 
GeoEngineers -Seatfle & Project OregonMetals Evahuation \\
600 StewartSt. Suite 1700 & Project Humber. 2787-050-000 \\
Seattle, WA 98101 & Project Manager. Neil Morton & Reported \\
\hline
\end{tabular}

Seattle, WA 98101

Project Manager. Neil Morton

$5 / 131022: 21$

SAMPLE PREPARATION INFORMATION

\begin{tabular}{|c|c|c|c|c|c|c|c|}
\hline \multicolumn{8}{|c|}{ Total hetals by EPA 6020 (ICPHS) } \\
\hline Prep: EPA 3051A & & & & & Sample & Default & RL Prep \\
\hline Lab Number & Matix & Method & Sanpled & Prepared & Iritial/Final & Iritial/Final & Factor \\
\hline A10D053-33 & Soil & EPA 6020 & 01/01/9400:00 & $04,08 / 1012: 16$ & $0.472 \mathrm{~g} / 50 \mathrm{~mL}$ & $0.5 \mathrm{~g} / 50 \mathrm{~mL}$ & 1.06 \\
\hline A10D053-34 & Soil & EPA 6020 & 01/01/9400:00 & $04,08 / 1012: 16$ & $0.456 \mathrm{~g} / 50 \mathrm{~mL}$ & $0.5 \mathrm{~g} / 50 \mathrm{~mL}$ & 1.10 \\
\hline A10D053-35 & Soil & EPA 6020 & 01/01/9400:00 & $04,08 / 1012: 16$ & $0.479 \mathrm{~g} / 50 \mathrm{~mL}$ & $0.5 \mathrm{~g} / 50 \mathrm{~mL}$ & 1.04 \\
\hline A10D053-36 & Soil & EPA 6020 & 01:01/9400:00 & $04,08 / 1012: 16$ & $0.46 \mathrm{~g} / 50 \mathrm{~mL}$ & $0.5 \mathrm{~g} / 50 \mathrm{~mL}$ & 1.09 \\
\hline A10D053-37 & Soil & EPA 6020 & 01/01/9400:00 & $04,08 / 1012: 16$ & $0.45 \mathrm{~g} / 50 \mathrm{~mL}$ & $0.5 \mathrm{~g} / 50 \mathrm{~mL}$ & 1.11 \\
\hline A10D053-38 & Soil & EPA 6020 & 01/01/9400:00 & $04 / 08 / 1012: 16$ & $0.51 \mathrm{~g} / 50 \mathrm{~mL}$ & $0.5 \mathrm{~g} / 50 \mathrm{~mL}$ & 0.98 \\
\hline \multicolumn{8}{|l|}{ Batch: 1004123} \\
\hline A10D053-39 & Soil & EPA 6020 & 01/01/9400:00 & $04,09 / 1008: 49$ & $0.503 \mathrm{~g} / 50 \mathrm{~mL}$ & $0.5 \mathrm{~g} / 50 \mathrm{~mL}$ & 0.99 \\
\hline A10D053-41 & Soil & EPA 6020 & 01:01:9400:00 & $04,09 / 1008: 49$ & $0.5 \mathrm{~g} / 50 \mathrm{~mL}$ & $0.5 \mathrm{~g} / 50 \mathrm{~mL}$ & 1.00 \\
\hline A10D053-42 & Soil & EPA 6020 & 01/01/9400:00 & $04,09 / 1008: 49$ & $0.501 \mathrm{~g} / 50 \mathrm{~mL}$ & $0.5 \mathrm{~g} / 50 \mathrm{~mL}$ & 1.00 \\
\hline A10D053-43 & Soil & EPA 6020 & 01/01/9400:00 & $04,09 / 1008: 49$ & $0.48 \mathrm{~g} / 50 \mathrm{~mL}$ & $0.5 \mathrm{~g} / 50 \mathrm{~mL}$ & 1.04 \\
\hline A10D053-44 & Soil & EPA 6020 & 01/01/9400:00 & $04,09 / 1008: 49$ & $0.49 \mathrm{~g} / 50 \mathrm{~mL}$ & $0.5 \mathrm{~g} / 50 \mathrm{~mL}$ & 1.02 \\
\hline A10D053-45 & Soil & EPA 6020 & 01/01/9400:00 & $04,09 / 1008: 49$ & $0.497 \mathrm{~g} / 50 \mathrm{~mL}$ & $0.5 \mathrm{~g} / 50 \mathrm{~mL}$ & 1.01 \\
\hline A10D053-46 & Soil & EPA 6020 & 01/01/9400:00 & $04,09 / 1008: 49$ & $0.479 \mathrm{~g} / 50 \mathrm{~mL}$ & $0.5 \mathrm{~g} / 50 \mathrm{~mL}$ & 1.04 \\
\hline A10D053-47 & Soil & EPA 6020 & 01/01/9400:00 & $04 / 09 / 1008: 49$ & $0.515 \mathrm{~g} / 50 \mathrm{~mL}$ & $0.5 \mathrm{~g} / 50 \mathrm{~mL}$ & 0.97 \\
\hline A10D053-48 & Soil & EPA 6020 & 01/01/9400:00 & $04 / 09 / 1008: 49$ & $0.51 \mathrm{~g} / 50 \mathrm{~mL}$ & $0.5 \mathrm{~g} / 50 \mathrm{~mL}$ & 0.98 \\
\hline A10D053-49 & Soil & EPA 6020 & 01/01/9400:00 & $04,09 / 1008: 49$ & $0.48 \mathrm{~g} / 50 \mathrm{~mL}$ & $0.5 \mathrm{~g} / 50 \mathrm{~mL}$ & 1.04 \\
\hline A10D053-50 & Soil & EPA 6020 & $01 / 01 / 9400: 00$ & 04/09/1008:49 & $0.469 \mathrm{~g} / 50 \mathrm{~mL}$ & $0.5 \mathrm{~g} / 50 \mathrm{~mL}$ & 1.07 \\
\hline A10D053-51 & Soil & EPA 6020 & 01:01/9400:00 & $04 / 09 / 1008: 49$ & $0.501 \mathrm{~g} / 50 \mathrm{~mL}$ & $0.5 \mathrm{~g} / 50 \mathrm{~mL}$ & 1.00 \\
\hline A10D053-53 & Soil & EPA 6020 & 01:01/9400:00 & $04 / 09 / 1008: 49$ & $0.484 \mathrm{~g} / 50 \mathrm{~mL}$ & $0.5 \mathrm{~g} / 50 \mathrm{~mL}$ & 1.03 \\
\hline A10D053-54 & Soil & EPA 6020 & 01/01/9400:00 & $04,09 / 1008: 49$ & $0.482 \mathrm{~g} / 50 \mathrm{~mL}$ & $0.5 \mathrm{~g} / 50 \mathrm{~mL}$ & 1.04 \\
\hline A10D053-55 & Soil & EPA 6020 & 01:01/9400:00 & $04 / 09 / 1008: 49$ & $0.493 \mathrm{~g} / 50 \mathrm{~mL}$ & $0.5 \mathrm{~g} / 50 \mathrm{~mL}$ & 1.01 \\
\hline A10D053-56 & Soil & EPA 6020 & 01:01/9400:00 & $04,09 / 1008: 49$ & $0.487 \mathrm{~g} / 50 \mathrm{~mL}$ & $0.5 \mathrm{~g} / 50 \mathrm{~mL}$ & 1.03 \\
\hline A10D053-57 & Soil & EPA 6020 & 01/01/9400:00 & $04 / 09 / 1008: 49$ & $0.488 \mathrm{~g} / 50 \mathrm{~mL}$ & $0.5 \mathrm{~g} / 50 \mathrm{~mL}$ & 1.02 \\
\hline \multicolumn{8}{|l|}{ Batch: 1004125} \\
\hline A10D053-58 & Soil & EPA 6020 & 01/01/9400:00 & 04/09/1011:01 & $0.455 \mathrm{~g} / 50 \mathrm{~mL}$ & $0.5 \mathrm{~g} / 50 \mathrm{~mL}$ & 1.10 \\
\hline A10D053-59 & Soil & EPA 6020 & 01/01/9400:00 & 04/09/10 11:01 & $0.492 \mathrm{~g} / 50 \mathrm{~mL}$ & $0.5 \mathrm{~g} / 50 \mathrm{~mL}$ & 1.02 \\
\hline A10D053-60 & Soil & EPA 6020 & 01/01/9400:00 & 04/09/10 11:01 & $0.496 \mathrm{~g} / 50 \mathrm{~mL}$ & $0.5 \mathrm{~g} / 50 \mathrm{~mL}$ & 1.01 \\
\hline A10D053-61 & Soil & EPA 6020 & 01/01/9400:00 & 04/09/10 11:01 & $0.453 \mathrm{~g} / 50 \mathrm{~mL}$ & $0.5 \mathrm{~g} / 50 \mathrm{~mL}$ & 1.10 \\
\hline A10D053-62 & Soil & EPA 6020 & 01:01:9400:00 & 04/09/10 11:01 & $0.441 \mathrm{~g} / 50 \mathrm{~mL}$ & $0.5 \mathrm{~g} / 50 \mathrm{~mL}$ & 1.13 \\
\hline A10D053-63 & Soil & EPA 6020 & 01/01/9400:00 & 04/09/10 11:01 & $0.482 \mathrm{~g} / 50 \mathrm{~mL}$ & $0.5 \mathrm{~g} / 50 \mathrm{~mL}$ & 1.04 \\
\hline A10D053-64 & Soil & EPA 6020 & 01:01/9400:00 & 04/09/10 11:01 & $0.484 \mathrm{~g} / 50 \mathrm{~mL}$ & $0.5 \mathrm{~g} / 50 \mathrm{~mL}$ & 1.03 \\
\hline A10D053-65 & Soil & EPA 6020 & 01:01:9400:00 & 04/09/10 11:01 & $0.477 \mathrm{~g} / 50 \mathrm{~mL}$ & $0.5 \mathrm{~g} / 50 \mathrm{~mL}$ & 1.05 \\
\hline A10D053-66 & Soil & EPA 6020 & 01/01/9400:00 & 04/09/10 11:01 & $0.466 \mathrm{~g} / 50 \mathrm{~mL}$ & $0.5 \mathrm{~g} / 50 \mathrm{~mL}$ & 1.07 \\
\hline
\end{tabular}

Apex Laboratories

The results is this report appisy to the samples analyzed in accoriance with the chnin of

custody document This andstical repon mus be reproduced in it entivety.

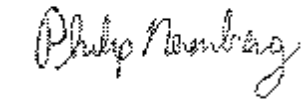

Philip Nerenberg For Darwin Thomas, Business Development Director

Puge 48 of 53 


\section{Apex Labs}

12232 S.W. Garden Place

Tigard, OR 97223

503-718-2323 Phone

503-718-0333 Fax

\begin{tabular}{|lcr|}
\hline GeoEngineers -Seatfle & Project & OregonMetals Evahuation \\
600 S tewartS t. Suite 1700 & Project Number. 2787-050-000 \\
Seattle, WA 98101 & Project Manager. Neil Morton & Reported \\
\hline
\end{tabular}

SAMPLE PREPARATION INF ORMATION

\begin{tabular}{|c|c|c|c|c|c|c|c|}
\hline \multicolumn{8}{|c|}{ Total Metals by EPA 6020 (ICPMS) } \\
\hline Prep: EPA 3051A & & & & & Sample & Default & RL Prep \\
\hline Lab Number & Matrix & Method & Sarpled & Phepared & Iritial/Final & Iritial/Final & Factor \\
\hline A10D053-67 & Soil & EPA 6020 & 01/01/9400:00 & 04,09/1011:01 & $0.465 \mathrm{~g} / 50 \mathrm{~mL}$ & $0.5 \mathrm{~g} / 50 \mathrm{~mL}$ & 1.08 \\
\hline A10D053-68 & Soil & EPA 6020 & 01/01/9400:00 & 04/09/10 11:01 & $0.454 \mathrm{~g} / 50 \mathrm{~mL}$ & $0.5 \mathrm{~g} / 50 \mathrm{~mL}$ & 1.10 \\
\hline A10D053-69 & Soil & EPA 6020 & 01:01:9400:00 & 04/09/10 11:01 & $0.479 \mathrm{~g} / 50 \mathrm{~mL}$ & $0.5 \mathrm{~g} / 50 \mathrm{~mL}$ & 1.04 \\
\hline A10D053-70 & Soil & EPA 6020 & 01/01:9400:00 & 04,09/10 11:01 & $0.404 \mathrm{~g} / 50 \mathrm{~mL}$ & $0.5 \mathrm{~g} / 50 \mathrm{~mL}$ & 1.24 \\
\hline A10D053-71 & Soil & EPA 6020 & 01/01/9400:00 & 04/09/10 11:01 & $0.493 \mathrm{~g} / 50 \mathrm{~mL}$ & $0.5 \mathrm{~g} / 50 \mathrm{~mL}$ & 1.01 \\
\hline A10D053-72 & Soil & EPA 6020 & 01/01/9400:00 & 04/09/10 11:01 & $0.452 \mathrm{~g} / 50 \mathrm{~mL}$ & $0.5 \mathrm{~g} / 50 \mathrm{~mL}$ & 1.11 \\
\hline A10D053-73 & Soil & EPA 6020 & 01/01/9400:00 & 04/09/10 11:01 & $0.515 \mathrm{~g} / 50 \mathrm{~mL}$ & $0.5 \mathrm{~g} / 50 \mathrm{~mL}$ & 0.97 \\
\hline A10D053-74 & Soil & EPA 6020 & 01/01/9400:00 & 04/09/10 11:01 & $0.516 \mathrm{~g} / 50 \mathrm{~mL}$ & $0.5 \mathrm{~g} / 50 \mathrm{~mL}$ & 0.97 \\
\hline A10D053-75 & Soil & EPA 6020 & 01/01/9400:00 & 04/09/10 11:01 & $0.469 \mathrm{~g} / 50 \mathrm{~mL}$ & $0.5 \mathrm{~g} / 50 \mathrm{~mL}$ & 1.07 \\
\hline A10D053-76 & Soil & EPA 6020 & 01:01/9400:00 & 04/09/10 11:01 & $0.506 \mathrm{~g} / 50 \mathrm{~mL}$ & $0.5 \mathrm{~g} / 50 \mathrm{~mL}$ & 0.99 \\
\hline \multicolumn{8}{|l|}{ Batch: 1004142} \\
\hline A10D053-40 & Soil & EPA 6020 & 01/01/9400:00 & $04 / 12 / 1010: 03$ & $0.205 \mathrm{~g} / 50 \mathrm{~mL}$ & $0.5 \mathrm{~g} / 50 \mathrm{~mL}$ & 2.44 \\
\hline A10D053-77 & Soil & EPA 6020 & 01:01:9400:00 & $04 / 12 / 1010: 03$ & $0.473 \mathrm{~g} / 50 \mathrm{~mL}$ & $0.5 \mathrm{~g} / 50 \mathrm{~mL}$ & 1.06 \\
\hline A10D053-78 & Soil & EPA 6020 & 01:01:9400:00 & $04 / 12 / 1010: 03$ & $0.443 \mathrm{~g} / 50 \mathrm{~mL}$ & $0.5 \mathrm{~g} / 50 \mathrm{~mL}$ & 1.13 \\
\hline A10D053-79 & Soil & EPA 6020 & 01:01:9400:00 & $04 / 12 / 1010: 03$ & $0.456 \mathrm{~g} / 50 \mathrm{~mL}$ & $0.5 \mathrm{~g} / 50 \mathrm{~mL}$ & 1.10 \\
\hline A10D053-80 & Soil & EPA 6020 & 01/01/9400:00 & $04 / 12 / 1010: 03$ & $0.466 \mathrm{~g} / 50 \mathrm{~mL}$ & $0.5 \mathrm{~g} / 50 \mathrm{~mL}$ & 1.07 \\
\hline A10D053-81 & Soil & EPA 6020 & 01/01/9400:00 & $04 / 12 / 1010: 03$ & $0.52 \mathrm{~g} / 50 \mathrm{~mL}$ & $0.5 \mathrm{~g} / 50 \mathrm{~mL}$ & 0.96 \\
\hline A10D053-82 & Soil & EPA 6020 & 01/01/9400:00 & $04 / 12 / 1010: 03$ & $0.44 \mathrm{~g} / 50 \mathrm{~mL}$ & $0.5 \mathrm{~g} / 50 \mathrm{~mL}$ & 1.14 \\
\hline A10D053-83 & Soil & EPA 6020 & 01:01:9400:00 & $04 / 12 / 1010: 03$ & $0.46 \mathrm{~g} / 50 \mathrm{~mL}$ & $0.5 \mathrm{~g} / 50 \mathrm{~mL}$ & 1.09 \\
\hline A10D053-84 & Soil & EPA 6020 & 01:01/9400:00 & $04 / 12 / 1010: 03$ & $0.445 \mathrm{~g} / 50 \mathrm{~mL}$ & $0.5 \mathrm{~g} / 50 \mathrm{~mL}$ & 1.12 \\
\hline A10D053-85 & Soil & EPA 6020 & 01:01:9400:00 & $04 / 12 / 1010: 03$ & $0.5 \mathrm{~g} / 50 \mathrm{~mL}$ & $0.5 \mathrm{~g} / 50 \mathrm{~mL}$ & 1.00 \\
\hline A10D053-86 & Soil & EPA 6020 & 01/01/9400:00 & 04/12/10 10:03 & $0.456 \mathrm{~g} / 50 \mathrm{~mL}$ & $0.5 \mathrm{~g} / 50 \mathrm{~mL}$ & 1.10 \\
\hline A10D053-87 & Soil & EPA 6020 & 01/01/9400:00 & $04 / 12 / 1010: 03$ & $0.459 \mathrm{~g} / 50 \mathrm{~mL}$ & $0.5 \mathrm{~g} / 50 \mathrm{~mL}$ & 1.09 \\
\hline A10D053-88 & Soil & EPA 6020 & 01/01/9400:00 & 04/12/10 10:03 & $0.478 \mathrm{~g} / 50 \mathrm{~mL}$ & $0.5 \mathrm{~g} / 50 \mathrm{~mL}$ & 1.05 \\
\hline A10D053-89 & Soil & EPA 6020 & 01/01/9400:00 & $04 / 12 / 1010: 03$ & $0.516 \mathrm{~g} / 50 \mathrm{~mL}$ & $0.5 \mathrm{~g} / 50 \mathrm{~mL}$ & 0.97 \\
\hline A10D053-90 & Soil & EPA 6020 & 01/01/9400:00 & 04/12/10 10:03 & $0.455 \mathrm{~g} / 50 \mathrm{~mL}$ & $0.5 \mathrm{~g} / 50 \mathrm{~mL}$ & 1.10 \\
\hline \multicolumn{8}{|l|}{ Batch: 1004144} \\
\hline A10D053-52 & Soil & EPA 6020 & 01:01:9400:00 & $04 / 12 / 1010: 52$ & $0.505 \mathrm{~g} / 50 \mathrm{~mL}$ & $0.5 \mathrm{~g} / 50 \mathrm{~mL}$ & 0.99 \\
\hline
\end{tabular}

\footnotetext{
Apex Laboratories The results in this report aspily to the samples anabyed in accordaxe with the cknin of custo dy document This anditicolrepon mus be reproduced in it entivety.

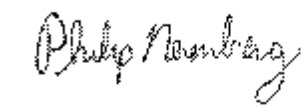

Philip Nererberg For Darwin Thomas, Business Development Director

Puge 49 of 53
} 


\section{Apex Labs}

12232 S.W. Garden Place

Tigard, OR 97223

503-718-2323 Phone

503-718-0333 Fax

Thursday, May 13, 2010

Neil Morton

GeoEngineers -Seattle

600 Stewart St. Suite 1700

Seattle, WA 98101

RE: Oregon Metals Evaluation / 2787-050-000

Enclosed are the results of analyses for work order $\mathrm{A10D059}$, which was received by the laboratory on $4 / 2 / 2010$ at $3: 35: 00 \mathrm{PM}$

Thank you for using Apex Labs. We appreciate your business and strive to provide the highest quality services to the environmental industry.

If you have any questions concerning this report or the sewices we offer, please feel free to contact me by email at: pnerenberg@apex-labs.com, or by phone at 503-718-2323.

Apex Laboratories

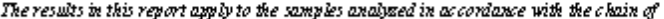

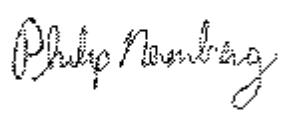

cutody document This anditicolvepon must be reproduced in it entivety.

Philip Nerenberg For Darwin Thomas, Business Development Director

Page 1 of 55 


\section{Apex Labs}

12232 S. W. Garden Place

Tigard, OR 97223

503-718-2323 Phone

503-718-0333 Fax

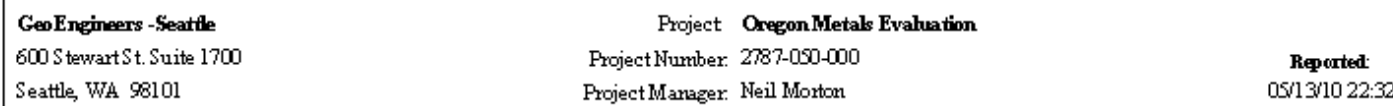

ANAL YTICAL REPORT FOR SAMPLES

\begin{tabular}{|c|c|c|c|c|}
\hline \multicolumn{5}{|c|}{ SAMPLE INF ORMATION } \\
\hline S:mple ID & Laboratory ID & Matrix & Date Sampled & Date Received \\
\hline $\mathrm{CO} 1 \mathrm{~A} 2 \mathrm{~b}$ & A10D059-01 & Soil & 01:01/9400:00 & $04 / 02 / 1015: 35$ \\
\hline ColBz & A10D059-02 & Soil & 01:01/9400:00 & $0402 / 1015: 35$ \\
\hline $\mathrm{CO} 2 \mathrm{Alb}$ & A10D059-03 & Soil & 01:01/9400:00 & $04 / 02 / 1015: 35$ \\
\hline CO2BIb & A10D059-04 & Soil & 01:01/9400:00 & $0402 / 1015: 35$ \\
\hline C03A2B & A10D059-05 & Soil & 01:01/9400:00 & $04,02 / 1015: 35$ \\
\hline C03B2 & A10D059-06 & Soil & 01:01/9400:00 & $0402 / 1015: 35$ \\
\hline $\mathrm{CO4A2a}$ & A10D059-07 & Soil & 01/01/9400:00 & $04 / 02 / 1015: 35$ \\
\hline $\mathrm{CO} 4 \mathrm{~B} 2 \mathrm{a}$ & A10D059-08 & Soil & 01:01/9400:00 & $0402 / 1015: 35$ \\
\hline Co5Alb & A10D059-09 & Soil & 01:01/9400:00 & $0402 / 1015: 35$ \\
\hline Co5B Ib & A10D059-10 & Soil & 01/01/9400:00 & $04,02 / 1015: 35$ \\
\hline Co6Alb & A10D059-11 & Soil & 01:01/9400:00 & $04 / 02 / 1015: 35$ \\
\hline С0бВ Ib & A10D059-12 & Soil & 01:01/9400:00 & $04 / 02 / 1015: 35$ \\
\hline COTAlb & A10D059-13 & Soil & 01:01/9400:00 & $0402 / 1015: 35$ \\
\hline COTBIb & A10D059-14 & Soil & 01,01/9400:00 & $04,02 / 1015: 35$ \\
\hline C08A2a & A10D059-15 & Soil & 01:01/9400:00 & $04 / 02 / 1015: 35$ \\
\hline $\mathrm{CO8B2a}$ & A10D059-16 & Soil & 01:01/9400:00 & $0402 / 1015: 35$ \\
\hline $\mathrm{C} 09 \mathrm{~A} 2 \mathrm{~b}$ & A10D059-17 & Soil & 01:01/9400:00 & $0402 / 1015: 35$ \\
\hline C09Bz & A10D059-18 & Soil & 01/01/9400:00 & $04 / 02 / 1015: 35$ \\
\hline Cl0Alb & A10D059-19 & Soil & 01,01/9400:00 & $04 / 02 / 1015: 35$ \\
\hline Cl0BIb & A10D059-20 & Soil & 01:01/9400:00 & $0402 / 1015: 35$ \\
\hline C11A2a & A10D059-21 & Soil & 01:01/9400:00 & $0402 / 1015: 35$ \\
\hline CllB2a & A10D059-22 & Soil & 01,01/9400:00 & $04 / 02 / 1015: 35$ \\
\hline Cl2Alb & A10D059-23 & Soil & 01:01/9400:00 & $0402 / 1015: 35$ \\
\hline Cl2BIb & A10D059-24 & Soil & 01:01/9400:00 & $0402 / 1015: 35$ \\
\hline Cl3Ala & A10D059-25 & Soil & 01,01/9400:00 & $0402 / 1015: 35$ \\
\hline Cl3Bla & A10D059-26 & Soil & 01,01/9400:00 & $04 / 02 / 1015: 35$ \\
\hline Cl4Ala & A10D059-27 & Soil & 01:01/9400:00 & $0402 / 1015: 35$ \\
\hline Cl4Bla & A10D059-28 & Soil & 01:01/9400:00 & $0402 / 1015: 35$ \\
\hline Cl5Ala & A10D059-29 & Soil & 01/01/9400:00 & $04 / 02 / 1015: 35$ \\
\hline Cl5Bla & A10D059-30 & Soil & 01:01/9400:00 & $04 / 02 / 1015: 35$ \\
\hline $\mathrm{Cl5Cla}$ & A10D059-31 & Soil & 01:01/9400:00 & $0402 / 1015: 35$ \\
\hline Cl6Ala & A10D059-32 & Soil & 01:01/9400:00 & $0402 / 1015: 35$ \\
\hline Cl6B la & A10D059-33 & Soil & 01:01/9400:00 & $0402 / 1015: 35$ \\
\hline Mola2b & A10D059-34 & Soil & 01,01/9400:00 & $04 / 02 / 1015: 35$ \\
\hline MolB $2 b$ & A10D059-35 & Soil & 01:01/9400:00 & $04 / 02 / 1015: 35$ \\
\hline
\end{tabular}

Apex Laboratories

The results in this report apply to the samples analysed in accoriase with the chain of

$$
\text { (1) }
$$

custody document This anditical regton mus be reproduced in it entivety. 


\section{Apex Labs}

12232 S.W. Garden Phace

Tigard, OR 97223

503-718-2323 Phone

503-718-0333 Fax
GeoEngineers -Seattle

600 S tewartSt. Suite 1700

Seattle, WA 98101
Project Oregon Metals Evahuation

Project Number. 2787-050-000

Froject Manazer. Heil Morton
Reported

$0513 / 1022: 3$

ANAL YTICAL REPORT FOR SAMPLES

\begin{tabular}{|c|c|c|c|c|}
\hline \multicolumn{5}{|c|}{ SAMPLE INF ORHATION } \\
\hline Sample ID & Laboratory ID & Matrix & Date Sampied & Date Received \\
\hline M02A2b & A10D059-36 & Soil & 01/01/9400:00 & $04 / 02 / 1015: 35$ \\
\hline $\operatorname{M02B} 2 b$ & A10D059-37 & Soil & 01:01/9400:00 & $04 / 02 / 1015: 35$ \\
\hline M03Alb & A10D059-38 & Soil & 01:01/9400:00 & $04 / 02 / 1015: 35$ \\
\hline M03Blb & A10D059-39 & Soil & 01/01/9400:00 & $04 / 02 / 1015: 35$ \\
\hline $\mathrm{M} 0442 \mathrm{~b}$ & A10D059-40 & Soil & 01:01/9400:00 & $04 / 02 / 1015: 35$ \\
\hline M04B2b & A10D059-41 & Soil & 01:01/9400:00 & $04 / 02 / 1015: 35$ \\
\hline Mo5Ala & A10D059-42 & Soil & 01:01/9400:00 & $04,02 / 1015: 35$ \\
\hline MosBla & A10D059-43 & Soil & 01:01/9400:00 & $04 / 02 / 1015: 35$ \\
\hline M06A2a & A10D059-44 & Soil & 01/01/9400:00 & $04 / 02 / 1015: 35$ \\
\hline M06B2a & A10D059-45 & Soil & 01:01/9400:00 & $04 / 02 / 1015: 35$ \\
\hline M0TA2b & A10D059-46 & Soil & 01/01/9400:00 & $04 / 02 / 1015: 35$ \\
\hline MOTB2b & A10D059-47 & Soil & 01:01/9400:00 & $04 / 02 / 1015: 35$ \\
\hline M08A2b & A10D059-48 & Soil & 01/01/9400:00 & $04 / 02 / 1015: 35$ \\
\hline M08B2a & A10D059-49 & Soil & 01:01/9400:00 & $04 / 02 / 1015: 35$ \\
\hline Mo9Alb & A10D059-50 & Soil & 01/01/9400:00 & $04 / 02 / 1015: 35$ \\
\hline M09Blb & A10D059-51 & Soil & 01/01/9400:00 & $04 / 02 / 1015: 35$ \\
\hline MlOAla & A10D059-52 & Soil & 01/01/9400:00 & $04 / 02 / 1015: 35$ \\
\hline Ml0Bla & A10D059-53 & Soil & 01:01/9400:00 & $04 / 02 / 1015: 35$ \\
\hline Mllala & A10D059-54 & Soil & 01:01/9400:00 & $04 / 02 / 1015: 35$ \\
\hline MllBla & A10D059-55 & Soil & 01/01/9400:00 & $04 / 02 / 1015: 35$ \\
\hline $\mathrm{Ml2A2a}$ & A10D059-56 & Soil & 01:01/9400:00 & $04,02 / 1015: 35$ \\
\hline $\operatorname{Ml} 2 \mathrm{~B} 2 \mathrm{a}$ & A10D059-57 & Soil & 01/01/9400:00 & $04 / 02 / 1015: 35$ \\
\hline Ml3Ala & A10D059-58 & Soil & 01/01/9400:00 & $04 / 02 / 1015: 35$ \\
\hline Ml3Bla & A10D059-59 & Soil & 01:01/9400:00 & $04 / 02 / 1015: 35$ \\
\hline Ml44la & A10D059-60 & Soil & 01/01/9400:00 & $04 / 02 / 1015: 35$ \\
\hline MldBla & A10D059-61 & Soil & 01:01/9400:00 & $04 / 02 / 1015: 35$ \\
\hline Ml4B2a & A10D059-62 & Soil & 01/01/9400:00 & $04 / 02 / 1015: 35$ \\
\hline Ml5Ala & A10D059-63 & Soil & 01/01/9400:00 & $04,02 / 1015: 35$ \\
\hline MlsBla & A10D059-64 & Soil & 01/01/9400:00 & $04 / 02 / 1015: 35$ \\
\hline Ml6A2a & A10D059-65 & Soil & 01/01/9400:00 & $04 / 02 / 1015: 35$ \\
\hline Ml6B2a & A10D059-66 & Soil & 01/01/9400:00 & $04 / 02 / 1015: 35$ \\
\hline MlTA2a & A10D059-6? & Soil & 01/01/9400:00 & $04 / 02 / 1015: 35$ \\
\hline MlTB2a & A10D059-68 & Soil & 01:01/9400:00 & $04 / 02 / 1015: 35$ \\
\hline Ml8A2a & A10D059-69 & Soil & 01/01/9400:00 & $04,02 / 1015: 35$ \\
\hline Ml8B2a & A10D059-70 & Soil & 01:01/9400:00 & $04 / 02 / 1015: 35$ \\
\hline
\end{tabular}

Apex Laboratories

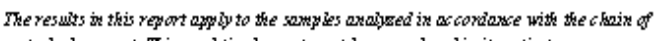

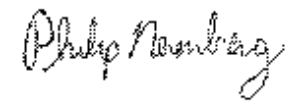




\section{Apex Labs}

12232 S.W. Garden Phace

Tigard, OR 97223

503-718-2323 Phone

503-718-0333 Fax

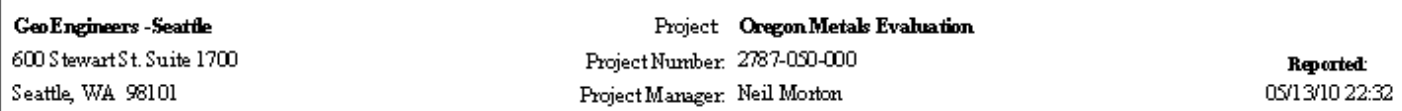

ANAL YTICAL REPORT FOR SAMPLES

\begin{tabular}{|c|c|c|c|c|}
\hline \multicolumn{5}{|c|}{ SAMPLE INF ORMATION } \\
\hline Sample ID & Laboratory ID & Matrix & Date Sampled & Date Received \\
\hline M19A2a & A10D059-71 & Soil & 01:01/9400:00 & $04,02 / 1015: 35$ \\
\hline $\mathrm{M} 20 \mathrm{~A} 2 \mathrm{a}$ & A10D059-72 & Soil & 01:01/9400:00 & $04,02 / 1015: 35$ \\
\hline M20Bla & A10D059-73 & Soil & 01:01/9400:00 & $04,02 / 1015: 35$ \\
\hline M2lA2a & A10D059-74 & Soil & 01/01/9400:00 & $04 / 02 / 1015: 35$ \\
\hline $\mathrm{M} 2 \mathrm{lB} 2 \mathrm{a}$ & A10D059-75 & Soil & 01:01/9400:00 & $04: 02 / 1015: 35$ \\
\hline M22Ala & A10D059-76 & Soil & 01:01/9400:00 & $04 / 02 / 1015: 35$ \\
\hline M22Bla & A10D059-77 & Soil & 01/01/9400:00 & $04,02 / 1015: 35$ \\
\hline M23Ala & A10D059-78 & Soil & 01/01/9400:00 & $04,02 / 1015: 35$ \\
\hline M23Bla & A10D059-79 & Soil & 01:01/9400:00 & $04: 02 / 1015: 35$ \\
\hline M2442a & A10D059-80 & Soil & 01/01/9400:00 & $04,02 / 1015: 35$ \\
\hline $\mathrm{M} 24 \mathrm{~B} 2 \mathrm{a}$ & A10D059-81 & Soil & 01/01/9400:00 & $04,02 / 1015: 35$ \\
\hline P01A & A10D059-82 & Soil & 01:01/9400:00 & $04,02 / 1015: 35$ \\
\hline P01B & A10D059-83 & Soil & 01:01/9400:00 & $04,02 / 1015: 35$ \\
\hline P02A & A10D059-84 & Soil & 01:01/9400:00 & $04,02 / 1015: 35$ \\
\hline P02B & A10D059-85 & Soil & 01:01/9400:00 & $04 / 02 / 1015: 35$ \\
\hline P03A & A10D059-86 & Soil & 01:01/9400:00 & $04,02 / 1015: 35$ \\
\hline P03B & A10D059-87 & Soil & 01:01/9400:00 & $04,02 / 1015: 35$ \\
\hline P04A & A10D059-88 & Soil & 01:01/9400:00 & $04,02 / 1015: 35$ \\
\hline P04B & A10D059-89 & Soil & 01:01/9400:00 & $04,02 / 1015: 35$ \\
\hline P05A & A10D059-90 & Soil & 01/01/9400:00 & $04,02 / 1015: 35$ \\
\hline
\end{tabular}

\footnotetext{
Apex Laboratories

The results in this report aspiy to the samples analyzed in accordaxce with the chain of

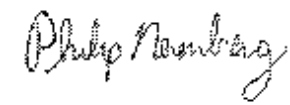

custody document This andoticolvepon mus be reproduced in it entivety.

Philip Nerenberg For Danwin Thornas, Business Development Director

Page 4 of 55
} 


\section{Apex Labs}

12232 S.W. Garden Phace Tigard, OR 97223

503-718-2323 Phone

503-718-0333 Fax

\begin{tabular}{|lcr|}
\hline GeoEngineers - Seattle & Project OregonMetals Evaluation \\
600 S tewartS t. Suite 1700 & Project Humber. $2787-050-000$ \\
Seattle, WA 98101 & Project Mamager. Neil Morton \\
\hline
\end{tabular}

QUALITY CONTROL (QC) SAMPLE RESULTS

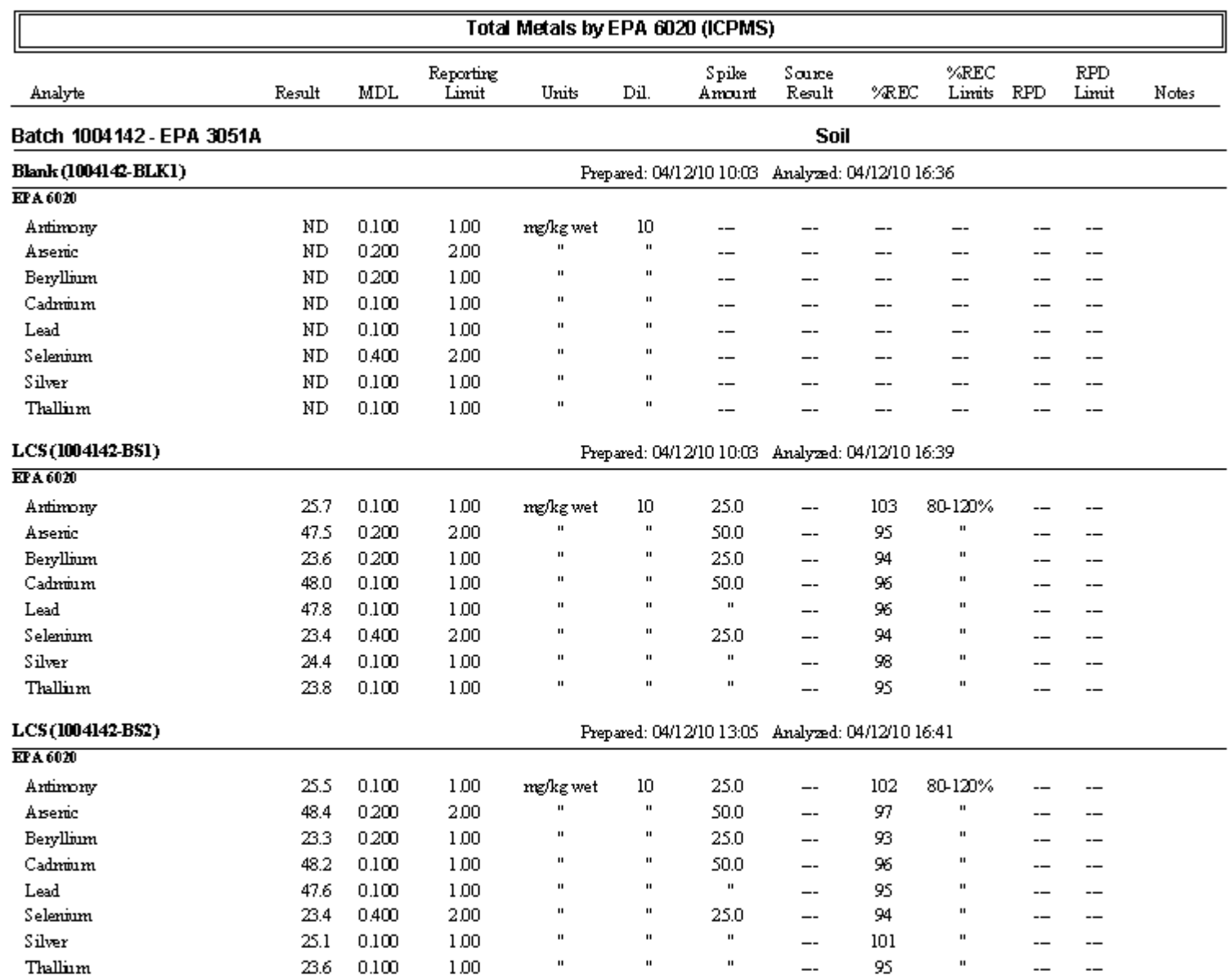

Matric Spile (1004142-MSs)

Frepared: 04/12/10 10:03 Analyzed: 04/12/10 17:56

QC S aurce S mple: c02Alb (Al0D659-03)

EFA 6020

$\begin{array}{llllllllllllll}\text { Antimory } & 23.9 & 0.105 & 105 & \mathrm{mg} / \mathrm{kg} \mathrm{d} y & 10 & 26.3 & 0.276 & 90 & 75-125 \% & -- & -\end{array}$

Apex Laboratories

The results in this report ayply to the samples analysed in accordaxe with the chan of

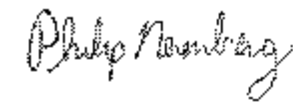

cutody document This anditical report mus be reproduced in it entrety.

Philip Nerenberg For Darwin Thomas, Business Development Director

Page 34 of 55 


\section{Apex Labs}

12232 S.W. Garden Place

Tigard, OR 97223

503-718-2323 Phone

503-718-0333 Fax

GeoEngineers -Seatil

600 S tewartSt. Suite 1700

Project OregonMetals Evaluation

Project Humber. 2787-050-000

Reported:

Project Manager. Heil Morton

QUALITY CONTROL (QC) SAMPLE RESULTS

\begin{tabular}{|c|c|c|c|c|c|c|c|c|c|c|c|c|}
\hline \multicolumn{13}{|c|}{ Total hetals by EPA 6020 (ICPMS) } \\
\hline Analyte & Result & MDL & $\begin{array}{c}\text { Reporting } \\
\text { Limit }\end{array}$ & Units & Dil. & $\begin{array}{l}\text { Spike } \\
\text { Amourt }\end{array}$ & $\begin{array}{l}\text { Source } \\
\text { Reult }\end{array}$ & $\% R E C$ & $\begin{array}{l}\text { \%REC } \\
\text { Limits }\end{array}$ & RPD & $\begin{array}{l}\text { RFD } \\
\text { Limit }\end{array}$ & Wotes \\
\hline
\end{tabular}

Batch 1004142 - EPA 3051A

Soil

Matrix Spile (1004142-MSs)

Frepared: 04/12/10 10:03 Analyred: 04/12/10 17:56

Qc Saurce S mqle: c02Alb (A10D059-03)

Aseric

Beryllium

Cadrimim

Lead

Selenim

Silver

Thallinm

$\begin{array}{lll}53.0 & 0210 & 2.10 \\ 24.6 & 0210 & 1.05 \\ 53.1 & 0.105 & 1.05 \\ 92.1 & 0.105 & 1.05 \\ 25.2 & 0.420 & 2.10 \\ 25.7 & 0.105 & 1.05 \\ 25.3 & 0.105 & 1.05\end{array}$

$\begin{array}{cccccccc}m g / k g d x y & " & 52.5 & 3.25 & 95 & " & - & - \\ " & " & 26.3 & 0.584 & 91 & " & - & - \\ " & " & 52.5 & 0.639 & 100 & " & - & - \\ " & " & " & 41.6 & 96 & " & - & - \\ " & " & 26.3 & \text { ND } & 96 & " & - & - \\ " & " & " & \text { HD } & 102 & " & - & - \\ " & " & " & 0.187 & 96 & \text { " } & - & -\end{array}$

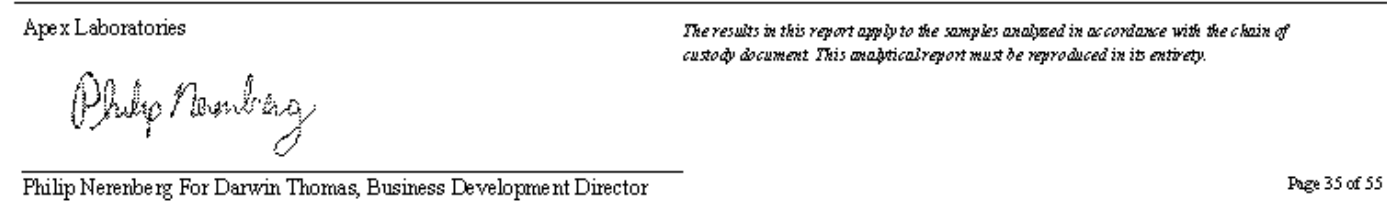




\section{Apex Labs}

12232 S.W. Garden Place

Tigard, OR 97223

503-718-2323 Phone

503-718-0333 Fax
GeoEngineers -Seattle

600 S tewart $S t$. Suite 1700

Seattle, WA 98101
Project OregonMetals Evahuation

Project Number. 2787-050-000

Project Manazer. Neil Morton
Reported:

$05 / 13 / 1022: 32$

QUALITY CONTROL (QC) SAMPLE RESULTS

\begin{tabular}{|c|c|c|c|c|c|c|c|c|c|c|c|c|}
\hline \multicolumn{13}{|c|}{ Total hietals by EPA 6020 (ICPHS) } \\
\hline Analyte & Result & MDL & $\begin{array}{l}\text { Reporting } \\
\text { Limit }\end{array}$ & Units & Dil. & $\begin{array}{c}\text { Spike } \\
\text { Amourt }\end{array}$ & $\begin{array}{l}\text { Source } \\
\text { Result }\end{array}$ & $\%$ REC & $\begin{array}{l}\text { \%REC } \\
\text { Linnits }\end{array}$ & RPD & $\begin{array}{l}\text { RPD } \\
\text { Limit }\end{array}$ & Notes \\
\hline Batch 1004144 - EPA 3051A & & & & & & & Soi & & & & & \\
\hline Blank (1004144-BLK1) & \multicolumn{12}{|c|}{ Prepared: 04/12/10 10:52 Analyzed: 04/14/10 13:57 } \\
\hline \multicolumn{13}{|l|}{ EPA 6020 } \\
\hline Artimory & HD & 0.100 & 100 & $\mathrm{mg} / \mathrm{kg}$ wet & 10 & -- & -- & -- & -- & - & -- & \\
\hline Aseric & 0.310 & 0200 & 200 & $"$ & $"$ & -- & -- & -- & -- & -- & -- & $\mathrm{J}$ \\
\hline Beryllim & $\mathrm{ND}$ & 0200 & 100 & $"$ & $"$ & -- & -- & -- & -- & -- & -- & \\
\hline Cadnwim & $\mathrm{HD}$ & 0.100 & 100 & $"$ & $"$ & -- & -- & -- & -- & - & -- & \\
\hline Lead & 0.180 & 0.100 & 100 & $"$ & $"$ & -- & -- & -- & -- & - & -- & $\mathrm{J}$ \\
\hline Selenium & 202 & 0.400 & 200 & $"$ & $"$ & -- & -- & -- & -- & -- & -- & B \\
\hline Silver & $\mathrm{ND}$ & 0.100 & 100 & $"$ & $"$ & - & -- & -- & -- & - & -- & \\
\hline Thallinm & $\mathrm{HD}$ & 0.100 & 100 & $"$ & $"$ & -- & -- & -- & -- & - & -- & \\
\hline
\end{tabular}

LCS(1004144BS1)

Prepared: 04/12/10 10:52 Analyzed: 04/14/10 14:00

EPA 6020

\begin{tabular}{|c|c|c|c|c|c|c|c|c|c|c|c|}
\hline Antimory & 25.0 & 0.100 & 100 & $\mathrm{mg} / \mathrm{kg}$ wet & 10 & 25.0 & -- & 104 & $80-120 \%$ & -- & - \\
\hline Aseruc & 47.8 & 0200 & 200 & $"$ & $"$ & 50.0 & - & 96 & $"$ & -- & - \\
\hline Beryllium & 23.5 & 0200 & 100 & $"$ & $"$ & 25.0 & - & 94 & $"$ & - & -- \\
\hline Cadnim & 48.5 & 0.100 & 100 & $"$ & $"$ & 50.0 & -- & 97 & $"$ & - & -- \\
\hline Lead & 46.8 & 0.100 & 100 & $"$ & $"$ & $"$ & - & 94 & $"$ & -- & -- \\
\hline Selenium & 23.4 & 0.400 & 200 & $"$ & $"$ & 25.0 & -- & 94 & $"$ & - & - \\
\hline Silver & 24.1 & 0.100 & 100 & $"$ & $"$ & $"$ & -- & 96 & $"$ & -- & -- \\
\hline Thaلlinm & 23.1 & 0.100 & 100 & $"$ & $"$ & $"$ & -- & 93 & $"$ & -- & -- \\
\hline
\end{tabular}

Duplicate (1004144DUPI)

Prepared: 04/12/10 10:52 Analyrad: 04/14/10 14:21

QC S aurce S ample: c03BD (A10D059-06)

EFA 6020

Antimory

Aseric

Beryllim

Cadrinim

Lead

Selenium

Silver

Thallinm

$\begin{array}{ccc}\mathbf{0 . 2 6 2} & 0.109 & 109 \\ \mathbf{8 0 6} & 0219 & 2.19 \\ \mathbf{0 . 8 0 9} & 0219 & 109 \\ \mathbf{0 . 4 4 8} & 0.109 & 1.09 \\ \mathbf{1 7 . 4} & 0.109 & 109 \\ \text { HD } & 0.437 & 2.19 \\ \text { HD } & 0.109 & 109 \\ \mathbf{0 . 2 6 2} & 0.109 & 109\end{array}$

Matrix spife (1004144MS1)

\begin{tabular}{|c|c|c|c|c|c|c|c|c|}
\hline$m g / k g d r y$ & 10 & - & 0.244 & -- & -- & 7 & $40 \%$ & $\mathrm{~J}$ \\
\hline " & " & - & 8.40 & -- & -- & 4 & $40 \%$ & \\
\hline$"$ & $"$ & - & 0.797 & -- & -- & 1 & $40 \%$ & J \\
\hline$"$ & $"$ & - & 0.399 & -- & -- & 12 & $40 \%$ & J \\
\hline$"$ & $"$ & -- & 18.0 & -- & -- & 3 & $40 \%$ & \\
\hline$"$ & $"$ & -- & 0.443 & -- & -- & & $40 \%$ & \\
\hline$"$ & $"$ & -- & $\mathrm{ND}$ & -- & -- & & $40 \%$ & \\
\hline " & " & -- & 0.256 & -- & -- & 1 & $40 \%$ & $\mathrm{~J}$ \\
\hline
\end{tabular}

OC S aurce S mple: C03BD (AlOD05906)

Prepared: 04/12/10 10:52 Analyzed: 04/14/10 14:24

Apex Laboratories

Prowentions
The results in this report apply to the samples analyzed in accordaxce with the chnin of custody document This andatical repon mus be reproduced in it entrets.

Philip Nerenberg For Darwin Thomas, Business Development Director 


\section{Apex Labs}

12232 S.W. Garden Place

Tigard, OR 97223

503-718-2323 Phone

503-718-0333 Fax

GeoEngineers -Seattle

600 S tewartSt. Suite 1700

Seattle, WA 98101
Project Oregon Metals Evahuation

Project Number. 2787-050-000

Project Manager. Neil Morton
Reported

$05 / 131022: 32$

QUALITY CONTROL (QC) SAMPLE RESULTS

\begin{tabular}{|c|c|c|c|c|c|c|c|c|c|c|c|c|}
\hline \multicolumn{13}{|c|}{ Total hetals by EPA 6020 (ICPHS) } \\
\hline Analyte & Result & MDL & $\begin{array}{l}\text { Reporting } \\
\text { Limit }\end{array}$ & Units & Dil. & $\begin{array}{l}\text { Spike } \\
\text { Amourt }\end{array}$ & $\begin{array}{l}\text { Source } \\
\text { Result }\end{array}$ & $\%$ REC & $\begin{array}{l}\% \mathrm{REC} \\
\text { Limits }\end{array}$ & RPD & $\begin{array}{l}\text { RPD } \\
\text { Limit }\end{array}$ & Hotes \\
\hline
\end{tabular}

Batch 1004144 - EPA 3051A

Soil

Matrix Spile (1004144MS1)

Prepared: 04/12/10 10:52 Analyzd: 04/14/10 14:24

QC S aurce S mple: C03BD (Al0D059-06)

EPA 6020

\begin{tabular}{|c|c|c|c|c|c|c|c|c|c|c|c|c|}
\hline Antimory & 10.6 & 0.115 & 1.15 & $m g / k g d r y$ & 10 & 28.8 & 0.244 & 36 & $75-125 \%$ & - & -- & $\mathrm{Q}-01$ \\
\hline Aseric & 57.5 & 0231 & 231 & $"$ & $"$ & 57.7 & 8.40 & 85 & $"$ & - & - & \\
\hline Beryllium & 25.5 & 0231 & 1.15 & $"$ & $"$ & 28.8 & 0.797 & 89 & $"$ & - & - & \\
\hline Cadrinim & 57.8 & 0.115 & 1.15 & $"$ & $"$ & 57.7 & 0.399 & 100 & $"$ & - & - & \\
\hline Selervim & 24.7 & 0.461 & 231 & $"$ & $"$ & 28.8 & 0.443 & 84 & $"$ & - & - & B \\
\hline Silver & 27.8 & 0.115 & 1.15 & $"$ & $"$ & $"$ & $\mathrm{HD}$ & 96 & $"$ & -- & -- & \\
\hline Thallinm & 26.3 & 0.115 & 1.15 & $"$ & $"$ & $"$ & 0.256 & 90 & $"$ & - & - & \\
\hline
\end{tabular}

Matric Spire (1004144Ms)

Prepared: 04/12/10 10:52 Analyzed: 04/14/10 14:57

QC S aurce S ample: c0rBD (Al0D059-14)

EPA 6020

Antimory

Aseric

Beryllium

Cadrium

Lead

Selerinum

Silver

Thallim

$\begin{array}{lll}18.3 & 0.120 & 120 \\ 61.4 & 0240 & 2.40 \\ 25.4 & 0240 & 120 \\ 57.5 & 0.120 & 120 \\ 63.4 & 0.120 & 120 \\ 25.7 & 0.480 & 2.40 \\ 28.8 & 0.120 & 120 \\ 27.0 & 0.120 & 120\end{array}$

Post Spife(1004144-PS1)

$m g / \mathrm{kg} d x \quad 10$

$\begin{array}{cc}30.0 & 0.208 \\ 60.0 & 7.12 \\ 30.0 & 0.947 \\ 60.0 & 0.196 \\ " & 10.7 \\ 30.0 & \text { ND } \\ " & 0.243 \\ " & 0.289\end{array}$

Prepared: 04/14/10 16:46 Analyzed: 04/14/10 16:48

QC S aurce S mqle: c03BD (A10D059-06)

\section{EPA 6020}

Artimory

244

$\mathrm{ug} / \mathrm{L}$

Prepared: 04/14/10 16:46 Analyzed: 04/14/10 16:51

Post Spile (1004144-PS2)

(n)

Qc S aurce S mqle: c07BDb (Al0D059-14)

EFA 6020

Antimory

232

$\mathrm{ug} / \mathrm{L} \quad 10$

244

1.76

The results in this report apyly to the samples analyzed in accoriaxe with the c hain of

Apex Laboratories

custody document This andaticalrepon must be reproduced in it entivety.

ifon

Philip Nerenberg For Darwin Thomas, Business Development Director

Puge 37 of 55 


\section{Apex Labs}

12232 S.W. Garden Place

Tigard, OR 97223

503-718-2323 Phone

503-718-0333 Fax

\begin{tabular}{|lcr|}
\hline GeoEngineers -Seattle & Project OregonMetals Evaluation \\
600 S tewartSt. Suite 1700 & Project Humber. 2787-050-000 \\
Seattle, WA 98101 & Project Manager. Neil Morton & Reported \\
\hline
\end{tabular}

QUALITY CONTROL (QC) SAMPLE RESULTS

\begin{tabular}{|c|c|c|c|c|c|c|c|c|c|c|c|c|}
\hline \multicolumn{13}{|c|}{ Total hetals by EPA 6020 (ICPhiS) } \\
\hline Analyte & Result & MDL & $\begin{array}{l}\text { Reporting } \\
\text { Limit }\end{array}$ & Units & Dil. & $\begin{array}{c}\text { Spike } \\
\text { Amourt }\end{array}$ & $\begin{array}{l}\text { Source } \\
\text { Reult }\end{array}$ & $\mathscr{R E C}$ & $\begin{array}{l}\% \mathrm{REC} \\
\text { Limits }\end{array}$ & RPD & $\begin{array}{l}\text { RPD } \\
\text { Limit }\end{array}$ & Notes \\
\hline
\end{tabular}

Batch 1004156 - EPA 3051A

Soil

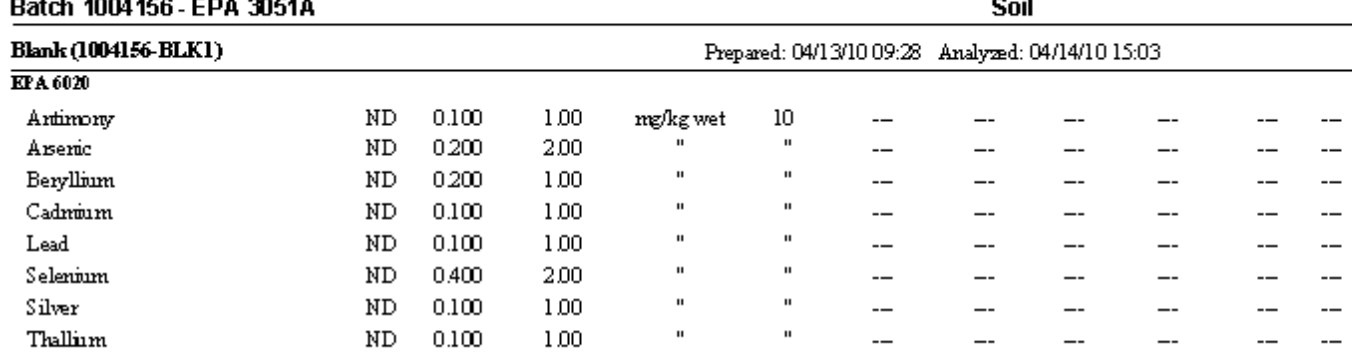

LCS(1004156-BS1) $\quad$ Prepared: 04/13/1009:28 Analyzed: 04/14/10 15:06

EP 6020

\begin{tabular}{|c|c|c|c|c|c|c|c|c|c|c|c|}
\hline Antimory & 25.3 & 0.100 & 100 & $\mathrm{mg} / \mathrm{kg}$ wet & 10 & 25.0 & - & 101 & $80-120 \%$ & -- & - \\
\hline Aseric & 48.0 & 0200 & 200 & $"$ & $"$ & 50.0 & - & 96 & $"$ & - & - \\
\hline Beryllium & 23.5 & 0200 & 100 & $"$ & $"$ & 25.0 & -- & 94 & $"$ & - & - \\
\hline Cadrumim & 48.1 & 0.100 & 100 & $"$ & $"$ & 50.0 & -- & 96 & $"$ & -- & - \\
\hline Lead & 47.2 & 0.100 & 100 & $"$ & $"$ & $"$ & -- & 94 & $"$ & -- & - \\
\hline Selenvim & 23.1 & 0.400 & 200 & $"$ & $"$ & 25.0 & -- & $9_{2}$ & $"$ & -- & - \\
\hline Silver & 24.5 & 0.100 & 100 & $"$ & $"$ & $"$ & -- & 98 & $"$ & - & - \\
\hline Thallinm & 23.4 & 0.100 & 100 & $"$ & $"$ & $"$ & -- & 94 & $"$ & - & - \\
\hline
\end{tabular}

Duplicate (1004156-DUPI)

Prepared: 04/13/10 09:28 Analyzed: 04/14/10 15:26

QC S aurce S mqle: c10Alb (A10DOS9-19)

EPA 6020

Antimory

Aseric

Beryllium

Cadrium

Lead

Selenium

Silver

Thallium

$\begin{array}{ccc}\mathbf{0 . 4 6 9} & 0.124 & 124 \\ \mathbf{7 9 5} & 0247 & 2.47 \\ \text { HD } & 0247 & 124 \\ \text { HD } & 0.124 & 124 \\ \mathbf{8 9 . 5} & 0.124 & 124 \\ \mathbf{2 0 1} & 0.494 & 2.47 \\ \mathbf{0 . 1 8 5} & 0.124 & 124 \\ \text { HD } & 0.124 & 124\end{array}$

Matric Spile (1004156-MS1)

QC S aurce S mqle: cloklb (Al0Dos9-19)

Apex Laboratories

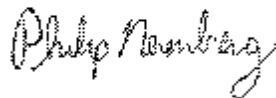

The results in this reyort apply to the samples analyed in accoriase with the chain of

custody document This andoticalrepon mus be reproduced in it entrety.

Philip Nerenberg For Danwin Thomas, Business Development Director

Puge 38 of 55 


\section{Apex Labs}

12232 S.W. Garden Phace

Tigard, OR 97223

503-718-2323 Phone

503-718-0333 Fax
GeoEngineers -Seattle

600 S tewartSt. Suite 1700

Seattle, WA 98101
Project OregonMetals Evaluation

Project Number. 2787-050-000

Project Manager. Heil Mortom
Reported:

$05 / 13 / 1022: 32$

QUALITY CONTROL (QC) SAMPLE RESULTS

\begin{tabular}{|c|c|c|c|c|c|c|c|c|c|c|c|c|}
\hline \multicolumn{13}{|c|}{ Total Metals by EPA 6020 (ICPMS) } \\
\hline Analyte & Result & MDL & $\begin{array}{l}\text { Reporting } \\
\text { Limit }\end{array}$ & Units & Dil. & $\begin{array}{l}\text { Spike } \\
\text { Amourt }\end{array}$ & $\begin{array}{l}\text { Source } \\
\text { Reult }\end{array}$ & $\% R \mathrm{RC}$ & $\begin{array}{l}\% \mathrm{REC} \\
\text { Limits }\end{array}$ & RFD & $\begin{array}{l}\text { RPP } \\
\text { Limit }\end{array}$ & Notes \\
\hline
\end{tabular}

Soil

Batch 1004156 - EPA 3051A

Matrix Spile (1004156-MS1)

Prepared: 04/13/10 09:28 Analyzed: 04/14/10 15:29

QC Sarces ample: c10Alb (Al0DO59-19)

EPA 6020

\begin{tabular}{|c|c|c|c|c|c|c|c|c|c|c|c|}
\hline Antimory & 25.4 & 0.124 & 124 & $m z / k g d r y$ & 10 & 30.9 & 0.445 & 84 & $75-125 \%$ & -- & - \\
\hline Aseric & 65.1 & 0248 & 2.48 & $"$ & $"$ & 61.9 & 8.25 & 92 & $"$ & - & -- \\
\hline Beryllim & 27.6 & 0248 & 124 & $"$ & $"$ & 30.9 & $\mathrm{HD}$ & 89 & $"$ & - & - \\
\hline Cadrnim & 57.8 & 0.124 & 124 & $"$ & $"$ & 61.9 & 0.120 & 93 & $"$ & -- & -- \\
\hline Lead & 143 & 0.124 & 124 & $"$ & $"$ & $"$ & 81.4 & 99 & $"$ & -- & -- \\
\hline Selenium & 30.2 & 0.495 & 2.48 & $"$ & $"$ & 30.9 & 2.16 & 90 & $"$ & - & -- \\
\hline Silver & 28.9 & 0.124 & 124 & $"$ & $"$ & $"$ & 0.180 & 93 & $"$ & -- & -- \\
\hline Thallinm & 28.0 & 0.124 & 124 & $"$ & $"$ & $"$ & HD & 91 & $"$ & -- & -- \\
\hline
\end{tabular}

Matrix spile (1004156-Mse)

Frepared: 04/13/10 09:28 Analyrsd: 04/14/10 16:24

QC S aurce S ample: M0Lanh (Al0D059-34)

EPA 6020

Antimory

Aseric

Beryllium

Cadrim

Lead

Selenium

Silver

Thallim

$\begin{array}{lll}28.1 & 0.114 & 1.14 \\ 56.3 & 0229 & 229 \\ 25.7 & 0229 & 1.14 \\ 55.2 & 0.114 & 1.14 \\ 83.8 & 0.114 & 1.14 \\ 27.8 & 0.458 & 229 \\ 27.9 & 0.114 & 1.14 \\ 27.0 & 0.114 & 1.14\end{array}$

$m g / k g d r y \quad 10$

$\begin{array}{cc}28.6 & 0.222 \\ 57.2 & 1.25 \\ 28.6 & \text { HD } \\ 57.2 & 0.246 \\ " & 32.7 \\ 28.6 & 0.554 \\ " & \text { HD } \\ " & \text { HD }\end{array}$

98
96
93
96
89
95
98

$75-125 \%$

$--$

" $\quad-3+$

"

" - $\quad-$

$"$

$--$

\section{Apex Laboratories

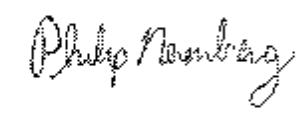

The results in this report apply to the samples andysed in ac cordaxce with the chnin of

custody document This anditicalrepon mus be reproduced in it entivety.

Philip Neremberg For Darwin Thormas, Business Development Director

Puge 39 of 55 


\section{Apex Labs}

12232 S.W. Garden Place

Tigard, OR 97223

503-718-2323 Phone

503-718-0333 Fax

\begin{tabular}{|llr|}
\hline GeoEngineers - Seattle & Project OregonMetals Evaluation \\
600 S tewartSt. Suite 1700 & Project Humber. 2787-050-000 & Reported \\
Seattle, WA 98101 & Project Manager. Neil Morton & $05 / 13 / 1022: 32$ \\
\hline
\end{tabular}

QUALITY CONTROL (QC) SAMPLE RESULTS

\begin{tabular}{|c|c|c|c|c|c|c|c|c|c|c|c|c|}
\hline \multicolumn{13}{|c|}{ Total hetals by EPA 6020 (ICPHS) } \\
\hline Analyte & Result & MDL & $\begin{array}{l}\text { Reporting } \\
\text { Limit }\end{array}$ & Units & Dil. & $\begin{array}{c}\text { Spike } \\
\text { Amourt }\end{array}$ & $\begin{array}{l}\text { Source } \\
\text { Result }\end{array}$ & $\%$ REC & $\begin{array}{l}\text { \% } \mathrm{REC} \\
\text { Limits }\end{array}$ & RPD & $\begin{array}{l}\text { RPD } \\
\text { Limit }\end{array}$ & Notes \\
\hline
\end{tabular}

Batch 1004187 - EPA 3051A

Soil

\begin{tabular}{|c|c|c|c|c|c|c|c|c|c|c|c|}
\hline \multicolumn{4}{|l|}{ Batch 1004187 - EPA 3051A } & \multicolumn{8}{|c|}{ Soil } \\
\hline Blank (1004187-BLK1) & & & \multicolumn{9}{|c|}{ Prepared: 04/14/10 14:42 Analyzed: 04/16/10 16:33 } \\
\hline \multicolumn{12}{|l|}{$\overline{\text { EPA 6020 }}$} \\
\hline Antimory & $\mathrm{HD}$ & 0.100 & 100 & $m g / k g$ wet & 10 & -- & - & -- & -- & -- & -- \\
\hline Aseric & $\mathrm{ND}$ & 0200 & 200 & $"$ & $"$ & -- & -- & -- & -- & -- & -- \\
\hline Beryllium & $\mathrm{HD}$ & 0200 & 1.00 & $"$ & $"$ & -- & -- & -- & -- & -- & -- \\
\hline Cadruim & $\mathrm{HD}$ & 0.100 & 1.00 & $"$ & $"$ & -- & -- & - & -- & - & - \\
\hline Lead & $\mathrm{HD}$ & 0.100 & 100 & $"$ & $"$ & -- & -- & -- & -- & - & - \\
\hline Selenium & $\mathrm{HD}$ & 0.400 & 200 & $"$ & $"$ & -- & -- & -- & -- & - & - \\
\hline Silver & $\mathrm{HD}$ & 0.100 & 100 & $"$ & $"$ & -- & - & -- & -- & -- & -- \\
\hline Thallinm & $\mathrm{ND}$ & 0.100 & 100 & $"$ & $"$ & -- & - & -- & -- & -- & -- \\
\hline
\end{tabular}

LCS(1004187-BS1) $\quad$ Prepared: 04/14/10 14:42 Analyæad: 04/16/10 16:36

\begin{tabular}{|c|c|c|c|c|c|c|c|c|c|c|c|}
\hline$\overline{\text { EPA 6020 }}$ & & & & & & & & & & & \\
\hline Antimory & 25.7 & 0.100 & 100 & $\mathrm{mg} / \mathrm{kg}$ wet & 10 & 25.0 & - & 103 & $80-120 \%$ & - & - \\
\hline Aseric & 48.0 & 0200 & 200 & $"$ & $"$ & 50.0 & -- & 96 & $"$ & - & - \\
\hline Beryllium & 23.7 & 0200 & 100 & $"$ & $"$ & 25.0 & - & 95 & $"$ & - & -- \\
\hline Cadnimim & 49.2 & 0.100 & 1.00 & $"$ & $"$ & 50.0 & - & 98 & $"$ & -- & -- \\
\hline Lead & 48.3 & 0.100 & 100 & $"$ & $"$ & $"$ & -- & 97 & $"$ & -- & -- \\
\hline Selenvium & 23.3 & 0.400 & 200 & $"$ & $"$ & 25.0 & -- & 93 & $"$ & -- & -- \\
\hline Silver & 24.6 & 0.100 & 100 & $"$ & $"$ & $"$ & - & 98 & $"$ & - & -- \\
\hline Thallinm & 23.6 & 0.100 & 100 & $"$ & $"$ & $"$ & -- & 94 & $"$ & -- & -- \\
\hline
\end{tabular}

Duplicate (1004187-DUPI)

Prepared: 04/14/10 14:42 Analyzed: 04/16/10 17:06

QC Sarce S mqle: MOdAzb (Al0D059-40)

EFA 6020

Antimory

Aseric

Beryllium

Cadrixim

Lead

Selenium

Silver

Thallium

$\begin{array}{ccc}\mathbf{0 . 4 7} & 0.165 & 165 \\ \mathbf{1 6 5} & 0329 & 329 \\ \text { HD } & 0329 & 165 \\ \mathbf{0 . 2 6 3} & 0.165 & 165 \\ \mathbf{1 7 5} & 0.165 & 165 \\ \text { HD } & 0.658 & 329 \\ \text { HD } & 0.165 & 165 \\ \text { HD } & 0.165 & 165\end{array}$

Matrix Spile (1004187-MS1)

QC S aurces ample: MOdA2b (Al0D059-40)

Apex Laboratories

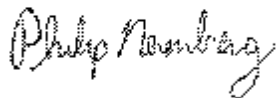

The results in this report appiy to the samples analyzed in accoriase with the chain of

custody document This andoticalrepon mus be reproduced in it entrety.

Philip Nerenberg For Danwin Thomas, Business Development Director

Puge 40 of 55 


\section{Apex Labs}

12232 S.W. Garden Place

Tigard, OR 97223

503-718-2323 Phone

503-718-0333 Fax
GeoEngineers - Seatlle

600 S tewartSt. Suite 1700

Seattle, WA 98101
Project OregonMetals Evahuation

Project Humber. 2787-050-000

Project Manager. Heil Morton
Reported: 05/1310 22:32

QUALITY CONTROL (QC) SAMPLE RESULTS

\begin{tabular}{|c|c|c|c|c|c|c|c|c|c|c|c|c|}
\hline \multicolumn{13}{|c|}{ Total hetals by EPA 6020 (ICPMS) } \\
\hline Analyte & Result & MDL & $\begin{array}{l}\text { Reporting } \\
\text { Limit }\end{array}$ & Units & Dil. & $\begin{array}{l}\text { Spike } \\
\text { Amourt }\end{array}$ & $\begin{array}{l}\text { Sounce } \\
\text { Rerult }\end{array}$ & $\% R E C$ & $\begin{array}{l}\% \mathrm{REC} \\
\text { Linnits }\end{array}$ & RPD & $\begin{array}{l}\text { RPD } \\
\text { Limit }\end{array}$ & Notes \\
\hline
\end{tabular}

Batch 1004187 - EPA 3051A

Soil

Matrix Spile (1004187-MS1)

Prepared: 04/14/10 14:42 Analyzed: 04/16/10 17:09

QC S aurces ample: M04A2h (A10D059-40)

EPA 6020

Antimory

Aseric

Beryllium

Cadrimem

Lead

Seleriim

Silver

Thallinm

$\begin{array}{lll}36.2 & 0.151 & 151 \\ 73.2 & 0302 & 302 \\ 34.7 & 0302 & 151 \\ 72.2 & 0.151 & 151 \\ 245 & 0.151 & 151 \\ 35.5 & 0.603 & 3.02 \\ 36.0 & 0.151 & 151 \\ 33.8 & 0.151 & 151\end{array}$

Matric Spile (1004187-MS2)

QC S aurce S mqle: M08B2a (A10D059-49)

EPA 6020

\begin{tabular}{|c|c|c|c|c|c|c|c|c|c|c|c|}
\hline Antimory & 22.5 & 0.104 & 104 & $m g / k g d r y$ & 10 & 26.1 & 0.116 & 86 & $75-125 \%$ & - & - \\
\hline Aseric & 49.7 & 0200 & 209 & $"$ & $"$ & 52.2 & 0.582 & 94 & $"$ & - & - \\
\hline Beryllium & 25.0 & 0200 & 104 & $"$ & $"$ & 26.1 & 0.381 & 94 & $"$ & - & - \\
\hline Cadrimim & 50.4 & 0.104 & 1.04 & $"$ & $"$ & 52.2 & 0.211 & 96 & $"$ & -- & - \\
\hline Lead & 49.3 & 0.104 & 1.04 & $"$ & $"$ & $"$ & 2.68 & 89 & $"$ & -- & - \\
\hline Selenium & 22.9 & 0.418 & 209 & $"$ & $"$ & 26.1 & $\mathrm{HD}$ & 88 & $"$ & - & - \\
\hline Silver & 25.3 & 0.104 & 104 & $"$ & $"$ & $"$ & ND & 97 & $"$ & -- & - \\
\hline Thallinm & 22.9 & 0.104 & 104 & $"$ & $"$ & $"$ & HD & 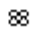 & $"$ & -- & - \\
\hline
\end{tabular}

Apex Laboratories

The results in this report apply to the samples analyzed in accoriaxe with the ckain of

custody document This anditicalrepont mus be reproduced in it entivety.

Philip Nerenberg For Darwin Thomas, Business Development Director

Phge 41 of 55 


\section{Apex Labs}

12232 S.W. Garden Phace

Tigard, OR 97223

503-718-2323 Phone

503-718-0333 Fax

GeoEngineers -Seattle

600 S tewartSt. Suite 1700

Project OregonMetals Evaluation

Project Number. 2787-050-000

Project Manager. Neil Morton

Reparted

$05 / 1311022: 32$

QUALITY CONTROL (QC) SAMPLE RESULTS

\begin{tabular}{|c|c|c|c|c|c|c|c|c|c|c|c|c|}
\hline \multicolumn{13}{|c|}{ Total hetals by EPA 6020 (ICPHSS) } \\
\hline Analyte & Result & MDL & $\begin{array}{l}\text { Reporting } \\
\text { Limit }\end{array}$ & Units & Dil. & $\begin{array}{l}\text { Spike } \\
\text { Amourt }\end{array}$ & $\begin{array}{l}\text { Source } \\
\text { Result }\end{array}$ & $\% R E C$ & $\begin{array}{l}\% \mathrm{REC} \\
\text { Limits }\end{array}$ & RPD & $\begin{array}{l}\text { RPD } \\
\text { Limit }\end{array}$ & Notes \\
\hline
\end{tabular}

Batch 1004193 - EPA 3051A

Soil

\begin{tabular}{|c|c|c|c|c|c|c|c|c|c|c|c|}
\hline \multirow{2}{*}{$\begin{array}{l}\text { Blank (1004193-BLK1) } \\
\text { EPA 6020 }\end{array}$} & & & \multicolumn{4}{|c|}{ Prepared: 04/15/10 09:00 } & \multicolumn{3}{|c|}{ Analyzed: 04/16/10 17:59 } & & \\
\hline & & & & & & & & & & & \\
\hline Antimory & ND & 0.100 & 100 & $\mathrm{mg} / \mathrm{kg}$ wet & 10 & - & - & -- & -- & - & -- \\
\hline Aseric & $\mathrm{HD}$ & 0200 & 200 & " & $"$ & - & -- & -- & -- & -- & -- \\
\hline Beryllium & HD & 0200 & 100 & $"$ & $"$ & -- & -- & -- & -- & -- & -- \\
\hline Cadrinim & $\mathrm{HD}$ & 0.100 & 100 & $"$ & $"$ & - & - & -- & - & - & - \\
\hline Lead & HD & 0.100 & 100 & $"$ & $"$ & - & -- & -- & -- & -- & -- \\
\hline Selenium & HD & 0.400 & 200 & $"$ & $"$ & - & - & - & -- & - & - \\
\hline Silver & HD & 0.100 & 100 & $"$ & $"$ & - & - & -- & -- & -- & -- \\
\hline Thallinm & HD & 0.100 & 100 & $"$ & $"$ & - & -- & -- & -- & -- & - \\
\hline
\end{tabular}

LCS(1004193-BS1)

Prepared: 04/15/1009:00 Analyzed: 04/16/10 18:02

EPA 6020

\begin{tabular}{|c|c|c|c|c|c|c|c|c|c|c|}
\hline Antimory & 26.6 & 0.100 & 100 & $\mathrm{mg} / \mathrm{kg}$ wet & 10 & 25.0 & -- & 106 & $80-120 \%$ & -- \\
\hline Aseric & 49.0 & 0200 & 200 & $"$ & $"$ & 50.0 & -- & 98 & $"$ & -- \\
\hline Beryllium & 24.0 & 0200 & 100 & $"$ & $"$ & 25.0 & -- & 96 & $"$ & -- \\
\hline Cadruim & 48.5 & 0.100 & 100 & $"$ & $"$ & 50.0 & -- & 97 & $"$ & -- \\
\hline Lead & 47.7 & 0.100 & 100 & $"$ & $"$ & $"$ & -- & 95 & $"$ & -- \\
\hline Selenium & 23.6 & 0.400 & 200 & $"$ & $"$ & 25.0 & -- & 94 & $"$ & - \\
\hline Silver & 24.6 & 0.100 & 100 & $"$ & $"$ & $"$ & - & 99 & $"$ & -- \\
\hline Thallinm & 23.4 & 0.100 & 100 & $"$ & $"$ & $"$ & -- & 94 & $"$ & - \\
\hline
\end{tabular}

Duplicate (1004193-DUPI)

Prepared: 04/15/1009:00 Analyzd: 04/16/10 18:29

OC Sarces mqule: MIrB2a (AlOD059-57)

EPA 6020

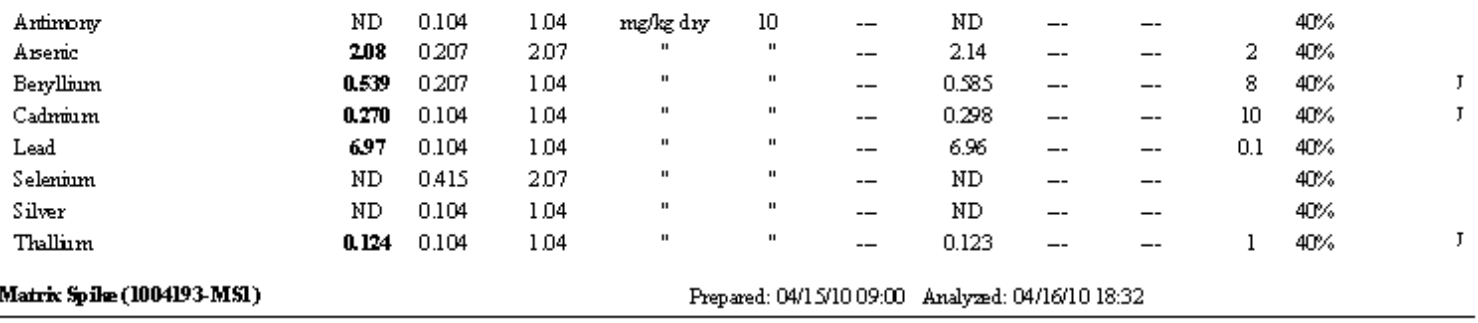

QC S aurce S mqle: MIzB2a (A10D059-57)

Apex Laboratories

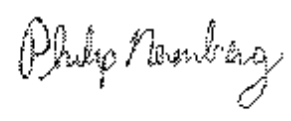

Philip Nerenberg For Darwin Thomas, Business Development Director
The results in this report aspiy to the samplys analysed in accordaxce with the chnin of custody do cument This anditicalrepont mus be reproduced in it entrety. 


\section{Apex Labs}

12232 S.W. Garden Place Tigard, OR 97223

503-718-2323 Phone

503-718-0333 Fax

GeoEngineers -Seatt

600 S tewartSt. Suite 1700

Seattle, WA 98101

Project OregonMetals Evaluation

Project Humber. 2787-050-000

Reported:

Project Manazer. Neil Morton

QUALITY CONTROL (QC) SAMPLE RESULTS

\begin{tabular}{|c|c|c|c|c|c|c|c|c|c|c|c|c|}
\hline \multicolumn{13}{|c|}{ Total hetals by EPA 6020 (ICPMS) } \\
\hline Analyte & Result & MDL & $\begin{array}{l}\text { Reporting } \\
\text { Limit }\end{array}$ & Units & Dil. & $\begin{array}{l}\text { Spike } \\
\text { Amourt }\end{array}$ & $\begin{array}{l}\text { Soure } \\
\text { Reult }\end{array}$ & $\% R E C$ & $\begin{array}{l}\% \mathrm{REC} \\
\text { Limits }\end{array}$ & RPD & $\begin{array}{l}\text { RPD } \\
\text { Limit }\end{array}$ & Notes \\
\hline
\end{tabular}

Batch 1004193 - EPA $3051 A$

Soil

Matrix Spile (1004193-MS1)

Prepared: 04/15/1009:00 Analysed: 04/16/10 18:32

QC S aurce S mqle: M12B2a (A10D059-57)

\section{EPA 6020}

\begin{tabular}{|c|c|c|c|c|c|c|c|c|c|c|c|}
\hline Antimory & 20.9 & 0.104 & 104 & $m g / k g d r y$ & 10 & 26.0 & HD & 81 & $75-125 \%$ & - & -- \\
\hline Aseric & 48.7 & 0208 & 208 & $"$ & $"$ & 52.0 & 2.14 & 90 & $"$ & - & -- \\
\hline Beryllimm & 24.6 & 0208 & 104 & $"$ & $"$ & 26.0 & 0.585 & 92 & $"$ & -- & - \\
\hline Cadnimum & 50.0 & 0.104 & 104 & $"$ & $"$ & 52.0 & 0.298 & 96 & $"$ & -- & -- \\
\hline Lead & 53.7 & 0.104 & 104 & $"$ & $"$ & $"$ & 6.96 & 90 & $"$ & -- & -- \\
\hline Selervium & 21.9 & 0.416 & 208 & $"$ & $"$ & 26.0 & HD & 84 & $"$ & - & -- \\
\hline Silver & 25.1 & 0.104 & 104 & $"$ & $"$ & $"$ & HD & 97 & $"$ & - & -- \\
\hline Thallinm & 23.0 & 0.104 & 104 & $"$ & $"$ & $"$ & 0.123 & $\otimes$ & $"$ & -- & -- \\
\hline
\end{tabular}

Matrix spile (1004193-Ms2)

Prepared: 04/15/1009:00 Analyred: 04/16/10 19:01

QC S aurce S mqle: M15Bla (A10D059-64)

EPA 6020

Antimory

Aseric

Beryllim

Cadrimim

Lead

Seleninum

Silver

Thallinm

$\begin{array}{lll}21.1 & 0.105 & 105 \\ 50.8 & 0210 & 2.10 \\ 25.3 & 0210 & 1.05 \\ 51.3 & 0.105 & 105 \\ 58.7 & 0.105 & 105 \\ 23.6 & 0.420 & 2.10 \\ 25.7 & 0.105 & 1.05 \\ 22.9 & 0.105 & 105\end{array}$

\begin{tabular}{|c|c|c|c|}
\hline$m g / \mathrm{kg} d x$ & 10 & 26.2 & HD \\
\hline$"$ & " & 52.4 & 1.78 \\
\hline$"$ & " & 26.2 & 1.23 \\
\hline$"$ & $"$ & 52.4 & 0.231 \\
\hline$"$ & $"$ & $"$ & 12.3 \\
\hline$"$ & $"$ & 26.2 & HD \\
\hline$"$ & $"$ & $"$ & $\mathrm{HD}$ \\
\hline$"$ & $"$ & $"$ & 0.147 \\
\hline
\end{tabular}

$\begin{array}{ccc}75-125 \% & - & - \\ " & - & - \\ " & - & - \\ " & - & - \\ " & - & - \\ " & - & - \\ " & - & - \\ " & - & -\end{array}$

Apex Laboratories

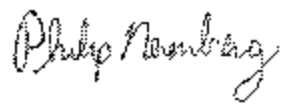

Philip Nerenberg For Darwin Thomas, Business Development Director

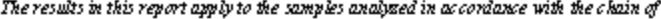

custody document This andaticalrepon mus be reproduced in it entivety. 


\section{Apex Labs}

12232 S.W. Garden Place

Tigard, OR 97223

503-718-2323 Phone

503-718-0333 Fax
GeoEngineers -Seattle

600 S tewartSt. Suite 1700

Seattle, WA 98101
Project OregonMetals Evaluation

Project Number. 2787-050-000

Project Manager. Neil Morton
Reported:

$05 / 131022: 32$

QUALITY CONTROL (QC) SAMPLE RESULTS

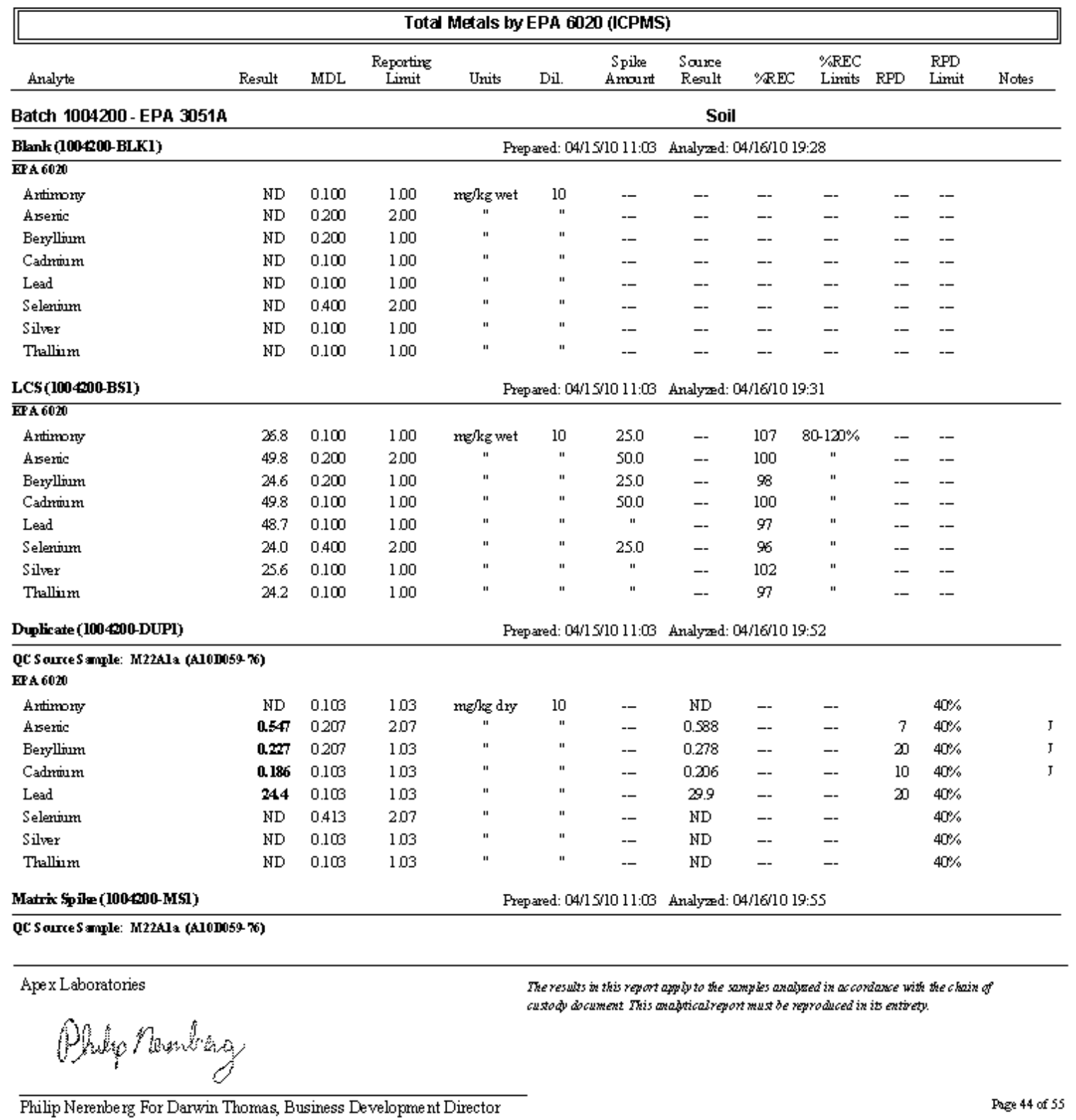




\section{Apex Labs}

12232 S.W. Garden Place

Tigard, OR 97223

503-718-2323 Phone

503-718-0333 Fax
GeoEngineers -Seattle

600 S tewartSt. Suite 1700

Seattle, WA 98101
Project Oregon Metals Evahuation

Project Humber. 2787-050-000

Project Marager. Neil Mortom
Reported

$05 / 13 / 1022: 32$

QUALITY CONTROL (QC) SAMPLE RESULTS

\begin{tabular}{|c|c|c|c|c|c|c|c|c|c|c|c|c|}
\hline \multicolumn{13}{|c|}{ Total Metals by EPA 6020 (ICPMS) } \\
\hline Analyte & Result & MDL & $\begin{array}{l}\text { Reporting } \\
\text { Limit }\end{array}$ & Units & Dil. & $\begin{array}{c}\text { Spike } \\
\text { Amourt }\end{array}$ & $\begin{array}{l}\text { Source } \\
\text { Result }\end{array}$ & $\%$ REC & $\begin{array}{l}\% \mathrm{REC} \\
\text { Limits }\end{array}$ & $\mathrm{RPD}$ & $\begin{array}{l}\text { RPP } \\
\text { Limit }\end{array}$ & Wotes \\
\hline
\end{tabular}

Soil

Batch 1004200 - EPA 3051A

Matrix Spile (100400-MS1)

Prepared: 04/15/10 11:03 Analyrad: 04/16/10 19:55

QC S aurce S mqle: M22ala (Al0D059-76)

\section{EPA 6020}

Antimory

Aseric

Beryllium

Cadruim

Lead

Selenimim

Silver

Thallium

Matrix Spile (100400-MS2)

QC Sarces ample: POYB (A10D059-8)

EFA 6020

Antimory

Aseric

Beryllium

Cadnim

Lead

Selerium

Silver

Thallinm

$\begin{array}{lll}24.4 & 0.104 & 1.04 \\ 50.8 & 0208 & 2.08 \\ 25.0 & 0206 & 1.04 \\ 50.3 & 0.104 & 1.04 \\ 74.7 & 0.104 & 1.04 \\ 24.0 & 0.417 & 208 \\ 25.4 & 0.104 & 1.04 \\ 23.1 & 0.104 & 1.04\end{array}$

$\begin{array}{cccc}m g / k \mathrm{~d} r y & 10 & 26.0 & \text { ND } \\ " & " & 52.1 & 0.588 \\ " & " & 26.0 & 0.278 \\ " & " & 52.1 & 0.206 \\ " & " & " & 29.9 \\ " & \text { " } & 26.0 & \text { ND } \\ " & \text { " } & \text { " } & \text { ND } \\ \text { " } & \text { " } & & \end{array}$

$\begin{array}{cccc}94 & 75-125 \% & - & - \\ 96 & " & -- & - \\ 95 & 1 & -- & - \\ 96 & 1 & -- & - \\ 86 & 1 & -- & - \\ 92 & 1 & -- & - \\ 97 & 1 & -- & - \\ 89 & 1 & - & -\end{array}$

Prepared: 04/15/10 11:03 Analyæad: 04/16/10 20:30

\begin{tabular}{|c|c|c|c|c|c|c|c|c|}
\hline $20.6 \quad 0.105$ & 105 & $m g / k g d r y$ & 10 & 26.2 & 0.313 & $n$ & $75-125 \%$ & - \\
\hline $54.1 \quad 0200$ & 209 & $"$ & $"$ & 52.3 & 6.55 & 91 & $"$ & - \\
\hline 0200 & 1.05 & $"$ & $"$ & 26.2 & 0.615 & 91 & $"$ & - \\
\hline 0.105 & 1.05 & $"$ & $"$ & 52.3 & 0.490 & 95 & $"$ & - \\
\hline 0.105 & 105 & $"$ & $"$ & $"$ & 23.0 & 86 & $"$ & - \\
\hline 0.419 & 209 & $"$ & $"$ & 26.2 & $\mathrm{HD}$ & 83 & $"$ & - \\
\hline 0.105 & 105 & $"$ & $"$ & $"$ & $\mathrm{ND}$ & 95 & $"$ & - \\
\hline 0.105 & 105 & $"$ & $"$ & $"$ & 0.125 & 85 & $"$ & - \\
\hline
\end{tabular}

Apex Laboratories

$$
\text { Pritprounding }
$$

Philip Nerenberg For Darwin Thomas, Business Development Director

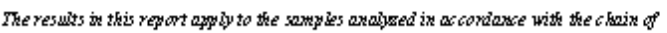
custody document This masticalrepon mus be reproduced in it entivety. 


\section{Apex Labs}

12232 S.W. Garden Place

Tigard, OR 97223

503-718-2323 Phone

503-718-0333 Fax
GeoEngineers - Seatlle

600 S tewart St. Suite 1700

Seattle, WA 98101
Project Oregon Metals Evahuation

Project Humber. 2787-050-000

Project Manager. Heil Morton
Reparted: 05/1310 22:32

QUALITY CONTROL (QC) SAMPLE RESULTS

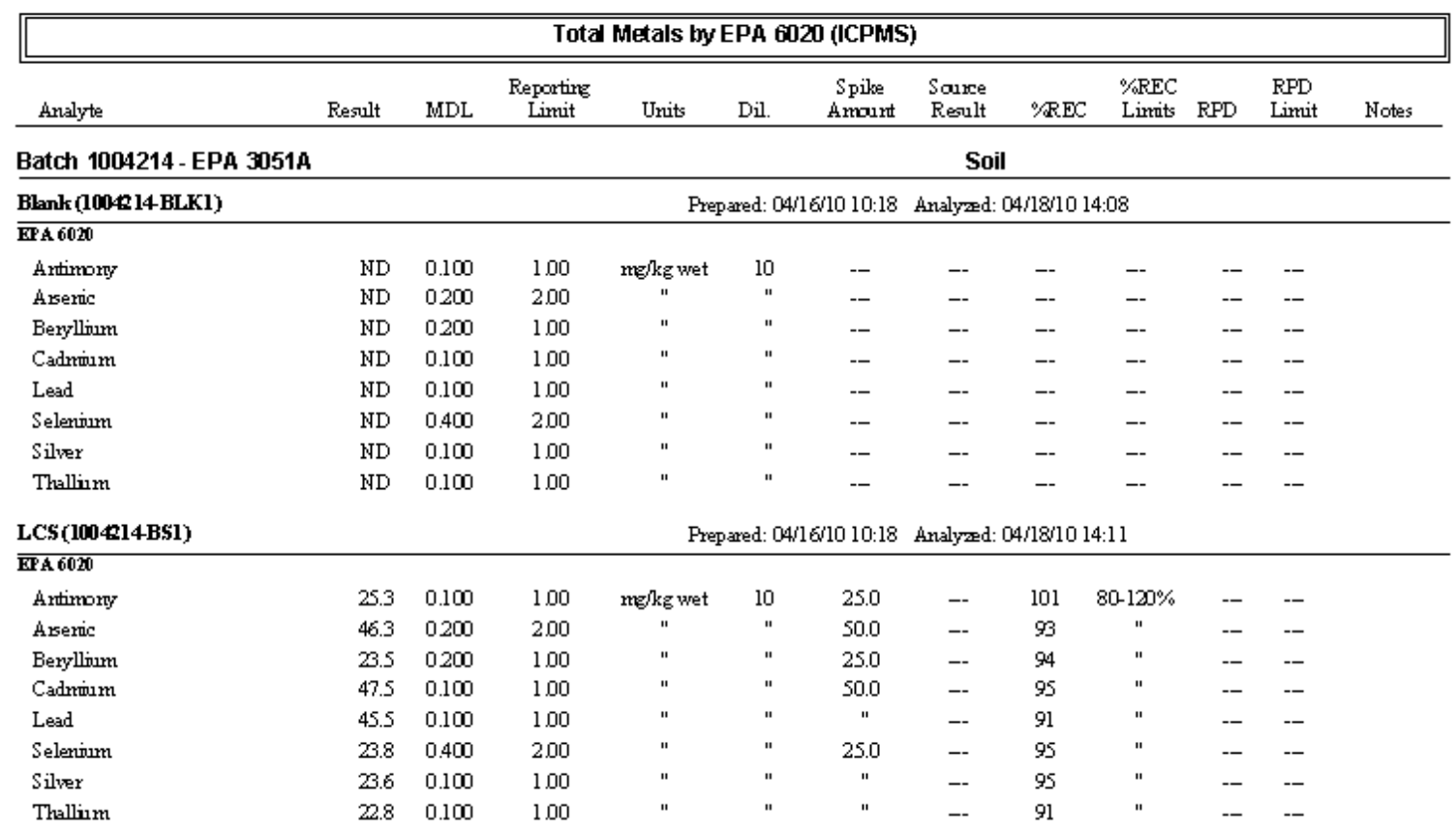

Apex Laboratories

$$
\text { (1) }
$$

Philip Nerenberg For Darwin Thomas, Business Development Director
The results in this report apply to the samples analyzed in accoriaxe with the chnin of

custody document This arabticalrepon mus be reproduced in it entivety. 


\section{Apex Labs}

12232 S.W. Garden Place

Tigard, OR 97223

503-718-2323 Phone

503-718-0333 Fax

\section{GeoEngineers -Seatle}

600 S tewartSt. Suite 1700

Seattle, WA 98101
Project OregonMetals Evahuation

Project Number. 2787-050-000

Project Manazer. Neil Morton
Reported

$05 / 13 / 1022: 32$

QUALITY CONTROL (QC) SAMPLE RESULTS

\begin{tabular}{|c|c|c|c|c|c|c|c|c|c|c|c|c|}
\hline \multicolumn{13}{|c|}{ Percent Dry Weight by D2216 } \\
\hline Analyte & Result & MDL & $\begin{array}{l}\text { Reporting } \\
\text { Limit }\end{array}$ & Units & Dil. & $\begin{array}{c}\text { Spike } \\
\text { Amourt }\end{array}$ & $\begin{array}{l}\text { Source } \\
\text { Result }\end{array}$ & $\% \mathrm{REC}$ & $\begin{array}{l}\% \mathrm{REC} \\
\text { Linrits }\end{array}$ & RPD & $\begin{array}{l}\text { RPD } \\
\text { Limit }\end{array}$ & Notes \\
\hline
\end{tabular}

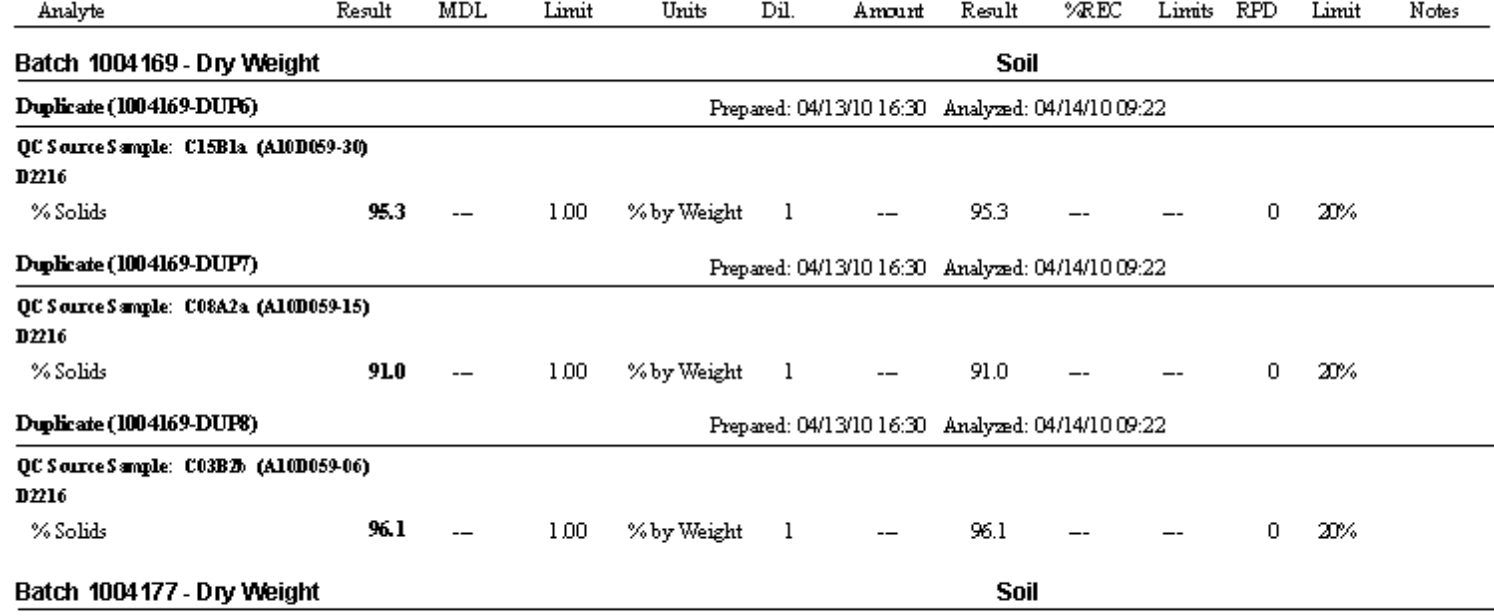

Batch 1004177 - Dry Weight

Prepared: 04/14/10 09:48 Analyzed: 04/15/1008:59

Duplicate (1004177-DUPI)

QC Sarce S ample: M02A2b (A10D059-30)

D2m16

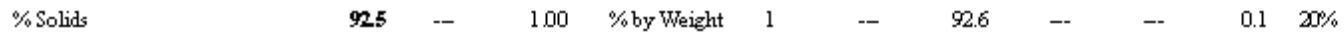

Duplicate (1004177-DUP2)

Prepared: 04/14/1009:48 Analyzed: 04/15/1008:59

QC S aurce S mqle: M06A2a (A10D059-4) D216
$\%$ Solids
91.4
100
$\%$ by Weight 1
- $91.3 \quad-$

$--$
$0.120 \%$

Duplicate (1004177-DUP3)

Prepared: 04/14/10 09:48 Analyzd: 04/15/1008:59

QC S aurce S mqle: M13Ala (A10D059-58)

D216

$\begin{array}{llllllllllllllll}\% \text { Solids } & 980 & - & 100 & \% \text { by Weight } & 1 & - & 98.0 & -- & - & 0 & 20 \%\end{array}$

Duplicate (1004177-DUP4)

Prepared: 04/14/10 09:48 Analyzed: 04/15/1008:59

QC Sarce S mple: M16B2a (A10D059-60)

$\mathbf{D} 216$

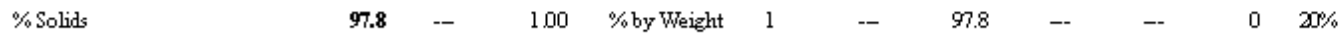

Apex Laboratories

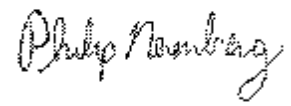

Philip Nerenberg For Darwin Thomas, Business Development Director
The results in this report appiy to the samples analysed in accoriaxe with the chain of custody document This madticalireport must be regroduced in it entrety. 


\section{Apex Labs}

12232 S. W. Garden Phace

Tigard, OR 97223

503-718-2323 Phone

503-718-0333 Fax

GeoEngineers - Seattle

600 S tewartSt. Suite 1700

Seattle, WA 98101

Project OregonMetals Evaluation

Project Number. 2787-050-000

Reported

$05 / 13 / 1022: 32$

QUALITY CONTROL (QC) SAMPLE RESULTS

\begin{tabular}{|c|c|c|c|c|c|c|c|c|c|c|c|c|}
\hline \multicolumn{13}{|c|}{ Percent Dry Weight by D2216 } \\
\hline Analyte & Result & MDL & $\begin{array}{l}\text { Reporting } \\
\text { Limit }\end{array}$ & Units & Dil. & $\begin{array}{l}\text { Spilke } \\
\text { Amourt }\end{array}$ & $\begin{array}{l}\text { Source } \\
\text { Revult }\end{array}$ & $\%$ REC & $\begin{array}{l}\% \mathrm{REC} \\
\text { Limits }\end{array}$ & RPD & $\begin{array}{l}\text { RPD } \\
\text { Limit }\end{array}$ & Notes \\
\hline
\end{tabular}

Soil

Batch 1004177 - Dry Weight

Duplicate (1004177-DUP5)

Prepared: 04/14/10 09:48 Analyzed: 04/15/1008:59

QC Sarces ample: MrzBla (Al0D059-77)

D216

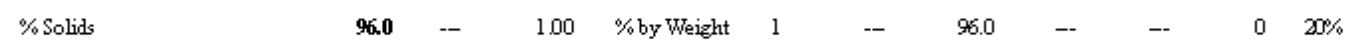

Duplicate (1004177-DUF)

Prepared: 04/14/1009:48 Analyzed: 04/15/1008:59

QC Sarces ample: P02B (Al0D059- \&)

D2m16

$\begin{array}{lllllllllllllll}\% \text { Solids } & 97.0 & - & 100 & \% \text { by Weight } & 1 & - & & 97.1 & -- & - & 0.1 & 20 \%\end{array}$

Duplicate (1004177-DUP8)

Prepared: 04/1 4/10 09:48 Analyrad: 04/15/1008:59

QC Sarce S mqle: c15cla (A10D059-31)

D2m6

$\%$ Solids

$96.0 \quad--\quad 100 \quad \%$ by Weight 1

$96.1 \quad--$

$-$

$0.120 \%$

Apex Laboratories

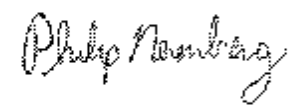

Philip Nerenberg For Dawwin Thomas, Business Development Director
The results in this report apsiy to the samples analyzed in accoriance with the chnin of custody bocument This madticalreport must be reproduced in it entivety. 


\section{Apex Labs}

12232 S.W. Garden Phace

Tigard, OR 97223

503-718-2323 Phone

503-718-0333 Fax

\begin{tabular}{|ll|}
\hline GeoEngineers -Seatfle & Project OregonMetals Evahuation \\
600 S tewartSt. Suite 1700 & Project Number. 2787-050-000 \\
Seattle, WA 98101 & Project Manager. Neil Morton \\
\hline
\end{tabular}

SAMPLE PREPARATION INF ORMATION

\begin{tabular}{|c|c|c|c|c|c|c|c|}
\hline \multicolumn{8}{|c|}{ Total Metals by EPA 6020 (ICPMS) } \\
\hline Prep: EPA 3051A & & & & & Sarmple & Default & RL Prep \\
\hline Lab Number & Matrix & Method & Sarmpled & Prepared & Iritial/Final & Iritial/Final & Factor \\
\hline \multicolumn{8}{|l|}{ Batch: 1004142} \\
\hline A10D059-01 & Soil & EPA 6020 & 01/01/9400:00 & 04/12/10 10:03 & $0.491 \mathrm{~g} / 50 \mathrm{~mL}$ & $0.5 \mathrm{~g} / 50 \mathrm{~mL}$ & 1.02 \\
\hline A10D059-02 & Soil & EPA 6020 & 01/01/9400:00 & 04/12/10 10:03 & $0.481 \mathrm{~g} / 50 \mathrm{~mL}$ & $0.5 \mathrm{~g} / 50 \mathrm{~mL}$ & 1.04 \\
\hline A10D059-03 & Soil & EPA 6020 & 01/01/9400:00 & 04/12/10 10:03 & $0.468 \mathrm{~g} / 50 \mathrm{~mL}$ & $0.5 \mathrm{~g} / 50 \mathrm{~mL}$ & 1.07 \\
\hline A10D059-03 & Soil & EPA 6020 & 01/01/9400:00 & $04 / 12 / 1013: 06$ & $0.468 \mathrm{~g} / 50 \mathrm{~mL}$ & $0.5 \mathrm{~g} / 50 \mathrm{~mL}$ & 1.07 \\
\hline \multicolumn{8}{|l|}{ Batch: 1004144} \\
\hline A10D059-04 & Soil & EPA 6020 & 01/01/9400:00 & $04 / 12 / 1010: 52$ & $0.502 \mathrm{~g} / 50 \mathrm{~mL}$ & $0.5 \mathrm{~g} / 50 \mathrm{~mL}$ & 1.00 \\
\hline A10D059-05 & Soil & EPA 6020 & 01/01/9400:00 & $04 / 12 / 1010: 52$ & $0.395 \mathrm{~g} / 50 \mathrm{~mL}$ & $0.5 \mathrm{~g} / 50 \mathrm{~mL}$ & 1.27 \\
\hline A10D059-06 & Soil & EPA 6020 & 01/01/9400:00 & $04 / 12 / 1010: 52$ & $0.47 \mathrm{~g} / 50 \mathrm{~mL}$ & $0.5 \mathrm{~g} / 50 \mathrm{~mL}$ & 1.06 \\
\hline A10D059-0? & Soil & EPA 6020 & 01/01/9400:00 & $04 / 12 / 1010: 52$ & $0.413 \mathrm{~g} / 50 \mathrm{~mL}$ & $0.5 \mathrm{~g} / 50 \mathrm{~mL}$ & 1.21 \\
\hline A10D059-08 & Soil & EPA 6020 & 01/01/9400:00 & $04 / 12 / 1010: 52$ & $0.445 \mathrm{~g} / 50 \mathrm{~mL}$ & $0.5 \mathrm{~g} / 50 \mathrm{~mL}$ & 1.12 \\
\hline A10D059-09 & Soil & EPA 6020 & 01/01/9400:00 & $04 / 12 / 1010: 52$ & $0.411 \mathrm{~g} / 50 \mathrm{~mL}$ & $0.5 \mathrm{~g} / 50 \mathrm{~mL}$ & 1.22 \\
\hline A10D059-10 & Soil & EPA 6020 & 01/01/9400:00 & $04 / 12 / 1010: 52$ & $0.47 \mathrm{~g} / 50 \mathrm{~mL}$ & $0.5 \mathrm{~g} / 50 \mathrm{~mL}$ & 1.06 \\
\hline A10D059-11 & Soil & EPA 6020 & 01/01/9400:00 & $04 / 12 / 1010: 52$ & $0.417 \mathrm{~g} / 50 \mathrm{~mL}$ & $0.5 \mathrm{~g} / 50 \mathrm{~mL}$ & 1.20 \\
\hline A10D059-12 & Soil & EPA 6020 & 01:01/9400:00 & $04 / 12 / 1010: 52$ & $0.455 \mathrm{~g} / 50 \mathrm{~mL}$ & $0.5 \mathrm{~g} / 50 \mathrm{~mL}$ & 1.10 \\
\hline A10D059-13 & Soil & EPA 6020 & 01/01/9400:00 & $04 / 12 / 1010: 52$ & $0.435 \mathrm{~g} / 50 \mathrm{~mL}$ & $0.5 \mathrm{~g} / 50 \mathrm{~mL}$ & 1.15 \\
\hline A10D059-14 & Soil & EPA 6020 & 01/01/9400:00 & $04 / 12 / 1010: 52$ & $0.449 \mathrm{~g} / 50 \mathrm{~mL}$ & $0.5 \mathrm{~g} / 50 \mathrm{~mL}$ & 1.11 \\
\hline A10D059-15 & Soil & EPA 6020 & 01/01/9400:00 & $04 / 12 / 1010: 52$ & $0.342 \mathrm{~g} / 50 \mathrm{~mL}$ & $0.5 \mathrm{~g} / 50 \mathrm{~mL}$ & 1.46 \\
\hline \multicolumn{8}{|l|}{ Batch: 1004156} \\
\hline A10D059-16 & Soil & EPA 6020 & 01/01/9400:00 & $04 / 13 / 1009: 28$ & $0.458 \mathrm{~g} / 50 \mathrm{~mL}$ & $0.5 \mathrm{~g} / 50 \mathrm{~mL}$ & 1.09 \\
\hline A10D059-17 & Soil & EPA 6020 & 01/01/9400:00 & 04/13/1009:28 & $0.456 \mathrm{~g} / 50 \mathrm{~mL}$ & $0.5 \mathrm{~g} / 50 \mathrm{~mL}$ & 1.10 \\
\hline A10D059-18 & Soil & EPA 6020 & 01/01/9400:00 & 04/13/1009:28 & $0.46 \mathrm{~g} / 50 \mathrm{~mL}$ & $0.5 \mathrm{~g} / 50 \mathrm{~mL}$ & 1.09 \\
\hline A10D059-19 & Soil & EPA 6020 & 01/01/9400:00 & 04/13/1009:28 & $0.452 \mathrm{~g} / 50 \mathrm{~mL}$ & $0.5 \mathrm{~g} / 50 \mathrm{~mL}$ & 1.11 \\
\hline A10D059-20 & Soil & EPA 6020 & 01/01/9400:00 & $04 / 13 / 1009: 28$ & $0.485 \mathrm{~g} / 50 \mathrm{~mL}$ & $0.5 \mathrm{~g} / 50 \mathrm{~mL}$ & 1.03 \\
\hline A10D059-21 & Soil & EPA 6020 & 01/01/9400:00 & 04/13/1009:28 & $0.475 \mathrm{~g} / 50 \mathrm{~mL}$ & $0.5 \mathrm{~g} / 50 \mathrm{~mL}$ & 1.05 \\
\hline A10D059-22 & Soil & EPA 6020 & 01/01/9400:00 & 04/13/1009:28 & $0.478 \mathrm{~g} / 50 \mathrm{~mL}$ & $0.5 \mathrm{~g} / 50 \mathrm{~mL}$ & 1.05 \\
\hline A10D059-23 & Soil & EPA 6020 & 01/01/9400:00 & 04/13/1009:28 & $0.459 \mathrm{~g} / 50 \mathrm{~mL}$ & $0.5 \mathrm{~g} / 50 \mathrm{~mL}$ & 1.09 \\
\hline A10D059-24 & Soil & EPA 6020 & 01/01/9400:00 & 04/13/1009:28 & $0.434 \mathrm{~g} / 50 \mathrm{~mL}$ & $0.5 \mathrm{~g} / 50 \mathrm{~mL}$ & 1.15 \\
\hline A10D059-25 & Soil & EPA 6020 & 01/01/9400:00 & 04/13/1009:28 & $0.517 \mathrm{~g} / 50 \mathrm{~mL}$ & $0.5 \mathrm{~g} / 50 \mathrm{~mL}$ & 0.97 \\
\hline A10D059-26 & Soil & EPA 6020 & 01/01/9400:00 & $04 / 13 / 1009: 28$ & $0.469 \mathrm{~g} / 50 \mathrm{~mL}$ & $0.5 \mathrm{~g} / 50 \mathrm{~mL}$ & 1.07 \\
\hline A10D059-27 & Soil & EPA 6020 & 01/01/9400:00 & 04/13/1009:28 & $0.457 \mathrm{~g} / 50 \mathrm{~mL}$ & $0.5 \mathrm{~g} / 50 \mathrm{~mL}$ & 1.09 \\
\hline A10D059-28 & Soil & EPA 6020 & 01/01/9400:00 & 04/13/1009:28 & $0.47 \mathrm{~g} / 50 \mathrm{~mL}$ & $0.5 \mathrm{~g} / 50 \mathrm{~mL}$ & 1.06 \\
\hline A10D059-29 & Soil & EPA 6020 & 01/01/9400:00 & 04/13/1009:28 & $0.444 \mathrm{~g} / 50 \mathrm{~mL}$ & $0.5 \mathrm{~g} / 50 \mathrm{~mL}$ & 1.13 \\
\hline A10D059-30 & Soil & EPA 6020 & 01/01/9400:00 & 04/13/1009:28 & $0.473 \mathrm{~g} / 50 \mathrm{~mL}$ & $0.5 \mathrm{~g} / 50 \mathrm{~mL}$ & 1.06 \\
\hline
\end{tabular}

Apex Laboratories

The results in this report asply to the samples andigned in accordance with the chain of

custody document This anditicalvepont mus be reproduced in it entivety.

\section{Powetions}

Philip Nerenberg For Darwin Thomas, Business Development Director

Puge 49 of 55 


\section{Apex Labs}

12232 S.W. Garden Phace

Tigard, OR 97223

503-718-2323 Phone

503-718-0333 Fax

\begin{tabular}{|lcr|}
\hline GeoEngineers -Seatle & Project OregonMetals Evahuation \\
600 StewartSt. Suite 1700 & Project Humber. $2787-050-000$ & Reported \\
Seattle, WA 98101 & Project Marager. Neil Morton & $05 / 3 / 1022: 32$ \\
\hline
\end{tabular}

SAM PLE PREPARATION INF ORMATION

\begin{tabular}{|c|c|c|c|c|c|c|c|}
\hline \multicolumn{8}{|c|}{ Total Metals by EPA 6020 (ICPMS) } \\
\hline Prep: EPA 3051A & & & & & Sample & Default & RL Frep \\
\hline Lab Number & Matix & Method & Sarmled & Prepared & Iritial/Final & Iritial/Final & Factor \\
\hline A10D059-31 & Soil & EPA 6020 & 01/019400:00 & $04 / 13 / 1009: 28$ & $0.451 \mathrm{~g} / 50 \mathrm{~mL}$ & $0.5 \mathrm{~g} / 50 \mathrm{~mL}$ & 1.11 \\
\hline A10D059-32 & Soil & EPA 6020 & 01:01:9400:00 & $04 / 13 / 1009: 28$ & $0.477 \mathrm{~g} / 50 \mathrm{~mL}$ & $0.5 \mathrm{~g} / 50 \mathrm{~mL}$ & 1.05 \\
\hline A10D059-33 & Soil & EPA 6020 & 01/01/9400:00 & $04 / 13 / 1009: 28$ & $0.435 \mathrm{~g} / 50 \mathrm{~mL}$ & $0.5 \mathrm{~g} / 50 \mathrm{~mL}$ & 1.15 \\
\hline A10D059-34 & Soil & EPA 6020 & 01:01:9400:00 & $04 / 13 / 1009: 28$ & $0.434 \mathrm{~g} / 50 \mathrm{~mL}$ & $0.5 \mathrm{~g} / 50 \mathrm{~mL}$ & 1.15 \\
\hline \multicolumn{8}{|l|}{ Batch: 1004187} \\
\hline A10D059-35 & Soil & EPA 6020 & 01/01/9400:00 & $04 / 14 / 1014: 42$ & $0.493 \mathrm{~g} / 50 \mathrm{~mL}$ & $0.5 \mathrm{~g} / 50 \mathrm{~mL}$ & 1.01 \\
\hline A10D059-36 & Soil & EPA 6020 & 01/01/9400:00 & $04 / 14 / 1014: 42$ & $0.501 \mathrm{~g} / 50 \mathrm{~mL}$ & $0.5 \mathrm{~g} / 50 \mathrm{~mL}$ & 1.00 \\
\hline A10D059-37 & Soil & EPA 6020 & 01:01/9400:00 & $04 / 14 / 1014: 42$ & $0.489 \mathrm{~g} / 50 \mathrm{~mL}$ & $0.5 \mathrm{~g} / 50 \mathrm{~mL}$ & 1.02 \\
\hline A10D059-38 & Soil & EPA 6020 & 01/01/9400:00 & $04 / 14 / 1014: 42$ & $0.487 \mathrm{~g} / 50 \mathrm{~mL}$ & $0.5 \mathrm{~g} / 50 \mathrm{~mL}$ & 1.03 \\
\hline A10D059-39 & Soil & EPA 6020 & 01/01/9400:00 & $04 / 14 / 1014: 42$ & $0.493 \mathrm{~g} / 50 \mathrm{~mL}$ & $0.5 \mathrm{~g} / 50 \mathrm{~mL}$ & 1.01 \\
\hline A10D059-40 & Soil & EPA 6020 & 01/01/9400:00 & $04 / 14 / 1014: 42$ & $0.322 \mathrm{~g} / 50 \mathrm{~mL}$ & $0.5 \mathrm{~g} / 50 \mathrm{~mL}$ & 1.55 \\
\hline A10D059-41 & Soil & EPA 6020 & 01/01/9400:00 & $04 / 14 / 1014: 42$ & $0.482 \mathrm{~g} / 50 \mathrm{~mL}$ & $0.5 \mathrm{~g} / 50 \mathrm{~mL}$ & 1.04 \\
\hline A10D059-42 & Soil & EPA 6020 & 01/01/9400:00 & $04 / 14 / 1014: 42$ & $0.475 \mathrm{~g} / 50 \mathrm{~mL}$ & $0.5 \mathrm{~g} / 50 \mathrm{~mL}$ & 1.05 \\
\hline A10D059-43 & Soil & EPA 6020 & 01/01/9400:00 & $04 / 14 / 1014: 42$ & $0.493 \mathrm{~g} / 50 \mathrm{~mL}$ & $0.5 \mathrm{~g} / 50 \mathrm{~mL}$ & 1.01 \\
\hline A10D059-44 & Soil & EPA 6020 & 01/01/9400:00 & $04 / 14 / 1014: 42$ & $0.329 \mathrm{~g} / 50 \mathrm{~mL}$ & $0.5 \mathrm{~g} / 50 \mathrm{~mL}$ & 1.52 \\
\hline A10D059-45 & Soil & EPA 6020 & 01/01/9400:00 & $04 / 14 / 1014: 42$ & $0.495 \mathrm{~g} / 50 \mathrm{~mL}$ & $0.5 \mathrm{~g} / 50 \mathrm{~mL}$ & 1.01 \\
\hline A10D059-46 & Soil & EPA 6020 & 01/01/9400:00 & $04 / 14 / 1014: 42$ & $0.341 \mathrm{~g} / 50 \mathrm{~mL}$ & $0.5 \mathrm{~g} / 50 \mathrm{~mL}$ & 1.47 \\
\hline A10D059-47 & Soil & EPA 6020 & 01/01/9400:00 & $04 / 14 / 1014: 42$ & $0.48 \mathrm{~g} / 50 \mathrm{~mL}$ & $0.5 \mathrm{~g} / 50 \mathrm{~mL}$ & 1.04 \\
\hline A10D059-48 & Soil & EPA 6020 & 01/01/9400:00 & $04 / 14 / 1014: 42$ & $0.487 \mathrm{~g} / 50 \mathrm{~mL}$ & $0.5 \mathrm{~g} / 50 \mathrm{~mL}$ & 1.03 \\
\hline A10D059-49 & Soil & EPA 6020 & 01/01/9400:00 & $04 / 14 / 1014: 42$ & $0.485 \mathrm{~g} / 50 \mathrm{~mL}$ & $0.5 \mathrm{~g} / 50 \mathrm{~mL}$ & 1.03 \\
\hline A10D059-50 & Soil & EPA 6020 & 01:01/9400:00 & $04 / 14 / 1014: 42$ & $0.505 \mathrm{~g} / 50 \mathrm{~mL}$ & $0.5 \mathrm{~g} / 50 \mathrm{~mL}$ & 0.99 \\
\hline A10D059-51 & Soil & EPA 6020 & 01/01/9400:00 & $04 / 14 / 1014: 42$ & $0.485 \mathrm{~g} / 50 \mathrm{~mL}$ & $0.5 \mathrm{~g} / 50 \mathrm{~mL}$ & 1.03 \\
\hline \multicolumn{8}{|l|}{ Batch: 1004193} \\
\hline A10D059-52 & Soil & EPA 6020 & 01:01/9400:00 & 04/15/1009:00 & $0.49 \mathrm{~g} / 50 \mathrm{~mL}$ & $0.5 \mathrm{~g} / 50 \mathrm{~mL}$ & 1.02 \\
\hline A10D059-53 & Soil & EPA 6020 & 01/01/9400:00 & 04/15/1009:00 & $0.497 \mathrm{~g} / 50 \mathrm{~mL}$ & $0.5 \mathrm{~g} / 50 \mathrm{~mL}$ & 1.01 \\
\hline A10D059-54 & Soil & EPA 6020 & 01:01/9400:00 & 04/15/1009:00 & $0.492 \mathrm{~g} / 50 \mathrm{~mL}$ & $0.5 \mathrm{~g} / 50 \mathrm{~mL}$ & 1.02 \\
\hline A10D059-55 & Soil & EPA 6020 & 01/01/9400:00 & 04/15/1009:00 & $0.483 \mathrm{~g} / 50 \mathrm{~mL}$ & $0.5 \mathrm{~g} / 50 \mathrm{~mL}$ & 1.04 \\
\hline A10D059-56 & Soil & EPA 6020 & 01:01/9400:00 & 04/15/1009:00 & $0.495 \mathrm{~g} / 50 \mathrm{~mL}$ & $0.5 \mathrm{~g} / 50 \mathrm{~mL}$ & 1.01 \\
\hline A10D059-57 & Soil & EPA 6020 & 01/01/9400:00 & 04/15/1009:00 & $0.5 \mathrm{~g} / 50 \mathrm{~mL}$ & $0.5 \mathrm{~g} / 50 \mathrm{~mL}$ & 1.00 \\
\hline A10D059-58 & Soil & EPA 6020 & 01/01/9400:00 & 04/15/1009:00 & $0.492 \mathrm{~g} / 50 \mathrm{~mL}$ & $0.5 \mathrm{~g} / 50 \mathrm{~mL}$ & 1.02 \\
\hline A10D059-59 & Soil & EPA 6020 & 01/01/9400:00 & 04/15/1009:00 & $0.499 \mathrm{~g} / 50 \mathrm{~mL}$ & $0.5 \mathrm{~g} / 50 \mathrm{~mL}$ & 1.00 \\
\hline A10D059-60 & Soil & EPA 6020 & 01/01/9400:00 & 04/15/1009:00 & $0.486 \mathrm{~g} / 50 \mathrm{~mL}$ & $0.5 \mathrm{~g} / 50 \mathrm{~mL}$ & 1.03 \\
\hline A10D059-61 & Soil & EPA 6020 & 01/01:9400:00 & 04/15/1009:00 & $0.491 \mathrm{~g} / 50 \mathrm{~mL}$ & $0.5 \mathrm{~g} / 50 \mathrm{~mL}$ & 1.02 \\
\hline A10D059-62 & Soil & EPA 6020 & 01/01/9400:00 & 04/15/1009:00 & $0.486 \mathrm{~g} / 50 \mathrm{~mL}$ & $0.5 \mathrm{~g} / 50 \mathrm{~mL}$ & 1.03 \\
\hline
\end{tabular}

Apex Laboratories

The results in this report asply to the samples andiged in accordaxe with the chnin of

(1)

custody document This anditicalrepont mus be reproduced in it entivety

Philip Nerenberg For Darwin Thomas, Business Development Director

Fuge 50 of 55 


\section{Apex Labs}

12232 S.W. Garden Phace

Tigard, OR 97223

503-718-2323 Phone

503-718-0333 Fax

\begin{tabular}{|c|c|c|}
\hline GeoEngineers -Seattle & Project OregonMetals Evaluation & \\
\hline 600 S tewartSt. Suite 1700 & Project Number: $2787-050-000$ & Reported: \\
\hline Seattle, WA 98101 & Project Manager. Neil Morton & $05 / 13 / 1022: 32$ \\
\hline
\end{tabular}

SAMPLE PREPARATION INF ORMATION

\begin{tabular}{|c|c|c|c|c|c|c|c|}
\hline \multicolumn{8}{|c|}{ Total hetals by EPA 6020 (ICPHS) } \\
\hline Prep: EPA 3051A & & & & & Sample & Default & RL Prep \\
\hline Lab Number & Matrix & Method & Sarpled & Prepared & Iruitial/Final & Iritial/Final & Factor \\
\hline A10D059-63 & Soil & EPA 6020 & 01/01/9400:00 & 04/15/1009:00 & $0.492 \mathrm{~g} / 50 \mathrm{~mL}$ & $0.5 \mathrm{~g} / 50 \mathrm{~mL}$ & 1.02 \\
\hline A10D059-64 & Soil & EPA 6020 & 01/01/9400:00 & 04/15/1009:00 & $0.493 \mathrm{~g} / 50 \mathrm{~mL}$ & $0.5 \mathrm{~g} / 50 \mathrm{~mL}$ & 1.01 \\
\hline A10D059-65 & Soil & EPA 6020 & 01/01/9400:00 & 04/15/1009:00 & $0.484 \mathrm{~g} / 50 \mathrm{~mL}$ & $0.5 \mathrm{~g} / 50 \mathrm{~mL}$ & 1.03 \\
\hline A10D059-66 & Soil & EPA 6020 & 01/01/9400:00 & 04/15/1009:00 & $0.495 \mathrm{~g} / 50 \mathrm{~mL}$ & $0.5 \mathrm{~g} / 50 \mathrm{~mL}$ & 1.01 \\
\hline A10D059-67 & Soil & EPA 6020 & 01/01/9400:00 & 04/15/1009:00 & $0.492 \mathrm{~g} / 50 \mathrm{~mL}$ & $0.5 \mathrm{~g} / 50 \mathrm{~mL}$ & 1.02 \\
\hline A10D059-68 & Soil & EPA 6020 & 01:01/9400:00 & 04/15/1009:00 & $0.499 \mathrm{~g} / 50 \mathrm{~mL}$ & $0.5 \mathrm{~g} / 50 \mathrm{~mL}$ & 1.00 \\
\hline A10D059-69 & Soil & EPA 6020 & 01/01/9400:00 & 04/15/1009:00 & $0.488 \mathrm{~g} / 50 \mathrm{~mL}$ & $0.5 \mathrm{~g} / 50 \mathrm{~mL}$ & 1.02 \\
\hline A10D059-70 & Soil & EPA 6020 & 01:01/9400:00 & 04/15/1009:00 & $0.498 \mathrm{~g} / 50 \mathrm{~mL}$ & $0.5 \mathrm{~g} / 50 \mathrm{~mL}$ & 1.00 \\
\hline \multicolumn{8}{|l|}{ Eatch: 1004200} \\
\hline A10D059-71 & Soil & EPA 6020 & 01:01/9400:00 & $04 / 15 / 1011: 03$ & $0.474 \mathrm{~g} / 50 \mathrm{~mL}$ & $0.5 \mathrm{~g} / 50 \mathrm{~mL}$ & 1.05 \\
\hline A10D059-72 & Soil & EPA 6020 & 01/01/9400:00 & 04/15/10 11:03 & $0.487 \mathrm{~g} / 50 \mathrm{~mL}$ & $0.5 \mathrm{~g} / 50 \mathrm{~mL}$ & 1.03 \\
\hline A10D059-73 & Soil & EPA 6020 & 01:01/9400:00 & 04/15/10 11:03 & $0.487 \mathrm{~g} / 50 \mathrm{~mL}$ & $0.5 \mathrm{~g} / 50 \mathrm{~mL}$ & 1.03 \\
\hline A10D059-74 & Soil & EPA 6020 & 01/01/9400:00 & 04/15/10 11:03 & $0.489 \mathrm{~g} / 50 \mathrm{~mL}$ & $0.5 \mathrm{~g} / 50 \mathrm{~mL}$ & 1.02 \\
\hline A10D059-75 & Soil & EPA 6020 & 01/01/9400:00 & $04 / 15 / 1011: 03$ & $0.496 \mathrm{~g} / 50 \mathrm{~mL}$ & $0.5 \mathrm{~g} / 50 \mathrm{~mL}$ & 1.01 \\
\hline A10D059-76 & Soil & EPA 6020 & 01/01/9400:00 & $04 / 15 / 1011: 03$ & $0.499 \mathrm{~g} / 50 \mathrm{~mL}$ & $0.5 \mathrm{~g} / 50 \mathrm{~mL}$ & 1.00 \\
\hline A10D059-77 & Soil & EPA 6020 & 01/01/9400:00 & $04 / 15 / 1011: 03$ & $0.497 \mathrm{~g} / 50 \mathrm{~mL}$ & $0.5 \mathrm{~g} / 50 \mathrm{~mL}$ & 1.01 \\
\hline A10D059-78 & Soil & EPA 6020 & 01/01/9400:00 & $04 / 15 / 1011: 03$ & $0.505 \mathrm{~g} / 50 \mathrm{~mL}$ & $0.5 \mathrm{~g} / 50 \mathrm{~mL}$ & 0.99 \\
\hline A10D059-79 & Soil & EPA 6020 & 01/01/9400:00 & 04/15/1011:03 & $0.503 \mathrm{~g} / 50 \mathrm{~mL}$ & $0.5 \mathrm{~g} / 50 \mathrm{~mL}$ & 0.99 \\
\hline A10D059-80 & Soil & EPA 6020 & 01:01:9400:00 & 04/15/10 11:03 & $0.495 \mathrm{~g} / 50 \mathrm{~mL}$ & $0.5 \mathrm{~g} / 50 \mathrm{~mL}$ & 1.01 \\
\hline A10D059-81 & Soil & EPA 6020 & 01:01:9400:00 & $04 / 15 / 1011: 03$ & $0.497 \mathrm{~g} / 50 \mathrm{~mL}$ & $0.5 \mathrm{~g} / 50 \mathrm{~mL}$ & 1.01 \\
\hline A10D059-82 & Soil & EPA 6020 & 01:01/9400:00 & $04 / 15 / 1011: 03$ & $0.488 \mathrm{~g} / 50 \mathrm{~mL}$ & $0.5 \mathrm{~g} / 50 \mathrm{~mL}$ & 1.02 \\
\hline A10D059-83 & Soil & EPA 6020 & 01:01:9400:00 & 04/15/10 11:03 & $0.495 \mathrm{~g} / 50 \mathrm{~mL}$ & $0.5 \mathrm{~g} / 50 \mathrm{~mL}$ & 1.01 \\
\hline A10D059-84 & Soil & EPA 6020 & 01/01/9400:00 & 04/15/1011:03 & $0.493 \mathrm{~g} / 50 \mathrm{~mL}$ & $0.5 \mathrm{~g} / 50 \mathrm{~mL}$ & 1.01 \\
\hline A10D059-85 & Soil & EPA 6020 & 01/01/9400:00 & 04/15/1011:03 & $0.494 \mathrm{~g} / 50 \mathrm{~mL}$ & $0.5 \mathrm{~g} / 50 \mathrm{~mL}$ & 1.01 \\
\hline A10D059-86 & Soil & EPA 6020 & 01/01/9400:00 & 04/15/1011:03 & $0.496 \mathrm{~g} / 50 \mathrm{~mL}$ & $0.5 \mathrm{~g} / 50 \mathrm{~mL}$ & 1.01 \\
\hline \multicolumn{8}{|l|}{ Batch: 1004214} \\
\hline A10D059-87 & Soil & EPA 6020 & 01/01/9400:00 & $04 / 16 / 1010: 18$ & $0.487 \mathrm{~g} / 50 \mathrm{~mL}$ & $0.5 \mathrm{~g} / 50 \mathrm{~mL}$ & 1.03 \\
\hline A10D059-88 & Soil & EPA 6020 & 01:01/9400:00 & $04 / 16 / 1010: 18$ & $0.496 \mathrm{~g} / 50 \mathrm{~mL}$ & $0.5 \mathrm{~g} / 50 \mathrm{~mL}$ & 1.01 \\
\hline A10D059-89 & Soil & EPA 6020 & 01/01/9400:00 & $04 / 16 / 1010: 18$ & $0.499 \mathrm{~g} / 50 \mathrm{~mL}$ & $0.5 \mathrm{~g} / 50 \mathrm{~mL}$ & 1.00 \\
\hline A10D059-90 & Soil & EPA 6020 & 01:01/9400:00 & $04 / 16 / 1010: 18$ & $0.495 \mathrm{~g} / 50 \mathrm{~mL}$ & $0.5 \mathrm{~g} / 50 \mathrm{~mL}$ & 1.01 \\
\hline
\end{tabular}

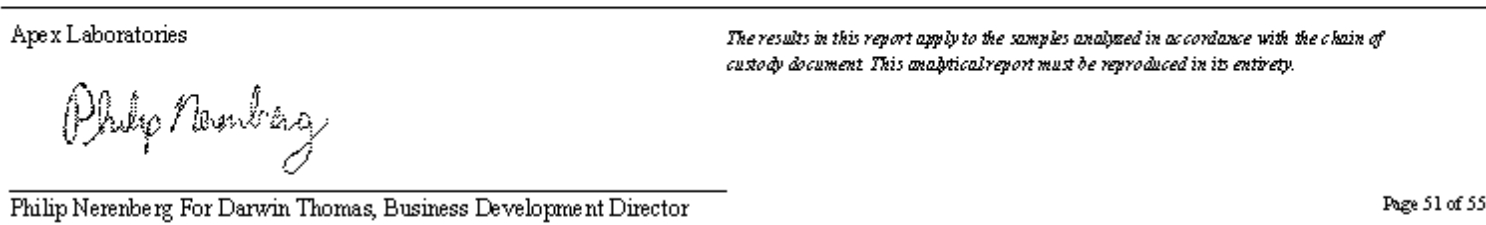




\section{Apex Labs}

12232 S.W. Garden Place

Tigard, OR 97223

503-718-2323 Phone

503-718-0333 Fax

Thursday, May 13, 2010

Neil Morton

GeoEngineers-Seattle

600 Stewart St. Suite 1700

Seattle, WA 98101

RE: Oregon Metals Evaluation / 2787-050-000

Enclosed are the results of analyses for work order A10D066, which was received by the laboratory on $4 / 5 / 2010$ at $3: 35: 00 \mathrm{PM}$

Thank you for using Apex Labs. We appreciate your business and strive to provide the highest quality services to the environmental industry.

If you have any que stions concerning this report or the services we offer, please feel free to contact me by email at: pnerenberg@apex-labs.com, or by phone at 503-718-2323.

Apex Laboratories

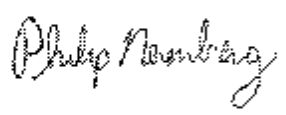

Philip Nerenberg For Darwin Thomas, Business Development Director

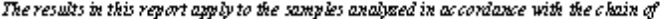

custody document This andatical regon mus be reproduced in it entivety.

Page 1 of $5 ?$ 


\section{Apex Labs}

12232 S.W. Garden Place

Tigard, OR 97223

503-718-2323 Phone

503-718-0333 Fax
GeoEngineers -Seatile

600 S tewart St. Suite 1700

Seattle, WA 98101
Project OregonMetals Evahuation

Project Humber. 2787-050-000

Project Manazer. Neil Morton
Reported

$05 / 13 / 1022: 44$

ANAL YTICAL REPORT FOR SAMPLES

\begin{tabular}{|c|c|c|c|c|}
\hline \multicolumn{5}{|c|}{ SAMPLE INF ORMATION } \\
\hline Sample ID & Laboratory ID & Matrix & Date Sampled & Date Received \\
\hline KL04B1 & A10D066-01 & Soil & 01/01/9400:00 & $04,05 / 1015: 35$ \\
\hline KL05Al & A10D066-02 & Soil & 01:01/9400:00 & $04,05 / 1015: 35$ \\
\hline KL05B1 & A10D066-03 & Soil & 01:01/9400:00 & $04 / 05 / 1015: 35$ \\
\hline KL06Al & A10D066-04 & Soil & 01/01/9400:00 & $04,05 / 1015: 35$ \\
\hline KL0бB1 & A10D066-05 & Soil & 01/01/9400:00 & $04,05 / 1015: 35$ \\
\hline KLOTAl & A10D066-06 & Soil & 01:01/9400:00 & $04,05 / 1015: 35$ \\
\hline KLOTB1 & A10D066-0? & Soil & 01:01/9400:00 & $0405 / 1015: 35$ \\
\hline KL08A1 & A10D066-08 & Soil & 01/01/9400:00 & $04 / 05 / 1015: 35$ \\
\hline KL08BB & A10D066-09 & Soil & 01/01/9400:00 & $04,05 / 1015: 35$ \\
\hline KL0:8B2 & A10D066-10 & Soil & 01/01/9400:00 & $04 / 05 / 1015: 35$ \\
\hline $\mathrm{KLO} A \mathrm{Al}$ & A10D066-11 & Soil & 01:01/9400:00 & $04 / 05 / 1015: 35$ \\
\hline KL09B1 & A10D066-12 & Soil & 01/01/9400:00 & $04,05 / 1015: 35$ \\
\hline KL10Al & A10D066-13 & Soil & 01/01/9400:00 & $04,05 / 1015: 35$ \\
\hline KL10B1 & A10D066-14 & Soil & 01:01/9400:00 & $04,05 / 1015: 35$ \\
\hline KLllA1 & A10D066-15 & Soil & 01:01/9400:00 & $04,05 / 1015: 35$ \\
\hline KLllB1 & A10D066-16 & Soil & 01/01/9400:00 & $04,05 / 1015: 35$ \\
\hline KL12A2 & A10D066-17 & Soil & 01/01/9400:00 & $04,05 / 1015: 35$ \\
\hline KL12B2 & A10D066-18 & Soil & 01:01/9400:00 & $04,05 / 1015: 35$ \\
\hline KLL13A2 & A10D066-19 & Soil & 01:01/9400:00 & $04,05 / 1015: 35$ \\
\hline KL13B2 & A10D066-20 & Soil & 01/01/9400:00 & $04,05 / 1015: 35$ \\
\hline KL14A1 & A10D066-21 & Soil & 01/01/9400:00 & $04 / 05 / 1015: 35$ \\
\hline KL14BI & A10D066-22 & Soil & 01:01/9400:00 & $04,05 / 1015: 35$ \\
\hline KLLA1 & A10D066-23 & Soil & 01/01/9400:00 & $04,05 / 1015: 35$ \\
\hline KLl5Bl & A10D066-24 & Soil & 01:01/9400:00 & 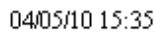 \\
\hline KLl6Al & A10D066-25 & Soil & 01/01/9400:00 & $04,05 / 1015: 35$ \\
\hline KLl6Bl & A10D066-26 & Soil & 01:01/9400:00 & $04,05 / 1015: 35$ \\
\hline KL 16B2 & A10D066-27 & Soil & 01:01/9400:00 & $04,05 / 1015: 35$ \\
\hline KLITAl & A10D066-28 & Soil & 01:01/9400:00 & $04 / 05 / 1015: 35$ \\
\hline KLITB1 & A10D066-29 & Soil & 01/01/9400:00 & $04,05 / 1015: 35$ \\
\hline KL18Al & A10D066-30 & Soil & 01:01/9400:00 & $04,05 / 1015: 35$ \\
\hline KLl8B1 & A10D066-31 & Soil & 01:01/9400:00 & $04,05 / 1015: 35$ \\
\hline KL20Al & A10D066-32 & Soil & 01:01/9400:00 & $04,05 / 1015: 35$ \\
\hline KL20B1 & A10D066-33 & Soil & 01/01/9400:00 & $04,05 / 1015: 35$ \\
\hline KL2lAl & A10D066-34 & Soil & 01:01/9400:00 & $04,05 / 1015: 35$ \\
\hline KL2lBl & A10D066-35 & Soil & 01/01/9400:00 & $04,05 / 1015: 35$ \\
\hline
\end{tabular}

Apex Laboratories

The results in this report apply to the samples analysed in ac coriance with the chain of

Pfow

custody document This masticalrepon mus be reproduced in it entivety.

Philip Nerenberg For Dawin Thomas, Business Development Director

Page 2 of 57 


\section{Apex Labs}

12232 S.W. Garden Place

Tigard, OR 97223

503-718-2323 Phone

503-718-0333 Fax

\begin{tabular}{|llr}
\hline GeoEngineers -Seattle & Project OregonMetals Evaluation \\
600 S tewartSt. Suite 1700 & Project Humber. 2787-050-000 \\
Seattle, WA 98101 & Project Manager. Neil Morton & Reported \\
\hline
\end{tabular}

ANALYTICAL REPORT FOR SAMPLES

\begin{tabular}{|c|c|c|c|c|}
\hline \multicolumn{5}{|c|}{ SAMPLE INF ORMATION } \\
\hline Sample II & Laboratory ID & Matrix & Date Sampiled & Date Recrived \\
\hline KL23Al & A10D066-36 & Soil & 01:01/9400:00 & $04,05 / 1015: 35$ \\
\hline KL23B 1 & A10D066-37 & Soil & 01:01/9400:00 & $04 / 05 / 1015: 35$ \\
\hline KL25A1 & A10D066-38 & Soil & 01:01/9400:00 & $04,05 / 1015: 35$ \\
\hline KL25B1 & A10D066-39 & Soil & 01/01/9400:00 & $04 / 05 / 1015: 35$ \\
\hline KL26A 1 & A10D066-40 & Soil & 01:01/9400:00 & $04,05 / 1015: 35$ \\
\hline KL26B1 & A10D066-41 & Soil & 01:01/9400:00 & $04 / 05 / 1015: 35$ \\
\hline $\mathrm{KL} 28 \mathrm{Al}$ & A10D066-42 & Soil & 01/01/9400:00 & $04,05 / 1015: 35$ \\
\hline KL28B 1 & A10D066-43 & Soil & 01/01/9400:00 & $04,05 / 1015: 35$ \\
\hline LMOIA I & A10D066-44 & Soil & 01:01/9400:00 & $04,05 / 1015: 35$ \\
\hline LM01Bl & A10D066-45 & Soil & 01:01/9400:00 & $04,05 / 1015: 35$ \\
\hline LM01B2 & A10D066-46 & Soil & 01/01/9400:00 & $04,05 / 1015: 35$ \\
\hline LM02A I & A10D066-47 & Soil & 01:01/9400:00 & $04,05 / 1015: 35$ \\
\hline LM03B1 & A10D066-48 & Soil & 01:01/9400:00 & $04,05 / 1015: 35$ \\
\hline LMO5A & A10D066-49 & Soil & 01:01/9400:00 & $04,05 / 1015: 35$ \\
\hline LM05B2 & A10D066-50 & Soil & 01/01/9400:00 & $04 / 05 / 1015: 35$ \\
\hline LM0бB1 & A10D066-51 & Soil & 01:01/9400:00 & $04 / 05 / 1015: 35$ \\
\hline LMOTAl & A10D066-52 & Soil & 01:01/9400:00 & $04,05 / 1015: 35$ \\
\hline LMOBA I & A10D066-53 & Soil & 01:01/9400:00 & $04,05 / 1015: 35$ \\
\hline LMO:B I & A10D066-54 & Soil & 01:01/9400:00 & $04,05 / 1015: 35$ \\
\hline LM10Al & A10D066-55 & Soil & 01/01/9400:00 & $04,05 / 1015: 35$ \\
\hline LM 10B1 & A10D066-56 & Soil & 01:01/9400:00 & $04,05: 1015: 35$ \\
\hline LMIlBl & A10D066-57 & Soil & 01:01/9400:00 & $04,05 / 1015: 35$ \\
\hline LM12Al & A10D066-58 & Soil & 01:01/9400:00 & $04 / 05 / 1015: 35$ \\
\hline LMI3Al & A10D066-59 & Soil & 01:01/9400:00 & $04,05 / 1015: 35$ \\
\hline LM13B1 & A10D066-60 & Soil & 01/01/9400:00 & $04,05 / 1015: 35$ \\
\hline LM15Al & A10D066-61 & Soil & 01:01/9400:00 & 04/05/10 15:35 \\
\hline LM15Bl & A10D066-62 & Soil & 01/01/9400:00 & $04 / 05 / 1015: 35$ \\
\hline LM 16B1 & A10D066-63 & Soil & 01:01/9400:00 & $04,05 / 1015: 35$ \\
\hline LMITAl & A10D066-64 & Soil & 01/01/9400:00 & $04,05 / 1015: 35$ \\
\hline LM19B1 & A10D066-65 & Soil & 01:01/9400:00 & $04,05 / 1015: 35$ \\
\hline LM20A2 & A10D066-66 & Soil & 01:01/9400:00 & $04 / 05 / 1015: 35$ \\
\hline LM2lB2 & A10D066-67 & Soil & 01:01/9400:00 & $04,05 / 1015: 35$ \\
\hline LM22A2 & A10D066-68 & Soil & 01:01/9400:00 & 04/05/10 15:35 \\
\hline $\mathrm{LM} 22 \mathrm{~B} 2$ & A10D066-69 & Soil & 01:01/9400:00 & $04,05 / 1015: 35$ \\
\hline EO02A2 & A10D066-70 & Soil & 01/01/9400:00 & $0405 / 1015: 35$ \\
\hline
\end{tabular}

Apex Laboratories

The results in this report aspiy to the samples analysed in accoriasce with the c knin of

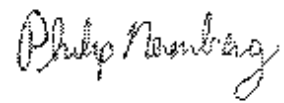

custody document This arditicalrepont mus be reproduced in it entrety.

Philip Nerenberg For Darwin Thornas, Business Development Director

Puge 3 of 57 


\section{Apex Labs}

12232 S.W. Garden Place

Tigard, OR 97223

503-718-2323 Phone

503-718-0333 Fax

$\begin{array}{lc}\text { GeoEnejiners -Seattle } & \text { Project OregonMetals Evaluation } \\ 600 \text { StewartSt. Suite } 1700 & \text { Project Number. } 2787-050-000 \\ \text { Seattle WA } 98101 & \text { Project Mamager. Heil Morton }\end{array}$

Seattle, WA 98101

ANAL YTICAL REPORT FOR SAMPLES

\begin{tabular}{|c|c|c|c|c|}
\hline \multicolumn{5}{|c|}{ SAMPLE INF ORHATION } \\
\hline Sample ID & Laboratory ID & Matrix & Date Sampled & Date Received \\
\hline EO02B1 & A10D066-71 & Soil & $01 / 01 / 9400: 00$ & $04 / 05 / 1015: 35$ \\
\hline EOOTA1 & A10D066-72 & Soil & 01/01/9400:00 & $04,05 / 1015: 35$ \\
\hline EO08A2 & A10D066-73 & Soil & 01:01/9400:00 & $04 / 05 / 1015: 35$ \\
\hline EO0:B 2 & A10D066-74 & Soil & 01/01/9400:00 & $04,05 / 1015: 35$ \\
\hline EO09B1 & A10D066-75 & Soil & 01:01/9400:00 & $04,05 / 1015: 35$ \\
\hline EOllB1 & A10D066-76 & Soil & 01:01/9400:00 & $04,05 / 1015: 35$ \\
\hline EO13B1 & A10D066-77 & Soil & 01:01/9400:00 & $04,05 / 1015: 35$ \\
\hline EO14A2 & A10D066-78 & Soil & 01/01/9400:00 & $04,05 / 1015: 35$ \\
\hline EO14B2 & A10D066-79 & Soil & 01/01/9400:00 & $04 / 05 / 1015: 35$ \\
\hline EOl6A2 & A10D066-80 & Soil & 01/01/9400:00 & $04 / 05 / 1015: 35$ \\
\hline EOl6B2 & A10D066-81 & Soil & 01:01/9400:00 & $04,05 / 1015: 35$ \\
\hline EO1TA2 & A10D066-82 & Soil & 01/01/9400:00 & $04,05 / 1015: 35$ \\
\hline EOITB2 & A10D066-83 & Soil & 01/01/9400:00 & $04,05 / 1015: 35$ \\
\hline EO18B2 & A10D066-84 & Soil & 01/01/9400:00 & $04,05 / 1015: 35$ \\
\hline EO20A2 & A10D066-85 & Soil & 01:01/9400:00 & $04,05 / 1015: 35$ \\
\hline EO20B2 & A10D066-86 & Soil & 01:01/9400:00 & $0405 / 1015: 35$ \\
\hline $\mathrm{EO} 22 \mathrm{~A} 2$ & A10D066-87 & Soil & 01/01/9400:00 & $04 / 05 / 1015: 35$ \\
\hline $\mathrm{EO} 22 \mathrm{~B} 2$ & A10D066-88 & Soil & 01/01/9400:00 & $04 / 05 / 1015: 35$ \\
\hline EO23A2 & A10D066-89 & Soil & 01:01/9400:00 & $04 / 05 / 1015: 35$ \\
\hline $\mathrm{EO} 23 \mathrm{~B} 2$ & A10D066-90 & Soil & 01:01/9400:00 & $0405 / 1015: 35$ \\
\hline EO24A2 & A10D066-91 & Soil & 01/01/9400:00 & $04,05 / 1015: 35$ \\
\hline
\end{tabular}

The results in this report aspiy to the samples analyzed in accordaxce with the c knin of

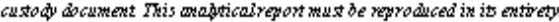

Reported:

05/13/1022:44 


\section{Apex Labs}

12232 S. W. Garden Phace

Tigard, OR 97223

503-718-2323 Phone

503-718-0333 Fax

GeoEngineers -Seattle

600 S tewartSt. Suite 1700

Seattle, WA 98101
Project OregonMetals Evaluation

Project Number. 2787-050-000

Project Marazer. Neil Morton
Reported

$05 / 13 / 1022: 44$

QUALITY CONTROL (QC) SAMPLE RESULTS

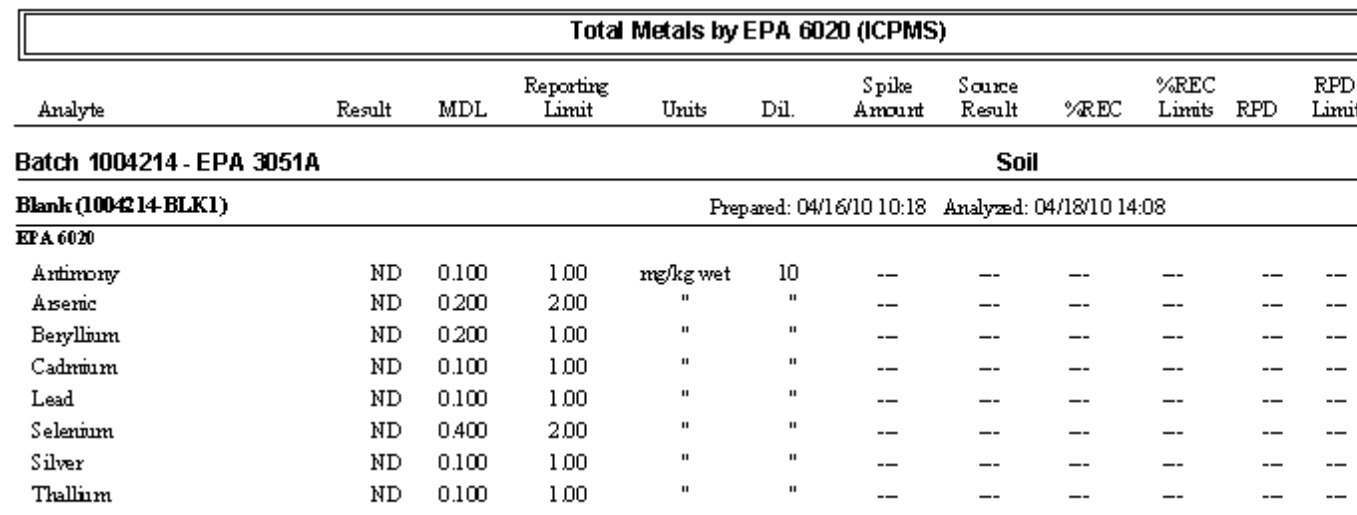

LCS (100414-BS1)

Prepared: 04/16/10 10:18 Analyzed: 04/18/10 14:11

EPA 602

\begin{tabular}{|c|c|c|c|c|c|c|c|c|c|c|c|}
\hline Antimory & 25.3 & 0.100 & 100 & $\mathrm{mg} / \mathrm{kg}$ wet & 10 & 25.0 & - & 101 & $80-120 \%$ & - & -- \\
\hline Aseric & 46.3 & 0200 & 200 & $"$ & $"$ & 50.0 & - & 93 & $"$ & - & -- \\
\hline Beryllium & 23.5 & 0200 & 100 & $"$ & $"$ & 25.0 & - & 94 & $"$ & - & -- \\
\hline Cadrimem & 47.5 & 0.100 & 100 & $"$ & $"$ & 50.0 & -- & 95 & $"$ & - & -- \\
\hline Selenium & 23.8 & 0.400 & 200 & $"$ & $"$ & 25.0 & - & 95 & $"$ & - & -- \\
\hline Silver & 23.6 & 0.100 & 100 & $"$ & $"$ & $"$ & -- & 95 & $"$ & - & -- \\
\hline Thallinm & 22.8 & 0.100 & 100 & $"$ & $"$ & $"$ & - & 91 & $"$ & - & -- \\
\hline
\end{tabular}

Duplicate (100414DUPI)

Frepared: 04/16/10 10:18 Analyzed: 04/18/10 14:38

QC Sarre S mqle: KLC5Al (A10D066-(2)

EPA 6020

Antimory

Asseric

Beryllium

Cadrinum

Lead

Selenimum

Silver

Thallium

$\begin{array}{rrr}\mathbf{0 . 2 3 1} & 0.110 & 1.10 \\ \mathbf{4 7 4} & 0220 & 220 \\ \mathbf{0 . 3 3 0} & 0220 & 1.10 \\ \mathbf{0 . 2 2 0} & 0.110 & 1.10 \\ \mathbf{1 2 7} & 0.110 & 1.10 \\ \mathbf{0 . 5 2 7} & 0.440 & 220 \\ \text { HD } & 0.110 & 1.10 \\ \text { HD } & 0.110 & 1.10\end{array}$

Matrix spile (100214Ms1)

$\begin{array}{cccccc}m g / k g d r y & 10 & -- & 0.122 & -- & - \\ " & " & -- & 5.25 & -- & - \\ " & " & -- & 0.365 & -- & - \\ " & " & -- & 0.144 & -- & - \\ " & " & -- & 13.2 & -- & - \\ " & \text { " } & -- & \text { HD } & -- & - \\ " & \text { " } & -- & \text { HD } & -- & - \\ " & \text { " } & -- & \text { HD } & -- & -\end{array}$

\begin{tabular}{rrrr}
-- & 62 & $40 \%$ & Q-05, J \\
-- & 11 & $40 \%$ & \\
-- & 10 & $40 \%$ & J \\
-- & 42 & $40 \%$ & Q-05, J \\
-- & 4 & $40 \%$ & \\
-- & & $40 \%$ & J \\
-- & & $40 \%$ & \\
-- & & $40 \%$ & \\
& & & \\
\hline
\end{tabular}

QC S aurce S mple: KLO5Al (A10D066-O)

Prepared: 04/16/10 10:18 Analyzed: 04/18/10 14:41

Apex Laboratories

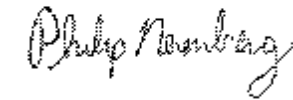

The results in this report appiy to the samples analyzed in accoriase with the chain of custody do cument This masticalrepon mus be reproduced in it entrety.

Philip Nerenberg For Darwin Thomas, Business Development Director 


\section{Apex Labs}

12232 S.W. Garden Place

Tigard, OR 97223

503-718-2323 Phone

503-718-0333 Fax

GeoEngineers -Seatt

600 S tewartSt. Suite 1700

Seattle, WA 98101
Project Oregon Metals Evahuation

Project Humber. 2787-050-000

Project Manager. Neil Morton
Reported

$05 / 13 / 1022: 44$

QUALITY CONTROL (QC) SAMPLE RESULTS

\begin{tabular}{|c|c|c|c|c|c|c|c|c|c|c|c|c|}
\hline \multicolumn{13}{|c|}{ Total hetals by EPA 6020 (ICPMS) } \\
\hline Analyte & Result & MDL & $\begin{array}{l}\text { Reporting } \\
\text { Limit }\end{array}$ & Units & Dil. & $\begin{array}{c}\text { Spike } \\
\text { Amourt }\end{array}$ & $\begin{array}{l}\text { Source } \\
\text { Result }\end{array}$ & $\%$ REC & $\begin{array}{l}\% \mathrm{REC} \\
\text { Limits }\end{array}$ & RPD & $\begin{array}{l}\text { RPD } \\
\text { Limit }\end{array}$ & Wotes \\
\hline
\end{tabular}

Batch 1004214 - EPA 3051A

Soil

Matrix Spile (100214-MS1)

Prepared: 04/16/10 10:18 Analyzed: 04/18/10 14:41

OC Saurce S mple: KLC6Al (A10D066-(12)

EPA 6020

\begin{tabular}{|c|c|c|c|c|c|c|c|c|c|c|c|}
\hline Antimory & 23.7 & 0.111 & 1.11 & $m g / k g d r y$ & 10 & 27.7 & 0.122 & 85 & $75-125 \%$ & - & - \\
\hline Aseric & 57.7 & 0222 & 222 & $"$ & $"$ & 55.4 & 5.25 & 95 & $"$ & - & - \\
\hline Beryllium & 25.3 & 0222 & 1.11 & $"$ & $"$ & 27.7 & 0.365 & 90 & $"$ & - & - \\
\hline Cadrimem & 54.4 & 0.111 & 1.11 & $"$ & $"$ & 55.4 & 0.144 & 98 & $"$ & - & - \\
\hline Lead & 64.1 & 0.111 & 1.11 & $"$ & $"$ & $"$ & 13.2 & $9_{2}$ & $"$ & - & - \\
\hline Selenvium & 25.6 & 0.443 & 222 & $"$ & $"$ & 27.7 & $\mathrm{HD}$ & 96 & $"$ & - & -- \\
\hline Silver & 25.5 & 0.111 & 1.11 & $"$ & $"$ & $"$ & HD & 96 & $"$ & - & - \\
\hline Thallium & 25.2 & 0.111 & 1.11 & $"$ & $"$ & $"$ & HD & 91 & $"$ & - & - \\
\hline
\end{tabular}

Matrix Spile (100414MS2) Prepared: 04/16/10 10:18 Analyzed: 04/18/10 15:04

QC S aurce S mple: KL:BDI (A10D066-09)

EPA 6020

Antimory

Aseric

Beryllium

Cadrim

Lead

Selenimim

Silver

Thallinm

$\begin{array}{lll}21.6 & 0.106 & 1.06 \\ 51.2 & 0213 & 2.13 \\ 24.2 & 0213 & 1.06 \\ 51.2 & 0.106 & 1.06 \\ 53.8 & 0.106 & 1.06 \\ 23.5 & 0.425 & 2.13 \\ 25.0 & 0.106 & 1.06 \\ 23.1 & 0.106 & 106\end{array}$

$m g / k g d r y \quad 10$

$\begin{array}{cc}26.6 & 0.127 \\ 53.2 & 5.04 \\ 26.6 & \text { ND } \\ 53.2 & \text { HD } \\ " & 6.45 \\ 26.6 & 2.51 \\ " & \text { HD } \\ " & \text { HD }\end{array}$

$\begin{array}{cccc}81 & 75-125 \% & -- & - \\ 87 & " & -- & - \\ 91 & " & - & - \\ 96 & " & -- & - \\ 89 & " & -- & - \\ 79 & " & - & - \\ 94 & " & - & - \\ 87 & " & - & -\end{array}$

Apex Laboratories

Polith nowh

Philip Nerenberg For Darwin Thormas, Business Development Director

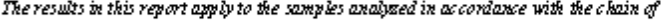
custody doument This and atical repon mus be reproduced in it entivety. 


\section{Apex Labs}

12232 S.W. Garden Place

Tigard, OR 97223

503-718-2323 Phone

503-718-0333 Fax
GeoEngineers -Seattle

600 S tewartSt. Suite 1700

Seattle, WA 98101
Project OregonMetals Evaluation

Project Humber. 2787-050-000

Project Manager. Heil Mortom
Reported:

$05 / 13 / 1022: 44$

QUALITY CONTROL (QC) SAMPLE RESULTS

\begin{tabular}{|c|c|c|c|c|c|c|c|c|c|c|c|c|}
\hline \multicolumn{13}{|c|}{ Total hetals by EPA 6020 (ICPMS) } \\
\hline Analyte & Result & MDL & $\begin{array}{l}\text { Reporting } \\
\text { Limit }\end{array}$ & Units & Dil. & $\begin{array}{l}\text { Spike } \\
\text { Amourt }\end{array}$ & $\begin{array}{l}\text { Source } \\
\text { Result }\end{array}$ & $\% \mathrm{REC}$ & $\begin{array}{l}\% \mathrm{REC} \\
\text { Limits }\end{array}$ & RPD & $\begin{array}{l}\text { RPD } \\
\text { Limit }\end{array}$ & Notes \\
\hline
\end{tabular}

Soil

Batch 1004274 - EPA 3051A

Blank(1004:74-BLK1)

Prepared: 04/20/10 11:S9 Analyzed: 04/23/10 16:38

\section{EPA 6020}

Antimory

Aseric

Beryllium

Cadrimim

Lead

Selenium

Silver

Thallinm

LCS(100474BS1)

EFA6020

Antimory

Aseric

Beryllium

Cadrimim

Lead

Seleninum

Silver

Thallinm

Duplicate (100474DUPI)

Frepared: 04/20/10 11:39 Analyrsd: 04/23/10 17:03

QC Sarces ample: KILAA (Al0D066-2)

EPA 6020

Antimory

Aseric

Beryllium

Cadrimim

Lead

Selenium

Silver

Thalling

$\begin{array}{ccc}\text { ND } & 0.106 & 106 \\ \mathbf{2 7 3} & 0212 & 2.12 \\ \mathbf{0 . 2 4 4} & 0212 & 106 \\ \mathbf{0 . 2 9 7} & 0.106 & 1.06 \\ \mathbf{4 8 8} & 0.106 & 1.06 \\ \mathbf{0 . 4 6 6} & 0.424 & 2.12 \\ \text { ND } & 0.106 & 1.06 \\ \text { HD } & 0.106 & 1.06\end{array}$

Matrix Spile (100474MS1)

\begin{tabular}{|c|c|c|c|c|c|c|c|c|c|}
\hline 25.1 & 0.100 & 100 & $\mathrm{mg} / \mathrm{kg}$ wet & 10 & 25.0 & -- & 100 & $80-120 \%$ & -- \\
\hline 48.0 & 0200 & 200 & $"$ & $"$ & 50.0 & -- & 96 & $"$ & -- \\
\hline 23.0 & 0200 & 100 & $"$ & $"$ & 25.0 & -- & 92 & $"$ & -- \\
\hline 48.9 & 0.100 & 100 & $"$ & $"$ & 50.0 & -- & 98 & $"$ & -- \\
\hline 48.0 & 0.100 & 100 & $"$ & $"$ & $"$ & -- & 96 & $"$ & -- \\
\hline 23.3 & 0.400 & 200 & $"$ & $"$ & 25.0 & -- & 93 & $"$ & -- \\
\hline 24.0 & 0.100 & 100 & $"$ & $"$ & $"$ & -- & 96 & $"$ & -- \\
\hline 23.6 & 0.100 & 100 & $"$ & $"$ & $"$ & -- & 95 & $"$ & -- \\
\hline
\end{tabular}

Prepared: 04/20/10 11:59 Analyzed: 04/23/10 16:41

QC S aurce S mple: KL14AI (A10D066-21)

Apex Laboratories

(1)
The results in this report aspiy to the samples analyzed in accordase with the $c$ knin of

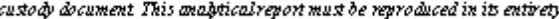

Philip Nerenberg For Dawin Thomas, Business Development Director 


\section{Apex Labs}

12232 S.W. Garden Place

Tigard, OR 97223

503-718-2323 Phone

503-718-0333 Fax

GeoEngineers -Seatt

600 S tewartSt. Suite 1700

Project OregonMetals Evaluation

Project Humber. 2787-050-000

Project Manager. Neil Morton

Reporte

$05 / 131022: 44$

Seattle, WA 98101

QUALITY CONTROL (QC) SAMPLE RESULTS

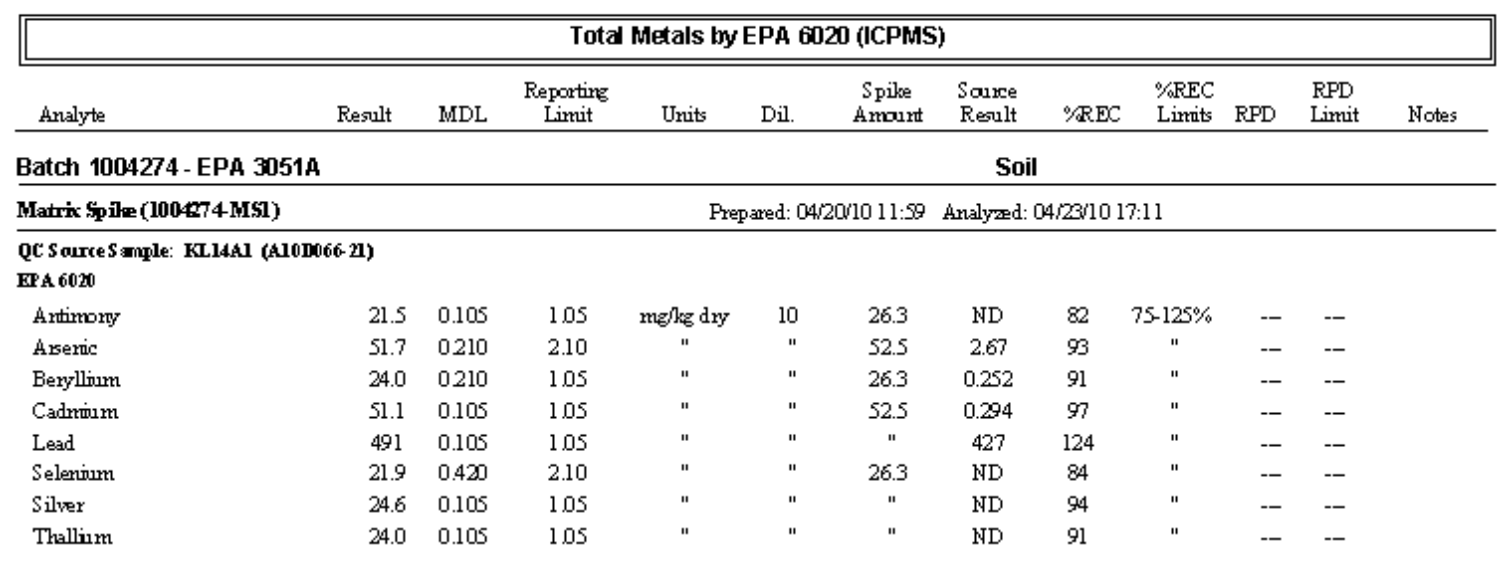

\footnotetext{
Apex Laboratories

The results is this report apply to the samples analyzed in accoriaxe with the cknin of

$$
\text { (1) }
$$




\section{Apex Labs}

12232 S.W. Garden Place

Tigard, OR 97223

503-718-2323 Phone

503-718-0333 Fax

GeoEngineers -Seattle

600 S tewart St. Suite 1700

Seattle, WA 98101

Project OregonMetals Evahuation

Project Number. 2787-050-000

Reported.

Project Manager. Neil Morton

QUALITY CONTROL (QC) SAMPLE RESULTS

\begin{tabular}{|c|c|c|c|c|c|c|c|c|c|c|c|c|}
\hline \multicolumn{13}{|c|}{ Total Metals by EPA 6020 (ICPHS) } \\
\hline Analyte & Result & MDL & $\begin{array}{l}\text { Reporting } \\
\text { Limit }\end{array}$ & Units & Dil. & $\begin{array}{c}\text { Spike } \\
\text { Amourt }\end{array}$ & $\begin{array}{l}\text { Sounce } \\
\text { Reult }\end{array}$ & $\%$ REC & $\begin{array}{l}\% \mathrm{REC} \\
\text { Limrits }\end{array}$ & RPD & $\begin{array}{l}\text { RPD } \\
\text { Limit }\end{array}$ & Notes \\
\hline
\end{tabular}

Batch 1004324 - EPA $3051 A$

Soil

Blank (1004324BLK2)

Prepared: 04/22/10 08:28 Analyzd: 04/20/10 20:13

\section{EPA 6020}

Antimory

Aseric

Beryllim

Cadrimim

Lead

Selenium

Thallinm

Result MDL Limit

il

Blank (1004324-BLK3)

EPA 6020

Frepared: 04/22/10 08:28 Analyzed: 04/23/10 15:54

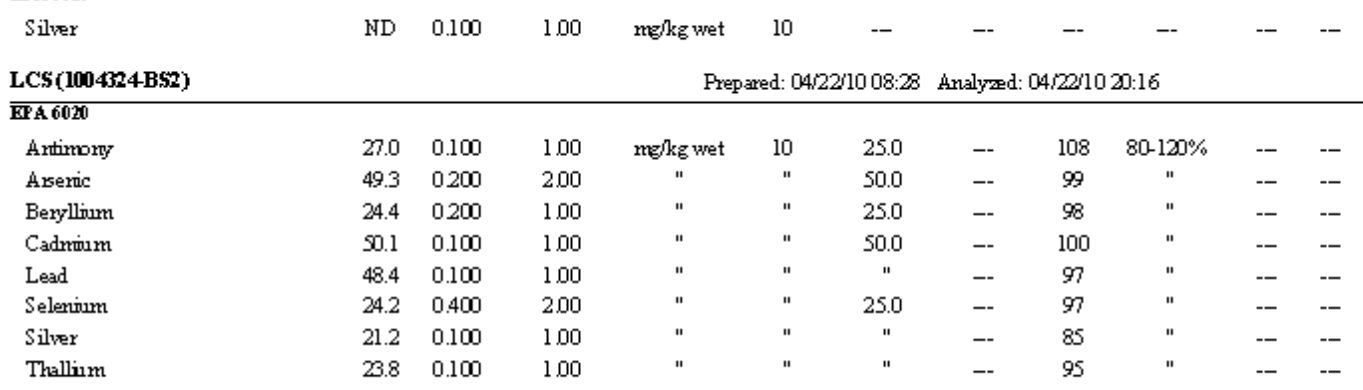

Duplicate (1004324DUP1)

Prepared: 04/22/10 08:28 Analyzd: 04/25/10 19:06

QC S aurce S mqle: KL20Al (Al0D066-32)

EPA 6020

Antimory

Aseric

Beryllium

Cadrium

Lead

Selenium

Silver

Thallium

$\begin{array}{lll}\text { HD } & 0.100 & 100 \\ \text { HD } & 0200 & 2.00 \\ \text { HD } & 0200 & 1.00 \\ \text { HD } & 0.100 & 100 \\ \text { HD } & 0.100 & 100 \\ \text { HD } & 0.400 & 200 \\ \text { HD } & 0.100 & 100\end{array}$

mg/kg wet 10

$--\quad-$

$-\quad--\quad-$

$-\quad--\quad-$

$-\quad-$

$--$

$\begin{array}{llll}-- & -- & - & - \\ -- & -- & - & - \\ -- & -- & - & - \\ -- & -- & - & - \\ -- & -- & - & - \\ -- & -- & - & - \\ -- & -- & -- & -\end{array}$

$\begin{array}{lll}\mathbf{0 . 8 8 0} & 0.125 & 126\end{array}$

Apex Laboratories

The results in this reyor apply to the samples analyzed in accoriaxe with the chain of

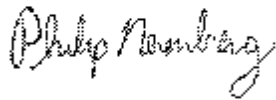

Philip Nerenberg For Darwin Thomas, Business Development Director

Puge 39 of 57 


\section{Apex Labs}

12232 S. W. Garden Phace

Tigard, OR 97223

503-718-2323 Phone

503-718-0333 Fax
GeoEngineers -Seatfle

600 S tewart $S t$. Suite 1700

Seattle, WA 98101
Project OregonMetals Evaluation

Project Number: 2787-050-000

Project Manager. Neil Morton
Reported:

$05 / 131022: 44$

QUALITY CONTROL (QC) SAMPLE RESULTS

\begin{tabular}{|c|c|c|c|c|c|c|c|c|c|c|c|c|}
\hline \multicolumn{13}{|c|}{ Total hetals by EPA 6020 (ICPhS) } \\
\hline Analyte & Result & MDL & $\begin{array}{l}\text { Reporting } \\
\text { Limit }\end{array}$ & Units & Dil. & $\begin{array}{c}\text { Spike } \\
\text { Amount }\end{array}$ & $\begin{array}{l}\text { Source } \\
\text { Reult }\end{array}$ & $\%$ REC & $\begin{array}{l}\% \mathrm{REC} \\
\text { Limits }\end{array}$ & RPD & $\begin{array}{l}\text { RPD } \\
\text { Limit }\end{array}$ & Notes \\
\hline
\end{tabular}

Batch 1004324 - EPA $3051 A$

Soil

Matrix Spile (1004324-MS1)

Prepared: 04/22/10 08:28 Analyrad: 04/26/10 19:15

QC Sarces ample: KL20Al (A10D066-32)

EPA 6020

$\begin{array}{llll}\text { Antimory } & 25.4 & 0.122 & 122 \\ \text { Aseric } & 59.3 & 0244 & 2.44 \\ \text { Beryllimm } & 29.1 & 0244 & 122 \\ \text { Cadrimim } & 62.3 & 0.122 & 122 \\ \text { Lead } & 65.4 & 0.122 & 122 \\ \text { Selerinim } & 25.6 & 0.488 & 2.44 \\ \text { Silver } & 25.6 & 0.122 & 122 \\ \text { Thallim } & 29.5 & 0.122 & 122\end{array}$

Matrix spile (1004324-Ms2)

Frepared: 04/22/1008:28 Analyzed: 04/25/10 19:38

QC S aurce S ample: KI2SB1 (A10D066-39)

EPA 6020

\begin{tabular}{|c|c|c|c|c|c|c|c|c|c|c|c|}
\hline Antimory & 22.8 & 0.112 & 1.12 & $m g / k g d r y$ & 10 & 28.0 & $\mathrm{ND}$ & 81 & $75-125 \%$ & - & - \\
\hline Aseric & 56.0 & 0224 & 224 & $"$ & $"$ & 56.0 & 3.12 & 94 & $"$ & - & - \\
\hline Beryllium & 26.3 & 0224 & 1.12 & $"$ & $"$ & 28.0 & 0.272 & 93 & $"$ & - & - \\
\hline Cadrinim & 55.2 & 0.112 & 1.12 & $"$ & $"$ & 56.0 & $\mathrm{HD}$ & 99 & $"$ & - & - \\
\hline Lead & 54.3 & 0.112 & 1.12 & $"$ & $"$ & $"$ & 2.55 & $9_{2}$ & $"$ & - & - \\
\hline Selenvium & 25.1 & 0.448 & 224 & $"$ & $"$ & 28.0 & HD & 90 & $"$ & - & - \\
\hline Silver & 23.2 & 0.112 & 1.12 & $"$ & $"$ & $"$ & ND & 83 & $"$ & - & - \\
\hline Thallium & 25.7 & 0.112 & 1.12 & $"$ & $"$ & $"$ & $\mathrm{HD}$ & 92 & $"$ & - & - \\
\hline
\end{tabular}

Apex Laboratories

(1)

Philip Nerenberg For Darwin Thomas, Business Development Director

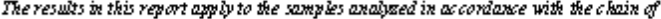

custody document This mapticolveyon mus be reproduced in it entivety. 


\section{Apex Labs}

12232 S.W. Garden Phace

Tigard, OR 97223

503-718-2323 Phone

503-718-0333 Fax

GeoEngineers -Seattle

600 S tewart St. Suite 1700

Froject OregonMetals Evahuation

Project Number. 2787-050-000

Project Manager. Neil Morton

Reporte

05/13/1022:44

QUALITY CONTROL (QC) SAMPLE RESULTS

\begin{tabular}{|c|c|c|c|c|c|c|c|c|c|c|c|c|}
\hline \multicolumn{13}{|c|}{ Total Metals by EPA 6020 (ICPhS) } \\
\hline Analyte & Result & MDL & $\begin{array}{l}\text { Reporting } \\
\text { Limit }\end{array}$ & Units & Dil. & $\begin{array}{c}\text { Spike } \\
\text { Amount }\end{array}$ & $\begin{array}{l}\text { Source } \\
\text { Result }\end{array}$ & $\% \mathrm{REC}$ & $\begin{array}{l}\% \mathrm{REC} \\
\text { Limits }\end{array}$ & RPD & $\begin{array}{l}\text { RPD } \\
\text { Limit }\end{array}$ & Notes \\
\hline
\end{tabular}

Batch 1004361 - EPA $3051 \mathrm{~A}$

Soil

Matrix spile (1004361-MS1)

Frepared: 04/23/10 12:27 Analyzed: 04/27/10 11:48

QC S aurces ample: LMO1B? (A10D066-46)

EPA 6020

$\begin{array}{llll}\text { Antimory } & 23.7 & 0.114 & 228 \\ \text { Axeric } & 59.3 & 0228 & 228 \\ \text { Beryllium } & 27.1 & 0228 & 1.14 \\ \text { Cadrimim } & 55.1 & 0.114 & 1.14 \\ \text { Lead } & 100 & 0.114 & 1.14 \\ \text { Selenium } & 23.6 & 0.457 & 228 \\ \text { Silver } & 27.3 & 0.114 & 1.14 \\ \text { Thallim } & 25.1 & 0.114 & 1.14\end{array}$

Matrix Spile (100436 1-MS2)

Prepared: 04/23/10 12:27 Analyzed: 04/27/10 12:42

QC S aurce S mqle: LM11BI (A10D066-57)

EPA 6020

\begin{tabular}{|c|c|c|c|c|c|c|c|c|c|c|}
\hline Antimory & 25.0 & 0.108 & 2.16 & $m g / l g d r y$ & 10 & 27.0 & HD & 96 & $75-125 \%$ & - \\
\hline Aseric & 51.9 & 0216 & 2.16 & $"$ & $"$ & 54.0 & 0.977 & 94 & $"$ & - \\
\hline Beryllium & 25.5 & 0216 & 108 & $"$ & $"$ & 27.0 & ND & 94 & $"$ & - \\
\hline Cadnuim & 53.1 & 0.108 & 108 & $"$ & $"$ & 54.0 & 0.160 & 98 & $"$ & - \\
\hline Lead & 53.6 & 0.108 & 108 & $"$ & $"$ & $"$ & 3.00 & 94 & $"$ & - \\
\hline Seleninum & 23.9 & 0.432 & 2.16 & $"$ & $"$ & 27.0 & $\mathrm{HD}$ & 89 & $"$ & - \\
\hline Silver & 26.0 & 0.108 & 108 & $"$ & $"$ & $"$ & HD & 96 & $"$ & - \\
\hline Thallinm & 24.9 & 0.108 & 108 & $"$ & $"$ & $"$ & $\mathrm{HD}$ & 92 & $"$ & - \\
\hline
\end{tabular}

Apex Laboratories

$$
\text { Prolptions }
$$

Philip Nerenberg For Darwin Thomas, Business Development Director
The results in this report apply to the samp bes analysed in accoriance with the chain of

custody document This madtical repon mus be reproduced in it entivety.

Puge 42 of 57 


\section{Apex Labs}

12232 S.W. Garden Place

Tigard, OR 97223

503-718-2323 Phone

503-718-0333 Fax

GeoEngineers -Seatt

600 S tewart St. Suite 1700

Project OregonMetals Evahuation

Project Humber. 2787-050-000

Project Manager. Neil Morton

Reporte

$05 / 131022: 44$

QUALITY CONTROL (QC) SAMPLE RESULTS

\begin{tabular}{|c|c|c|c|c|c|c|c|c|c|c|c|c|}
\hline \multicolumn{13}{|c|}{ Total hetals by EPA 6020 (ICPHS) } \\
\hline Analyte & Result & MDL & $\begin{array}{l}\text { Reporting } \\
\text { Limit }\end{array}$ & Units & Dil. & $\begin{array}{c}\text { Spike } \\
\text { Amourt }\end{array}$ & $\begin{array}{l}\text { Source } \\
\text { Reult }\end{array}$ & $\% \mathrm{REC}$ & $\begin{array}{l}\% \mathrm{REC} \\
\text { Limits }\end{array}$ & RPD & $\begin{array}{l}\text { RPD } \\
\text { Limit }\end{array}$ & Notes \\
\hline
\end{tabular}

Batch 1004367 - EPA 3051A

Soil

Matrix Spile (1004367-MS1)

Prepared: 04/23/10 16:56 Analyzed: 04/27/10 13:15

QC S aurce S mple: LM15Al (A10D066-61)

EPA 6020

\begin{tabular}{|c|c|c|c|c|c|c|c|c|c|c|}
\hline Antimory & 24.6 & 0.121 & 2.43 & $m g / k g d r y$ & 10 & 30.4 & HD & 81 & $75-125 \%$ & - \\
\hline Aseric & 59.0 & 0243 & 2.43 & $"$ & $"$ & 60.7 & 2.38 & 93 & $"$ & -- \\
\hline Beryllium & 29.0 & 0243 & 121 & $"$ & $"$ & 30.4 & 0.892 & 93 & $"$ & -- \\
\hline Cadrimim & 60.3 & 0.121 & 121 & $"$ & $"$ & 60.7 & 0.352 & 99 & $"$ & - \\
\hline Lead & 67.7 & 0.121 & 121 & $"$ & $"$ & $"$ & 11.4 & 93 & $"$ & -- \\
\hline Seleninum & 25.0 & 0.486 & 2.43 & $"$ & $"$ & 30.4 & $\mathrm{ND}$ & 83 & $"$ & -- \\
\hline Silver & 29.5 & 0.121 & 121 & $"$ & $"$ & $"$ & ND & 97 & $"$ & -- \\
\hline Thallium & 27.3 & 0.121 & 121 & $"$ & $"$ & $"$ & 0.154 & 89 & $"$ & -- \\
\hline
\end{tabular}

Matrix Spile (1004367-MS2)

Prepared: 04/23/10 16:56 Analyzed: 04/27/10 14:11

OC S aurce $S$ ample: EOHBI (Al0Dot6-70)

EPA 6020

Antimon

Aseric

Beryllium

Cadrimim

Lead

Selenium

Silver

Thallinm

$\begin{array}{lll}28.6 & 0.119 & 237 \\ 59.1 & 0237 & 237 \\ 28.9 & 0237 & 1.19 \\ 59.0 & 0.119 & 1.19 \\ 57.8 & 0.119 & 1.19 \\ 27.4 & 0.475 & 237 \\ 28.9 & 0.119 & 1.19 \\ 27.3 & 0.119 & 1.19\end{array}$

mellg dry 10

29.7 ND

$59.3 \quad 1.13$

$29.7 \quad 0.301$

$\begin{array}{ll}59.3 & 0.129\end{array}$

2.74

29.7 HD

" HD

$\begin{array}{cccc}96 & 75-125 \% & -- & - \\ 98 & " & -- & - \\ 96 & 1 & -- & - \\ 99 & " & -- & - \\ 93 & 1 & -- & - \\ 93 & 1 & - & - \\ 98 & 1 & - & - \\ 92 & \text { " } & - & -\end{array}$

\section{Apex Laboratories \\ (1)}

The results in this report apyly to the samples anajyed in accoriaxe with the cknin of 


\section{Apex Labs}

12232 S.W. Garden Place

Tigard, OR 97223

503-718-2323 Phone

503-718-0333 Fax

GeoEngineers -Seattle

600 S tewartSt. Suite 1700

Seattle, WA 98101
Project Oregon Metals Evaluation

Project Humber. 2787-050-000

Project Marazer. Neil Morton
Reported

05/13/1022:44

QUALITY CONTROL (QC) SAMPLE RESULTS

\begin{tabular}{|c|c|c|c|c|c|c|c|c|c|c|c|c|}
\hline \multicolumn{13}{|c|}{ Total hetals by EPA 6020 (ICPhS) } \\
\hline Analyte & Result & MDL & $\begin{array}{c}\text { Reporting } \\
\text { Limit }\end{array}$ & Units & Dil. & $\begin{array}{l}\text { Spike } \\
\text { Amourt }\end{array}$ & $\begin{array}{l}\text { Source } \\
\text { Reault }\end{array}$ & $\%$ RC & $\begin{array}{l}\text { \%REC } \\
\text { Limits }\end{array}$ & RPD & $\begin{array}{l}\text { RPD } \\
\text { Limit }\end{array}$ & Notes \\
\hline Batch 1004371 - EPA 3051A & & & \multicolumn{10}{|c|}{ Soil } \\
\hline Blank (1004371-BLK1) & \multicolumn{12}{|c|}{ Prepared: 04/23/10 18:42 Analyzed: $04 / 27 / 10$ 14:23 } \\
\hline \multicolumn{13}{|l|}{$\overline{\text { EPA 6020 }}$} \\
\hline Antimory & 0.110 & 0.100 & 200 & $\mathrm{mg} / \mathrm{kg}$ wet & 10 & -- & -- & - & -- & - & - & \\
\hline Aseric & HD & 0200 & 200 & $"$ & $"$ & - & -- & -- & -- & - & - & \\
\hline Beryllium & HD & 0200 & 100 & $"$ & $"$ & - & -- & -- & -- & - & - & \\
\hline Cadrumim & HD & 0.100 & 100 & $"$ & $"$ & - & -- & -- & -- & - & - & \\
\hline Lead & $\mathrm{HD}$ & 0.100 & 100 & $"$ & $"$ & - & -- & -- & -- & - & - & \\
\hline Selenium & $\mathrm{HD}$ & 0.400 & 200 & $"$ & $"$ & - & -- & -- & -- & - & - & \\
\hline Silver & $\mathrm{HD}$ & 0.100 & 100 & $"$ & $"$ & - & -- & -- & -- & -- & - & \\
\hline Thallinm & $\mathrm{HD}$ & 0.100 & 100 & $"$ & $"$ & - & -- & -- & -- & - & - & \\
\hline
\end{tabular}

LCS (100437 1-BS1)

Prepared: 04/23/10 18:42 Analyzed: 04/27/10 14:26

EPA 602

\begin{tabular}{|c|c|c|c|c|c|c|c|c|c|c|c|}
\hline Antimory & 26.3 & 0.100 & 200 & $\mathrm{mg} / \mathrm{kg}$ wet & 10 & 25.0 & -- & 105 & $80-120 \%$ & - & -- \\
\hline Aseric & 48.8 & 0200 & 200 & $"$ & $"$ & 50.0 & - & 98 & $"$ & - & -- \\
\hline Beryllium & 23.7 & 0200 & 100 & $"$ & $"$ & 25.0 & -- & 95 & $"$ & -- & -- \\
\hline Cadnimam & 48.9 & 0.100 & 100 & $"$ & $"$ & 50.0 & -- & 98 & $"$ & - & -- \\
\hline Lead & 45.8 & 0.100 & 100 & $"$ & $"$ & $"$ & -- & $9_{2}$ & $"$ & - & -- \\
\hline Selenvium & 23.1 & 0.400 & 200 & $"$ & $"$ & 25.0 & -- & 93 & $"$ & - & -- \\
\hline Silver & 23.8 & 0.100 & 100 & $"$ & $"$ & $"$ & -- & 95 & $"$ & - & -- \\
\hline Thallinm & 22.8 & 0.100 & 100 & $"$ & $"$ & $"$ & -- & 91 & $"$ & - & -- \\
\hline
\end{tabular}

Duplicate (100437 1-DUPI)

Frepared: 04/23/10 18:42 Analyzed: 04/27/10 14:41

QC Sarces ample: E016A2 (A10D066-80)

EPA 6020

Antimory

Asseric

Beryllium

Cadrinum

Lead

Selenium

Silver

Thallium

$\begin{array}{ccc}\text { HD } & 0.103 & 206 \\ \mathbf{L . 1 8} & 0206 & 206 \\ \mathbf{0 . 3 5 0} & 0206 & 1.03 \\ \mathbf{0 . 2 7 8} & 0.103 & 1.03 \\ \mathbf{7 . 4 9} & 0.103 & 1.03 \\ \text { HD } & 0.412 & 2.06 \\ \text { HD } & 0.103 & 1.03 \\ \text { HD } & 0.103 & 1.03\end{array}$

Matrix Spile (100437 1-Ms1)

\begin{tabular}{|c|c|c|c|c|c|c|c|}
\hline $\mathrm{mg} / \mathrm{kg} \mathrm{d} y$ & 10 & -- & ND & -- & -- & & $40 \%$ \\
\hline " & $"$ & - & 1.31 & -- & -- & 11 & $40 \%$ \\
\hline$"$ & $"$ & - & 0.351 & -- & -- & 0.2 & $40 \%$ \\
\hline$"$ & $"$ & - & 0.372 & - & -- & 29 & $40 \%$ \\
\hline$"$ & $"$ & -- & 8.20 & -- & -- & 9 & $40 \%$ \\
\hline$"$ & $"$ & - & ND & -- & -- & & $40 \%$ \\
\hline$"$ & $"$ & - & HD & -- & -- & & $40 \%$ \\
\hline " & " & -- & HD & -- & -- & & $40 \%$ \\
\hline
\end{tabular}

QC S aurce S mple: E0 16A2 (A10D066-80)

Prepared: 04/23/10 18:42 Analyzed: 04/27/10 14:44

Apex Laboratories

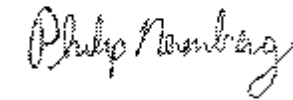

The results in this report appiy to the samples analyzed in accoriase with the chain of

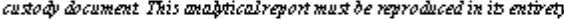

Philip Nerenberg For Darwin Thomas, Business Development Director 


\section{Apex Labs}

12232 S.W. Garden Phace

Tigard, OR 97223

503-718-2323 Phone

503-718-0333 Fax
GeoEngineers - Seatlle

600 S tewartSt. Suite 1700

Seattle, WA 98101
Project Oregon Metals Evahuation

Project Humber. 2787-050-000

Project Manager. Neil Morton
Reported

$05 / 13 / 1022: 44$

QUALITY CONTROL (QC) SAMPLE RESULTS

\begin{tabular}{|c|c|c|c|c|c|c|c|c|c|c|c|c|}
\hline \multicolumn{13}{|c|}{ Total Metals by EPA 6020 (ICPHS) } \\
\hline Analyte & Result & MDL & $\begin{array}{c}\text { Reporting } \\
\text { Limit }\end{array}$ & Units & Dil. & $\begin{array}{l}\text { Spike } \\
\text { Amourt }\end{array}$ & $\begin{array}{l}\text { Sounce } \\
\text { Rerult }\end{array}$ & $\% R E C$ & $\begin{array}{l}\% \mathrm{REC} \\
\text { Limits }\end{array}$ & RPD & $\begin{array}{l}\text { RPD } \\
\text { Limit }\end{array}$ & Notes \\
\hline
\end{tabular}

Batch 1004371 - ЕРA 3051A

Soil

Matrix Spile (100437 1-MS1)

QC S aurce S mple: E016A2 (A10D066-60)

EPA 6020

Artimory

Aseric

Beryllium

Cadrium

Lead

Selenium

Silver

Thallinm

Prepared: 04/23/10 18:42 Analyrad: 04/27/10 14:44

Matrix Spile (100437 1-MS)

QC S aurces mmle: E0 24A2 (A10D066-91)

EPA 6020

Antimory

Axeric

Beryllium

Cadrium

Lead

Selenium

Silver

Thallinm

$\begin{array}{lll}23.4 & 0.105 & 2.1 \\ 50.0 & 0210 & 2.10 \\ 23.9 & 0.10 & 1.05 \\ 49.4 & 0.105 & 1.05 \\ 52.8 & 0.105 & 1.05 \\ 23.2 & 0.420 & 2.10 \\ 24.2 & 0.105 & 105 \\ 22.8 & 0.105 & 105\end{array}$

$m g / \mathrm{lg} d r \quad 10 \quad 26.2$

$\begin{array}{llll}26 y & 10 & 26.2 & \text { HD }\end{array}$

"

"

26.2

525

18.20

26.2 HD

210

105

105

Prepared: 04/23/10 18:42 Analyzad: 04/27/10 15:37

$\begin{array}{cccc}89 & 75-125 \% & - & - \\ 93 & " & - & -- \\ 90 & " & - & -- \\ 93 & " & - & -- \\ 85 & " & - & - \\ 88 & " & - & - \\ 92 & " & - & - \\ 87 & 1 & - & -\end{array}$

$-$

$-$

$-$

$-$

$-$

\begin{tabular}{|c|c|c|c|c|c|c|c|c|}
\hline $0.10 \theta$ & 2.17 & $\mathrm{mg} / \mathrm{kg} \mathrm{d} y$ & 10 & 27.2 & 0.218 & 91 & $75-125 \%$ & -- \\
\hline 0217 & 2.17 & $"$ & $"$ & 54.4 & 1.22 & 96 & $"$ & - \\
\hline 0217 & 109 & $"$ & $"$ & 27.2 & 0.240 & 92 & $"$ & -- \\
\hline 0.100 & 109 & $"$ & $"$ & 54.4 & 0.240 & 95 & $"$ & - \\
\hline 0.100 & 109 & $"$ & $"$ & $"$ & 8.55 & 87 & $"$ & -- \\
\hline 0.435 & 2.17 & $"$ & $"$ & 27.2 & ND & 89 & $"$ & - \\
\hline 0.100 & 109 & $"$ & $"$ & $"$ & $\mathrm{HD}$ & 93 & $"$ & - \\
\hline 0.100 & 109 & $"$ & $"$ & $"$ & 0.120 & 87 & $"$ & - \\
\hline
\end{tabular}

Apex Laboratories

$$
\text { Ufoptos }
$$

Philip Nerenberg For Darwin Thomas, Business Development Director
The results in this report apply to the samples analysed in accoridaxe with the chain of custody document This andaptical report must be reproduced in is entivety. 


\section{Apex Labs}

12232 S.W. Garden Place

Tigard, OR 97223

503-718-2323 Phone

503-718-0333 Fax
GeoEnginers -Seatlle

600 S tewartSt. Suite 1700

Seattle, WA 98101
Project OregonMetals Evaluation

Project Humber. 2787-050-000

Project Manager. Neil Morton
Reported

05/13/10 22:44

QUALITY CONTROL (QC) SAMPLE RESULTS

\begin{tabular}{|c|c|c|c|c|c|c|c|c|c|c|c|c|}
\hline \multicolumn{13}{|c|}{ Percent Dry Weight by D2216 } \\
\hline Analyte & Result & MDL & $\begin{array}{l}\text { Reporting } \\
\text { Limit }\end{array}$ & Units & Dil. & $\begin{array}{c}\text { Spike } \\
\text { Amourt }\end{array}$ & $\begin{array}{l}\text { Soure } \\
\text { Rerult }\end{array}$ & $\% R E C$ & $\begin{array}{l}\text { \%REC } \\
\text { Limits }\end{array}$ & RPD & $\begin{array}{l}\text { RPD } \\
\text { Limit }\end{array}$ & Notes \\
\hline
\end{tabular}

Batch 1004201 - Dry Weight

Soil

Duplicate (1004001-DUPI)

Prepared: 04/15/10 11:15 Analyzed: 04/16/10 10:31

QC S aurces mqle: KLOSBI (Al0D066-03)

D2m16

$\begin{array}{lllllllllllllllll}\% \text { Solids } & 97.4 & - & & 100 & \% \text { by Weight } & 1 & - & & 97.4 & -- & - & 0 & 25 \%\end{array}$

Duplicate (100401-DUP2)

Prepared: 04/15/10 11:15 Analyzed: 04/16/10 10:31

QC Sarces ample: KLOAl (AlOD066-11)

D2m16

$\%$ Solids

96.0

$100 \%$ by Weight 1

96.1

$0.120 \%$

Duplicate (1004001-DUP3)

Prepared: 04/15/10 11:15 Analyrsd: 04/16/10 10:31

QC S aurce S mple: KL15BI (A10D066-24)

Dm16

$\begin{array}{llllllllllllllll}\% \text { Solids } & \mathbf{9 4 6} & - & 100 & \% \text { by Weight } & 1 & - & 94.6 & -- & - & 0 & 20 \%\end{array}$

Duplicate (1004001-DUP4)

Prepared: 04/15/10 11:15 Analyrsd: 04/16/10 10:31

QC S arce S mqle: KI $3 \mathrm{Al}$ (A10D066-36)

D216

$\begin{array}{llllllllllllllll}\% \text { Solids } & 97.0 & - & & 100 & \% \text { by Weight } & 1 & - & & 97.1 & -- & - & 0.1 & 20 \%\end{array}$

Duplicate (1004001-DUPS)

Prepared: 04/1510 11:15 Analyred: 04/16/10 10:31

QC S aurces mmle: LMO2Al (A10D066-47)

$\mathbf{D} 216$

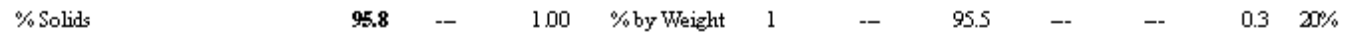

Duplicate (1004001-DUP8)

Frepared: 04/15/10 16:12 Analyrad: 04/16/10 10:31

QC Sarces ample: LM08Al (AloDot6-53)

D2m16

$\begin{array}{lllllllllllllll}\% \text { Solids } & 921 & - & 100 & \% \text { by Weight } & 1 & - & & 91.9 & -- & - & 0.2 & 20 \%\end{array}$

Duplicate (1004001-DUP9)

Prepared: 04/15/10 16:12 Analyzd: 04/16/10 10:31

QC S aurce S mqle: LM19B1 (A10D066-65)

D2m16

$\begin{array}{lllllllllllllllll}\% \text { Solids } & \mathbf{9 5 . 6} & - & & 100 & \% \text { by Weight } & 1 & - & & 95.5 & -- & -- & 0.1 & 20 \%\end{array}$

Duplicate (100401-DUPA)

Prepared: 04/15/10 16:12 Analyzed: 04/16/10 10:31

Apex Laboratories

$$
\text { 1) }
$$

Philip Nerenberg For Darwin Thomas, Business Development Director
The results is this report apy ty to the samples anabyed in accoriance with the chain of custody boument This mabticalyeport mus be reproduced in it entivety. 


\section{Apex Labs}

12232 S.W. Garden Place

Tigard, OR 97223

503-718-2323 Phone

503-718-0333 Fax

\section{GeoEneineers -Seattle}

600 S tewartSt. Suite 1700

Seattle, WA 98101
Project Oregon Metals Evahuation

Project Humber. 2787-050-000

Project Manazer. Heil Morton
Reported

$05 / 1311022: 44$

QUALITY CONTROL (QC) SAMPLE RESULTS

\begin{tabular}{|c|c|c|c|c|c|c|c|c|c|c|c|c|}
\hline \multicolumn{13}{|c|}{ Percent Dry Weight by D2216 } \\
\hline Analyte & Result & MDL & $\begin{array}{l}\text { Reporting } \\
\text { Limit }\end{array}$ & Units & Dil. & $\begin{array}{c}\text { Spike } \\
\text { Amourt }\end{array}$ & $\begin{array}{l}\text { Source } \\
\text { Result }\end{array}$ & $\%$ REC & $\begin{array}{l}\text { \%REC } \\
\text { Limrits }\end{array}$ & RPD & $\begin{array}{l}\text { RPD } \\
\text { Limit }\end{array}$ & Notes \\
\hline
\end{tabular}

Soil

Batch 1004201 - Dry Weight

Duplicate (100401-DUPA)

Prepared: 04/15/10 16:12 Analyrad: 04/16/10 10:31

QC Saurce S mqle: E00BI (Al0D066-75)

Dm16

$\begin{array}{llllllllllllll}\% \text { Solids } & 97.7 & - & - & 100 & \% \text { by Weight } & 1 & - & 97.9 & -- & -- & 0.2 & 20 \%\end{array}$

Duplicate (100401-DUPB) $\quad$ Prepared: 04/15/10 16:12 Analyzd: 04/16/10 10:31

QC S aurce S ample: E0 BA2 (A10D066- 9 )

nm16

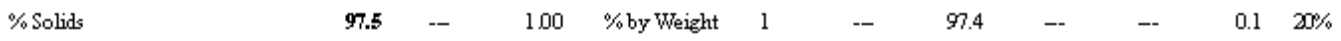

Apex Laboratories

$$
\text { Pritprounding }
$$

Philip Nerenberg For Darwin Thomas, Business Development Director
The results in this report apply to the samples analyed in accordaxe with the $c$ knin of custody document This madticalrepont mus be regroduced in it entivety. 


\section{Apex Labs}

12232 S. W. Garden Place

Tigard, OR 97223

503-718-2323 Phone

503-718-0333 Fax

\begin{tabular}{|llr|}
\hline GeoEneineers -Seattle & Project OregonMetals Evahuation \\
600 StewartSt. Suite 1700 & Project Number. 2787-050-000 & Reported \\
Seattle, WA 98101 & Project Manager. Neil Morton & $05 / 13 / 1022: 44$ \\
\hline
\end{tabular}

SAMPLE PREPARATION INFORMATION

\begin{tabular}{|c|c|c|c|c|c|c|c|}
\hline \multicolumn{8}{|c|}{ Total Metals by EPA 6020 (ICPhIS) } \\
\hline Prep: EPA 3051A & & & & & Sarmle & Default & RL Prep \\
\hline Lab Number & Matrix & Method & Sanqled & Prepared & Iritial/Final & Iritial/Final & Factor \\
\hline \multicolumn{8}{|l|}{ Batch: 1004214} \\
\hline A10D066-01 & Soil & EPA 6020 & 01/01/9400:00 & $04 / 16 / 1010: 18$ & $0.501 \mathrm{~g} / 50 \mathrm{~mL}$ & $0.5 \mathrm{~g} / 50 \mathrm{~mL}$ & 1.00 \\
\hline A10D066-02 & Soil & EPA 6020 & 01/01/9400:00 & 04/16/10 10:18 & $0.475 \mathrm{~g} / 50 \mathrm{~mL}$ & $0.5 \mathrm{~g} / 50 \mathrm{~mL}$ & 1.05 \\
\hline A10D066-03 & Soil & EPA 6020 & 01/01/9400:00 & 04/16/10 10:18 & $0.499 \mathrm{~g} / 50 \mathrm{~mL}$ & $0.5 \mathrm{~g} / 50 \mathrm{~mL}$ & 1.00 \\
\hline A10D066-04 & Soil & EPA 6020 & 01/01/9400:00 & 04/16/10 10:18 & $0.5 \mathrm{~g} / 50 \mathrm{~mL}$ & $0.5 \mathrm{~g} / 50 \mathrm{~mL}$ & 1.00 \\
\hline A10D066-05 & Soil & EPA 6020 & 01:01:9400:00 & 04/16/10 10:18 & $0.494 \mathrm{~g} / 50 \mathrm{~mL}$ & $0.5 \mathrm{~g} / 50 \mathrm{~mL}$ & 1.01 \\
\hline A10D066-06 & Soil & EPA 6020 & 01/01/9400:00 & 04/16/10 10:18 & $0.5 \mathrm{~g} / 50 \mathrm{~mL}$ & $0.5 \mathrm{~g} / 50 \mathrm{~mL}$ & 1.00 \\
\hline A10D066-07 & Soil & EPA 6020 & 01/01/9400:00 & $04 / 16 / 1010: 18$ & $0.495 \mathrm{~g} / 50 \mathrm{~mL}$ & $0.5 \mathrm{~g} / 50 \mathrm{~mL}$ & 1.01 \\
\hline A10D066-08 & Soil & EPA 6020 & 01/01/9400:00 & $04 / 16 / 1010: 18$ & $0.489 \mathrm{~g} / 50 \mathrm{~mL}$ & $0.5 \mathrm{~g} / 50 \mathrm{~mL}$ & 1.02 \\
\hline A10D066-09 & Soil & EPA 6020 & 01/01:9400:00 & $04 / 16 / 1010: 18$ & $0.497 \mathrm{~g} / 50 \mathrm{~mL}$ & $0.5 \mathrm{~g} / 50 \mathrm{~mL}$ & 1.01 \\
\hline A10D066-10 & Soil & EPA 6020 & 01/01/9400:00 & $04 / 16 / 1010: 18$ & $0.493 \mathrm{~g} / 50 \mathrm{~mL}$ & $0.5 \mathrm{~g} / 50 \mathrm{~mL}$ & 1.01 \\
\hline A10D066-11 & Soil & EPA 6020 & 01/01/9400:00 & $04 / 16 / 1010: 18$ & $0.479 \mathrm{~g} / 50 \mathrm{~mL}$ & $0.5 \mathrm{~g} / 50 \mathrm{~mL}$ & 1.04 \\
\hline A10D066-12 & Soil & EPA 6020 & 01/01/9400:00 & $04 / 16 / 1010: 18$ & $0.492 \mathrm{~g} / 50 \mathrm{~mL}$ & $0.5 \mathrm{~g} / 50 \mathrm{~mL}$ & 1.02 \\
\hline A10D066-13 & Soil & EPA 6020 & 01/01/9400:00 & 04/16/10 10:18 & $0.477 \mathrm{~g} / 50 \mathrm{~mL}$ & $0.5 \mathrm{~g} / 50 \mathrm{~mL}$ & 1.05 \\
\hline A10D066-14 & Soil & EPA 6020 & 01:01:9400:00 & $04 / 16 / 1010: 18$ & $0.487 \mathrm{~g} / 50 \mathrm{~mL}$ & $0.5 \mathrm{~g} / 50 \mathrm{~mL}$ & 1.03 \\
\hline A10D066-15 & Soil & EPA 6020 & 01/01/9400:00 & $04 / 16 / 1010: 18$ & $0.494 \mathrm{~g} / 50 \mathrm{~mL}$ & $0.5 \mathrm{~g} / 50 \mathrm{~mL}$ & 1.01 \\
\hline \multicolumn{8}{|l|}{ Batch: 1004274} \\
\hline A10D066-16 & Soil & EPA 6020 & 01/01/9400:00 & $04 / 20 / 1011: 59$ & $0.494 \mathrm{~g} / 50 \mathrm{~mL}$ & $0.5 \mathrm{~g} / 50 \mathrm{~mL}$ & 1.01 \\
\hline A10D066-17 & Soil & EPA 6020 & 01:01/9400:00 & $04 / 20 / 1011: 59$ & $0.499 \mathrm{~g} / 50 \mathrm{~mL}$ & $0.5 \mathrm{~g} / 50 \mathrm{~mL}$ & 1.00 \\
\hline A10D066-18 & Soil & EPA 6020 & 01/01/9400:00 & $04 / 20 / 1011: 59$ & $0.49 \mathrm{~g} / 50 \mathrm{~mL}$ & $0.5 \mathrm{~g} / 50 \mathrm{~mL}$ & 1.02 \\
\hline A10D066-19 & Soil & EPA 6020 & 01/01/9400:00 & $04 / 20 / 1011: 59$ & $0.495 \mathrm{~g} / 50 \mathrm{~mL}$ & $0.5 \mathrm{~g} / 50 \mathrm{~mL}$ & 1.01 \\
\hline A10D066-20 & Soil & EPA 6020 & 01/01/9400:00 & $04 / 20 / 1011: 59$ & $0.493 \mathrm{~g} / 50 \mathrm{~mL}$ & $0.5 \mathrm{~g} / 50 \mathrm{~mL}$ & 1.01 \\
\hline A10D066-21 & Soil & EPA 6020 & 01/01/9400:00 & $04 / 20 / 1011: 59$ & $0.501 \mathrm{~g} / 50 \mathrm{~mL}$ & $0.5 \mathrm{~g} / 50 \mathrm{~mL}$ & 1.00 \\
\hline A10D066-22 & Soil & EPA 6020 & 01/019400:00 & $04 / 20 / 1011: 59$ & $0.501 \mathrm{~g} / 50 \mathrm{~mL}$ & $0.5 \mathrm{~g} / 50 \mathrm{~mL}$ & 1.00 \\
\hline A10D066-23 & Soil & EPA 6020 & 01/019400:00 & $04 / 20 / 1011: 59$ & $0.489 \mathrm{~g} / 50 \mathrm{~mL}$ & $0.5 \mathrm{~g} / 50 \mathrm{~mL}$ & 1.02 \\
\hline A10D066-24 & Soil & EPA 6020 & 01/01/9400:00 & $04 / 20 / 1011: 59$ & $0.487 \mathrm{~g} / 50 \mathrm{~mL}$ & $0.5 \mathrm{~g} / 50 \mathrm{~mL}$ & 1.03 \\
\hline A10D066-25 & Soil & EPA 6020 & 01/01/9400:00 & $04 / 20 / 1011: 59$ & $0.49 \mathrm{~g} / 50 \mathrm{~mL}$ & $0.5 \mathrm{~g} / 50 \mathrm{~mL}$ & 1.02 \\
\hline A10D066-26 & Soil & EPA 6020 & 01/01/9400:00 & $04 / 20 / 1011: 59$ & $0.499 \mathrm{~g} / 50 \mathrm{~mL}$ & $0.5 \mathrm{~g} / 50 \mathrm{~mL}$ & 1.00 \\
\hline \multicolumn{8}{|l|}{ Batch: 1004324} \\
\hline A10D066-27 & Soil & EPA 6020 & 01/01/9400:00 & $04 / 22 / 1008: 28$ & $0.47 \mathrm{~g} / 50 \mathrm{~mL}$ & $0.5 \mathrm{~g} / 50 \mathrm{~mL}$ & 1.06 \\
\hline A10D066-28 & Soil & EPA 6020 & 01/01/9400:00 & $04 / 22 / 1008: 28$ & $0.427 \mathrm{~g} / 50 \mathrm{~mL}$ & $0.5 \mathrm{~g} / 50 \mathrm{~mL}$ & 1.17 \\
\hline A10D066-29 & Soil & EPA 6020 & 01/01/9400:00 & $04 / 22 / 1008: 28$ & $0.487 \mathrm{~g} / 50 \mathrm{~mL}$ & $0.5 \mathrm{~g} / 50 \mathrm{~mL}$ & 1.03 \\
\hline A10D066-30 & Soil & EPA 6020 & 01/019400:00 & $04 / 22 / 1008: 28$ & $0.487 \mathrm{~g} / 50 \mathrm{~mL}$ & $0.5 \mathrm{~g} / 50 \mathrm{~mL}$ & 1.03 \\
\hline A10D066-31 & Soil & EPA 6020 & 01:01/9400:00 & $04 / 22 / 1008: 28$ & $0.462 \mathrm{~g} / 50 \mathrm{~mL}$ & $0.5 \mathrm{~g} / 50 \mathrm{~mL}$ & 1.08 \\
\hline
\end{tabular}

Apex Laboratories

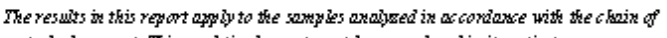

Pateptos 


\section{Apex Labs}

12232 S.W. Garden Place

Tigard, OR 97223

503-718-2323 Phone

503-718-0333 Fax

\begin{tabular}{|llr|}
\hline GeoEnginers -Seattle & Project OregonMetals Evahuation \\
600 StewartSt. Suite 1700 & Project Number. 2787-050-000 & Reported \\
Seattle, WA 98101 & Project Marager. Neil Mortom & $05 / 13 / 1022: 44$ \\
\hline
\end{tabular}

SAMPLE PREPARATION INF ORMATION

\begin{tabular}{|c|c|c|c|c|c|c|c|}
\hline \multicolumn{8}{|c|}{ Total hetals by EPA 6020 (ICPMS) } \\
\hline Prep: EPA 3051A & & & & & Sample & Default & RL Prep \\
\hline Lab Number & Matrix & Method & Sarpled & Prepared & Iritial/Final & Iritial/Final & Factor \\
\hline A10D066-32 & Soil & EPA 6020 & 01/01/9400:00 & $04 / 22 / 1008: 28$ & $0.434 \mathrm{~g} / 50 \mathrm{~mL}$ & $0.5 \mathrm{~g} / 50 \mathrm{~mL}$ & 1.15 \\
\hline A10D066-33 & Soil & EPA 6020 & 01:01:9400:00 & $04 / 22 / 1008: 28$ & $0.467 \mathrm{~g} / 50 \mathrm{~mL}$ & $0.5 \mathrm{~g} / 50 \mathrm{~mL}$ & 1.07 \\
\hline A10D066-34 & Soil & EPA 6020 & 01:01/9400:00 & $04 / 22 / 1008: 28$ & $0.477 \mathrm{~g} / 50 \mathrm{~mL}$ & $0.5 \mathrm{~g} / 50 \mathrm{~mL}$ & 1.05 \\
\hline A10D066-35 & Soil & EPA 6020 & 01/01/9400:00 & $04 / 22 / 1008: 28$ & $0.469 \mathrm{~g} / 50 \mathrm{~mL}$ & $0.5 \mathrm{~g} / 50 \mathrm{~mL}$ & 1.07 \\
\hline A10D066-36 & Soil & EPA 6020 & 01/01/9400:00 & $04 / 22 / 1008: 28$ & $0.47 \mathrm{~g} / 50 \mathrm{~mL}$ & $0.5 \mathrm{~g} / 50 \mathrm{~mL}$ & 1.06 \\
\hline A10D066-37 & Soil & EPA 6020 & 01/01/9400:00 & $04 / 22 / 1008: 28$ & $0.512 \mathrm{~g} / 50 \mathrm{~mL}$ & $0.5 \mathrm{~g} / 50 \mathrm{~mL}$ & 0.98 \\
\hline A10D066-38 & Soil & EPA 6020 & 01:01:9400:00 & $04 / 22 / 1008: 28$ & $0.47 \mathrm{~g} / 50 \mathrm{~mL}$ & $0.5 \mathrm{~g} / 50 \mathrm{~mL}$ & 1.06 \\
\hline A10D066-39 & Soil & EPA 6020 & 01:01:9400:00 & $04 / 22 / 1008: 28$ & $0.454 \mathrm{~g} / 50 \mathrm{~mL}$ & $0.5 \mathrm{~g} / 50 \mathrm{~mL}$ & 1.10 \\
\hline A10D066-40 & Soil & EPA 6020 & 01:01/9400:00 & $04 / 22 / 1008: 28$ & $0.471 \mathrm{~g} / 50 \mathrm{~mL}$ & $0.5 \mathrm{~g} / 50 \mathrm{~mL}$ & 1.06 \\
\hline A10D066-41 & Soil & EPA 6020 & 01/01/9400:00 & $04 / 22 / 1008: 28$ & $0.525 \mathrm{~g} / 50 \mathrm{~mL}$ & $0.5 \mathrm{~g} / 50 \mathrm{~mL}$ & 0.95 \\
\hline A10D066-42 & Soil & EPA 6020 & 01/01/9400:00 & $04 / 22 / 1008: 28$ & $0.474 \mathrm{~g} / 50 \mathrm{~mL}$ & $0.5 \mathrm{~g} / 50 \mathrm{~mL}$ & 1.05 \\
\hline \multicolumn{8}{|l|}{ Eatch: 1004361} \\
\hline A $10 D 066-43$ & Soil & EPA 6020 & 01/01/9400:00 & $04 / 23 / 1012: 27$ & $0.467 \mathrm{~g} / 50 \mathrm{~mL}$ & $0.5 \mathrm{~g} / 50 \mathrm{~mL}$ & 1.07 \\
\hline A10D066-44 & Soil & EPA 6020 & 01/01/9400:00 & $04 / 23 / 1012: 27$ & $0.437 \mathrm{~g} / 50 \mathrm{~mL}$ & $0.5 \mathrm{~g} / 50 \mathrm{~mL}$ & 1.14 \\
\hline A10D066-45 & Soil & EPA 6020 & 01/01/9400:00 & $04 / 23 / 1012: 27$ & $0.486 \mathrm{~g} / 50 \mathrm{~mL}$ & $0.5 \mathrm{~g} / 50 \mathrm{~mL}$ & 1.03 \\
\hline A10D066-46 & Soil & EPA 6020 & 01:01/9400:00 & $04 / 23 / 1012: 27$ & $0.465 \mathrm{~g} / 50 \mathrm{~mL}$ & $0.5 \mathrm{~g} / 50 \mathrm{~mL}$ & 1.08 \\
\hline A10D066-47 & Soil & EPA 6020 & 01:01/9400:00 & $04 / 23 / 1012: 27$ & $0.437 \mathrm{~g} / 50 \mathrm{~mL}$ & $0.5 \mathrm{~g} / 50 \mathrm{~mL}$ & 1.14 \\
\hline A10D066-48 & Soil & EPA 6020 & 01:01:9400:00 & $04 / 23 / 1012: 27$ & $0.492 \mathrm{~g} / 50 \mathrm{~mL}$ & $0.5 \mathrm{~g} / 50 \mathrm{~mL}$ & 1.02 \\
\hline A10D066-49 & Soil & EPA 6020 & 01:01/9400:00 & $04 / 23 / 1012: 27$ & $0.435 \mathrm{~g} / 50 \mathrm{~mL}$ & $0.5 \mathrm{~g} / 50 \mathrm{~mL}$ & 1.15 \\
\hline A10D066-50 & Soil & EPA 6020 & 01:01/9400:00 & $04 / 23 / 1012: 27$ & $0.512 \mathrm{~g} / 50 \mathrm{~mL}$ & $0.5 \mathrm{~g} / 50 \mathrm{~mL}$ & 0.98 \\
\hline A10D066-51 & Soil & EPA 6020 & 01/01/9400:00 & $04 / 23 / 1012: 27$ & $0.439 \mathrm{~g} / 50 \mathrm{~mL}$ & $0.5 \mathrm{~g} / 50 \mathrm{~mL}$ & 1.14 \\
\hline A10D066-52 & Soil & EPA 6020 & 01:01/9400:00 & $04 / 23 / 1012: 27$ & $0.503 \mathrm{~g} / 50 \mathrm{~mL}$ & $0.5 \mathrm{~g} / 50 \mathrm{~mL}$ & 0.99 \\
\hline A10D066-53 & Soil & EPA 6020 & 01:01/9400:00 & $04 / 23 / 1012: 27$ & $0.474 \mathrm{~g} / 50 \mathrm{~mL}$ & $0.5 \mathrm{~g} / 50 \mathrm{~mL}$ & 1.05 \\
\hline A10D066-54 & Soil & EPA 6020 & 01/01/9400:00 & $04 / 23 / 1012: 27$ & $0.486 \mathrm{~g} / 50 \mathrm{~mL}$ & $0.5 \mathrm{~g} / 50 \mathrm{~mL}$ & 1.03 \\
\hline A10D066-55 & Soil & EPA 6020 & 01/01/9400:00 & $04 / 23 / 1012: 27$ & $0.428 \mathrm{~g} / 50 \mathrm{~mL}$ & $0.5 \mathrm{~g} / 50 \mathrm{~mL}$ & 1.17 \\
\hline A10D066-56 & Soil & EPA 6020 & 01:01/9400:00 & $04 / 23 / 1012: 27$ & $0.448 \mathrm{~g} / 50 \mathrm{~mL}$ & $0.5 \mathrm{~g} / 50 \mathrm{~mL}$ & 1.12 \\
\hline A10D066-57 & Soil & EPA 6020 & 01:01/9400:00 & $04 / 23 / 1012: 27$ & $0.511 \mathrm{~g} / 50 \mathrm{~mL}$ & $0.5 \mathrm{~g} / 50 \mathrm{~mL}$ & 0.98 \\
\hline \multicolumn{8}{|l|}{ Batch: 1004367} \\
\hline A10D066-58 & Soil & EPA 6020 & 01:01/9400:00 & $04 / 23 / 1016: 56$ & $0.442 \mathrm{~g} / 50 \mathrm{~mL}$ & $0.5 \mathrm{~g} / 50 \mathrm{~mL}$ & 1.13 \\
\hline A10D066-59 & Soil & EPA 6020 & 01/01/9400:00 & $04 / 23 / 1016: 56$ & $0.454 \mathrm{~g} / 50 \mathrm{~mL}$ & $0.5 \mathrm{~g} / 50 \mathrm{~mL}$ & 1.10 \\
\hline A10D066-60 & Soil & EPA 6020 & 01/01/9400:00 & $04 / 23 / 1016: 56$ & $0.447 \mathrm{~g} / 50 \mathrm{~mL}$ & $0.5 \mathrm{~g} / 50 \mathrm{~mL}$ & 1.12 \\
\hline A10D066-61 & Soil & EPA 6020 & 01:01/9400:00 & $04 / 23 / 1016: 56$ & $0.484 \mathrm{~g} / 50 \mathrm{~mL}$ & $0.5 \mathrm{~g} / 50 \mathrm{~mL}$ & 1.03 \\
\hline A10D066-62 & Soil & EPA 6020 & 01:01/9400:00 & $04 / 23 / 1016: 56$ & $0.43 \mathrm{~g} / 50 \mathrm{~mL}$ & $0.5 \mathrm{~g} / 50 \mathrm{~mL}$ & 1.16 \\
\hline A10D066-63 & Soil & EPA 6020 & 01:01/9400:00 & $04 / 23 / 1016: 56$ & $0.458 \mathrm{~g} / 50 \mathrm{~mL}$ & $0.5 \mathrm{~g} / 50 \mathrm{~mL}$ & 1.09 \\
\hline
\end{tabular}

Apex Laboratories

The results in this report apply to the samples analysed in accoriance with the chnin of

Protoptows

custody document This anditicalrepont mus be regroduced in it entivety.

Philip Nerenberg For Darxin Thomas, Business Development Director

Puge 50 of 57 


\section{Apex Labs}

12232 S.W. Garden Phace

Tigard, OR 97223

503-718-2323 Phone

503-T18-0333 Fax

\begin{tabular}{|lcr}
\hline GeoEngineers -Seatfle & Project OregonMetals Evahuation \\
600 StewartSt. Suite 1700 & Project Number. $2787-050-000$ \\
Seattle, WA 98101 & Project Manager. Neil Morton & Reported \\
\hline
\end{tabular}

Seattle, WA 98101

Project Manager. Neil Morton

$05 / 13 / 1022: 44$

SAMPLE PREPARATION INFORMATION

\begin{tabular}{|c|c|c|c|c|c|c|c|}
\hline \multicolumn{8}{|c|}{ Total hetals by EPA 6020 (ICPHS) } \\
\hline Prep: EPA 3051A & & & & & Sarmple & Default & RL Prep \\
\hline Lab Number & Matix & Method & Sarmpled & Prepared & Iritial/Final & Iritial/Final & Factor \\
\hline A10D066-64 & Soil & EPA 6020 & 01/01/9400:00 & $04 / 23 / 1016: 56$ & $0.459 \mathrm{~g} / 50 \mathrm{~mL}$ & $0.5 \mathrm{~g} / 50 \mathrm{~mL}$ & 1.09 \\
\hline A10D066-65 & Soil & EPA 6020 & 01/01/9400:00 & $04 / 23 / 1016: 56$ & $0.435 \mathrm{~g} / 50 \mathrm{~mL}$ & $0.5 \mathrm{~g} / 50 \mathrm{~mL}$ & 1.15 \\
\hline A10D066-66 & Soil & EPA 6020 & 01/01/9400:00 & $04 / 23 / 1016: 56$ & $0.445 \mathrm{~g} / 50 \mathrm{~mL}$ & $0.5 \mathrm{~g} / 50 \mathrm{~mL}$ & 1.12 \\
\hline A10D066-6? & Soil & EPA 6020 & 01/01/9400:00 & $04 / 23 / 1016: 56$ & $0.475 \mathrm{~g} / 50 \mathrm{~mL}$ & $0.5 \mathrm{~g} / 50 \mathrm{~mL}$ & 1.05 \\
\hline A10D066-68 & Soil & EPA 6020 & 01:01/9400:00 & $04 / 23 / 1016: 56$ & $0.438 \mathrm{~g} / 50 \mathrm{~mL}$ & $0.5 \mathrm{~g} / 50 \mathrm{~mL}$ & 1.14 \\
\hline A10D066-69 & Soil & EPA 6020 & 01:01/9400:00 & $04 / 23 / 1016: 56$ & $0.456 \mathrm{~g} / 50 \mathrm{~mL}$ & $0.5 \mathrm{~g} / 50 \mathrm{~mL}$ & 1.10 \\
\hline A10D066-70 & Soil & EPA 6020 & 01:01/9400:00 & $04 / 23 / 1016: 56$ & $0.464 \mathrm{~g} / 50 \mathrm{~mL}$ & $0.5 \mathrm{~g} / 50 \mathrm{~mL}$ & 1.08 \\
\hline A10D066-71 & Soil & EPA 6020 & 01/01/9400:00 & $04 / 23 / 1016: 56$ & $0.477 \mathrm{~g} / 50 \mathrm{~mL}$ & $0.5 \mathrm{~g} / 50 \mathrm{~mL}$ & 1.05 \\
\hline A10D066-72 & Soil & EPA 6020 & 01/01/9400:00 & $04 / 23 / 1016: 56$ & $0.462 \mathrm{~g} / 50 \mathrm{~mL}$ & $0.5 \mathrm{~g} / 50 \mathrm{~mL}$ & 1.08 \\
\hline A10D066-73 & Soil & EPA 6020 & 01/01/9400:00 & $04 / 23 / 1016: 56$ & $0.439 \mathrm{~g} / 50 \mathrm{~mL}$ & $0.5 \mathrm{~g} / 50 \mathrm{~mL}$ & 1.14 \\
\hline A10D066-74 & Soil & EPA 6020 & 01/01/9400:00 & $04 / 23 / 1016: 56$ & $0.472 \mathrm{~g} / 50 \mathrm{~mL}$ & $0.5 \mathrm{~g} / 50 \mathrm{~mL}$ & 1.06 \\
\hline A10D066-75 & Soil & EPA 6020 & 01/01/9400:00 & $04 / 23 / 1016: 56$ & $0.494 \mathrm{~g} / 50 \mathrm{~mL}$ & $0.5 \mathrm{~g} / 50 \mathrm{~mL}$ & 1.01 \\
\hline A10D066-76 & Soil & EPA 6020 & 01/01/9400:00 & $04 / 23 / 1016: 56$ & $0.474 \mathrm{~g} / 50 \mathrm{~mL}$ & $0.5 \mathrm{~g} / 50 \mathrm{~mL}$ & 1.05 \\
\hline \multicolumn{8}{|l|}{ Batch: 1004371} \\
\hline A10D066-77 & Soil & EPA 6020 & 01:01/9400:00 & $04 / 23 / 1018: 42$ & $0.499 \mathrm{~g} / 50 \mathrm{~mL}$ & $0.5 \mathrm{~g} / 50 \mathrm{~mL}$ & 1.00 \\
\hline A10D066-78 & Soil & EPA 6020 & 01/01/9400:00 & $04 / 23 / 1018: 42$ & $0.487 \mathrm{~g} / 50 \mathrm{~mL}$ & $0.5 \mathrm{~g} / 50 \mathrm{~mL}$ & 1.03 \\
\hline A10D066-79 & Soil & EPA 6020 & 01:01/9400:00 & $04 / 23 / 1018: 42$ & $0.489 \mathrm{~g} / 50 \mathrm{~mL}$ & $0.5 \mathrm{~g} / 50 \mathrm{~mL}$ & 1.02 \\
\hline A10D066-80 & Soil & EPA 6020 & 01/01/9400:00 & $04 / 23 / 1018: 42$ & $0.497 \mathrm{~g} / 50 \mathrm{~mL}$ & $0.5 \mathrm{~g} / 50 \mathrm{~mL}$ & 1.01 \\
\hline A10D066-81 & Soil & EPA 6020 & 01:01/9400:00 & $04 / 23 / 1018: 42$ & $0.484 \mathrm{~g} / 50 \mathrm{~mL}$ & $0.5 \mathrm{~g} / 50 \mathrm{~mL}$ & 1.03 \\
\hline A10D066-82 & Soil & EPA 6020 & 01/01/9400:00 & $04 / 23 / 1018: 42$ & $0.478 \mathrm{~g} / 50 \mathrm{~mL}$ & $0.5 \mathrm{~g} / 50 \mathrm{~mL}$ & 1.05 \\
\hline A10D066-83 & Soil & EPA 6020 & 01/01/9400:00 & $04 / 23 / 1018: 42$ & $0.487 \mathrm{~g} / 50 \mathrm{~mL}$ & $0.5 \mathrm{~g} / 50 \mathrm{~mL}$ & 1.03 \\
\hline A10D066-84 & Soil & EPA 6020 & 01/01/9400:00 & $04 / 23 / 1018: 42$ & $0.485 \mathrm{~g} / 50 \mathrm{~mL}$ & $0.5 \mathrm{~g} / 50 \mathrm{~mL}$ & 1.03 \\
\hline A10D066-85 & Soil & EPA 6020 & 01/01/9400:00 & $04 / 23 / 1018: 42$ & $0.489 \mathrm{~g} / 50 \mathrm{~mL}$ & $0.5 \mathrm{~g} / 50 \mathrm{~mL}$ & 1.02 \\
\hline A10D066-86 & Soil & EPA 6020 & 01:01/9400:00 & $04 / 23 / 1018: 42$ & $0.48 \mathrm{~g} / 50 \mathrm{~mL}$ & $0.5 \mathrm{~g} / 50 \mathrm{~mL}$ & 1.04 \\
\hline A10D066-87 & Soil & EPA 6020 & 01:01:9400:00 & $04 / 23 / 1018: 42$ & $0.487 \mathrm{~g} / 50 \mathrm{~mL}$ & $0.5 \mathrm{~g} / 50 \mathrm{~mL}$ & 1.03 \\
\hline A10D066-88 & Soil & EPA 6020 & 01/01/9400:00 & $04 / 23 / 1018: 42$ & $0.491 \mathrm{~g} / 50 \mathrm{~mL}$ & $0.5 \mathrm{~g} / 50 \mathrm{~mL}$ & 1.02 \\
\hline A10D066-89 & Soil & EPA 6020 & 01/01/9400:00 & $04 / 23 / 1018: 42$ & $0.492 \mathrm{~g} / 50 \mathrm{~mL}$ & $0.5 \mathrm{~g} / 50 \mathrm{~mL}$ & 1.02 \\
\hline A10D066-90 & Soil & EPA 6020 & 01/01/9400:00 & $04 / 23 / 1018: 42$ & $0.488 \mathrm{~g} / 50 \mathrm{~mL}$ & $0.5 \mathrm{~g} / 50 \mathrm{~mL}$ & 1.02 \\
\hline A10D066-91 & Soil & EPA 6020 & 01/01/9400:00 & $04 / 23 / 1018: 42$ & $0.474 \mathrm{~g} / 50 \mathrm{~mL}$ & $0.5 \mathrm{~g} / 50 \mathrm{~mL}$ & 1.05 \\
\hline
\end{tabular}

\footnotetext{
Apex Laboratories

The results in this report apply to the samples analyzed in accordance with the chain of

(1) custody document This madtical reyon mus be regroduced in it entivety.
}

Philip Nerenberg For Darwin Thomas, Business Development Director

Page 51 of 5 ? 


\section{Apex Labs}

12232 S.W. Garden Pace

Tigard, OR 97223

503-718-2323 Phone

503-718-0333 Fax

Thursday, May 13, 2010

Neil Morton

GeoEngineers-Seattle

600 Stewart St. Suite 1700

Seattle, WA 98101

RE: Oregon Metals Evaluation / 2787-050-000

Enclosed are the results of analyses for work order A10D071, which was received by the laboratory on $4 / 2 / 2010$ at $3: 35: 00 \mathrm{PM}$

Thank you for using Apex Labs. We appreciate your business and strive to provide the highest quality services to the environmental industry.

If you have any questions concerning this report or the services we offer, please feel free to contact me by email at: nnerenberg@apex-labs.com, or by phone at 503-718-2323.

Apex Laboratories

$$
\text { (1) }
$$

Prilip Nerenberg For Darwin Thomas, Business Development Director

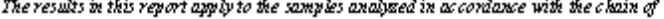

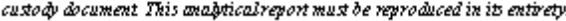




\section{Apex Labs}

12232 S.W. Garden Place

Tigard, OR 97223

503-718-2323 Phone

503-718-0333 Fax

$\begin{array}{ll}\text { GeoEngineers -Seattle } & \text { Project OregonMetals Evaluation } \\ 600 \text { S tewartSt. Suite } 1700 & \text { Project Number. } 2787-050-000 \\ \text { Seattle, WA } 98101 & \text { Project Manager. Neil Morton }\end{array}$

ANAL YTICAL REPORT FOR SAMPLES

\begin{tabular}{|c|c|c|c|c|}
\hline \multicolumn{5}{|c|}{ SAMPLE INF ORMATION } \\
\hline Sample ID & Laboratory ID & Matrix & Date Sampled & Date Received \\
\hline E025A2 & A10D071-01 & Soil & 01:01/9400:00 & $04,02 / 1015: 35$ \\
\hline $\mathrm{E} 025 \mathrm{~B} 2$ & A10D071-02 & Soil & 01:01/9400:00 & $04 / 02 / 1015: 35$ \\
\hline E026B2 & A10D071-03 & Soil & 01:01/9400:00 & $04,02 / 1015: 35$ \\
\hline $\mathrm{E} 027 \mathrm{~A} 2$ & A10D071-04 & Soil & 01:01/9400:00 & $04 / 02 / 1015: 35$ \\
\hline E030A2 & A10D071-05 & Soil & 01/01/9400:00 & $04,02 / 1015: 35$ \\
\hline E030B2 & A10D071-06 & Soil & 01/01/9400:00 & $04 / 02 / 1015: 35$ \\
\hline E031B2 & A10D071-07 & Soil & 01:01/9400:00 & $04,02 / 1015: 35$ \\
\hline $\mathrm{E} 032 \mathrm{~A} 2$ & A10D071-08 & Soil & 01:01/9400:00 & $04,02 / 1015: 35$ \\
\hline E032B2 & A10D071-09 & Soil & 01:01/9400:00 & $04,02 / 1015: 35$ \\
\hline E034A2 & A10D071-10 & Soil & 01/01/9400:00 & $04,02 / 1015: 35$ \\
\hline E034B2 & A10D071-11 & Soil & 01:01/9400:00 & $04 / 02 / 1015: 35$ \\
\hline $\mathrm{E} 035 \mathrm{~A} 2$ & A10D071-12 & Soil & 01:01/9400:00 & $04,02 / 1015: 35$ \\
\hline E036B2 & A10D071-13 & Soil & 01:01/9400:00 & $04 / 02 / 1015: 35$ \\
\hline LC01Al & A10D071-14 & Soil & 01/01/9400:00 & $04,02 / 1015: 35$ \\
\hline LC01Bl & A10D071-15 & Soil & 01:01/9400:00 & $04,02 / 1015: 35$ \\
\hline LC02Btll & A10D071-16 & Soil & 01:01/9400:00 & $04,02 / 1015: 35$ \\
\hline LC03Al & A10D071-17 & Soil & 01:01/9400:00 & $04,02 / 1015: 35$ \\
\hline LC03Bl & A10D071-18 & Soil & 01/01/9400:00 & $04,02 / 1015: 35$ \\
\hline LC04Al & A10D071-19 & Soil & 01:01/9400:00 & $04,02 / 1015: 35$ \\
\hline LC04Bl & A10D071-20 & Soil & 01:01/9400:00 & $04,02 / 1015: 35$ \\
\hline LC06Al & A10D071-21 & Soil & 01:01/9400:00 & $04,02 / 1015: 35$ \\
\hline LC06Bl & A10D071-22 & Soil & 01/01/9400:00 & $04 / 02 / 1015: 35$ \\
\hline LC08Al & A10D071-23 & Soil & 01:01/9400:00 & $04,02 / 1015: 35$ \\
\hline LC08Bl & A10D071-24 & Soil & 01/01/9400:00 & $04,02 / 1015: 35$ \\
\hline LC09Al & A10D071-25 & Soil & 01:01/9400:00 & $04,02 / 1015: 35$ \\
\hline LC09Bl & A10D071-26 & Soil & 01/01/9400:00 & $04,02 / 1015: 35$ \\
\hline LC11Al & A10D071-27 & Soil & 01:01/9400:00 & $04 / 02 / 1015: 35$ \\
\hline LC11Bl & A10D071-28 & Soil & 01:01/9400:00 & $04,02 / 1015: 35$ \\
\hline LCl1B2 & A10D071-29 & Soil & 01:01/9400:00 & $04,02 / 1015: 35$ \\
\hline LCl2Bl & A10D071-30 & Soil & 01:01/9400:00 & $0402 / 1015: 35$ \\
\hline LC13Al & A10D071-31 & Soil & 01:01/9400:00 & $04,02 / 1015: 35$ \\
\hline LCl3Cl & A10D071-32 & Soil & 01:01/9400:00 & $04,02 / 1015: 35$ \\
\hline LC14A1 & A10D071-33 & Soil & 01:01/9400:00 & $04 / 02 / 1015: 35$ \\
\hline LC15B2 & A10D071-34 & Soil & 01:01/9400:00 & $04 / 02 / 1015: 35$ \\
\hline LCl6Al & A10D071-35 & Soil & 01/01/9400:00 & $04 / 02 / 1015: 35$ \\
\hline
\end{tabular}

Apex Laboratories

The results in this report aspiy to the samples analyzed in accoriaxce with the 6 knin of

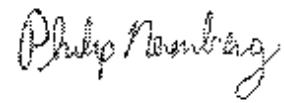

custody document This anditicalrepont mus be reproduced in it entivety. 


\section{Apex Labs}

12232 S.W. Garden Phace

Tigard, OR 97223

503-718-2323 Phone

503-718-0333 Fax
GeoEngineers -Seattle

600 S tewrartSt. Suite 1700

Seattle, WA 98101
Project OregonMetals Evaluation

Project Humber. 2787-050-000

Froject Manager. Heil Morton
Reparted:

$0513 / 1022: 51$

ANAL YTICAL REPORT FOR SAMPLES

\begin{tabular}{|c|c|c|c|c|}
\hline \multicolumn{5}{|c|}{ SAMPLE INF ORMATION } \\
\hline Sample II & Laburatory ID & Matrix & Date Sampied & Date Recrived \\
\hline LCl7Bl & A10D071-36 & Soil & $01 / 01 / 9400: 00$ & $04 / 02 / 1015: 35$ \\
\hline LC18Al & A10D071-37 & Soil & 01:01/9400:00 & $04 / 02 / 1015: 35$ \\
\hline LC18BI & A10D071-38 & Soil & 01:01/9400:00 & 04,02/10 15:35 \\
\hline LC19Al & A10D071-39 & Soil & 01:01/9400:00 & $04 / 02 / 1015: 35$ \\
\hline LC20B1 & A10D071-40 & Soil & 01:01/9400:00 & $04 / 02 / 1015: 35$ \\
\hline LC21Al & A10D071-41 & Soil & $01 / 01 / 9400: 00$ & $04 / 02 / 1015: 35$ \\
\hline LC22BI & A10D071-42 & Soil & 01:01/9400:00 & $04 / 02 / 1015: 35$ \\
\hline LC23Al & A10D071-43 & Soil & 01:01/9400:00 & $04 / 02 / 1015: 35$ \\
\hline LC23Bl & A10D071-44 & Soil & 01:01/9400:00 & 04:02/10 15:35 \\
\hline $\mathrm{EO} 22 \mathrm{Bl}$ & A10D071-45 & Soil & 01/01/9400:00 & 04/02/10 15:35 \\
\hline M19B2a & A10D071-46 & Soil & $01: 01 / 9400: 00$ & $04,02 / 1015: 35$ \\
\hline
\end{tabular}

Apex Laboratories

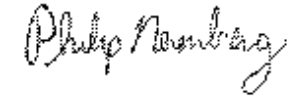

Frilip Nererberg For Darwin Thomas, Business Development Director
The results in this report appiy to the somples anajsed in accoridaxe with the chain of custody document This anditicalvepont mus be reproduced in is entrivety. 


\section{Apex Labs}

12232 S.W. Garden Place

Tigard, OR 97223

503-718-2323 Phone

503-718-0333 Fax

GeoEngineers -Seatle

600 S tewart St. Suite 1700

Project Oregon Metals Evaluation

Project Humber. 2787-050-000

Project Manager. Neil Morton

Reported

$0513 / 1022: 51$

QUALITY CONTROL (QC) SAMPLE RESULTS

\begin{tabular}{|c|c|c|c|c|c|c|c|c|c|c|c|c|}
\hline \multicolumn{13}{|c|}{ Total Metals by EPA 6020 (ICPHS) } \\
\hline Analyte & Result & MDL & $\begin{array}{l}\text { Reporting } \\
\text { Limit }\end{array}$ & Units & Dil. & $\begin{array}{l}\text { Spike } \\
\text { Amourt }\end{array}$ & $\begin{array}{l}\text { Sounce } \\
\text { Reult }\end{array}$ & $\%$ REC & $\begin{array}{l}\% \mathrm{REC} \\
\text { Limits }\end{array}$ & RPD & $\begin{array}{l}\text { RPD } \\
\text { Limit }\end{array}$ & Notes \\
\hline
\end{tabular}

Batch 1004235 - EPA 3051A

Soil

Blank (1002)3E-BLK1)

\section{EF A 6020}

Antimory

Aseric

Beryllium

Cadrimim

Lead

Selenium

Silver

Thallinm

LCS (1004235-BS1)

EPA 6020

Antimory

Aseric

Beryllium

Cadrimım

Lead

Selenium

Silver

Thallinm

Prepared: 04/18/10 12:07 Analyrad: 04/19/10 18:21

\begin{tabular}{|c|c|c|c|c|c|c|c|c|c|}
\hline $\mathrm{HD}$ & 0.100 & 100 & $\mathrm{mg} / \mathrm{kg}$ wet & 10 & -- & -- & -- & -- & - \\
\hline $\mathrm{HD}$ & 0200 & 200 & $"$ & $"$ & -- & -- & -- & -- & - \\
\hline $\mathrm{HD}$ & 0200 & 100 & $"$ & $"$ & -- & -- & -- & -- & - \\
\hline $\mathrm{HD}$ & 0.100 & 100 & $"$ & $"$ & -- & -- & -- & -- & -- \\
\hline $\mathrm{HD}$ & 0.100 & 100 & $"$ & $"$ & -- & -- & -- & -- & - \\
\hline $\mathrm{ND}$ & 0.400 & 200 & $"$ & $"$ & - & -- & -- & -- & -- \\
\hline $\mathrm{ND}$ & 0.100 & 100 & $"$ & $"$ & - & -- & -- & -- & -- \\
\hline $\mathrm{HD}$ & 0.100 & 100 & $"$ & $"$ & - & -- & -- & -- & -- \\
\hline
\end{tabular}

Prepared: 04/18/10 12:07 Analyzed: 04/19/10 18:24

Duplicate (1004235-DUPI)

Prepared: 04/18/10 12:07 Analyzed: 04/19/10 18:45

oc S aurces ample: E027A? (A10DOn1-04)

EP A 6020

Artimory

Aseric

Beryllium

Cadrimim

Lead

Selenium

Silver

Thallimm

$\begin{array}{lll}27.4 & 0.100 & 1.00 \\ 49.5 & 0200 & 200 \\ 23.9 & 0200 & 1.00 \\ 48.2 & 0.100 & 1.00 \\ 45.8 & 0.100 & 1.00 \\ 24.6 & 0.400 & 200 \\ 24.0 & 0.100 & 1.00 \\ 23.0 & 0.100 & 1.00\end{array}$

$\mathrm{mg} / \mathrm{kg}$ wet 10

25.0

$\begin{array}{lllll}-- & 110 & 80-120 \% & - & -\end{array}$

200

100

100

100

200

100

50.0
25.0

$\begin{array}{ccc}" & \text { " } & 50.0 \\ " & \text { " } & \text { " }\end{array}$

"

"

"

25.0

$--$

- 90

- 96

92

$-$

- 92

$\begin{array}{ccc}80-120 \% & - & - \\ " & - & - \\ " & - & - \\ " & - & - \\ " & - & - \\ " & - & - \\ " & - & - \\ " & - & -\end{array}$

Matrix Spile (1004235-MS1)

QC S aurce S mple: B027A2 (A10DG1-04)

$\begin{array}{ccc}\mathbf{0 . 2 5 6} & 0.111 & 1.11 \\ \mathbf{1 . 9 9} & 0.222 & 222 \\ \mathbf{0 . 2 7 8} & 0222 & 1.11 \\ \mathbf{0 . 2 6 7} & 0.111 & 1.11 \\ \mathbf{1 6 . 0} & 0.111 & 1.11 \\ \text { HD } & 0.445 & 222 \\ \text { HD } & 0.111 & 1.11 \\ \mathbf{0 . 2 6 7} & 0.111 & 1.11\end{array}$

$\begin{array}{ccc}m g / k g d r y & 10 & - \\ " & " & - \\ " & " & - \\ " & " & - \\ " & " & - \\ \text { " } & \text { " } & -\end{array}$

$\begin{array}{cc}- & \text { HD } \\ -- & 2.15 \\ -- & 0.291 \\ -- & 0.315 \\ -- & 16.7 \\ -- & \text { HD } \\ -- & \text { HD } \\ -- & 0.291\end{array}$

$--$

$--$

$-$

$-$

$--$

$0.201--$

Prepared: 04/18/10 12:07 Analyzed: 04/19/10 18:47

Apex Laboratories

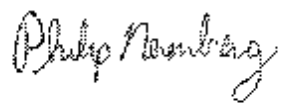

Philip Nerenberg For Darwin Thomas, Business Development Director
The results in this report apply to the samples andiswed in accoriaxe with the cknin of custody doument This arahticolveyon mus be reproduced in is entivety. 


\section{Apex Labs}

12232 S.W. Garden Place

Tigard, OR 97223

503-718-2323 Phone

503-718-0333 Fax

GeoEngineers -Seattle

600 S tewartSt. Suite 1700

Project OregonMetals Evaluation

Project Number. 2787-050-000

Reported.

Project Manager. Neil Morton

Seattle, WA 98101 $05 / 1311022: 51$

QUALITY CONTROL (QC) SAMPLE RESULTS

\begin{tabular}{|c|c|c|c|c|c|c|c|c|c|c|c|c|}
\hline \multicolumn{13}{|c|}{ Total Metals by EPA 6020 (ICPHS) } \\
\hline Analyte & Result & MDL & $\begin{array}{l}\text { Reporting } \\
\text { Limit }\end{array}$ & Units & Dil. & $\begin{array}{l}\text { Spike } \\
\text { Amourt }\end{array}$ & $\begin{array}{l}\text { Source } \\
\text { Rerult }\end{array}$ & $\% R E C$ & $\begin{array}{l}\% \mathrm{REC} \\
\text { Limits }\end{array}$ & RPD & $\begin{array}{l}\text { RPD } \\
\text { Limit }\end{array}$ & Notes \\
\hline
\end{tabular}

Batch 1004235 - EPA 3051A

Soil

Matrix spife (100425-MS1)

Prepared: 04/18/10 12:07 Analyad: 04/19/10 18:47

Qc S aurces ample: E027A2 (AlODOn1-04)

EFA 6020

\begin{tabular}{|c|c|c|c|c|c|c|c|c|c|c|c|}
\hline Antimory & 29.6 & 0.125 & 125 & $m g / k g d r y$ & 10 & 31.2 & ND & 95 & $75-125 \%$ & -- & -- \\
\hline Aseric & 63.1 & 0249 & 2.49 & $"$ & $"$ & 62.4 & 2.15 & 98 & $"$ & -- & -- \\
\hline Beryllium & 29.1 & 0249 & 125 & $"$ & $"$ & 31.2 & 0.291 & 92 & $"$ & -- & -- \\
\hline Cadnim & 59.2 & 0.125 & 125 & $"$ & $"$ & 62.4 & 0.315 & 94 & $"$ & -- & -- \\
\hline Lead & 70.0 & 0.125 & 125 & $"$ & $"$ & $"$ & 16.7 & 85 & $"$ & -- & -- \\
\hline Selenvium & 29.8 & 0.499 & 2.49 & $"$ & $"$ & 31.2 & $\mathrm{HD}$ & 96 & $"$ & -- & - \\
\hline Silver & 29.0 & 0.125 & 125 & $"$ & $"$ & $"$ & HD & 93 & $"$ & - & -- \\
\hline Thallinm & 27.3 & 0.125 & 125 & $"$ & $"$ & $"$ & 0.291 & 87 & $"$ & -- & - \\
\hline
\end{tabular}

Matrix Spife (1004235-MS2)

Prepared: 04/18/10 12:07 Analyrsd: 04/19/10 19:41

Qc S aurces ample: LCO4Al (A10D071-19)

EPA 6020

Antimory

Aseric

Beryllium

Cadrimim

Lead

Selenium

Silver

Thallim

$\begin{array}{lll}21.8 & 0.100 & 1.00 \\ 49.8 & 0201 & 201 \\ 24.1 & 0201 & 1.00 \\ 48.4 & 0.100 & 1.00 \\ 56.6 & 0.100 & 1.00 \\ 22.2 & 0.401 & 2.01 \\ 23.7 & 0.100 & 100 \\ 22.7 & 0.100 & 100\end{array}$

$\begin{array}{cccc}m g / k g d y & 10 & 25.1 & 0.101 \\ " & " & 50.1 & 2.10 \\ " & " & 25.1 & 0.393 \\ " & " & 50.1 & \text { ND } \\ " & " & " & 10.5 \\ " & " & 25.1 & \text { ND } \\ " & " & " & \text { ND } \\ " & \text { " } & " & 0.141\end{array}$

$\begin{array}{cccc}86 & 75-125 \% & - & - \\ 95 & " & -- & - \\ 95 & 1 & -- & - \\ 96 & 1 & - & - \\ 92 & 1 & - & - \\ 89 & 1 & - & - \\ 95 & 1 & - & - \\ 90 & 1 & - & -\end{array}$

Apex Laboratories

The results in this report apply to the samples analyzed in accoriaxse with the $\mathrm{c}$ knin of cusody document This madticalreyon mux be reproduced in it entirety.

Philip Nerenberg For Darwin Thomas, Business Development Director

Puge 20 of 30 


\section{Apex Labs}

12232 S.W. Garden Place

Tigard, OR 97223

503-718-2323 Phone

503-718-0333 Fax
GeoEngineers -Seattle

600 S tewartSt. Suite 1700

Seattle, WA 98101
Project OregonMetals Evaluation

Project Number. 2787-050-000

Project Manager. Neil Morton
Reported

$05 / 13 / 1022: 51$

QUALITY CONTROL (QC) SAMPLE RESULTS

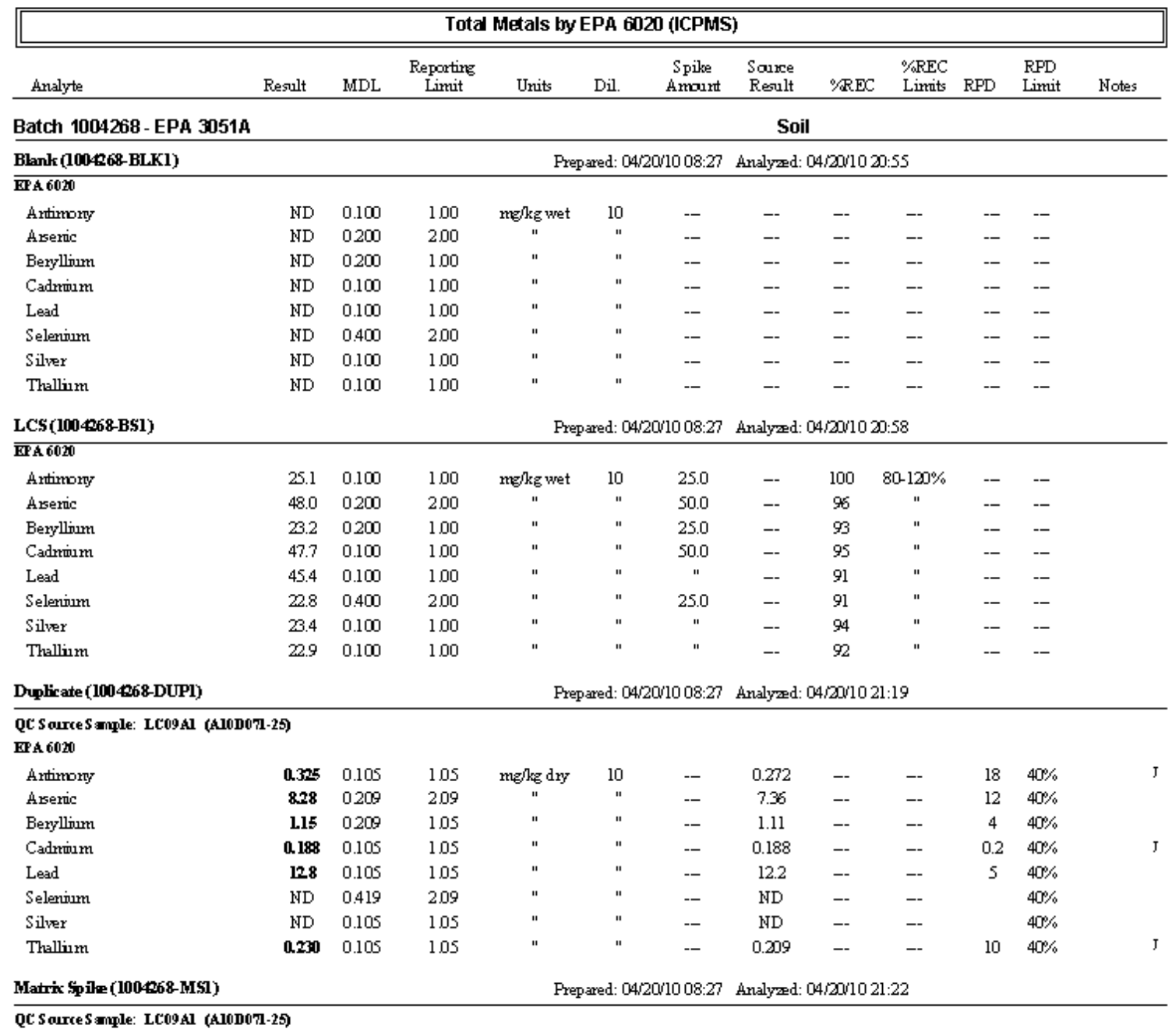

Apex Laboratories

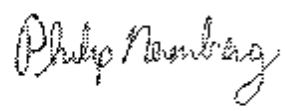

Philip Nerenberg For Darwin Thomas, Business Development Director
The results in this report aspiy to the samples analyzed in accoriaxe with the chnin of custody do cument This anditicalrepont mus be reproduced in it entivety. 


\section{Apex Labs}

12232 S.W. Garden Place

Tigard, OR 97223

503-718-2323 Phone

503-718-0333 Fax

\begin{tabular}{|llc|}
\hline GeoEngineers -Seattle & Project OregonMetals Evaluation & \\
600 StewartSt. Suite 1700 & Project Humber. 2787-050-000 & Reported \\
Seattle, WA 98101 & Project Manager. Neil Morton & $05 / 13 / 1022: 51$ \\
\hline
\end{tabular}

QUALITY CONTROL (QC) SAMPLE RESULTS

\begin{tabular}{|c|c|c|c|c|c|c|c|c|c|c|c|c|}
\hline \multicolumn{13}{|c|}{ Total hetals by EPA 6020 (ICPHS) } \\
\hline Analyte & Result & MDL & $\begin{array}{c}\text { Reporting } \\
\text { Limit }\end{array}$ & Units & Dil. & $\begin{array}{l}\text { Spike } \\
\text { Amourt }\end{array}$ & $\begin{array}{l}\text { Source } \\
\text { Result }\end{array}$ & $\%$ REC & $\begin{array}{l}\% \mathrm{REC} \\
\text { Limnits }\end{array}$ & RPD & $\begin{array}{l}\text { RPD } \\
\text { Limit }\end{array}$ & Notes \\
\hline
\end{tabular}

Batch 1004268 - EPA 3051A

Soil

Matrix Spile (100468-MS1)

Prepared: 04/20/10 08:27 Analyzd: 04/20/1021:22

QC S aurce S mple: LC09Al (A10D071-25)

EPA 6020

Antimory

Aseric

Beryllium

Cadrium

Lead

Selenium

Silver

Thalling

$\begin{array}{lll}22.2 & 0.104 & 104 \\ 59.1 & 0208 & 20 \\ 23.8 & 0208 & 1.04 \\ 50.8 & 0.104 & 104 \\ 60.7 & 0.104 & 104 \\ 24.0 & 0.416 & 20 \\ 24.3 & 0.104 & 104 \\ 23.6 & 0.104 & 10\end{array}$

Matrix Spile (100468-MS2)

QC S aurce S ample: LC13 C1 (A10D071-32)

EPA 6020

\begin{tabular}{|c|c|c|c|c|c|c|c|c|c|c|}
\hline Antimory & 24.8 & 0.102 & 102 & $m g / \mathrm{kg} d r y$ & 10 & 25.6 & ND & 97 & $75-125 \%$ & -- \\
\hline Aseric & 50.9 & 0205 & 205 & $"$ & $"$ & 51.2 & 2.31 & 95 & $"$ & -- \\
\hline Beryllium & 23.3 & 0205 & 102 & $"$ & $"$ & 25.6 & HD & 91 & $"$ & -- \\
\hline Cadnim & 49.2 & 0.102 & 1.02 & $"$ & $"$ & 51.2 & ND & 96 & $"$ & -- \\
\hline Lead & 48.1 & 0.102 & 102 & $"$ & $"$ & $"$ & 0.742 & 92 & $"$ & -- \\
\hline Selenium & 22.7 & 0.410 & 205 & $"$ & $"$ & 25.6 & ND & 89 & $"$ & -- \\
\hline Silver & 24.0 & 0.102 & 1.02 & $"$ & $"$ & $"$ & HD & 94 & $"$ & -- \\
\hline Thallinm & 23.6 & 0.102 & 102 & $"$ & $"$ & $"$ & HD & 92 & $"$ & -- \\
\hline
\end{tabular}

Apex Laboratories

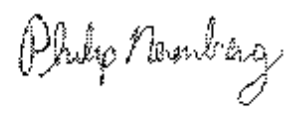

Philip Nerenberg For Darwin Thomas, Business Development Director
The results in this report apsiy to the samples analysed in accoriasce with the chnin of

custody document This madticalrepon mus be reproduced in it entivety. 


\section{Apex Labs}

12232 S.W. Garden Phace

Tigard, OR 97223

503-718-2323 Phone

503-718-0333 Fax

GeoEngineers -Seatle

600 S tewartSt. Suite 1700

Project Oregon Metals Evaluation

Project Humber. 2787-050-000

Project Marager. Neil Mortom

Reporte

$05 / 131022: 51$

QUALITY CONTROL (QC) SAMPLE RESULTS

\begin{tabular}{|c|c|c|c|c|c|c|c|c|c|c|c|c|}
\hline \multicolumn{13}{|c|}{ Total Metals by EPA 6020 (ICPMS) } \\
\hline Analyte & Result & MDL & $\begin{array}{c}\text { Reporting } \\
\text { Limit }\end{array}$ & Units & Dil. & $\begin{array}{c}\text { Spike } \\
\text { Amourt }\end{array}$ & $\begin{array}{l}\text { Sounce } \\
\text { Reult }\end{array}$ & $\% \mathrm{REC}$ & $\begin{array}{l}\text { \%REC } \\
\text { Limits }\end{array}$ & RPD & $\begin{array}{l}\text { RPD } \\
\text { Limit }\end{array}$ & Notes \\
\hline Batch 1004274 - EPA 3051A & & & \multicolumn{10}{|c|}{ Soil } \\
\hline Blank (100474-BLK1) & \multicolumn{12}{|c|}{ Frepared: 04/20/10 11:59 Analyred: $04 / 23 / 10$ 16:38 } \\
\hline \multicolumn{13}{|l|}{$\overline{\text { EPA 6020 }}$} \\
\hline Antimory & HD & 0.100 & 100 & $\mathrm{mg} / \mathrm{kg}$ wet & 10 & -- & -- & -- & -- & - & - & \\
\hline Aseric & ND & 0200 & 200 & $"$ & $"$ & - & -- & - & - & -- & -- & \\
\hline Beryllium & HD & 0200 & 100 & $"$ & $"$ & - & -- & -- & -- & -- & -- & \\
\hline Cadnimim & ND & 0.100 & 100 & $"$ & " & - & - & -- & - & -- & - & \\
\hline Lead & 0.100 & 0.100 & 100 & $"$ & $"$ & - & -- & -- & - & - & -- & J \\
\hline Selenium & $\mathrm{HD}$ & 0.400 & 200 & $"$ & $"$ & - & -- & -- & -- & -- & - & \\
\hline Silver & ND & 0.100 & 100 & $"$ & $"$ & - & -- & -- & -- & - & - & \\
\hline Thallinm & HD & 0.100 & 100 & $"$ & $"$ & - & -- & -- & -- & -- & - & \\
\hline
\end{tabular}

LCS (1004274BS1)

EPA 6020

\begin{tabular}{|c|c|c|c|c|c|c|c|c|c|c|}
\hline Antimory & 25.1 & 0.100 & 100 & $\mathrm{mg} / \mathrm{kg}$ wet & 10 & 25.0 & -- & 100 & $80-120 \%$ & -- \\
\hline Aseric & 48.0 & 0200 & 200 & $"$ & $"$ & 50.0 & -- & 96 & $"$ & -- \\
\hline Beryllium & 23.0 & 0200 & 100 & $"$ & $"$ & 25.0 & -- & 92 & $"$ & - \\
\hline Cadrimim & 48.9 & 0.100 & 100 & $"$ & $"$ & 50.0 & -- & 98 & $"$ & -- \\
\hline Lead & 48.0 & 0.100 & 100 & $"$ & $"$ & $"$ & -- & 96 & $"$ & -- \\
\hline Selenium & 23.3 & 0.400 & 200 & $"$ & $"$ & 25.0 & -- & 93 & $"$ & -- \\
\hline Silver & 24.0 & 0.100 & 100 & $"$ & $"$ & $"$ & -- & 96 & $"$ & -- \\
\hline Thallinm & 23.6 & 0.100 & 100 & " & " & " & -- & 95 & " & -- \\
\hline
\end{tabular}

Matrix Spile (100474MS2)

Prepared: 04/20/10 11:59 Analyrad: 04/23/10 17:38

QC Saurces ample: LC20B1 (A10D071-40)

EPA 6020

\begin{tabular}{|c|c|c|c|c|c|c|c|c|c|c|c|c|}
\hline Antimory & 19.4 & 0.106 & 106 & $m g / k g d r y$ & 10 & 26.5 & $\mathrm{ND}$ & 73 & $75-125 \%$ & - & - & $0-00,0-04$ \\
\hline Aseric & 51.2 & 0212 & 2.12 & $"$ & $"$ & 53.0 & 2.33 & 92 & $"$ & -- & -- & \\
\hline Cadrixum & 51.3 & 0.106 & 1.06 & $"$ & $"$ & 53.0 & 0.147 & 97 & $"$ & -- & -- & \\
\hline Selenvium & 22.2 & 0.424 & 2.12 & $"$ & $"$ & 26.5 & ND & 84 & $"$ & -- & -- & \\
\hline Silver & 25.2 & 0.106 & 106 & $"$ & $"$ & $"$ & $\mathrm{ND}$ & 95 & $"$ & -- & -- & \\
\hline Thallinm & 23.7 & 0.106 & 1.06 & $"$ & $"$ & $"$ & ND & 89 & $"$ & -- & -- & \\
\hline
\end{tabular}

\section{Apex Laboratories \\ 1)}

The results in this report asphy to the samples andyzed in accoriance with the c knin of custody document This andaticalvepon mus be reproduced in it entivety.

Philip Nerenberg For Darwin Thomas, Business Development Director

Puge 23 of 30 


\section{Apex Labs}

12232 S.W. Garden Place

Tigard, OR 97223

503-718-2323 Phone

503-718-0333 Fax
GeoEngineers -Seattle

600 S tewartS t. Suite 1700

Seattle, WA 98101
Project Oregon Metals Evahuation

Project Humber. 2787-050-000

Project Manager. Heil Morton
Reported $05 / 13 / 1022: 51$

QUALITY CONTROL (QC) SAMPLE RESULTS

\begin{tabular}{|c|c|c|c|c|c|c|c|c|c|c|c|c|}
\hline \multicolumn{13}{|c|}{ "Percent Dry Weight by D2216 } \\
\hline Analyte & Result & MDL & $\begin{array}{c}\text { Reporting } \\
\text { Limit }\end{array}$ & Units & Dil. & $\begin{array}{c}\text { Spike } \\
\text { Amourt }\end{array}$ & $\begin{array}{l}\text { Source } \\
\text { Result }\end{array}$ & $\% \mathrm{REC}$ & $\begin{array}{l}\text { \%REC } \\
\text { Limits }\end{array}$ & RPD & $\begin{array}{l}\text { RPD } \\
\text { Limit }\end{array}$ & Notes \\
\hline
\end{tabular}

Batch 1004219 - Dry Weight

Soil

Duplicate (100419-DUPI)

QC S aurces ample: E030A2 (A10DOn1-05)

D216

$\begin{array}{llllllllllllllll}\% \text { Solids } & 98.7 & - & 100 & \% \text { by Weight } & 1 & - & 98.7 & -- & - & 0 & 20 \%\end{array}$

Duplicate (100419-DUP2)

Prepared: 04/16/10 11:43 Analyrad: 04/17/10 10:06

QC Sarre S mqle: LC09Al (A10D071-25)

D2m16

$\%$ Solids

95.9

$100 \%$ by Weight 1

95.9

$--$

$020 \%$

The results in this report apply to the samples analyzed in accoriaxe with the chnin of

custody document This anditical regon must be reproduced in it entivety. 


\section{Apex Labs}

12232 S.W. Garden Place

Tigard, OR 97223

503-718-2323 Phone

503-718-0333 Fax

\begin{tabular}{|c|c|c|}
\hline GeoEngineers -Seatfle & Project Oregon Metals Evahuation & \\
\hline 600 S tewart St. Suite 1700 & Project Number. $2787-050-000$ & Reported: \\
\hline Seattle, WA 98101 & Project Manager. Neil Morton & $05 / 131022: 51$ \\
\hline
\end{tabular}

SAMPLE PREPARATION INF ORMATION

\begin{tabular}{|c|c|c|c|c|c|c|c|}
\hline \multicolumn{8}{|c|}{ Total hetals by EPA 6020 (ICPHS) } \\
\hline Prep: EPA 3051A & & & & & Sarmle & Default & RL Prep \\
\hline Lab Number & Matix & Method & Sarpled & Phepared & Iritial/Final & Iritial/Final & Factor \\
\hline \multicolumn{8}{|l|}{ Batch: 1004235} \\
\hline A10D071-01 & Soil & EPA 6020 & 01/01/9400:00 & $04 / 18 / 1012: 07$ & $0.434 \mathrm{~g} / 50 \mathrm{~mL}$ & $0.5 \mathrm{~g} / 50 \mathrm{~mL}$ & 1.15 \\
\hline A10D071-02 & Soil & EPA 6020 & 01/01/9400:00 & $04 / 18 / 1012: 07$ & $0.485 \mathrm{~g} / 50 \mathrm{~mL}$ & $0.5 \mathrm{~g} / 50 \mathrm{~mL}$ & 1.03 \\
\hline A10D071-03 & Soil & EPA 6020 & 01/01/9400:00 & $04 / 18 / 1012: 07$ & $0.441 \mathrm{~g} / 50 \mathrm{~mL}$ & $0.5 \mathrm{~g} / 50 \mathrm{~mL}$ & 1.13 \\
\hline A10D071-04 & Soil & EPA 6020 & 01/01/9400:00 & $04 / 18 / 1012: 07$ & $0.43 \mathrm{~g} / 50 \mathrm{~mL}$ & $0.5 \mathrm{~g} / 50 \mathrm{~mL}$ & 1.16 \\
\hline A10D071-05 & Soil & EPA 6020 & 01/01/9400:00 & $04 / 18 / 1012: 07$ & $0.485 \mathrm{~g} / 50 \mathrm{~mL}$ & $0.5 \mathrm{~g} / 50 \mathrm{~mL}$ & 1.03 \\
\hline A10D071-06 & Soil & EPA 6020 & 01/01/9400:00 & $04 / 18 / 1012: 07$ & $0.49 \mathrm{~g} / 50 \mathrm{~mL}$ & $0.5 \mathrm{~g} / 50 \mathrm{~mL}$ & 1.02 \\
\hline A10D071-0? & Soil & EPA 6020 & 01/01/9400:00 & $04 / 18 / 1012: 07$ & $0.455 \mathrm{~g} / 50 \mathrm{~mL}$ & $0.5 \mathrm{~g} / 50 \mathrm{~mL}$ & 1.10 \\
\hline A10D071-08 & Soil & EPA 6020 & 01:01/9400:00 & $04 / 18 / 1012: 07$ & $0.46 \mathrm{~g} / 50 \mathrm{~mL}$ & $0.5 \mathrm{~g} / 50 \mathrm{~mL}$ & 1.09 \\
\hline A10D071-09 & Soil & EPA 6020 & 01:01/9400:00 & $04 / 18 / 1012: 07$ & $0.484 \mathrm{~g} / 50 \mathrm{~mL}$ & $0.5 \mathrm{~g} / 50 \mathrm{~mL}$ & 1.03 \\
\hline A10D071-10 & Soil & EPA 6020 & 01/01/9400:00 & $04 / 18 / 1012: 07$ & $0.45 \mathrm{~g} / 50 \mathrm{~mL}$ & $0.5 \mathrm{~g} / 50 \mathrm{~mL}$ & 1.11 \\
\hline A10D071-11 & Soil & EPA 6020 & 01:01/9400:00 & $04 / 18 / 1012: 07$ & $0.488 \mathrm{~g} / 50 \mathrm{~mL}$ & $0.5 \mathrm{~g} / 50 \mathrm{~mL}$ & 1.02 \\
\hline A10D071-12 & Soil & EPA 6020 & 01/01/9400:00 & $04 / 18 / 1012: 07$ & $0.47 \mathrm{~g} / 50 \mathrm{~mL}$ & $0.5 \mathrm{~g} / 50 \mathrm{~mL}$ & 1.06 \\
\hline A10D071-13 & Soil & EPA 6020 & 01:01/9400:00 & $04 / 18 / 1012: 07$ & $0.448 \mathrm{~g} / 50 \mathrm{~mL}$ & $0.5 \mathrm{~g} / 50 \mathrm{~mL}$ & 1.12 \\
\hline A10D071-14 & Soil & EPA 6020 & 01/01/9400:00 & $04 / 18 / 1012: 07$ & $0.429 \mathrm{~g} / 50 \mathrm{~mL}$ & $0.5 \mathrm{~g} / 50 \mathrm{~mL}$ & 1.17 \\
\hline A10D071-15 & Soil & EPA 6020 & 01/01/9400:00 & $04 / 18 / 1012: 07$ & $0.492 \mathrm{~g} / 50 \mathrm{~mL}$ & $0.5 \mathrm{~g} / 50 \mathrm{~mL}$ & 1.02 \\
\hline A10D071-16 & Soil & EPA 6020 & 01/01/9400:00 & $04 / 18 / 1012: 07$ & $0.451 \mathrm{~g} / 50 \mathrm{~mL}$ & $0.5 \mathrm{~g} / 50 \mathrm{~mL}$ & 1.11 \\
\hline A10D071-17 & Soil & EPA 6020 & 01:01/9400:00 & $04 / 18 / 1012: 07$ & $0.47 \mathrm{~g} / 50 \mathrm{~mL}$ & $0.5 \mathrm{~g} / 50 \mathrm{~mL}$ & 1.06 \\
\hline A10D071-18 & Soil & EPA 6020 & 01:01/9400:00 & $04 / 18 / 1012: 07$ & $0.478 \mathrm{~g} / 50 \mathrm{~mL}$ & $0.5 \mathrm{~g} / 50 \mathrm{~mL}$ & 1.05 \\
\hline A10D071-19 & Soil & EPA 6020 & 01:01/9400:00 & $04 / 18 / 1012: 07$ & $0.51 \mathrm{~g} / 50 \mathrm{~mL}$ & $0.5 \mathrm{~g} / 50 \mathrm{~mL}$ & 0.98 \\
\hline \multicolumn{8}{|l|}{ Batch: 1004268} \\
\hline A10D071-20 & Soil & EPA 6020 & 01:01/9400:00 & $04 / 20 / 1008: 27$ & $0.497 \mathrm{~g} / 50 \mathrm{~mL}$ & $0.5 \mathrm{~g} / 50 \mathrm{~mL}$ & 1.01 \\
\hline A10D071-21 & Soil & EPA 6020 & 01/01/9400:00 & $04 / 20 / 1008: 27$ & $0.495 \mathrm{~g} / 50 \mathrm{~mL}$ & $0.5 \mathrm{~g} / 50 \mathrm{~mL}$ & 1.01 \\
\hline A10D071-22 & Soil & EPA 6020 & 01/01/9400:00 & $04 / 20 / 1008: 27$ & $0.501 \mathrm{~g} / 50 \mathrm{~mL}$ & $0.5 \mathrm{~g} / 50 \mathrm{~mL}$ & 1.00 \\
\hline A10D071-23 & Soil & EPA 6020 & 01/01/9400:00 & $04 / 20 / 1008: 27$ & $0.494 \mathrm{~g} / 50 \mathrm{~mL}$ & $0.5 \mathrm{~g} / 50 \mathrm{~mL}$ & 1.01 \\
\hline A10D071-24 & Soil & EPA 6020 & 01/01/9400:00 & $04 / 20 / 1008: 27$ & $0.503 \mathrm{~g} / 50 \mathrm{~mL}$ & $0.5 \mathrm{~g} / 50 \mathrm{~mL}$ & 0.99 \\
\hline A10D071-25 & Soil & EPA 6020 & 01/01/9400:00 & $04 / 20 / 1008: 27$ & $0.499 \mathrm{~g} / 50 \mathrm{~mL}$ & $0.5 \mathrm{~g} / 50 \mathrm{~mL}$ & 1.00 \\
\hline A10D071-26 & Soil & EPA 6020 & 01:01/9400:00 & $04 / 20 / 1008: 27$ & $0.486 \mathrm{~g} / 50 \mathrm{~mL}$ & $0.5 \mathrm{~g} / 50 \mathrm{~mL}$ & 1.03 \\
\hline A10D071-27 & Soil & EPA 6020 & 01:01/9400:00 & $04 / 20 / 1008: 27$ & $0.492 \mathrm{~g} / 50 \mathrm{~mL}$ & $0.5 \mathrm{~g} / 50 \mathrm{~mL}$ & 1.02 \\
\hline A10D071-28 & Soil & EPA 6020 & 01:01/9400:00 & $04 / 20 / 1008: 27$ & $0.496 \mathrm{~g} / 50 \mathrm{~mL}$ & $0.5 \mathrm{~g} / 50 \mathrm{~mL}$ & 1.01 \\
\hline A10D071-29 & Soil & EPA 6020 & 01:01/9400:00 & $04 / 20 / 1008: 27$ & $0.5 \mathrm{~g} / 50 \mathrm{~mL}$ & $0.5 \mathrm{~g} / 50 \mathrm{~mL}$ & 1.00 \\
\hline A10D071-30 & Soil & EPA 6020 & 01:01/9400:00 & $04 / 20 / 1008: 27$ & $0.494 \mathrm{~g} / 50 \mathrm{~mL}$ & $0.5 \mathrm{~g} / 50 \mathrm{~mL}$ & 1.01 \\
\hline A10D071-31 & Soil & EPA 6020 & 01:01/9400:00 & $04 / 20 / 1008: 27$ & $0.493 \mathrm{~g} / 50 \mathrm{~mL}$ & $0.5 \mathrm{~g} / 50 \mathrm{~mL}$ & 1.01 \\
\hline A10D071-32 & Soil & EPA 6020 & 01:01/9400:00 & $04 / 20 / 1008: 27$ & $0.494 \mathrm{~g} / 50 \mathrm{~mL}$ & $0.5 \mathrm{~g} / 50 \mathrm{~mL}$ & 1.01 \\
\hline
\end{tabular}

Apex Laboratories

The results in this report asply to the samples analysed in accoriaxe with the ckain of

custody document This masticalvepon mus be reproduced in it entidety.

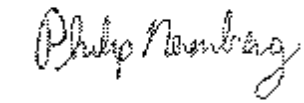

Philip Nerenberg For Darwin Thomas, Business Development Director

Puge 25 of 30 


\section{Apex Labs}

12232 S.W. Garden Place Tigard, OR 97223

503-718-2323 Phone

503-718-0333 Fax

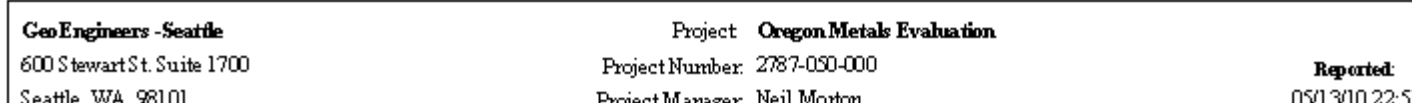

SAM PLE PREPARATION INF ORMATION

\begin{tabular}{|c|c|c|c|c|c|c|c|}
\hline \multicolumn{8}{|c|}{ Total Metals by EPA 6020 (ICPMS) } \\
\hline Prep: EPA 3051A & & & & & Sample & Default & RL Prep \\
\hline Lab Number & Matix & Method & Sarmpled & Prepared & Iritial/Final & Iritial/Final & Factor \\
\hline A10D071-33 & Soil & EPA 6020 & 01/01/9400:00 & $04 / 20 / 1008: 27$ & $0.485 \mathrm{~g} / 50 \mathrm{~mL}$ & $0.5 \mathrm{~g} / 50 \mathrm{~mL}$ & 1.03 \\
\hline A10D071-34 & Soil & EPA 6020 & 01/01/9400:00 & $04 / 20 / 1008: 27$ & $0.492 \mathrm{~g} / 50 \mathrm{~mL}$ & $0.5 \mathrm{~g} / 50 \mathrm{~mL}$ & 1.02 \\
\hline A10D071-35 & Soil & EPA 6020 & 01/01/9400:00 & $04 / 20 / 1008: 27$ & $0.501 \mathrm{~g} / 50 \mathrm{~mL}$ & $0.5 \mathrm{~g} / 50 \mathrm{~mL}$ & 1.00 \\
\hline A10D071-36 & Soil & EPA 6020 & 01/01/9400:00 & $04 / 20 / 1008: 27$ & $0.497 \mathrm{~g} / 50 \mathrm{~mL}$ & $0.5 \mathrm{~g} / 50 \mathrm{~mL}$ & 1.01 \\
\hline A10D071-37 & Soil & EPA 6020 & 01/01/9400:00 & $04 / 20 / 1008: 27$ & $0.498 \mathrm{~g} / 50 \mathrm{~mL}$ & $0.5 \mathrm{~g} / 50 \mathrm{~mL}$ & 1.00 \\
\hline A10D071-38 & Soil & EPA 6020 & 01/01/9400:00 & $04 / 20 / 1008: 27$ & $0.492 \mathrm{~g} / 50 \mathrm{~mL}$ & $0.5 \mathrm{~g} / 50 \mathrm{~mL}$ & 1.02 \\
\hline \multicolumn{8}{|l|}{ Batch: 1004274} \\
\hline A10D071-39 & Soil & EPA 6020 & 01/01/9400:00 & $04 / 20 / 1011: 59$ & $0.498 \mathrm{~g} / 50 \mathrm{~mL}$ & $0.5 \mathrm{~g} / 50 \mathrm{~mL}$ & 1.00 \\
\hline A10D071-40 & Soil & EPA 6020 & 01/01/9400:00 & $04 / 20 / 1011: 59$ & $0.497 \mathrm{~g} / 50 \mathrm{~mL}$ & $0.5 \mathrm{~g} / 50 \mathrm{~mL}$ & 1.01 \\
\hline A10D071-41 & Soil & EPA 6020 & 01/01/9400:00 & $04 / 20 / 1011: 59$ & $0.5 \mathrm{~g} / 50 \mathrm{~mL}$ & $0.5 \mathrm{~g} / 50 \mathrm{~mL}$ & 1.00 \\
\hline A10D071-42 & Soil & EPA 6020 & 01/01/9400:00 & $04 / 20 / 1011: 59$ & $0.484 \mathrm{~g} / 50 \mathrm{~mL}$ & $0.5 \mathrm{~g} / 50 \mathrm{~mL}$ & 1.03 \\
\hline A10D071-43 & Soil & EPA 6020 & 01/01/9400:00 & $04 / 20 / 1011: 59$ & $0.491 \mathrm{~g} / 50 \mathrm{~mL}$ & $0.5 \mathrm{~g} / 50 \mathrm{~mL}$ & 1.02 \\
\hline A10D071-44 & Soil & EPA 6020 & 01/01/9400:00 & $04 / 20 / 1011: 59$ & $0.495 \mathrm{~g} / 50 \mathrm{~mL}$ & $0.5 \mathrm{~g} / 50 \mathrm{~mL}$ & 1.01 \\
\hline A10D071-45 & Soil & EPA 6020 & 01/01/9400:00 & $04 / 20 / 1011: 59$ & $0.497 \mathrm{~g} / 50 \mathrm{~mL}$ & $0.5 \mathrm{~g} / 50 \mathrm{~mL}$ & 1.01 \\
\hline A10D071-46 & Soil & EPA 6020 & 01/01/9400:00 & $04 / 20 / 1011: 59$ & $0.497 \mathrm{~g} / 50 \mathrm{~mL}$ & $0.5 \mathrm{~g} / 50 \mathrm{~mL}$ & 1.01 \\
\hline
\end{tabular}

Apex Laboratories

The results in this report asply to the samples analysed in accordaxe with the $c$ knin of custody document This anditicalveyont must be regroduced in it entivety.

Philip Nerenberg For Darwin Thomas, Business Development Director

Puge 26 of 30 


\section{Apex Labs}

12232 S.W. Garden Place

Tigard, OR 97223

503-718-2323 Phone

503-718-0333 Fax

Thursday, May 13, 2010

Neil Morton

GeoEngineers -Seattle

600 Stewart St. Suite 1700

Seattle, WA 98101

RE: Oregon Metals Evaluation As / 2727-050-00

Enclosed are the results of analyses for work order $\mathrm{A10D077}$, which was received by the laboratory on $4 / 2 / 2010$ at $3: 35: 00 \mathrm{PM}$

Thank you for using Apex Labs. We appreciate your business and strive to provide the highest quality services to the environmental industry.

If you have any questions concerning this report or the services we offer, please feel free to contact me by email at: pnerenberg@apex-labs.com, or by phone at 503-718-2323.

Apex Laboratories




\section{Apex Labs}

12232 S.W. Garden Place

Tigard, OR 97223

503-718-2323 Phone

503-718-0333 Fax
GeoEngineers -Seattle

600 S tewart St. Suite 1700

Seattle, WA 98101
Project Oregon Metals Evahuation As

Project Humber. 2727-050-00

Project Manager. Neil Mortom
Reported

$0513 / 1022: 55$

ANAL YTICAL REPORT FOR SAMPLES

\begin{tabular}{|c|c|c|c|c|}
\hline \multicolumn{5}{|c|}{ SAMPLE INF ORMATION } \\
\hline Sample ID & Laboratory ID & Matrix & Date Sampled & Date Received \\
\hline $\mathrm{KL} 19 \mathrm{Al}$ & A10D077-01 & Soil & 01:01/9400:00 & $0402 / 1015: 35$ \\
\hline KL 19B1 & A10D077-02 & Soil & 01:01/9400:00 & $0402 / 1015: 35$ \\
\hline $\mathrm{KL} 22 \mathrm{~A} 2$ & A10D077-03 & Soil & 01:01/9400:00 & $04 / 02 / 1015: 35$ \\
\hline $\mathrm{KL} 22 \mathrm{~B} 2$ & A10D077-04 & Soil & 01:01/9400:00 & $0402 / 1015: 35$ \\
\hline KL24A 1 & A10D077-05 & Soil & 01:01/9400:00 & $0402 / 1015: 35$ \\
\hline $\mathrm{K} L 24 \mathrm{~B} 1$ & A10D077-06 & Soil & 01:01/9400:00 & $0402 / 1015: 35$ \\
\hline $\mathrm{K} \perp 27 \mathrm{Al}$ & A10D077-07 & Soil & 01:01/9400:00 & $04 / 02 / 1015: 35$ \\
\hline KL $27 \mathrm{Bl}$ & A10D077-08 & Soil & 01:01/9400:00 & $0402 / 1015: 35$ \\
\hline KL 30A 1 & A10D077-09 & Soil & 01:01/9400:00 & $0402 / 1015: 35$ \\
\hline KL30B1 & A10D077-10 & Soil & 01:01/9400:00 & $0402 / 1015: 35$ \\
\hline LM02B1 & A10D077-11 & Soil & 01:01/9400:00 & $04 / 02 / 1015: 35$ \\
\hline LMO3Al & $\mathrm{A} 10 \mathrm{D} 077-12$ & Soil & 01,01/9400:00 & $04 / 02 / 1015: 35$ \\
\hline LM04B 1 & A10D077-13 & Soil & 01:01/9400:00 & $04 / 02 / 1015: 35$ \\
\hline LM06А 1 & A10D077-14 & Soil & 01:01/9400:00 & $0402 / 1015: 35$ \\
\hline LM0TBl & A10D077-15 & Soil & 01:01/9400:00 & $04 / 02 / 1015: 35$ \\
\hline LM09A 1 & A10D077-16 & Soil & 01:01/9400:00 & $04 / 02 / 1015: 35$ \\
\hline LM09B1 & A10D077-17 & Soil & 01:01/9400:00 & $0402 / 1015: 35$ \\
\hline LMIlA1 & A10D077-18 & Soil & 01:01/9400:00 & $0402 / 1015: 35$ \\
\hline LM 12B1 & A10D077-19 & Soil & $01,01 / 9400: 00$ & $04,02 / 1015: 35$ \\
\hline LM14A 1 & A10D077-20 & Soil & 01:01/9400:00 & $04 / 02 / 1015: 35$ \\
\hline LM14BI & A10D077-21 & Soil & 01:01/9400:00 & $0402 / 1015: 35$ \\
\hline LMl6A1 & A10D077-22 & Soil & 01:01/9400:00 & $04 / 02 / 1015: 35$ \\
\hline LMITB 1 & A10D077-23 & Soil & 01:01/9400:00 & $0402 / 1015: 35$ \\
\hline LM20B2 & A10D077-24 & Soil & 01:01/9400:00 & $0402 / 1015: 35$ \\
\hline LM2lA2 & A10D077-25 & Soil & 01:01/9400:00 & $04 / 02 / 1015: 35$ \\
\hline E001A2 & A10D077-26 & Soil & 01:01/9400:00 & $04 / 02 / 1015: 35$ \\
\hline EO01B2 & A10D077-2? & Soil & 01:01/9400:00 & $0402 / 1015: 35$ \\
\hline EO0TB1 & A10D077-28 & Soil & 01:01/9400:00 & $0402 / 1015: 35$ \\
\hline EO10B1 & A10D077-29 & Soil & 01:01/9400:00 & $0402 / 1015: 35$ \\
\hline EO12B2 & A10D077-30 & Soil & 01/01/9400:00 & $04 / 02 / 1015: 35$ \\
\hline EO15A2 & A10D077-31 & Soil & 01,01/9400:00 & $04 / 02 / 1015: 35$ \\
\hline EO15B2 & A10D077-32 & Soil & 01:01/9400:00 & $0402 / 1015: 35$ \\
\hline EO18A2 & A10D077-33 & Soil & 01,01/9400:00 & $04 / 02 / 1015: 35$ \\
\hline EO19B1 & A10D077-34 & Soil & 01:01/9400:00 & $0402 / 1015: 35$ \\
\hline EO21A2 & A10D077-35 & Soil & 01:01/9400:00 & $0402 / 1015: 35$ \\
\hline
\end{tabular}

Apex Laboratories

The results in this report appiy to the samples andysed in accoriance with the chnin of

$$
\text { (1) }
$$

Philip Nerenberg For Dawin Thomas, Business Development Director

Puge 2 of 27 


\section{Apex Labs}

12232 S.W. Garden Place

Tigard, OR 97223

503-718-2323 Phone

503-718-0333 Fax

\begin{tabular}{|llc}
\hline GeoEngineers -Seatte & Project OregonMetals Evaluation As & \\
600 Stewart St. Suite 1700 & Project Number. $2727-050-00$ & Reported \\
Seattle, WA 98101 & Project Manager. Neil Morton & $05 / 13 / 1022: 55$
\end{tabular}

ANAL YTICAL REPORT FOR SAMPLES

\begin{tabular}{|c|c|c|c|c|}
\hline \multicolumn{5}{|c|}{ SAMPLE INF ORMATION } \\
\hline Sample ID & Laboratary ID & Matrix & D:te Sampled & Date Received \\
\hline EO2lB2 & A10D077-36 & Soil & 01/01/9400:00 & $04,02 / 1015: 35$ \\
\hline $\mathrm{EO} 24 \mathrm{~B} 2$ & A10D077-37 & Soil & 01:01/9400:00 & $04,02 / 1015: 35$ \\
\hline EO26A2 & A10D077-38 & Soil & 01/01/9400:00 & $04,02 / 1015: 35$ \\
\hline EO27B2 & A10D077-39 & Soil & 01/01/9400:00 & $04,02 / 1015: 35$ \\
\hline EO31A2 & A10D077-40 & Soil & 01/01/9400:00 & $04,02 / 1015: 35$ \\
\hline EO33A2 & A10D077-41 & Soil & 01:01/9400:00 & $04,02 / 1015: 35$ \\
\hline EO33B2 & A10D077-42 & Soil & 01/01/9400:00 & $04,02 / 1015: 35$ \\
\hline E035B1 & A10D077-43 & Soil & 01/01/9400:00 & $04,02 / 1015: 35$ \\
\hline EO36A2 & A10D077-44 & Soil & 01:01/9400:00 & $04,02 / 1015: 35$ \\
\hline LC02Al & A10D077-45 & Soil & 01:01/9400:00 & $04,02 / 1015: 35$ \\
\hline LC02Btl2 & A10D077-46 & Soil & 01:01/9400:00 & $04,02 / 1015: 35$ \\
\hline LC05Al & A10D077-47 & Soil & 01/01/9400:00 & $04,02 / 1015: 35$ \\
\hline LC05Bl & A10D077-48 & Soil & 01/01/9400:00 & $04,02 / 1015: 35$ \\
\hline LCOTAI & A10D077-49 & Soil & 01:01/9400:00 & $04,02 / 1015: 35$ \\
\hline LCOTBI & A10D077-50 & Soil & 01/01/9400:00 & $04,02 / 1015: 35$ \\
\hline LC10Al & A10D077-51 & Soil & 01/01/9400:00 & $04,02 / 1015: 35$ \\
\hline LC10B1 & A10D077-52 & Soil & 01/01/9400:00 & $04,02 / 1015: 35$ \\
\hline LC12Al & A10D077-53 & Soil & 01:01/9400:00 & $04,02 / 1015: 35$ \\
\hline LC14B1 & A10D077-54 & Soil & 01/01/9400:00 & $04,02 / 1015: 35$ \\
\hline LC15A2 & A10D077-55 & Soil & 01/01/9400:00 & $04,02 / 1015: 35$ \\
\hline LC16Bl & A10D077-56 & Soil & 01/01/9400:00 & $04,02 / 1015: 35$ \\
\hline LC1TAl & A10D077-57 & Soil & 01/01/9400:00 & $04 / 02 / 1015: 35$ \\
\hline LC19B1 & A10D077-58 & Soil & 01/01/9400:00 & $04,02 / 1015: 35$ \\
\hline LC20Al & A10D077-59 & Soil & 01/01/9400:00 & $04 / 02 / 1015: 35$ \\
\hline LC21Bl & A10D077-60 & Soil & 01/01/9400:00 & $04,02 / 1015: 35$ \\
\hline LC22Al & A10D077-61 & Soil & 01/01/9400:00 & $04,02 / 1015: 35$ \\
\hline LC01B2 & A10D077-62 & Soil & 01:01/9400:00 & $04,02 / 1015: 35$ \\
\hline $\mathrm{EO} 22 \mathrm{Cl}$ & A10D077-63 & Soil & 01/01/9400:00 & $04,02 / 1015: 35$ \\
\hline
\end{tabular}

\footnotetext{
Apex Laboratories

The results in this report apyly to the somples analyzed in accoriance with the $c$ knin of

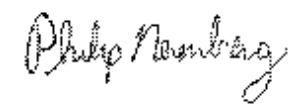
cusody document This aradicalrepont mus be reproduced in it entrety.

Philip Nerenberg For Darwin Thomas, Business Development Director

Page 3 of 27
} 


\section{Apex Labs}

12232 S.W. Garden Place

Tigard, OR 97223

503-718-2323 Phone

503-718-0333 Fax
GeoEngineers -Seatile

600 S tewartSt. Suite 1700

Seattle, WA 98101
Project OregonMetals Evaluation As

Project Number. 2727-050-00

Project Manager. Neil Morton
Reported

05/13/1022:55

QUALITY CONTROL (QC) SAMPLE RESULTS

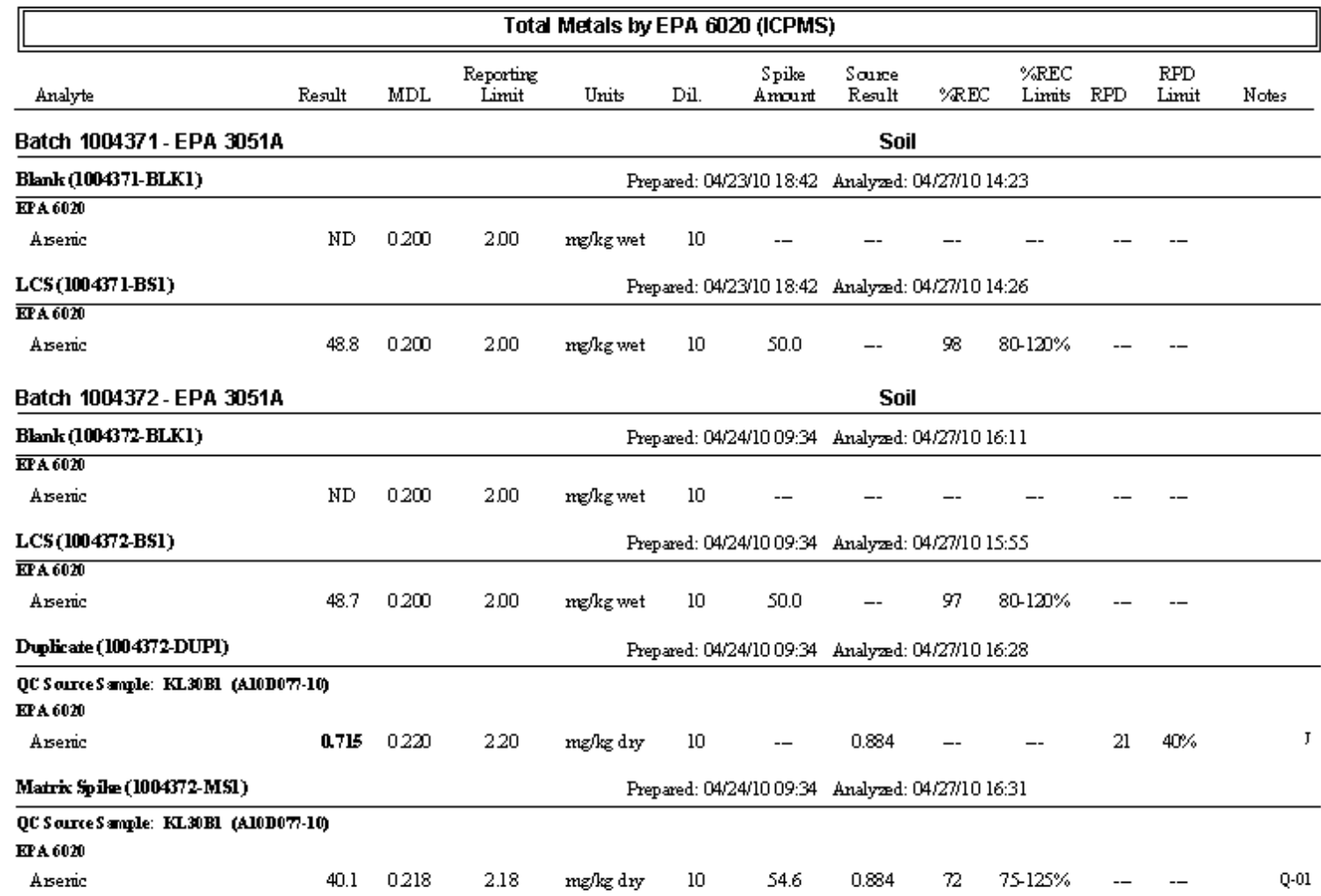

Matrix Spile (1004372-MS)

Prepared: 04/24/10 09:34 Analyzid: 04/27/10 17:05

QC Sarce S mple: LMO9BI (AI0D07n-17)

EPA 6020

$\begin{array}{lllllllllllll}\text { Aseric } & 55.2 & 0223 & 223 & \mathrm{mg} / \mathrm{kg} \mathrm{d} r y & 10 & 55.8 & 1.79 & 96 & 75-125 \% & -- & -\end{array}$

Post Spile (1004372-PS1)

Prepared: 04/28/10 14:14 Analyrad: 04/28/10 14:42

QC Sarce S ample: KL30BI (AI0D07-10)

EPA 6020

Aseris

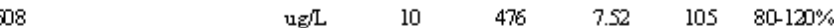

Apex Laboratories

The results in this report apply to the samples anajyed in accoriaxe with the chnin of

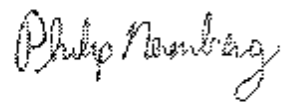

Philip Nerenberg For Darwin Thomas, Business Development Director 


\section{Apex Labs}

12232 S.W. Garden Place

Tigard, OR 97223

503-718-2323 Phone

503-718-0333 Fax

GeoEngineers -Seattle

600 S tewartSt. Suite 1700

Seattle, WA 98101

Project OregonMetals Evaluation As

Project Humber. 2727-050-00

Reported:

Project Manager. Neil Mortom

QUALITY CONTROL (QC) SAMPLE RESULTS

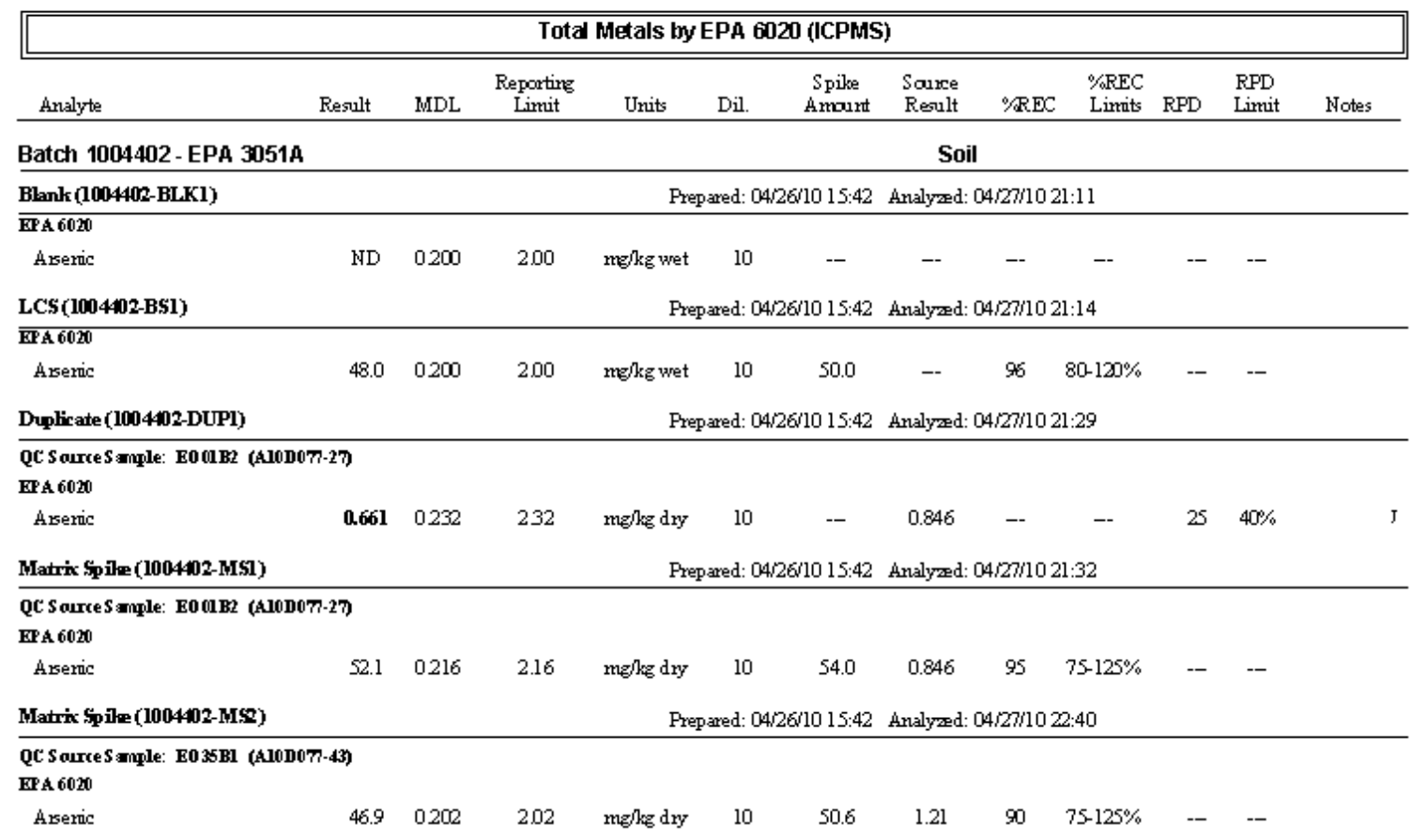

Apex Laboratories

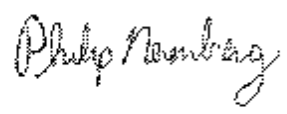

Philip Nerenberg For Darwin Thomas, Business Development Director
The results in this report apply to the somplys analyzed in accoriance with the chnin of custody document This anabticalyegon mus be reproduced in it entivety. 


\section{Apex Labs}

12232 S.W. Garden Phace

Tigard, OR 97223

503-718-2323 Phone

503-718-0333 Fax
GeoEngineers -Seattle

600 S tewart St. Suite 1700

Seattle, WA 98101
Project OregonMetals Evaluation As

Project Humber. 2727-050-00

Project Manager. Neil Morton
Reported

$0513 / 1022: 55$

QUALITY CONTROL (QC) SAMPLE RESULTS

\begin{tabular}{|c|c|c|c|c|c|c|c|c|c|c|c|c|}
\hline \multicolumn{13}{|c|}{ Total Metals by EPA 6020 (ICPMS) } \\
\hline Analyte & Result & MDL & $\begin{array}{l}\text { Reporting } \\
\text { Limit }\end{array}$ & Units & Dil. & $\begin{array}{c}\text { Spike } \\
\text { Amount }\end{array}$ & $\begin{array}{l}\text { Sounce } \\
\text { Reult }\end{array}$ & $\%$ REC & $\begin{array}{l}\text { \%REC } \\
\text { Limits }\end{array}$ & $\mathrm{RPD}$ & $\begin{array}{l}\text { RPD } \\
\text { Limit }\end{array}$ & Notes \\
\hline
\end{tabular}

Soil

Batch 1004409 - EPA 3051A

Blank (1004409-BLK1)

Prepared: 04/27/10 08:23 Analyªd: 04/28/10 15:56

\section{EPA 602}

Axeric

HD $\quad 0200 \quad 200 \quad \mathrm{mg} / \mathrm{kg}$ wet $\quad 10$

LCS (1004409-BS1)

EPA 6020

Aseric

$50.2 \quad 0200 \quad 200 \quad \mathrm{mg} / \mathrm{kg}$ wet $\quad 10$

Prepared: 04/27/1008:23 Analyzed: 04/28/10 15:59

Duplicate (1004409-DUP1)

Prepared: 04/27/1008:23 Analyzed: 04/28/10 17:00

QC S aurce S mqle: LCO7Al (A10D07-49)

EPA 6020

Aseric

$325 \quad 0380$

380

$m g / k g d r y \quad 10$

Prepared: 04/27/1008:23 Analyred: 04/28/10 17:03

Matrix Spile (1004409-MS1)

QC S aurce S mqle: LC07Al (Al0D07-49)

EPA 6020

$\begin{array}{llllllllllll}\text { Aseric } & 96.4 & 0382 & 382 & \mathrm{mg} / \mathrm{kg} \mathrm{dry} & 10 & 95.6 & 3.64 & 97 & 75-125 \% & -- & --\end{array}$

Matrix Spile (1004409-MS2)

Prepared: 04/27/10 08:23 Analyzed: 04/28/10 17:49

QC S aurce S mqle: LC16B1 (A10D07n-56)

EPA 6020

Aseric

$65.2 \quad 0252$

252

$m g / k d r y$

10

63.0

7.31

$92 \quad 75-125 \% \quad--\quad--$

Apex Laboratories

$$
\text { 1) }
$$

Philip Nerenberg For Dawwin Thomas, Business Development Director
The results in this report apy iy to the samples analyzed in accoriance with the chain of custody document This mabticalirepont mus be reproduced in it entivety. 


\section{Apex Labs}

12232 S.W. Garden Phace

Tigard, OR 97223

503-718-2323 Phone

503-718-0333 Fax

GeoEngineers -Seattle

600 S tewart St. Suite 1700

Seattle, WA 98101
Froject Oregon Metals Evahuation As

Project Humber. 2727-050-00

Project Manager. Neil Morton
Reported

05/13/1022:55

QUALITY CONTROL (QC) SAMPLE RESULTS

\begin{tabular}{|c|c|c|c|c|c|c|c|c|c|c|c|c|}
\hline \multicolumn{13}{|c|}{ Percent Dry Weight by D2216 } \\
\hline Analyte & Result & MDL & $\begin{array}{l}\text { Reporting } \\
\text { Limit }\end{array}$ & Units & Dil. & $\begin{array}{c}\text { Spike } \\
\text { Amourt }\end{array}$ & $\begin{array}{l}\text { Sounce } \\
\text { Reult }\end{array}$ & $\%$ REC & $\begin{array}{l}\% \mathrm{REC} \\
\text { Limits }\end{array}$ & RPD & $\begin{array}{l}\text { RPD } \\
\text { Limit }\end{array}$ & Notes \\
\hline
\end{tabular}

Batch 1004219 - Dry Weight

Soil

Duplicate (100419-DUP3) $\quad$ Frepared: 04/16/10 11:43 Analyrad: 04/17/10 10:06

QC Sarces mqle: KI.10A (AlODOnn-01)

D2m16

$\begin{array}{llllllllllllll}\% \text { Solids } & 97.6 & - & 100 & \% \text { by Weight } & 1 & - & 97.5 & -- & -- & 0.1 & 20 \%\end{array}$

Duplicate (100419-DUP4)

Prepared: 04/16/10 11:43 Analyrad: 04/17/10 10:06

QC S aurce S mqle: KIDBI (A10D07-02)

D2m16

$\begin{array}{llllllllllllll}\% \text { Solids } & 929 & - & 100 & \% \text { by Weight } & 1 & - & & 92.9 & -- & -- & 0 & 20 \%\end{array}$

Batch 1004232 - Dry Weight

Soil

Duplicate (1004232-DUP1) $\quad$ Prepared: 04/18/10 09:49 Analyrad: 04/19/1000:18

QC S aurces ample: KL27BI (A10D07-08)

$\mathbf{D} 216$

$\begin{array}{llllllllllllllll}\% \text { Solids } & 97.4 & - & 100 & \% \text { by Weight } & 1 & -- & 97.4 & -- & -- & 0 & 20 \%\end{array}$

$\begin{array}{ll}\text { Duplicate (100432-DUP2) } & \text { Prepared: 04/18/10 09:49 Analyzid: 04/19/1009:18 }\end{array}$

QC S aurceS mqle: LM12B1 (Al0D077-19)

$\mathbf{D} 216$

$\begin{array}{lllllllllllll}\% \text { Solids } & \mathbf{8 9 . 8} & - & - & 100 & \% \text { by Weight } & 1 & - & 89.8 & -- & -- & 0 & 20 \%\end{array}$

Duplicate (1004232-DUP3)

Prepared: 04/18/10 09:49 Analyzed: 04/19/1009:18

QC S aurce S mqle: E001B? (Al0D07-27)

D2m16

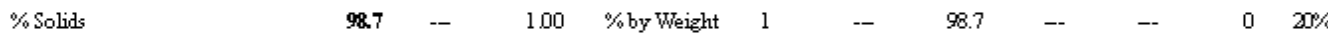

Duplicate (1004232-DUP4) $\quad$ Frepared: 04/18/10 09:49 Analyrad: 04/19/1000:18

QC S aurces mqle: E026A2 (Al0D077-38)

Dm16

$\begin{array}{lllllllllllllll}\% \text { Solids } & 97.0 & - & 100 & \% \text { by Weight } & 1 & -- & 97.2 & -- & - & 0.2 & 20 \%\end{array}$

Duplicate (1004232-DUF5)

Frepared: 04/18/1009:49 Analyzed: 04/19/1000:18

QC S aurce S mqle: LCO2B:12 (Al0D077-46)

D2m16

$\begin{array}{llllllllllllll}\% \text { Solids } & \mathbf{9 0 . 4} & - & & 100 & \% \text { by Weight } & 1 & - & & 90.4 & -- & - & 0 & 20 \%\end{array}$

Apex Laboratories

$$
\text { 1) }
$$

Philip Nerenberg For Darwin Thomas, Business Development Director

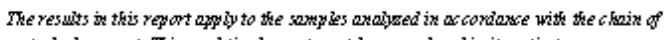
custody document This arahticalregon must be reproduced in it entivety. 


\section{Apex Labs}

12232 S.W. Garden Place

Tigard, OR 97223

503-718-2323 Phone

503-718-0333 Fax

GeoEngineers -Seatte

600 S tewartSt. Suite 1700

Project OregonMetals Evaluation As

Project Number. 2727-050-00

Reported

Project Marager. Neil Mortom

QUALITY CONTROL (QC) SAMPLE RESULTS

\begin{tabular}{|c|c|c|c|c|c|c|c|c|c|c|c|c|}
\hline \multicolumn{13}{|c|}{ Percent Dry Weight by D2216 } \\
\hline Analyte & Result & MDL & $\begin{array}{c}\text { Reporting } \\
\text { Limit }\end{array}$ & Units & Dil. & $\begin{array}{c}\text { Spike } \\
\text { Amourt }\end{array}$ & $\begin{array}{l}\text { Source } \\
\text { Result }\end{array}$ & $\% R E C$ & $\begin{array}{l}\% \mathrm{REC} \\
\text { Limits }\end{array}$ & RPD & $\begin{array}{l}\text { RPD } \\
\text { Limit }\end{array}$ & Notes \\
\hline
\end{tabular}

Batch 1004232 - Dry Weight

Soil

Duplicate (100422-DUF5)

Prepared: 04/18/10 09:49 Analyzed: 04/19/1000:18

QC Sarces ample: LCO1B? (AlODonn-ar)

D2m16

$\begin{array}{llllllllllllllll}\% \text { Solids } & 95.8 & - & 100 & \% \text { by Weight } & 1 & - & & 95.8 & -- & - & 0 & 20 \%\end{array}$

\footnotetext{
Apex Laboratories

The results in this report asply to the samples analysed in accoriase with the chnin of

(P)

custody document This anditicolrepont must be reproduced in it entivety.
}

Philip Nerenberg For Darwin Thomas, Business Development Director

Poge 18 of 27 


\section{Apex Labs}

12232 S.W. Garden Phace

Tigard, OR 97223

503-718-2323 Phone

503-718-0333 Fax

\begin{tabular}{|lcc|}
\hline GeoEngineers -Seattle & Project OregonMetals Evaluation As & Reported \\
600 S tewartSt. Suite 1700 & Project Humber. $2727-050-00$ & $05 / 13 / 1022: 55$ \\
Seattle, WA 98101 & Project Marager. Neil Morton & \\
\hline
\end{tabular}

\begin{tabular}{|c|c|c|c|c|c|c|c|}
\hline \multicolumn{8}{|c|}{ SAMPLE PREPARATION INF ORMATION } \\
\hline \multicolumn{8}{|c|}{ Total Metals by EPA 6020 (ICPMS) } \\
\hline Prep: EPA 3051A & & & & & Sample & Default & RL Prep \\
\hline Lab Number & Matix & Method & Sarmled & Prepared & Iritial/Final & Iritial/Final & Factor \\
\hline \multicolumn{8}{|l|}{ Batch: 1004371} \\
\hline A10D077-01 & Soil & EPA 6020 & 01/01/9400:00 & $04 / 23 / 1018: 42$ & $0.498 \mathrm{~g} / 50 \mathrm{~mL}$ & $0.5 \mathrm{~g} / 50 \mathrm{~mL}$ & 1.00 \\
\hline A10D077-02 & Soil & EPA 6020 & 01/01/9400:00 & $04 / 23 / 1018: 42$ & $0.481 \mathrm{~g} / 50 \mathrm{~mL}$ & $0.5 \mathrm{~g} / 50 \mathrm{~mL}$ & 1.04 \\
\hline A10D077-03 & Soil & EPA 6020 & 01/01/9400:00 & $04 / 23 / 1018: 42$ & $0.484 \mathrm{~g} / 50 \mathrm{~mL}$ & $0.5 \mathrm{~g} / 50 \mathrm{~mL}$ & 1.03 \\
\hline A10D077-04 & Soil & EPA 6020 & 01/01/9400:00 & $04 / 23 / 1018: 42$ & $0.488 \mathrm{~g} / 50 \mathrm{~mL}$ & $0.5 \mathrm{~g} / 50 \mathrm{~mL}$ & 1.02 \\
\hline \multicolumn{8}{|l|}{ Eatch: 1004372} \\
\hline A10D077-05 & Soil & EPA 6020 & 01/01/9400:00 & $04 / 24 / 1009: 34$ & $0.48 \mathrm{~g} / 50 \mathrm{~mL}$ & $0.5 \mathrm{~g} / 50 \mathrm{~mL}$ & 1.04 \\
\hline A10D077-06 & Soil & EPA 6020 & 01/01/9400:00 & $04 / 24 / 1009: 34$ & $0.486 \mathrm{~g} / 50 \mathrm{~mL}$ & $0.5 \mathrm{~g} / 50 \mathrm{~mL}$ & 1.03 \\
\hline A10D077-0? & Soil & EPA 6020 & 01/01/9400:00 & 04/24/1009:34 & $0.493 \mathrm{~g} / 50 \mathrm{~mL}$ & $0.5 \mathrm{~g} / 50 \mathrm{~mL}$ & 1.01 \\
\hline A10D077-08 & Soil & EPA 6020 & 01/01/9400:00 & $04 / 24 / 1009: 34$ & $0.492 \mathrm{~g} / 50 \mathrm{~mL}$ & $0.5 \mathrm{~g} / 50 \mathrm{~mL}$ & 1.02 \\
\hline A10D077-09 & Soil & EPA 6020 & 01/01/9400:00 & 04/24/1009:34 & $0.487 \mathrm{~g} / 50 \mathrm{~mL}$ & $0.5 \mathrm{~g} / 50 \mathrm{~mL}$ & 1.03 \\
\hline A10D077-10 & Soil & EPA 6020 & 01/01/9400:00 & 04/24/1009:34 & $0.475 \mathrm{~g} / 50 \mathrm{~mL}$ & $0.5 \mathrm{~g} / 50 \mathrm{~mL}$ & 1.05 \\
\hline A10D077-11 & Soil & EPA 6020 & 01/01/9400:00 & 04/24/1009:34 & $0.49 \mathrm{~g} / 50 \mathrm{~mL}$ & $0.5 \mathrm{~g} / 50 \mathrm{~mL}$ & 1.02 \\
\hline A10D077-12 & Soil & EPA 6020 & 01/01/9400:00 & $04 / 24 / 1009: 34$ & $0.482 \mathrm{~g} / 50 \mathrm{~mL}$ & $0.5 \mathrm{~g} / 50 \mathrm{~mL}$ & 1.04 \\
\hline A10D077-13 & Soil & EPA 6020 & 01/01/9400:00 & $04 / 24 / 1009: 34$ & $0.485 \mathrm{~g} / 50 \mathrm{~mL}$ & $0.5 \mathrm{~g} / 50 \mathrm{~mL}$ & 1.03 \\
\hline A10D077-14 & Soil & EPA 6020 & 01/01/9400:00 & $04 / 24 / 1009: 34$ & $0.487 \mathrm{~g} / 50 \mathrm{~mL}$ & $0.5 \mathrm{~g} / 50 \mathrm{~mL}$ & 1.03 \\
\hline A10D077-15 & Soil & EPA 6020 & 01:01:9400:00 & $04 / 24 / 1009: 34$ & $0.501 \mathrm{~g} / 50 \mathrm{~mL}$ & $0.5 \mathrm{~g} / 50 \mathrm{~mL}$ & 1.00 \\
\hline A10D077-16 & Soil & EPA 6020 & 01/01/9400:00 & $04 / 24 / 1009: 34$ & $0.487 \mathrm{~g} / 50 \mathrm{~mL}$ & $0.5 \mathrm{~g} / 50 \mathrm{~mL}$ & 1.03 \\
\hline A10D077-17 & Soil & EPA 6020 & 01/01/9400:00 & 04/24/1009:34 & $0.491 \mathrm{~g} / 50 \mathrm{~mL}$ & $0.5 \mathrm{~g} / 50 \mathrm{~mL}$ & 1.02 \\
\hline A10D077-18 & Soil & EPA 6020 & 01/01/9400:00 & 04/24/1009:34 & $0.482 \mathrm{~g} / 50 \mathrm{~mL}$ & $0.5 \mathrm{~g} / 50 \mathrm{~mL}$ & 1.04 \\
\hline A10D077-19 & Soil & EPA 6020 & 01/01/9400:00 & 04/24/1009:34 & $0.481 \mathrm{~g} / 50 \mathrm{~mL}$ & $0.5 \mathrm{~g} / 50 \mathrm{~mL}$ & 1.04 \\
\hline A10D077-20 & Soil & EPA 6020 & 01/01/9400:00 & 04/24/1009:34 & $0.491 \mathrm{~g} / 50 \mathrm{~mL}$ & $0.5 \mathrm{~g} / 50 \mathrm{~mL}$ & 1.02 \\
\hline A10D077-21 & Soil & EPA 6020 & 01/01/9400:00 & 04/24/1009:34 & $0.488 \mathrm{~g} / 50 \mathrm{~mL}$ & $0.5 \mathrm{~g} / 50 \mathrm{~mL}$ & 1.02 \\
\hline A10D077-22 & Soil & EPA 6020 & 01/01/9400:00 & 04/24/1009:34 & $0.498 \mathrm{~g} / 50 \mathrm{~mL}$ & $0.5 \mathrm{~g} / 50 \mathrm{~mL}$ & 1.00 \\
\hline A10D077-23 & Soil & EPA 6020 & 01/01/9400:00 & $04 / 24 / 1009: 34$ & $0.485 \mathrm{~g} / 50 \mathrm{~mL}$ & $0.5 \mathrm{~g} / 50 \mathrm{~mL}$ & 1.03 \\
\hline \multicolumn{8}{|l|}{ Batch: 1004402} \\
\hline A10D077-24 & Soil & EPA 6020 & 01/01/9400:00 & $04 / 26 / 1015: 42$ & $0.502 \mathrm{~g} / 50 \mathrm{~mL}$ & $0.5 \mathrm{~g} / 50 \mathrm{~mL}$ & 1.00 \\
\hline A10D077-25 & Soil & EPA 6020 & 01/01/9400:00 & 04/26/10 15:42 & $0.439 \mathrm{~g} / 50 \mathrm{~mL}$ & $0.5 \mathrm{~g} / 50 \mathrm{~mL}$ & 1.14 \\
\hline A10D077-26 & Soil & EPA 6020 & 01/01/9400:00 & 04/26/10 15:42 & $0.457 \mathrm{~g} / 50 \mathrm{~mL}$ & $0.5 \mathrm{~g} / 50 \mathrm{~mL}$ & 1.09 \\
\hline A10D077-27 & Soil & EPA 6020 & 01/01/9400:00 & $04 / 26 / 1015: 42$ & $0.455 \mathrm{~g} / 50 \mathrm{~mL}$ & $0.5 \mathrm{~g} / 50 \mathrm{~mL}$ & 1.10 \\
\hline A10D077-28 & Soil & EPA 6020 & 01/01/9400:00 & $04 / 26 / 1015: 42$ & $0.507 \mathrm{~g} / 50 \mathrm{~mL}$ & $0.5 \mathrm{~g} / 50 \mathrm{~mL}$ & 0.99 \\
\hline A10D077-29 & Soil & EPA 6020 & 01/01/9400:00 & $04 / 26 / 1015: 42$ & $0.483 \mathrm{~g} / 50 \mathrm{~mL}$ & $0.5 \mathrm{~g} / 50 \mathrm{~mL}$ & 1.04 \\
\hline A10D077-30 & Soil & EPA 6020 & 01/01/9400:00 & $04 / 26 / 1015: 42$ & $0.513 \mathrm{~g} / 50 \mathrm{~mL}$ & $0.5 \mathrm{~g} / 50 \mathrm{~mL}$ & 0.98 \\
\hline A10D077-31 & Soil & EPA 6020 & 01/01/9400:00 & $04 / 26 / 1015: 42$ & $0.469 \mathrm{~g} / 50 \mathrm{~mL}$ & $0.5 \mathrm{~g} / 50 \mathrm{~mL}$ & 1.07 \\
\hline
\end{tabular}

Apex Laboratories

The results in this report apply to the samples andigned in accoriase with the chain of

1) 


\section{Apex Labs}

12232 S.W. Garden Phace

Tigard, OR 97223

503-718-2323 Phone

503-718-0333 Fax

\begin{tabular}{|c|c|c|}
\hline GeoEngineers -Seattle & Project OregonMetals Evahuation As & \\
\hline 600 S tewartSt. Suite 1700 & Project Number. $2727-050-00$ & Reported: \\
\hline Seattle, WA 98101 & Project Manager. Neil Morton & $05 / 13 / 1022: 55$ \\
\hline
\end{tabular}

SAMPLE PREPARATION INF ORMATION

\begin{tabular}{|c|c|c|c|c|c|c|c|}
\hline \multicolumn{8}{|c|}{ Total Metals by EPA 6020 (ICPMS) } \\
\hline Prep: EPA 3051A & & & & & Sarmle & Default & RL Prep \\
\hline Lab Number & Matrix & Method & Sampled & Phepared & Iritial/Final & Iritial/Final & Factor \\
\hline A10D077-32 & Soil & EPA 6020 & 01/01/9400:00 & $04 / 26 / 1015: 42$ & $0.519 \mathrm{~g} / 50 \mathrm{~mL}$ & $0.5 \mathrm{~g} / 50 \mathrm{~mL}$ & 0.96 \\
\hline A10D077-33 & Soil & EPA 6020 & 01:01/9400:00 & $04 / 26 / 1015: 42$ & $0.447 \mathrm{~g} / 50 \mathrm{~mL}$ & $0.5 \mathrm{~g} / 50 \mathrm{~mL}$ & 1.12 \\
\hline A10D077-34 & Soil & EPA 6020 & 01/01/9400:00 & $04 / 26 / 1015: 42$ & $0.468 \mathrm{~g} / 50 \mathrm{~mL}$ & $0.5 \mathrm{~g} / 50 \mathrm{~mL}$ & 1.07 \\
\hline A10D077-35 & Soil & EPA 6020 & 01/01/9400:00 & $04 / 26 / 1015: 42$ & $0.463 \mathrm{~g} / 50 \mathrm{~mL}$ & $0.5 \mathrm{~g} / 50 \mathrm{~mL}$ & 1.08 \\
\hline A10D077-36 & Soil & EPA 6020 & 01:01/9400:00 & $04 / 26 / 1015: 42$ & $0.469 \mathrm{~g} / 50 \mathrm{~mL}$ & $0.5 \mathrm{~g} / 50 \mathrm{~mL}$ & 1.07 \\
\hline A10D077-37 & Soil & EPA 6020 & 01:01/9400:00 & $04 / 26 / 1015: 42$ & $0.472 \mathrm{~g} / 50 \mathrm{~mL}$ & $0.5 \mathrm{~g} / 50 \mathrm{~mL}$ & 1.06 \\
\hline A10D077-38 & Soil & EPA 6020 & 01:01/9400:00 & $04 / 26 / 1015: 42$ & $0.501 \mathrm{~g} / 50 \mathrm{~mL}$ & $0.5 \mathrm{~g} / 50 \mathrm{~mL}$ & 1.00 \\
\hline A10D077-39 & Soil & EPA 6020 & 01/01/9400:00 & $04 / 26 / 1015: 42$ & $0.461 \mathrm{~g} / 50 \mathrm{~mL}$ & $0.5 \mathrm{~g} / 50 \mathrm{~mL}$ & 1.08 \\
\hline A10D077-40 & Soil & EPA 6020 & 01:01/9400:00 & $04 / 26 / 1015: 42$ & $0.47 \mathrm{~g} / 50 \mathrm{~mL}$ & $0.5 \mathrm{~g} / 50 \mathrm{~mL}$ & 1.06 \\
\hline A10D077-41 & Soil & EPA 6020 & 01:01:9400:00 & $04 / 26 / 1015: 42$ & $0.462 \mathrm{~g} / 50 \mathrm{~mL}$ & $0.5 \mathrm{~g} / 50 \mathrm{~mL}$ & 1.08 \\
\hline A10D077-42 & Soil & EPA 6020 & 01/01/9400:00 & $04 / 26 / 1015: 42$ & $0.492 \mathrm{~g} / 50 \mathrm{~mL}$ & $0.5 \mathrm{~g} / 50 \mathrm{~mL}$ & 1.02 \\
\hline A10D077-43 & Soil & EPA 6020 & 01:01/9400:00 & $04 / 26 / 1015: 42$ & $0.446 \mathrm{~g} / 50 \mathrm{~mL}$ & $0.5 \mathrm{~g} / 50 \mathrm{~mL}$ & 1.12 \\
\hline \multicolumn{8}{|l|}{ Batch: 1004409} \\
\hline A10D077-44 & Soil & EPA 6020 & 01:01/9400:00 & $04 / 27 / 1008: 23$ & $0.446 \mathrm{~g} / 50 \mathrm{~mL}$ & $0.5 \mathrm{~g} / 50 \mathrm{~mL}$ & 1.12 \\
\hline A10D077-45 & Soil & EPA 6020 & 01:01/9400:00 & $04 / 27 / 1008: 23$ & $0.456 \mathrm{~g} / 50 \mathrm{~mL}$ & $0.5 \mathrm{~g} / 50 \mathrm{~mL}$ & 1.10 \\
\hline A10D077-46 & Soil & EPA 6020 & 01/01/9400:00 & $04 / 27 / 1008: 23$ & $0.45 \mathrm{~g} / 50 \mathrm{~mL}$ & $0.5 \mathrm{~g} / 50 \mathrm{~mL}$ & 1.11 \\
\hline A10D077-47 & Soil & EPA 6020 & 01/01/9400:00 & $04 / 27 / 1008: 23$ & $0.475 \mathrm{~g} / 50 \mathrm{~mL}$ & $0.5 \mathrm{~g} / 50 \mathrm{~mL}$ & 1.05 \\
\hline A10D077-48 & Soil & EPA 6020 & 01:01/9400:00 & $04 / 27 / 1008: 23$ & $0.502 \mathrm{~g} / 50 \mathrm{~mL}$ & $0.5 \mathrm{~g} / 50 \mathrm{~mL}$ & 1.00 \\
\hline A10D077-49 & Soil & EPA 6020 & 01:01/9400:00 & $04 / 27 / 1008: 23$ & $0.326 \mathrm{~g} / 50 \mathrm{~mL}$ & $0.5 \mathrm{~g} / 50 \mathrm{~mL}$ & 1.53 \\
\hline A10D077-50 & Soil & EPA 6020 & 01:01/9400:00 & $04 / 27 / 1008: 23$ & $0.502 \mathrm{~g} / 50 \mathrm{~mL}$ & $0.5 \mathrm{~g} / 50 \mathrm{~mL}$ & 1.00 \\
\hline A10D077-51 & Soil & EPA 6020 & 01:01/9400:00 & $04 / 27 / 1008: 23$ & $0.494 \mathrm{~g} / 50 \mathrm{~mL}$ & $0.5 \mathrm{~g} / 50 \mathrm{~mL}$ & 1.01 \\
\hline A10D077-52 & Soil & EPA 6020 & 01:01/9400:00 & $04 / 27 / 1008: 23$ & $0.475 \mathrm{~g} / 50 \mathrm{~mL}$ & $0.5 \mathrm{~g} / 50 \mathrm{~mL}$ & 1.05 \\
\hline A10D077-53 & Soil & EPA 6020 & 01/01/9400:00 & $04 / 27 / 1008: 23$ & $0.444 \mathrm{~g} / 50 \mathrm{~mL}$ & $0.5 \mathrm{~g} / 50 \mathrm{~mL}$ & 1.13 \\
\hline A10D077-54 & Soil & EPA 6020 & 01:01:9400:00 & $04 / 27 / 1008: 23$ & $0.501 \mathrm{~g} / 50 \mathrm{~mL}$ & $0.5 \mathrm{~g} / 50 \mathrm{~mL}$ & 1.00 \\
\hline A10D077-55 & Soil & EPA 6020 & 01/01/9400:00 & $04 / 27 / 1008: 23$ & $0.439 \mathrm{~g} / 50 \mathrm{~mL}$ & $0.5 \mathrm{~g} / 50 \mathrm{~mL}$ & 1.14 \\
\hline A10D077-56 & Soil & EPA 6020 & 01/01/9400:00 & $04 / 27 / 1008: 23$ & $0.453 \mathrm{~g} / 50 \mathrm{~mL}$ & $0.5 \mathrm{~g} / 50 \mathrm{~mL}$ & 1.10 \\
\hline A10D077-57 & Soil & EPA 6020 & 01/01/9400:00 & $04 / 27 / 1008: 23$ & $0.33 \mathrm{~g} / 50 \mathrm{~mL}$ & $0.5 \mathrm{~g} / 50 \mathrm{~mL}$ & 1.52 \\
\hline A10D077-58 & Soil & EPA 6020 & 01:01/9400:00 & $04 / 27 / 1008: 23$ & $0.501 \mathrm{~g} / 50 \mathrm{~mL}$ & $0.5 \mathrm{~g} / 50 \mathrm{~mL}$ & 1.00 \\
\hline A10D077-59 & Soil & EPA 6020 & 01:01:9400:00 & $04 / 27 / 1008: 23$ & $0.458 \mathrm{~g} / 50 \mathrm{~mL}$ & $0.5 \mathrm{~g} / 50 \mathrm{~mL}$ & 1.09 \\
\hline A10D077-60 & Soil & EPA 6020 & 01:01/9400:00 & $04 / 27 / 1008: 23$ & $0.483 \mathrm{~g} / 50 \mathrm{~mL}$ & $0.5 \mathrm{~g} / 50 \mathrm{~mL}$ & 1.04 \\
\hline A10D077-61 & Soil & EPA 6020 & 01/01/9400:00 & $04 / 27 / 1008: 23$ & $0.474 \mathrm{~g} / 50 \mathrm{~mL}$ & $0.5 \mathrm{~g} / 50 \mathrm{~mL}$ & 1.05 \\
\hline A10D077-62 & Soil & EPA 6020 & 01/01/9400:00 & $04 / 27 / 1008: 23$ & $0.488 \mathrm{~g} / 50 \mathrm{~mL}$ & $0.5 \mathrm{~g} / 50 \mathrm{~mL}$ & 1.02 \\
\hline A10D077-63 & Soil & EPA 6020 & 01:01/9400:00 & $04 / 27 / 1008: 23$ & $0.508 \mathrm{~g} / 50 \mathrm{~mL}$ & $0.5 \mathrm{~g} / 50 \mathrm{~mL}$ & 0.98 \\
\hline
\end{tabular}

Apex Laboratories

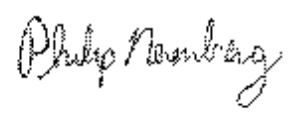

The results in this report appiy to the samples anajued in accoriance with the chnin of custody document This anditicalrepon mus be reproduced in it entivety. 


\section{Apex Labs}

12232 S.W. Garden Place

Tigard, OR 97223

503-718-2323 Phone

503-718-0333 Fax

Thursday, May 27, 2010

Neil Morton

GeoEngineers

15055 SW Sequoia Pkwy, \# 140

Portland, OR 97224

RE: Oregon Metals Evaluation / 002787-050-00

Enclosed are the results of analyses for work order $\mathrm{A10E125}$, which was received by the laboratory on $5 / 13 / 2010$ at 2:05:00PM.

Thank you for using Apex Labs. We appreciate your business and strive to provide the highest quality services to the environmental industry.

If you have any questions concerning this report or the sewices we offer, please feel free to contact me by email at: AGreiner@Apex-Labs.com, or by phone at 503-718-2323.

Apex Laboratories

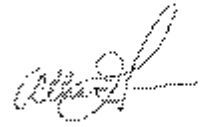

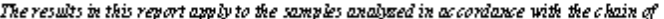
custody document This mabticolvegon mus be reproduced in it entivety. 


\section{Apex Labs}

12232 S.W. Garden Place

Tigard, OR 97223

503-718-2323 Phone

503-718-0333 Fax

GeoEngineers

15055 S WS equoia Pkwy, \# 140

Project OregonMetals Evahuation

Project Humber. 002787-050-00

Project Manager. Neil Morton

Reported

05/27/10 15:01

ANAL YTICAL REPORT FOR SAMPLES

\begin{tabular}{|llllc|}
\hline \multicolumn{5}{c|}{ SAMPLE INF ORHATION } \\
\hline Sample I & Laboratory D & Matrix & Dste Sampled & Date Received \\
\hline TR1A & A10E125-01 & Soil & $05 / 12 / 1000: 00$ & $05 / 13 / 1014: 05$ \\
TR1B & A10E125-02 & Soil & $05 / 12 / 1000: 00$ & $05 / 13 / 1014: 05$ \\
TR2A & A10E125-03 & Soil & $05 / 12 / 1000: 00$ & $05 / 13 / 1014: 05$ \\
TR2B & A10E125-04 & Soil & $05 / 12 / 1000: 00$ & $05 / 13 / 1014: 05$
\end{tabular}

Apex Laboratories

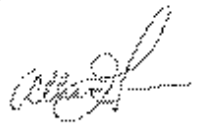

The results in this report apply to the somples analyzed in accordaxe with the $\mathrm{cknin}$ of custody document This andicalicepont mus be reproduced in it entivety. 


\section{Apex Labs}

12232 S.W. Garden Place

Tigard, OR 97223

503-718-2323 Phone

503-718-0333 Fax
GeoEngineers

15055 S WS equoia Pkwy, \# 140

Portland, OR 97224
Project Oregon Metals Evahuation

Project Number. 002787-050-00

Project Manager. Neil Morton
Reported

05/27/10 15:01

QUALITY CONTROL (QC) SAMPLE RESULTS

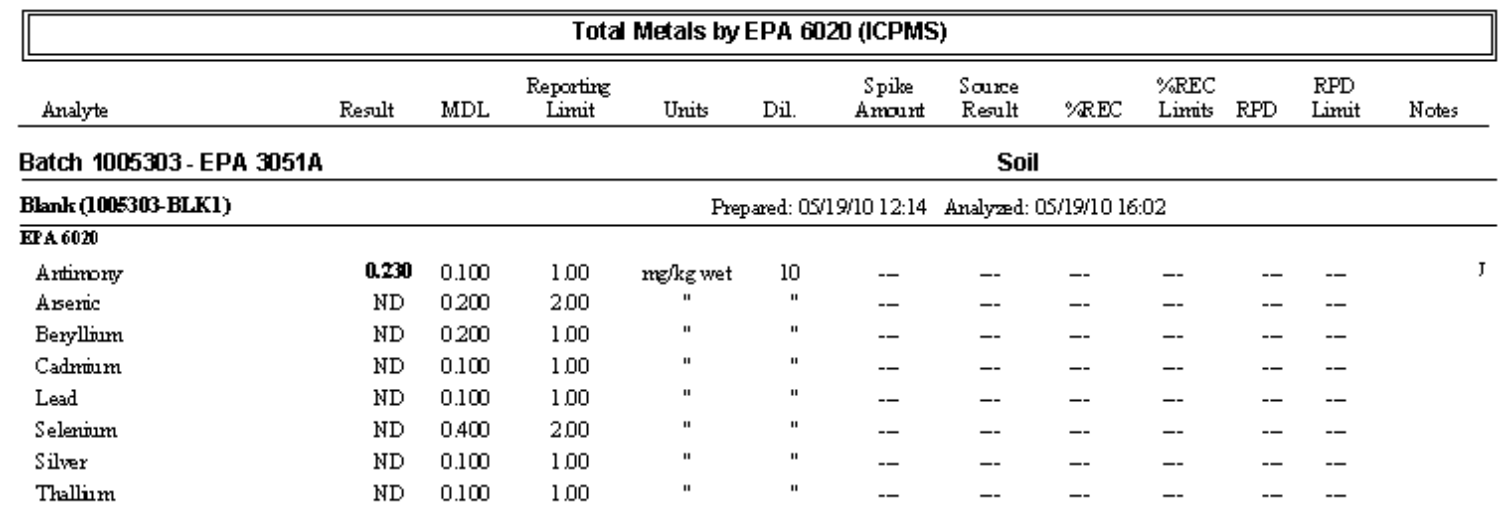

LCS (1005303-BS1) EPA 6020

Artimory

Aseric

Beryllium

Cadnimim

Lead

Selenium

Silver

Thallim

Prepared: 05/19/10 12:14 Analyzd: 05/19/10 16:05

\begin{tabular}{|c|c|c|c|c|c|c|c|c|c|}
\hline 27.1 & 0.100 & 100 & $\mathrm{mg} / \mathrm{kg}$ wet & 10 & 25.0 & -- & 108 & $80-120 \%$ & - \\
\hline 48.7 & 0200 & 200 & $"$ & $"$ & 50.0 & -- & 97 & $"$ & - \\
\hline 23.7 & 0200 & 100 & $"$ & $"$ & 25.0 & -- & 95 & $"$ & -- \\
\hline 49.2 & 0.100 & 100 & $"$ & " & 50.0 & -- & 98 & $"$ & - \\
\hline 45.0 & 0.100 & 100 & $"$ & $"$ & $"$ & -- & 90 & $"$ & - \\
\hline 22.7 & 0.400 & 200 & $"$ & " & 25.0 & -- & 91 & $"$ & -- \\
\hline 23.6 & 0.100 & 100 & $"$ & $"$ & $"$ & -- & 94 & $"$ & - \\
\hline 22.3 & 0.100 & 100 & $"$ & $"$ & $"$ & -- & 89 & $"$ & - \\
\hline
\end{tabular}

The results in this report appiy to the samples analyed in accoriaxce with the chanin of

custody document This anditicalveyont must be reproduced in it entrety.
Apex Laboratories

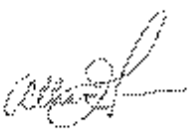

Allison Gre iner For Darwin Thomas, Business Deve lopment Director
Pas 5 of 9 


\section{Apex Labs}

12232 S.W. Garden Phace

Tigard, OR 97223

503-718-2323 Phone

503-718-0333 Fax

GeoEngineers

1 soss S WS equoia Plkwy, \# 140

Project Oregon Metals Evaluation

Project Humber. 002787-050-00

Reporter

Project Manager. Neil Morton

QUALITY CONTROL (QC) SAMPLE RESULTS

\begin{tabular}{|c|c|c|c|c|c|c|c|c|c|c|c|c|}
\hline \multicolumn{13}{|c|}{ Percent Dry Weight by D2216 } \\
\hline Analyte & Result & MDL & $\begin{array}{l}\text { Reporting } \\
\text { Limit }\end{array}$ & Units & Dil. & $\begin{array}{c}\text { Spike } \\
\text { Amount }\end{array}$ & $\begin{array}{l}\text { Source } \\
\text { Revult }\end{array}$ & $\% R E C$ & $\begin{array}{l}\% \mathrm{REC} \\
\text { Limits }\end{array}$ & RPD & $\begin{array}{l}\text { RPD } \\
\text { Limit }\end{array}$ & Notes \\
\hline
\end{tabular}

Batch 1005248 - Dry Weight

Soil

Duplicate (1005248-DUPI)

Prepared: 05/17/10 10:00 Analyzed: 05/18/1000:36

QC S aurce S ample: TR2B (A10EI25-(4)

Apex SOP

$\%$ Solids

$0 \quad 20 \%$

No Client related Batch QC s amples analyrsd for tris b atch See notes page for more irformation.

Apex Laboratories

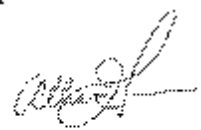

Allison Gre iner For Darwin Thomas, Business Deve lopment Director
The results in this report asply to the samples analysed in accordaxe with the $\mathrm{cknin}$ of

custody document This madticalrepont wus be reproduced in it entrety. 


\section{Apex Labs}

12232 S.W. Garden Place

Tigard, OR 97223

503-718-2323 Phone

503-718-0333 Fax

\begin{tabular}{|c|c|c|}
\hline GeoEngineers & Project Oregon Metals Evaluation & \\
\hline 15055 S WS equoia Pkwy, \# 140 & Project Number. $002787-050-\infty$ & Reparted \\
\hline Portland, OR 97224 & Project Manager. Neil Morton & $05 / 27 / 1015: 01$ \\
\hline
\end{tabular}

SAMPLE PREPARATION INF ORMATION

\begin{tabular}{|c|c|c|c|c|c|c|c|}
\hline \multicolumn{8}{|c|}{ Total Metals by EPA 6020 (ICPHS) } \\
\hline$\frac{\text { Prep: EPA 3051A }}{\text { La Number }}$ & Matix & Method & Sarmpled & Prepared & $\begin{array}{c}\text { Sarmple } \\
\text { Iritial/Final }\end{array}$ & $\begin{array}{c}\text { Default } \\
\text { Iritial/Final }\end{array}$ & $\begin{array}{l}\text { RL Prep } \\
\text { Factor }\end{array}$ \\
\hline \multicolumn{8}{|l|}{ Batch: 1005303 } \\
\hline A10E125-01 & Soil & EPA 6020 & $05 / 12 / 1000: 00$ & $05 / 19 / 1012: 14$ & $0.489 \mathrm{~g} / 50 \mathrm{~mL}$ & $0.5 \mathrm{~g} / 50 \mathrm{~mL}$ & 1.02 \\
\hline A10E125-01 & Soil & EPA 6020 & $05 / 12 / 1000: 00$ & $05 / 19 / 1012: 14$ & $0.489 \mathrm{~g} / 50 \mathrm{~mL}$ & $0.5 \mathrm{~g} / 50 \mathrm{~mL}$ & 1.02 \\
\hline A10E125-01 & Soil & EPA 6020 & $05 / 12 / 1000: 00$ & $05 / 19 / 1012: 14$ & $0.489 \mathrm{~g} / 50 \mathrm{~mL}$ & $0.5 \mathrm{~g} / 50 \mathrm{~mL}$ & 1.02 \\
\hline A10E125-01 & Soil & EPA 6020 & $05 / 12 / 1000: 00$ & $05 / 19 / 1012: 14$ & $0.489 \mathrm{~g} / 50 \mathrm{~mL}$ & $0.5 \mathrm{~g} / 50 \mathrm{~mL}$ & 1.02 \\
\hline A10E125-01 & Soil & EPA 6020 & $05 / 12 / 1000: 00$ & $05 / 19 / 1012: 14$ & $0.489 \mathrm{~g} / 50 \mathrm{~mL}$ & $0.5 \mathrm{~g} / 50 \mathrm{~mL}$ & 1.02 \\
\hline A10E125-01 & Soil & EPA 6020 & $05 / 12 / 1000: 00$ & $05 / 19 / 1012: 14$ & $0.489 \mathrm{~g} / 50 \mathrm{~mL}$ & $0.5 \mathrm{~g} / 50 \mathrm{~mL}$ & 1.02 \\
\hline A10E125-01 & Soil & EPA 6020 & $05 / 12 / 1000: 00$ & $05 / 19 / 1012: 14$ & $0.489 \mathrm{~g} / 50 \mathrm{~mL}$ & $0.5 \mathrm{~g} / 50 \mathrm{~mL}$ & 1.02 \\
\hline A10E125-01 & Soil & EPA 6020 & 05/12/10 00:00 & $05 / 19 / 1012: 14$ & $0.489 \mathrm{~g} / 50 \mathrm{~mL}$ & $0.5 \mathrm{~g} / 50 \mathrm{~mL}$ & 1.02 \\
\hline A10E125-02 & Soil & EPA 6020 & 05/12/1000:00 & $05 / 19 / 1012: 14$ & $0.501 \mathrm{~g} / 50 \mathrm{~mL}$ & $0.5 \mathrm{~g} / 50 \mathrm{~mL}$ & 1.00 \\
\hline A10E125-02 & Soil & EPA 6020 & $05 / 12 / 1000: 00$ & $0 5 \longdiv { 1 9 / 1 0 1 2 : 1 4 }$ & $0.501 \mathrm{~g} / 50 \mathrm{~mL}$ & $0.5 \mathrm{~g} / 50 \mathrm{~mL}$ & 1.00 \\
\hline A10E125-02 & Soil & EPA 6020 & $05 / 12 / 1000: 00$ & $05 / 19 / 1012: 14$ & $0.501 \mathrm{~g} / 50 \mathrm{~mL}$ & $0.5 \mathrm{~g} / 50 \mathrm{~mL}$ & 1.00 \\
\hline A10E125-02 & Soil & EPA 6020 & $05 / 12 / 1000: 00$ & $05 / 19 / 1012: 14$ & $0.501 \mathrm{~g} / 50 \mathrm{~mL}$ & $0.5 \mathrm{~g} / 50 \mathrm{~mL}$ & 1.00 \\
\hline A10E125-02 & Soil & EPA 6020 & $05 / 12 / 1000: 00$ & $05 / 19 / 1012: 14$ & $0.501 \mathrm{~g} / 50 \mathrm{~mL}$ & $0.5 \mathrm{~g} / 50 \mathrm{~mL}$ & 1.00 \\
\hline A10E125-02 & Soil & EPA 6020 & 05/12/10 00:00 & $05 / 19 / 1012: 14$ & $0.501 \mathrm{~g} / 50 \mathrm{~mL}$ & $0.5 \mathrm{~g} / 50 \mathrm{~mL}$ & 1.00 \\
\hline A10E125-02 & Soil & EPA 6020 & 05/12/1000:00 & $05 / 19 / 1012: 14$ & $0.501 \mathrm{~g} / 50 \mathrm{~mL}$ & $0.5 \mathrm{~g} / 50 \mathrm{~mL}$ & 1.00 \\
\hline A $10 \mathrm{E} 125-02$ & Soil & EPA 6020 & $05 / 12 / 1000: 00$ & $05 / 19 / 1012: 14$ & $0.501 \mathrm{~g} / 50 \mathrm{~mL}$ & $0.5 \mathrm{~g} / 50 \mathrm{~mL}$ & 1.00 \\
\hline A10E125-03 & Soil & EPA 6020 & $05 / 12 / 1000: 00$ & $05 / 19 / 1012: 14$ & $0.487 \mathrm{~g} / 50 \mathrm{~mL}$ & $0.5 \mathrm{~g} / 50 \mathrm{~mL}$ & 1.03 \\
\hline A10E125-03 & Soil & EPA 6020 & $05 / 12 / 1000: 00$ & $05 / 19 / 1012: 14$ & $0.487 \mathrm{~g} / 50 \mathrm{~mL}$ & $0.5 \mathrm{~g} / 50 \mathrm{~mL}$ & 1.03 \\
\hline A10E125-03 & Soil & EPA 6020 & $05 / 12 / 1000: 00$ & $05 / 19 / 1012: 14$ & $0.487 \mathrm{~g} / 50 \mathrm{~mL}$ & $0.5 \mathrm{~g} / 50 \mathrm{~mL}$ & 1.03 \\
\hline A10E125-03 & Soil & EPA 6020 & $05 / 12 / 1000: 00$ & $05 / 19 / 1012: 14$ & $0.487 \mathrm{~g} / 50 \mathrm{~mL}$ & $0.5 \mathrm{~g} / 50 \mathrm{~mL}$ & 1.03 \\
\hline A10E125-03 & Soil & EPA 6020 & $05 / 12 / 1000: 00$ & $05 / 19 / 1012: 14$ & $0.487 \mathrm{~g} / 50 \mathrm{~mL}$ & $0.5 \mathrm{~g} / 50 \mathrm{~mL}$ & 1.03 \\
\hline A10E125-03 & Soil & EPA 6020 & 05/12/1000:00 & $05 / 19 / 1012: 14$ & $0.487 \mathrm{~g} / 50 \mathrm{~mL}$ & $0.5 \mathrm{~g} / 50 \mathrm{~mL}$ & 1.03 \\
\hline A10E125-03 & Soil & EPA 6020 & $05 / 12 / 1000: 00$ & $05 / 19 / 1012: 14$ & $0.487 \mathrm{~g} / 50 \mathrm{~mL}$ & $0.5 \mathrm{~g} / 50 \mathrm{~mL}$ & 1.03 \\
\hline A10E125-03 & Soil & EPA 6020 & $05 / 12 / 1000: 00$ & $05 / 19 / 1012: 14$ & $0.487 \mathrm{~g} / 50 \mathrm{~mL}$ & $0.5 \mathrm{~g} / 50 \mathrm{~mL}$ & 1.03 \\
\hline A10E125-04 & Soil & EPA 6020 & $05 / 12 / 1000: 00$ & $05 / 19 / 1012: 14$ & $0.493 \mathrm{~g} / 50 \mathrm{~mL}$ & $0.5 \mathrm{~g} / 50 \mathrm{~mL}$ & 1.01 \\
\hline A10E125-04 & Soil & EPA 6020 & 05:12/1000:00 & $05 / 19 / 1012: 14$ & $0.493 \mathrm{~g} / 50 \mathrm{~mL}$ & $0.5 \mathrm{~g} / 50 \mathrm{~mL}$ & 1.01 \\
\hline A10E125-04 & Soil & EPA 6020 & $05 / 12 / 1000: 00$ & $05 / 19 / 1012: 14$ & $0.493 \mathrm{~g} / 50 \mathrm{~mL}$ & $0.5 \mathrm{~g} / 50 \mathrm{~mL}$ & 1.01 \\
\hline A10E125-04 & Soil & EPA 6020 & $05 / 12 / 1000: 00$ & $05 / 19 / 1012: 14$ & $0.493 \mathrm{~g} / 50 \mathrm{~mL}$ & $0.5 \mathrm{~g} / 50 \mathrm{~mL}$ & 1.01 \\
\hline A10E125-04 & Soil & EPA 6020 & 05/12/10 00:00 & $05 / 19 / 1012: 14$ & $0.493 \mathrm{~g} / 50 \mathrm{~mL}$ & $0.5 \mathrm{~g} / 50 \mathrm{~mL}$ & 1.01 \\
\hline A10E125-04 & Soil & EPA 6020 & 05/12/1000:00 & $05 / 19 / 1012: 14$ & $0.493 \mathrm{~g} / 50 \mathrm{~mL}$ & $0.5 \mathrm{~g} / 50 \mathrm{~mL}$ & 1.01 \\
\hline A10E125-04 & Soil & EPA 6020 & $05 / 12 / 1000: 00$ & $05 / 19 / 1012: 14$ & $0.493 \mathrm{~g} / 50 \mathrm{~mL}$ & $0.5 \mathrm{~g} / 50 \mathrm{~mL}$ & 1.01 \\
\hline A10E125-04 & Soil & EPA 6020 & 05/12/1000:00 & $05 / 19 / 1012: 14$ & $0.493 \mathrm{~g} / 50 \mathrm{~mL}$ & $0.5 \mathrm{~g} / 50 \mathrm{~mL}$ & 1.01 \\
\hline
\end{tabular}

Apex Laboratories

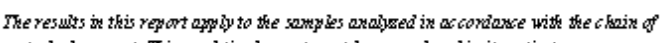

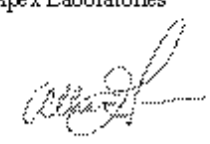

custody document This anditicalrepon must be regroduced in it entivety.

Allison Gre iner For Darwin Thomas, Business Deve lopment Director

Page 7 of 9 


\section{Apex Labs}

12232 S.W. Garden Place

Tigard, OR 97223

503-718-2323 Phone

503-718-0333 Fax
GeoEngineers -Seattle

600 S tewartSt. Suite 1700

Seattle, WA 98101
Project Oregon Metals Evaluation

Project Number. 2787-050-000

Project Manager. Neil Morton
Reported

$05131022: 21$

\section{Notes and Definitions}

\section{Qualifiers:}

B Analyte detected in an associated blank at a level above the MRL. (See Notes and Convertions bebw.)

H-01 This sample was amalyzed outside the EPA reoormended holding time.

H-06 This sample was received outside the EPA recommended holding time.

J Es timated Result. Result detected below the lowest poirt of the calibration curve, but bove the specified MDL

Q-01 Percent recovery andior RPD is outside acostance linits.

Q-05 Analyses are not cortrolled on RPD vahes from sample or duplicate concentrations near or below the reporting level.

Notes and Convertions:

DET Analyte DETECTED

HD Analyte HOT DETECTED at or bove the reporting limit

HR Not Reported

dry Sarmle results reported on a dryweight basis. Results listed as 'wet' or without 'dry'desiznation are not dryweight comected.

RPD Relative Percent Difference

MDL If MDL is not listed, data has been evahated to the Method Reporting Lirrit only.

WMSC Water Miscible Solvert Conection has been applied to Results and MRLs for wolatiles soil samples per EPA $8000 \mathrm{C}$.

Batch Unless specifically requested, this report contains only results for Batch QC derived from client sarmples inchuded in this report. All

QC analyses were performed with the appropriate Batch QC (inchuding Sarple Duplicates, Matrix S pikes and/or Matrix Spike Duplicates) in order to meetor exceed method and rezulatory requiremerts. Any exoeptions to this will be qualified in this report. Cormplete Batch QC results are avalable upon request. In cases where there is insufficient sample provided for S anqle Duplicates andior Matrix Spikes, a Lab Contol Sample Duplicate (LCS Dup) is analyred to demonstrate accuracy and precision of the extraction and analysis.

Blank A pex ases ses b lank data for potential high bias down to a level equal to $1 / 2$ the method reporting limit (MRL), except for convertional

Policy cherristry and $\mathrm{HCD}$ analyses which are asessed only to the MRL. Sample results flagged with a B or B-02 qualifier are potentially biased high if they are less than ten times the level found in the blank for inorgaric analyses or less than five times the level found in the blank for org anic analyses.

For accurate cormarison of volatile results to the level found in the blank; water sample results should be divided by the dibution factor, and soil sample results should be divided by $1 / 50$ of the sample dibution to accourt for the sample prep factor.

Results qualified as reported below the MRL may inchude a potential ligh bias if as sociated with a B or B-02 qualified blank. B and B-02 qualifications are not applied to J qualified results reported below the MRL

Apex Laboratories

Aly

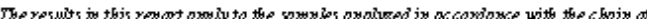
custody document This anaticalrepont mus be reproduced in it entivety.

Philip Nererberg For Darwin Thomas, Business Development Director

Puge 50 of 53 